ANA CRISTINA CHAGAS DOS ANJOS

Diálogos entre Patrimônio, Meio Ambiente e Aprendizagem Social: uma experiência de Educação Patrimonial em pesquisa-ação no bairro paulistano de Santo Amaro 

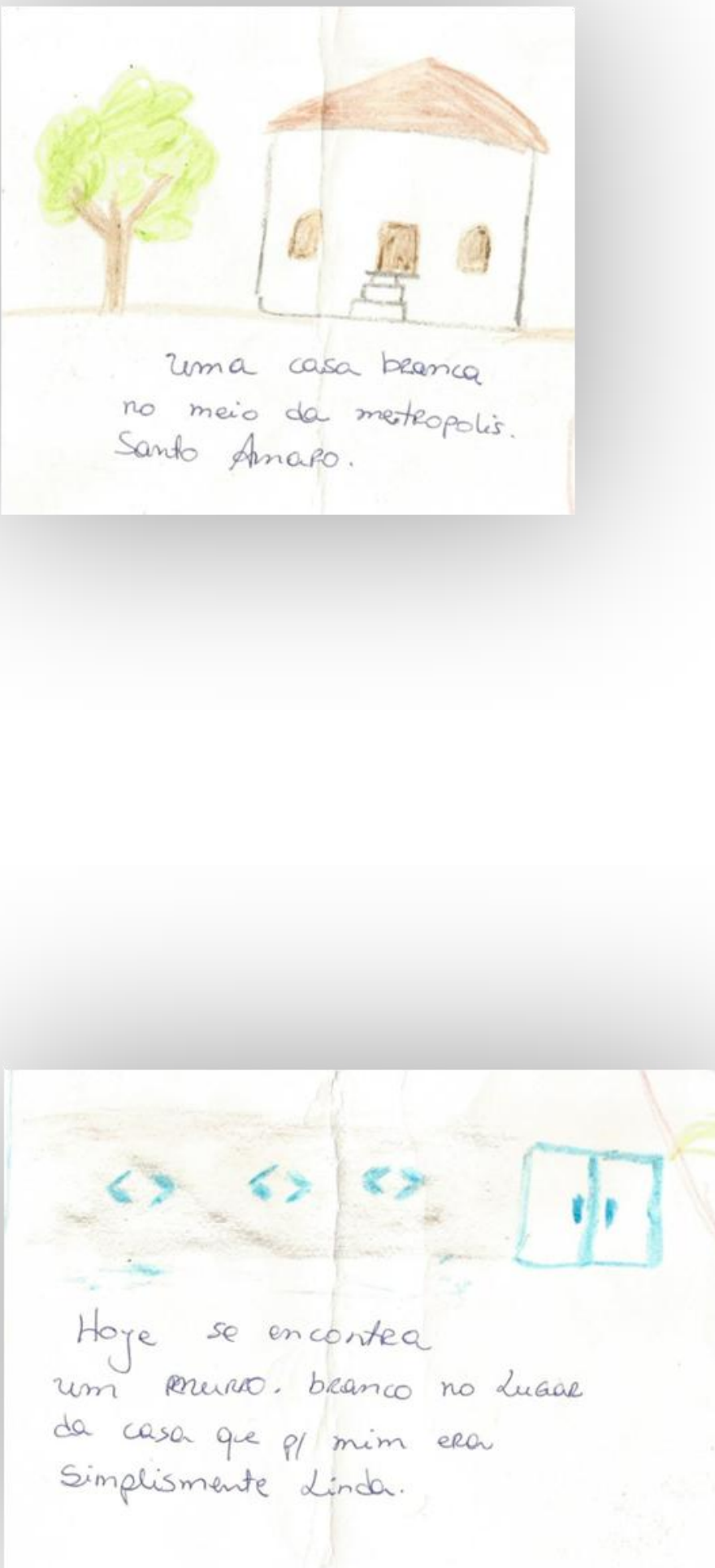
Ana Cristina Chagas dos Anjos

\section{Diálogos entre Patrimônio, Meio Ambiente e Aprendizagem Social: uma experiência de Educação Patrimonial em pesquisa-ação no bairro paulistano de Santo Amaro}

Tese apresentada à Faculdade de Educação da Universidade de São Paulo (USP) para obtenção do título de Doutora em Educação.

Área de Concentração: Cultura, Organização e Educação.

Orientador: Prof. Dr. Pedro Roberto Jacobi 
AUTORIZO A REPRODUÇÃO E DIVULGAÇÃO TOTAL OU PARCIAL DESTE TRABALHO, POR QUALQUER MEIO CONVENCIONAL OU ELETRÔNICO, PARA FINS DE ESTUDO E PESQUISA, DESDE QUE CITADA A FONTE.

Catalogação na Publicação

Serviço de Biblioteca e Documentação

Faculdade de Educação da Universidade de São Paulo

375.991

Anjos, Ana Cristina Chagas dos

A599d

Diálogos entre Patrimônio, Meio Ambiente e Aprendizagem Social: uma experiência de Educação Patrimonial em pesquisa-ação no bairro paulistano de Santo Amaro / Ana Cristina Chagas dos Anjos; orientação Pedro Roberto Jacobi. São Paulo: s. n., 2016.

330 p. ils.; tabs.; anexos

Tese (Doutorado - Programa de Pós-Graduação em Educação. Área de Concentração: Cultura, Organização e Educação) - - Faculdade de Educação da Universidade de São Paulo.

1. Educação patrimonial 2. Aprendizagem social 3. Patrimônio Cultural 4. Metodologia de pesquisa 5. Pesquisa-ação I. Jacobi, Pedro Roberto, orient. 
Nome: Ana Cristina Chagas dos Anjos

Título: Diálogos entre Patrimônio, Meio Ambiente e Aprendizagem Social: uma experiência de Educação Patrimonial em pesquisa-ação no bairro paulistano de Santo Amaro

Tese apresentada à Faculdade de Educação da Universidade de São Paulo (USP) para obtenção do título de Doutora em Educação.

Área de Concentração: Cultura, Organização e Educação.

Aprovado em:

Banca Examinadora

Prof. Dr.

Instituição:

Julgamento:

Assinatura:

Prof. Dr.

Instituição:

Julgamento:

Assinatura:

Prof. Dr.

Instituição:

Julgamento:

Assinatura:

Prof. Dr.

Instituição:

Julgamento:

Assinatura: 
Torno a dedicar este trabalho à minha avó Therezinha (agora in memoriam) a quem a vida é que concedeu o título de Educadora, no sentido mais amplo e honrado da Educação.

Aos meus pais, Tina e Francisco (in memoriam), pelo exemplo de luta na vida, pelo carinho, compreensão e tanto amor!

À minha família, meus irmãos Alexandre, André e Terezinha (Heloísa ... ), tios, tias, meus primos e primas (incluindo seus filhos - "a nova geração de primos”) e meus sobrinhos todos muito queridos e amados e tão importantes na minha vida.

E ao meu amor e sempre co-autor dos projetos de nossa história juntos Rogério e às nossas filhas que representam a esperança que temos na vida e que são a nossa própria vida: Carolina, Mariana (e Luiza e agora Miguel também). 


\section{AGRADECIMENTOS}

Ao meu orientador Prof. Dr. Pedro Roberto Jacobi, pelo apoio e pela confiança.

À Prof. Dr. Ermelinda Pataca e à também colega da FEUSP e do LAPPES - IEE-USP Prof. Dr. Renata Ferraz de Toledo, pelas importantes indicações no processo de qualificação.'

A todos aqueles que participaram da construção desse trabalho e que espero ter nomeado no registro dessa prazerosa aprendizagem na tese; muitos dos quais se tornaram meus amigos e pessoas que admiro. E também aqueles que, embora não tenham sido nomeados, sabem o quanto colaboraram e compartilharam comigo essa construção.

Aos meus colegas da FEUSP e do LAPPES - IEE-USP.

À Prof. Ana Mae Barbosa, com respeito e admiração.

Às queridas e sempre atenciosas Prof. Dr. Maria Christina de Souza Lima Rizzi, Prof. Dr. Denise de La Corte Bacci, Prof. Dr. Vânia Maria Nunes dos Santos e Prof. Dr. Carla Gibertoni Carneiro.

Ao Rogério e Alexandre pelas valiosas ideias e pelos lindos e cuidadosos desenhos para a composição final dessa tese. 


\title{
RESUMO
}

Diálogos entre Patrimônio, Meio Ambiente e Aprendizagem Social: uma experiência de Educação Patrimonial em pesquisa-ação no bairro paulistano de Santo Amaro.

No sentido de uma construção coletiva de conhecimento e de significados atribuídos ao patrimônio cultural (material e imaterial) de Santo Amaro que foi desenvolvida essa pesquisaação. Partindo de atividades de Educação Patrimonial e com base na Aprendizagem Social, buscou-se o estabelecimento de uma interação da pesquisadora com alguns dos diversos atores e interlocutores de Santo Amaro para a evidenciação e valorização dos bens culturais da região.

A pesquisa-ação elaborou e desenvolveu atividades pautadas pela aplicação de metodologias participativas que visaram estimular o interesse, o engajamento e uma participação mais ativa de moradores tradicionais do bairro, do público participante das ações culturais mantidas por algumas instituições e entidades locais, agentes culturais e formadores de opinião da região e alunos e professores de escolas públicas existentes em Santo Amaro para com seu patrimônio cultural.

Palavras chave: Educação Patrimonial; Aprendizagem Social; Patrimônio Cultural; Metodologias Participativas; Pesquisa-ação; Santo Amaro

Dialogues between Heritage, Environment and Social Learning: a heritage education experience in action research in São Paulo neighborhood of Santo Amaro.

\begin{abstract}
In order to a collective construction of knowledge and meanings attributed to Santo Amaro's cultural heritage (material and immaterial) that was developed this action research. Starting with Heritage Education activities and based on Social Learning sought to establish a researcher's interaction with some of the various Santo Amaro's actors and interlocutors for the disclosure and presentation of region cultural objects.

The action research drafted and developed guided activities by the application of participatory methodologies which aimed to encourage the interesting, engagement and participation more active by the traditional neighborhood residents, the public that participated of the cultural actions maintained by some institutions and local entities, cultural agents and opinion formers of the region and students and teachers of public school that exist in Santo Amaro for with its cultural heritage.
\end{abstract}

Keywords: Heritage Education; Social Learning; Cultural Heritage; Participatory Methodologies; Action Research; Santo Amaro 


\section{LISTA DE FIGURAS}

Figura 1: Região Centro-Sul e Subprefeitura de Santo Amaro

Figura 2: Antiga sede da Prefeitura de Santo Amaro

Figura 3: Praça Floriano Peixoto

Figura 4: Coreto da Praça Floriano Peixoto

Figura 5: Casa Amarela com as apresentações da Orquestra Sinfônica de Santo Amaro e do Grupo Mirim do Tradicional Samba da Vela

Figura 6: Antigo Mercado Municipal (Mercadão)

Figura 7: Monumento aos Romeiros

Figuras 8 e 9: Biblioteca Pública Municipal Prestes Maia

Figura 10: Casa de Cultura de Santo Amaro

Figuras 11, 12 e 13: Rua Tenente Coronel Carlos da Silva Araújo

Figura 14: Praça Salim Farah Maluf

Figura 15: Calçadão Rua Capitão Tiago Luz

Figura 16: Casa Amarela (Paço Cultural Júlio Guerra)

Figura 17: Praça Floriano Peixoto

Figuras 18 e 19: Calçadão da Rua Capitão Tiago Luz

Figuras 20 e 21: Detalhes de duas fachadas de casario da Rua Tenente Coronel Carlos da Silva Araújo e do calçadão da Rua Capitão Tiago Luz

Figura 22: Igreja Matriz de Santo Amaro

Figura 23: Largo Treze de Maio

Figuras 24 e 25: Avenida Adolfo Pinheiro

Figuras 26 e 27: Teatro Paulo Eiró

Figura 28: Fragmento do mapa da Commissão Geographica e Geologica, de 1906-1908

Figuras 29 e 30: Estátua do Borba Gato e Painel em homenagem ao poeta Paulo Eiró de Julio Guerra

Figura 31: Detalhe do mapa do antropólogo Nimuendaju de 1981, com a localização dos povos indígenas do séc. XVI ao XX

Figura 32: Desenho de Vallandro Keating da exposição Escavando o Passado: a Arqueologia na cidade de São Paulo

Figura 33: Vista de chaminé da Fábrica de Ferro de Santo Amaro na década de 1970 c. 
Figuras 34 e 35: Trilhos e dormentes do antigo traçado da linha de bonde que ligava Santo Amaro à região central da cidade de São Paulo

Figuras 36 e 37: Auto-estrada Santo Amaro em 1928

Figuras 38 e 39: Obras de pavimentação na auto-estrada Washington Luís e na estrada Santo Amaro em 1928

Figuras 40 e 41: Exposição permanente $O$ Bonde em Santo Amaro na Estação Adolfo Pinheiro Figuras 42 e 43: Exposição Itinerante Arqueologia, Memória e Cidade, na Estação Paraíso Figuras 44 a 47: Aspectos dos slides utilizados nas reuniões com os gestores escolares sobre a proposta de desenvolvimento de workshops com professores

Figuras 48 e 49: Aspectos dos slides de abertura dos Workshop Educação Patrimonial: Arqueologia e Patrimônio Cultural

Figuras 50 a 62: Alguns dos slides utilizados nas atividades

Figura 63: Aspecto de slide sobre patrimônio material e imaterial

Figura 64: Professores reunidos em grupo no exercício Mapa Patrimonial

Figuras 65 e 66: Dois desenhos ("mapas") com os lugares significativos de Santo Amaro representados pelos professores participantes da atividade Mapa Patrimonial

Figura 67: Tabela Prática de Educação Patrimonial

Figura 68: Material didático do MAE-USP

Figura 69: Roda de conversa sobre patrimônio, herança, Arqueologia

Figura 70: Alguns dos recursos utilizados nas oficinas de Arte-Educação

Figura 71: Capa do livro de história infantil de Jonas Ribeiro

Figura 72: Momento de criação pelos alunos da EMEI Borba Gato de suas próprias histórias numa das oficinas de Arte Educação

Figuras 73 a 75: Imagens de cerâmicas projetadas nas oficinas de cerâmica desenvolvidas na Biblioteca Belmonte

Figura 76: Mapa Etnográfico Ilustrado do Brasil

Figura 77: Mostra Educativa Arqueologia, Memória e Patrimônio

Figuras 78 e 79: Duas das faixas no Dia das Tradições de Santo Amaro

Figuras 80: Paper da atividade Café da Manhã "Santo Amaro, meu bem - querer: como te quero"

Figura 81: Folheto com a programação mensal de atividades da Biblioteca Belmonte.

Figuras 82 e 83: Cartazes de divulgação dos Encontros em Santo Amaro. 
Figura 84: Sr. Tarcísio Silva na atividade do Exercício do Objeto: o objeto significativo do primeiro encontro.

Figura 85: D. Irene Kiss Fontes na atividade Mapa Patrimonial no segundo encontro.

Figuras 86 e 87: Painéis da Mostra Educativa dos Encontros Memória e Patrimônio Cultural de Santo Amaro

Figura 88: Convite com Comprovante de Inscrição

Figura 89: Ficha de Inscrição acompanhada do Termo de Autorização de Uso de Imagem.

Figura 90: Tela de abertura dos slides utilizados nos Encontros.

Figura 91: Participantes observando os objetos e pranchas com imagens ampliadas (recursos patrimoniais e educativos) no primeiro Encontro.

Figuras 92 e 93: Letras de canções sobre dois bens patrimoniais de Santo Amaro: Borba Gato e Romaria, de autoria do Sr. Tarcísio Silva.

Figura 94: Trófeu Romeiro Santamarense do Sr. Tarcísio Silva.

Figura 95: Ferro de passar

Figura 96: Lamparina

Figura 97: A participante Dorinha com os objetos e fotografias

Figuras 98 e 99: Slides utilizados no segundo Encontro

Figura 100: Slide utilizado no segundo Encontro

Figura 101 a 103: D. Cida e sua filha Vanessa e seus desenhos

Figura 104: D. Teresa Discher e D. Irene Kiss produzindo o mapa patrimonial

Figura 105: D. Teresa Discher Câmara

Figuras 106 e 107: Modelo da Lista de Presença e do Certificado

Figura 108: Sr. Tarcísio e D. Cida junto à Igreja Matriz

Figura 109: Visita à Estação Largo Treze do Metrô

Figuras 110 e 111: Grupo de participantes na visita ao CETRASA

Figuras 112 e 113: Objetos e pranchas expostos e em utilização no Exercício do Objeto: Objeto Significativo

Figuras 114 a 117: Slides sobre patrimônio imaterial

Figura 118: Capa do Manual de Educação Patrimonial do Programa Mais Educação

Figura 119: Ficha (frente) para entrevista da oficina de inventário

Figuras 120 e 121: Duas fichas das atividades de Laboratório de Arqueologia

Figuras 122 a 127: Reuniões de curadoria, ensaio e preparação das atividades de visitação e novas exibições da Mostra Educativa 
Figura 128: Convite da primeira exibição da I Mostra Educativa

Figura 129: D. Maria Alice das Dores, no dia da abertura da Mostra na Biblioteca Belmonte

Figura 130: D. Teresa Discher Câmara e sua coleção de bonecas exposta na Mostra Educativa Figuras 131 e 132: Pranchas e objetos utilizados como recursos educativos

Figura 133: Uma das performances do Grupo Yellow

Figuras 134 a 140: Painéis da I Mostra Educativa dos Encontros

Figuras 141 a 143: Abertura da I Mostra Educativa Encontros Memória e Patrimônio Cultural de Santo Amaro

Figuras 144 e 145: Apresentação do Sr. Tarcísio e de D. Arlen no Sarau da I Mostra Educativa na Casa de Cultura de Santo Amaro

Figura 146: Cartaz de divulgação da Domingueira Sertaneja

Figuras 147 e 148: Alunos do EJA na visita à Mostra Educativa e Sarau

Figuras 149 e 150: Capa e contra capa do projeto para o Edital VAI de 2016

\section{LISTA DE QUADROS}

Quadro 1: Ações da pesquisa-ação para o Inventário Comunitário e Escolar de Bens Culturais e as instituições escolares e culturais de Santo Amaro e os atores sociais envolvidos.

Quadro 2: Dados Demográficos dos Distritos pertencentes à Subprefeitura de Santo Amaro.

Quadro 3: Plano educativo do Workshop com Professores Educação Patrimonial: Arqueologia e Patrimônio Cultural.

Quadro 4: As Pranchas Educativas e alguns dos temas e conteúdos trabalhados

Quadro 5: Plano didático das oficinas desenvolvidas com as turmas definidas pela EMEFM Prof. Lineu Prestes 


\section{SIGLAS E ABREVIATURAS}

APT - Abertura de Processo de Tombamento

CEDUC - Coordenação de Educação Patrimonial

CETRASA - Centro de Tradições de Santo Amaro

COGEP - Coordenação Geral de Planejamento

CONDEPHAAT - Conselho de Defesa do Patrimônio Histórico, Arqueológico, Artístico e Turístico

CONPRESP - Conselho Municipal de Preservação do Patrimônio Histórico, Cultural e Ambiental da Cidade de São Paulo

CRM - Cultural Resource Management

DAC - Departamento de Assuntos Culturais

DAF - Departamento de Articulação e Fomento do IPHAN

DPH - Departamento do Patrimônio Histórico da Secretaria Municipal de Cultura de São Paulo

EACH - Escola de Artes, Ciências e Humanidades

EF - Ensino Fundamental

EM - Ensino Médio

EE - Escola Estadual

EMEFM - Escola Municipal de Ensino Fundamental e Médio

ENEM- Exame Nacional do Ensino Médio

FAPESP - Fundação de Amparo à Pesquisa do Estado de São Paulo

FE - Faculdade de Educação

HTPC - Horário de Trabalho Pedagógico Complementar

IBAMA - Instituto Brasileiro do Meio Ambiente e dos Recursos Naturais Renováveis

IBPC - Instituto Brasileiro de Patrimônio Cultural

IBRAM - Instituto Brasileiro de Museus

ICOM - Conselho Internacional de Museus

ICOMOS - Conselho Internacional de Monumentos e Sítios

IDEB - Índice de Desenvolvimento de Educação Básica

IDESP - Índice de Desenvolvimento da Educação do Estado de São Paulo

IEE - Instituto de Energia e Ambiente

IGc - Instituto de Geociências

IGEPAC - Inventário Geral do Patrimônio Ambiental e Cultural Urbano de São Paulo 
INEP - Instituto Nacional de Estudos e Pesquisas Educacionais Anísio Teixeira

INRC - Inventário Nacional de Referências Culturais

IO - Instituto de Oceanografia

IPHAN - Instituto do Patrimônio Histórico Artístico e Nacional

IUCN - União Internacional para a Conservação da Natureza e dos Recursos Naturais

LAPPES - Laboratório de Pesquisa e Práticas em Educação e Sustentabilidade

LDB- Lei de Diretrizes e Bases da Educação

MEC - Ministério da Educação

MinC - Ministério da Cultura

MMA - Ministério do Meio Ambiente

OEA - Organização dos Estados Americanos

ONU - Organização das Nações Unidas

PCN - Parâmetros Curriculares Nacionais

PNMA - Política Nacional do Meio Ambiente

PNPI - Programa Nacional de Patrimônio Imaterial

PÓLIS - Instituto de Estudos, Formação e Assessoria em Política Sociais

PROCAM - Programa de Pós-Graduação em Ciência Ambiental

RAE - Regulamentação de Área Envoltória

SAE -Sistema Nacional de Avaliação da Educação Básica

SARESP - Sistema de Avaliação de Rendimento Escolar do Estado de São Paulo

SEB - Secretaria de Educação Básica do MEC

SEMA - Secretaria Especial do Meio Ambiente

SEMPLA - Secretaria Municipal de Planejamento

SESC - Serviço Social do Comércio

SMA - Secretaria do Estado do Meio Ambiente

SMC- Secretaria Municipal de Cultura

SNMA - Sistema Nacional do Meio Ambiente

SPHAN - Serviço do Patrimônio Histórico e Artístico Nacional

$\mathrm{T}$ - Tombamento

TEO - Tombamento Exofficio

UNESCO - Organização das Nações Unidas para a Educação, a Ciência e a Cultura

VSE- Ventilação e Saída de Emergência

ZEPEC - Zonas Especiais de Preservação Cultural 


\section{Sumário}

APRESENTAÇÃ 0 ............................................................................................................................23

INTRODUÇÃO ................................................................................................................29

CAPÍTULO 1 ....................................................................................................................................35

1. PATRIMÔNIO E MEIO AMBIENTE............................................................................35

1.1 A Noção de Preservação do Patrimônio 35

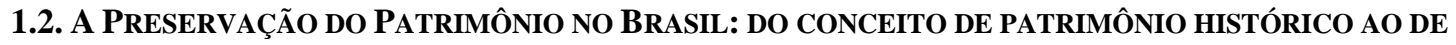
PATRIMÔNIO CULTURAL

1.3. O Patrimônio Natural no Patrimônio Cultural Brasileiro 47

1.4. A Abordagem Preservacionista do Patrimônio Ambiental Urbano em São Paulo 54

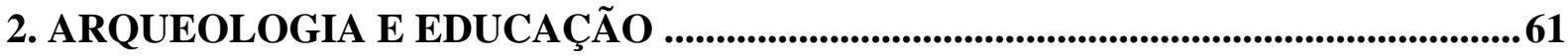

2.1. A ARQUeOlogia $r$\begin{tabular}{l}
61 \\
\hline 2.2.
\end{tabular}

2.2. A Arqueologia PÚblica $\quad 66$

2.3. ARQUEOLOGIA NO BRASIL E SUA ORIGEM NOS MUSEUS $\quad 69$

2.4. EduCAÇÃo Patrimonial $\quad 75$

2.5. A Abordagem da Aprendizagem Social e Comunidades de Práticas 82

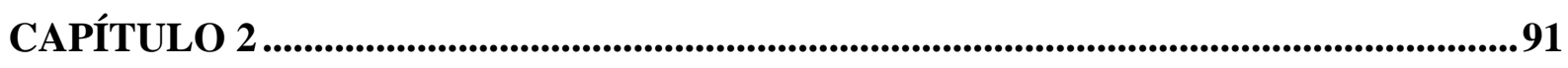

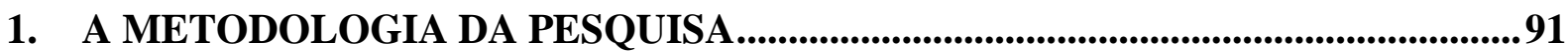

$\begin{array}{lr}\text { 1.1 A PESQUiSA-AÇão } & 91\end{array}$

1.2 O Método: O InVENTÁRio Comunitário e ESCOLAR de Bens Culturais 96

$\begin{array}{ll}\text { 1.3 OS ATORES DA PESQUiSA } & 112\end{array}$

1.4. O Território do ESTUdo: O SUbdistrito de SANTO AMARo E SEU Eixo Histórico 114

1.4.1 Aspectos de sua História - Santo Amaro Município ................................................................... 127

1.4.2 Santo Amaro Distrito de São Paulo........................................................................................... 137

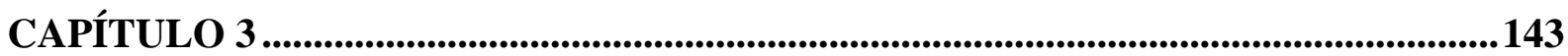

1. A PESQUISA-AÇÃO: SEU CONTEXTO, SUA TRAJETÓRIA E ALGUNS DOS

SEUS RESULTADOS ....................................................................................................................143

1.1 O CONTEXTO 143

1.2 A FORMATAÇão da PESQUiSA-AÇãO E OS PASSOS INICIAIS dO INVENTÁRIO 152

1.2.1 As primeiras entrevistas, reuniões e atividades educativas na região............................................. 152

1.3 Os Encontros sobre Memória e Patrimônio Cultural de Santo Amaro 187

1.3.1 Do planejamento dos Encontros à formação do seu Grupo de Trabalho e de Ação .......................... 198

1.3.2 A Mostra Educativa dos Encontros Memória e Patrimônio Cultural de Santo Amaro...................... 217

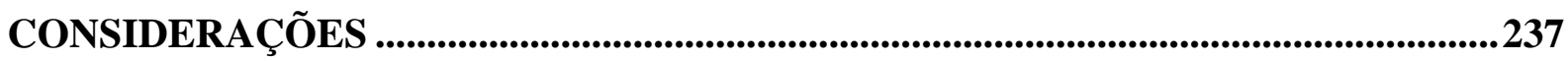

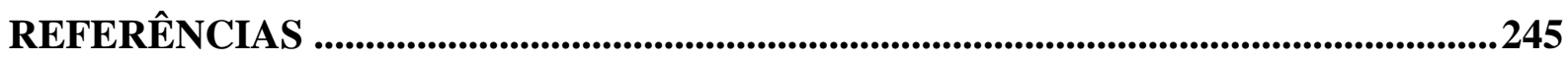


I. Bens Patrimoniais InVENTARIAdos

II. InSTRUMentos DA PESQUisa 


\section{APRESENTAÇÃO}

Comentei com ela de uma casa. Era uma casa branca. Era só ela ali no meio de um monte de coisa de um lado e de outro e aquele quintal enorme [...] no meio de uma Santo Amaro que se transformava. (Vanessa Barros, num dos Encontros Memória e Patrimônio Cultural de Santo Amaro).

Nos estudos que abordaram sob perspectivas diversas as ações de Educação Patrimonial no âmbito da Arqueologia Preventiva, são encontrados aqueles ora relacionados à Arqueologia Pública ora à Musealização da Arqueologia (CARNEIRO, 2009). E mais recentemente, o Programa de Mestrado Profissional do IPHAN tem possibilitado o incremento nos estudos sobre Programas Arqueológicos e de Educação Patrimonial. ${ }^{1}$

Essa tese busca também dar sua contribuição, apoiada numa experiência de pesquisaação com atividades de Educação Patrimonial, concebendo o processo educativo iniciando já nas ações de identificação e valorização do patrimônio para a preservação e com base em processos promotores da Aprendizagem Social para o entendimento de problemas e conflitos socioambientais e culturais locais e para a gestação de iniciativas da sociedade e de movimentos sociais de elencar e atribuir valores a bens a serem preservados e encaminhar propostas de tombamento e registros.

A Educação Patrimonial desenvolvida com base em processos educativos participativos poderia contribuir significativamente no desenvolvimento de uma abordagem crítica, política e reflexiva do meio socioambiental e para uma política de preservação de bens patrimoniais culturais?

A Aprendizagem Social, que enfatiza a colaboração entre os diferentes atores sociais, poderia estimular o diálogo e motivar a formação de um pensamento capaz de analisar as complexas relações entre os processos naturais, sociais e culturais?

A abordagem da Aprendizagem Social e a aplicação de metodologias participativas nas atividades de Educação Patrimonial promoveriam a ampliação da participação de setores

\footnotetext{
1 Carneiro (2009) destaca, dentre esses estudos: ALMEIDA, 2002, FERNANDES, 2007, ROBRAHNGONZÁLEZ, 2005 e BRUNO, 1995, 1996, 1999, 2001, 2005. SIVIERO, 2014 e ARÉVALO, 2013 são alguns exemplos de pesquisas provenientes do Programa de Mestrado do IPHAN. Nesse campo, também são de destaque: FUNARI et al., 2008, BASTOS, 2010, as pesquisas de OLIVEIRA, 2011, KASEKER, 2014, entre outros. Ver: CARNEIRO, Carla Gibertoni. Ações educacionais no contexto da arqueologia preventiva: uma proposta para a Amazônia. Tese (Doutorado), MAE-USP, São Paulo, 2009. Tratava-se de um dos poucos estudos existentes sobre a temática. Foi realizado a partir de três campos do conhecimento: arqueologia pública, musealização da arqueologia e educação patrimonial.
} 
da sociedade civil na promoção, valorização e preservação/proteção de seus bens patrimoniais?

A pesquisa partiu do pressuposto de que a Aprendizagem Social ${ }^{2}$ poderia ser peça chave para se trabalhar com um quadro tão diverso de percepções e interesses, como é o caso dos bens patrimoniais culturais, no sentido de lidar melhor com conflitos, numa construção coletiva de ações e numa visão segundo a qual para ser sustentável, o gerenciamento de recursos ambientais e culturais deve estar amparado na construção de visões de mundo compartilhadas entre os diversos atores sociais envolvidos no seu uso e na atuação de forma coletiva dos grupos de interesse (stakeholders). O compartilhamento de visões de mundo e de conhecimentos pelos atores sociais é que constrói um processo de Aprendizagem Social e uma articulação em comunidade de práticas (MONTEIRO, 2009).

Paulo Freire (1966) já havia antecipado a importância de processos de aprendizagem como forma de emancipação social e política. Assim, a proposição do autor e compartilhada nessa tese foi a de que "o aprimoramento do referencial conceitual sobre aprendizagem social e de metodologias que facilitem o diálogo e a ação concertada entre os diversos atores podem contribuir para ampliar a cooperação, a superação de conflitos e a emancipação de grupos marginalizados" (MONTEIRO, 2009, p.30).

Ao destacar a ideia de Aprendizagem Social, a pesquisa-ação se propôs a contribuir para que os diferentes atores de Santo Amaro envolvidos participassem da promoção, valorização e preservação/proteção de seus bens culturais.

A Aprendizagem Social deve contemplar o reconhecimento da interdependência dos atores sociais; a integração entre eles; transparência e confiança; auto-reflexão crítica; percepção compartilhada dos problemas e soluções; desenvolvimento e valorização crítica das soluções possíveis; processo decisório conjunto, com base na reciprocidade; e instrumentos e meios para promover a implantação das decisões (HARMONICOP, 2003). E seria base para a aprendizagem da cidadania ambiental e para incorporação de atitudes individuais e coletivas para a sustentabilidade (JACOBI, 2011).

Segundo Jacobi (2011, p.117), uma ideia central para pensar o papel da Aprendizagem Social seria imaginar como músicos que não se conhecem se organizam para tocar juntos. Os músicos entram no espírito de uma dinâmica coletiva e produzem uma acústica que seria produto da colaboração, do processo de aprendizagem, da criação de sinergias e de conexões,

\footnotetext{
${ }^{2}$ Ver: BANDURA, A. Social Learning Theory. New Jersey: Prentice-Hall, 1977.
} 
remetendo à importância de "fortalecer redes, reciprocidade, flexibilidade e principalmente uma visão de sustentabilidade".

A pergunta que norteou a pesquisa foi se as atividades de Educação Patrimonial, primeiramente vinculadas ao Programa de Arqueologia Preventiva do trecho Largo Treze de Maio - Adolfo Pinheiro da Linha 5 do Metrô, além de levarem informação às comunidades diretamente afetadas pelo empreendimento sobre todo e qualquer bem patrimonial arqueológico evidenciado pela pesquisa arqueológica, poderiam também promover uma participação ativa em especial dos moradores da região nas ações de valorização, preservação e salvaguarda dos bens patrimoniais locais, se desenvolvidas por metodologias participativas.

A Educação Patrimonial poderia levar segmentos da comunidade de Santo Amaro a prescrever o que deve ser valorado, reconhecido, protegido, salvaguardado e tombado, estimulando uma participação mais ativa no debate dos seus destinos, se direcionada a uma pratica voltada para a construção coletiva e propositora de conhecimento e de reflexão sobre a questão patrimonial no âmbito participativo e democrático, com base na Aprendizagem Social?

A pesquisa buscou desenvolver atividades de Educação Patrimonial com foco na sustentabilidade socioambiental e cultural e na perspectiva da Aprendizagem Social, almejando contribuir para a promoção da identificação e reconhecimento, da valorização, da proteção e da fruição do patrimônio cultural da região pela comunidade local afetada ou impactada pelas obras do empreendimento. Objetivou contribuir para uma cultura de participação e corresponsabilização de setores da sociedade civil - moradores do bairro paulistano de Santo Amaro e de seu entorno e participantes das atividades culturais e sociais promovidas pelas instituições e entidades da região - na política preservacionista dos seus bens culturais.

Suas hipóteses foram: 1) O desenvolvimento de ações e atividades educativas relacionadas ao patrimônio cultural mediadas por metodologias participativas e colaborativas podem favorecer o fortalecimento de uma cultura de participação e de corresponsabilidade de uma sociedade sustentável; 2) As metodologias participativas podem subsidiar o desenvolvimento de práticas educativas promotoras de atitudes críticas e participativas em colaboração à sustentabilidade, bem como podem contribuir no desenvolvimento de procedimentos didático-pedagógicos para o estudo do ambiente local; 3) Conhecimento crítico e apropriação consciente pelas comunidades do seu patrimônio a partir de atividades e ações de caráter educativo-formativo e reflexivo mediadas por metodologias participativas e 
colaborativas são fatores que colaboram para o processo de preservação sustentável de bens ambientais e culturais, assim como no fortalecimento dos sentimentos de identidade e cidadania.

Quanto aos seus objetivos específicos, eles se caracterizaram por: 1) Conhecer e analisar conjuntamente com os atores sociais locais a trajetória de reflexões e proposições que fundamentaram os tombamentos e ações de preservação realizadas na região de Santo Amaro, em especial aquele relativo ao chamado Eixo Histórico; 2) Desenvolver ações e processos educativos para e com os atores sociais locais relacionados ao inventário e à reflexão sobre o patrimônio cultural em geral e o arqueológico em especial da região de Santo Amaro, para a promoção do fortalecimento de valores coletivos e solidários; 3) Investigar a contribuição de metodologias participativas aplicadas a partir do trabalho pedagógico com a questão do patrimônio, como ferramentas de Aprendizagem Social no desenvolvimento de práticas mediadoras em Educação para a Sustentabilidade Socioambiental e Cultural; 4) Promover diversos espaços de aprendizado coletivo, envolvendo pessoas com conhecimentos específicos e representações sociais bem peculiares e circunscritos aos seus modos particulares de viver; 5) Contribuir com parâmetros para a elaboração de programas educacionais com foco na sustentabilidade e com base na Aprendizagem Social, vinculados ao desenvolvimento das pesquisas arqueológicas em processos de licenciamentos ambientais; 6) Colaborar para a inserção da questão do patrimônio cultural e arqueológico também no âmbito das preocupações e do programa curricular das escolas envolvidas no processo, fomentando o uso do Patrimônio Cultural Material e Imaterial como recurso pedagógico no contexto escolar, objetivando criar situações de vivência e reflexões sobre a memória, herança, território, preservação e novas gerações junto aos alunos.

A pesquisa-ação, além de ter iniciado junto com o desenvolvimento do mencionado Programa de Educação Patrimonial vinculado às obras do Metrô na região, promoveu nesse momento a identificação e o primeiro contato com alguns dos atores sociais locais, para conhecimento e reconhecimento do território (fase de diagnóstico e formatação do projeto), dando já início ao processo participativo de desenvolvimento do Inventário Escolar e Comunitário de Bens Culturais.

As atividades educativas desenvolvidas para e em conjunto com esses atores permitiram um mapeamento inicial do conhecimento que estes possuíam sobre o patrimônio cultural em geral da região e especialmente aquele relacionado ao chamado Eixo Histórico representativo de Santo Amaro, tombado pelo Conselho Municipal de Preservação do 
Patrimônio Histórico, Cultural e Ambiental da Cidade de São Paulo - CONPRESP e Conselho de Defesa do Patrimônio Histórico, Arqueológico, Artístico e Turístico - CONDEPHAAT. Abordaram o material arqueológico resgatado na região da Av. Adolfo Pinheiro, constituído por trilhos e dormentes do antigo traçado da linha de bonde que ligava Santo Amaro à região central da cidade de São Paulo e os resultados das pesquisas sobre as ocupações pré-coloniais (Arqueologia Pré-História) e históricas (séculos XVIII e XIX) na região e na cidade de São Paulo em geral, como patrimônio arqueológico e cultural e gerador de conhecimento sobre modos de vida do passado e do presente. E tiveram o objetivo principal de estimular as percepções, enraizar o pertencimento e promover o envolvimento da comunidade com seu patrimônio cultural local.

As atividades de Educação Patrimonial desenvolvidas, voltadas e elaboradas em parceria com os gestores escolares e educadores em geral das escolas públicas locais e agentes culturais e sociais de instituições culturais e entidades e ONG's localizadas no trecho abrangido, envolveram alunos e comunidade em geral (jovens, adultos e idosos) da região. Foram conduzidas com o propósito de promover uma reflexão sobre a questão do patrimônio no âmbito participativo e democrático, no qual a sociedade (comunidade) é que, em última instância, deve prescrever o que deve ser protegido. Apresentaram aos participantes o surgimento e a trajetória de desenvolvimento no Brasil do conceito de patrimônio cultural: do Patrimônio Cultural Brasileiro; e trataram a memória e patrimônio como direitos constitucionais que os são. Procuraram contribuir para a socialização de antigos e novos conhecimentos sobre a Arqueologia na região das obras e sobre sua importância e a relevância do patrimônio cultural em geral, no contexto da cidade, do Estado e do país.

No final de 2014 e em 2015, a pesquisa-ação, aprofundando as parcerias estabelecidas com as entidades e instituições da região, em especial com a Coordenadoria de Cultura da Subprefeitura de Santo Amaro, a Biblioteca Pública Temática Belmonte, a Casa de Cultura de Santo Amaro Manoel Cardoso de Mendonça, a Casa Amarela/Paço Cultural Julio Guerra e a Biblioteca Pública Municipal Prestes Maia, e com os atores sociais locais, incorporou os resultados das primeiras ações em 2013 e realizou novas etapas de desenvolvimento do Inventário Escolar e Comunitário de Bens Culturais com os Encontros sobre Memória e Patrimônio Cultural de Santo Amaro e a I Mostra Educativa dos bens inventariados.

Essas novas atividades objetivaram o empoderamento e fortalecimento de ações e saberes locais relacionados à questão patrimonial em Santo Amaro, preliminarmente conhecidos e reconhecidos em 2013. E possibilitaram a constituição de Grupos de Trabalho e 
de Pesquisa e a consolidação do desenvolvimento na região do Inventário. Intituladas de Encontros Memória e Patrimônio Cultural de Santo Amaro: Conversando sobre Arqueologia, Memória, Patrimônio Cultural, Identidade e História de Santo Amaro foram realizadas em conjunto com diferentes grupos identificados na região: Grupos da Terceira Idade participantes das atividades promovidas pela Casa de Cultura de Santo Amaro Manoel Cardoso de Mendonça, Turmas do Curso Vocacional de Dança da Casa Amarela; Formadores de Opinião (gestores e agentes culturais locais); Alunos do último ano do Ensino Fundamental, do Ensino Médio e dos cursos de EJA da Escola Municipal de Ensino Fundamental e Médio Linneu Prestes, entre outros interessados. 


\section{INTRODUÇÃO}

O Patrimônio Cultural Brasileiro é presente como direito desde a Constituição de 1988, reflexo do processo de redemocratização do país nessa década. E até mesmo antes da promulgação da Constituição começaram a surgir instrumentos que possibilitam hoje aos cidadãos exigirem dos poderes públicos o exercício de seu direito à memória e ao patrimônio: o tombamento de bens materiais, o registro oficial de festividades, folguedos, rituais e outras manifestações de caráter popular consideradas importantes para sua identidade cultural e a chancela de paisagem cultural $^{3}$.

Entretanto, historicamente, a política brasileira sobre o patrimônio foi implementada por especialistas que decidiam o que deveria ser preservado. E o faziam com base em documentos sobre a temática patrimonial, firmados, internacionalmente, por diversas nações.

De acordo com o projeto de nação que fora desenhado ao país, a partir de 1937, quando foi criado o Serviço do Patrimônio Histórico e Artístico Nacional - SPHAN e até mais ou menos a década de 1970, profissionais da História, Arqueologia, Belas Artes e da Arquitetura salvaguardavam bens (monumentos) que representavam e expressavam a história de personagens grandiosos e áreas naturais com excepcional beleza e biodiversidade do Brasil.

A sociedade de modo geral era mantida distante dessa política preservacionista do patrimônio brasileiro. Somente objetos e saberes - bens imóveis, monumentos, conjuntos arquitetônicos, obras de artes, arquivos e coleções de livros e de mobiliário - gerados por grupos pertencentes à elite econômica e intelectual desse país, profundamente marcado por desigualdade social, é que eram preservados. Numa sociedade desigual, caracterizada por diferenças e desigualdades, a apropriação dos valores pertinentes ao patrimônio se faz de modo também desigual (ZANIRATO, 2009, 2011).

\footnotetext{
${ }^{3}$ A chancela da paisagem cultural foi definida pela Portaria 127 de 30 de abril de 2009, com a finalidade de contribuir para a preservação do patrimônio cultural representativo do processo de interação do homem com o meio natural. "[...] CONSIDERANDO, a necessidade de ações e iniciativas administrativas e institucionais de preservação de contextos culturais complexos, que abranjam porções do território nacional e destaquem-se pela interação peculiar do homem com o meio natural; CONSIDERANDO, que o reconhecimento das paisagens culturais é mundialmente praticado com a finalidade de preservação do patrimônio e que sua adoção insere o Brasil entre as nações que protegem institucionalmente o conjunto de fatores que compõem as paisagens [...]". (Trecho da Portaria, disponível em: http://portal.iphan.gov.br/uploads/ckfinder/arquivos/Livreto_paisagem_cultural.pdf $>$ Acesso em: 03 mar 2016. Ver também: IPHAN, 2009).
} 
Mesmo com o processo de descentralização da política federal de preservação aos Estados e Municípios, que teve início no final dos anos 1960, essa história e esse estado de coisas ainda se mantiveram pouco alterados. Somente nesses últimos trinta anos que esse quadro tem mudado, embora de forma muita lenta; e a questão da valorização e preservação do patrimônio assume-se como "uma arena político-social-epistemológica e como um direito social, para deixar de ser "uma prerrogativa política do Estado e epistemológica de grupos especializados no assunto" (SIVIERO, 2014, p.16). O Capítulo 1 da tese traz aspectos dessa história. $^{4}$

No caso tratado por essa pesquisa - a cidade de Santo Amaro que se transformou em bairro de São Paulo em 1935 - a história não foi muito diferente. Embora sob a noção de valorização do Patrimônio Ambiental Urbano e não mais se associando aos valores estéticos e artísticos de bens arquitetônicos e edificados, oficialmente, encontra-se tombado na região o Eixo Histórico de Santo Amaro, composto por logradouros públicos e pelos edifícios protegidos: o antigo Mercado Municipal (hoje Casa de Cultura Manoel Cardoso de Mendonça), a antiga sede da Prefeitura de Santo Amaro (o Paço Júlio Guerra, conhecido como Casa Amarela), o Teatro Municipal Paulo Eiró, e mais recentemente a Escola Estadual Prof. Alberto Conte. O Museu de Santo Amaro, inaugurado em 14 de janeiro de 1999 e administrado pelo CETRASA - Centro de Tradições de Santo Amaro, mantém preservada a história da região, seus costumes e sua memória. ${ }^{5}$

Além de fotos, documentos e mobiliário de Santo Amaro que fazem parte de seu acervo, o Museu mantém o Espaço Júlio Guerra com trabalhos do artista plástico santamarense, nascido em 1912, e que retrava aspectos de Santo Amaro e que são hoje documentos iconográficos e históricos da região.

Os órgãos de proteção do patrimônio do Estado (CONDEPHAAT) e da cidade de São Paulo (Departamento do Patrimônio Histórico - DPH/ CONPRESP), criados nesses anos de mudanças estruturais (de descentralização de ações) e também conceituais, quando o patrimônio histórico passa a ser concebido como patrimônio cultural, ainda têm atuado com

\footnotetext{
${ }^{4}$ Com base especialmente nos estudos de PRATA (2009) e FIGUEIREDO (2014), entre outros autores brasileiros sobre a temática do patrimônio. Ver: PRATA, J. M. Patrimônio Cultural e Cidade: práticas de preservação em São Paulo. Tese (Doutorado). Faculdade de Arquitetura e Urbanismo da Universidade de São Paulo, São Paulo, 2009; e FIGUEIREDO, Vanessa Gayego Belo. Da tutela dos monumentos à gestão sustentável das paisagens culturais complexas: inspirações à política de preservação cultural do Brasil. Tese (Doutorado). Faculdade de Arquitetura e Urbanismo da Universidade de São Paulo, São Paulo, 2014.

${ }^{5}$ É mantido pelo Dr. Alexandre Moreira Neto e outros santamarenses tradicionais e conta com a colaboração da historiadora Prof. Dr. Inez Peralta .
} 
ações de alargamento do conceito de patrimônio. Os esforços para a incorporação do Registro de Bens Culturais de Natureza Imaterial na política preservacionista e as discussões sobre os territórios de interesse da cultura e da paisagem no âmbito do Plano Diretor de São Paulo são alguns exemplos dessas ações.

Assim, no sentido de uma construção coletiva de conhecimento e de significados atribuídos ao patrimônio cultural (material e imaterial) de Santo Amaro que foi desenvolvida essa pesquisa-ação. Partindo de atividades de Educação Patrimonial e com base na Aprendizagem Social, buscou-se o estabelecimento de uma interação da pesquisadora com alguns dos diversos atores e interlocutores de Santo Amaro para a evidenciação e valorização dos bens culturais da região.

A pesquisa-ação elaborou e desenvolveu atividades pautadas pela aplicação de metodologias participativas e colaborativas que visaram estimular o interesse, o engajamento e uma participação mais ativa de moradores tradicionais do bairro, do público participante das ações culturais mantidas por algumas instituições e entidades locais, agentes culturais e formadores de opinião da região e alunos e professores de uma das importantes escolas públicas existentes em Santo Amaro para com seu patrimônio cultural: uma postura de açãoreflexão-ação em torno da problemática patrimonial, baseada na premissa "aprender juntos para gerir juntos" (HARMONICOP, 2003).

Por meio de um processo educativo e investigativo de inventário de bens patrimoniais locais, a pesquisa-ação levantou e problematizou em conjunto e de forma colaborativa com esses atores sociais locais histórias e memórias da região de Santo Amaro. Promoveu também diálogos com a presença de ocupações pré-históricas e coloniais, evidenciada por artefatos arqueológicos identificados e resgatados durante a pesquisa arqueológica que acompanhou as obras em duas novas estações da Linha 5 Lilás da Companhia do Metropolitano de São Paulo na região (Estações Largo Treze de Maio e Adolfo Pinheiro do Metrô) ${ }^{6}$, e com as ações no presente de grupos locais nos espaços culturais da região, buscando favorecer a capacidade crítica e de participação desses grupos na política de preservação de bens culturais de Santo Amaro.

\footnotetext{
${ }^{6}$ Por resgate arqueológico entende-se a escavação e documentação de remanescentes culturais pré-históricos ou históricos sob risco de destruição, decorrente de ações antrópicas diversas (FERDIÈRE, 1998 in: A LASCA, 2009). A obra de extensão da Linha 5 - Lilás da Companhia do Metropolitano de São Paulo - Metrô em Santo Amaro inicia no Largo Treze até a Estação Adolfo Pinheiro em Santo Amaro, ligando o bairro de Capão Redondo ao Largo Treze, em Santo Amaro. A obra fez parte do chamado Projeto Sul, desenvolvido em conjunto com a modernização da Linha C do trem metropolitano da CPTM. A Linha 5 Lilás, Trecho Capão Redondo/Largo Treze teve funcionamento na cidade de São Paulo em outubro de 2002. Disponível em: (http://www.metro.sp.gov.br/obras/linha-5-lilas/index.aspx > Acesso em: 02 mar 2016.
} 
A pesquisa teve início em 2013, durante os estudos de diagnóstico arqueológico nesse novo trecho da Linha 5 - Lilás do Metrô de São Paulo em Santo Amaro, que avaliaram os impactos da construção das estações: "Largo Treze" e "Adolfo Pinheiro" sobre o patrimônio cultural local e arqueológico, em conformidade com a legislação ambiental brasileira e, em especial, com as normativas relacionadas à preservação do patrimônio cultural arqueológico nacional. E teve continuidade nos anos de 2014 e 2015, com o desenvolvimento das ações relacionadas diretamente a um Inventário Escolar e Comunitário de Bens Culturais, embora também iniciado em 2013.

O processo de formatação inicial, a sua construção e organização e a trajetória de desenvolvimento da pesquisa-ação com os moradores e agentes e gestores escolares e culturais da região sobre a problemática do patrimônio de Santo Amaro, bem como as adequações metodológicas no decorrer das etapas de pesquisa e os instrumentos aplicados estão apresentados e analisados nos Capítulos 2 e 3 dessa Tese. 


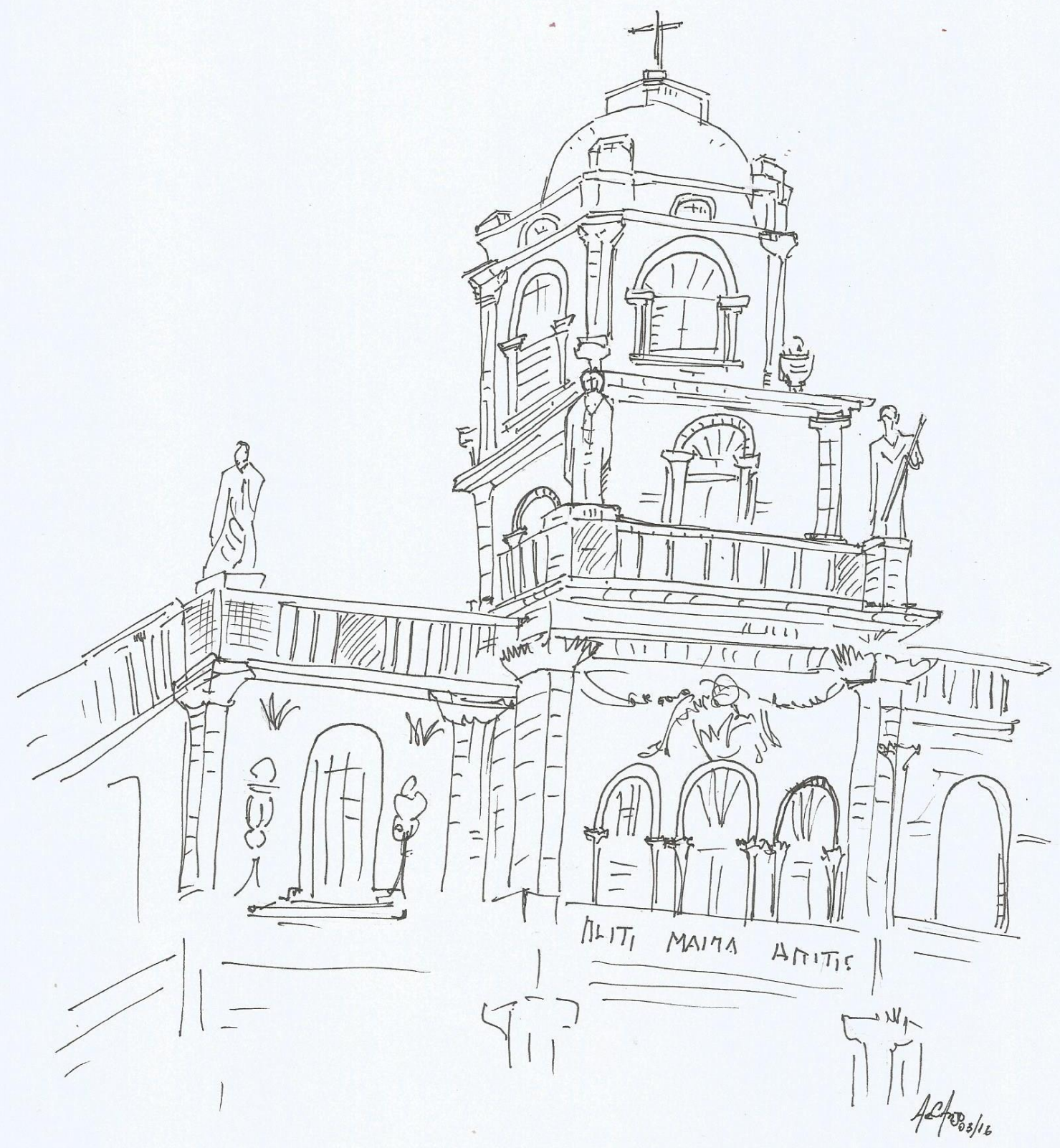




\section{CAPÍTULO 1}

\section{Patrimônio e Meio Ambiente}

\subsection{A Noção de Preservação do Patrimônio}

A ideia de patrimônio etimologicamente é vinculada à de herança, a bens materiais transmitidos de pais para filhos. Embora durante muito tempo as concepções e ações de preservação do patrimônio tenham produzido uma coleção patrimonial material de bens representativos intocáveis (sacralizados) e musealizados (CHOAY, 2006), sabemos que herdamos dos nossos antepassados, além da carga genética, conhecimentos, hábitos e práticas culturais, crenças e valores.

No entanto, foi somente nas ultimas três décadas que o conceito de patrimônio se apropriou da noção de cultura da Antropologia, enquanto "processo global em que não se separam as condições do meio ambiente daquelas do fazer do homem, em que não se deve privilegiar o produto - habitação, templo, artefato, dança, canto, palavra - em detrimento das condições históricas, socioeconomicas, étnicas e do espaço ecológico em que tal produto se encontra inserido e principalmente do homem, seu gerador." (Diretrizes para Operacionalização da Política Cultural no MEC (1981-1982) in: IPHAN, 2014, p.8).

São três as fases das práticas da preservação do patrimônio apresentadas por autores como CHOAY (2006), FONSECA (2005), ANDRADE (1993), ARANTES (1984), CAMPOFIORITO (1985), que estudaram a construção da nação de patrimônio na perspectiva histórica da sua origem e transformações. A primeira fase corresponderia à Monumentalista, com início com a criação, no século XIX (1837), na França, da Comissão dos Monumentos Históricos, perdurando até a Segunda Guerra Mundial (PRATA, 2009).

Nessa fase, os valores de antiguidade e beleza transformavam edifícios isolados em referenciais monumentos históricos e artísticos, materializando as memórias nacionais. Esses monumentos históricos que ganharam beleza, poder e grandiosidade compuseram boa parte do patrimônio de todas as nações. O Monumento Histórico representou uma operação da sociedade ocidental moderna de promoção da identidade nacional na formação dos estados nacionais (CHOAY, 2006).

A partir de 1913, a legislação francesa instituiu como instrumento jurídico para reconhecimento e tutela do Estado de bens patrimoniais: o Classement; e esse procedimento 
foi disseminado em todo mundo (SANT'ANNA, 1995). No Brasil, recebeu o nome de tombamento. Com ele, o direito de propriedade foi limitado pelo Estado, que passou a participar financeiramente da conservação do bem imóvel protegido, obrigando o proprietário a solicitar autorizações para qualquer modificação e/ou alteração (RODRIGUES, 2000).

A segunda fase, chamada de Centro Historicista, que se estendeu até 1975 (Ano do Patrimônio Arquitetônico Europeu), deslocou as práticas preservacionistas, ainda sob os valores de antiguidade, beleza e monumentalidade, para os centros históricos de cidades destruídas pela Segunda Guerra. Na fase da Cidade Contemporânea (terceira fase), as práticas não se referiam mais somente aos edifícios ou centros históricos e ganharam uma dimensão urbana, passando a ser implementadas em associação ao planejamento urbano das cidades (PRATA, 2009).

Foi no contexto de devastação de monumentos, conjuntos urbanos e cidades inteiras do pós-guerra que organismos internacionais passaram a formular e pactuar princípios de conservação e restauração de bens por meio das chamadas Cartas Patrimoniais. Aplicados de acordo com as especificidades de cada nação e formulados por diversas organizações de proteção do patrimônio criadas (ONU, UNESCO, ICOM, OEA, IUCN, ICOMOS, por exemplo) ${ }^{7}$, esses princípios e diretrizes geraram recomendações e convenções internacionais que influenciaram e redirecionaram as políticas nacionais (CURY, 2004).

O Brasil foi signatário de uma série dessas resoluções elaboradas nessas convenções internacionais sobre conceitos, normas e práticas aplicáveis ao gerenciamento do patrimônio cultural, como, por exemplo: a Conferência de Atenas sobre a Conservação Artística e Histórica de Monumentos, de 1931; a Conferência da UNESCO em Nova Delhi, de 1956; a de Veneza, de 1964; as das Normas de Quito, de 1968; a 15 Sessão da UNESCO em Paris, de 1968; a de Nairobi, de 1976; e a da Carta de Burra, de 1980, entre outras (SANT'ANNA, 1995; FIGUEIREDO, 2014).

Foi, em novembro de 1968, que a UNESCO, ao final de sua Conferência Geral, realizada em Paris, entendera que os monumentos, os testemunhos e os vestígios do passado pré-histórico, proto-histórico e histórico estavam cada vez mais sendo ameaçados pelos empreendimentos públicos ou privados, resultantes do desenvolvimento da indústria e da urbanização e, assim, estabeleceu como dever dos governos assegurar a proteção e a

\footnotetext{
${ }^{7}$ UNESCO - Organização das Nações Unidas para a Educação, a Ciência e a Cultura; IUCN - União Internacional para a Conservação da Natureza e dos Recursos Naturais; ICOM - Conselho Internacional de Museus; ICOMOS - Conselho Internacional de Monumentos e Sítios; OEA - Organização dos Estados Americanos; ONU - Organização das Nações Unidas
} 
preservação da herança cultural da humanidade tanto quanto promover o desenvolvimento social e econômico. Dessa forma, fora recomendado que se adotassem medidas preventivas e corretivas com a finalidade de garantir a proteção ou o salvamento dos bens culturais ameaçados por obras públicas ou privadas. ${ }^{8}$

A Conferência de Atenas sobre a Conservação Artística e Histórica de Monumentos, realizada pelo Escritório Internacional de Museus da Sociedade, em 1931, resultou na primeira carta patrimonial internacional - a Carta de Atenas (foi reeditada pela ONU/UNESCO pós 1945) - que já tratava, dentre outros assuntos, do entorno e da visibilidade (vizinhança) dos monumentos, recomendando o respeito ao caráter e fisionomia das cidades e o controle de interferências (fiação elétrica etc.). A Carta de Atenas ou Carta do Urbanismo do CIAM de 1933 falava em ambiência da cidade ao invés de fisionomia (FIGUEIREDO, 2014; PRATA, 2009).

O primeiro documento produzido no pós-guerra pela UNESCO foi aquele que, ratificado em Haia, em 1954, falava da proteção dos bens culturais em momentos de conflito armado. A Recomendação de Nova Delhi, de 1956, sistematizou princípios internacionais para as pesquisas arqueológicas e tratou sobre a propriedade científica das descobertas. E a de Paris de 1960 foi o primeiro documento internacional a mencionar as áreas rurais e naturais como de interesse patrimonial, voltando-se para a questão da preservação das áreas urbanas e suas paisagens, por intermédio de novos instrumentos no âmbito da legislação urbanística e do planejamento territorial (do espaço urbano) e não a partir de leis de proteção aos monumentos; as áreas naturais, conservadas por sua beleza e função ecológica, ficariam sob a tutela da legislação ambiental (FIGUEIREDO, 2014).

Com a Lei Malraux de 1962, na França, a preservação se inseriu no planejamento territorial e diversas instâncias governamentais passaram a atuar conjuntamente por meio da Comissão Nacional de Setores Preservados, mesmo tendo permanecido os critérios de integridade e autenticidade estética e histórica na seleção dos bens para proteção. (RODRIGUES, 2000). A Carta Internacional sobre Conservação e Restauração de Monumentos e Sítios, elaborada em Veneza, em 1964 - primeiro documento internacional e principal referencial teórico do ICOMOS - forjou um "modelo" de conservação de conjuntos históricos urbanos, a partir de planos de desenvolvimento integrado e enfatizou a importância da ação interdisciplinar no gerenciamento, estudo e preservação do patrimônio edificado,

${ }^{8}$ Disponível em: <http://www.unesco.org/new/pt/brasilia/culture/international-instruments-clt/\#c1052695> Acesso em: 02 mar 2016. 
ressaltando a contribuição da pesquisa arqueológica e histórica no processo de intervenção no bem cultural. A Carta falava em salvaguardar:

[...] a criação arquitetônica isolada, bem como o sítio urbano ou rural que dá testemunho de uma civilização em particular, de uma evolução significativa ou de um acontecimento histórico. Estende-se não só as grandes criações, mas também as obras modestas, que tenham adquirido com o tempo uma significação cultural. ${ }^{9}$

Nesse contexto, foram protegidos, considerando os ambientes que os integravam, cidades históricas, bairros urbanos antigos, aldeias tradicionais, parques e jardins históricos. A ideia inicial de preservar a visibilidade do bem se transformou em garantir a manutenção da ambiência (FONSECA, 2005).

Na cidade de Bolonha, o trabalho de revitalização do centro histórico iniciou-se em 1964; nele não se considerou a excepcionalidade dos bens, mas o fato de comporem a paisagem histórica que guardava as marcas de várias gerações que sucessivamente a haviam construído. A paisagem histórica era o presente dos espaços e foi tratada tendo em vista sua configuração presente, através de planos urbanísticos (RODRIGUES, 2000, p.66).

Entretanto, a preservação do patrimônio - originária do conceito de patrimônio histórico e das políticas públicas nessa área - ainda permanecia vinculada à noção de excepcionalidade e ligada à ideia de uma nação (de suscitar um sentimento de nacionalidade), representando determinados períodos históricos ou estilos estéticos, mesmo tendo se relacionado, a partir dos anos 1970, no plano internacional, e nas últimas décadas no Brasil, a questões como exercício da cidadania e busca de qualidade de vida.

A discussão sobre preservação do patrimônio, no final do XX e início desse século, deixou de materializar somente as memórias nacionais, considerando a noção de monumento histórico isolado, e passou a integrar esse patrimônio ao planejamento urbano e territorial (RODRIGUES, 2000).

[...] elas passaram a considerar a dimensão territorial desse patrimônio. Por essa razão, sua integração às demais políticas públicas, em busca de uma relação sincrônica e diacrônica com o desenvolvimento e o futuro, deve apontar para além do que tem sido nossa atuação histórica. (Luis Fernando de Almeida, presidente do IPHAN de 2006-2012, em 2012 - FIGUEIREDO, 2014, p.184).

O $1^{\circ}$. e o $2^{\circ}$. Encontros de Governadores (Encontros Nacionais para a Defesa do Patrimônio), em Brasília e Salvador, que geraram os documentos "Compromisso de Brasília" e "Compromissos de Salvador", respectivamente em 1970 e 1971, foram as primeiras iniciativas de descentralização da proteção dos bens culturais de valor nacional sob a tutela federal para os estados e municípios e de incentivo à adoção de planos diretores e ao

${ }^{9}$ Disponível em: <http://www.unesco.org/new/pt/brasilia/culture/international-instruments-clt/\#c1052695> Acesso em: 02 mar 2016. 
envolvimento dos órgãos ligados ao turismo com a questão do patrimônio (RODRIGUES, 2000).

Essas nossas cartas nacionais destacavam os potenciais turísticos dos bens culturais e levaram à criação do Programa Integrado de Reconstrução das Cidades Históricas, de 1973. Nesses documentos, era recomendado que estados e municípios exercessem uma atuação supletiva à então Secretaria do Patrimônio Histórico e Artístico Nacional - SPHAN na proteção dos bens culturais de valor nacional e a assunção daqueles de valor regional, criando para isso instituições e legislação próprias (FONSECA, 2005).

A Carta de Nairóbi da UNESCO de 1976 também propôs ações para a conservação integrada, ampliando a noção de entorno para ambiência e a relacionando com aspectos sociais, econômicos e culturais (PRATA, 2009; FIGUEIREDO, 2014):

\begin{abstract}
Considera-se "conjunto histórico ou tradicional" todo grupamento de construções e de espaços, inclusive os sítios arqueológicos e paleontológicos, que constituam um assentamento humano, tanto no meio urbano quanto no rural e cuja coesão e valor são reconhecidos do ponto de vista arqueológico, arquitetônico, pré-histórico, histórico, estético ou sociocultural. Entre esses conjuntos, que são muito variados, podem-se distinguir especialmente os sítios históricos, as classes históricas, os bairros urbanos antigos, as aldeias e lugarejos, assim como os conjuntos monumentais homogêneos, ficando entendido que estes últimos deverão, em regra, ser conservados em sua integridade (CURY, 2004).
\end{abstract}

A Lei Federal 6.513, de 1977 declarou os patrimônios culturais e naturais como "áreas e locais de interesse turístico". ${ }^{10}$ E o próprio conceito de patrimônio foi ampliado, passando a compreender não só o edifício isolado enquanto monumento histórico, mas também a chamada arquitetura menor, ou seja, todo o seu entorno e a vizinhança, pois ganhou um sentido mais antropológico e não mais somente vinculado à arquitetura de "pedra e cal".

Ampliaram-se os objetos, os períodos ou os espaços geográficos da preservação. E o patrimônio passou a ser compreendido, ainda que artístico e histórico (muito pouco essas noções alteraram-se), de outra forma (PRATA, 2009).

Tratou-se de um progressivo alargamento daquilo que era considerado objeto de interesse para a preservação, que passou do monumento, como elemento destacado (natural e construído), aos conjuntos arquitetônicos e urbanos, centros e cidades históricas reconhecidos em seus valores estéticos e históricos.

Enquanto política preservacionista do patrimônio, esse alargamento do conceito de patrimônio ganhou, na Fase Cidade Contemporânea, o adjetivo "cultural” e se aproximou ainda mais das questões urbanas, representando alterações na forma mais "tradicional" dessa

\footnotetext{
${ }^{10}$ Disponível em: http://www.planalto.gov.br/ccivil_03/leis/L6513.htm> Acesso em: 02 mar 2016.
} 
política, baseada no olhar do especialista, pois vários grupos sociais passaram a reivindicar seu direto social de manifestar seu sentimento de pertencimento e de escolha de bens para proteção.

As primeiras políticas de proteção e preservação do monumento histórico, natural e do patrimônio histórico e artístico estiveram nas mãos de especialistas e eruditos das áreas de História, Arqueologia e das Artes e, depois, da Arquitetura, que identificaram e selecionaram como representantes significativos da arquitetura do passado conjuntos imóveis, com excepcionalidade histórica e/ou estética. Mesmo para o patrimônio cultural eram os produtos da cultura erudita dos grupos e segmentos sociais dominantes que eram os bens reconhecidos e selecionados (CASTRIOTA, 2007).

Quando narrado sob o regime da monumentalidade, o patrimônio cultural é definido pela tradição, deslocando-se para segundo plano a experiência individual e coletiva dos bens culturais. Há uma visão homogênea da nação (GONÇALVES, 2002, p.119).

Efetivamente, somente em 1972, com a Lista do Patrimônio Mundial, é que passaram a ser incluídos bens, conceitos e práticas externas ao mundo europeu, ampliando a noção de patrimônio que começa a incorporar as dimensões cultural, natural, material e imaterial dos bens. Foi depois da Convenção sobre a Proteção do Patrimônio Mundial, Cultural e Natural, realizada em 16 de novembro de 1972, que se nota nas discussões dos encontros internacionais preocupações sobre os bens culturais imateriais (festas, tradições e outras manifestações de cunho popular).

O patrimônio começou a se constituir como a representação da diversidade cultural presente em uma sociedade nacional e a se associar à experiência pessoal e coletiva dos diversos grupos sociais e suas diferentes práticas sociais e memórias (SCIFONI, 2006):

O passado, portanto, torna-se relativo. Ele vai depender de pontos de vistas particulares (GONÇALVES, 2002, p.114).

No Brasil, Andrade (1993) considera que a fase Monumentalista da preservação do patrimônio se deu a partir da criação do SPHAN em 1937 com final nos anos de 1960, enquanto que a fase Centro-Historicista se referiria ao início do período da urbanização e de complexidade da dinâmica urbana, nos anos 1960 e 1970. No final dos anos 1970, é que teria início a fase da Cidade Contemporânea, na qual ocorreria esse entendimento de que a legislação só seria eficiente se incorporada às leis de uso e parcelamento do solo urbano, como também sobre a necessidade de proteção de um número de bens mais significativo e 
com maior diversidade regional. Nesse momento, houve também uma ampliação da rede de órgãos de preservação nos âmbitos estaduais e municipais (PRATA, 2009).

\subsection{A Preservação do Patrimônio no Brasil: do conceito de patrimônio histórico ao de patrimônio cultural}

Depois da Revolução que dissolveu o Congresso Nacional e que pôs fim à vigência da Constituição de 1891, é que surgiram as primeiras leis federais brasileiras sobre a preservação do patrimônio nacional e a organização de um serviço de proteção aos monumentos históricos e às obras de arte tradicionais do Brasil.

Mesmo com o projeto de Mario de Andrade de criação de um museu nacional para o patrimônio arqueológico e etnográfico, os museus formados no final do século XIX ainda procuravam revelar as características do país a partir das coleções catalogadas e estudadas e distanciavam-se das populações menos favorecidas (BRUNO, 1995).

As primeiras iniciativas para proteger o patrimônio cultural no país aconteceram a partir da segunda década do século $\mathrm{XX}^{11}$. A Nova Carta Fundamental de 1934 dedicava seu segundo capítulo à educação e à cultura, e, no artigo 148, falava em “[...] proteger os objetos de interesse histórico e o patrimônio artístico do país [...]” (SPHAN; PRO-MEMÓRIA, 1980, p. 16).

Em 13 de abril de 1936, a partir do projeto de Mario de Andrade para a criação de um Serviço do Patrimônio Histórico e Artístico Nacional, coube a Gustavo Capanema, Ministro da Educação de 1934 a 1945,

[...] solicitar à Câmara dos Deputados, onde tramitava projeto de reorganização geral do Ministério da Educação, que aprovasse emenda incluindo na estrutura ministerial o Serviço de Patrimônio Histórico e Artístico Nacional (SPHAN; PRO-MEMÓRIA, 1980, p. 16).

A iniciativa de Capanema foi aprovada por Getúlio Vargas, então Presidente da República, e o SPHAN foi entregue à direção do jornalista e escritor Rodrigo Melo Franco de Andrade, auxiliado por um conselho consultivo de especialistas, composto majoritariamente por arquitetos, historiadores, historiadores de arte e artistas:

Art. 46 - Fica criado o Serviço do Patrimônio Histórico e Artístico Nacional, com a finalidade de promover, em todo o país e de modo permanente, o tombamento, a

\footnotetext{
${ }^{11}$ O Decreto $^{\circ}$. 22.928, de 12 de julho de 1933 e o Decreto ${ }^{\circ} .24 .735$, de 14 de julho de 1934. Por meio desses decretos, o governo federal iniciou a "[...] organização de um serviço de proteção aos monumentos históricos e às obras de arte tradicionais do Brasil, aprovando um novo regulamento para o Museu Histórico Nacional" (SPHAN; PRO-MEMÓRIA, 1980, p. 16).
} 
conservação, o enriquecimento e o conhecimento do patrimônio histórico e artístico nacional.

Parágrafo $1^{\circ}$. - O Serviço do Patrimônio Histórico e Artístico Nacional terá, além de outros órgãos que se tornarem necessários ao seu funcionamento, o Conselho Consultivo.

Parágrafo $2^{\circ}$. - O Conselho Consultivo se constituirá do diretor do Serviço do Patrimônio Histórico e Artístico Nacional, dos diretores dos museus nacionais de coisas históricas e artísticas, e de mais dez membros, nomeados pelo Presidente da República.

Parágrafo 3. - O Museu Histórico Nacional, o Museu de Belas-Artes e outros museus nacionais de coisas históricas ou artísticas, que forem criados cooperarão nas atividades do Serviço do Patrimônio Histórico e Artístico Nacional, pela forma que for estabelecida em regulamento (SPHAN; PRO-MEMÓRIA, 1980, p. 17).

O SPHAN - Serviço do Patrimônio Histórico e Artístico Nacional fora organizado nos moldes de uma "academia" (alicerçado na autoridade acadêmica) que comprovava os valores históricos e estéticos nacionais e universais aos bens tombados pelo Estado (SANTOS, 1992). Depois de ter se transformado em Departamento em 1946, instituto (IPHAN) em 1970 e Secretaria do Patrimônio Histórico e Artístico Nacional nove anos depois, com a reforma institucional no MEC; em 1981, com a criação da Secretaria de Cultura, transformou-se em Subsecretaria; em 1990, com a criação do Ministério da Cultura em 1985, foi extinta por decreto do governo Collor e passou a denominar-se Instituto Brasileiro de Patrimônio Cultural (IBPC); em 1994, novamente IPHAN: Instituto do Patrimônio Histórico e Artístico Nacional (RODRIGUES, 2000).

Com a atuação baseada na noção de monumento histórico, o SPHAN deu especial atenção aos monumentos arquitetônicos, religiosos e civis do período colonial. Em 1938, seis cidades mineiras históricas - Ouro Preto, Diamantina, Serro, Tiradentes, Mariana e São João Del Rei - foram tombadas com base em critérios artísticos, constando no Livro do Tombo de Belas Artes (RUBINO, 1992).

O SPHAN consolidou no Brasil algumas diretrizes da política de preservação durante todo o século XX, instituindo, a partir do instrumento de tombamento, o princípio do direito difuso (dever do Estado na preservação do patrimônio que não é privado e sim de todos); a função social da propriedade, a partir da ideia de que toda propriedade teria uma face pública além da privada (CASTRO, 1991), com outorga de valor associada à limitação do direito de construir e ocupar; e a preservação do patrimônio (conservação dos bens reconhecidos) enquanto atribuição do Estado e, nesse contexto, como política pública (FONSECA, 2005), sem, no entanto, constituir uma Política Nacional de Patrimônio (AZEVEDO, 2013).

Somente a partir da década de 1970, momento da discussão no plano internacional da integração do patrimônio ao planejamento urbano e territorial, que, no Brasil, ocorreu a intensificação do debate sobre cultura e sobre a incorporação de novos elementos à memória 
histórica (RODRIGUES, 2000) e houve mudanças na política de preservação do patrimônio no país.

Durante mais de trinta anos a eleição do patrimônio nacional, ou seja, o reconhecimento e a proteção oficiais davam-se a partir das justificativas da História da Arquitetura Brasileira. Sob forte atuação sobre o patrimônio material, avalizado sob critérios artísticos e históricos, o SPHAN, valendo-se do tombamento, construiu uma imagem ("colonial", "barroca", "moderna") da identidade brasileira associada às representações materiais do passado (RODRIGUES, 2000).

O período de 1937 a 1967 de atuação do SPHAN é chamado de Fase de Estruturação ou Fase Heróica (IPHAN, 2014). Nela, a chamada "Academia SPHAN", produziu intensa pesquisa e se consolidou num órgão estritamente técnico, no qual uma culta e erudita elite selecionava o patrimônio representante da identidade da nação, excluindo setores populares da discussão sobre a preservação do patrimônio no país. De 1968 e 1979, a "Fase Moderna", caracterizada pelo início da modernização do aparelho estatal e pelo desenvolvimento das “cidades turísticas"; e entre 1980 e 1999, fase marcada por debates conceituais, conflitos ideológicos e pela instituição pela Constituição Federal Brasileira de competências concorrentes entre os órgãos de patrimônio nas esferas federal, estadual e municipal de governo (ANDRADE, 1993; IPHAN, 2014).

O Decreto-Lei 25 de 30 de novembro de 1937 organizou a proteção do patrimônio histórico e artístico nacional, definido como composto por monumentos: os monumentos históricos, os naturais, os sítios e as paisagens de valor artístico, histórico e arqueológico. $\mathrm{O}$ processo de tombamento foi regulamentado por esse decreto que estabelecia que nada poderia ser construído na vizinhança do bem tombado sem a prévia autorização do órgão preservacionista, de forma a ser garantida a sua visibilidade. Por meio dele foram criados quatro livros do tombo: o de Belas Artes, para aqueles bens de reconhecido valor artístico; o das Artes Aplicadas em bens móveis e para obras de engenharia urbana, como pontes e viadutos; o Livro do Tombo Histórico; e o do Tombo Arqueológico, Etnográfico e Paisagístico.

RUBINO (1992 apud FIGUEIREDO, 2014) destaca que somente no ano de 1938 (seu primeiro ano de atuação), o SPHAN tombou 215 bens: $20 \%$ do total até 2012; incluindo aqueles reconhecidos até 1940 , seria $40 \%$ do total de tombamentos de todo o século XX.

O tombamento, em 1938, das cidades mineiras, embora revelasse uma ação pioneira do SPHAN diante do contexto internacional o foi, na grande maioria, de edifícios isolados - 
83\%; até 1946, 93,76\% - segundo Chuva (2009 apud FIGUEIREDO, 2014). Os conjuntos urbanos e arquitetônicos representaram apenas 3,8\%; os arqueológicos, 2,5\%; e os paisagísticos (parques e áreas naturais), menos de $1 \%$.

Foram tombados bens valorados como obras de arte e/ou representativos do passado do país: a arquitetura colonial religiosa, especialmente o barroco dos séculos XVII e XVIII e exemplares arquitetônicos como a Igreja de São Francisco da Pampulha (Belo Horizonte), de Oscar Niemeyer, em 1947, e a sede do MEC - Ministério da Educação e Saúde no Rio de Janeiro, em 1948. O tombamento do Parque do Flamengo, de Burle Marx, em 1965, também é um exemplo (CHUVA, 2009 apud FIGUEIREDO, 2014).

Os tombamentos se concentraram nos Estados de Minas Gerais (23,9\%), do Rio de Janeiro (20,3\%), da Bahia (19,9\%) e de Pernambuco (8,1\%) (RUBINO, 1992) e deram preferência a certos cânones da arquitetura e não aqueles de valor etnográfico e paisagístico, tão enfocados por Mario de Andrade em seu anteprojeto de 1936, para a criação do SPHAN, e desvinculados da matriz europeia vigente e mais plural da cultura brasileira (FIGUEIREDO, 2014).

Com a morte de Rodrigo de Melo Franco tem início a direção de Renato Soeiro e a chamada Fase Moderna do SPHAN, de 1968 a 1979, marcada pelo esforço em descentralizar a política preservacionista pelos estados e municípios da federação e pela implantação pela Secretaria de Planejamento da Presidência da República do Programa Integrado de Reconstrução das Cidades Históricas (PCH), lançado em 1973, com o objetivo de conciliar desenvolvimento, turismo e preservação do patrimônio, buscando nos bens culturais indicadores para um desenvolvimento apropriado e procurando demonstrar que os interesses da preservação e do desenvolvimento poderiam ser compatíveis e não conflitantes (FONSECA, 2005). Soeiro também colaborou na institucionalização do setor cultural no Brasil por meio de sua participação no Departamento de Assuntos Culturais (DAC) do MEC (AZEVEDO, 2013):

[...] criar infra-estrutura adequada ao desenvolvimento e suporte de atividades turísticas e ao uso de bens culturais como fonte de renda para regiões carentes do Nordeste revitalizando monumentos em degradação (FONSECA, 2005, p.143).

A partir dos anos 1970, tanto conjuntos urbanos quanto exemplares do patrimônio natural e paisagístico são inscritos no Livro de Tombo Histórico, em razão da própria participação do país no debate internacional sobre preservação e gestão de bens culturais: Recomendação de Paris de 1962, Carta de Veneza, do Simpósio Pan-Americano sobre Preservação de Monumentos Históricos (OEA, 1965), Norma de Quito, Conferência Geral de 
Genebra, em 1972 e a Conservação para a Proteção do Patrimônio Mundial Cultural e Natural, com a ideia de patrimônio como herança comum de todos os povos.

Nesse período, houve tanto um incremento no tombamento dos conjuntos urbanos (26,5\%, no período de 1968-1979), como também do patrimônio natural e paisagístico (reflexos da Recomendação de Paris de 1962, sobre a beleza das paisagens e sítios, e da própria Convenção do Patrimônio Mundial da UNESCO) (FIGUEIREDO, 2014).

Em 1979, o Programa Integrado de Reconstrução das Cidades Históricas - PCH (1973-1993) junto com o Centro Nacional de Referência Cultural (1975-1982) passou a integrar o IPHAN, sob a direção de Aloísio Magalhães (morto prematuramente em 1982). Com a sua nomeação como diretor em 1979, o IPHAN passou por mudanças estruturais e também conceituais, as quais representaram uma tentativa de revisão de conceitos e práticas que tinham se consolidado nos primeiros trinta anos de sua atuação. $\mathrm{O}$ conceito de patrimônio histórico e artístico daria lugar ao de patrimônio cultural e o de monumentos nacionais ao de referências culturais (FONSECA, 2005).

De 1980 a 1990, o IPHAN tinha seu poder interno disputado entre os técnicos da "academia" e da "ortodoxia", de abordagem técnica baseada em valores históricos e artísticos e visão elitista na seleção de bens materiais para a proteção, e o grupo formado a partir da anexação do Centro Nacional de Referência Cultural com valores ligados à proteção de bens imateriais representantes da diversidade cultural brasileira. Coexistiam duas linhas de atuação: a da "pedra e cal" do antigo SPHAN e a das referências culturais do CNRC, criado em 1975 (FONSECA, 2005).

O objetivo do CNRC, inicialmente com sede na Universidade de Brasília e fruto de conversas de um pequeno grupo de professores dessa universidade, era a documentação e a análise da realidade cultural brasileira (com a produção de um quadro de referências culturais e um centro de documentação para acesso aos produtos culturais do país). Vinculava a questão cultural a do desenvolvimento (desenvolvimento adequado aos diferentes contextos e referências culturais), concebendo a cultura local como fonte de desenvolvimento econômico (FONSECA, 2005).

Com o lema "a comunidade é a melhor guardiã de seu patrimônio", defendia a população como agente preservacionista do patrimônio (seleção dos bens e realização da sua preservação), ou seja, trabalhava com a ideia de um diálogo da política de preservação do patrimônio do país com a sociedade civil, de forma as referências culturais se apresentarem como fonte e/ou recurso de valorização da diversidade sociocultural e de desenvolvimento das 
comunidades detentoras desses bens culturais. O patrimônio cultural nacional deixaria de ser somente um objeto de contemplação e afirmação da identidade nacional e se aproximaria das comunidades detentoras como recurso de desenvolvimento local, afirmação e valorização da diversidade sociocultural.

Com CNRC, nascia um novo conceito de patrimônio, relacionado à dimensão imaterial, e de cultura, menos identificado com o das elites, e que, posteriormente, fora incorporado pela Constituição Federal de 1988, sendo fundamental para a concepção de Patrimônio Cultural Brasileiro (FONSECA, 2005) e da nova política de preservação da memória dos processos culturais, numa abordagem antropológica, baseada na diversidade cultural, no fazer popular e na dinâmica cotidiana, lançando "as sementes" para as mudanças conceituais e estruturais deste século (FIGUEIREDO, 2014).

A preservação do patrimônio cultural - bens materiais e imateriais que determinado grupo reconhece como produtores de um determinado valor - foi oficialmente incorporada pela política cultural do país pelas mencionadas "Diretrizes para operacionalização da política cultural do MEC (1981-1982)" e, depois, pela Constituição Federal de 1988, ao dispor no parágrafo $1^{\text {o }}$ do artigo 216 que "o Poder Público, com a colaboração da comunidade, promoverá e protegerá o patrimônio cultural brasileiro por meio de inventários, registros, vigilância, tombamento e desapropriação, e de outras formas de acautelamento e preservação" (BRASIL, 1988).

Equiparou-se a noção de cultura com a de patrimônio cultural, muito embora nem todo o produto da relação homem com a natureza (noção antropológica de cultura) seja patrimônio, pois este último envolve escolha e seleção daqueles bens culturais que seriam herdados pelas futuras gerações. Os patrimônios culturais são construídos. Não são simplesmente coleções de objetos. Expressam diferentes visões de mundo e, inclusive, diversas concepções de patrimônio (CONÇALVES, 2002).

A questão da preservação do patrimônio, depois de ter se vinculado ao monumento (Fase Monumentalista) e aos conjuntos arquitetônicos e urbanos e centros e cidades históricas, passou, com o CNRC, a ter como foco o patrimônio cultural em geral, podendo ser histórico, artístico, arquitetônico, afetivo, paisagístico ou ambiental. A atribuição de valor também deixava de ser responsabilidade de especialistas, passando a sociedade a ser concebida como produtora e agente preservacionista de referências e bens culturais:

Era o poder público que instituía o patrimônio cultural, o qual só se comporia de bens tombados. O tombamento, portanto, tinha papel instituinte do valor cultural daquele valor que credenciava a inclusão do bem num rol formalmente definido. Ao inverso, a nova Constituição Federal reconheceu aquilo que é posição corrente, há 
muito tempo, nas ciências sociais: os valores culturais (os valores, em geral) não são criados pelo poder público, mas pela sociedade. O patrimônio é antes de mais nada um fato social - essa afirmação, nos órgãos de preservação, nas décadas de 1970 e 1980, provocava escândalo e alimentava mal-entendidos (MENESES, 2012, pp.33 e 34)

O conceito de patrimônio cultural, naquele momento, representava um avanço no debate sobre a questão da preservação até então estabelecido. Relacionava-se a bens materiais e naturais, como também a bens culturais imateriais (cultura popular, celebrações, saberes e fazeres) representativos da diversidade cultural brasileira (originários das culturas indígena e negra, por exemplo, e não mais somente aqueles pertencentes à tradição cristã e europeia); e voltava-se ao processo e ao papel da comunidade no registro, tombamento e na proteção de modo geral desses bens. Com esse conceito de patrimônio alargado, começa-se a falar em participação da sociedade na construção e gerenciamento da política cultural de nosso país (FONSECA, 2005).

Fonseca (2005) que pesquisou os processos de tombamento no IPHAN abertos a partir de 1 de janeiro de 1970, ressalta que, entre os anos de 1970 e 1990, apenas 13\% das solicitações de tombamento partiram do IPHAN. Os pedidos de tombamento deixaram de ser exclusividade dos funcionários do órgão federal, como acontecia nas décadas anteriores, e passaram a envolver assembleias legislativas de Estados, prefeitos e profissionais de instituições. Somente os pedidos provenientes de associações da sociedade ainda eram uma exceção e os mecanismos de decisão continuavam restritos aos técnicos do IPHAN. Suas justificativas enfatizavam o valor histórico do bem (não o valor artístico) e incorporavam dentre os argumentos: seu potencial turístico e o valor afetivo para a comunidade. Entretanto, nesse período, em que o patrimônio "se abriu para novos tipos de bens, a Sphan ainda não sabia exatamente como fazer para proteger esses bens" (FONSECA, 2005, p.209).

\subsection{O Patrimônio Natural no Patrimônio Cultural Brasileiro}

O conceito de patrimônio cultural abriu espaço para a valorização de bens que testemunhavam a ocupação do território brasileiro, a evolução das cidades, tecnologias e aspectos imateriais ligados às práticas espirituais de diferentes grupos étnicos e aos saberes e fazeres tradicionais (FONSECA, 2005), de forma os testemunhos da industrialização e da imigração, a diversidade religiosa e de culto e a etnia negra passaram a ser objetos "tombáveis": 
bens representativos da etnia afro-brasileira (Terreiro da Casa Branca, BA e Serra da Barriga, AL); das diferentes correntes de imigração (Casa Presser, RS; Casa do Professor e Escola Rural, e Cemitério Protestante, SC, testemunhos da imigração alemã; Casarão do Chá, SP, testemunho da imigração japonesa; cidade de Antônio Prado, RS, testemunho da imigração italiana); marcos da história da ciência e da tecnologia no Brasil (Casa de Saúde Carlos Chagas e Estação Ferroviária de Lassance, MG, Escola de Enfermagem Ana Neri, Fundação Osvaldo Cruz e hospital São Francisco de Assis, RJ); inúmeros exemplares da arquitetura em ferro, como pontes, mercados, caixas e conjuntos habitacionais populares; e até fazeres, objetos da proposta de tombamento da Fábrica de Vinho de Caju Tito Silva, Paraíba (FONSECA, 2005, p. 208).

Embora o reconhecimento formal ao patrimônio intangível tenha se dado apenas entre 1997 e 2003 pela UNESCO e, em 2000, no Brasil, com Decreto-Lei n. 3.551, que instituiu o Registro dos Bens Culturais de Natureza Imaterial e criou Programa Nacional do Patrimônio Imaterial - PNPI, esses novos tipos de bens culturais foram sendo incorporados ao Patrimônio Cultural Brasileiro.

Em 1997, que foi instituída a chancela Obra Prima do Patrimônio Oral e Imaterial da Humanidade, seguida pela Declaração Universal sobre a Diversidade Cultural (2002) e pela Convenção para a Salvaguarda do Patrimônio Cultural Imaterial (2003):

A cultura adquire formas diversas através do tempo e do espaço. Essa diversidade se manifesta na originalidade e na pluralidade de identidades que caracterizam os grupos e as sociedades que compõem a humanidade. Fonte de intercâmbios, de inovação e de criatividade, a diversidade cultural é, para o gênero humano tão necessária como a diversidade biológica para a natureza. Nesse sentido, constitui patrimônio comum da humanidade e deve ser reconhecida e consolidada em benefício das gerações presentes e futuras (UNESCO, 2002). ${ }^{12}$

Mesmo que associado ao conceito de patrimônio cultural, o patrimônio natural, após a Convenção sobre a Proteção do Patrimônio Mundial, Cultural e Natural, continuava não vinculando as áreas naturais aos conjuntos urbanos e aos centros e cidades históricas. As áreas com notável valor estético, científico e ecológico é que eram compreendidas como patrimônio natural e, reconhecidas para proteção, como excepcionais áreas naturais e paisagísticas do mundo, devendo ser expressão de um valor universal.

A Convenção sobre a Proteção do Patrimônio Mundial, Cultural e Natural de 1972 foi o primeiro documento a apresentar conjuntamente os patrimônios culturais e naturais, distinguindo-os e definindo separadamente a avaliação de cada tipologia pela IUCN (União Internacional para a Conservação) e ICOMOS.

O caráter desta Convenção é sumamente original e consagra novas e importantes ideias. Ela liga as noções de natureza e cultura, até agora vistas como diferentes e, mais do que isso, antagônicas. De fato, durante muito tempo natureza e cultura que se opunham: o homem devia conquistar uma natureza hostil, enquanto a cultura simbolizava os valores espirituais. Mas, na verdade, natureza e cultura se

12 Disponível em: 〈http://www.unesco.org/new/pt/brasilia/culture/international-instruments-clt/\#c1052695> Acesso em: 02 mar 2016. 
complementam: a identidade cultural dos povos é forjada no meio em que vivem e, em geral, parte da beleza das mais belas obras criadas pelo homem provém exatamente da integração com o lugar em que se encontram (UNESCO, 1985). ${ }^{13}$

Nela, o monumento natural foi apresentado como uma categoria específica de área protegida; e a noção de patrimônio natural reafirmou sua relação com questões da estética da paisagem e valores cênicos (SCIFONI, 2006):

\begin{abstract}
Artigo 2 - Para os fins da presente convenção serão considerados como patrimônio natural:

- os monumentos naturais constituídos por formações físicas e biológicas ou por grupos de tais formações, que tenham valor universal excepcional do ponto de vista estético ou científico;

- as formações geológicas e fisiográficas e as áreas nitidamente delimitadas que constituam o habitat de espécies animais e vegetais ameaçadas e que tenham valor universal excepcional do ponto de vista da ciência ou da conservação;

- os sítios naturais ou as zonas naturais nitidamente delimitadas, que tenham valor universal excepcional do ponto de vista da ciência, da conservação ou da beleza natural (UNESCO, 1985). ${ }^{14}$
\end{abstract}

E em 1978 (com revisão em 1994), a IUCN conceituou o monumento natural como uma "área que contém uma ou mais características naturais/culturais específicas de valor relevante ou excepcional por sua raridade implícita, suas qualidades representativas ou estéticas ou sua importância cultural". ${ }^{15}$

Historicamente, o patrimônio natural nasce da monumentalidade, como expressão de grandiosidade e beleza de testemunhos da natureza poupados da intervenção humana (sentido de intocabilidade). Gestado, em fins do século XIX e início do XX, relacionando-se à monumentalidade e valores estéticos, foi decorrente da ideia ocidental de monumento natural. A noção de monumento ganhou, para além do histórico, a nova derivação "natural", qualificando-o e destacando seus valores artísticos e históricos e não vinculados às práticas sociais e ao cotidiano (SCIFONI, 2006).

O Monumento Natural correspondia aos ambientes naturais protegidos de qualquer intervenção do homem (sem interação homem-natureza), reconhecidos como monumentos a serem conservados e resguardados e existentes apenas para contemplação:

Monumento natural - As regiões, os objetos ou as espécies vivas de animais ou
plantas, de interesse estético ou valor histórico ou científico, aos quais é dada
proteção absoluta, a fim de conservar um objeto específico ou uma espécie
determinada de flora ou fauna, declarando uma região, um objeto ou uma espécie
isolada, monumento natural inviolável, exceto para a realização de investigações
científicas devidamente autorizadas ou inspeções oficiais. (Convenção para a
Proteção da Flora, da Fauna e das Belezas Cênicas Naturais dos Países da América,

13 Disponível em: 〈http://www.unesco.org/new/pt/brasilia/culture/international-instruments-clt/\#c1052695 > Acesso em: 02 mar 2016.

14 Disponível em: http://www.unesco.org/new/pt/brasilia/culture/international-instruments-clt/\#c1052695> Acesso em: 02 mar 2016.

${ }^{15}$ IUCN, 1998, p.198 apud SCIFONI, 2006, p. 35 . . 
de 1940. A noção foi referendada no Brasil pelo Decreto n. 3, de 13 de fevereiro de 1948). ${ }^{16}$

A proteção dessas áreas naturais (paisagens excepcionais e, mais tarde, espaços com atributos ecológicos importantes) ocorreu a partir da criação de parques e reservas e ligava-se à noção de "mundo natural em seu estado primitivo, anterior à intervenção humana" (DIEGUES, 2008, p.20).

Baseada nos primeiros conservacionistas norte-americanos, a ideia de parque como área selvagem e desabitada tinha sua origem

\begin{abstract}
nos mitos do 'paraíso terrestre', próprios do Cristianismo. A concepção cristã de paraíso, existente no final da Idade Média e no período anterior ao descobrimento da América, era de uma região natural, de grande beleza e rigorosamente desabitada, de onde o homem tinha sido expulso após o pecado original. [...] Dessa forma, os primeiros conservacionistas pareciam recriar e reinterpretar o mito do paraíso terrestre mediante a criação dos parques nacionais desabilitados, onde o homem poderia contemplar as belezas da Natureza (DIEGUES, 2008, pp. 29 e 30).
\end{abstract}

No Brasil, essas áreas naturais protegidas (os parques nacionais) foram implantadas a partir dos anos 1930. O Decreto-lei no. 25, de 1937, que elevou os monumentos naturais à qualidade de patrimônio nacional:

\begin{abstract}
Artigo $1^{\circ}$. - Constitui o patrimônio histórico e artístico nacional o conjunto dos bens móveis e imóveis existentes no país e cuja conservação seja de interesse público, quer por sua vinculação a fatos memoráveis da História do Brasil, quer por seu excepcional valor arqueológico ou etnográfico, bibliográfico ou artístico.

Parágrafo $2^{\circ}$. - Equiparam-se aos bens a que se refere o presente artigo e são também sujeitos a tombamento os monumentos naturais, bem como os sítios e paisagens que importe conservar e proteger pela feição notável com que tenham sido dotados pela natureza ou agenciados pela indústria humana (SPHAN; PROMEMÓRIA, 1980, p. 16).
\end{abstract}

Diegues (2008) destaca a disseminação do modelo de conservacionismo norteamericano, de criação de parques nacionais, como responsável pela devastação das populações tradicionais nos países onde foram implantados. Segundo o autor, os territórios brasileiros transformados em parques nacionais também eram habitados por populações tradicionais - extrativistas, pescadores, índios - que foram transferidas das regiões onde viveram seus antepassados para regiões ecológica e culturalmente diferentes. Os parques nacionais criados no nosso país inviabilizaram em grande parte a sobrevivência dessas populações, pois restringiam o uso dos recursos naturais:

O Brasil é um país que apresenta grande variedade de modos de vida e culturas diferenciadas que podem ser considerados 'tradicionais'. Eles incluem os 'caiçara' que habitam o litoral de São Paulo, Rio de Janeiro e Paraná; os 'caipiras' dos estados do Sudeste; os habitantes de rios e várzeas do Norte e Nordeste (os varjeiros); as

\footnotetext{
${ }^{16}$ Disponível em: http://www.mma.gov.br/port/gab/asin/inter01.html> Acesso em: 02 mar 2016.
} 
comunidades pantaneiras e ribeirinhas do Pantanal Mato-Grossense; os pescadores artesanais, como os jangadeiros do litoral nordestino; as comunidades de pequenos produtores litorâneos açorianos de Santa Catarina etc. São populações de pequenos produtores que se constituíram no período colonial, frequentemente nos interstícios da monocultura e de outros ciclos econômicos. Com isolamento relativo, essas populações desenvolveram modos de vida particulares que envolvem grande dependência dos ciclos naturais, conhecimento profundo dos ciclos biológicos e dos recursos naturais, tecnologias patrimoniais, simbologias, mitos e até uma linguagem específica, com sotaques e inúmeras palavras de origem indígena e negra. [...] Foi justamente nesses espaços territoriais [...] que se implantaram grande parte das chamadas áreas naturais protegidas, a partir dos anos 30, no Brasil (DIEGUES, 2008, pp. 18 e 19).

Com a criação do Parque Nacional de Yellowstone, em 1872, que foram lançadas as bases teóricas e legais para se conservar áreas naturais de grande beleza cênica para contemplação. E com a Convenção para a Preservação da Flora e Fauna, em 1933, em Londres, que se definiram as características do parque nacional: controle do poder público, interesse estético, geológico e arqueológico e na preservação da fauna e flora e a visitação pública (DIEGUES, 2008).

A primeira Lista dos Parques Nacionais e Reservas Equivalentes foi organizada em 1959, e em 1960 e 1962 respectivamente, a IUCN, criada em 1948, estabeleceu a Comissão de Parques Nacionais e Área Protegidas e realizou, em Seattle, nos Estados Unidos, a Primeira Conferencia Mundial sobre Parques Nacionais (SCIFONI, 2006).

As questões ecológicas que também eram uma das bandeiras de luta dos movimentos de 1968, nos Estados Unidos e na Europa, estiveram presentes tanto na Conferência das Nações Unidas sobre o Meio Ambiente Humano, em Estocolmo, quanto na Convenção do Patrimônio Mundial da UNESCO, em 1972, por intermédio da IUCN. Além da incorporação do valor ecológico à noção de conservação (DIEGUES, 2008), nessas convenções, as noções de proteção e conservação do patrimônio natural e cultural foram relacionadas à sustentabilidade.

A Conferência das Nações Unidas sobre o Meio Ambiente Humano de 1972 primeira das grandes conferências da ONU a debater os vínculos entre desenvolvimento e meio ambiente - introduziu a complexidade da questão ambiental na agenda internacional, definindo, a partir do seu documento "Declaração sobre o Meio Ambiente Humano", uma agenda padrão e uma política comum internacionais para ações ambientais. Foi um marco na percepção dos problemas decorrentes do binômio desenvolvimento/meio ambiente.

Nesses debates sobre os limites do desenvolvimento, que surge, em 1973, o conceito de ecodesenvolvimento, precursor do termo desenvolvimento sustentável e que fora consolidado no Relatório Brundtland de 1987. Utilizado para caracterizar uma proposta de 
desenvolvimento ecologicamente orientado para os trabalhos do PNUMA - Programa das Nações Unidas Para o Meio Ambiente (1983), foi concebido por Maurice Strong - primeiro dirigente do PNUMA e organizador da Conferência das Nações Unidas em Estocolmo e secretário executivo da ECO 92 (TRISTÃO, 2011).

Os princípios básicos deste conceito, estabelecidos por Ignacy Sachs - economista e autor de diversas obras sobre um modelo de desenvolvimento e conselheiro especial da Conferência das Nações Unidas no Rio de Janeiro em 1992 - basearam-se na combinação entre crescimento econômico, aumento do bem-estar social e preservação ambiental:

[...] um processo criativo de transformação do meio com a ajuda de técnicas ecologicamente prudentes, concebidas em função das potencialidades deste meio, impedindo o desperdício inconsiderado dos recursos, e cuidando para que estes sejam empregados na satisfação de todos os membros da sociedade, dada a diversidade dos meios naturais e dos contextos culturais (SACHS, 1986, p. 82 apud TRISTÃO, 2011).

O Documento Diretrizes Operacionais para Implementação do Patrimônio Mundial, de 1977 (UNESCO), que norteou as primeiras inscrições de bens na Lista do Patrimônio Mundial apresentava como critérios para o reconhecimento do valor universal do patrimônio natural: o valor estético, expresso nas paisagens notáveis e de extraordinária beleza natural; o valor ecológico, que correspondia à sua importância como habitat de espécies em risco de extinção e ao fato de deter processos ecológicos e biológicos importantes; e o valor científico, relacionado a áreas com formações ou fenômenos naturais importantes para o conhecimento científico da história natural do planeta (SCIFONI, 2006).

No caso do Brasil, as associações ambientalistas surgem diretamente influenciadas por esse movimento ambientalista norte-americano e europeu, especialmente no que se refere aos questionamentos (denúncias e campanhas de conscientização pública) sobre os impactos devastadores sobre a natureza causados pela civilização urbano-industrial, promoção da ecologia como a ciência da sobrevivência e de uma nova ética ecológica, combate à poluição gerada por indústrias e veículos, preservação da flora e fauna nativas, luta contra o uso de agrotóxicos, dentre outras questões (VIOLA; LEIS, 1992).

Segundo Viola e Leis (1992, p.83), o Brasil liderou, na Conferência das Nações Unidas sobre Meio Ambiente Humano, a aliança dos países periféricos contrários ao reconhecimento da importância da problemática ambiental "sob o argumento de que a principal poluição era a miséria", tendo em vista o reinante modelo de desenvolvimento baseado em uma forte depleção dos recursos naturais considerados infinitos, em sistemas industriais muito poluentes e na intensa exploração de uma mão de obra desqualificada e 
barata. Em 1973, foi criada a Secretaria Especial do Meio Ambiente (SEMA), vinculada ao Ministério do Interior, mas, somente, nos anos 1980, que o movimento ambientalista no Brasil ganhou caráter público e social efetivo (LOUREIRO, 2004b), caracterizando-se por um aumento da conscientização em relação aos problemas ambientais.

A partir do final dos anos 1970, para além do discurso ecológico, a preservação do patrimônio natural começou a levar em consideração a relação que determinados grupos tinham com o espaço "natural”, com o lugar e as suas práticas sócio-espaciais; com o valor social e afetivo que esses grupos lhe conferiam; a natureza como parte da memória coletiva, das histórias de vida; “[...] um patrimônio natural que antes de tudo faz parte da vida humana e não se opõe a ela" (SCIFONI, 2006, p.43).

Os congressos internacionais sobre parques nacionais e áreas protegidas, organizados pela IUCN, como, por exemplo, o IV Congresso Internacional, em Caracas, em fevereiro de 1992, começaram a tratar da contribuição das populações tradicionais para a conservação (DIEGUES, 2008). O patrimônio cultural ganhava mais uma dimensão: a da natureza ("bens naturais") (SCIFONI, 2006):

A partir daí um novo segmento do patrimônio cultural passou a ser admitido com legitimidade. O patrimônio cultural passou a ser definido em duas dimensões: as obras, os artefatos, os bens materiais e a natureza, como objeto de ação cultural, matéria prima a partir da qual a cultura é produzida (SCIFONI, 2006, p.46).

Nesse contexto, que foi instituída, na área de planejamento urbano em São Paulo (Programa de Preservação e Revitalização do Patrimônio Ambiental Urbano), pela Secretaria de Economia e Planejamento do Estado, a noção de patrimônio ambiental urbano, responsável pela aproximação da questão patrimonial com a experiência de vida coletiva e com o cotidiano (RODRIGUES, 2000):

Finalmente, deve-se esclarecer que a noção de patrimônio cultural inclui tanto produtos da ação humana, quanto da natureza, já que é a apropriação social que utiliza e permite entender, por exemplo, artefatos e paisagens. (Diretrizes para a formulação de uma política de atuação do Condephaat, de 1984 IN: RODRIGUES, 2000, p.80).

Rodrigues (2000) destaca ter havido uma renovação conceitual em São Paulo em função da adoção da noção de patrimônio ambiental urbano. Também incorporada nos estudos e no quadro conceitual do CONDEPHAAT, criado em 1968, com ela, o patrimônio foi apresentado como "fato cultural", com valores sociais, afetivos e históricos (culturais) adquiridos pelos bens nas relações sociais que contemplam diferentes sujeitos históricos.

Os valores são produzidos "no jogo concreto das relações sociais". O patrimônio ambiental urbano é fato social. Embora sejam suporte da memória e de apropriação das 
práticas sociais, as "coisas" e os objetos/artefatos não têm valor em si. São os homens que lhes atribuem valores: cognitivos, relativos à possibilidade de conhecimento; formais (propriedade física do objeto); afetivos e ligados ao sentimento de pertencimento; e aqueles pragmáticos, relacionados a valores de uso (MENESES, 1992, p.193)

O patrimônio ambiental urbano é um sistema de objetos: artefatos e "coisas" produzidas pelo homem e a natureza transformada em objetos da ação cultural, incorporada pela vida urbana e que não podem ser compreendidos fora do contexto de sua produção (MENESES, 1978).

\subsection{A Abordagem Preservacionista do Patrimônio Ambiental Urbano em São Paulo}

Em São Paulo, de 1937 a 1968, era o poder federal que instituía como patrimônio do Estado representações do passado paulista, tais como: remanescentes do povoamento do litoral, as casas rurais bandeiristas, sedes de antigas fazendas de café e capelas e igrejas dos seiscentos.

A Secretaria de Cultura, Esporte e Turismo do Estado de São Paulo, criada em 1967, a partir de uma reforma administrativa, uniu as atividades de turismo às da cultura e esportes e ficou responsável pelo CONDEPHAAT - órgão de preservação do patrimônio, criado em 1968.

\footnotetext{
A preservação de tal patrimônio constitui, antes de mais nada, dever do Estado, não só pelo resguardo desses valores culturais da população, mas também pelos atrativos que deles resultam como imediata repercussão no âmbito do turismo. (Governador Sodré nas Considerações Preliminares do projeto de criação do CONDEPHAT apud RODRIGUES, 2000, p.48)
}

Segundo Rodrigues (2000, p.41), a proteção do patrimônio cultural de São Paulo, com a criação do CONDEPHAAT, esteve vinculada à reafirmação da identidade bandeirante pelas "frações conservadoras e tradicionalistas da burguesia paulista" e visava ao interesse em promover o turismo, "nos contornos do culto cívico ao passado e da consagração pragmática desse mesmo passado, enquanto produto de consumo cultural valorizado com a expansão da indústria do turismo". ${ }^{17}$

Sob a influência das Normas de Quito, de 1967, que destacaram a relação do monumento histórico com seu contexto urbano e ambiental e a possibilidade de se apresentar

\footnotetext{
${ }^{17}$ Segundo Rodrigues (2000, p. 46), "Diferente da matriz modernista presente na formação do SPHAN em que o passado fora referência para a constituição da nacionalidade e fonte de conhecimento da História da Arquitetura".
} 
como um instrumento do progresso, dado o seu valor econômico, mediante o turismo, que, entre 1967 e 1969, foi criado, organizado e regulamentado o Conselho de Defesa do Patrimônio Histórico, Arqueológico, Artístico e Turístico (CONDEPHAAT) e foram estabelecidas as normas de tombamento no âmbito do Estado de São Paulo (PRATA, 2009), indo de encontro ao que foi posteriormente firmado no Compromisso de Brasília de 1970, sobre a ampliação da participação dos estados e municípios em diversas áreas da produção cultural (RODRIGUES, 2000).

Art. $1^{\circ}$. - Constitui o patrimônio histórico, arqueológico, artístico e turístico do Estado o conjunto de bens existentes em seu território, que, pelo valor arqueológico, etnológico, histórico, artístico e paisagístico, fica sob a proteção especial do Poder Público, nos termos do artigo 180 e parágrafo único da Constituição Federal e 129 da Constituição Estadual (Decreto Estadual de 19 de dezembro de 1969 in: SÃO PAULO, 1998).

O Departamento do Patrimônio Histórico (DPH) da Secretaria Municipal de Cultura de São Paulo (órgão técnico) também foi criado nesse contexto, em 1975, com as atribuições de identificação, proteção e fiscalização do patrimônio cultural e natural da cidade de São Paulo, muito embora o Conselho Municipal de Preservação do Patrimônio Histórico, Cultural e Ambiental da Cidade de São Paulo - CONPRESP, a quem coube a deliberação sobre tombamento, tenha sido organizado somente em 1985 e instalado em 1988 (PRATA, 2009).

Dentre as atribuições hoje definidas (de acordo com a Lei 14.516, de 11 de outubro de 2007) para o CONPRESP, órgão colegiado que trabalha em conjunto com o DPH, estão:

1) delibere sobre o tombamento de bens móveis e imóveis; 2) defina a área envoltória destes bens e promova a preservação da paisagem, ambientes e espaços ecológicos importantes para a cidade, instituindo áreas de proteção ambiental; 3) formule diretrizes que visem à preservação e à valorização de bens culturais; 4) comunique o tombamento aos órgãos assemelhados nas outras instâncias de governo e aos cartórios de registro - de imóveis ou de documentos; 5) pleiteie benefícios aos proprietários desses bens; 6) solicite apoio a organizações de fomento para obtenção de recursos e cooperação técnica, visando à revitalização do conjunto protegido; e 7) fiscalize o uso apropriado destes bens, arbitrando e aplicando as sansões previstas na forma da legislação em vigor (PRATA, 2009).

A preservação ambiental e da memória passaram a ser vistas como um direito social (RODRIGUES, 2000) e as políticas de preservação do patrimônio, a se relacionar com a cidade e com a questão urbana (ao complexo, dinâmico e vivo meio urbano), integrando-se as demais políticas públicas; com o exercício da cidadania (reivindicação do patrimônio por vários grupos sociais) e com a qualidade de vida.

Planejamento urbano não é simplesmente questão de tombamento. Nossos interesses estão ligados à legislação de zoneamento que não é passado, mas presente vivo. (Benjamim Ribeiro, presidente da Coordenadoria Geral de Planejamento da Prefeitura de SP, hoje SEMPLA apud RODRIGUES, 2000, p. 72) 
Com a noção de valorização do Patrimônio Ambiental Urbano, as cidades se apresentaram como documentos históricos sobre os processos econômicos e sociais da sua formação e não foram mais associadas somente aos valores estéticos e artísticos de seus bens arquitetônicos e edificados. Há mudança do foco do objeto para um sistema de relações, no qual a discussão sobre o patrimônio incluiu o entendimento de como se dão as relações sociais hoje e como o foram no passado (MENESES, 1978).

A compreensão do patrimônio foi atrelada à complexidade das cidades, à emergência de questões de cunho ambiental (como o problema da poluição e a necessidade de conservação dos recursos naturais) e associada com a qualidade de vida. Os tombamentos relacionaram a preservação do patrimônio com questões urbanas, ambientais e de cidadania.

Falava-se também em divisão da tarefa da tutela com a sociedade. ${ }^{18}$ Embora estivesse presente o papel essencial das instituições e seus instrumentos, tanto as de patrimônio quanto as de planejamento urbano na gestão, era de destaque o discurso da promoção do papel político da sociedade, no sentido do aprofundamento da consciência cidadã a respeito de suas responsabilidades e direitos para com o patrimônio (na preservação de modo geral e no processo decisório) (MENESES, 1978).

Em 1974, a Coordenação Geral de Planejamento (COGEP), da Prefeitura de São Paulo (Secretaria Municipal de Planejamento - SEMPLA), com base no conceito de Patrimônio Ambiental Urbano, iniciou o cadastramento das edificações e logradouros paulistanos a serem protegidos, sob a orientação da noção de bem cultural, que "permitia congelar certas 'fatias' da cidade, até as de época mais recente, o que não era cabível no 'velho sistema', o do patrimônio histórico que 'preocupava-se com a forma externa e a excepcionalidade estética, o purismo do estilo"”. (Carlos Lemos, em uma entrevista, in: RODRIGUES, 2000, p.71)

Tratava-se de uma proposta de política de proteção e preservação por zoneamento, plano diretor e outras normas urbanísticas, em que “o reconhecimento das 'manchas urbanas', o zoneamento especial e o conceito de patrimônio ambiental urbano (...) tentavam tratar o patrimônio inserido na dinâmica e na complexidade urbana" (PRATA, 2009, p.54) ${ }^{19}$

[...] Ao Condephaat caberia prestar assistência e supervisão técnica às prefeituras e tombar ex-officio os bens já tombados pelo Patrimônio Nacional. Suas atenções se concentrariam nos bens de interesse estadual 'relacionados à história sócioeconômica e à arte da terra paulista', sobre os quais deveria efetuar um esboço histórico com o fim determinado de isolar e caracterizar nossos vários ciclos

\footnotetext{
${ }^{18}$ Os chamados novos movimentos sociais urbanos dos anos 1980 que estimularam as aproximações dos órgãos preservacionistas com a sociedade. Nos anos 1990, as instituições estaduais e municipais de patrimônio começaram a se proliferar. (RODRIGUES, 2000).

${ }^{19}$ A lei de zoneamento do município de São Paulo é de 1972 e 1973 (7.805, de 01.11 .1972 e 8.001 de 24.12.1973).
} 
econômicos que plasmaram no tempo e no espaço nossa sociedade e, então passará a procurar e a escolher exemplares significativos desses vários ciclos com o fito de tombá-los (...) no campo da arquitetura, irá o Condephaat tombar e preservar restos relativos ao ciclo das bandeiras. Seriam tombados exemplares construtivos civis e religiosos urbanos e rurais, exemplares escolhidos após triagem amparada por justos critérios críticos[...] Ainda que presa ao período colonial, a proposta considerava outros 'ciclos' econômicos, como o do café, no Vale do Paraíba e o industrial. [...] A consideração do 'ciclo industrial' significou, porém, um avanço em relação às concepções até então predominantes. Reconhecer a indústria como possível elemento definidor do valor de um bem significou incorporar a produção cultural de fase mais recente da história como parte do que deveria ser preservado, representou a aproximação com espaços cuja importância persistia viva na memória de boa parte da população urbana (RODRIGUES, 2000, p.64)

Patrimônio Ambiental Urbano foi um sistema de objetos socialmente apropriado, com definição sempre histórica e sociológica: paisagens, espaços, construções e objetos móveis com sentidos manifestados pelas articulações que estabeleciam entre si (MENESES, 1978).

O conceito além de possibilitar a aproximação do campo da preservação com o planejamento urbano, resultando numa abordagem conjunta dos aspectos relativos aos setores históricos e das demandas da cidade como um todo, promoveu o alargamento da noção de patrimônio, passando a ser entendido em sua dimensão urbana, como instrumento de elevação da qualidade de vida, influenciando as ações preservacionistas tanto do CONDEPHAAT ${ }^{20}$, quanto do DPH, que, a partir de 1983, passa a realizar o Inventário Geral do Patrimônio Ambiental e Cultural Urbano de São Paulo - IGEPAC-SP e trabalhar com esse conceito amplo de patrimônio, reconhecendo a necessidade da preservação participar das políticas de desenvolvimento urbano (RODRIGUES, 2000).

O trabalho, inspirado na experiência francesa de criação de 'setores preservados', tinha por objetivo orientar a nova legislação de zoneamento urbano em São Paulo, cidade então convulsionada pelas obras do Metrô, a partir da consideração de 'manchas', nas quais se incluíam os bens culturais significativos dos diferentes períodos de desenvolvimento da cidade, classificadas como Z8-200, e sujeitas a medidas específicas incluídas na legislação de uso e ocupação do solo do município, a lei 8.328/75 (RODRIGUES, 2000, p. 72).

Prata (2009, pp. 57 e 58) destaca que a participação da sociedade, a questão ambiental e da qualidade de vida foram centrais para o conceito de Patrimônio Ambiental Urbano e hoje esse conceito possibilita entender a problemática do tombamento de bairros e das regulamentações de área envoltória existentes, que partiam também da memória social para a

\footnotetext{
${ }^{20}$ Segundo RODRIGUES (2000), em 1974, um convênio entre o Ministério de Educação e Cultura e a Universidade de São Paulo possibilitou a realização de um curso coordenado pela CONDEPHAAT, IPHAN e Departamento de História da Arquitetura da FAU-USP, com a participação de especialistas estrangeiros, dentre os quais Hugues de Varine-Bohan, que havia dirigido o Conselho Internacional de Museu (ICOM) da UNESCO, que abriu aos especialistas o caminho para a compreensão da complexidade das cidades, suas questões de cunho ambiental e relacionadas à qualidade de vida, bem como do patrimônio como direito social.
} 
preservação de artefatos materiais, como foi o caso de Santo Amaro e a proteção de seu eixo central histórico, estudado por essa pesquisa.

Nesse período, um número crescente de cientistas sociais passou a participar das ações governamentais de preservação do patrimônio cultural, apoiando populações tradicionais na defesa de direitos de posse e uso de recursos patrimoniais (ARANTES, 2006).

O que na década de 1980 era indício isolado de interesse acadêmico ou político por essa temática tornou-se hoje manifestação de um campo de atividade intelectual em franco processo de consolidação (ARANTES, 2006, p.425).

Rubino (apud PRATA, 2009), no Seminário Diversidade Cultural: Patrimônio Brasileiro, de 2005, destacou a entrada de antropólogos em órgãos de preservação e das ciências sociais na questão do patrimônio cultural - tradicionalmente um domínio dos arquitetos e historiadores; como também ressaltou nesse processo a influência de A Invenção das Tradições, de Eric Hobsbawn (1984) e Os Lugares de Memória, de Pierre Nora (1984), ao lado do pioneiro seminário/livro organizado por Arantes: Produzindo o Passado. ${ }^{21}$

Embora, o processo de tombamento enquanto procedimento administrativo ainda continue muito centrado na "tecnicidade" do órgão preservacionista ${ }^{22}$, o estudo do patrimônio cultural na sua relação com a cidade revela ter havido "não apenas uma ampliação do objeto (de um edifício, para um conjunto), mas fundamentalmente uma mudança de foco": do objeto para um "sistema de relações" e a inclusão das pessoas que se relacionam com os bens: como os homens em sociedade viviam, com que se identificavam, como se dão as relações sociais

\footnotetext{
${ }^{21}$ Segundo Prata (2009, p.58), trabalhos acadêmicos que tinham como objeto as instituições de preservação foram fundamentais para se problematizar os conceitos e práticas dos próprios órgãos, tais como: A Retórica da Perda, de José Reginaldo Santos Gonçalves (1989); As Fachadas da História: as origens, a criação e os trabalhos do Serviço do Patrimônio Histórico e Artístico Nacional, 1936-1967, de Silvana Rubino (1992); Patrimônio em Processo: trajetória da política federal de preservação no Brasil, de Maria Cecília Londres Fonseca (1992); O Tecido do Tempo: a constituição da ideia de patrimônio cultural no Brasil entre 1920-1970, de Mariza Veloso Motta Santos (1992); MILET, Vera Milet. A Teimosia das Pedras (1985); o artigo de Lia Mota (1987) sobre A SPHAN em Outro Preto: uma história de conceitos e critérios; ANDRADE, Antonio Luiz Dias de. Um Estado Completo que pode jamais ter existido (1993); RODRIGUES, Marly. Imagens do Passado: a instituição do patrimônio em São Paulo (1994); e O que é patrimônio histórico, de Carlos Lemos (1981). Destaca também o Congresso Internacional Patrimônio Histórico e Cidadania, organizado pelo DPH, em agosto de 1991, que gerou o livro de 1992: O direito à Memória: patrimônio histórico e cidadania. Ver também: Fenerich (2000) analisa os tombamentos na cidade de São Paulo e os valores atribuídos aos bens; Rodrigues (2001) estuda casos de mobilização social em favor da preservação de bens culturais, enfocando o tombamento e o território; Cunha (2005) apresenta a experiência da preservação pela cidade de Sorocaba; Scifoni (2006) que, em sua tese, trata de como a preservação de áreas naturais via tombamento influiu no padrão de ocupação do litoral norte.

${ }^{22}$ Segundo Saviero (2014, p. 17), “[...] a atribuição de valores culturais a recortes geográficos específicos do tecido urbano ainda se mantinha baseada em categorias interpretativas especializadas e, na grande maioria dos casos, não levava em consideração o próprio fato social presente nesse território. As categorias interpretativas especializadas ainda permaneciam oriundas principalmente do universo da arquitetura e urbanismo, da história e da arte".
} 
hoje e como eram ontem, mesmo com os órgãos de proteção do patrimônio ainda convivendo com estruturas conceituais e administrativas tradicionais (PRATA, 2009, pp. 61 e 65). 


\section{Arqueologia e Educação}

\subsection{A Arqueologia}

A Arqueologia é concebida como uma ciência humana e social que tem como propósito a compreensão das relações humanas do passado e a busca de interpretações sobre os processos e significados das transformações sociais e culturais (TRIGGER, 2004; FUNARI, 1994; PATTERSON, 1990). Dedica-se ao estudo dos sistemas sociais, sua estrutura, funcionamento e transformação com o decorrer do tempo, tendo por objeto de análise a cultura material existente no presente.

A Arqueologia volta-se para a compreensão das culturas do passado (e do presente), mediante o estudo de seus remanescentes artefatuais. ${ }^{23}$ Tendo em vista que seu objeto de estudo é o patrimônio arqueológico que reflete a própria construção e a reelaboração de valores e interesses gerados pela sociedade com quem dialoga, apresenta-se como uma Ciência Social (FUNARI, 1999-2000).

Funari (1999-2000) destaca que a Arqueologia, assim como qualquer ciência humana e social, possui um comprometimento com a formação de sujeitos históricos ou atores sociais conscientes de seu papel na sociedade em que vivem. O arqueólogo não é um observador neutro que está acima e além das classes e dos conflitos sociais; e as disciplinas científicas não estão livres de liames sociais e políticos. A Arqueologia Pública é um campo científico da Arqueologia destinado a discutir, intervir e rever a própria relação dialética entre a ciência arqueológica e a sociedade. ${ }^{24}$

\footnotetext{
${ }^{23}$ Desde cedo se viu com a necessidade de dialogar com outras áreas de conhecimento em busca de método e técnicas que a pudessem auxiliar na compreensão desse seu objeto de estudo: os artefatos e as sociedades às quais pertencem: "Esta aparente fraqueza da Arqueologia, acrescida ora de influências teóricas da História, ora da Antropologia, neste início de século XXI, parece ter virado às avessas e não mais se configurado como uma deficiência, mas como uma virtude. Uma ciência que agora bem clarificada em seu objeto de estudo tem no diálogo e na interação com outros campos do conhecimento o seu maior trunfo, ou seja, uma ciência verdadeiramente interdisciplinar, não só na abordagem de seu objeto, mas no exercício de sua prática, consubstanciando diversos olhares, sejam eles históricos, antropológicos, sociológicos, geográficos, geológicos" (CARVALHO, 2012).

${ }^{24}$ Novos desafios têm se colocado para essa disciplina do conhecimento: os aspectos sociais relacionados às comunidades e seus territórios - espaços sociais de vida e trabalho, nos quais o arqueólogo participa diretamente pelo seu trabalho cotidiano -; e os aspectos legais, éticos, econômicos, como nos projetos de licenciamento ambiental, culturais ou patrimoniais, que realçam que o exercício arqueológico não é apenas um campo do saber, mas uma prática profissional que tem a sua faceta social e política, enquanto atuação de um sujeito social com empoderamento teórico e legal legítimo no jogo dos conflitos sociais, no âmbito da produção capitalista. Está imersa na emaranhada teia de problemáticas, participante das questões sociais emergentes e em constante diálogo minado entre o campo do saber científico e as responsabilidades profissionais perante a comunidade científica, a sociedade em geral e as comunidades locais, em que desenvolve a sua atividade diária, construindo
} 
No século XIX, a Arqueologia nasce atendendo à demanda dos Estados-nação em formação. Interpretados como estágios de desenvolvimento cultural, os artefatos arqueológicos serviam como referenciais identitários (TRIGGER, 2004). ${ }^{25}$

Em meados do século XIX, a disciplina se solidificou e se estabeleceu com o Histórico-Culturalismo. Desenvolvido a partir dos seguidores do arqueólogo Gordon Childe, de forte identificação com as ideias marxistas, tinha feição descritiva e interpretava o registro arqueológico como culturas arqueológicas e com possibilidade de identificar origens e movimentos de interação de povos pré-históricos. Para Childe, a arqueologia históricocultural possibilitava o estudo e a explicação das variações geográfica e temporal no registro arqueológico (CARNEIRO, 2009).

Na década de 1960, a Arqueologia Processual (Processualismo) ou New Archaeology desenvolveu-se nos Estados Unidos a partir do arqueólogo norte-americano Lewis Binford, como a crítica desse modelo histórico-cultural, vinculando a Arqueologia à Antropologia. ${ }^{26}$

Binford (1994) vai além da descrição do registro arqueológico para adentrar na interpretação da cultura material, por acreditar haver regularidades no comportamento humano não observáveis diretamente no registro, que os estudos etnográficos comparativos poderiam revelar. Sua preocupação estava em identificar características generalizantes relacionadas às adaptações ecológicas ao longo do desenvolvimento humano (CARNEIRO, 2009).

Os arqueólogos processualistas buscavam as regularidades e passaram a tratar a cultura como um sistema simbólico em que o indivíduo da Pré-História seria o sujeito da ação, que levaria a transformações culturais; a cultura material teria um papel ativo nas dinâmicas culturais (TRIGGER, 2004).

Nas décadas de 1980 e 1990, Ian Hodder (1986) - crítico da Arqueologia Processual e uma das principais referências da Arqueologia Pós-Processual - destacou a dimensão simbólica da cultura e a influência dos contextos sociais na produção do conhecimento. Acreditava que "as ações humanas são direcionadas por crenças e conceitos simbólicos e que o objeto de estudo propriamente dito é a estrutura do pensamento (as ideias) existente na

um trabalho que possa no futuro ser criticado nos limites e nas responsabilidades de seu tempo (CARVALHO, 2012).

${ }^{25}$ Nesse período, também é quando se dá o crescimento dos acervos de material arqueológico resultando na formação de museus, institutos de pesquisa e a criação de cadeiras de arqueologia nas universidades (CARNEIRO, 2009).

26 “(...) explanações históricas específicas, se isso puder se demonstrado, explica simplesmente os mecanismos do processo cultural. Eles não somam nada à explicação da mudança e evolução dos processos culturais" (BINFORD, 1994, p. 94). 
mente dos agentes humanos que elaboraram os artefatos e criaram o registro arqueológico" (RENFREW \& BAHN, 1993, p. 446). ${ }^{27}$

Desenvolvida no contexto da chamada Escola de Frankfurt, a Arqueologia PósProcessual baseava-se na ideia de que todo conhecimento é histórico e qualquer construção de conhecimento tem uma perspectiva interpretativa, dando ênfase ao papel da ideologia nos processos de mudanças das sociedades do passado (RENFREW \& BAHN, 1993). Na trajetória do surgimento da Arqueologia Pública, foi a que buscou uma aproximação com a sociedade e que a incorporou no rol de suas discussões (FERNANDES, 2007; CARNEIRO, 2009). ${ }^{28}$

A Arqueologia Pública, apesar da diversidade de aspectos que permeiam o tratamento desse conceito, é associada à responsabilidade social da Arqueologia:

\begin{abstract}
A responsabilidade social e profissional da arqueologia remete à existência de questões dentro da mesma que vão além de problemas teóricos e metodológicos. Esses temas podem ser considerados questões públicas da Arqueologia, pois estariam situados na interface da arqueologia com a sociedade (FERNANDES, 2007, p.7).
\end{abstract}

Há hoje publicações especializadas tanto em âmbito nacional como internacional que buscam uma consolidação conceitual da Arqueologia Pública. No entanto, Carneiro (2009) destaca que ela não tem se envolvido com a arqueologia musealizada ${ }^{29}$ e não tem levado a uma discussão sobre a administração pública dos recursos culturais e nem sobre o papel social da produção científica da Arqueologia, de forma a participar mais ativamente na sociedade.

A Arqueologia Pública apareceu, na bibliografia especializada, segundo Carneiro (2009), com a publicação da obra Public Archaeology, do arqueólogo norte-americano Charles McGimsey III, em 1972, e esteve atrelada à questão da destruição de sítios arqueológicos devido ao crescimento acelerado, nas décadas de 1960 e 1970, em razão da crescente urbanização e industrialização nos Estados Unidos. Referiu-se ao comércio ilícito

\footnotetext{
${ }^{27}$ Por isso foi chamada de arqueologia contextual, preocupada com o contexto histórico e social da produção de conhecimento, com subjetividade e comprometimento dos arqueólogos com os grupos sociais. Ver: CARNEIRO, 2009.

28 Segundo Fernandes (2007, p.25), essas reflexões estiveram presentes em encontros como World Archaeological Congress, de 1986, na Inglaterra (o primeiro foi em 1982), gerando a publicação The excluded past: archaeology in education, que refletia por que a pré-história e os grupos tradicionais eram excluídos dos currículos escolares da Escola Formal. Resultou no aparecimento do debate teórico sobre a arqueologia mundial, que visava estudar a mudança social e cultural de grupos humanos, entendendo não só como viviam no passado, como também como e por que mudanças ocorreram e resultaram nas formas da sociedade e cultura que existem hoje. Abria-se a Arqueologia para o diálogo com outros estudos interpretativos do patrimônio arqueológico (antropólogos, educadores, historiadores), além de reforçar a questão do seu papel social. Ver: FENANDES, 2007.

${ }^{29}$ Quanto à musealização da arqueologia no Brasil, são de destaque os trabalhos de Maria Cristina Bruno (1995, 2001) que pesquisou e denunciou o abandono das fontes arqueológicas na interpretação da sociedade brasileira, chamando-o de "estratigrafia do abandono" (BRUNO, 1995, p.7).
} 
de artefatos, da atuação de amadores na escavação de sítios arqueológicos e sobre a baixa qualidade dos trabalhos desenvolvidos por arqueólogos profissionais (FERNANDES, 2007).

Esta discussão esteve atrelada ao desenvolvimento da legislação referente ao gerenciamento dos recursos naturais (CRM - Cultural Resource Management) naquele país, voltando-se para as questões da administração pública dos recursos culturais e do compromisso social da disciplina. Foi responsável pelas primeiras reflexões sobre a necessidade da apresentação da Arqueologia para o púbico (MERRIMAN, 2004; FERNANDES, 2007).

Hoje é a Arqueologia de salvamento de sítios arqueológicos em áreas de empreendimentos, que faz parte da gestão de recursos culturais, assim como o turismo cultural, programas e projetos de inventário cultural, valorização e projetos de restauração de edificações históricas; e a $\mathrm{CRM}^{30}$ pode ser considerada Arqueologia como gestão pública do patrimônio arqueológico, pois gerou debates que favoreceram o papel das sociedades arqueológicas profissionais e proporcionaram a inserção da Arqueologia em nome de interesses públicos da disciplina e da coletividade (FERNANDES, 2007).

Almeida (2002) ressalta que o discurso preservacionista desencadeou o despertar da Arqueologia Pública como um campo preocupado com as questões pautadas na interface da ciência com a sociedade.

Embora a perspectiva mais ampla da Arqueologia Pública tenha ocorrido no âmbito do Pós-Processualismo, pode-se dizer que o desenvolvimento inicial do campo acompanhou o processo de profissionalização da arqueologia americana. Num período de efervescência da New Archaeology, buscava-se, sobretudo, o reconhecimento acadêmico e público, a valoração científica e o desenvolvimento teórico da disciplina (ALMEIDA, 2002).

Nos Estados Unidos, segundo Merriman (2004 apud FERNANDES, 2007), a aproximação com a sociedade se deu por meio de discussões sobre a importância da preservação dos bens arqueológicos para as gerações futuras. E o envolvimento dos cidadãos americanos foi direcionado para a participação na gestão dos recursos culturais e fiscalização das ações destruidoras dos sítios arqueológicos.

A crescente associação do termo Arqueologia Pública ocorreu enquanto estratégias relacionadas diretamente à participação da sociedade nas ações geradas pela gestão dos

\footnotetext{
${ }^{30}$ Os recursos culturais (cultural resources) foram definidos como todos os fenômenos de valor cultural para a nação, o estado, uma localidade ou um grupo de pessoas, incluindo bens históricos, instituições sociais, tradições, culturas populares e bens que perderam sua integridade, mas ainda são julgados de valor pela sociedade ou por parte dela (JULIANI, 1996).
} 
recursos culturais e nas ações educacionais desenvolvidas em escolas, parques e museus, considerando a participação pública no seu desenvolvimento. Os bens arqueológicos cada vez mais foram associados às questões políticas e econômicas que se refletiam na vida de todos os cidadãos (MERRIMAN, 2004 apud FERNANDES, 2007).

A Lei de Antiguidades (Antiquites Act) de 1906 definiu monumentos contendo sítios e estruturas de valor histórico ou científico em terras públicas e passou a requerer permissões para examinar ou escavar ruínas históricas ou pré-históricas, limitando a emissão de licenças a instituições científicas reconhecidas. E a Lei Orgânica do Serviço de Parques Nacionais (National Park Service Organic Act) de 1916 fundou o Serviço de Parques Nacionais (National Park Service). Em 1935, a Lei de Sítios Arqueológicos (Historic Sites Act) foi publicada e estabeleceu uma política nacional de preservação para o uso público de sítios históricos e arqueológicos, edificações históricas e objetos de importância nacional (FERNANDES, 2007).

O departamento do interior através do Serviço de Parques Nacionais, assessorado pelo conselho consultivo denominado National Park System Advisory Board, passou também a assessorar o desenvolvimento de programas educacionais e pesquisas para avaliação de informações sobre sítios arqueológicos históricos e pré-históricos. O Conselho, composto por 16 pessoas, cidadãos dos Estados Unidos e não necessariamente especialistas, devia recomendar ações sobre a designação de marcos históricos nacionais e áreas naturais. Assim, o conjunto de sítios históricos, monumentos, parques nacionais e estaduais tornou-se mais acessível ao grande público e possibilitou o interesse da sociedade por vestígios materiais e suas representações históricas (JAMESON, 2004 apud FERNANDES, 2007).

Nas décadas de 1960 e 1970, diante do contexto de esgotamento dos recursos culturais arqueológicos e ações de vandalismo, ocorreu a publicação da Lei de Preservação Histórica Nacional - NHPA (National Historic Preservation Act), de 1966, da Lei que estabeleceu a Política Nacional de Meio Ambiente (National Environmental Policy Act), de 1969, do Decreto-Lei 11593 - Proteção do Ambiente Cultural (Protection of the Cultural Environment) de 1971 e da Lei de Preservação Histórica e Arqueológica (Archaeological and Historic Preservation Act) de 1974, que, segundo Jameson (2004 apud FERNANDES, 2007), deu início à mudança na forma de administração da Arqueologia que passou a contar com financiamentos para pesquisas arqueológicas mitigatórias no contexto do licenciamento de empreendimentos e regulamentações obrigatórias para a identificação, avaliação e proteção de sítios arqueológicos. 
Fernandes (2007, p.27) destaca que o primeiro estatuto e código de ética do Arqueólogo foi criado em 1960, pela Sociedade de Arqueologia Americana - SAA: as Quatro Regras para Arqueologia, que até hoje servem como referência como primeiro estatuto profissional. Em 1974, foi criada a Sociedade de Arqueólogos Profissionais - SOPA, que retomou os princípios da certificação do trabalho arqueológico e criou um estatuto profissional: o Código de Ética e do Estatuto de Performance Profissional, estabelecendo diretrizes para a execução de pesquisas de campo, procedimentos de curadoria e análise e divulgação de resultados de pesquisa e concebendo o registro arqueológico como "recipientes de informação" sobre aspectos do passado e que deveriam ser disponibilizados para o desenvolvimento cultural da sociedade.

Os debates se estenderam pelas décadas de 1980 e 1990 e o número de associados cresceu de 147 em 1976 para 550 membros em 1988. O SOPA foi extinto e no lugar foi criado um registro profissional nacional: o Registro de Arqueólogos Profissionais (ROPA), que passou a divulgar os estudos de impacto ambiental realizados por arqueólogos e casos sobre a má conduta de conservação dos recursos arqueológicos (FERNANDES, 2007).

Essa preocupação com a apresentação da Arqueologia para o público proporcionou a sua aproximação com a Museologia, a Comunicação Social e a Educação. Esta última tornouse uma questão pública essencial na Arqueologia no diálogo com a sociedade, passando a Arqueologia Pública a ser apresentada como um campo de pesquisa destinado a dialogar com a sociedade sobre as questões públicas da disciplina, tais como: legislação, gestão, ética e educação (FERNANDES, 2007).

Hoje, Sociedades de Arqueologia também têm promovido grupos de discussão e de trabalho sobre educação pública, além de programações como feiras itinerantes com publicações didáticas sobre Arqueologia e outras ações. E empresas de consultoria em Arqueologia também têm desenvolvido apresentação da Arqueologia dialogando com educação pública, no contexto de escavações mitigatórias (FERNANDES, 2007).

\subsection{A Arqueologia Pública}

A Arqueologia Pública surge décadas atrás como um conjunto de ações e de reflexões que objetiva saber a quem interessa o conhecimento produzido pela Arqueologia, de que forma as pesquisas afetam a sociedade, como estão sendo apresentadas ao público, ou seja, 
mais do que uma linha de pesquisa dentro da disciplina, a Arqueologia Pública é inerente ao exercício da profissão (ALMEIDA, 2002; FUNARI, 2001).

No Brasil, seu desenvolvimento ainda é incipiente (SILVEIRA; BEZERRA, 2007). Apesar de o papel da Arqueologia perante a sociedade nacional ser cada vez mais marcante, só agora começa a ser discutido pela comunidade arqueológica brasileira. ${ }^{31}$

A crescente prática da Arqueologia Contratual no Brasil confere ao arqueólogo não só o poder de avaliar a relevância e a importância do patrimônio arqueológico para a sociedade nacional como um todo, como também o de tomar decisões irreversíveis sobre qual parte desse patrimônio deve ser preservada (BRUNO, 1999).

Funari $(1999-2000 ; 2001 ; 2008)$ tem investigado agendas políticas e ideológicas no discurso de determinados grupos na história da Arqueologia Brasileira. Embora veja de forma positiva as diferentes formas de inserção da Arqueologia junto à sociedade nos últimos anos, a partir do aumento da quantidade de livros didáticos, das inserções em meios de comunicação e das pesquisas acadêmicas, diz:

(...) nos países mais desenvolvidos, a Arqueologia está bem inserida na sociedade, de uma forma ou de outra, enquanto no Brasil, ainda está muito afastada, especialmente, dos valores indígenas, das comunidades tradicionais e da grande massa em geral (FUNARI, 2001, p.83).

Carvalho (2012, p.28), apoiado no próprio Funari (1999-2000), também destaca ter havido um grande amadurecimento do campo da Arqueologia, influenciado por diversas questões e mais precisamente em decorrência de novas demandas sociais como a intensificação da percepção das comunidades locais sobre o fazer arqueológico, exigências provenientes da legislação ambiental, dos aspectos legais que disciplinam a atuação do profissional, e o aumento da Arqueologia dita de Contrato. (grifo do autor).

A Lei Federal no. 3.924, de 1961 e a Portaria SPHAN no. 007, de 1988 passaram a exigir uma posição política e ética do arqueólogo no exercício profissional e uma abertura ao diálogo com o seu olhar mediado por sua origem social e trajetória de vida, destacando o seu papel formativo e educacional, cultural e científico, como pedra angular de todo o seu trabalho na identificação de todo e qualquer bem patrimonial a ser evidenciado como relevante para as diversas comunidades e para a nação (CARVALHO, 2012).

\footnotetext{
$31 \mathrm{Na}$ América Latina, uma preocupação constante no desenvolvimento da Arqueologia tem sido "as conseqüências sociais, políticas e culturais do trabalho da Arqueologia, ressaltando a importância decisiva das inspirações técnicas adotadas para a definição de questões como as relativas à identidade cultural, preservação do patrimônio, ou à projeção da produção científica na educação" (BRUNO, 1999, p. 202).
} 
Consensual entre os arqueólogos é que os vestígios materiais das culturas do passado são o objeto da Arqueologia, que tem como objetivo a compreensão dos sistemas socioculturais e das sociedades pregressas mediadas por estes vestígios. A Arqueologia estuda os sistemas socioculturais, sua estrutura, funcionamento, comportamento ao longo do tempo e sua mudança (MENESES, 1983; FUNARI, 1994). Também relevante é a discussão sobre o papel político-ético-profissional do arqueólogo, que interfere nos espaços sociais, construindo e reinterpretando as trajetórias históricas das várias comunidades estudadas.

Segundo Carvalho (2012), a Arqueologia ocorre em meio à prática social, dialogando, relacionando-se, interferindo e propondo novos significados para a memória e identidade dos diversos grupos sociais em seu espaço social e geográfico; percorrendo os espaços do universo político, econômico, social e cultural e realçando a responsabilidade do arqueólogo em sua atuação profissional, fazendo aflorar aspectos éticos, através da avaliação dos impactos de sua atuação e escolha.

Concordamos com Carvalho (2012, p.32) quando diz que "não considerar este indicador para as questões e os problemas colocados pelo pesquisador em relação aos materiais arqueológicos com que trabalha é não reconhecer que a ciência é um processo de conhecimento humano e que sua práxis ocorre no tempo e no espaço, mediada pelas condições sociopolíticas que se apresentam”.

A Arqueologia, em sua dinâmica natural e no diálogo do arqueólogo com o seu objeto de estudo, impõe no processo de pesquisa questões não contempladas de antemão e que vão paulatinamente sendo incorporadas ao estudo. A cada sítio localizado, surgem novas indagações e novos temas que necessitam ser compreendidos, objetivando gerar um contexto para o trabalho (CARVALHO, 2012).

A evidenciação de bens patrimoniais locais pela Arqueologia pode atuar como propositora para a valorização do patrimônio arqueológico, histórico e cultural local, gerando o empoderamento das comunidades da região e ofertando instrumentos efetivos para uma Educação Patrimonial local. Pode instrumentalizar a comunidade em um contexto de formação para a cidadania, partindo do pressuposto de que a real proteção somente é alcançada quando a comunidade se apropria de seus bens patrimoniais, apoiada em referenciais de luta, resistência e riqueza cultural, alicerçada na legislação que lhe dá forma. ${ }^{32}$

\footnotetext{
${ }^{32}$ A Arqueologia pode se associar com a Educação, com a Museologia e com a História, por exemplo, "para realizar uma reflexão crítica da produção do conhecimento sobre o passado; de sua interação com a sociedade e seus objetivos para com a ciência; com o seu objeto de estudo e por fim com a sociedade e suas contradições" (FERNANDES, 2007, p.34).
} 
Os arqueólogos estão sempre lidando com o patrimônio do outro e, assim, essa experiência implica a percepção dos outros sujeitos destas relações e o reconhecimento do uso do passado como um caminho para o fortalecimento de comunidades envolvidas e a Educação Patrimonial pode ser um valioso instrumento de mediação (SIVEIRA \& BEZERRA, 2007).

Como destaca Funari \& Carvalho (2011, p. 9), a Educação Patrimonial pode se apresentar como alternativa ao distanciamento entre a sociedade e seus diversos patrimônios e a consolidação das políticas da diversidade como um patrimônio, pois deve agir no sentido de, democraticamente, construir diálogos entre a sociedade e seus patrimônios. ${ }^{33}$

\subsection{Arqueologia no Brasil e sua origem nos museus}

A Arqueologia no Brasil tem sua gênese no universo museológico, em termos de desenvolvimento das pesquisas arqueológicas e constituição das coleções museais. Somente em meados da década de 1950 do século XX é que as universidades passaram a abrigar ou a criar instituições museológicas. ${ }^{34}$

Os museus iniciaram as investigações científicas no país. Os museus brasileiros - o Museu Nacional, o Museu Paraense (hoje Emílio Goeldi), o Museu Paranaense e o Museu Paulista - que surgiram no século XIX, com base no modelo de História Natural, já nasceram científicos, pois utilizavam seus acervos e coleções como fonte de estudos e pesquisas.

Formados a partir de pesquisas de naturalistas europeus no país, abrigavam acervos arqueológicos, seguindo paradigmas novecentistas com conceitos classificatórios, evolucionistas e enciclopédicos herdados do século XIX e início do XX (LOPES, 1993):

idéia do museu universal, de caráter metropolitano, construído em moldes europeus, que almeja ser completo sim, mas com coleções que representassem o mundo todo, tal qual os museu das nações civilizadas entre os quais almejávamos nos incluir (LOPES, 1993, p.69).

O Museu Nacional foi a primeira instituição do país a encarregar-se da Arqueologia, a partir da aquisição de uma coleção mineralógica. No mesmo período, o museu contou também com pesquisas sobre sambaquis (CARNEIRO, 2009).

\footnotetext{
33 "Não se almeja atribuir à sociedade um conhecimento enciclopédico sobre quais são seus patrimônios, datas de fundação, autores, características físicas, entre outros dados”. Ver: FUNARI, P. P.; CARVALHO, A. Patrimônio cultural, diversidade e comunidades. Campinas-SP: IFCH/UNICAMP, 2011.

${ }^{34}$ Segundo Bruno (1995), esse envolvimento arqueológico-universitário, se, por um lado, garantiu a pesquisa, por outro, esvaziou as atribuições museológicas na comunicação arqueológica.
} 
Segundo Carneiro (2009), Ladislau Netto, quando à frente da direção do Museu, além de ter sido responsável pela transformação da antiga Quarta Seção - Arqueologia, Etnografia e Numismática em anexo do Museu, parece ter almejado a criação de um museu Arqueológico e Etnográfico independente. Para tanto enviou missões ao sul do litoral brasileiro para coletar objetos encontrados nos sambaquis; realizou a Exposição Antropológica Brasileira, de 1882; e contratou o egiptólogo e americanista Paul l'Lepine que estudou a cerâmica marajoara e associou suas decorações aos hieróglifos egípcios, indianos, chineses e mexicanos. Em 1895, a direção do Museu Nacional passou para o médico João Baptista de Lacerda - um dos precursores dos estudos antropológicos sobre a raça brasileira e um novo Regulamento (de 1911) propôs a criação de um Museu Escolar de História Natural voltado para crianças, a exemplo do que ocorria nos países da Europa, América Latina e Estados Unidos (LOPES, 1993; CARNEIRO, 2009).

A abertura do Museu (à época Museu Real/Imperial) ao público se deu em 1821, uma vez por semana, ou seja, de forma lenta e gradual, seguindo o modelo de publicização dos museus na Europa (LOPES, 1993; CARNEIRO, 2009); e a Seção de Assistência ao Ensino (SAE) foi criada em 1927.

Além do Museu Nacional, o Museu Paraense Emilio Goeldi, criado em 1871 e o Museu Paulista também possuíam acervos arqueológicos provenientes de pesquisas de naturalistas. Foi principalmente com os achados arqueológicos (vasos, urnas funerárias, tangas) e os estudos e registros sobre as comunidades indígenas contatadas (registros etnográficos) das expedições de naturalistas estrangeiros que o acervo do Museu Paraense Emilio Goeldi foi formado (CARNEIRO, 2009).

E com relação às suas ações de Educação, foi em 1891, quando da contratação do zoólogo suíço Goeldi, que o Museu passou a ser aberto às visitações de grupos de alunos. Mais tarde, sob a direção de Goeldi e depois de transformado em um museu reconhecido nacional e internacionalmente pelas suas coleções científicas e pela qualidade de suas investigações, houve modificações no seu Regimento Interno, autorizando a abertura do Museu para visitantes em geral (CARNEIRO, 2009).

O Museu Paulista de São Paulo, criado em 1893, também impulsionou o desenvolvimento das pesquisas arqueológicas no Brasil. Formado a partir das coleções do Coronel da Guarda Nacional Joaquim Sertório e da Associação Auxiliadora do Progresso da Província de São Paulo, o Museu teve como seu primeiro diretor à frente da instituição por 22 anos, Hermann Von Ilhering, pesquisador da Comissão Geográfica e Geológica, e se 
apresentou como um museu de história natural do século XIX, de acordo com o modelo enciclopédico em outros países, com pesquisas em grande parte na área da Zoologia, como também em Etnologia (CARNEIRO, 2009).

A área de Arqueologia desse Museu foi formada a partir de coletas de naturalistas e compras e permutas, por exemplo, com os Museus argentinos, de Buenos Aires e La Plata. Peças arqueológicas dos índios do Brasil Meridional, coletas de sambaquis, materiais mineralógicos, paleontológicos, material das grutas calcáreas do vale do Ribeira constituíram o acervo do Museu que, depois, somando-se às coleções do antigo Museu de Arqueologia e Etnologia, do Instituto de Pré-História e do acervo Plínio Ayrosa, do Departamento de Antropologia da Faculdade de Filosofia, Letras e Ciências Humanas da USP, formaram o atual Museu de Arqueologia e Etnologia da USP. A partir de 1917, sob a direção de Affonso de Taunay, o Museu foi voltado para as comemorações do Centenário da Independência Nacional de 1922, apresentando-se como um museu histórico e as coleções de Zoologia foram transferidas para o recém criado Departamento de Zoologia do Estado de São Paulo e atual Museu de Zoologia da USP (CARNEIRO, 2009):

voltado para a civilização das massas, dividindo suas atenções entre o passado colonial paulista, a epopéia bandeirante e a sofisticação social e intelectual do período cafeeiro. A glorificação de personagens oitocentistas, como Carlos Gomes, Bernardino de Campos e Santos Dumont completava o quadro (ELIAS, 1996 apud CARNEIRO, p.46).

Apresentando uma fase de intercâmbio de pesquisadores e publicações com os museus europeus e norte-americanos e mantendo coleções arqueológicas relacionadas à história natural, essas instituições perduraram até 1930, quando foram esvaziadas em virtude do movimento dos etnólogos e arqueólogos que passaram a desenvolver pesquisas nas recémestabelecidas universidades (LOPES, 1993; BRUNO, 1995; CARNEIRO, 2009).

Os objetos provenientes das primeiras pesquisas arqueológicas no país foram tratados segundo modelos da Arqueologia colonial europeia do século XVIII, destacando seu exotismo em relação aos padrões culturais europeus: Arqueologia do Outro, como apontado por Barreto (1999):

A história da arqueologia brasileira é a história do confronto do brasileiro com seu passado cultural. Por isso reflete a ambigüidade a que se refere Antonio Cândido na nossa cultura. A arqueologia brasileira fica entre uma arqueologia do 'outro' (o outro, no caso, sendo sobretudo o indígena), e uma arqueologia 'de nós mesmos' na qual uma real identificação cultural com as sociedades passadas estudadas (BARRETO, 1999, p.204.).

A perspectiva essencialmente colonialista, de incentivo ao estudo das antigas culturas indígenas, no sentido de fortalecer a imagem de um país vasto, diversificado, e cheio de 
riquezas naturais e sem qualquer uso social e político, continua preponderante mesmo com a vinda da corte ao Brasil no início do século XIX (LOPES, 1993; BARRETO, 1999):

\begin{abstract}
A arqueologia nasce no Brasil esvaziada de sentido político quanto à identificação da sociedade com o passado estudado, contrastando fortemente com uma outra tradição latino-americana, tanto em países andinos quanto no México, na qual a preservação e o estudo do patrimônio arqueológico tornaram-se, ao longo da história, instrumento quer de resistência política ao colonialismo europeu, quer de afirmação de ideologias nacionalistas, anti-coloniais e revolucionárias (BARRETO,1999, p.205).
\end{abstract}

A Arqueologia foi concebida com mais próxima das práticas classificatórias das ciências naturais, da história natural implantada no país, sobretudo, por naturalistas alemães no fim do século XIX e início do XX, sem relações com movimentos com interesses políticos ou ideológicos, como nos casos de países como o México e Peru, nos quais a Arqueologia assumiu orientações nacionalistas (BARRETO, 1999).

Após o movimento modernista das décadas de 1920 e 1930 de revalorização do passado nacional e de nossas raízes pré-coloniais, rompendo com o modelo de cultura nacional europeizado, o patrimônio arqueológico passa a ser revalorizado dentro de um novo contexto mais amplo de patrimônio cultural nacional, as pesquisas arqueológicas começaram a receber apoio governamental para a formação de quadros e para a criação de diversos centros universitários com a participação de equipes estrangeiras. No entanto, elas surgem dentro das universidades à margem dos projetos mais amplos de ensino das Ciências Sociais no Brasil e a partir de ações de alguns intelectuais (BARRETO, 1999, p. 207).

Enquanto o campo da Antropologia e o estudo das sociedades indígenas floresceram no Brasil a partir dos anos 1940 com Lèvi-Strauss e Radcliffe-Brown, a Arqueologia no Brasil desenvolveu-se sem incorporar as teorias estruturalistas ou funcional-estruturalistas e seguiu o modelo francês, como o estudo do passado pré-histórico humano, isto é como PréHistória:

\footnotetext{
'com uma sub-disciplina da História (como Pré-História), jamais como uma ciência social ou, mais especificamente como Arqueologia', mantendo-a 'isolada da 'Arqueologia Social' desenvolvida e compartilhada por comunidades arqueológicas em países como a Venezuela, a Colômbia, o Peru e o México' (BARRETO, 1999, pp.208 e 209).
}

Intelectuais como Castro Faria, Loureiro Fernandes e Paulo Duarte, a partir de seus contatos internacionais, promoveram a vinda de missões estrangeiras para a realização de pesquisas acadêmicas em convênio com suas instituições de pesquisa, episódio considerado por vários autores como o início da pesquisa arqueológica acadêmica no país (CARNEIRO, 2009). Dentre os arqueólogos estrangeiros estavam Joseph Emperaire e Annette Laming que escavaram os sambaquis no Paraná e em São Paulo a convite de Paulo Duarte; Wesley R. 
Hurt Jr, com estudos em conjunto com Castro Faria na região da Lagoa Santa; e o casal Clifford Evans e Betty Meggers ${ }^{35}$ e Paul Hilbert com trabalhos na Amazônia:

(...) enquanto os arqueólogos brasileiros se dedicaram a um único e vasto projeto de
levantamento de dados empíricos e se esforçaram em padronizar uma metodologia
relativamente simples com o PRONAPA (Dias, 1995), outros países das terras
baixas da América do Sul, quer por terem mantido contato com outros grupos de
arqueólogos americanos, ou quer por terem desenvolvido projetos mais orientados
por questões teóricas, acabaram com uma arqueologia mais diversificada e
modernizada na coleta de dados empíricos (BARRETO, 1999, p.210).

O PRONAPA (depois o PRONAPABA na Amazônia) criado a partir da ação do IPHAN em conjunto com a Smithsonian Institution, que agrupou pesquisadores do Sul e do Nordeste do país sem vinculação institucional e também do Museu Paraense Emílio Goeldi, promoveu, no período de 1965-1971, o mapeamento de sítios arqueológicos por todo o Brasil, para um quadro da ocupação pré-histórica no país.

Foram também várias e importantes as iniciativas de Paulo Duarte, Loureiro Fernandes e Castro Faria, ao longo das décadas de 1950 a 1970, relacionadas à legislação preservacionista e à divulgação científica (CARNEIRO, 2009).

Funari (1999-2000) destaca no intelectual Paulo Duarte seu humanismo baseado em uma abordagem ética para com a sociedade por propor, na sua época, medidas como o desenvolvimento de instituições arqueológicas acadêmicas e a proteção do patrimônio, que gestou uma legislação protecionista que aprofunda raízes até o presente.

Por outro lado, as pesquisas arqueológicas das universidades e mesmo os grupos de pesquisadores que participaram tanto do PRONAPA quanto do PRONAPABA na década de 1980, também não discutiram problemas preservacionistas e aqueles relacionados a processos de comunicação e difusão à sociedade, os quais continuaram quase que exclusivamente a cargo dos museus (CARNEIRO, 2009).

O serviço educativo estruturado pelo Museu Nacional o foi com base nos princípios da Escola Nova (ou escolanovismo), introduzida no Brasil a partir dos anos 1920 por Anísio Teixeira. As origens do papel pedagógico dos museus estiveram totalmente relacionadas aos ideais escolanovistas e às questões dos movimentos de Educação Popular e de Educação Permanente deflagrados no fim da década de 1950 (CARNEIRO, 2009).

Caracterizadas pela explicitação do sentido político da educação (LOPES, 1991), as experiências do "Método Paulo Freire" - apresentado por Paulo Freire, em 1970, no livro Pedagogia do Oprimido - pregavam a libertação, a emancipação, a autonomia, o diálogo, a

\footnotetext{
${ }^{35}$ Embora os americanos Betty Meggers e Clifford Evans tenham iniciado suas pesquisas na Amazônia na década de 1940, atuaram na formação de arqueólogos brasileiros a partir da década de 1960. (CARNEIRO, 2009).
} 
crítica, a democratização, a cidadania e a conscientização para a educação de cidadãos pobres, analfabetos e oprimidos.

Esses movimentos, embora apresentassem diferenças significativas entre si, problematizavam a educação fundamental comum, principalmente a dirigida a adultos, " [...] como uma tentativa de propor caminhos que superassem os programas paliativos de alfabetização que se sucediam no país" (CARNEIRO, 2009, p. 43).

Os movimentos de educação popular caracterizam-se por explicitar o sentido político da educação, por rebelarem-se contra o poder e a rotina das formas de ensino e trabalho, rompendo com as formas tradicionais do ensinar-aprender e com a institucionalização da cultura, que é o que inibe o seu potencial criativo. (BRANDÃO, 1996 apud CARNEIRO, p. 43).

Em 1958, o ICOM dedicou ao tema Museu-Educação e realizou várias reuniões com a preocupação de discutir o papel pedagógico do Museu e, no final da década de 1960, o MEC formou uma comissão de museólogos e educadores para diagnosticar potencialidades educacionais dos museus brasileiros. (CARNEIRO, 2009).

Entretanto, a Educação Permanente, nos anos de 1960, que foi disseminada pela UNESCO e que passou a fundamentar a concepção de museus como "agências educativoculturais" em uma "ilha de educação permanente", que visava possibilitar tanto o "atendimento educativo alternativo, de natureza não-convencional”, como o “desenvolvimento de ações complementares ao ensino formal” (LOPES, 1991, p.13).

A proposta de Educação Permanente, com forte vínculo com os ideais escolanovistas, tinha como um dos principais representantes no Brasil, Pierre Furter, que preconizava a substituição nos países periféricos do Ensino Regular pela Educação Continuada (Permanente), tornando-se a principal forma de educação, para a garantia de uma formação cultural (LOPES, 1991). No Brasil, foi vista como uma possibilidade de superação do subdesenvolvimento, pois poderia representar um avanço em termos tecnológicos rumo à industrialização e modernização do país (CARNEIRO, 2009).

Os museus brasileiros envolveram-se menos com as práticas de Educação Popular e mais com projetos e propostas europeias ligadas às discussões no contexto da Educação Permanente, que se apresentou como uma solução parcial ou mesmo complementar para os impasses da universalização do ensino formal na busca de tentar "resolver" a incapacidade estrutural da escola em garantir o processo de formação cultural (LOPES, 1991, p.13; CARNEIRO, 2009).

Em meados de 1980, o Programa Nacional de Museus foi estabelecido pelo Ministério da Cultura, como um órgão coordenador das ações desenvolvidas pelos museus e adotou a 
promoção de ações para complementação do ensino formal, como agências educativoculturais:

A partir deste cenário fica claro o caminho que se desenvolveu para uma escolarização dos serviços educativos nos museus brasileiros. Por um lado, as escolas foram incentivadas a buscar nos museus a ilustração, via contato direto com o acervo, dos conteúdos trabalhados em sala de aula e, por outro lado, os museus viram-se responsáveis em atender essa demanda - de complementaridade ao ensino formal e de comprometimento com as perspectivas escolares, uma vez, também, que não estavam envolvidos com políticas culturais e educacionais, reduzindo suas várias e específicas possibilidades de atuação (CARNEIRO, 2009, p.40).

Por outro lado, a Sociomuseologia ou Nova Museologia (BRUNO, 1995; 2001), também influenciada pela pedagogia popular (de Paulo Freire), embora muito mais em âmbito internacional que nacional, a partir da década de 1970, realizou discussões que se centraram na reflexão sobre o papel social dos museus, deslocando o interesse pela formação de coleções para as relações estabelecidas entre o indivíduo e o objeto patrimonial (sociedade e patrimônio) como fonte geradora de processos museológicos (BRUNO, 1995). ${ }^{36} \mathrm{E}$ os museus voltaram a ser foco de interesse para os estudos antropológicos e também enquanto análise dos discursos museológicos e museográficos. Engajando-se com questões sociais: de vertentes evolucionistas passaram a uma tendência de auto-representação cultural com os museus comunitários e étnicos, por exemplo (ABREU, 2005 apud CARNEIRO, 2009).

\subsection{Educação Patrimonial}

A expressão Educação Patrimonial (Heritage Education) foi formulada pela primeira vez no Brasil em 1983, a partir de um seminário realizado no Museu Imperial, em Petrópolis, no Rio de Janeiro (HORTA, 2005; HORTA et. al., 1999).

Nesse seminário, apresentou-se uma metodologia inspirada em uma iniciativa pedagógica adotada na Inglaterra desde os anos 1970 de uso de fontes primarias como ferramenta didática nas escolas (evidence-based history) para o ensino de História (SILVEIRA; BEZERRA, 2007) e de experiência de uso educacional de museus e monumentos (HORTA, 2005). ${ }^{37} \mathrm{E}$ ao conceito foi atribuído "o marco zero de trabalho com o

\footnotetext{
${ }^{36} \mathrm{O}$ modelo de museu fórum também se fundamenta no movimento de aproximação da Arqueologia com a sociedade, visando um processo transformador da realidade social (CARNEIRO, 2009).

${ }^{37} \mathrm{O}$ uso de fontes primárias na escola era a piece de resistence do Schools Council Project desenvolvido na Inglaterra nos anos 1970. Embora o Conselho não exista mais, a proposta de apropriação da cultura material como instrumento de aprendizagem ainda hoje é adotada em muitas escolas (SILVEIRA; BEZERRA, 2007).
} 
patrimônio cultural" (CARNEIRO, 2009, p.40), muito embora, segundo Chagas (2004, p.144):

Ao se fazer herdeira da heritage education, a educação patrimonial abriu mão de um diálogo possível e possivelmente fértil com os museólogos, antropólogos, sociólogos, psicológicos e filosóficos e educadores brasileiros. Esse formato de educação patrimonial desconsidera uma série de trabalhos anteriores (...). Nos últimos vinte anos, a expressão 'educação patrimonial' consagrou-se no Brasil. E consagrou-se não como metodologia, mas como campo de trabalho, reflexão e ação. A expressão educação patrimonial foi antropofagizada. Nesse sentido, as reflexões e práticas educativas desenvolvidas por uma série de profissionais (...) que tomam como ponto de partida a relação de indivíduos e grupos sociais com o patrimônio cultural (material e imaterial) - fazem parte desse campo amplo. Conclusão: a ideia de um marco zero para a educação patrimonial foi devorada e agora está sendo regurgitada com novas significações (CHAGAS, 2004, p.144).

Concordamos com Mário Chagas (2006, p.47) quando fala, no artigo Educação, museu e patrimônio: tensão, devoração e adjetivação, que a "educação é uma prática sóciocultural", não havendo como dissociar a prática educativa da ideia de cultura e patrimônio, pois "todo processo de educação relevante não pode se ater a uma formação exclusivamente livresca, é preciso o contato direto com as manifestações culturais":

Não há hipótese de se pensar e de se praticar a educação fora do campo do patrimônio ou pelo menos de um determinado entendimento de patrimônio. Por este prisma, a expressão 'educação patrimonial' constituiria uma redundância, seria o mesmo que falar em 'educação educacional' ou 'educação cultural'. No entanto, não se pode negar que a referida expressão tenha caído no gosto popular. Resta, neste caso, compreender os seus usos e os seus significados (CHAGAS, 2006, p.44).

A Educação é resultado da ação de todo o meio sociocultural sobre um indivíduo. As relações com a família, a casa, a rua, os amigos, o cotidiano do trabalho, todos os aspectos da vida são fundamentais para a formação de um sujeito (CHAGAS, 2006). Os homens se educam uns aos outros mediados pela cultura (FREIRE, 1966; 2006).

Ao participar do ato educativo, dentro ou fora do espaço legitimado pela escola, cada pessoa traz consigo o seu patrimônio cultural individual e aquele construído coletivamente na sua casa, na sua rua, no seu bairro, na sua cidade, no seu estado. E este se encontra com o patrimônio cultural das outras pessoas com as quais se relaciona e com um patrimônio herdado, legitimado pela sociedade e também pela escola. A aprendizagem é um processo de interação e interlocução do homem com o seu ambiente e com os outros homens, na busca de atribuir sentido ao mundo em que vive (SIVIERO, 2014).

As discussões relacionadas à Educação Patrimonial também estão associadas às questões preservacionistas: à valorização e à preservação do patrimônio cultural; e embora a expressão tenha sido comumente usada ao se tratar de práticas educacionais que têm por base 
determinados bens ou manifestações, considerados patrimônio cultural (FUNARI; PELEGRINI, 2006).

A Educação Patrimonial esteve presente em práticas museológicas do século XIX, no serviço educativo do Museu Nacional, formalmente criado em 1926, e de tantas outras instituições museais modernas e contemporâneas (CARNEIRO, 2009), passando a nomear inclusive boa parte das ações educativas desenvolvidas na área da Arqueologia, pelos projetos PARANAPANEMA e PRONAPA, por exemplo. ${ }^{38}$ (MORAIS, 2011; BASTOS, 2010).

Extrapolou as experiências museais, generalizando-se e tornando-se um campo de atuação em instituições da cultura, de memória e sociais. E está presente no Ensino Formal a partir dos Parâmetros Culturais Nacionais - PCN. ${ }^{39}$

Além dos PCN, seus objetivos convergem com as diretrizes da educação nacional da Constituição Federal e com a Lei de Diretrizes e Bases (LDB). E também com as matrizes de competências e habilidades estipuladas pelo INEP - Instituto Nacional de Estudos e Pesquisas Educacionais Anísio Teixeira e solicitadas em seus Exames Nacionais para Certificação de Competências de Jovens e Adultos e no Exame Nacional do Ensino Médio (ENEM/INEP) ${ }^{40}$, nos quais são presentes os diferentes aspectos da cultura, configurando-se em importante e reconhecido eixo cognitivo para a formação da identidade e da cidadania.

A Educação Patrimonial lida com a noção polissêmica de patrimônio ${ }^{41}$, e, assim, com as complexas nuances histórico-culturais envolvidas no fenômeno da (i)materialidade dos

\footnotetext{
${ }^{38}$ As origens do projeto Parapanema, realizado junto às comunidades da bacia do Paranapanema, remontam ao final da década de 1960 e às pesquisas empreendidas pela arqueóloga Luciana Palestrini. Teve continuidade na década de 1980, com as pesquisas do arqueólogo José Luiz de Morais (KASEKER, 2014). Ver: MORAIS, 2011.

${ }^{39}$ Muito embora se saiba que há pouca participação da escola como produtora de ações de e sobre a Educação Patrimonial.

${ }^{40}$ Entre as matrizes de competências de História e Geografia, do Ensino Fundamental, que contemplam os aspectos da cultura, destaca-se a de Compreender a importância do patrimônio cultural e suas relações com a organização da sociedade, para a qual se incluem as habilidades, como: (H11) Identificar características do patrimônio cultural ao longo da história; (H12) Identificar a presença dos recursos naturais na organização do espaço geográfico, relacionando transformações naturais e intervenção humana; (H13) Interpretar os significados de diferentes manifestações populares como representação do patrimônio regional e cultural; (H14) Analisar a diversidade morfoclimática do território brasileiro e as implicações sociais e ambientais do uso das tecnologias em diferentes contextos histórico- geográficos. (H15) Identificar propostas que reconheçam a importância do patrimônio cultural, tendo em vista a preservação das identidades nacionais e do meio físico; entre outras. Ver: http://www.inep.gov.br/> Acesso em: 02 mar 2016.

${ }^{41}$ A consideração no. 2 da Carta de Nova Olinda resultante do I Seminário de Avaliação e Planejamento das Casas do Patrimônio traz a seguinte contribuição para o entendimento da dimensão multifacetada do patrimônio cultural e, consequentemente, da Educação Patrimonial: "As ações educativas a serem implementadas nas Casas do Patrimônio [estratégia de descentralização das ações do IPHAN voltadas para projetos pedagógicos, tendo essas casas como pólos de referência local e regional] e por ela empreendidas se estruturam a partir de diferentes perspectivas e abordagens e em cujas ações de preservação convivem noções de patrimônio, que ao mesmo tempo se confrontam e se complementam...”. Disponível em:

<http://portal.iphan.gov.br/portal/montarPaginaSecao.do?id=15489\&retorno=paginaIphan> Acesso em $02 \mathrm{mar}$ 2016.
} 
bens patrimoniais (SILVEIRA; BEZERRA, 2007). Antes de interpretarmos as paisagens e os objetos como bens patrimoniais, devemos considerar que tais elementos estão imersos numa complexa teia de significações relacionadas ao contexto sócio-histórico em que aparecem; e podem ser protegidos muito mais pelo que significam e representam do que em relação a seus valores estéticos e de antiguidade (ZANIRATO, 2009, 2011). O patrimônio pode ser condição essencial para a manutenção do sentimento de enraizamento do sujeito com o espaço em que habita e para a configuração de suas identidades (ZANIRATO, 2009, 2011).

Assim também não devemos separar a Educação Patrimonial da discussão sobre práticas educativas e concepção de Educação, voltando-se apenas às questões do universo da cultura (SCIFONI, 2012), mesmo por que a Educação continua a se submeter às práticas de racionalização e a se apresentar predominantemente conteudista (FRANCO, 2010).

Concordamos com SILVEIRA; BEZERRA (2007, p.93) quando dizem que o conceito de Educação Patrimonial deve "servir como sinal que nos obriga a questionar o papel da educação na constituição do patrimônio, o papel do patrimônio no processo educativo e a função de ambos na dinâmica social que articula a lembrança e o esquecimento". Mas, deve ir além de difundir conhecimentos e informações, deve construir uma relação com as comunidades para possibilitar a apropriação social de conhecimentos tendo o patrimônio como suporte, apresentando-se como um campo ampliado de atuação que incorpora outras ações diversificadas educativas em especial aquelas participativas, "que possam permitir a inserção da população local no desafio de pensar a proteção dos bens referenciais de sua memória coletiva" (SCIFONI, 2012, p.37).

A proteção, a valorização e a seleção dos bens culturais devem ser construções coletivas, baseadas nas significações e nos valores que lhes são dados por diferentes setores da sociedade. Os mecanismos e instrumentos de preservação disponibilizados pelo Estado hoje - tombamento, registro de manifestações culturais e chancela de paisagem cultural dependem do significado e do valor simbólico que a sociedade atribui a esses bens. E o caminho para esse envolvimento e participação passa pela Educação, que deve promover processos de reflexão e do sentimento de pertencimento da sociedade.

São inúmeras as ações na área de Educação Patrimonial hoje desenvolvidas no Brasil por instituições públicas (CARNEIRO, 2009), organizações não governamentais e particulares (ROBRAHN-GONZÁLEZ, 2005), por municípios, dentre outras iniciativas dispersas em suas localidades de origem e que revelam uma multiplicidade de estratégias possíveis de ações educativas no campo do patrimônio cultural. Por outro lado, há uma 
carência de reflexão teórica e crítica sobre Educação Patrimonial ${ }^{42}$, que considere os dois sentidos que carrega: Educação e Patrimônio - ambos campos de enfrentamento políticoideológico (SCIFONI, 2012).

Freire (2011) apontou dois caminhos da "ação cultural": a serviço da dominação para manter a estrutura social como está; e outra que levaria à libertação dos homens, à transformação da realidade. E é essa tomada de posição política que a Educação Patrimonial deve fazer.

Desde a criação, em 2004, da Gerência de Educação e Projeto no IPHAN e com I Encontro Nacional de Educação Patrimonial realizado em 2005, em São Cristovão - SE, a Educação Patrimonial tem sido alvo de debates para a elaboração de diretrizes e de um desenho de uma política institucional para o campo (CASCO, s/d).

Anteriormente, foi presente no projeto "Interação entre a educação básica e os diferentes contextos culturais existentes no país”, criado pela Fundação Nacional PróMemória, e que fez parte do Centro Nacional de Referência Cultural - CNRC ${ }^{43}$, originalmente apresentado, em Brasília, em seminário com representantes dos órgãos ligados a então Secretaria da Cultura do MEC, em 1981 (IPHAN, 2014).

O projeto preconizava a participação da comunidade no processo educacional, procurando garantir a apreensão de conteúdos culturais a partir dos seus próprios valores, “através da interação do processo educacional às demais dimensões da vida comunitária e da geração e operacionalização de situações de aprendizagem com base no repertório regional e local” (BRANDÃO, 1996, p.293).

Almejava diminuir a distância entre a educação escolar e o cotidiano dos alunos, potencializando atividades das artes em geral, esportes, dos museus e dos locais históricos como ferramentas pedagógicas e atribuindo o estatuto de cultura às experiências que o aluno trazia de seu cotidiano (SILVEIRA; BEZERRA, 2007, p. 82).

Os recentes debates organizados e coordenados pelo IPHAN com representantes da sociedade civil, movimentos sociais e outros órgãos públicos, esferas de governo apresentaram a Educação Patrimonial como uma arena e uma prática político-social, em que o patrimônio cultural é apropriado como recurso pedagógico, oportunizando construção coletiva

\footnotetext{
42 O Guia Básico de Educação Patrimonial, publicado pelo IPHAN em 1999, apresenta-se e ainda acaba sendo usado por projetos na área como um preponderante referencial teórico.

${ }^{43} \mathrm{O}$ CRC foi resultado de discussões promovidas por funcionários do governo federal e do Distrito Federal na década de 1970 sobre preservação, modelos de desenvolvimento econômico e valorização da diversidade regional. (IPHAN, 2014). Propunha a formulação de um sistema de referência básico nacional a partir da coleta, processamento e divulgação de informações sobre a cultura brasileira (IPHAN, 2014), apostando na cultura como princípio norteador do ensino e aprendizagem (FONSECA, 2005, p.157).
} 
e democrática de conhecimento e afirmação e fortalecimento de alteridades e de vínculos de identidade e pertencimento (IPHAN, 2014; SIVIERO 2014).

Hoje há iniciativas da sociedade e de movimentos sociais de elencar e atribuir valores a bens a serem preservados e encaminhar propostas de tombamento e registros, resultantes talvez de uma disposição da sociedade em compartilhar as ações de preservação do Patrimônio Cultural Brasileiro (CASCO, s.d) ${ }^{44}$.

O contexto sócio-político nos campos da preservação e da Educação Patrimonial tem sido de iniciativas advindas da sociedade organizada e voltadas para a preservação do patrimônio e da memória de grupos sociais, sobretudo em situações de risco e abandono; e de demandas por uma ação estatal ao menos quanto a diretrizes e normas. Há, no Brasil, uma política de patrimônio voltada para educação ou de uma política de educação voltada para a preservação do patrimônio que considera o diverso universo onde as ações acontecem, tais como: a Educação Formal, o dos espaços culturais e museus e as iniciativas da sociedade em geral (CASCO, s/d).

Mas, por outro lado, ainda são necessárias diretrizes que orientem a ação institucional em Educação Patrimonial e mecanismos estatais de "escuta acurada" e de canais efetivos de participação da sociedade para ela gerar, alimentar e reproduzir seus bens culturais e patrimoniais. Ao Estado caberia "esclarecer, informar, tornar transparentes seus processos e mecanismos de atuação" e à sociedade "cobrar, fiscalizar, usar com criatividade a liberdade que tem de buscar alternativas para responder à realidade", de interagir com o meio em que vive (CASCO, s/d, p.8).

A Educação Patrimonial, após o mencionado esforço de conceituação e de estabelecimento de diretrizes pelo IPHAN, envolvendo uma rede de interlocutores que lidam com ações de valorização e preservação do patrimônio cultural nos dois Encontros Nacionais de Educação Patrimonial (de 2005 e de 2011, em Ouro Preto-MG), foi considerada "todos os processos educativos formais e não-formais, que têm como foco o patrimônio cultural em todas as suas manifestações, com o objetivo de colaborar para o reconhecimento, valorização e preservação dos bens culturais como recurso para a compreensão do presente e sua articulação com o passado e projeção para o futuro", devendo primar pela construção coletiva e democrática do conhecimento, por meio do diálogo permanente com os agentes sociais e pela participação efetiva das comunidades detentoras das referências culturais, onde convivem noções de patrimônio cultural diversas (IPHAN, 2014).

\footnotetext{
${ }^{44}$ Merece destaque também o trabalho que tem sido desenvolvido pela REPEP - Rede Paulista de Educação Patrimonial. Ver: http://repep.fflch.usp.br/.
} 
A educação que se vislumbra é aquela que se caracteriza como Mediação para a construção coletiva do conhecimento, a que identifica a comunidade como produtora de saberes, que reconhece, portanto a existência de um saber local. Enfim, a que reconhece que os bens culturais estão inseridos em contextos de significados próprios associados à memória local (FLORÊNCIO, 2012, p.27).

Com a reestruturação do IPHAN em 2009 e com o Departamento de Articulação e Fomento (DAF), a Gerência de Projetos e Educação, criada em 2004, tornou-se Coordenação de Educação Patrimonial - CEDUC (OLIVEIRA, 2011). A CEDUC, segundo Oliveira (2011, p.28), “considera a educação patrimonial como tema de trabalho transversal e proposta política. No que se refere ao conceito, acredita que são oportunidades para discutir e construir a valorização e proteção do patrimônio cultural. Isso faz com que um amplo espectro de atividades seja considerado educação patrimonial":

De um modo geral observamos que as discussões realizadas apontam para o fato de
que a educação não deve ser tratada por um único método ou modo de observar e
tratar o patrimônio cultural. Entendemos ser de grande importância considerar
sempre a possibilidade de construções locais, por atores locais, articulando-as a
experiências em curso em nível nacional e internacional. Parece-nos que o modelo
que temos internalizado não é esse e que precisamos, também, aprender a exercitar
essa outra maneira, mais democrática e participativa que reivindicamos (IPHAN,
2008 apud ARÉVALO, 2013, p.25).

Assim, espera-se que a educação assuma seu papel de agente no processo social, produtora de saber e não apenas consumidora e reprodutora de conhecimentos dados, contribuindo para a formação de sujeitos construtores de sua própria vida também coletiva e que se relaciona com cidadania, participação, responsabilidade e pertencimento (CASCO, s/d), na medida em que colabore para que as comunidades por elas mesmas tenham condições de valorizar os bens patrimonializáveis nos seus projetos de desenvolvimento (SILVEIRA; BEZERRA, 2007).

A participação dos grupos sociais vinculados aos bens por intermédio de práticas sociais e simbólicas cotidianas pode permitir que estes valorizem a sua cultura atual ou ancestral, sem torná-los como "pessoas que necessitam da luz do conhecimento para aclarar suas consciências obtusas", e resultar em experiências de sensibilização e participação crítica acerca do valor patrimonial que tais grupos humanos detêm (SILVEIRA; BEZERRA, 2007, p.87).

A partir da perspectiva dos bens culturais e as relações das pessoas reveladas e informadas por eles que a pesquisa-ação promoveu com a colaboração e participação de 
atores sociais de Santo Amaro um exercício de levantamento (inventário) de bens culturais de natureza material e imaterial. ${ }^{45}$

Esse processo, que é apresentado e analisado nos próximos dois capítulos, foi resultado das ações de Educação Patrimonial desenvolvidas com base na Aprendizagem Social na região e que, além de evidenciarem nos bens patrimoniais protegidos em Santo Amaro o conceito e a abordagem de Patrimônio Ambiental Urbano e seu destaque aos artefatos materiais, revelou a riqueza da dimensão imaterial desse patrimônio, que não é e nem pode ser tratado como algo isolado da vida das pessoas no passado e no presente. $\mathrm{O}$ patrimônio envolve, inclusive, a transmissão de valores para o futuro (ARÉVALO, 2013).

[...] valor cultural não está nas coisas, mas é produzido no jogo concreto das relações sociais. [...] o que chamamos de bens culturais não têm em si sua própria identidade, mas a identidade que os grupos sociais lhe impõem (MENESES, 1992, p.93).

O Inventário de Bens Culturais foi desenvolvido mediado por metodologias participativas e colaborativas e sob a responsabilidade de uma Comunidade Ampliada de Pesquisa composta pelos verdadeiros detentores dos patrimônios locais, partindo do pressuposto da inclusão desses novos protagonistas na formulação de planos de salvaguarda. Prata (2009) destaca que apenas a conservação material e o trabalho técnico não têm sido suficientes para o sucesso das políticas de preservação do país, que devem, inclusive, considerar o uso, as apropriações, as relações territoriais e a função social do patrimônio a ser preservado.

\subsection{A Abordagem da Aprendizagem Social e Comunidades de Práticas}

As transformações sociais em curso demandam cada vez mais concepções interdisciplinares para orientar tanto estratégias de pesquisa como de formação de políticas ambientais e de desenvolvimento sustentável, devendo-se reconhecer os efeitos das políticas econômicas vigentes sobre a dinâmica dos ecossistemas e sobre as condições de vida das sociedades (FUNTOWICZ \& RAVETZ, 1997; SACHS, 2007).

Hoje faz-se importante potencializar outras racionalidades; fortalecer conteudos e conhecimento baseados em valores e práticas sustentáveis, indispensáveis para estimular o

\footnotetext{
45 Após o IPHAN instituir o Registro do Patrimônio Imaterial pelo Decreto 3551 de 2000, passou a elaborar o Inventário Nacional de Referências Culturais. Até 2013, tinham sido registrados 28 bens imateriais. O primeiro foi o ofício das paneleiras de Goiabeiras, em Vitória (ES) (IPHAN, 2013).
} 
interesse, o engajamento e a responsabilização; refletir sobre os desafios que estão colocados para mudar as formas de pensar e agir em torno da questão ambiental (JACOBI, 2013, p.01).

Entretanto, a restrita consciência na sociedade a respeito das implicações do modelo hegemônico de desenvolvimento gera necessidade de mudança no acesso ao conhecimento, à informação, transformações institucionais e a lógica de governança governamental $^{46}$ e corporativa, e a formação de lideranças focadas nas premissas que norteiem a construção de uma sociedade sustentável (JACOBI, 2013).

A pesquisa-ação partiu do pressuposto de que a Educação Patrimonial podia e devia ser encarada e praticada de forma a colaborar no estabelecimento de corresponsabilidade entre Estado e sociedade civil na identificação, reconhecimento, proteção e preservação do patrimônio cultural. Não somente a inserção das comunidades na política preservacionista, mas também a apropriação por parte dos diversos grupos sociais da linguagem e dos instrumentos dessa política, buscando promover uma prática educativa que reconheça, valorize e fortaleça a diversidade cultural, as identidades e as alteridades (SIVIERO, 2014).

Na Educação Patrimonial, o diversificado patrimônio cultural atua como recurso para as discussões sobre a sua importância/relevância para a identidade, bem como sua necessária proteção em benefício das gerações futuras, podendo favorecer a aprendizagem e uma cultura de participação.

A Educação Patrimonial no Brasil tem como desafio lidar com o fato da população nem sempre se identificar ou se enxergar no patrimônio cultural nacional, que é resultado histórico de uma fraca participação social em todo o processo de gestão da preservação do patrimônio (da eleição de bens à definição de usos e sua conservação) e que tem culminado na sua imagem negativa e dos órgãos de preservação pela população que desconhece os valores atribuídos aos bens preservados e que não se reconhece neles.

Concordamos com Scifoni (2012), quando diz que a Educação Patrimonial pode estar dentre as formas de aproximação entre os órgãos de preservação do patrimônio cultural e a sociedade, exercendo um papel estratégico na experiência de construção coletiva de um patrimônio nacional. Isto na medida em que não seja entendida como atividade de divulgação e de transmissão de informações pós-tombamentos, e não ignore o saber empírico local e a relação que as populações estabelecem com os lugares e os patrimônios.

\footnotetext{
${ }^{46} \mathrm{O}$ conceito de Governança está relacionado com a implementação socialmente aceitável de políticas públicas, um termo mais inclusivo que governo, por abranger a relação Sociedade, Estado, mercado, direito, instituições, políticas e ações governamentais (JACOBI, 2013, p.2).
} 
Para a construção real de práticas capazes de estruturar as bases de uma sociedade sustentável, na perspectiva da valorização do caráter social do aprendizado, é que se coloca a necessidade de fortalecimento da Aprendizagem Social (GLASSER, 2007) e das Comunidades de Prática, como grupos de pessoas que interagem em ações e discussões, apóiam-se mutuamente, trocam informações e aprendem juntos, desenvolvendo um repertório compartilhado de experiências, histórias, ferramentas e de modos de lidar com problemas (WENGER, 1998; 2000).

Glasser (2007) considera como desafio criar oportunidades de aprendizagem social ativas, de forma que o envolvimento dos participantes favoreça a percepção da diversidade de opiniões e visões de mundo, a mediação de interesses individuais e coletivos, e a possibilidade de ampliação de repertórios que aumentem a capacidade de contextualizar e refletir.

Jacobi, Tristão e Franco (2009) destacam que a instalação de espaços de convívio entremeados pela experiência de pensar e agir de forma dialógica, solidária e ecologicamente sistêmica cria solo fértil para a cultura da participação e para a interlocução ativa entre atores, muito embora o sistema educacional frequentemente articule o ensino como se o aprendizado fosse um processo individual e desconectado das demais experiências da vida.

A Aprendizagem Social tem se revelado veículo importante na construção de uma nova cultura de diálogo e participação, podendo ser um elemento inovador para a construção de pactos de governança entre poder público e sociedade para a gestão ambiental numa perspectiva de avanço rumo à sustentabilidade socioambiental (JACOBI, 2006, 2013).

Pode-se definir Aprendizagem Social como o processo de aprendizagem no nível de grupo por meio de práticas que estimulam a interação social (WENGER, 2000; WOODHILL, 2002, CRAPS, 2003, ISON et al., 2004).

Wenger $(1998 ; 2000)$ aponta que é na perspectiva da valorização do caráter social do aprendizado e dos aspectos colaborativos envolvidos que as "Comunidades de Prática" podem ser analisadas como promotoras de aprendizagem, enfatizando que grande parte do dia a dia do indivíduo se dá dentro delas. Destaca o aprendizado como um fenômeno que reflete a natureza social do homem, no contexto de suas experiências de participação no mundo e recomenda que se pense em formas criativas de engajar os indivíduos em práticas significativas, em meios para que possam criar "comunidades de prática”, ingressar nas que já existem e ampliar sua interação naquelas em que já participam, vinculando-as como uma ação estratégica para alargar o potencial de aprendizagem e de formação de identidade e para 
enriquecer as próprias comunidades, beneficiando tanto o indivíduo quanto o coletivo (WENGER, 1998; 2000).

Para Jacobi (2013, p. 10):

Perceber a aprendizagem como ligada à vida, ao aprender vivendo, é reconhecer que não é apenas nas atividades especialmente programadas para o ensino que ela ocorre. Estes espaços tornam-se mais férteis quando, por intermédio do diálogo, todos se dispõem a dizer e ouvir, ensinar e aprender, individual e coletivamente.

A Aprendizagem Social promove o (re) pensar de conceitos e a construção de novos conhecimentos e valores capazes de contribuir para a transformação de práticas, bem como para o desenvolvimento de novas competências, visando à gestão de problemas/conflitos socioambientais locais por meio de processos de co-aprendizagem com o uso de metodologias participativas (SANTOS; JACOBI, 2013). O conceito perpassa diversas correntes das Ciências Sociais e visa contribuir para explicitar os objetivos de todos os atores envolvidos no processo; alcançar melhores soluções (mais democráticas) para as questões socioambientais e melhores maneiras de gerenciar os conflitos (HART, 2007).

O aprendizado conjunto é fundamental para a construção de uma visão coletiva para o entendimento da complexidade das questões socioambientais que precisam ser enfrentadas, para as tarefas comuns e construção de um acordo (JACOBI, 2011). E deve ser desenvolvido dentro do contexto, como co-reflexão-prática entre os atores envolvidos, permitindo o aprendizado e intervenção conjunta, o que pressupõe a contribuição de diferentes conhecimentos, interdisciplinaridade e transversalidade (HARMONICOP, 2003; WALS, 2007; JACOBI, 2011; 2013), reforçando a dimensão da participação, compartilhamento e corresponsabilização para decidir os cenários de sustentabilidade desejados, pois

é na experiência social que se desenvolve a linguagem e o pensamento. Por intermédio da reflexão e memória, bem como da imaginação e idealização do futuro, as experiências vividas ganham novos significados. Na experiência reflexiva do ser humano é onde se assenta, assim, o seu potencial de produzir cultura e intervir na história. Se entendermos as experiências de vida como berço das interações socioambientais que o indivíduo estabelece na formação contínua de sua identidade, veremos que a formação da consciência ambiental e o engajamento nas causas ecológicas estão associados à disponibilidade e à qualidade das experiências de aprendizagem que o indivíduo vivencia (SANTOS; JACOBI, 2013, p.13).

A Aprendizagem Social implica em aprender no e do ambiente, a partir da reflexão crítica sobre os problemas e desafios comuns a todos, sobre os conhecimentos de que dispomos para resolvê-los, refletir sobre nós mesmos e sobre nossas relações com os outros, visando à negociação de interesses para o uso democrático e sustentável do ambiente. Implica, essencialmente, (re) conhecer o lugar/ambiente em que se vive (SANTOS; JACOBI, 2013). 
Pahl-Wostl (et. al, 2007) argumenta sobre a necessidade de incorporar a concepção de Aprendizagem Social, na medida em que o conceito pretende integrar os seguintes fatores: uma reflexão crítica; o desenvolvimento de um processo participativo, múltiplo e democrático; a construção de uma percepção partilhada do problema em relação ao grupo de atores sociais envolvidos; e o reconhecimento das interdependências e das interações dos atores (PAHL-WOSTL, 2002, 2007; JIGGINS, 2002).

A complexidade e incerteza das atuais realidades e os contextos de gestão demandam novas formas de governança, substituindo as tradicionais formas de sistemas baseados em lógicas hierárquicas orientadas por comando e controle por sistemas flexíveis e participativos, baseados na experimentação e na aprendizagem social entre múltiplos atores (WOODHILL 2002).

Glasser (2007) chama à atenção para a multiplicidade de abordagens que o conceito de Aprendizagem Social tem recebido, associando-o a processos de aprendizagem de indivíduos e grupos que, por intermédio de interações sociais, permitem a aquisição de novas formas de compreender e agir sobre a realidade.

A Aprendizagem Social tem adquirido importância tanto nos discursos sobre questões relacionadas ao meio ambiente quanto nas práticas educativas no contexto do desenvolvimento e gestão de recursos naturais (MOSTERT, 2003, SLIM, 2004) e em outras áreas de pesquisa, como é o caso das mudanças climáticas (WOODHILL, 2002, CRAPS \& PRINS, 2004, SLIM, 2004, WARNER, 2007). Tem sido bastante utilizada pelos pesquisadores na Europa, na análise de projetos de gestão participativa (WARNER, 2006), dentro de uma perspectiva de governança democrática, que tem nas Plataformas de Múltiplos Atores, suporte metodológico de uma formalização participativa.

WARNER (2006; 2007) define Plataformas de Múltiplos Atores como processos nos quais os grupos de interesse (stakeholders) trabalham de forma coletiva para abordar um problema comum, cooperam para resolver problemas e desacordos relacionados com ele e desenvolvem ações conjuntas em relação aos problemas percebidos. Estas plataformas podem ter duração limitada para resolver um problema específico ou assumir um caráter permanente. Seu potencial, relacionado com a participação de diversos grupos de interesse, à cooperação e à ação coletiva, tem resultado na sua aplicação com muita frequência em diversos contextos e atividades. 
Para Jacobi (2013), no processo de Aprendizagem Social não basta que os atores estejam estruturalmente envolvidos no processo decisório, importa a qualidade das relações estabelecidas, havendo a necessidade da convergência de três premissas-chave:

a) nem todos os atores isoladamente têm as informações necessárias, as competências legais e os recursos para a gestão satisfatória do recurso, o que exige a colaboração entre eles; b) a gestão de recursos naturais requer uma forma de organização, ou seja, para facilitar a colaboração e coordenar as suas ações precisa-se estabelecer um processo cooperativo orientado ao longo prazo; e c) todo o processo de gestão, com destaque para os recursos naturais, é um processo de aprendizagem de longo prazo, o que demanda o desenvolvimento de novos conhecimentos, atitudes, habilidades para lidar com as diferenças de forma construtiva, adaptar-se às mudanças e enfrentar a incerteza (JACOBI, 2013, p.18).

A Aprendizagem Social também implica que os participantes aceitem a diversidade de interesses, de argumentos, de conhecimento, e se sustenta na disseminação de informação, conhecimento e atividades em rede (WALS, 2007).

$\mathrm{O}$ aprofundamento do conhecimento e dos principais aspectos que demandam ampliação do repertório das comunidades e do poder público para o aperfeiçoamento das relações dos participantes ao ser baseado em ferramentas participativas com o estudo das realidades locais potencializa a construir e estimular processos de colaboração e interconexão entre pessoas, ideias e ações, vislumbrando um futuro mais sustentável, com base nos conceitos de aprendizagem social, diálogo, participação e co-responsabilidade (JACOBI, 2013).

A construção de agendas socioambientais locais, pesquisa-ação: aprendizagem de saberes e práticas cidadãs; jogos de papéis: da atuação ao aprendizado; world café: método de diálogo e criação coletiva; monitoramento participativo dos riachos e mapeamento socioambiental como (re)conhecimento local abrem um estimulante espaço para conhecerem lugares de vivências e de trabalho, seus problemas e conflitos, possibilitam subsidiar diálogos e reflexões coletivas sobre as diferentes percepções da realidade socioambiental (SANTOS, 2006; SANTOS; BACCI, 2011; BACCI; SANTOS, 2013).

As metodologias participativas apresentam-se como ferramentas de aprendizagem social (SANTOS; JACOBI, 2013), ${ }^{47}$ no desafio de:

\footnotetext{
${ }^{47}$ Santos (2011) destaca o mapeamento socioambiental, metodologia participativa para o (re)conhecimento do ambiente que possibilita o levantamento de dados biofísicos e socioculturais do local; promove o diálogo reflexivo sobre os dados levantados e favorece a análise crítico-propositiva frente à realidade mapeada, visando ao diálogo com os desafios à sustentabilidade socioambiental; aborda suas contribuições no estabelecimento de conexões e articulações entre os processos cognitivos e o cotidiano de diferentes atores sociais com referência na escola (professores, alunos, comunidade e gestores públicos), tanto no entendimento de problemas/conflitos socioambientais locais como no desenvolvimento de projetos/ações colaborativas capazes de relacionar educação e ambiente numa perspectiva crítica, corresponsável e promotora de ações cidadãs transformadoras para o uso democrático e sustentável do ambiente.
} 
mobilizar, sensibilizar e promover conhecimento para a ação. (...) desenvolver ambientes pedagógicos com uma atitude reflexiva, em torno da problemática socioambiental na formação de novas mentalidades, conhecimentos, valores e comportamentos (JACOBI, 2013, p. 19).

$\mathrm{Na}$ Educação para a Sustentabilidade, promotora de processos de aprendizagem de novas práticas culturais e de educação reflexiva e engajada centrada nos saberes e fazeres construídos com e não para os sujeitos "aprendentes e ensinantes", o objetivo é instaurar mudanças efetivas na realidade por meio da construção de um conhecimento crítico e “intencionalmente engajado" (JACOBI, 2013, p.4).

A sustentabilidade associada com Aprendizagem Social implica num contínuo processo reflexivo de questionamento, recusa ou reavaliação de algumas das premissas criadas socialmente, como aquelas relacionadas às noções de tempo, espaço, natureza, para alcançar uma melhora na qualidade de vida, reduzindo os impactos negativos nos sistemas socioambientais.

Também implica em "aprendizagem sobre a dinâmica de mudança do sistema humano e do ecossistema, os quadros mentais que definem o processo decisório, e as consequências biofísicas das mudanças num sistema em interação" (CRAPS, 2003 apud JACOBI, 2004), pois uma relação mais justa, harmônica e sustentável deve partir do princípio de que devemos mudar a forma com que nos relacionamos, convivemos e interagimos.

As reflexões sobre a Aprendizagem Social contribuem para pensar as inter-relações entre ciência, sociedade e ambiente, entendendo que a melhora no acesso à informação e a participação social têm promovido mudanças de atitude que favorecem o desenvolvimento de uma consciência ambiental coletiva, um importante passo na direção da consolidação da cidadania (JACOBI, 2004). 


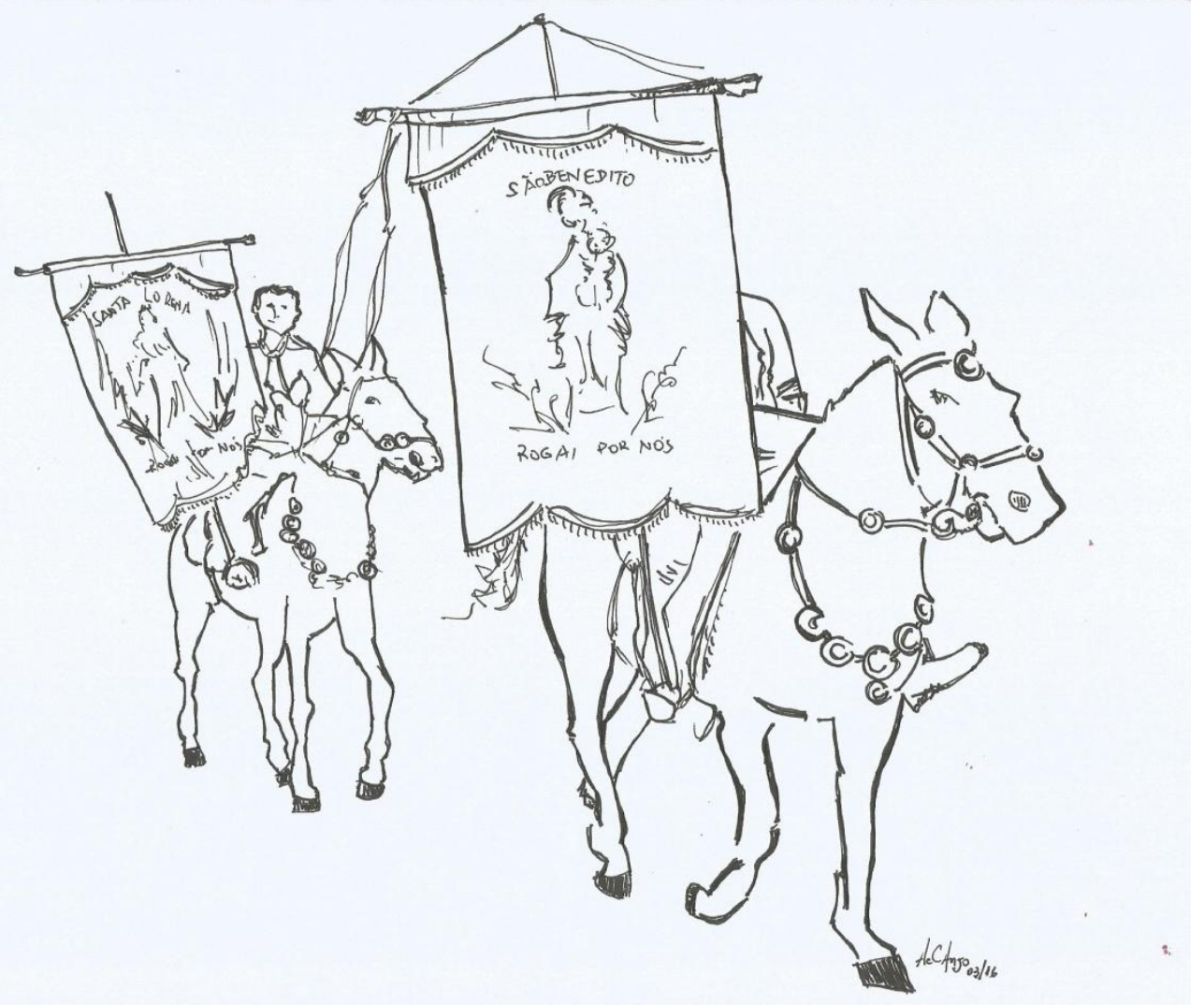




\title{
CAPÍTULO 2
}

\section{A METODOLOGIA DA PESQUISA}

\subsection{A Pesquisa-Ação}

As metodologias participativas e colaborativas favorecem a aprendizagem no plano individual e coletivo, o desenvolvimento de diagnósticos e a proposição de planos e agendas de intervenção/ação locais, pois visam à construção de processos colaborativos e de uma cultura de participação e de corresponsabilidade na aprendizagem de gestão compartilhada (JACOBI, 2011).

Objetivam a compreensão, apreensão e mobilização de valores e atitudes para a sustentabilidade socioambiental e enfatizam a troca de saberes e experiências entre sujeitos e os atores envolvidos no processo. Visam a construir e estimular processos de colaboração e interconexões entre pessoas, ideias e ações:

\begin{abstract}
Esse 'fazer coletivo' se configura em potenciais estratégias que englobam um conjunto de atores e práticas. Podem ser um elemento inovador na construção de pactos de governança (...) que possibilitem informar novas escolhas do poder público e da sociedade, numa perspectiva de avanço rumo à sustentabilidade socioambiental (JACOBI, 2011, p.21).
\end{abstract}

Dentre as metodologias de caráter participativo, a pesquisa-ação se caracteriza por uma estratégia metodológica e um conjunto de procedimentos, métodos e técnicas de pesquisa que asseguram a participação ativa de atores e a geração de conhecimentos associados às suas necessidades e às situações concretas apresentadas (THIOLLENT , 2011)

Thiollent (2011) destaca que a pesquisa-ação não é constituída apenas pela ação ou pela participação. Como qualquer estratégia de pesquisa, produz conhecimentos, adquiri-se experiência e contribui o avanço do debate sobre as questões abordadas.

O propósito ao se desenvolver uma pesquisa-ação, que pressupõe atuação de sujeitos individualmente ou de forma coletiva, é o de promoção de experiências compartilhadas diante de "situações problemáticas" e de ganhos de conhecimento, por parte tanto dos pesquisadores quanto dos atores sociais interessados (THIOLLENT, 2012, p.18). ${ }^{48}$

\footnotetext{
${ }^{48}$ No plano epistemológico, a pesquisa-ação tem se relacionado ao quadro de referência do construcionismo social, que pressupõe forte interação entre pesquisadores e atores sociais na construção do conhecimento, além da teoria da práxis, teoria crítica, abordagem existencial, fenomenologia e pragmatismo. Ver: THIOLLENT, Michel. Fundamentos e desafios da pesquisa-ação: contribuições na produção de conhecimento interdisciplinares. In: TOLEDO, Renata F. \& JACOBI, Pedro Roberto (org.). A Pesquisa-ação na interface da
} 
Trata-se de uma modalidade de pesquisa que deve desencadear uma ação planejada, decidida e avaliada conjuntamente com os atores sociais. Pesquisadores e atores sociais desenvolvem uma aprendizagem coletiva e uma troca de conhecimentos, mesmo reconhecendo que os saberes compartilhados são marcados por crenças e tradições, o que dificulta rápidas transformações:

Reconhece-se ainda que, assim como a aprendizagem social, a pesquisa-ação tem sido amplamente utilizada na área socioambiental e educacional (TRIPP, 2005; THIOLLENT, 2011; SATO, 2003; TOZONI-REIS, 2007), articulando teoria e prática; saberes técnicos/acadêmicos e saberes tradicionais, e processos cíclicos de ação-reflexão-ação (JACOBI, 2012, p.100) ${ }^{49}$.

O principal objetivo de uma pesquisa-ação é a identificação de problemas e de caminhos para sua resolução. Nesse sentido, qualquer "avanço" ou "ação significativa" são avaliados de forma positiva. O incremento da consciência (aumento dos "níveis de reflexão e comprometimento de atores ou dos participantes") também o é um objetivo, assim como o são a geração e a difusão de informações e conhecimentos produzidos ao longo de seu desenvolvimento (THIOLLENT, 2012, pp.19 e 20).

Assim, os seus objetivos podem ser mais instrumentais (práticos), conduzindo às soluções; e educacionais e de produção de conhecimentos, possibilitando o esclarecimento do problema identificado, para as ações transformadoras (para tomada de decisões), ou apenas a construção de conhecimento (conhecimentos relevantes não apenas para a situação e o problema investigados). Pode a pesquisa-ação ter como objetivo a tomada de consciência dos agentes implicados na atividade investigada tornando "mais evidente aos olhos dos interessados a natureza e a complexidade dos problemas considerados" (THIOLLENT, 2012, p.25).

A pesquisa-ação se mostra efetiva para a compreensão de problemas interrelacionados e complexos, colaborando para a não separação das várias dimensões que constituem a realidade complexa de uma problemática, por tratar-se de um processo de reflexão, análise da realidade, aprendizagem coletiva e fortalecimento comunitário. As práticas participativas contribuem para que diferentes atores compreendam melhor as percepções dos outros sujeitos envolvidos sobre os problemas, melhorando as relações entre os participantes. Proporcionam a base para colaboração e interconexão (JACOBI, 2011; 2012).

saúde, educação e ambiente. Princípios, desafios e experiências interdisciplinares. São Paulo: Annablume: FEUSP, PROCAM, IEE, FAPESP, 2012.

${ }^{49}$ Ver: TRIPP, D. Pesquisa-ação: uma introdução metodológica. Educação e Pesquisa. São Paulo, v.31, n.3, p. 443-466, set/dez, 2005; SATO, M; SANTOS, J.E. Tendências nas pesquisas em educação ambiental. In: NOAL, F; BARCELOS, V. (org). Educação ambiental e cidadania: cenários brasileiros. Santa Cruz do Sul: EDUNISC, 2003, p.253-284; TONOZI-REIS, M.F.C. (org.). A Pesquisa-ação participativa em educação ambiental: reflexões teóricas. São Paulo: Annablume, 2007, p.121-161. 
Os métodos qualitativos para a pesquisa possibilitam também a apreensão das dimensões subjetivas de sentido e sua complexidade em diferentes contextos de investigação. Numa pesquisa qualitativa, de caráter aberto e dialógico, muitas são as situações observadas, vivenciadas, novas, frutos do dinamismo das interações, dos entrelaçamentos que o campo, em constante interação com os sujeitos, propõe (FRANCO, 2010).

Nas abordagens qualitativas, a dimensão da vida cotidiana emerge junto aos sujeitos que "experimentam as oportunidades e os limites para a ação" (MORIN, 2004, p. 29). Para André Morin (2004), a pesquisa-ação designa em geral um método de ação estratégica que requer a participação dos atores e é identificada como nova forma de criação do saber na qual as relações entre teoria e prática e entre pesquisa e ação são constantes.

A pesquisa-ação permite aos atores a construção de teorias e estratégias que emergem e são confrontadas no campo e que valorizam as potencialidades, experiência, anseios, inteligência criativa e capacidade de organização de atores locais (FRANCO, 2010).

Aos estudos de formulação e sistematização da chamada action research na psicologia social de Kurt Lewin no pós-guerra, no ano de 1946, é que é relacionada sua origem. Alguns autores têm atribuído essa origem aos trabalhos desenvolvidos por Dewey, em 1929, sobre prática escolar e envolvimento dos sujeitos e, ainda na área educacional, a Stephen Corey, na década de 1950, nas pesquisas desenvolvidas sobre experimentação do currículo (TOLEDO, 2006).

Lewin (1946) apresenta a pesquisa-ação como cíclica, composta por três fases de desenvolvimento que são retomadas a cada ciclo, com a incorporação de novos instrumentos e de intervenções cada vez mais ajustadas às necessidades identificadas: de planejamento, para o conhecimento e reconhecimento da situação; a ação; e a interpretação dos fatos sobre os resultados da ação (LEWIN, 1946 apud TOLEDO; JACOBI, 2012).

$\mathrm{Na}$ América Latina, a pesquisa-ação surge na década de 1970, vinculada às experiências de Paulo Freire, Carlos Rodrigues Brandão e Danilo Strech e com a preocupação de garantir a participação de grupos sociais considerados excluídos da tomada de decisões em problemas sociais coletivos. Desde os anos 1960, sob influência de Paulo Freire, Carlos Rodrigues Brandão, entre outros, esteve inserida, mais com o uso do termo "pesquisa participante", numa perspectiva "crítica da realidade social, conscientizadora dos sujeitos", e 
associada à educação de adultos, à alfabetização e à educação popular (THIOLLENT, 2012, p.26). ${ }^{50}$

O Primeiro Simpósio Mundial sobre Pesquisa Participante foi realizado em Cartagena, Colômbia, em 1977 e, no Brasil, foi a partir da promulgação da Constituição Federal de 1988 e nos anos 1990, que a pesquisa-ação se intensificou respondendo às demandas por mobilização social e participação, devendo-se favorecer e garantir a participação ativa dos grupos sociais em assuntos que lhes diziam respeito, como instrumento de participação social. $^{51}$

Com objetivos e metas de interesse coletivo, a pesquisa-ação compartilha da crença na capacidade de transformação e influência dos grupos sociais em assuntos públicos. Procura oferecer subsídios para o conhecimento e reconhecimento de problemas, soluções, direitos e deveres, como também para o desenvolvimento de ações práticas e intervenções sociais (revelando seu caráter político). É indicada nos casos em que os objetivos são voltados à tomada de consciência dos agentes implicados na atividade investigada, de forma que caminhe na direção da transformação de uma realidade, com a participação dos sujeitos que são/estão envolvidos no processo. Não se limita a levantamentos de dados. Considera a voz dos sujeitos não apenas para registro e posterior interpretação do pesquisador (TOLEDO; JACOBI, 2012).

Seguindo os pressupostos e princípios da pesquisa participativa, a pesquisa-ação pode envolver a constituição de uma "Comunidade Ampliada de Pesquisa" ou "Comunidade de Práticas" que produz conhecimentos de modo compartilhado para transformar uma realidade. Assume um caráter emancipatório na medida em que, mediante a participação consciente, os

\footnotetext{
${ }^{50}$ Sobre a pesquisa-ação em Educação e em outras áreas interdisciplinares, ver: THIOLLENT, Michel. Metodologia da Pesquisa-ação. 18ª Edição. São Paulo: Cortez, 2011; e THIOLLENT, M (org.). Pesquisa-ação e projeto cooperativo na perspectiva de Henri Desroche. São Carlos-SP: EdUFScar, 2006. (para pesquisa permanente). Além de Henri Desroche (2006), o autor assinala outros autores da pesquisa-ação, como, por exemplo: André Morin (2004, 2010); Guy Avanzini (1996); Khalid Ed. El Andaloussi (2004); Hugues Dionne (2007), René Barbier (2002); e Marie-Renée Verspieren (1990). Consultar também: LAGO, Davide. Henri Desroche, thóricien de l'éducation permanente. Paris: Éditions Don Bosco, 2011.

${ }^{51}$ Toledo (2012) realizou pesquisa de pós-doutoramento junto à Faculdade de Educação da Universidade de São Paulo, com supervisão do Prof. Pedro Jacobi e apoio da FAPESP - Fundação de Amparo à Pesquisa do Estado de São Paulo sobre dissertações ou teses desenvolvidas nas universidades estaduais paulistas de 1990 a 2010 que se utilizaram da metodologia da pesquisa-ação. Além de uma multiplicidade de nomes atribuídos à pesquisaação, tais como: pesquisa-ação participante, pesquisa-ação integral e sistêmica, pesquisa-ação existencial, pesquisa-ação crítico colaborativa, pesquisa-ação cooperativa, pesquisa-ação intervenção, pesquisa-ação tutoria entre pares ou tutoria entre iguais; o estudo revelou a sua articulação com novos paradigmas nas relações de pesquisa, participação e intervenção. Ver: TOLEDO, Renata F.; JACOBI, Pedro Roberto (Org.). A Pesquisaação na interface da saúde, educação e ambiente. Princípios, desafios e experiências interdisciplinares. São Paulo: Annablume/FEUSP/PROCAM/IEE/FAPESP, 2012.
} 
sujeitos da pesquisa podem compreender melhor a realidade e atuar sobre ela (THIOLLENT, 2011).

Considerada como um sistema metodológico aberto, sujeito a constantes adequações, ela possibilita o desenvolvimento de diferentes rumos em função das demandas encontradas em campo e a multiplicidade de caminhos diante as diferentes situações diagnosticadas ao longo do processo (THIOLLENT, 2011; 2012) e favorece também a participação e a proatividade de todos (EL ANDALOUSSI, 2004).

Nessa tese, a pesquisa-ação se apresentou como uma proposta metodológica para a produção compartilhada de conhecimentos, revelada pela constituição de uma comunidade ampliada de pesquisa, na qual a pesquisadora e moradores, atores e grupos sociais de Santo Amaro (inseridos também como pesquisadores) iniciaram um estudo com o objetivo de conhecer os bens patrimoniais ou culturais materiais e imateriais existentes em Santo Amaro e discutir a questão patrimonial da região, pensando Santo Amaro como um lugar que poderia ser transformado a partir de suas próprias potencialidades patrimoniais, evidenciadas por conhecimentos oriundos das vivências, memórias, manifestações culturais, movimentos coletivos e políticas públicas de entidades e instituições socioculturais locais.

A pesquisa-ação foi a metodologia desse estudo e o Inventário Comunitário e Escolar de Bens Culturais ${ }^{52}$, o método para a pesquisa colaborativa e para a produção compartilhada de conhecimentos sobre os bens patrimoniais ou culturais materiais e imateriais existentes em Santo Amaro, visando à transformação da realidade social e/ou ao benefício coletivo (BRANDÃO, 1999), inspiradas na ideia de construção de uma Comunidade Ampliada de Pares, tal como sugerida por Funtowicz e Ravetz (1997), composta por moradores e atores sociais de Santo Amaro, pesquisadores, técnicos ou gestores locais em diálogo, almejando a participação na formulação de políticas públicas.

Para Funtowicz e Ravetz (1997), essa seria a garantia da qualidade de políticas públicas, programas e projetos informados também pelos saberes e valores desses protagonistas, da sustentabilidade e das formas de desenvolvimento sem injustiça social, que necessitam de uma ampliação da contribuição tanto de cientistas e especialistas como de representantes de interesses sociais.

\footnotetext{
${ }^{52}$ O Inventário Nacional de Referências Culturais - INRC é uma metodologia de pesquisa desenvolvida pelo IPHAN, como instrumento auxiliar à produção de conhecimento e de diagnósticos "sobre os domínios da vida social aos quais são atribuídos sentidos e valores que constituem referências de identidade para os grupos sociais" (Instrução Normativa no 01 de 2009 - Autorização de uso do INRC). (IPHAN, 2000). A sua aplicação contribui para a identificação e registro daquelas atividades, lugares e bens materiais relacionados ao patrimônio cultural imaterial, e que se constituem em marcos e referenciais de identidade para os grupos.
} 
As ações de formação e da Comunidade Ampliada de Pesquisa trouxeram outra perspectiva na abordagem patrimonial de Santo Amaro, baseada na coleta de narrativas, nos bens culturais inventariados e naqueles evidenciados pela Arqueologia na região. Uma perspectiva que procurou focar a dimensão imaterial do patrimônio cultural de Santo Amaro em diálogo com o conceito de Patrimônio Ambiental Urbano, que foi e ainda o é preponderante na abordagem preservacionista do patrimônio no Estado e na Cidade de São Paulo.

\subsection{O Método: O Inventário Comunitário e Escolar de Bens Culturais}

Resultantes da relação entre o homem e o seu meio, os bens patrimoniais ou culturais se apresentam como elementos naturais ou culturais, materiais ou imateriais, herdados do passado ou criados no presente, nos quais um determinado grupo de indivíduos reconhece sinais de sua identidade (CASTILLO RUIZ, 1996; GONZÁLEZ-VARAS, 2003; CHOAY, 2006). A partir desses bens, podemos compreender e identificar a cultura de um povo, em determinado lugar e momento histórico (GRUNBERG, 2007). ${ }^{53}$

São elementos do viver, do pensar, do fazer e do sentir que devem expressar a coletividade para ser patrimônio. O patrimônio é compreendido como um conjunto de bens intangíveis ou tangíveis reunidos por determinados grupos sociais para apropriação e exposição, tais como: edifícios, as festas, os centros históricos, as danças, as paisagens naturais, os sítios arqueológicos, as obras de arte e muitas outras expressões, e que comporta na sua salvaguarda uma pluralidade de discursos e práticas (HERNÁNDEZ- HERNÁNDEZ, 2002).

Assim, patrimônio está diretamente relacionado a algo a que atribuímos um valor, um significado; e pode ser material ou imaterial, daí sua íntima relação com nossa trajetória de vida e herança familiar.

\footnotetext{
${ }^{53}$ Grunberg (2007, p.01) apresenta alguns exemplos de bens culturais, tais como: “[...] um livro, uma casa, uma panela, um quadro, um documento, um instrumento musical, um jornal, uma fotografia... a execução de uma música, uma procissão, um ritual de umbanda, uma forma de plantio, um processo de fabricação de vinho etc." $E$ segundo a Constituição Federal de 1988, no artigo 216: "Constituem patrimônio cultural brasileiro os bens de natureza material e imaterial, tomados individualmente ou em conjunto, portadores de referência à identidade, à ação, à memória dos diferentes grupos formadores da sociedade brasileira, nos quais se incluem:I - as formas de expressão; II - os modos de criar, fazer e viver; III - as criações científicas, artísticas e tecnológicas; IV - as obras, objetos, documentos, edificações e demais espaços destinados às manifestações artístico-culturais; os conjuntos urbanos e sítios de valor histórico, paisagístico, artístico, arqueológico, paleontológico, ecológico e científico".(BRASIL, 1988).
} 
É nesse sentido que observamos ao longo da História e em diversas sociedades o costume de acumular memórias significativas dos antepassados, ou também de colecionar ou reverenciar objetos e estruturas - habitações (FUNARI \& PELEGRINI, 2006) ${ }^{54}$. Tudo isso, de alguma forma, adquiriu importância ou referência por ter pertencido a antepassados reverenciados por indivíduos, famílias ou comunidades. A esse conjunto de artefatos e monumentos construídos no passado que atribuímos a denominação de Patrimônio ${ }^{55}$. Podemos afirmar, ainda, que patrimônio é toda a produção cultural dos diversos grupos sociais que integram uma nação.

Não obstante, foi nas últimas décadas do século XX - abordagem do Capítulo 1 dessa Tese - que houve uma ampliação da noção de patrimônio histórico para a de patrimônio cultural (material/tangível ou imaterial/intangível):

A perspectiva reducionista inicial, circunscrita a recortes cronológicos arbitrários e
permeados por episódios militares e personagens emblemáticos, acabou sendo, aos
poucos, suplantada por uma visão muito mais abrangente. A definição de patrimônio
passou a ser pautada pelos referenciais culturais dos povos, pela percepção dos bens
culturais nas dimensões testemunhais do cotidiano e das realizações intangíveis. [...]
Essa abertura temática permitiu que construções menos prestigiadas ou mais
populares, como moinhos, mercados públicos ou estações de trem, fossem
reconhecidas como patrimônio (FUNARI \& PELEGRINI, 2006, p. 31).

O patrimônio cultural imaterial/intangível de uma nação engloba todas as formas tradicionais e populares de cultura transmitidas oralmente ou por gestos que, com o passar do tempo, são modificadas pelo processo de recriação coletiva, como, por exemplo, as relações humanas, as festas, os cultos religiosos, os saberes envolvidos nessa produção simbólica, os conhecimentos dos fazeres tradicionais, suas formas de expressão. ${ }^{56}$

\footnotetext{
${ }^{54}$ FUNARI \& PELEGRINI (2006, p.8) nos apresenta o conceito relacionando-o à ideia de herança de nossos antepassados, aos bens que transmitimos aos nossos herdeiros: "e que podem ser materiais, como uma casa ou uma jóia, com valor monetário determinado pelo mercado. Legamos, também, bens materiais de pouco valor comercial, mas de grande significado emocional, como uma foto, um livro autografado ou uma imagem religiosa do nosso altar doméstico. Tudo isso pode ser mencionado em um testamento e constitui o patrimônio de um indivíduo [...]. Quando pensamos no que recebemos dos nossos antepassados, lembramo-nos não apenas dos bens materiais, mas também da infinidade de ensinamentos e lições de vida que eles nos deixam [...] os ditados e provérbios que sabemos de cor e que nos guiam por toda a vida são exemplos de um patrimônio imaterial inestimável”.

${ }^{55}$ Embora seu significado não seja comum entre os diferentes povos e grupos sociais. A palavra "patrimônio", como a conhecemos, é de origem latina (patrimonium) e referia-se a tudo o que pertencia ao pai (pater) ou ao pai de família (pater famílias). Entre os romanos, o patrimônio era um valor aristocrático e privado que se referia à transmissão de bens no seio da elite patriarcal. Na época, ainda não havia o conceito de patrimônio público (FUNARI \& PELEGRINI, 2006). Na consolidação do Cristianismo (séculos IV e V) e na Idade Média ("Idade das Trevas") pelo predomínio das crenças religiosas (séculos VI-XV), o caráter religioso do patrimônio somouse ao aristocrático. Assim, houve a monumentalização das igrejas e a criação das grandes catedrais, as quais se constituíam de um patrimônio coletivo, que, no entanto, continuava aristocrático e ligado às elites.

${ }^{56}$ Em 2003, a UNESCO publicou uma classificação com vinte e oito dessas obras imateriais que já estão preservadas. Entre elas: Bolívia - a cosmovisão andina dos Kallawaya; Brasil - as expressões gráficas e orais dos Wajãpi (norte da Amazônia); Camboja - O Ballet Real do Camboja; República Central Africana - a tradição oral dos pigmeus Aka da África Central; China - A arte da música Guqin (do medievo chinês); Colômbia - O
} 
O patrimônio cultural imaterial é representado por todas as formas de expressão e todos aqueles saberes vinculados ao modo de criar, fazer e viver que façam referência à identidade e à memória dos diversos grupos sociais. Reúne a língua, danças, canções, música, celebrações, artesanato, literatura, artes plásticas, cinema, televisão, humor, cozinha e o próprio modo de ser e interpretar a vida (CUNHA, 2004), e que se enquadram naquelas categorias definidas para os Livros de Registros, de acordo com o Decreto Federal $\mathrm{n}^{\mathbf{o}} 3.551$, de 04 de agosto de 2000, que instituiu o Registro de Bens Culturais de Natureza Imaterial que constituem patrimônio cultural brasileiro e criou o Programa Nacional do Patrimônio Imaterial (IPHAN, 2000) ${ }^{57}$

Os bens imateriais, como patrimônio cultural, devem abranger:

[..] práticas, representações, expressões, conhecimentos e técnicas - junto com os instrumentos, objetos, artefatos e lugares que lhe são associados - que as comunidades, os grupos e, em alguns casos, os indivíduos reconhecem como parte integrante de seu patrimônio cultural (UNESCO, 2003).

As informações relativas aos bens culturais podem ser apreendidas a partir de manifestações materiais, ou suportes, tais como sítios, monumentos, conjuntos urbanos, artefatos, relatos, ritos, práticas, entre outros; porém, o que os caracteriza enquanto "referencial cultural" 58 é o valor a eles atribuído pelos membros do grupo e por isso lhes confere identidade (IPHAN, 2000)

Por outro lado, pensando a cultura de um modo mais processual, uma maneira mais simbólica que privilegia seus processos simbólicos, nós a entenderemos como relacionada ao universo da criação, da transmissão, da apropriação e da interpretação dos bens simbólicos e das relações que se estabelecem (FERREIRA SANTOS, 2004). E o ser humano se apresenta nesse processo também como um ser criador:

carnaval de Barranquilla; Cuba - La Tumba Francesa; Egito - O épico de Al-Sirah Al-Hilaliyyah; Índia - A tradição do canto védico; Indonésia - Teatro de bonecos Wayang; Japão - O teatro de bonecos Ningyo Johruri Bunraku; Coréia - O canto épico de Pansori; México - As festividades indígenas dedicadas à morte (Dia de los muertos); Vietnão - A música cortesão vietnamita de Le Nha nhac. Disponível em: http://www.unesco.org/new/pt/brasilia/culture/world-heritage/intangible-heritage/> Acesso em: 01 mar 2016.

${ }^{57}$ Nesse decreto, os bens culturais de natureza imaterial foram conceituados e foram instituídos quatro gêneros de livros de registro: dos Saberes, de Celebrações, das Formas de Expressão, de Lugares. Uma comissão que verifica o que deve ou não ser registrado. Ver: Instituto do Patrimônio Histórico e Artístico Nacional. Inventário Nacional de Referências Culturais - INRC, 2000. Manual de Aplicação. Departamento de Identificação e Documentação, IPHAN/MinC, 2000.

${ }^{58}$ As referências culturais: “[...] são edificações e são paisagens naturais. São também as artes, os ofícios, as formas de expressão e os modos de fazer. São as festas e os lugares a que a memória e a vida social atribuem sentido diferenciado: são as consideradas mais belas, são as mais lembradas, as mais queridas. São fatos, atividades e objetos que mobilizam a gente mais próxima e que reaproximam os que estão longe, para que se reviva o sentimento de participar e de pertencer a um grupo, de possuir um lugar. Em suma, referências são objetos, práticas e lugares apropriados pela cultura na construção de sentidos de identidade, são o que popularmente se chama de raiz de uma cultura" (IPHAN, 2013, p.8). 
não apenas um reprodutor ou criador inicial, mas um ser que cria constantemente. Se ele cria, ele também pode transpor essa sua criação para determinadas formas e comunicar essas criações e, portanto, transmitir ao outro, ao diferente, às novas gerações, enfim, dar comunicabilidade ao que foi criado (FERREIRA SANTOS, 2004, p. 5).

Na pesquisa-ação, o Inventário Escolar e Comunitário de Bens Culturais, como método, permitiu conhecer outros bens culturais ${ }^{59}$ de Santo Amaro, especialmente aqueles de natureza imaterial, como também outros sentidos atribuídos ao patrimônio estabelecido e tombado na região, principalmente por aqueles atores que passaram a participar da Comunidade Ampliada de Pesquisa e que estabelecem no presente outra relação com esse patrimônio. Para esses atores, o valor dos remanescentes é vivenciado no tempo presente, embora se apresente também como lugar significativo de uma trajetória em que a identidade de Santo Amaro foi se constituindo e se renova a cada dia.

Eu sai do salão para cuidar da minha mãe. Levava ela pra passear. Participava de palestras na Casa de Cultura. Aí apareceu o coral; depois violão, a dança do ventre (D. Aparecida Ferreira Barros Trecho transcrito das falas produzidas pelos participantes nas atividades educativas).

O Inventário e o processo de formação da Comunidade Ampliada de Pesquisa iniciaram-se em 2013, com as primeiras reuniões e com os workshops e atividades de Educação Patrimonial desenvolvidos na região de Santo Amaro sobre a temática do patrimônio cultural e o arqueológico, no contexto dos mencionados Programas de Arqueologia Preventiva e de Educação Patrimonial que acompanharam as obras das novas estações da Linha 5 do Metrô de São Paulo, e que foram baseados e tiveram um caráter de construção coletiva de conhecimentos com os gestores escolares (direção, vice direção e coordenação pedagógica) e professores das escolas públicas locais e agentes culturais e sociais de instituições e entidades da região.

Havia uma professora em especial, que cuidava da biblioteca da escola, que comentou que foi uma das últimas passageiras do "bonde" que cortava a região de Santo Amaro, em meados dos anos 1960; mencionou também o comércio popular da "Praça Floriano Peixoto", que acontece até hoje, que tem coreto e onde se realizava o footing (passeio e paquera que acontecia na praça). (Extraído do Caderno de Anotações da pesquisadora).

\footnotetext{
${ }^{59}$ No Brasil, o Decreto 8.124/2013 identifica no Artigo 2 ${ }^{\text {o }}$. os bens culturais: "I - bens culturais - todos os bens culturais e naturais que se transformam em testemunhos materiais e imateriais da trajetória do homem sobre o seu território; II - bens culturais musealizados - os descritos no inciso I do caput que, ao serem protegidos por museus, se constituem como patrimônio museológico; III - bens culturais passíveis de musealização - bens móveis e imóveis, de interesse público, de natureza material ou imaterial, considerados individualmente ou em conjunto, portadores de referência ao ambiente natural, à identidade, à cultura e à memória dos diferentes grupos formadores da sociedade brasileira (...)". Disponível em: http://www.planalto.gov.br/ccivil_03/_Ato20112014/2013/Decreto/D8124.htm> Acesso em: 01 mar 2016.
} 
Nas atividades educativo-culturais (de Educação Patrimonial e de Arte Educação) desenvolvidas, que também promoveram oficinas e exercícios de apresentação e representação daquilo que os participantes consideravam patrimônio da região - como o Exercício do Objeto/Objeto Significativo e Mapa Patrimonial, por exemplo, realizados com os educadores e com a comunidade escolar, incluindo pais e familiares dos alunos - a formação de grupos de trabalho e de pesquisa para um processo coletivo de inventário dos bens culturais em Santo Amaro era incentivada, estimulada e proposta.

[...] os professores a partir de outros objetos escolhidos e levados para o workshop apontaram suas histórias de vida, da escola, do bairro e da comunidade e se percebiam pertencentes ao espaço que eles ocupavam. (Extraído do Caderno de Anotações da Pesquisadora)

Entretanto, a Comunidade Ampliada de Pesquisa foi se constituindo no processo e foi consolidada somente no ano de 2015, com o Grupo de Trabalho formado pelos participantes dos Encontros sobre Memória e Patrimônio Cultural de Santo Amaro, desenvolvidos na Biblioteca Belmonte nos meses de agosto de 2015 a fevereiro de 2016; e pelo Grupo de Ação, com integrantes do curso de Dança Vocacional do Paço Cultural Júlio Guerra (Grupo Yellow). O Grupo de Dança se engajou na defesa da preservação e restauração desse edifício, também conhecido como Casa Amarela, que foi sede da Prefeitura de Santo Amaro, quando este era município.

Os Grupos de Trabalho e de Ação (a Comunidade Ampliada da Pesquisa-ação), que passaram, a partir de agosto de 2015, a dar continuidade ao processo de inventário iniciado desde as primeiras atividades da pesquisa-ação em 2013, no final de 2015 e início de 2016, como parte do processo de construção coletiva de conhecimentos, prepararam a Primeira Mostra dos bens inventariados, que também foi exibida como parte integrante das atividades de comemoração do aniversário de Santo Amaro, em 15 de janeiro de 2016. A trajetória da pesquisa-ação e os bens mapeados estão apresentados no capítulo a seguir.

A Educação Patrimonial propõe a articulação de saberes diferenciados. Pode unir o conhecimento dos programas curriculares da Educação Formal, por exemplo, com aqueles tradicionais das comunidades e pode também partir dos conhecimentos dos espaços e territórios de vida (no âmbito da Educação Não-Formal), dos contextos culturais das pessoas, para a formação dos sujeitos. Por esse motivo, dialoga com a Lei de Diretrizes e Bases da Educação - LDB (9.394/1996) que prevê, no artigo $1^{\circ}$. , que "a educação abrange os processos formativos que se desenvolvem na vida familiar, na convivência humana, no trabalho, nas 
instituições de ensino e pesquisa, nos movimentos sociais e organizações da sociedade civil e nas manifestações culturais". ${ }^{60}$

A concepção de Educação Patrimonial que permeou as ações educativas, responsáveis pelo Inventário de Bens Culturais e pela formação da Comunidade Ampliada da Pesquisaação considerou a vida cotidiana e as formas de representação dos participantes como materiais e recursos no processo de aprendizagem, estimulando a reflexão sobre quais bens culturais possuíam e desejariam transmitir como herança, de forma a protagonizarem também ações de preservação do patrimônio cultural.

O critério de escolha dos integrantes da Comunidade de Pesquisa foi o interesse em participar das ações coletivas de pesquisa e de inventário do patrimônio cultural em Santo Amaro nos Encontros sobre Memória e Patrimônio Cultural desenvolvidos, que foram amplamente divulgadas e incentivadas, a partir de convites e falas de esclarecimentos sobre o processo da pesquisa colaborativa, junto ao público frequentador (grupos de Terceira Idade e outros grupos) das instituições culturais locais parceiras: Biblioteca Pública Municipal Belmonte; Casa Amarela ou Paço Cultural Julio Guerra; Biblioteca Pública Municipal Prestes Maia e Casa de Cultura Manoel Cardoso Mendonça, nas atividades por elas promovidas: Cursos de Teatro, Coral, Artes Marciais, Baile da Saudade, Curso de Dança, entre outros eventos.

Prezado(a) Senhor(a),

A Biblioteca Belmonte, a Casa de Cultura de Santo Amaro e o LAPPES ${ }^{61}$ Laboratório de Pesquisa e Práticas em Educação e Sustentabilidade do IEE/USP convidam para o I Encontro Memória e Patrimônio Cultural de Santo Amaro: Conversando sobre Arqueologia, Memória, Patrimônio Cultural, Identidade e História de Santo Amaro, no próximo dia 25 de agosto (terça-feira), às 14h30, na Biblioteca Belmonte, na rua Paulo Eiró, 525 - Santo Amaro.

\footnotetext{
${ }^{60}$ Disponível em: http://www.planalto.gov.br/CCIVIL_03/leis/L9394.htm> Acesso em: Acesso em: 01 mar 2016.

${ }^{61}$ O LAPPES - Laboratório de Pesquisa e Práticas em Educação e Sustentabilidade do Instituto de Energia e Ambiente - IEE/USP envolve docentes, pesquisadores e estudantes de unidades da Universidade de São Paulo e desenvolve um enfoque interdisciplinar na abordagem sobre temas relacionados a Educação, Meio Ambiente e Cidadania. Foi criado como TEIA/USP - Laboratório de Educação e Ambiente na Faculdade de Educação em 2005, com o objetivo de estimular e promover um diálogo interdisciplinar que contribua para reflexões, debates, análise e construção de novos conhecimentos em Educação Ambiental. Além disso, tem a proposta de realizar intervenções de caráter socioeducativo, para uma prática reflexiva e engajada a partir da instituição acadêmica. Organiza-se por meio da agregação de diversos pesquisadores num espaço cooperativo de pesquisa/reflexão/disseminação de conhecimentos no campo ambiental - teoria, prática e políticas. Atualmente, o laboratório congrega, além da Faculdade de Educação - FE-USP e do Programa de Pós-Graduação em Ciência Ambiental - PROCAM, a Escola de Artes, Ciências e Humanidades - EACH, Instituto de Geociências - IGc e o Instituto de Oceanografia - IO da Universidade de São Paulo. Periodicamente, os envolvidos se reúnem para estudos sobre teorias e práticas articuladas com o campo da Educação Ambiental (Grupo de Estudo sobre Ciência Pós-Normal) e para planejamento de atividades como palestras, participação em eventos, organização de publicações, projetos de pesquisas e apoio ao desenvolvimento e atualização do site do laboratório. Ver: http://lappes.iee.usp.br/lappes/
} 
Venha compartilhar suas lembranças e recordações neste primeiro encontro de memórias e histórias de Santo Amaro.

Não esqueça de trazer para a atividade objetos, fotografias e qualquer outro documento que considere importante.

Saudações.

(Texto do convite distribuído nas atividades de divulgação dos Encontros do Inventário).

Os trabalhos de inventário da pesquisa-ação, além de um levantamento de bens com atribuição de valor pela comunidade, realizaram também um estudo sobre aqueles bens tombados e/ou em processo de tombamento na região, de forma a Comunidade de Pesquisa conhecer a realidade patrimonial de Santo Amaro e subsidiar o próprio desenvolvimento do inventário e suas ações e projetos de intervenção/preservação. (no Anexo 1).

Os encontros da Comunidade de Pesquisa foram desenvolvidos mediados por atividades participativas, como estratégica para o empoderamento e o exercício da cidadania. As atividades educativas realizadas procuraram proporcionar oportunidades de narração de histórias e memórias pelos participantes, que refletiam sobre ações e intervenções sobre a realidade pesquisada.

Nas histórias de vida narradas, também foram apresentados valores, visões de mundo e diferentes pontos de vistas. As narrativas falaram sobre o que era Santo Amaro, Vila das Belezas, Campo Belo, assim como o que foram, o que são hoje e o que desejavam para o futuro o Sr. Tarcísio, a D. Irene, a D. Maria Camargo, D. Tereza e D. Aparecida Barros, D. Maria Alice, D. Arlen, Sr. Angelo Diniz, a Dorinha e tantos outros, que revelaram aspectos da sua identidade e de Santo Amaro.

As atividades que objetivaram construir o conceito de patrimônio, a partir da relação da memória com a identidade, permitiram aos participantes pensarem o que poderia ser ou não patrimonializado, ou seja, o que deveria ou não ser preservado e/ou registrado para colaborar para a identidade das próximas gerações, de forma sentirem-se portador do direito de escolha de que bem cultural, revelado pela memória, deveria ser preservado, com atribuição do estatuto de patrimônio cultural. A construção do conceito de patrimônio nas atividades se dava mediada pela correlação das noções de identidade e memória e que envolvia crenças, valores e desejos (MARTINS, 2001 apud ARÉVALO, 2013).

Assim, foram levantados alguns dos conhecimentos e modos de fazer enraizados no cotidiano dos participantes; os rituais e festas que marcaram a vivência coletiva do trabalho, da religiosidade, do entretenimento e de outras práticas da vida social; as manifestações literárias, musicais, plásticas, cênicas e lúdicas; e os lugares, tais como: os mercados, feiras, 
santuários, praças e demais espaços onde se concentravam e reproduziam práticas culturais coletivas. $^{62}$

O Inventário sobre os bens patrimoniais de Santo Amaro possibilitou à Comunidade Ampliada da Pesquisa-ação evidenciar e conhecer aspectos do modo de ser e viver do santamarense, incluindo aqueles que adotaram a região para sua morada e exercício profissional, representados pelos estudantes do curso EJA da EMEFM Linneu Prestes, que participaram de dois Encontros (a grande maioria era migrante da região Nordeste do país). Ampliou o olhar para as ricas possibilidades da experiência humana, pois teve o compromisso de repensar o modo de ver a experiência patrimonial já conhecida e oficial em Santo Amaro, que gerou o tombamento de edificações remanescentes e logradouros públicos que compuseram o Eixo Histórico de Santo Amaro. E buscou compreender os sentidos e as especificidades da identidade de Santo Amaro e sua relação com a formação da cidade paulistana, tratando-o como território/espaço de vida (LDB In: IPHAN, 2013).

O Inventário, em se tratando de uma metodologia desenvolvida pelo IPHAN para documentar bens culturais, produz conhecimento sobre domínios da vida de determinados grupos sociais, identificando as práticas e expressões que constituem marcos de sua identidade (IPHAN, 2000). ${ }^{63}$

Fazer um inventário é fazer um levantamento, uma lista descrevendo os bens que pertencem a uma pessoa ou a um grupo. Quando falamos em inventariar os bens culturais de um lugar ou de um grupo social, estamos falando em identificar suas referências culturais (IPHAN, 2013, p.11).

A partir de 2000, que o Ministério da Cultura (MinC) assumiu a realização de projetos de valorização, por meio da implantação do Programa Nacional de Patrimônio Imaterial (PNPI), sob responsabilidade do IPHAN, instituição que elabora e executa a política de preservação, em âmbito nacional.

O Inventário organiza as chamadas referências culturais em quatro categorias (com alterações previstas), que correspondem aos Livros de Registro criados pelo Programa Nacional de Patrimônio Imaterial: Celebrações, Formas de Expressão, Saberes e Lugares,

\footnotetext{
${ }^{62}$ Com base no referido Decreto Federal $n^{\circ}$. 3551, de 4 de agosto de 2.000. Disponível em: http://www.planalto.gov.br/ccivil 03/decreto/D3551.htm> Acesso em: Acesso em: 01 mar 2016.

${ }^{63} \mathrm{O}$ inventariar, para o IPHAN, permite descrever minuciosamente e, num certo sentido, também revelar e difundir, pois prevê a incorporação da documentação produzida a um banco de dados de acesso público. Segundo o Ministério da Cultura, o seu propósito "é valorizar a diversidade cultural que caracteriza a sociedade brasileira, reconhecendo a autodeterminação dos grupos e dos povos formadores do Brasil. O Inventário Nacional de Referências Culturais - INRC é um poderoso instrumento, porque sua realização depende sempre da concordância e participação direta dos grupos contemplados, e seu foco é a identificação dos fazeres e saberes das comunidades, mais do que dos bens culturais em si. O objetivo do INRC é identificar e documentar, por meio de relatos, fotografias e filmes, aquilo que os membros de uma comunidade consideram fundamentos de seu modo de ser e ver o mundo, fundamentos de sua identidade" (IPHAN, 2000).
} 
tomando os grupos e as comunidades como partícipes do processo de identificação e documentação de suas referências culturais (IPHAN, 2000).

O Programa Nacional de Patrimônio Imaterial visou viabilizar projetos de identificação, reconhecimento, salvaguarda e promoção da dimensão imaterial do patrimônio cultural, criando além do inventário, como novo instrumento de preservação e metodologia de documentação da cultura, o Registro dos Bens Culturais, caracterizado como ato oficial de reconhecimento de saberes e práticas culturais que são consideradas fundamentais para a identidade dos grupos sociais (IPHAN, 2000).

Registrar um bem cultural significa inscrevê-lo num dos quatro Livros de Registros existentes: o Livro das Celebrações, o das Formas de Expressão, o dos Saberes e o dos Lugares $^{64}$ (IPHAN, 2000).

A Comunidade Ampliada da Pesquisa foi, ao longo do trabalho, apropriando-se da noção de patrimônio, e passou a dialogar ativamente sobre o reconhecimento de suas referências culturais, principalmente aquelas relacionadas às suas práticas e vivências na região de Santo Amaro. As atividades educativas participativas desenvolvidas, como por exemplo, a do Exercício do Objeto/Objeto Significativo, Mapa Patrimonial e as visitas e caminhadas pelo bairro (Visita Técnica ao CETRASA - Centro das Tradições de Santo Amaro e Fotografando Santo Amaro), entre outras, enquanto estratégias adotadas para a formação e nos encontros de trabalho da Comunidade Ampliada de Pesquisa foram fundamentais para revelação do caráter coletivo e tradicional das práticas culturais individuais e sua transposição às categorias propostas pelo Inventário. ${ }^{65}$

Esse Inventário, que passou, como já mencionado, a ter o seu caráter colaborativo consolidado com a Comunidade Ampliada de Pesquisa, formada a partir dos Encontros sobre Memória e Patrimônio Cultural de Santo Amaro, e com a elaboração e exibição da I Mostra Educativa com os itens inventariados, foi acompanhado pelo desenvolvimento de uma pesquisa documental que antecedeu e alimentou o trabalho de pesquisa coletiva, apresentando-se também como procedimento de coleta de dados.

\footnotetext{
${ }^{64}$ Lugares: uma feira, uma casa, uma paisagem, uma praça, um bosque, um sítio arqueológico, um centro histórico, uma rua, um rio, uma ruína de construção antiga que podem se tornar referência, por terem sido palco da algum acontecimento importante ou possuir significados especiais; Objetos - integrantes da história e memória de uma comunidade, podem se tornar importantes pelo papel social ou político de seus detentores, por sua função simbólica, utilitária, decorativa etc; Celebrações - eventos coletivos nos quais se comemora ou rememora algum acontecimento religioso, cívico, como podem se referir a ciclos produtivos ou marcar momentos especiais de uma comunidade; Formas de Expressão - música, dança, literatura, pinturas, esculturas, como também podem envolver várias dessas linguagens ao mesmo tempo; Saberes - formas próprias de produzir algum bem ou realizar alguma atividade (IPHAN, 2013).

${ }^{65}$ Um dos instrumentos para se conhecer o patrimônio cultural e perceber sua presença na vida das pessoas (IPHAN, 2013).
} 
Os dados coletados pela pesquisa documental (Anexo 1) e pelas atividades educativas pautadas pela aplicação de metodologias participativas e pela Aprendizagem Social junto à Comunidade Ampliada de Pesquisa compuseram o preliminar Inventário de Bens de Natureza Material e Imaterial de Santo Amaro, que foi o conteúdo da I Mostra Educativa: um dos conhecimentos construídos pela e na pesquisa - também apresentado no Capítulo 3 dessa Tese.

Foram os instrumentos de coleta/análise de dados da pesquisa-ação: a pesquisa bibliográfica sobre os temas do Patrimônio, Arqueologia, Educação Patrimonial e Aprendizagem Social; a pesquisa documental em fontes e bases de dados de bibliotecas públicas e acervos de instituições da região, bem como processos de tombamento, resoluções e decretos de órgãos públicos responsáveis pela salvaguarda de bens da cidade de São Paulo (CONPRESP e CONDEPHAAT); as entrevistas e as atividades educativas participativas e de construção de conhecimentos desenvolvidas com e sobre os bens culturais de Santo Amaro ao longo de todo o processo; e a observação participante em todo o período, caracterizada também pela participação direta no cotidiano das entidades e instituições abrangidas pela pesquisa. Desde o início da pesquisa-ação, foi utilizado um caderno de anotações para registro de impressões, falas e informações reveladas durante o desenvolvimento das atividades educativas participativas.

Além da pesquisa documental e visitas técnicas junto aos acervos de instituições da região e aos bens patrimoniais locais que também forneceram informações ao Inventário, nas atividades educativas desenvolvidas foram promovidas entrevistas com os detentores e produtores dos bens culturais e gestores oriundos do poder público local, considerados os sujeitos intérpretes e importantes para apreender e compreender melhor os bens e práticas culturais significativos e o processo de ressemantização, as quais colaboraram no processo de identificação dos referenciais culturais.

Essas entrevistas tiveram suas informações registradas com o uso de equipamentos eletrônicos de captação de dados, tais como: câmeras de filmagem e gravador de áudio. Sempre que possível, os bens informados foram documentados por meio de reportagens, fotografias, vídeos, desenhos e gravação de áudio. ${ }^{66}$

As primeiras entrevistas desenvolvidas procuraram identificar a noção que os entrevistados detinham sobre o conceito de patrimônio e suas tipologias (em especial, o patrimônio histórico, patrimônio cultural, patrimônio arqueológico) e sobre posturas, ações e

\footnotetext{
${ }^{66}$ Nos anexos, estão algumas leis, documentos e os instrumentos da pesquisa-ação.
} 
projetos relacionados à sua preservação, proteção e educação, de forma possibilitar uma primeira fase exploratória da pesquisa. E durante e ao longo dos Encontros Memória e Patrimônio de Santo Amaro, as entrevistas foram caracterizadas por diálogos, conversas informais, trocas de saberes e narrativas.

O Quadro 1 a seguir apresenta as ações e os atores sociais da pesquisa-ação.

Quadro 1. Ações da pesquisa-ação para o Inventário Comunitário e Escolar de Bens Culturais e as instituições escolares e culturais de Santo Amaro e os atores sociais envolvidos.

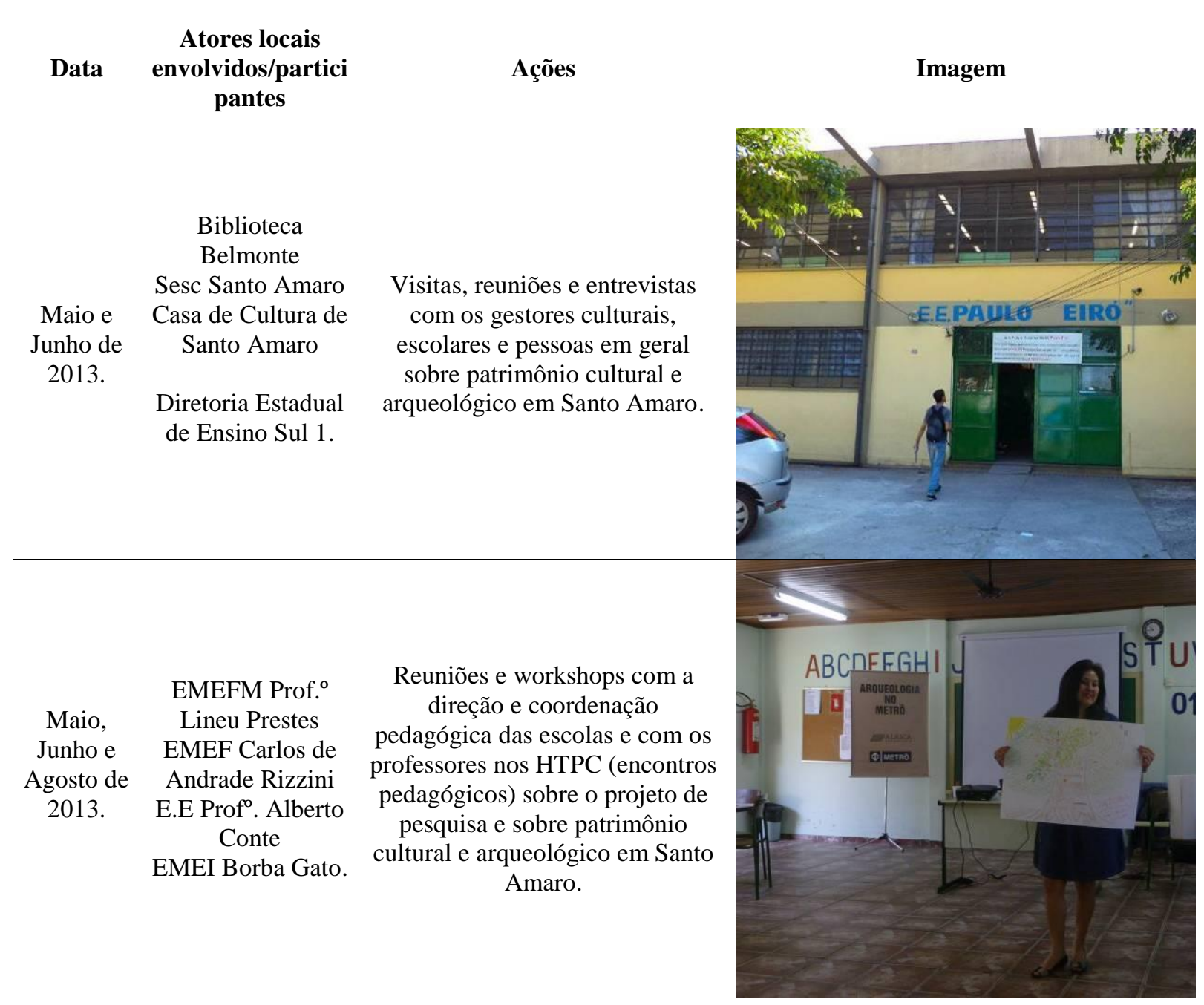




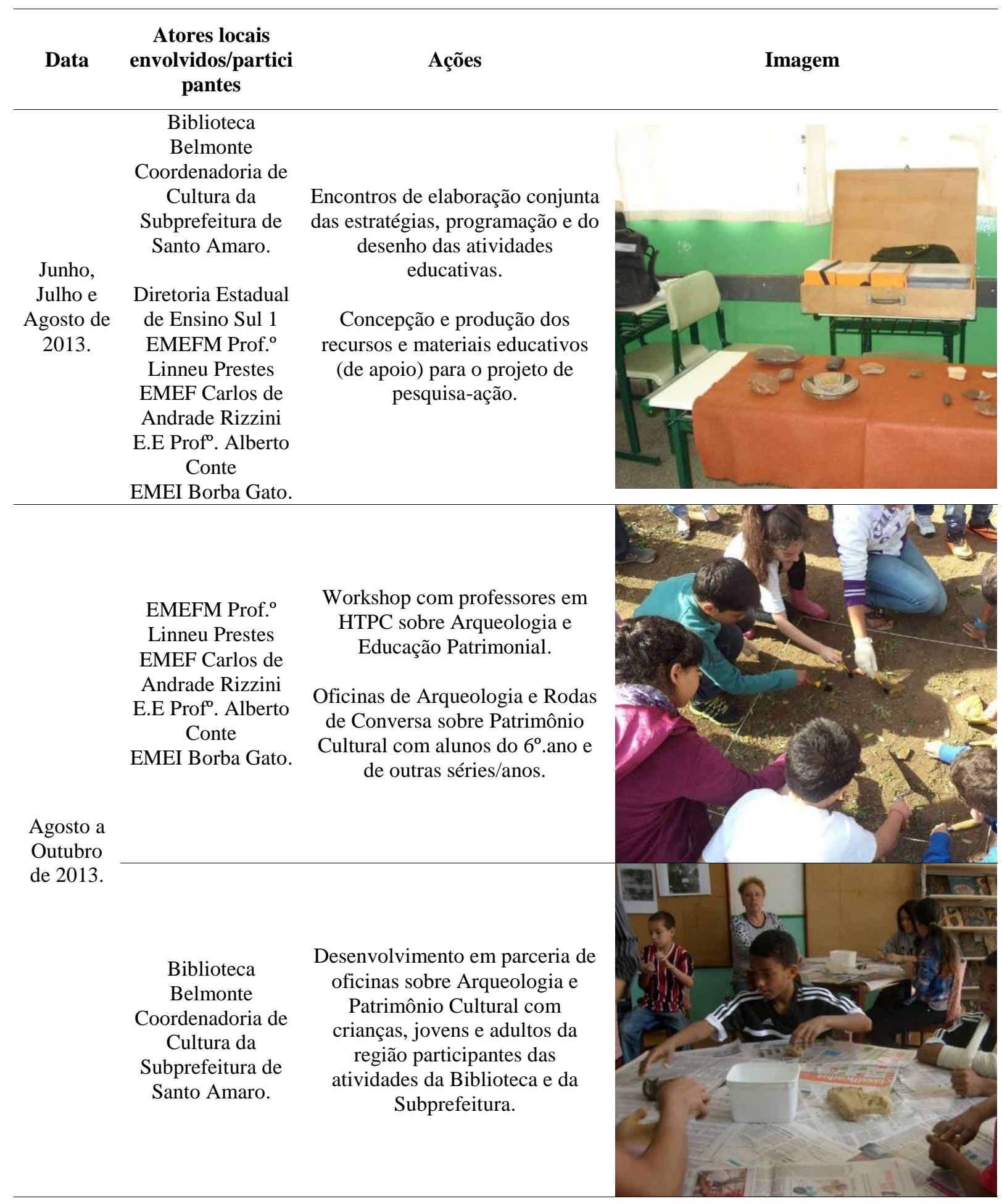




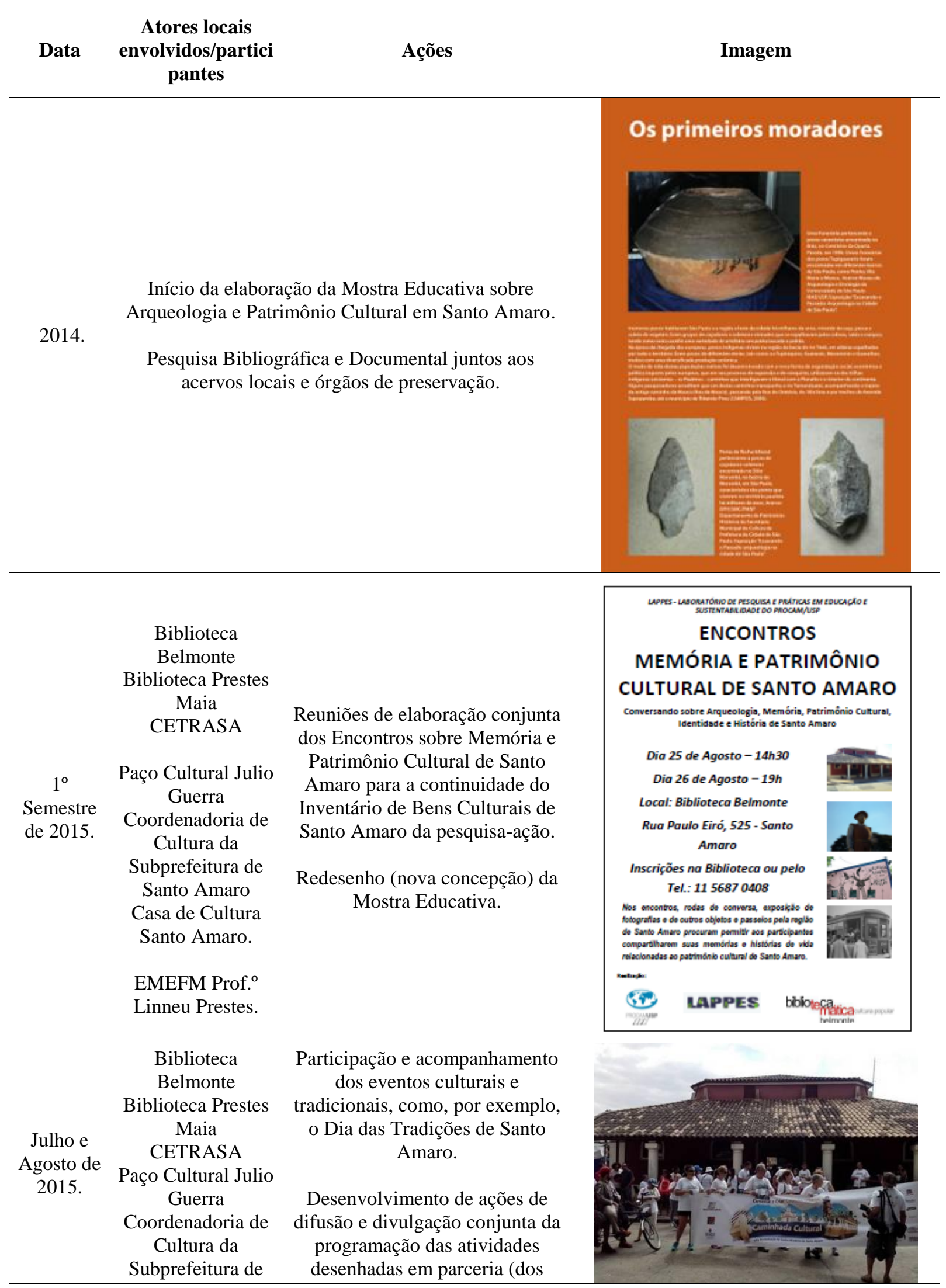




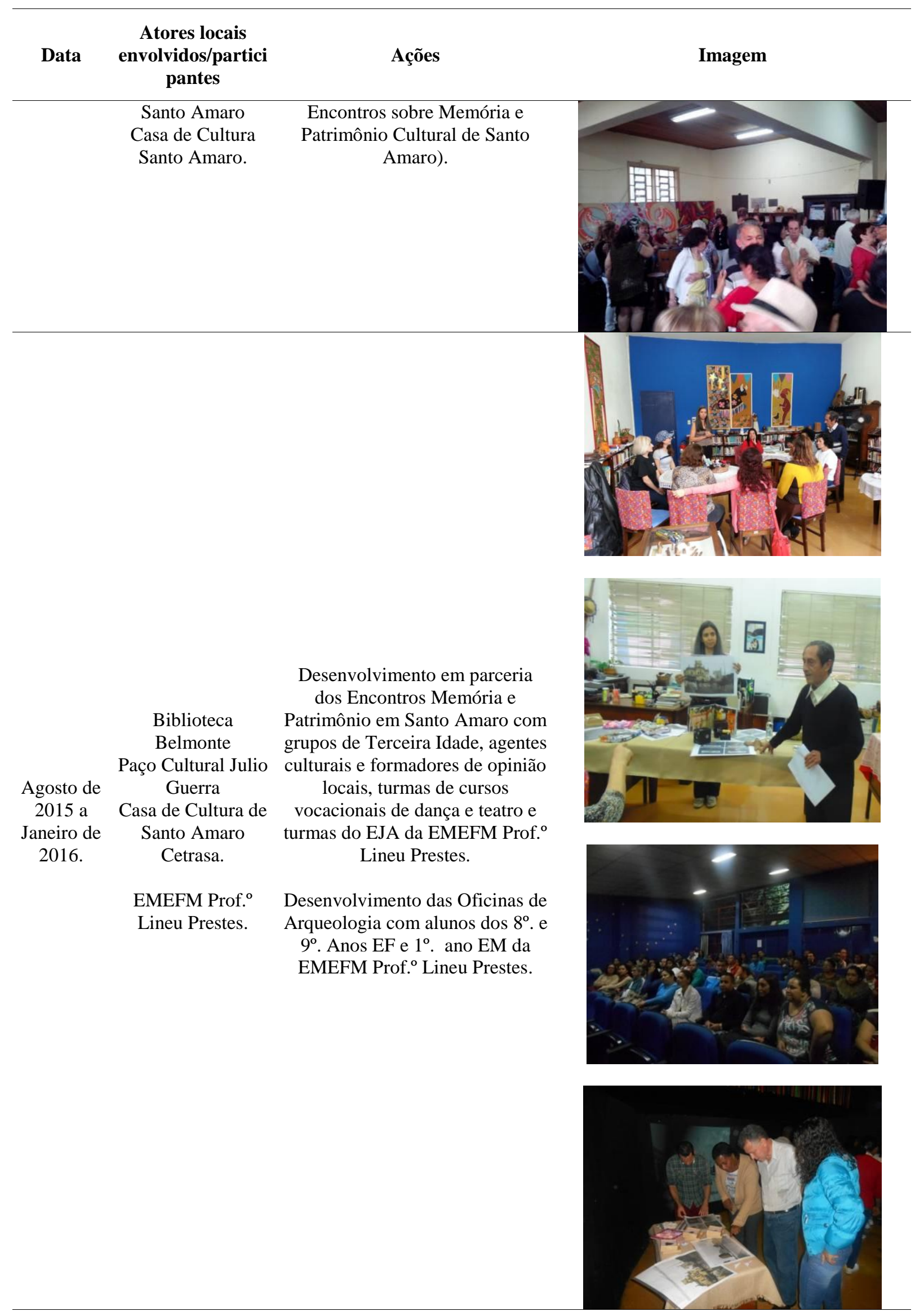




\section{Atores locais \\ envolvidos/partici pantes}

Ações

Imagem
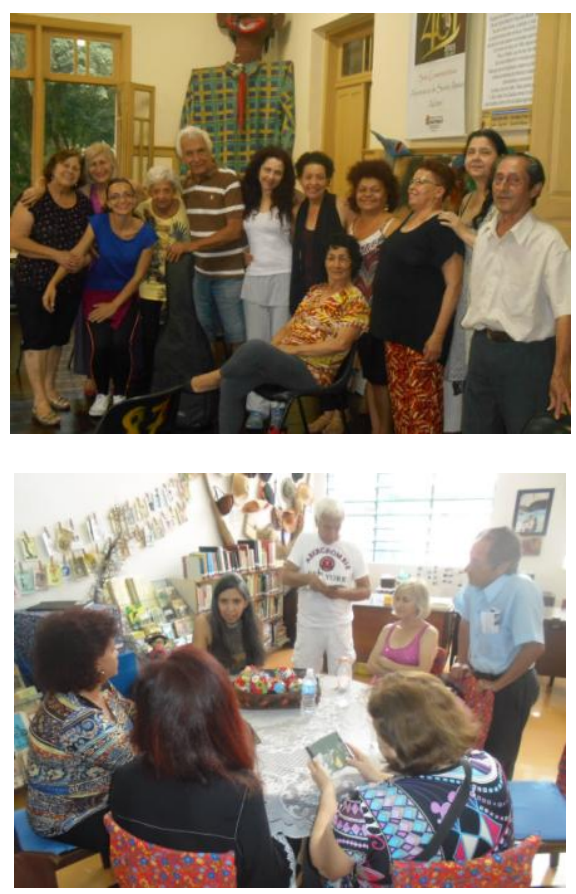

Turmas dos Cursos

Vocacionais de

Dança e Teatro do

Paço Cultural Julio

Guerra e Casa de

Cultura de Santo

Formação e atuação da

Comunidade de Pesquisa (Grupo

de Trabalho e de Ação) nas

atividades de Inventário dos Bens Culturais Inventariados.

Desenvolvimento de palestras e atividades de formação sobre Patrimônio Cultural junto ao Grupo de Ação. Amaro.
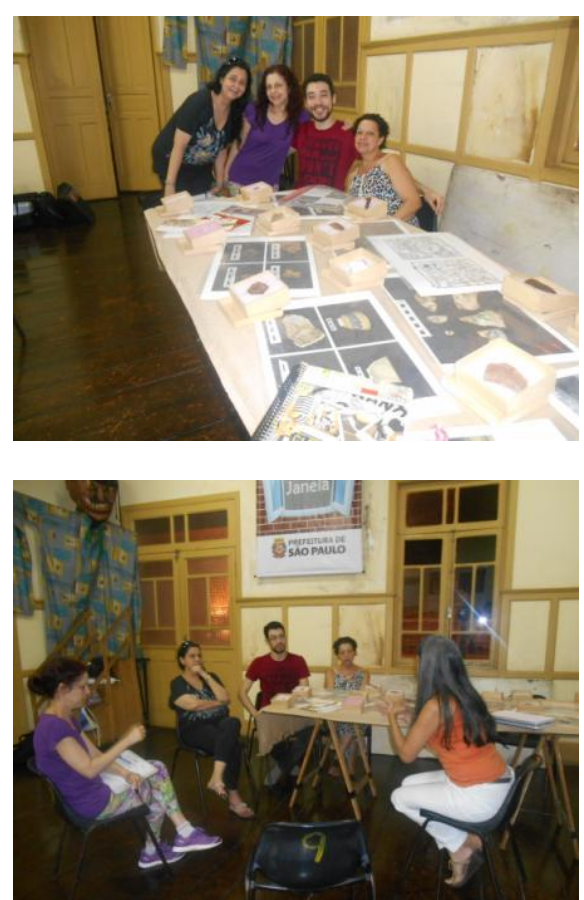


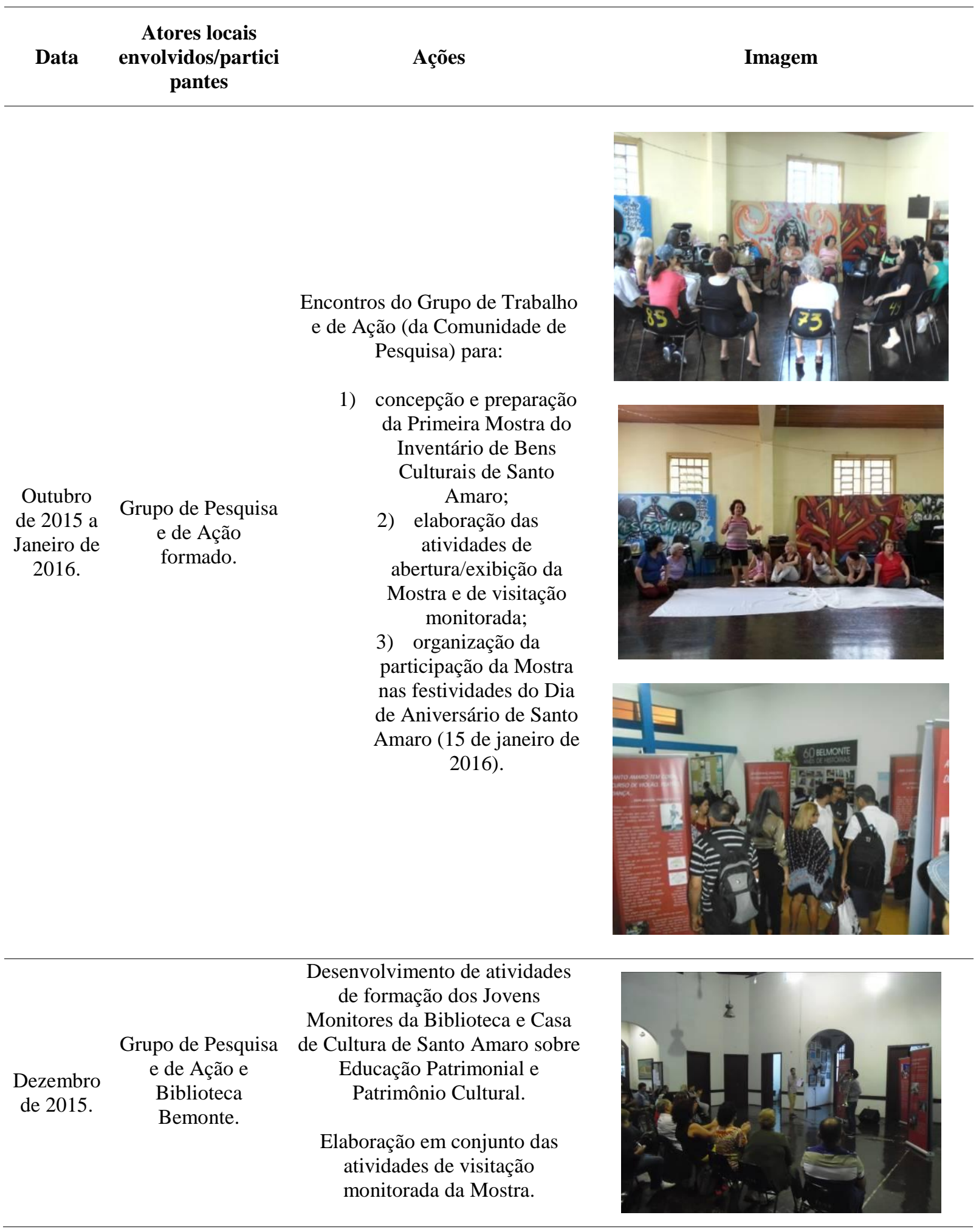




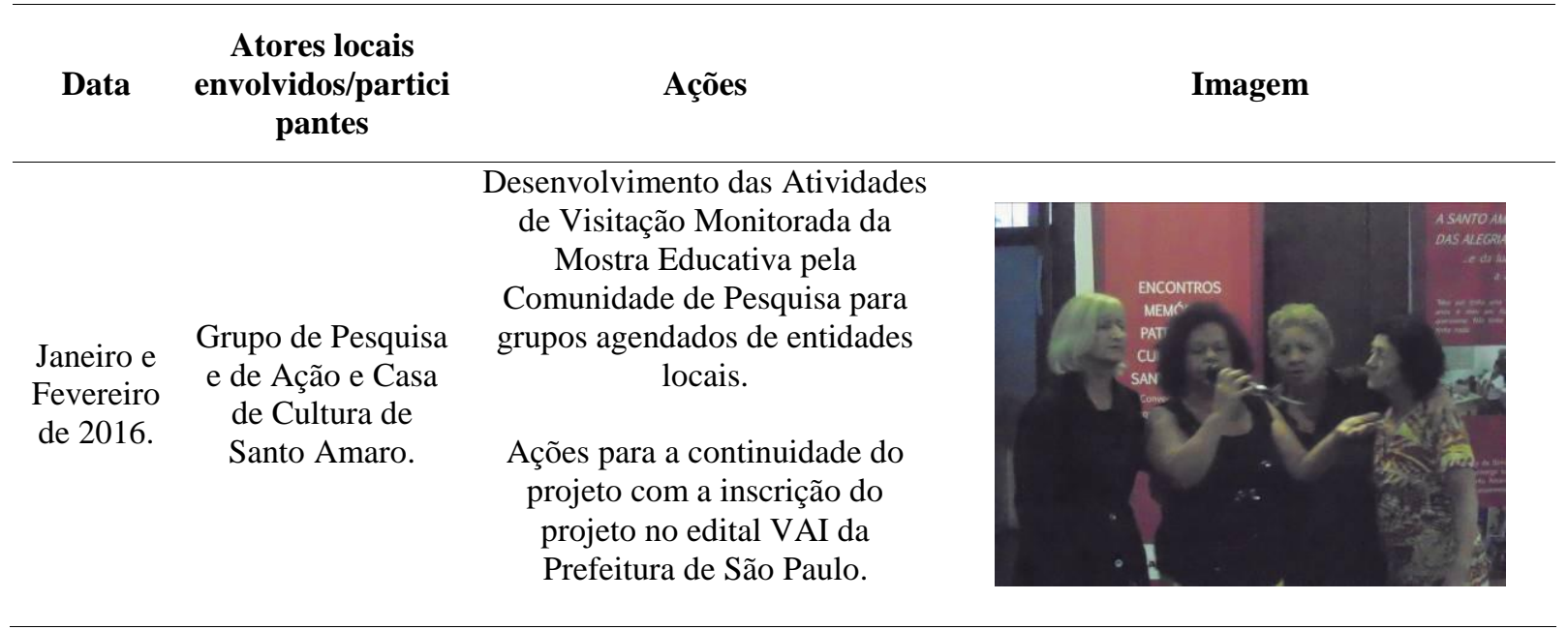

\subsection{Os Atores da Pesquisa}

De múltiplos espaços de manifestação cultural e artística e inserido num contexto rico de diversidade cultural de toda a Zona Sul, e que demandaria "uma parceria com capacidade técnica e metodológica para empreender uma exploração da riqueza" (SESC/PÓLIS, 2011), Santo Amaro apresentava, no mapeamento das dinâmicas socioculturais da Região Sul de São Paulo, realizado nos anos de 2009 e 2010, pelo SESC Santo Amaro e pelo Pólis - Instituto de Estudos, Formação e Assessoria em Política Sociais em parceria, destaque naquelas articuladas em torno das linguagens artísticas e da Educação Não Formal. A pesquisa considerou quinze distritos da região de Santo Amaro e mais quatro municípios adjacentes localizados no extremo dessa região ${ }^{67}$.

Observando os números, a Educação Não Formal conta com 117 mapeados, seguida das linguagens artísticas com 135. (SESC/PÓLIS, 2011, p.62).

O primeiro passo para o desenvolvimento da pesquisa-ação e do inventário foram as visitas, reuniões, entrevistas, os workshops e as oficinas de Educação Patrimonial (incluindo Arte Educação) em 2013 com os gestores escolares e culturais e educadores das escolas públicas e instituições culturais localizadas bem próximas dos bens patrimoniais constituintes do Eixo Histórico de Santo Amaro (fase exploratória, diagnóstica e de planejamento e formatação da pesquisa-ação).

As instituições culturais que participaram do projeto foram aquelas mapeadas na região de Santo Amaro e classificadas como de Educação Não Formal, Linguagens Artísticas

\footnotetext{
67 Campo Belo, Campo Grande, Campo Limpo, Capão Redondo, Cidade Ademar, Cidade Dutra, Diadema, Embu das Artes, Grajaú, Itapecerica da Serra, Jabaquara, Jardim Ângela, Jardim São Luís, Parelheiros, Pedreira, Santo Amaro, Capela do Socorro, Taboão da Serra e Vila Andrade
} 
(Biblioteca Belmonte) e Tradição (Casa de Cultura Santo Amaro), na publicação resultante desse mapeamento: Santo Amaro em rede: culturas de convivência (SESC/PÓLIS, 2011) ${ }^{68}$. Com exceção do Centro da Cidadania da Mulher - Santo Amaro, os demais grupos, espaços e entidades/instituições mapeados não ficavam nas proximidades do Eixo Histórico de Santo Amaro - o território de estudo da Tese. ${ }^{69}$

As escolas públicas visitadas também foram aquelas situadas bem próximo à área de abrangência do território de estudo definido. Sua importância "como parceira de ações socioculturais para articulação entre crianças, jovens e adolescentes" e "ponto de encontro da comunidade, em feriados e domingos" (SESC/PÓLIS, 2011, p.68) também foram razão de sua presença na pesquisa.

As escolas e os aparelhos culturais atuariam e atuaram em todo o processo da pesquisa-ação como polos de atração e de encontro da comunidade local para as ações de Educação Patrimonial, as quais se fundamentaram também no potencial multiplicador dos alunos, crianças e jovens que além da participação ativa nas atividades propostas, poderiam colaborar na mobilização da família para participação na pesquisa, além de disseminar os conhecimentos construídos nas suas redes de relacionamento.

A escola, além de ser o espaço privilegiado de formação e de vivência escolar formal, também se constitui hoje num dos aparelhos públicos de maior representatividade local, com intenso fluxo de pais e familiares que levam e buscam seus filhos, que participam de reuniões de pais e outros eventos festivos e de caráter cultural do calendário escolar (a Festa Junina, o Dia dos Pais e das Mães, Feira Cultural, Formatura, entre outros) e de programas/projetos de iniciativa governamental ou proveniente de alguma parceria com grupos e coletivos artísticos e outras iniciativas.

O objetivo dessas ações iniciais de caráter exploratório foi permitir um primeiro diagnóstico para o planejamento e formatação da pesquisa-ação, com base também em atividades de Educação Patrimonial desenvolvidas com ferramentas participativas, que almejaram a apresentação e discussão do conceito de patrimônio cultural para conhecimento, reflexão e apropriação pelos participantes, de forma possibilitar o reconhecimento e a

\footnotetext{
${ }^{68}$ Além da publicação, foi construída uma hipermídia com informações sobre as manifestações culturais do território pesquisado. Disponível em: http://www.mostrasescdeartes.com.br/stoamaroemrede/> Acesso em: 01 mar 2016. Ver também: http://polis.org.br/acoes/mapa-santo-amaro-em-rede-culturas-de-convivencia/.

${ }^{69}$ O Centro é localizado na Praça Salim Farah Maluf, no passado, ocupada pelo Colégio Paulo Eiró, demolido no final dos anos 1970. Embora não tenha sido visitado no início do projeto em 2013, teve 6 de suas freqüentadoras participando ativamente da pesquisa nos Encontros sobre Memória e Patrimônio Cultural de Santo Amaro de 2015, na vizinha Biblioteca Belmonte.
} 
identificação da riqueza patrimonial da região representada também, mas não apenas, pelo Eixo Histórico tombado, chamando atenção para as referências culturais presentes no cotidiano da vida das pessoas, que poderiam tornar-se bens patrimoniais coletivos.

Baseadas numa concepção de educação mais ampla entendida como um processo de aprendizado de habilidades para interpretação e entendimento do mundo, ultrapassando os limites de cada área e/ou disciplina escolar, tomando como referências tanto a mencionada LDB, que destaca a observância nos currículos dos Ensinos Fundamental e Médio das características regionais e locais da sociedade e da cultura, como os PCN, com seus temas transversais e interdisciplinares ${ }^{70}$ as atividades de Educação Patrimonial também foram realizadas com alunos do ensino regular dessas escolas, definidos conjuntamente com os professores que participaram dos workshops em 2013. Em 2015, foram os estudantes do EJA - Educação de Jovens e Adultos e dos $8^{\circ}, 9^{\circ}$. anos e séries iniciais do Ensino Médio da EMEFM Linneu Prestes que foram definidos pelos professores e coordenadores pedagógicos para participação nas atividades relacionadas ao Inventário.

\subsection{O Território do Estudo: o subdistrito de Santo Amaro e seu Eixo Histórico}

A apresentação do território de estudo - o Centro (Eixo) Histórico de Santo Amaro, com seus bens patrimoniais materiais tombados - foi realizada a partir de textos editados das entrevistas com os participantes do processo de pesquisa do inventário e publicações e produções de historiadores e de instituições locais levantadas e também consultadas, especialmente os aspectos de sua história quando município e depois como bairro da cidade de São Paulo, sem tratamento em profundidade, pois não era o objetivo da tese e nem o papel de um inventário.

Com base na memória "que é vida, sempre carregada por grupos vivos e, nesse sentido [...] aberta à dialética da lembrança e do esquecimento, inconsciente de suas deformações sucessivas, vulnerável a todos os usos e manipulações, susceptível de longas latências e de repentinas revitalizações" (NORA, 1993, p.9), que esse capítulo apresenta o bairro paulistano que já foi município de Santo Amaro.

\footnotetext{
${ }^{70}$ Elaborados pelo MEC, os PCN para o Ensino Fundamental introduzem os chamados "temas transversais"; aqueles que possibilitam a realização de projetos de educação patrimonial são os relacionados aos temas do meio ambiente e da pluralidade cultural
} 


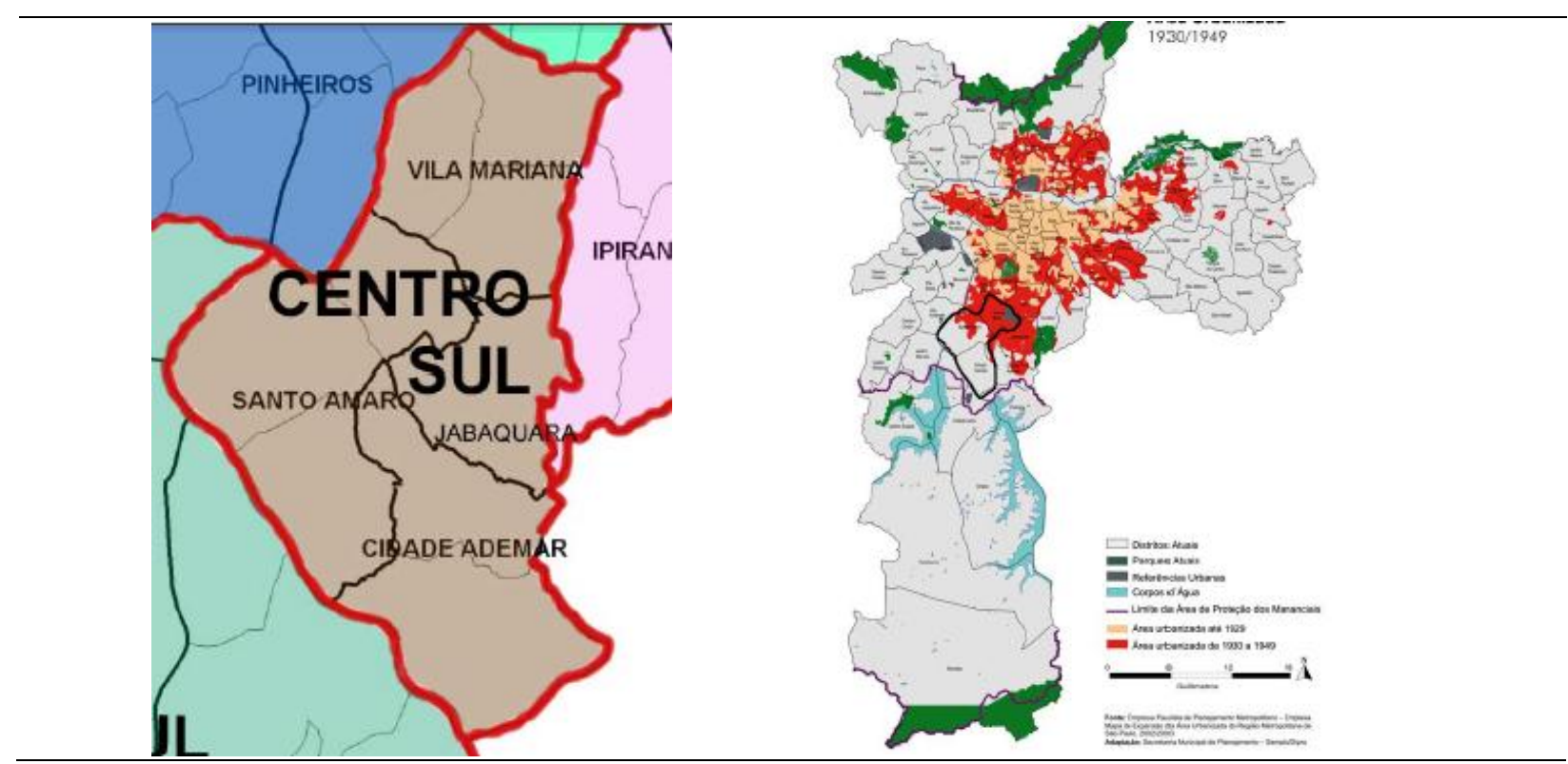

Figuras 1. Região Centro-Sul composta pelas Subprefeituras de Vila Mariana, Santo Amaro, Jabaquara e Cidade Ademar (2002) e Subprefeitura de Santo Amaro que compreendia os distritos de Santo Amaro, Campo Belo e Jabaquara, na década de 1950. Fonte: Programa Patrimônio e Referências Culturais nas Subprefeituras. Prefeitura do Município de São Paulo - PMSP, Secretaria Municipal de Cultura - SMC, Departamento do Patrimônio Histórico - DPH e Divisão de Preservação, s/d. (Pesquisa Bibliográfica e Documental do Inventário). Disponível em: http://www.prefeitura.sp.gov.br/cidade/upload/SantoAmaro_web_1392057658.pdf> Acesso em: 01 mar 2016.

O Conselho Municipal de Preservação do Patrimônio Histórico, Cultural e Ambiental da Cidade de São Paulo - CONPRESP, no uso de suas atribuições legais e nos termos da Lei no.10.032/85, com as alterações introduzidas pela Lei no. 10.236/86, conforme decisão unânime dos Conselheiros presentes à 270a . Reunião Ordinária, realizada em 13 de agosto de 2002,

CONSIDERANDO o valor histórico, urbanístico e ambiental da área identificada como Eixo Histórico de Santo Amaro, representativa da formação e desenvolvimento desse antigo núcleo urbano que hoje integra a cidade de São Paulo; CONSIDERANDO o valor arquitetônico e paisagístico de alguns dos elementos constitutivos desse ambiente urbano, reconhecidos por inventários e medidas legais de proteção da Prefeitura do Município de São Paulo; e

CONSIDERANDO o valor afetivo para a população do bairro de Santo Amaro e região, bem como para toda a cidade de São Paulo, desse Eixo Histórico no qual se concentram significativas formas de expressão cultural e social paulistanas,

RESOLVE:

Artigo $1^{\circ}$. - Tombar um conjunto de elementos constitutivos do ambiente urbano identificado como Eixo Histórico de Santo Amaro, definido pelos seguintes logradouros públicos, conforme contido no Processo no. 1993-0.007.834-8:

a) Rua Antonia Bandeira

b) Rua Visconde de Taunay

c) Praça Dr. Francisco Ferreira Lopes

d) Rua Dr. Francisco Ferreira Lopes

e) Rua Tenente Coronel Carlos da Silva Araújo

f) Rua Cerqueira César - trecho entre a Rua Paulo Eiró e Rua Tenente Cel. Carlos da Silva Araújo

g) Praça Salim Farah Maluf

h) Rua Mário Lopes Leão - trecho entre a Rua Paulo Eiró e a Rua Tenente Cel. Carlos da Silva Araújo

i) Rua Capitão Tiago Luz

j) Rua Senador José Bonifácio

k) Praça Floriano Peixoto

1) Rua Paulo Eiró - trecho entre a Rua Cerqueira César e a Rua da Matriz 
m) Largo Treze de Maio

n) Rua Senador Fláquer - trecho entre o Largo Treze de Maio e a Rua Herculano de Freitas

o) Rua Senador Dantas - trecho entre o Largo Treze de Maio e a Rua Herculado de Freitas

p) Avenida Padre José Maria - trecho entre a Rua Paulo Eiró e o Largo Treze de Maio.

Artigo $2^{\circ}$. - Os elementos constitutivos tombados, no ambiente urbano referido no Artigo $1^{\circ}$, são os seguintes:

I) Traçado viário dos logradouros públicos identificados no Artigo $1^{\circ}$;

II) Praça Floriano Peixoto;

III)Largo Treze de Maio;

IV)Praça Salim Farah Maluf;

V) Edifício da Antiga Prefeitura de Santo Amaro, localizado à Praça Floriano Peixoto - preservação integral;

VI)Imóvel localizado na Praça Dr. Francisco Ferreira Lopes no. 787 - preservação das características arquitetônicas externas;

VII) Igreja Matriz de Santo Amaro, localizada no Largo Treze de Maio preservação integral; e

VIII) Biblioteca Pública Presidente Kennedy, localizada à Avenida João Dias no. 822 - preservação das características arquitetônicas externas. (...)

(Resolução $\mathrm{n}^{\circ}$. 14/2002 - documento apresentado e discutido em atividade com o Grupo de Ação Yellow no Inventário). ${ }^{71}$

Santo Amaro, que, no século XVI, foi habitado por índios Guaianases, os quais formaram uma aldeia jesuítica em torno da Capela de Santo Amaro, hoje Largo de 13 de Maio, é um dos bairros mais antigos da cidade, que foi município de 1832, com a criação da Câmara Municipal de Santo Amaro, até 1935, quando após a Revolução Constitucionalista de 1932, volta a ser anexado a São Paulo (BERARDI, 1981). ${ }^{72}$

\footnotetext{
${ }^{71}$ O CONPRESP emite Resoluções de Abertura de Processo de Tombamento (APT), de Tombamento (T), de Tombamento Exofficio (TEO), de Regulamentação de Área Envoltória (RAE) que retificam, ratificam ou se restringem a procedimentos administrativos destinados à normatização do bom uso do espaço urbano e que são publicadas no Diário Oficial. As resoluções devem ser homologadas pelo Secretário de Cultura e os Cartórios de Registros devem ser notificados. A APT antecede o tombamento e confere ao bem o mesmo regime de preservação do bem tombado até a decisão final do Conselho. É a Resolução de Tombamento que apresenta a decisão do Conselho que ratifica o valor cultural, histórico, arquitetônico e ambiental do bem tombado e protegendo-o "da destruição, da descaracterização, além de reconhecer e manter seu valor para as futuras gerações. Ao proprietário do imóvel tombado compete, portanto, obedecer às diretrizes definidas na Resolução de Tombamento" (SÃO PAULO, s/d., p.23). Disponível em: <http://www.prefeitura.sp.gov.br/cidade/upload/SantoAmaro_web_1392057658.pdf> Acesso em: 01 mar 2016.

${ }^{72}$ Movimentos emancipacionistas ocorridos nas décadas de 1950 e 1970, contudo, não conseguiram sensibilizar a população para que Santo Amaro fosse novamente elevado à condição de município. Ver: BERARDI, Maria Helena Petrillo. Santo Amaro. Série História dos Barros de São Paulo IV. Prefeitura Municipal - Secretaria e Educação e Cultura - Departamento de Cultura, $4^{\circ}$. Volume-1981, $2^{\mathrm{a}}$. edição. Esse livro foi premiado com menção honrosa no I Concurso Municipal de História dos Bairros de São Paulo, promovido pelo Departamento de Cultura da Prefeitura Municipal e outorgado pela Comissão Julgadora constituída por Myriam Ellis, Ernani Silva Bruno e Pedro Brasil Bandecchi. Ver também: Berardi, Maria Helena Petrillo. Santo Amaro: memória e história: da botina amarela ao chapéu de couro. São Paulo: Scortecci, 2003.
} 

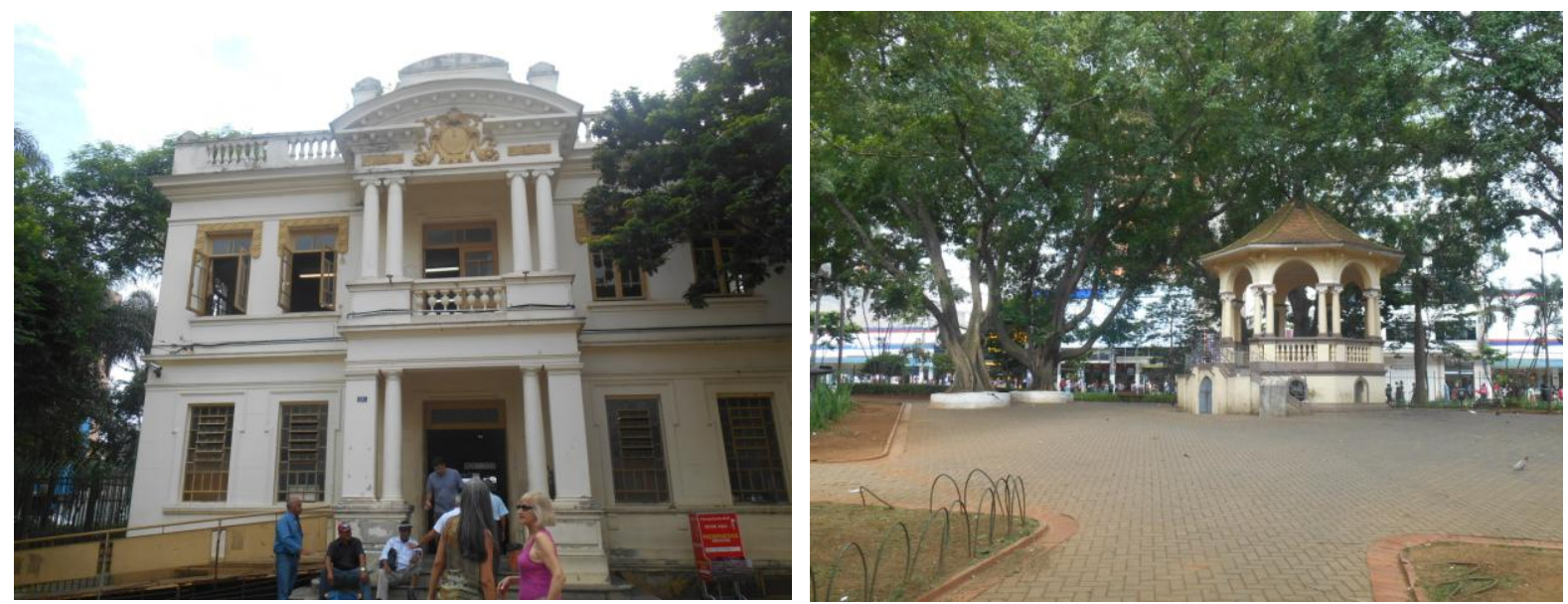

Figuras 2 e 3. Antiga sede da Prefeitura de Santo Amaro inaugurada em 1929 hoje Paço Cultural Julio Guerra (ou Casa Amarela) e Praça Floriano Peixoto. Fotos do Grupo de Trabalho dos Encontros (produzidas na atividade educativa Fotografando Santo Amaro pela Comunidade de Pesquisa para o Inventário).
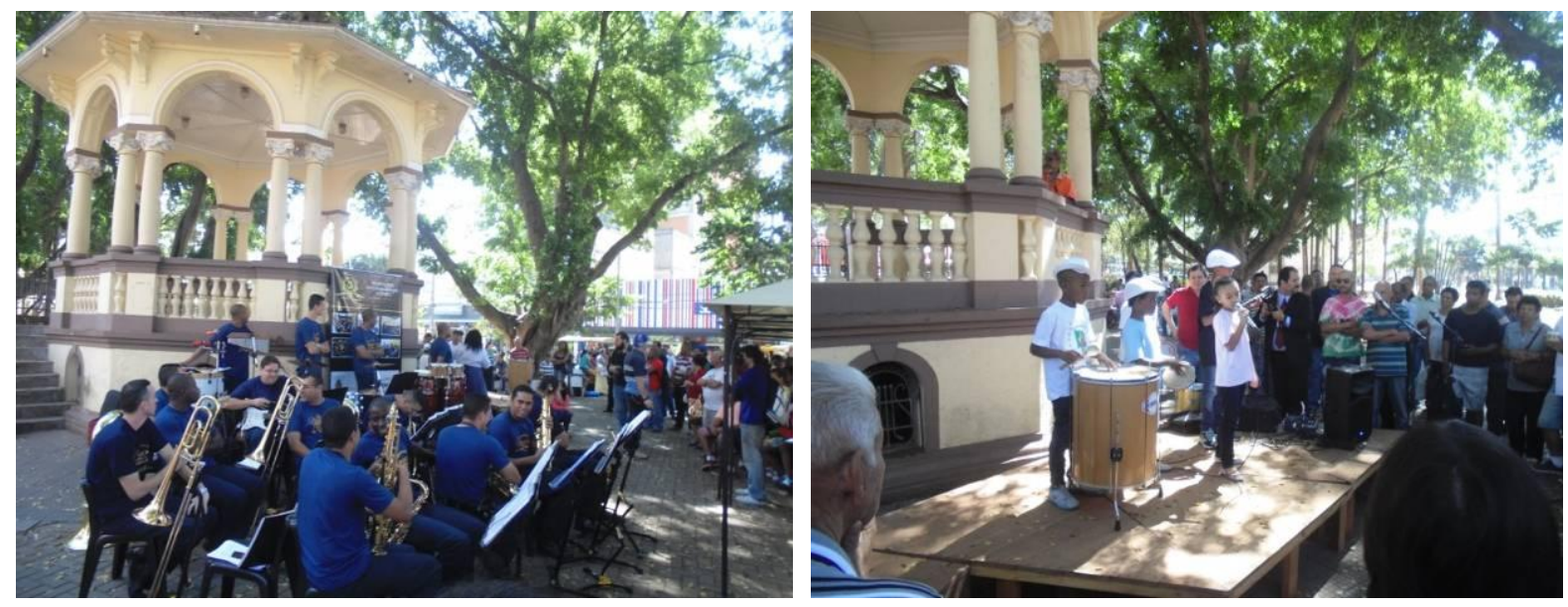

Figuras 4 e 5 . Coreto da Praça Floriano Peixoto (antigo Jardim de Santo Amaro) ao lado da Casa Amarela com as apresentações da Orquestra Sinfônica de Santo Amaro e do Grupo Mirim do Tradicional Samba da Vela no Dia das Tradições de Santo Amaro, em 13 de agosto de 2015, promovidas pela Subprefeitura de Santo Amaro. (C) Fotos da autora.
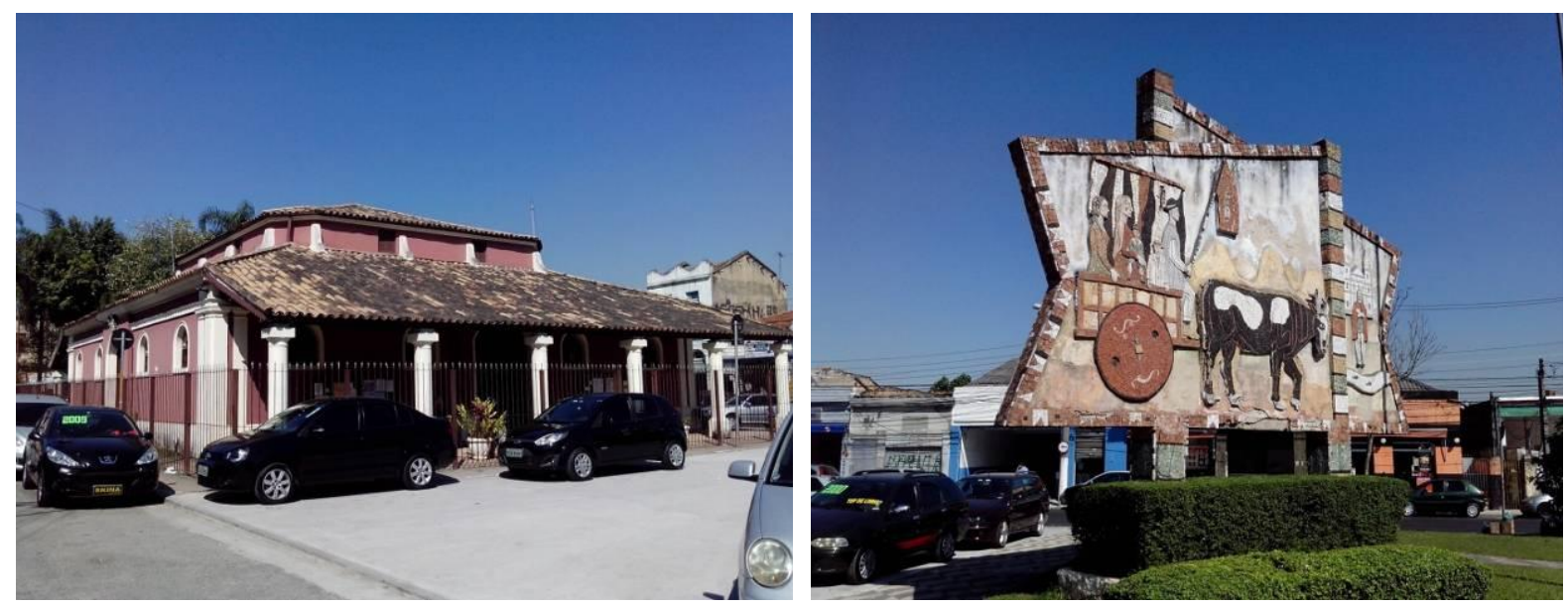

Figuras 6 e 7. Antigo Mercado Municipal (Mercadão) tombado, inaugurado em 1897, hoje Casa de Cultura Manoel Cardoso de Mendonça, e Monumento aos Romeiros à sua frente. Foi o ponto de encontro da Caminhada 
Cultural pelo Eixo Histórico de Santo Amaro, no Dia das Tradições de Santo Amaro, em 13 de agosto de 2015, promovida pela Subprefeitura e Rede de Santo Amaro. Fotos da autora.

Seu Eixo Histórico (ver Figuras 8 a 23 a seguir) começa na Praça Marcos Manzini em frente à Biblioteca Prestes Maia (anteriormente Biblioteca Presidente Kennedy, inaugurada em 1963), segue pela rua Tenente Coronel Carlos da Silva Araújo, Praça Salim Farah Maluf, Praça Floriano Peixoto, calçadão da Rua Capitão Tiago Luz até o Largo Treze de Maio (Igreja Matriz):

[...] Os moradores mais antigos se recordam que este solo foi testemunho e cenário dos acontecimentos das terras dos Botinas Amarelas; caminho de fé para os romeiros que iam a Bom Jesus de Pirapora; vereda de sucesso de Inezita Barroso, Tonico e Tinoco que, em carros de bois, seguiam até a Praça da Viola, e vereda romântica que os jovens percorriam até os jardins, hoje Praça Floriano Peixoto, para praticarem o footing ao redor do Coreto, e para o público que freqüentava o Cine São Francisco. (Boletim Informativo Santo Amaro Informa, ${ }^{\circ}$. 2, setembro de 2015, levantado pela D. Maria Camargo para os encontros do Grupo de Trabalho/Comunidade de Pesquisa).
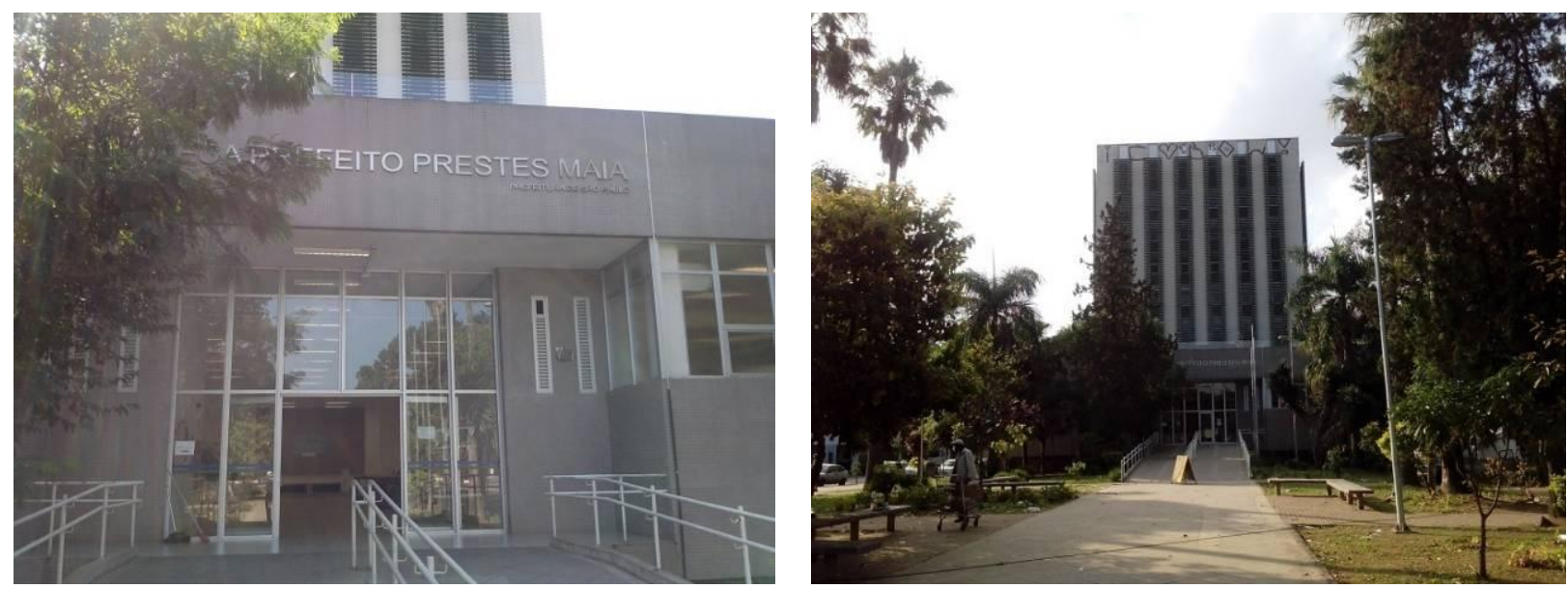

Figuras 8 e 9. Biblioteca Pública Municipal Prestes Maia, antiga Biblioteca Pública Roberto Kennedy de 1963, onde inicia o Eixo Central Histórico tombado. Fotos da autora no Dia das Tradições de Santo Amaro.
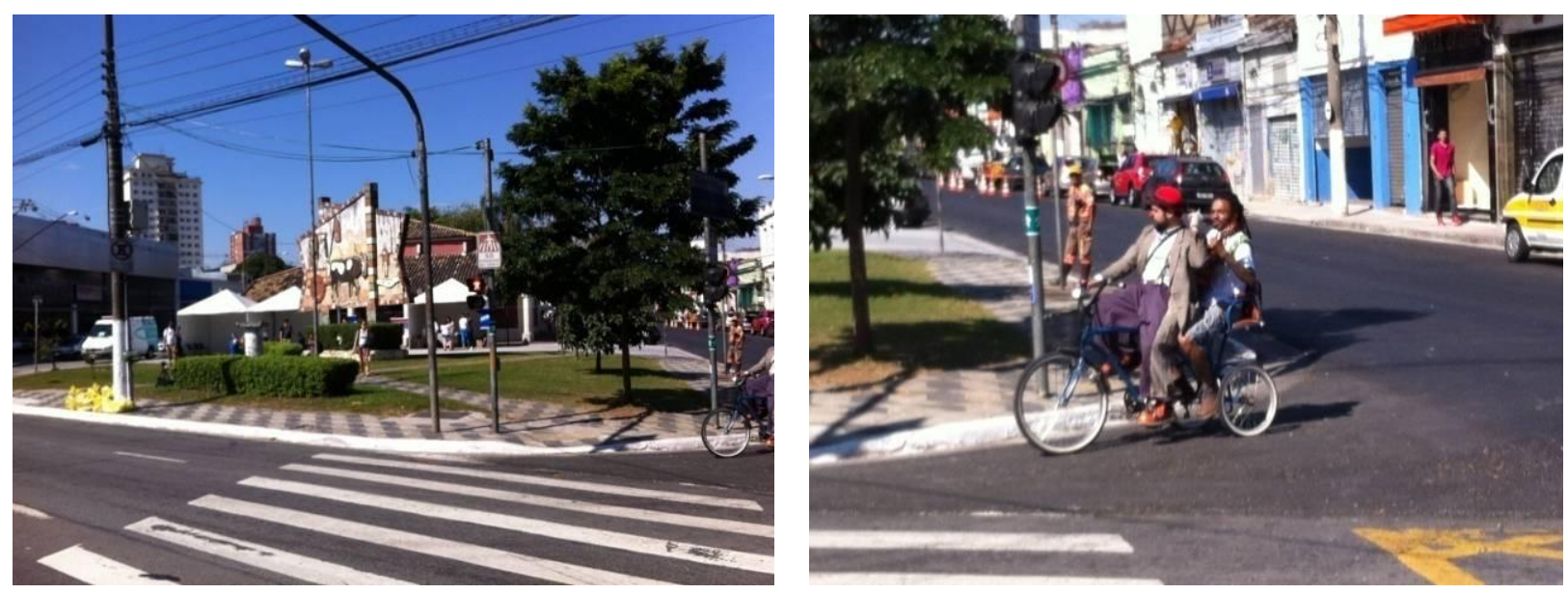

Figuras 10 e 11. Casa de Cultura de Santo Amaro e rua Tenente Coronel Carlos da Silva Araújo componentes do Eixo Histórico de Santo Amaro. Fotos da autora no Dia das Tradições de Santo Amaro. 

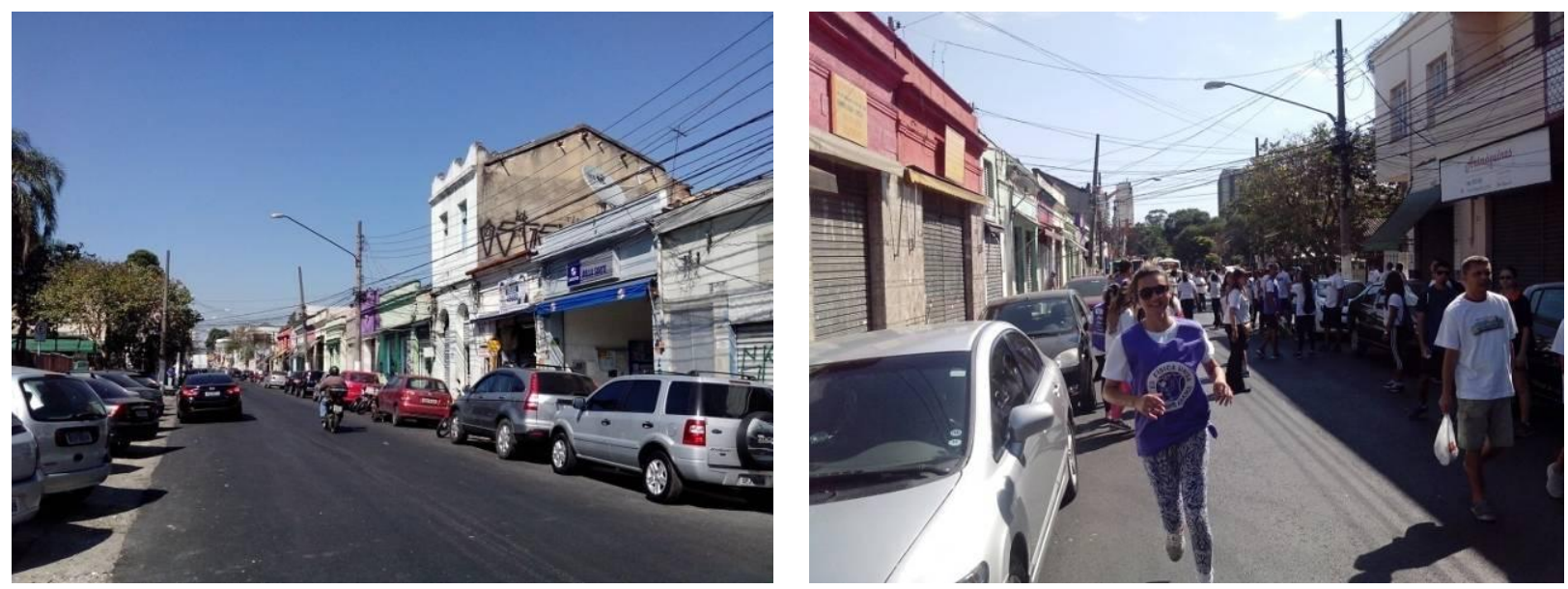

Figuras 12 e 13. Rua Tenente Coronel Carlos da Silva Araújo no dia da Caminhada Cultural pelo Eixo Histórico de Santo Amaro, em 13 de agosto de 2015 (Dia das Tradições de Santo Amaro), promovida pela Subprefeitura e Rede de Santo Amaro. Fotos da autora.
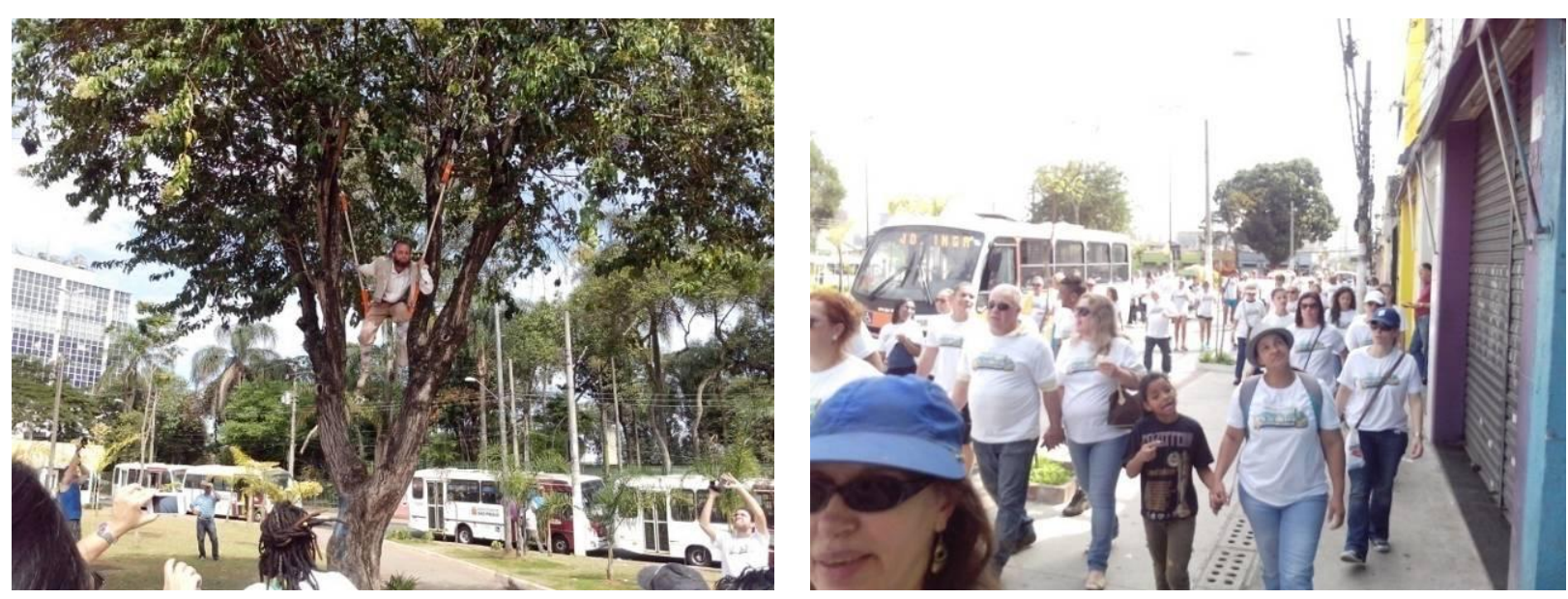

Figuras 14 e 15. Praça Salim Farah Maluf e o seu calçadão ao lado. Foi palco de apresentação teatral na Caminhada Cultural pelo Eixo Histórico de Santo Amaro, no Dia das Tradições de Santo Amaro, em 13 de agosto de 2015. Fotos da autora.
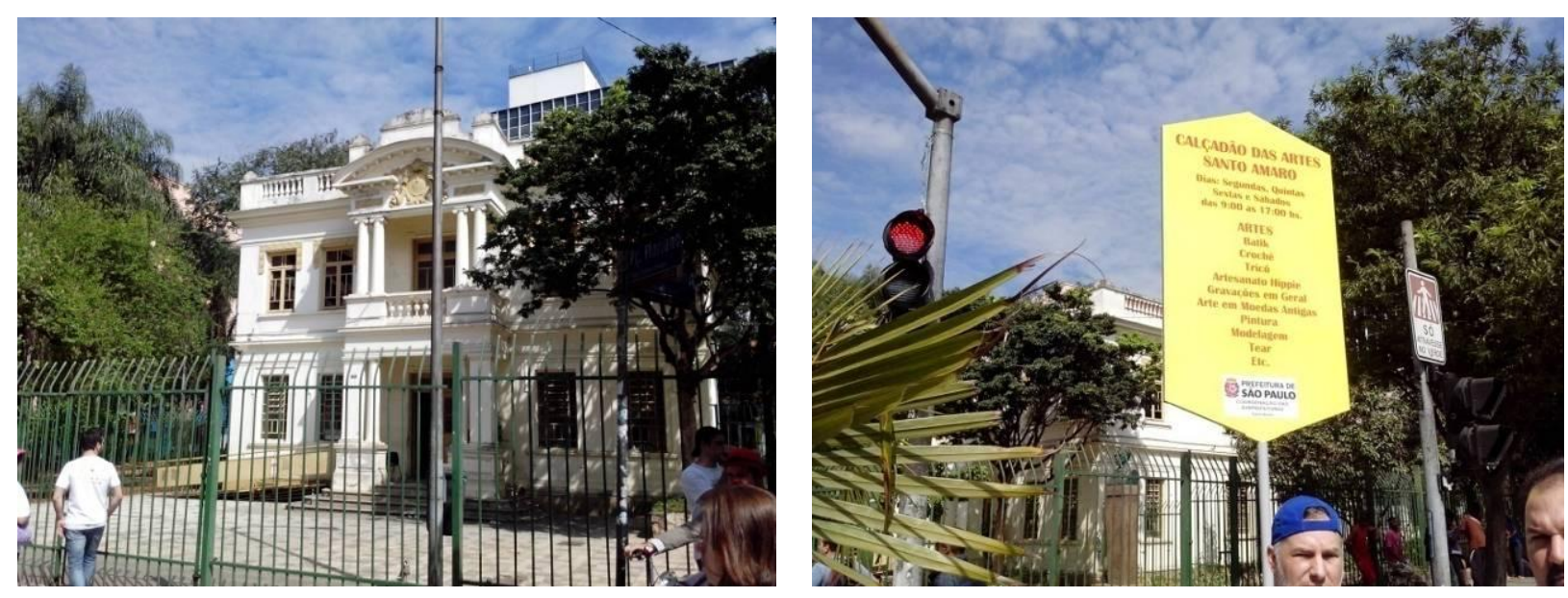
Figuras 16 e 17. Casa Amarela (Paço Cultural Júlio Guerra) ao lado da/na Praça Floriano Peixoto na Caminhada Cultural pelo Eixo Histórico de Santo Amaro, no Dia das Tradições de Santo Amaro, em 13 de agosto de 2015. Fotos da autora.
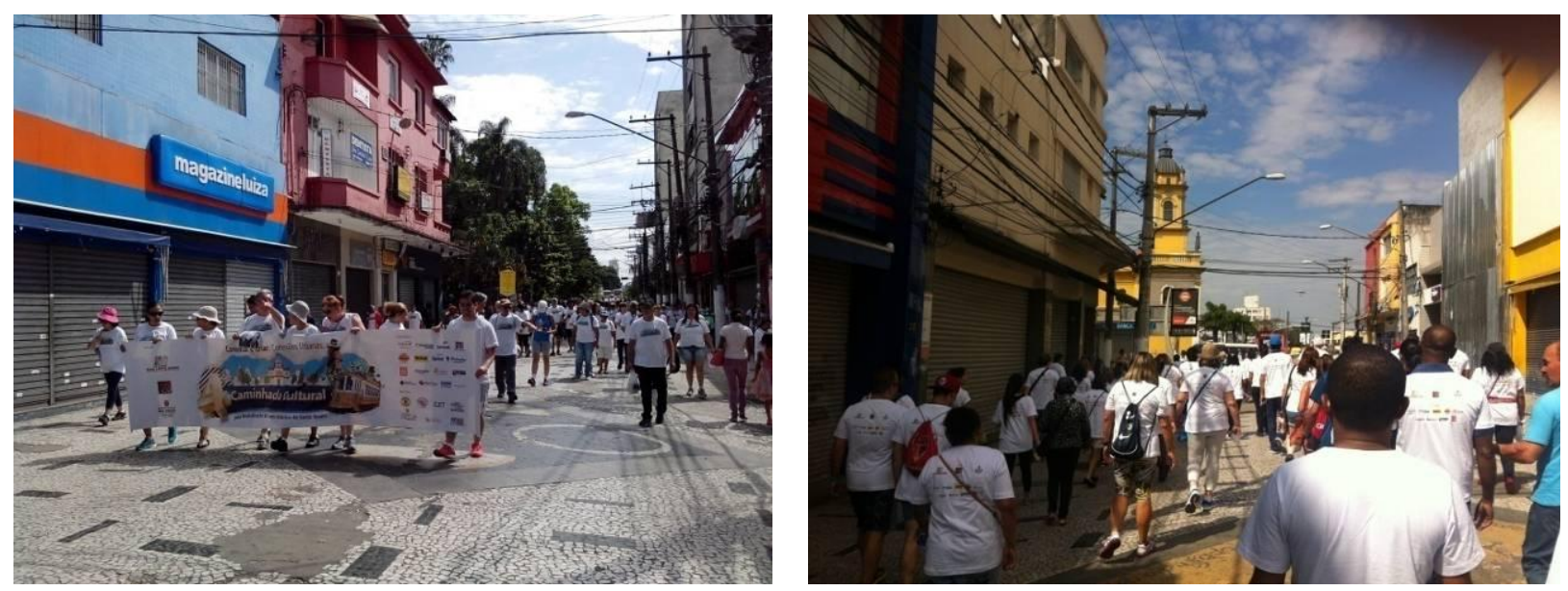

Figuras 18 e 19. Calçadão da Rua Capitão Tiago Luz do Eixo Histórico de Santo Amaro na Caminhada Cultural no Dia das Tradições de Santo Amaro, em 13 de agosto de 2015. Fotos da autora.
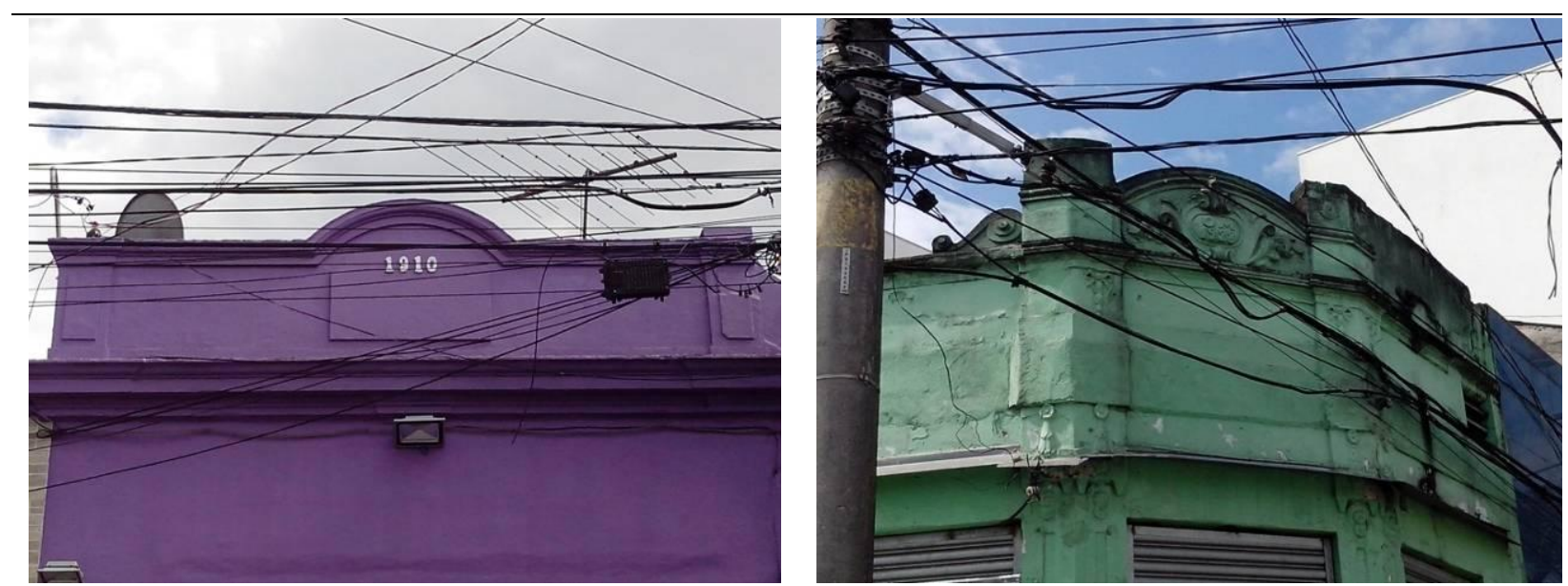

Figuras 20 e 21. Detalhes de duas fachadas de casario da rua Tenente Coronel Carlos da Silva Araújo e do calçadão da Rua Capitão Tiago Luz do Eixo Histórico de Santo Amaro. Fotos da autora
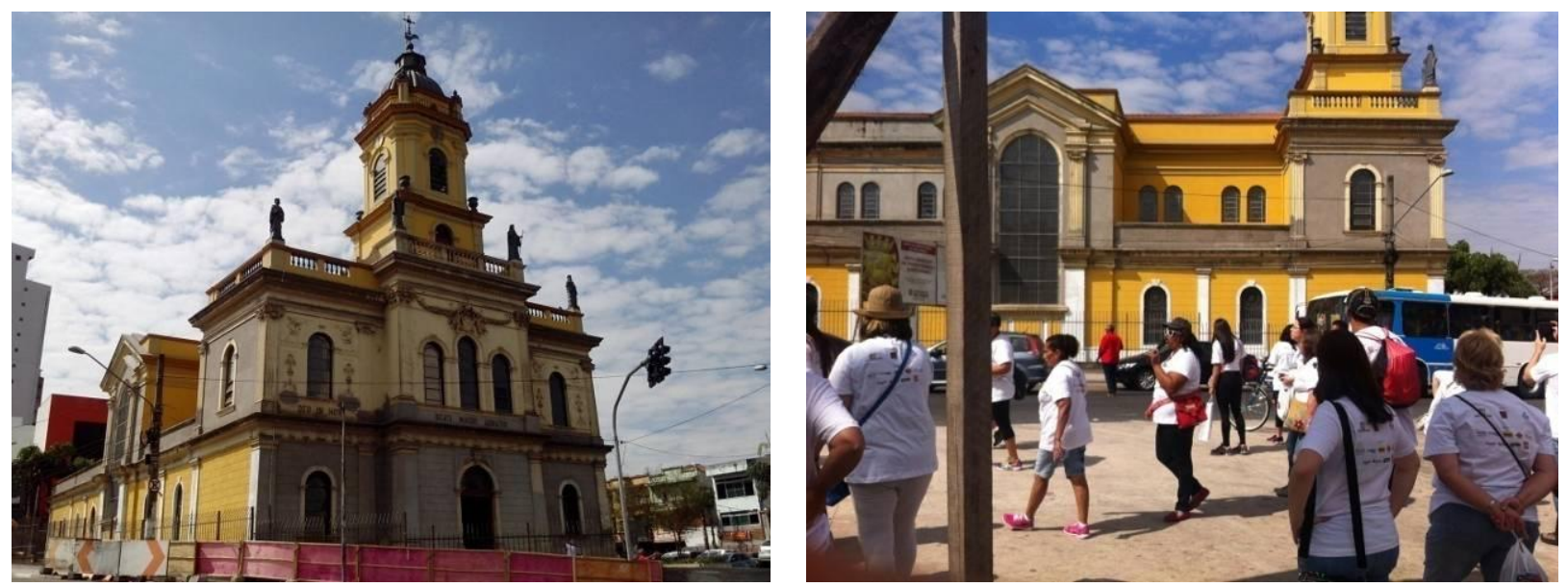
Figuras 22 e 23. Igreja Matriz de Santo Amaro (em reforma na ocasião) e Largo Treze de Maio na Caminhada Cultural pelo Eixo Histórico de Santo Amaro no Dia das Tradições de Santo Amaro, em 13 de agosto de 2015. A primeira Igreja Matriz data do fim do século XIX e a atual é de 1924, construída no lugar da capela inicial do século XVI. Fotos da autora..
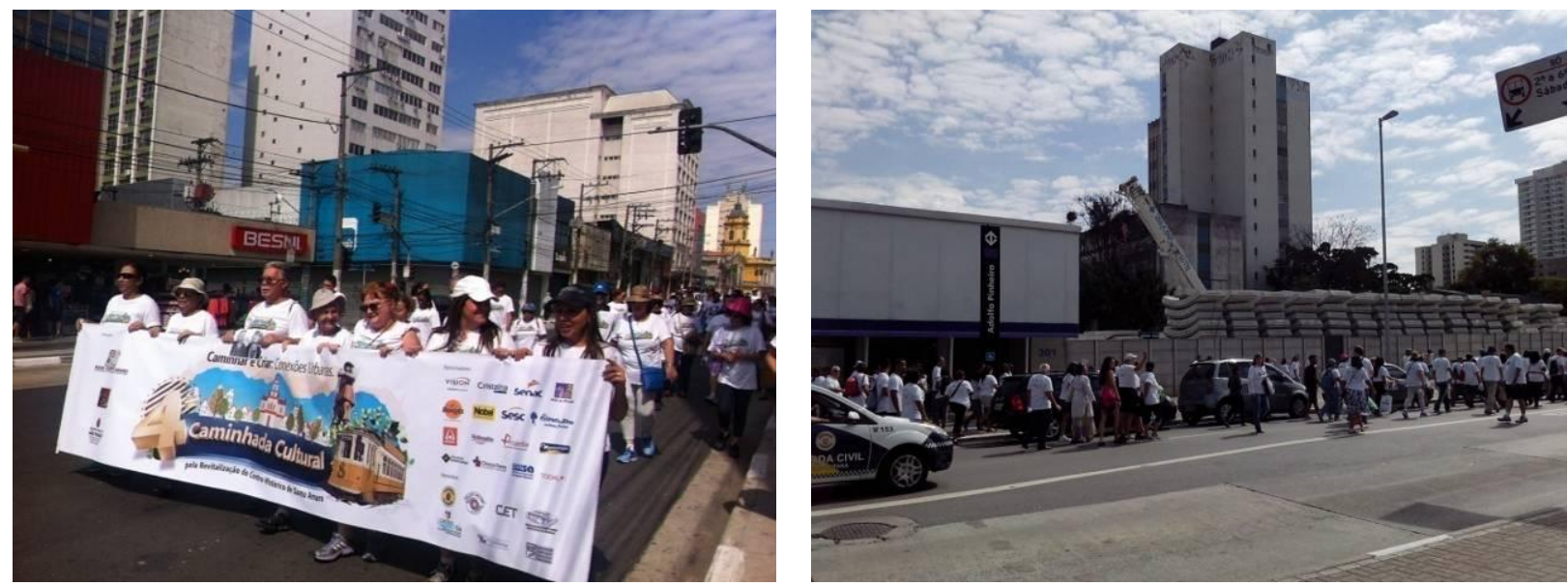

Figuras 24 e 25. Avenida Adolfo Pinheiro na Caminhada Cultural pelo Eixo Histórico de Santo Amaro em direção ao Teatro Municipal Paulo Eiró, outro bem cultural material local tombado. Fotos da autora.
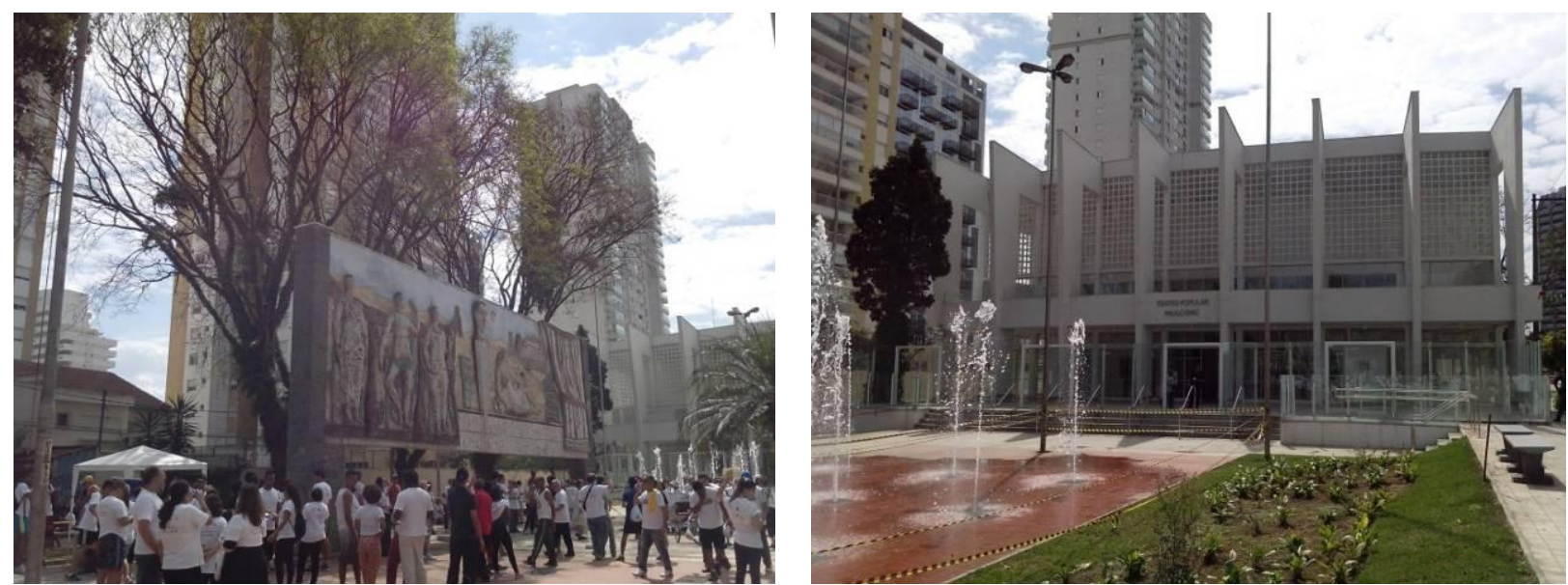

Figuras 26 e 27. Teatro Paulo Eiró, inaugurado no final dos anos 1950 e que possui em frente um painel/mural que homenageia o poeta santamarense Paulo Eiró de autoria do artista plástico local, nascido também em Santo Amaro em 1912, Julio Guerra. Recentemente reformado, foi tombado em 1989. Fotos da autora na Caminhada Cultural pelo Eixo Histórico de Santo Amaro, no Dia das Tradições de Santo Amaro.

O antigo município de Santo Amaro corresponde hoje às porções sul e sudoeste do atual território de São Paulo. Englobava os atuais distritos paulistanos de Santo Amaro, Campo Grande, Campo Belo, parte do distrito do Itaim Bibi, Cidade Ademar, Campo Limpo, Capão Redondo, Vila Andrade, Jardim Ângela, Jardim São Luís, Socorro, Cidade Dutra, Grajaú, Parelheiros e Marsilac. Correspondia a cerca de $43 \%$ do total da superfície do município de São Paulo. ${ }^{73}$

\footnotetext{
${ }^{73}$ Disponível em:

$\langle$ http://www.prefeitura.sp.gov.br/cidade/secretarias/subprefeituras/santo amaro/historico/index.php?p=450 $>$ Acesso em: 01 mar 2016
} 


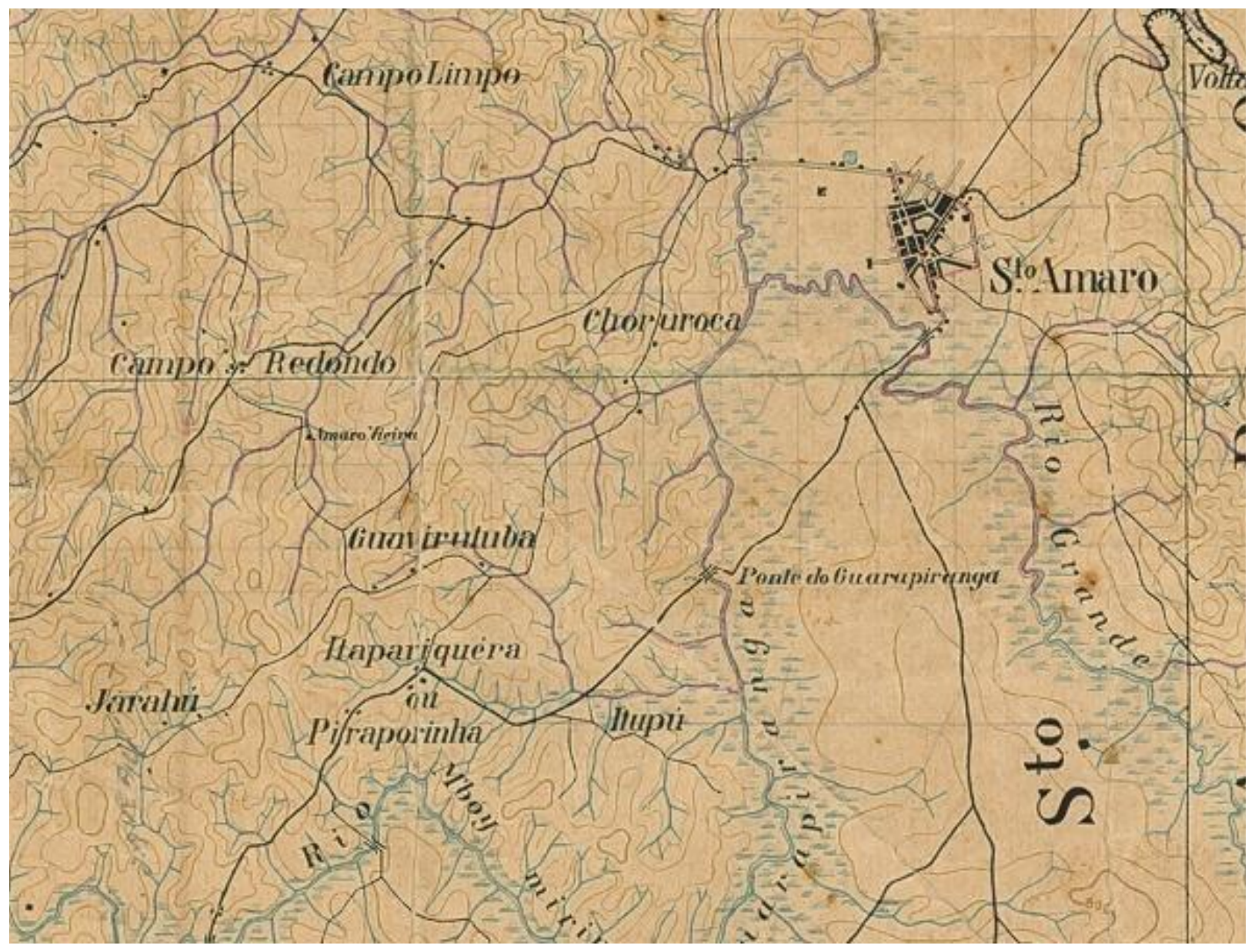

Figura 28. Fragmento do mapa da Commissão Geographica e Geologica, de 1906-1908. Fonte: Instituto Geográfico e Cartográfico - IGC.

A Região Centro Sul, composta pela Subprefeitura de Santo Amaro, além de Cidade Ademar, Jabaquara e Vila Mariana, totaliza 135 bairros, incluindo lugares que antes integravam o município de Santo Amaro. Sua ocupação esteve relacionada à "ampliação do trabalho assalariado e do número de fábricas" e à "implantação de serviços públicos, em especial o de transportes", a partir de 1870 (SÃO PAULO, s/d., p.16).

Hoje, a subprefeitura de Santo Amaro, que é o centro da zona sul do município de São Paulo e que continua a exercer considerável influência sobre os moradores desses outros distritos e bairros próximos que já pertenceram a seu território, abrange os distritos de Campo Belo, Campo Grande e Santo Amaro. 
Quadro 2. Dados Demográficos dos Distritos da Subprefeitura de Santo Amaro. Fonte: Disponível em: http://www.prefeitura.sp.gov.br/cidade/secretarias/subprefeituras/subprefeituras/dados demograficos/index.php? $\mathrm{p}=12758>$ Acesso em 01 mar 2016.

\begin{tabular}{|c|c|c|c|c|}
\hline Subprefeitura & Distritos & $\begin{array}{l}\text { Área } \\
\left(\mathbf{k m}^{2}\right)\end{array}$ & $\begin{array}{l}\text { População } \\
\text { (2010) }\end{array}$ & $\begin{array}{l}\text { Densidade } \\
\text { Demográfica } \\
\left(\mathrm{Hab} / \mathbf{k m}^{2}\right)\end{array}$ \\
\hline \multirow{4}{*}{ Santo Amaro } & Campo Belo & 8,80 & 65.752 & 7.472 \\
\hline & Campo Grande & 13,10 & 100.713 & 7.688 \\
\hline & Santo Amaro & 15,60 & 71.560 & 4.587 \\
\hline & TOTAL & 37,50 & 238.025 & 6.347 \\
\hline
\end{tabular}

Delimitado pelas avenidas Washington Luiz, Nações Unidas e Bandeirantes, faz divisa com Parelheiros, Taboão da Serra, Itapecerica da Serra, Diadema e Campo Belo. (ASSOCIAÇÃO COMERCIAL DE SANTO AMARO, 2004, p.54), Santo Amaro se constitui com cerca de 68 bairros e áreas de mananciais ${ }^{74}$. (SÃO PAULO, s/d, p.18).

Santo Amaro, que até meados do século XIX abastecia a cidade de São Paulo de produtos agrícolas, na década de 1960, tornou-se um pólo industrial. Concentrou importantes indústrias, sobretudo na região hoje entre Santo Amaro e Jurubatuba, que conta com terminais de ônibus e transportes ferroviários.

\begin{abstract}
Meu cunhado trabalhou muito tempo na Velnac. Era uma fábrica de veludo. Minha cunhada trabalhou lá, meu marido e o marido da minha cunhada também. (...) Era onde hoje é o Shopping Boa Vista. (...) Quando eu conheci meu marido, a Velnac era nos fundos. E tinha um sobradinho que era da Velnac e os funcionários moravam ali. (...) Meu marido trabalhou na Wapsa, Plavinil. (...) Tinha Laborterápica. Depois foram saindo... (D. Tereza Discher Câmara, integrante da Comunidade de Pesquisa em entrevista para o Inventário).
\end{abstract}

A região de Santo Amaro concentra um centro comercial no Largo Treze de Maio e atividades nos setores de serviços, com o estabelecimento de sedes de multinacionais, hotéis de padrão internacional, bancos e grandes escritórios próximos ao rio Pinheiros. ${ }^{75}$

\footnotetext{
74 “A Represa de Guarapiranga foi construída em 1907 pela Light para regularizar a vazão do rio Tietê, cujas águas se reduziam em época de estiagem, um problema que afetava o funcionamento da sua usina hidrelétrica de Santana do Parnaíba. Para a sua construção foi erguida a barragem do rio Guarapiranga, afluente do rio Pinheiros. Entre 1924 e 1925, como outra longa estiagem afetou o abastecimento de água de São Paulo, surgiu a ideia de se utilizar o reservatório de Guarapiranga. Em 1928, o então Governador do Estado Júlio Prestes, promulgou decreto que previa a retirada de até 4 metros cúbicos por segundo da Represa para garantir o abastecimento da Capital. A partir de 1958, por meio de um acordo entre o Governo do Estado e a Light, a Guarapiranga passou a ser usada exclusivamente para abastecer a cidade, e atualmente é responsável pelo fornecimento de água a 3 milhões de pessoas da Zona Sul." (SESC, 2006, p. 27 - Pesquisa Bibliográfica e Documental do Inventário).

${ }^{75}$ Segundo o advogado santamarense Teruo Yatabe, ex-superintendente da Distrital Santo Amaro da Associação Comercial de São Paulo, considerando a área do antigo município de Santo Amaro e seus limites anteriores, ela representa $640 \mathrm{~km} 2$ ou $45 \%$ do território de São Paulo. É habitada por mais de 3,5 milhões de pessoas e representada por mais de 1,6 milhões de eleitores. O empresariado da região conta com mais de 350 mil lojas 
Foi em 1993, que os Conselheiros do CONPRESP, reunidos em 07 de outubro, abriram processo de tombamento dos imóveis e logradouros que compuseram o Eixo Histórico de Santo Amaro (Resolução no 14/CONPRESP/02), cujo perímetro foi redefinido por outras aberturas de processo: Processo de Tombamento ( $n^{\circ}$ 2004-0.297.171-6) de imóveis enquadrados como ZEPEC pela Lei no 13.885/2004 (Resolução no 26/CONPRESP/2004), o de $\mathrm{n}^{\mathrm{o}}$ 2008-0.256.332-1, sobre o Eixo Histórico e que regulamentou a área envoltória do antigo Mercado de Santo Amaro.

$\mathrm{O}$ antigo Mercadão de Santo Amaro foi tombado pela Resolução ex-officio $\mathrm{n}^{\circ} 05$, do CONPRESP em 1991. Já era tombado pelo CONDEPHAAT, em 1972 (SÃO PAULO, s/d. p.24). ${ }^{76}$

Além do antigo Mercado de Santo Amaro, encontram-se tombados o Teatro Paulo Eiró (CONPRESP/1992) ${ }^{77}$ e o antigo Seminário do Espírito Santo do Verbo Divino (CONPRESP/2010). E mais recentemente, foram tombados em Santo Amaro pelas Resoluções $n^{\circ}$ 21/CONPRESP/2014 e $n^{\circ}$ 24/CONPRESP/2014 respectivamente, o antigo Instituto de Educação e atual Escola Estadual Professor Alberto Conte, situado à Avenida Mário Lopes Leão, $\mathrm{N}^{\circ} 120{ }^{78}$ e a antiga residência e estúdio do artista santamarense Júlio Guerra, situada à Avenida João Dias, no 750 e 754 :

CONSIDERANDO que o imóvel situado à Avenida João Dias, 750 e 754 é referência da ocupação urbana do antigo Município de Santo Amaro, propriedade do artista santamarense Júlio Guerra; CONSIDERANDO a necessidade de valorizar o significado da antiga residência e estúdio do consagrado artista plástico Júlio Guerra; CONSIDERANDO o valor arquitetônico, ambiental, histórico e afetivo dessa edificação, exemplar da primeira metade do século XX; CONSIDERANDO o

comerciais de pequeno, médio e grande porte - dando emprego a 100 mil trabalhadores - e 6 mil estabelecimentos industriais (ASSOCIAÇÃO COMERCIAL DE SANTO AMARO, 2004, p.54).

${ }^{76} \mathrm{O}$ atual Mercado Municipal de Santo Amaro foi criado em 1958, durante a prefeitura de Adhemar de Barros.

77،'Inicialmente o teatro tinha a função de complementar o programa pedagógico das escolas construídas na mesma época [anos 1950]. Ao longo dos seus 50 anos, os principais artistas de São Paulo brilharam em seu palco, e com mais freqüência o santamarense Raul Cortez" (SESC, 2006, p.22 - Pesquisa Bibliográfica e Documental).

${ }^{78} \mathrm{O}$ processo de tombamento foi aberto por moradores do bairro e pela Associação dos Amigos e Antigos Alunos do Alberto Conte, durante o desenvolvimento da pesquisa-ação. Segundo o Programa Patrimônio e Referências Culturais nas Subprefeituras (SÃO PAULO, s/d., p.33), em dezembro de 2013, estavam em processo de tombamento: o Centro Empresarial (CONPRESP - Resolução 26 de 2004 - APT); Centro de Processamento de Dados do Banco do Brasil (CONPRESP -Resolução 26 de 2004 - APT); Centro Histórico de Santo Amaro (CONPRESP - Resolução 26 de 2004 - APT); Colégio Doze de Outubro (CONPRESP - Resolução 26 de 2004 e CONDEPHAAT - Processo 45.954/2003); Edifício Gessylever (CONPRESP - Resolução 26 de 2004 - APT); Edifício Birman (CONPRESP - Resolução 26 de 2004); Estação Ferroviária de Santo Amaro (Resolução 26 de 2004 - APT); Residências na rua Com. Elias Zarzur, 895; rua Heron Domingues, 140; rua Angra dos Reis, 300; Rua Paulo Roberto Paes de Almeida, 51 (CONPRESP - Resolução 26 de 2004 - APT). "O Centro Empresarial SP foi o primeiro empreendimento no Brasil com o conceito de 'Escritórios Inteligentes'. O Centro Empresarial São Paulo, inaugurado em 1977, está instalado em uma área de $200 \mathrm{mil} \mathrm{m} 2$ que abriga mais de 60 empresas, shopping de conveniência, com mais de 70 lojas, restaurantes, agências bancárias e serviços. O projeto, pioneiro nesse sistema, é do arquiteto João Henrique Rocha" (SESC, 2006, p.32). 
contido no processo administrativo $\mathrm{n}^{\circ}$ 2014-0.092.668-4 que trata da antiga residência e estúdio do artista santamarense Júlio Guerra [...] (Resolução $\mathrm{n}^{\circ}$ 24/CONPRESP/2014 in: SÃO PAULO, s/d., p.25)
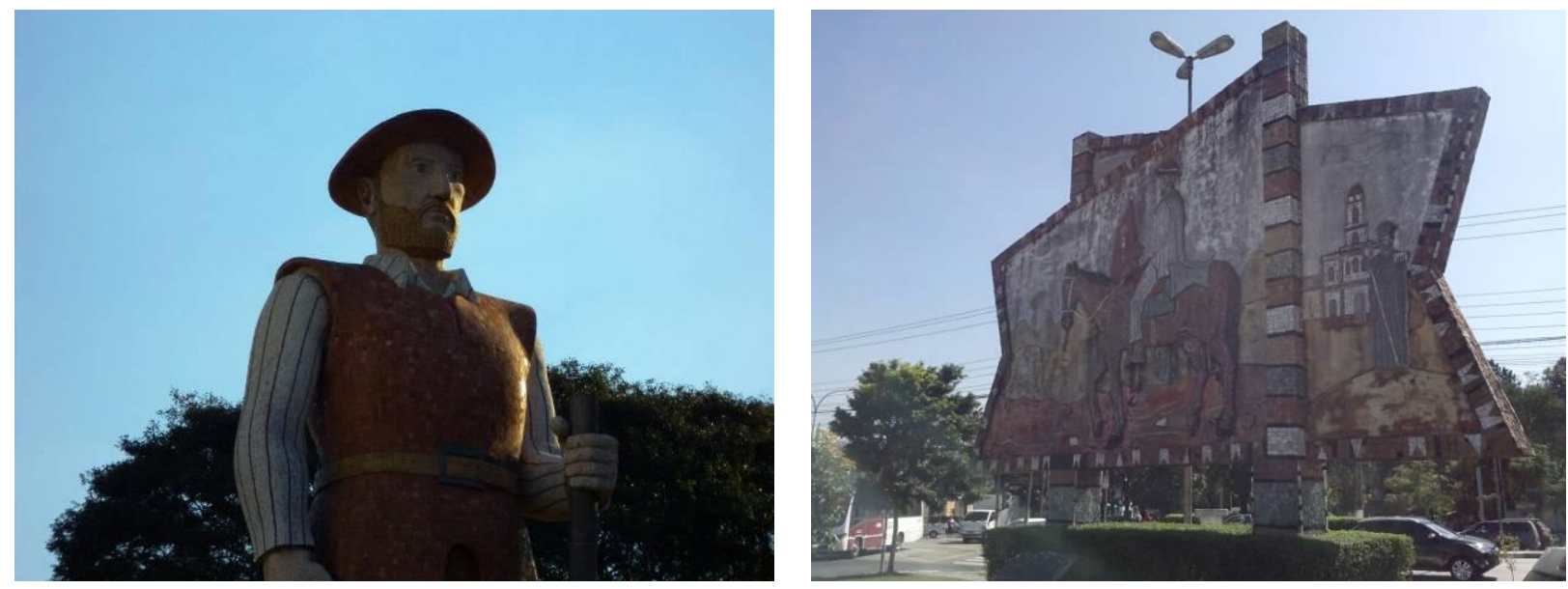

Figuras 29 e 30. Duas obras na região do artista Julio Guerra: a Estátua do Borba Gato e Painel em homenagem ao poeta Paulo Eiró. Fotos da autora.

Julio Guerra nasceu em 1912, quando Santo Amaro era cidade, e morreu em 2001. Filho, neto e bisneto de família santamarense, estudou, na década de 1930, na Faculdade de Belas Artes de São Paulo. Em Santo Amaro, estão suas obras públicas: os quatro atos em mosaicos que contam a história da fundação de Santo Amaro; outro mosaico, que retrata a Romaria de Cavaleiros a Pirapora; e o painel criado para homenagear o poeta Paulo Eiró, além da estátua de Borba Gato, construída para as comemorações dos 400 anos de Santo Amaro, entre outras (BERARDI, 1981)

A escultura de 1961 que retrata o bandeirante Borba Gato (filho de João de Borba Gato e Sebastiana Rodrigues, nascido em 1649 e que cresceu em Santo Amaro), instalada no encontro das avenidas Santo Amaro e Adolfo Pinheiro, com dez metros de altura, é porta de entrada do distrito e uma das principais referências do bairro, "revestida de mosaicos, e incrustada sobre um pedestal de 2,40 metros, simbolizando seu retorno à sua terra natal" (ASSOCIAÇÃO COMERCIAL DE SANTO AMARO, 2004, p.84 - Pesquisa Bibliográfica e Documental). ${ }^{79}$

Julio Guerra também retratou Santo Amaro em pinturas que hoje compõem a Sala especial dedicada ao artista no CETRASA. ${ }^{80}$

\footnotetext{
${ }^{79} \mathrm{O}$ artista também possui um monumento de 1955, dedicado à Mãe Preta, no Largo do Paissandu, criada para as comemorações do IV Centenário da Cidade de São Paulo; e ajudou o escultor Brecheret, de quem foi amigo, no monumento a Duque de Caxias, no centro da cidade (SESC, 2006, p.96; ASSOCIAÇÃO COMERCIAL DE SANTO AMARO, 2004, p.86; BERARDI, 1981 - Pesquisa Bibliográfica e Documental).

${ }^{80}$ Ver SCHMIDT, Afonso. A vida de Paulo Eiró. São Paulo: Companhia Nacional, 1940 (Coleção Brasiliana); e também: ZENHA, Edmundo. O Santo Amaro de Paulo Eiró. São Paulo: Departamento Municipal de Cultura,
} 
Quando terminava o filme, eu e meus amigos íamos para a Rua Direita passear e ver a banda de música tocar no coreto do jardim. Esse era o nosso domingo... Na avenida João Dias morava o famoso escultor e escritor Julio Guerra, que na época estava fazendo no quintal de sua casa a estátua do Borba Gato. Por eu ser de uma família tradicional de Santo Amaro e o Julio Guerra ser muito amigo de meus pais, ele me deu um quadro do Mercado Velho de Santo Amaro pintado por ele em 1928, que guardo com muito carinho. O bonde que vinha da Praça João Mendes até o Largo do Socorro era nossa diversão. Na porta de trás do bonde ficava uma pessoa para abrir e fechar a porta, quando essa pessoa faltava, era eu que estava lá, abrindo e fechando a porta. Às vezes, antes de o bonde parar, eu abria a porta, o bonde dava um tranco e um estouro. Levava uma bronca do motorneiro. Todos os anos saíam de Santo Amaro duas romarias a Pirapora, com muitos cavaleiros, charretes e ônibus. Uma era do Cinerino, que tinha um armazém. Na calçada, havia uma argola no chão para amarrar os cavalos dos donos que vinham fazer compras. (Agenor Borba Junior in: Santo Amaro, que saudades, publicado em 08 de março de 2010. Disponível em: http://www.encontrasantoamaro.com.br/historias-de-moradores-de-santo-amaro/Pesquisa Bibliográfica e Documental).

O Museu de Santo Amaro/CETRASA ${ }^{81}$ foi criado em 1997 e aberto em 1998, por uma iniciativa da Secretaria de Administrações Regionais da Prefeitura de São Paulo de criação de minimuseus em cada região da cidade, na Avenida Professor Alceu Maynard de Araújo, 32 (ASSOCIAÇÃO COMERCIAL DE SANTO AMARO, 2004 - Pesquisa Bibliográfica e Documental). Segundo Alexandre Moreira Neto, santamarense tradicional e presidente do Centro, "O CETRASA nasceu filosoficamente nos anos 70, mas existe por escritura pública desde os anos 80 e há apenas cinco anos com estatuto" (ASSOCIAÇÃO COMERCIAL DE SANTO AMARO, 2004, p.72).

Em 2013, Santo Amaro passou a comemorar o Dia das Tradições de Santo Amaro determinado pela Lei Municipal 15.871/2013, de autoria de um vereador local.

Pela primeira vez estive no Cetrasa - Centro de Tradições de Santo Amaro e fiquei impressionada com tantas fotos e lembranças sobre o bairro. Logo na entrada as fotos e tem as fotos das personalidades que receberam o troféu 'Botina Amarela'. Todos fizeram muito para elevar o nome do nosso bairro. O troféu, para quem o recebe é uma honra, é como se recebesse o 'Oscar', como disse o Dr. Alexandre, atual presidente do Centro de Tradições. Fotos sobre tudo que existiu no passado, desde quando Santo Amaro era apenas um povoado, e mostra também como ele evoluiu. Os nossos artistas, com suas obras, não deixaram que se apagasse de nossa memória tudo o que aconteceu, e o que está sendo feito, para que não se perca no tempo e fique registrado nas lembranças de todos os que amam Santo Amaro. (Sra. Romilda, que morou em Santo Amaro de 1958 a 1962, quando se casou em foi morar na Chácara Santo Antônio - SÃO PAULO, s.d. - Pesquisa Bibliográfica e Documental na Biblioteca Prestes Maia). ${ }^{82}$

1952. Alguns dos historiadores e memorialistas de Santo Amaro são: Edmundo Zenha (descendente de antigos colonos alemães), Júlio Guerra, Afonso Schmidt e EliziárioVenâncio de Melo (BERARDI, 1981).

${ }^{81}$ O CETRASA outorga o Troféu 'Botina Amarela' em homenagem e reconhecimento a pessoas e famílias de Santo Amaro. O nome se deve à vestimenta dos santamarenses com bombachas e botinas - "trajes típicos levados a Santo Amaro pelos mercenários do Pará na Guerra do Paraguai” (ASSOCIAÇÃO COMERCIAL DE SANTO AMARO, 2004, p.74).

${ }^{82}$ Projeto "Revivendo o Bairro de Santo Amaro" do Projeto São Paulo 450 Anos - Memória Viva e Cidadania, desenvolvido nos bairros: Aricanduva, Lapa, Mooca, Pinheiros, Sé e Santo Amaro. Organizadores/parceiros: Prefeitura SP, Secretaria Municipal de Saúde, Coordenação de Desenvolvimento da Gestão Descentralizada - 
Já Paulo Francisco Emílio de Sales, Paulo Eiró, nasceu na vila de Santo Amaro em 15 de abril de 1836 e foi aluno da Faculdade de Direto do Largo São Francisco. Seu pai Francisco Antonio das Chagas - foi o fundador da primeira escola da região e o primeiro presidente da Comarca de Santo Amaro. A paixão não correspondida pela prima Cherubina Angélica de Salles acompanhou toda a sua vida e obra. Internado no Hospício dos Alienados, aos 31 anos, faleceu aos 36, em 1871, com meningite (ASSOCIAÇÃO COMERCIAL DE SANTO AMARO, 2004, pp.88 e 86 - Pesquisa Bibliográfica e Documental).

Foi autor de "Sangue Limpo", uma de suas obras abolicionistas, que denunciava "a marca negra da escravidão" (SESC, 2006, p. 97 - Pesquisa Bibliográfica e Documental). ${ }^{83}$

\title{
1.4.1 Aspectos de sua História - Santo Amaro Município
}

\author{
Algumas datas importantes \\ 1500 - Descobrimento do Brasil \\ 1534 - Fundação de São Vicente; \\ 1554 - Fundação de São Paulo; \\ 1562 - Manuel da Nóbrega solicita uma légua de terras próximas ao Rio Jeribatiba; \\ 1575 - A Câmara de São Paulo manda realizar o caminho que vai para Virapuera; \\ 1609 - Formada a sociedade para a fábrica de ferro em Geribatiba; \\ 1686 - No dia14 de janeiro a Capela curada de Ibirapuera é elevada à Freguesia de \\ Santo Amaro pelo Bispo D. José de Barros; \\ 1832 - No dia 10 de julho por um Decreto da Regência (D. Pedro I) é elevada a Vila \\ de Santo Amaro; \\ 1833 - No dia 6 de maio, acontece a primeira Assembléia da Câmara dos \\ vereadores; \\ 1835 - Em 4 de março toma posse o Primeiro Prefeito: Manoel José Moraes; \\ 1835 - Criam-se corpos militares da Guarda Nacional em Santo Amaro, dois de \\ infantaria e um de cavalaria; \\ 1841 - Inauguração da Escola Pública; \\ 1868- Primeiro jornal "Santo Amaro"; \\ 1885 - Inauguração da iluminação a querosene; \\ 16 de novembro de 1886 - inauguração da linha férrea de São Paulo e Santo Amaro \\ e visita a Santo Amaro do Imperador D. Pedro II e Dona Leopoldina;
}

COGest, Área Temática da Saúde do Idoso, Coordenadoria da Saúde de Santo Amaro - UBS Chácara Santo Antonio e UBS Santo Amaro, Secretaria Municipal de Cultura - Biblioteca Presidente Kennedy Novatis Biociência S/A PUC-SP - Programa de Pós Graduação em Geroentologia Universidade Anhembi Morumbi Participantes/entrevistados: Diva Ieda Toledo Alves; Eduilda Neusa Weneck Russo; Judite Silva; Maria de Lourdes Hessel Torres; Maria Gomes Leite Pereira; Neusa Migotto de Souza; Romilda Alves Rodrigues (SÃO PAULO, s.d.).

${ }^{83}$ Outros artistas plásticos como Evandro Carlos Jardim e Wesley Duke Lee, entre outros, também são conhecidos da região. (ver Anexo I com alguns dos bens culturais de Santo Amaro) Desenhista, gravurista, pintor e professor da ECA - USP, Evandro Carlos Jardim, antes de se mudar para a região, vivia na chácara do seu avô em Santo Amaro, e retratava nas suas obras o bairro (ASSOCIAÇÃO COMERCIAL DE SANTO AMARO, 2004 - Pesquisa Bibliográfica e Documental). Wesley Duke Lee, artista plástico da vanguarda artística brasileira, teve casa e ateliê na região (ASSOCIAÇÃO COMERCIAL DE SANTO AMARO, 2004 Pesquise Bibliográfica e Documental). 
1894 - Inauguração do Mercado (atual Casa de Cultura);

1896 - Inauguração do Jardim Público (atual Praça Floriano Peixoto);

1899 - Inauguração da Santa Casa de Misericórdia e Capela (na atual localização);

1910 - Inauguração do prédio do Grupo Escolar de Santo Amaro, denominada posteriormente Grupo Escolar Paulo Eiró (atual Praça dos Mosaicos);

1924 - Inauguração da Matriz de Santo Amaro (atual Catedral de Santo Amaro);

1931 - Fundação do Conservatório Musical de Santo Amaro;

1932- Plano de reurbanização de Santo Amaro (pelo Engenheiro Alfredo Agache);

1935 - No dia 22 de fevereiro, pelo Decreto 6988, do Interventor do Estado, o município de Santo Amaro é anexado à cidade de São Paulo, retornando, assim, a condição de bairro. (Subprefeitura - Santo Amaro/Histórico - Pesquisa Bibliográfica e Documental do Inventário http://www.prefeitura.sp.gov.br/cidade/secretarias/subprefeituras/santo_amaro/).

Segundo estudos de 1944 do antropólogo Nimuendaju (1981), a região do Estado de São Paulo, no período colonial, era ocupada por índios das famílias Jê e Tupi-Guarani (Kayapó e Guarani, respectivamente). E na região metropolitana de São Paulo, localizavamse, sobretudo, indígenas de fala tupi: os Tupiniquim (MONTEIRO, 2013).
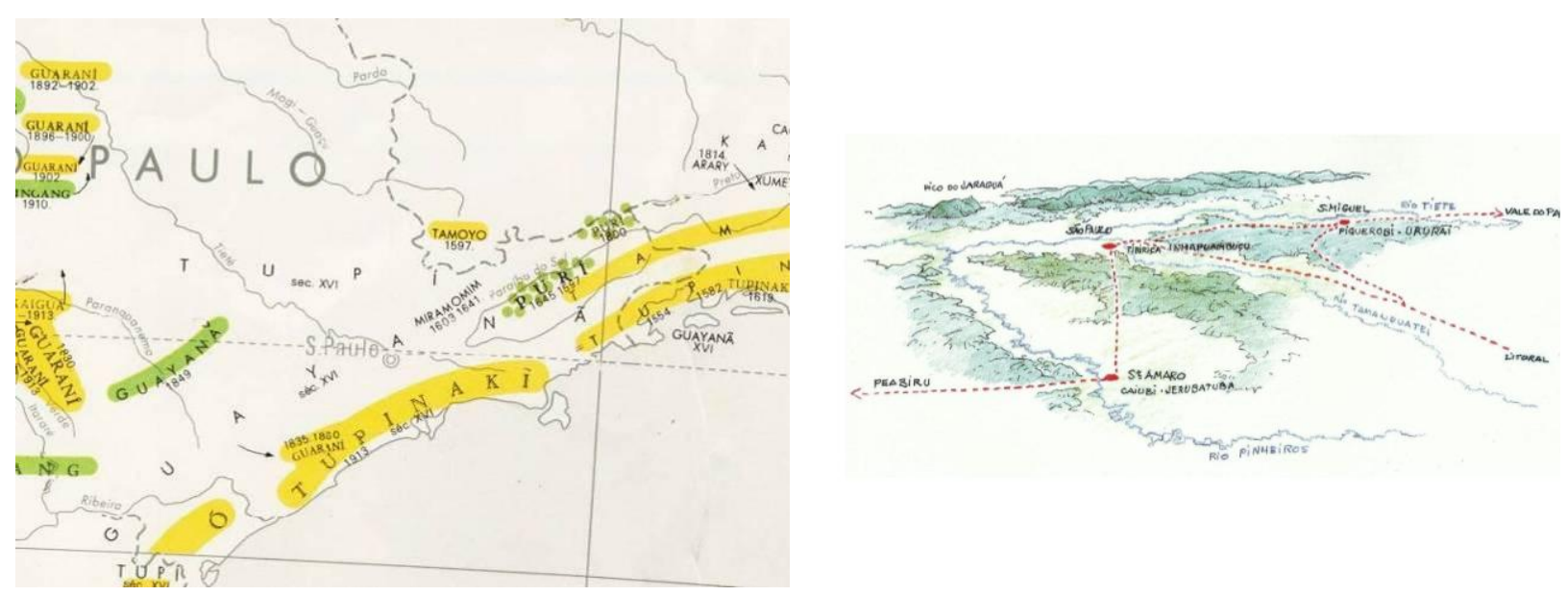

Figuras 31 e 32. Detalhe do mapa do antropólogo Nimuendaju de 1981, com a localização dos povos indígenas do séc. XVI ao XX e desenho de Vallandro Keating, 2009, com os aldeamentos indígenas jesuíticos, extraído do catálogo da exposição Escavando o Passado: a Arqueologia na cidade de São Paulo, que compôs o Kit com imagens ampliadas em pranchas do material educativo utilizado nas atividades de Educação Patrimonial com alunos nas escolas da região em 2015.

Segundo os relatos dos cronistas europeus e os estudos arqueológicos na cidade e em todo o Estado de São Paulo, no momento da chegada dos portugueses ao planalto, existiam três aldeias de relevo na região: uma, e que seria a principal aldeia, a do chefe Tibiriçá, conhecida por Inhapuambuçu (Piratininga); a segunda, de Jerubatuba (ou Jeribatiba), do chefe Caiubi, possível irmão de Tibiriçá, localizada na atual região de Santo Amaro, a cerca de doze quilômetros ao sul de Piratininga; e a terceira, também chefiada por um outro suposto irmão 
de Tibiriçá, chamado Piquerobi, localizada a seis quilômetros ao leste, conhecida por Ururaí (MONTEIRO, 2013). ${ }^{84}$

Esses agrupamentos indígenas foram reestruturados pelos europeus, em forma de aldeamento para os trabalhos de catequese dos jesuítas. ${ }^{85}$ Em 1554, a Companhia de Jesus iniciou a catequização dos indígenas de Piratininga, fundando o Colégio de São Paulo; por volta de 1560, Ururaí tornou-se base para o aldeamento jesuítico de São Miguel, e Jeribatiba, para o aldeamento próximo ao Rio Jeribatiba (atual Rio Pinheiros) (MONTEIRO, 2013):

Assim, em 12 de agosto de 1560, os jesuítas tomaram posse oficial de duas léguas de terras na margem esquerda do Rio Jurubatuba, que lhes foram doadas pelo Capitão Frâncisco de Morais, em nome do Padre Luís da Grã, província da Companhia de Jesus, em 26 de maio do mesmo ano (BERARDI, 1981, p.24).

Uma pequena imagem de madeira representando Santo Amaro foi doada por João Paes e sua esposa Suzana Rodrigues para a capela (BERARDI, 1981). ${ }^{86}$

Tudo começou no Largo 13. Santo Amaro nasceu onde era a aldeia dos índios guaianases comanda pelo cacique Caá-ubi, à beira do rio Jeribatiba, na localidade de Ibirapuera. Em uma de suas muitas visitas à Aldeia de Jeribatiba, o Padre José de Anchieta percebeu que, devido ao elevado número de índios catequizados e colonos instalados na região, era possível construir ali um povoado, ideia que os moradores aprovaram. Era necessário erguer uma capela e definir a quem essa capela seria dedicada. Ao saberem da proposta do Padre Anchieta, o colono João Paes e sua esposa, Suzana Rodrigues, doaram a imagem que possuíam do santo de sua devoção, Santo Amaro, para a capela feita de taipa de pilão. Por muito tempo a região será conhecida por diversos nomes indígenas - Birapuera, Virapuera, Ibirapuera, Geribatiba, Geribativa, Jeribatiba, Santo Amaro de Ibirapuera, até tomar definitivamente o nome de Santo Amaro. (Santo Amaro em Revista, 1961, p.2 material disponibilizado pela Dorinha da Biblioteca Belmonte e integrante do Grupo de Trabalho/Comunidade de Pesquisa para as pesquisas do inventário). ${ }^{87}$

Mas foi em 14 de janeiro de 1686, que o Bispo do Rio de Janeiro D. José E. Barros Alarcão elevou o povoado à categoria de freguesia ou paróquia com o nome de Santo Amaro e o local foi reconhecido enquanto um aglomerado com núcleo central, constituído pela igreja e circundado por fazendas e chácaras (LANGENBUCH, 1971 apud A LASCA, s/d.).

\footnotetext{
${ }^{84}$ Para Monteiro (2013), no século XVI, os grupos indígenas habitavam o território correspondente ao da Capitania de São Vicente (os Tupi) até a faixa litorânea do Rio de Janeiro (abrangendo Baixada Santista e parte do interior paulista); na área entre o Vale do Paraíba e a Serra da Mantiqueira (os Jê, além dos Puri, conhecidos como Guayaná e Maromi); a oeste da capitania (grupos não-tupi); e na região mais para o sul e sudoeste (os Guarani). Os Guayaná seriam os ancestrais dos Kaingang e teriam oferecido grande resistência ao avanço da lavoura cafeeira no oeste paulista durante o século XIX.

${ }^{85}$ (KOK, 2009 apud A LASCA, 2009). KOK, Glória. Peregrinações, conflitos e identidades indígenas nas aldeias quinhentistas de São Paulo. In: XXV SIMPÓSIO NACIONAL DE HISTÓRIA E ÉTICA. Fortaleza: Universidade Federal do Ceará, Jul.2009. Disponível em: <http://www.ifch.unicamp.br/ihb/Trabalhos/ST36Gloria.pdf>. Acesso em: 01 mar 2016.

${ }^{86}$ Santo Amaro ou São Mauro nasceu na Itália, em 513, e faleceu na França, em 585; foi discípulo direto de São Bento. Considerado padroeiro dos carregadores, carroceiros e fabricantes de vela. (BERARDI, 1981, p.15)

${ }^{87}$ Santo Amaro em Revista. Interlagos. São Paulo, n. XX, ano XI, set, 1961. (Edição Dedicada ao Quarto Centenário da Cidade de Santo Amaro). Sobre as divergências de interpretações quanto à existência de Jeribatiba e também de Ibirapuera, ver: ZENHA, 1977; TORRES, 1977; CAMPOS, 2006.
} 
Já metade do século, a pequena capela construída por Anchieta deixa partir a imagem de seu Santo, que é entronizada no nicho de uma capela maior, erguida no local que se determina como pedra bruta a ser esculpida por vertiginoso progresso. [...] Mas, existe grande dificuldade em torno do elemento principal, o vigário. Em toda a Capitania é comum a falta de padres. Dessa forma, é com grande alegria que a povoação recebe, no dia 25 de janeiro de 1686, o Padre Dr. João de Pontes, primeiro vigário da Paróquia de Santo Amaro (Santo Amaro em Revista, 1961, p.2).

Em fins do século XVI, descobriram-se minérios de ferro nas proximidades do rio Jurubatuba. Diogo Quadros e seu cunhado Francisco Lopes Pinto montaram o Engenho de Ferro de Nossa Senhora de Assunção, primeiro engenho de ferro do Brasil (BERARDI, 1981).

O engenho de Nossa Senhora da Assunção do Ibirapuera principiou a funcionar em 1607. Achava-se localizado a duas ou três léguas a SE do Rio Pinheiros. Ali havia minérios de ferro argiloso, de cor branca, ou às vezes vermelha. Nesse lugar, o metal corria em buchos numa rocha quartzoza. (Barão de Eschwege apud BERARDI, 1981$, p.29) $)^{88}$.

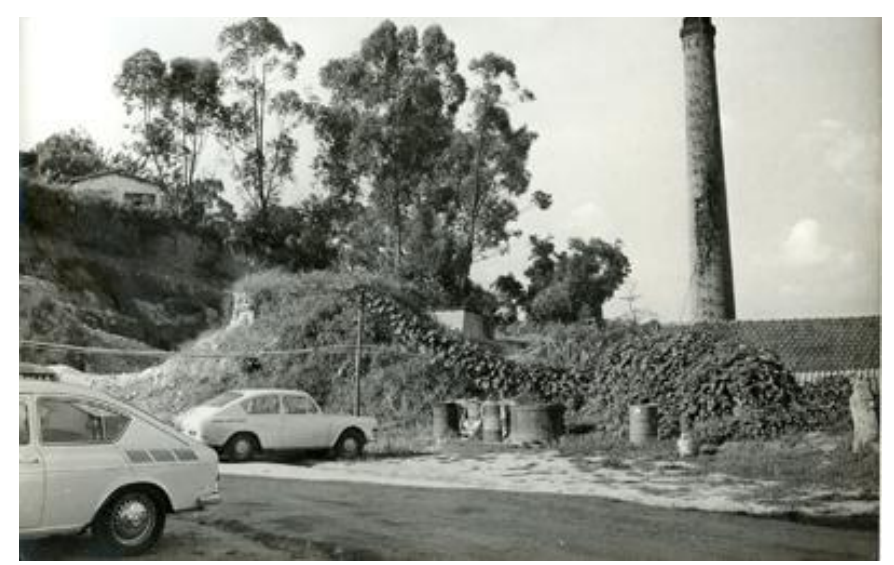

Figura 33. Vista da chaminé da Fábrica de Ferro de Santo Amaro na década de 1970 c. Fonte: Arquivo Histórico de São Paulo (Pesquisa Bibliográfica e Documental).

Entre os séculos XVIII e XIX, um cinturão de chácaras, sítios e fazendas formou-se em São Paulo, produzindo um pouco de quase tudo o que era vendido nas feiras e pequenos armazéns de secos e molhados dispersos pelas estradas e na área central da cidade.

A ocupação da freguesia de Santo Amaro era predominante rural, com sítios que produziam principalmente mandioca, milho, feijão, arroz e cana; criavam gado, galinhas e carneiros e também promoviam a extração de areia, pedra e lenha (LANGENBUCH , 1971 apud A LASCA, s/d.).

Nos dados censitários produzidos no século XVIII, em carta de 10 de dezembro de 1766, o Conde de Oeiras registrou que Santo Amaro possuía: 377 fogos, 880 mulheres e 890

\footnotetext{
${ }^{88}$ Ver Edmundo Zenha. Onde a primeira fundição de ferro no Brasil? Revista do Arquivo Municipal de São Paulo, São Paulo, CXL, 1951.
} 
homens; números não muito diferentes de São Paulo, que contava com 392 fogos, 649 homens e 867 mulheres, na mesma época (BERARDI, 1981).

Assim, na segunda metade do XIX, Santo Amaro foi considerado "celeiro da capital”, desempenhando papel chave no abastecimento de São Paulo, principalmente em relação aos gêneros de primeira necessidade. E no aglomerado urbano formado ao redor da igreja foram paulatinamente concentrando-se pequenos comércios e artesãos, que atendiam principalmente a demanda do entorno rural. Os agricultores rurais mais abastados também mantinham casas no núcleo urbano para nelas residirem temporariamente em dias de ofícios, festas e atividades religiosas (LANGENBUCH, 1971 apud A LASCA, s/d).

\begin{abstract}
A freguesia de Santo Amaro tinha então três ou quatro ruas curtas e várias chácaras, que rodeavam o povoado: a chácara do Chico Doce, a do Fidelão, a do Nardy, e a do pai do futuro Barão de Tietê... Havia como autoridades um juiz de paz e um Sargento Mor, José da Silva Carvalho, homem enérgico que acreditava mais em suas decisões que nas disposições legais (BERARDI, 1981, p.52).
\end{abstract}

Em 1826, o imperador Dom Pedro I incumbiu Von Schaeffer de obter colonos na Europa, tendo em vista a preocupação com o povoamento do país recém independente. Prometendo riquezas, honrarias e altos cargos, Von Schaeffer aliciou alemães principalmente na Baviera (ZENHA apud BERARDI, 1981). ${ }^{89}$

Sua Majestade o Imperador é servido que o Vice-Presidente da Província de São Paulo tome dede já as medidas que julgar conveniente para receber e alojar os colonos estrangeiros que em breve sairão desta Corte para essa Província, e os mais que sucessivamente lhe serão enviados à medida que forem chegando. Palácio do Rio de Janeiro, em 8 de novembro de 1827 - Visconde de São Leopoldo (ZENHA,1950 apud BERARDI, 1981, p.54).

No ano seguinte, os alemães desembarcavam no Brasil e deveriam se estabelecer na província de São Paulo, conforme a determinação do decreto imperial de 8 de novembro de 1827. Hospedados no Hospital Militar em São Paulo, tiveram como diretor nomeado para a colônia, Dr. Justiniano de Melo Franco, que falava alemão (BERARDI, 1981). ${ }^{90}$

A colônia alemã propiciou o aumento do volume dos gêneros alimentícios produzidos em Santo Amaro, que se apresentava como o único município que produzia batata, cultura tipicamente alemã. Em meados do século, a região fornecia todos os gêneros de primeira

\footnotetext{
${ }^{89}$ Ver: ZENHA, Edmundo. A colônia alemã de Santo Amaro: sua instalação em 1829. Revista do Arquivo. São Paulo: Departamento Municipal de Cultura, v. CXXXI, 1950.

${ }^{90} \mathrm{Em}$ 1828, vieram outras levas de colonos: $39 \mathrm{em}$ janeiro; $89 \mathrm{em}$ maio; $175 \mathrm{em}$ junho; e $257 \mathrm{em}$ dezembro. Entre eles, 129 aceitaram as terras devolutas a quatro léguas ao sul da freguesia de Santo Amaro, sendo feita a cerimônia de sorteio das vagas em 29 de junho de 1829. (BERARDI, 1981, p.55). Eram os Forster, Schunck, Hannickel, Helfstein, Klein, Teisen, Klauss, entre outros (ASSOCIAÇÃO COMERCIAL DE SANTO AMARO, 2004, p.46). "[...] 129 colonos aceitaram as terras na freguesia de Santo Amaro, e aqui ficaram os Klein, os Gilcher (depois Guilger), os Helpfstein, os Ulrich, os Heildrich, Pedro Schunk, João Conradt, Pedro Teisen (depois Theissen), os André Kaspers (Gaspar), Pedro Krist, João Schmidt, Roskemback, os Sellig, os Gottfried" (BERARDI, 1981, p.55).
} 
necessidade aos habitantes de São Paulo. Contudo "[...] Dos primeiros 229 indivíduos, dez anos depois restavam 157 pessoas. Em 1847, ali estavam nove famílias” (BERARDI, 1981, p.55).

Os colonos se ocupavam com atividades agrícolas ou em ofícios de alfaiataria e serralheria, entre outras (BERARDI, 1981). Dá-se a fundação da primeira escola, do primeiro jornal e da primeira corporação musical.

A escola da vila que se tornara pública em 1831, ainda sob a regência de Francisco das Chagas, recebeu Dna. Emygdia Maria das Dôres Salles como professora, em 1847. E, 8 anos depois, seu irmão, Paulo Eiró, assume esse cargo, completando o triângulo familiar responsável pela educação primária em seus primeiros passos em Santo Amaro (Santo Amaro em Revista, 1961, p.2).

Em 10 de julho de 1832, um decreto da Regência, em nome do Imperador Dom Pedro II, transformou algumas freguesias da província em vilas, incluindo a de Santo Amaro, que abrangia do sul do Córrego da Traição (hoje Avenida dos Bandeirantes) até a Serra do Mar:

A Regência, em nome do Imperador, o Senhor D. Pedro II, há por bem sancionar, e mandar que se execute a seguinte Resolução da Assembléia Geral Legislativa, tomada sobre outra do Conselho Geral da Província de S. Paulo.

Art. 1 - Ficam eretas em vilas as Freguesias de SANTO AMARO, do termo desta cidade $[\ldots]$

[...] Palácio do Rio de Janeiro, 10 de julho de 1832. Undécimo da Independência e do Império. Francisco Lima e Silva - José da Costa Carvalho - João Bráulio Muniz - José Lino Coutinho. (Folha 23 do Volume de Leis do Império de 1832) (in: BERARDI, 1981, p.57).

O fim do século XIX representa um período de elevado crescimento urbano em Santo Amaro, motivado em grande parte pela ferrovia.

$\mathrm{O}$ visconde de Taunay criou o brasão do município com os dizeres 'Antiquissimum Genus Paulista Meum' (pertenço a mais velha sociedade paulista). Instalaram os primeiros telefones. Os modernos lampiões a gás foram logo substituídos pela energia elétrica. Os jovens faziam 'footing' na praça, sob o olhar atentos dos mais velhos. Muitos casamentos que perduram até hoje foram forjados nesse vaivém de rapazes e garotas (ASSOCIAÇÃO COMERCIAL DE SANTO AMARO, 2004, p.50 - Pesquisa Bibliográfica e Documental do Inventário).

Dentre os equipamentos urbanos de Santo Amaro implementados nesse período, destacam-se: cemitério (1857), iluminação a querosene (1885), sede do governo Municipal $(1888)^{91}$, Jardim Público $(1896)^{92}$, Mercado Municipal (1897), Santa Casa de Misericórdia

\footnotetext{
${ }^{91}$ Prédio conhecido atualmente como Casa Amarela, que abriga hoje o Paço Cultural Júlio Guerra.

${ }^{92}$ Com o Teatro Pindorama e a Praça Floriano Peixoto (ASSOCIAÇÃO COMERCIAL DE SANTO AMARO, 2004). Hoje, a atual Praça Floriano Peixoto. O Jardim Público foi construído pelo Coronel Isaías quando Prefeito de Santo Amaro de 1917 a 1928 (BERARDI, 1981). O Teatro Pindorama foi inaugurado em 1900, em um terreno doado pela Câmara na Praça Floriano Peixoto: "[...] Francisco Sales, chamado também de Chico Turco, foi o primeiro da cinematografia em Santo Amaro. Trouxe para o Teatro Pindorama a Lanterna Mágica, que projetava em um lençol molhado pendurado na parede..[...]" Mais tarde, foi o Cine São Francisco incendiado em 1953 (BERARDI, 1981, p. 96).
} 
$(1899)^{93}$; e no lugar da capela inicial, a primeira Igreja da Matriz, reconstruída novamente em $1924^{94}$ (BERARDI, 1981).

E os anos marcam o fim de uma outra época. E, nesse fim, pontilham pequenos importantes acontecimentos. Agora, os trausentes erguem os olhos para a torre da Matriz, sempre que desejam saber as horas. À noite, as pessoas reúnem-se em grupos e passeiam às voltas pelo Jardim Público, sentando-se nos bancos novos, admirando as plantas ornamentais plantadas há pouco. E, de vez em quando, passando pelo Largo Municipal, param para ver as obras do teatro Pindorama, promessa de boa diversão. Outras e inúmeras obras erguem-se em todos os cantos, para diversos fins. Dessa forma, num dos últimos dias do século, 8 de dezembro, inauguram-se o edifício e a capela da Santa Casa (Santo Amaro em Revista, 1961, p.2).

Em 1886, foi inaugurada a linha férrea de São Paulo a Santo Amaro, com a presença do Imperador Dom Pedro II.

Em 1862, quando Santo Amaro era uma área rural com fazendas de criação de gado e produção de cereais, o transporte até São Paulo era feito em tropas de burros ou carros de bois. A implantação de uma ferrovia destinada a servir o sul da província levou o engenheiro Alberto Kuhlmann a pensar num projeto, com 200 quilômetros de extensão, que passaria por Santo Amaro. O projeto acabou sendo reduzido e transformado em uma linha de tram-ways a vapor, que partiria da Vila Mariana e chegaria a Santo Amaro. Assim, a 14 de março de 1886, o Presidente da Província de São Paulo, Conselheiro João Alfredo, inaugurou a nova lotação para 24 pessoas por vaga e o tempo de viagem era estimado em hora e meia. Seu percurso: saía da Estação São Joaquim, seguia pelas ruas Vergueiro e Domingos de Moraes, avenida Jabaquara até onde é hoje a igreja São Judas Tadeu. Ali, na estação de encontro, reabastecia-se de carvão e água, seguindo então para os bairros do Aeroporto e Campo Belo até o Brooklin Paulista. Depois, ia pela Chácara Flora, e entrava em Santo Amaro por uma curva, onde passava pelas ruas que agora se chamam Nove de Julho e São José, para acabar no ponto final em frente à Praça Santa Cruz (SESC, 2006, p.53). ${ }^{95}$
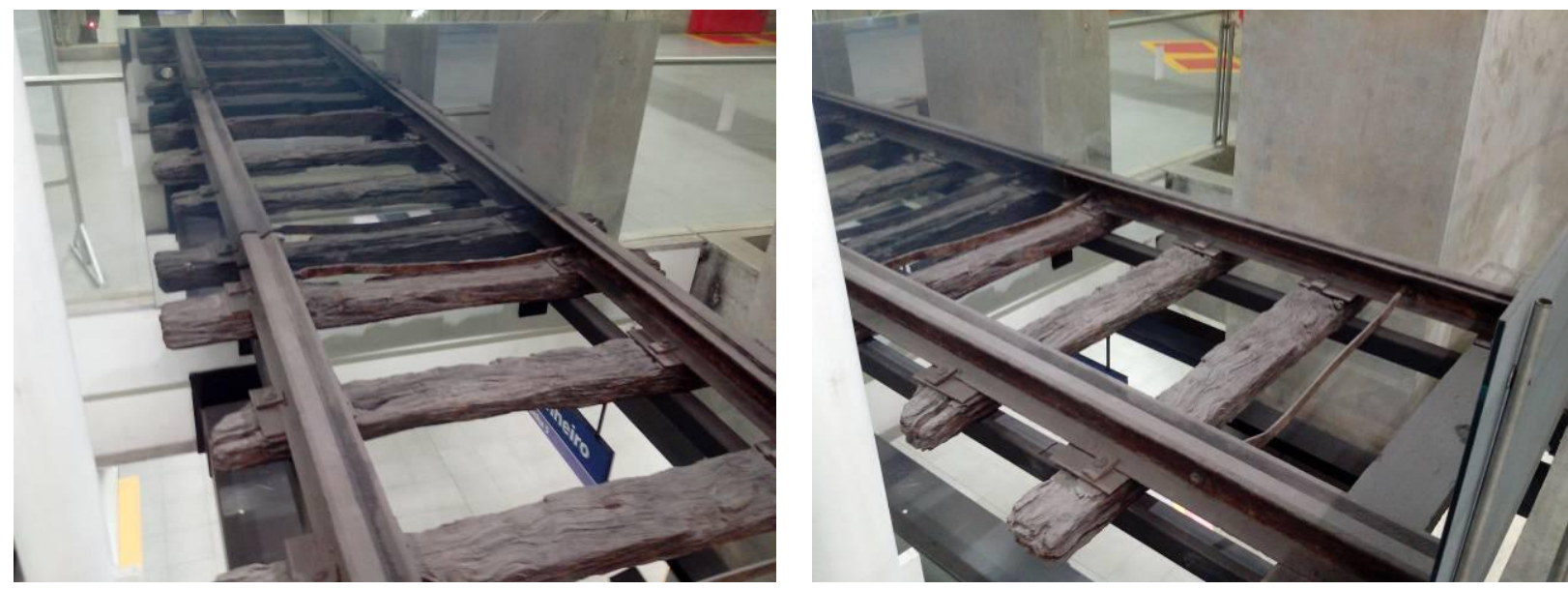

\footnotetext{
93 A Sociedade Beneficente Nossa Senhora da Conceição foi fundada em 15 de dezembro de 1895 e a pedra fundamental para construção do hospital em terreno cedido por Bona Bena Vieira de Morais foi lançada em 1896. Em 1899, foi inaugurado o edifício. (Ver o Anexo 1)

${ }^{94}$ A Igreja Matriz de Santo Amaro foi elevada a Catedral, com a criação em 27 de maio de 1989 da Diocese de Santo Amaro (BERARDI, 1981).

${ }^{95}$ Passava atrás de onde, mais tarde, seria construído o Aeroporto de Congonhas (em 1934), e daí seguia até Santo Amaro. Ver: STIEL, 1978.
} 
Figuras 34 e 35. Trilhos e dormentes do antigo traçado da linha de bonde que ligava Santo Amaro à região central da cidade de São (linha Biológico-Santo Amaro, que substituiu a linha férrea) resgatados pelas pesquisas arqueológicas desenvolvidas pelo Metrô na avenida Adolfo Pinheiro em Santo Amaro e expostos na Estação Adolfo Pinheiro: $O$ Bonde em Santo Amaro. Fotos da autora na visita à exposição. (Pesquisa Bibliográfica e Documental para o Inventário).

Em 7 julho de 1913, começava a funcionar o primeiro Bonde de Santo Amaro, substituindo a linha de trens (linha eletrificada de bondes), seguindo pelas regiões de Indianópolis, Campo Belo, Brooklin Paulista e Alto da Boa Vista, dando origem ao que hoje são a Avenida Ibirapuera e a Avenida Vereador José Diniz.

Tendo sido decretada a liquidação forçada da 'Companhia Carris de Ferro São Paulo - Santo Amaro', em 8 de fevereiro de 1900, foi seu acervo arrematado pela Companhia Light, que continuou explorando a linha a vapor até 1913, quando propôs à municipalidade, um acordo para a instalação dos serviços de luz elétrica, força e tramway, como era na época chamado o bonde (BERARDI, 1981, p.94).

Dados demográficos apontam um significativo crescimento populacional nesses anos.

Em 1877, a população alcança o número de 10.280 habitantes. Santo Amaro cresce e evolui. Em meados de 10 anos, inaugura-se a iluminação a querosene, através de 22 lampiões, de cuja limpeza e fornecimento de combustível é responsável o comerciante Manoel Branco de Araújo. Essa é uma apenas das inovações prodigiosas e de rápida sucessão, que marcam o fim do século. Pouco depois, chega a Santo Amaro a primeira composição a transitar pela estrada de ferro que se estende desde São Paulo, por 19 quilômetros. O mês de novembro dêsse ano de 1886 vem encontrar os santamarenses preocupados em reformas e modificações. Repara-se o edifício da Câmara, enfeita-se as ruas, aumenta-se a iluminação. Na manhã do dia 14, entram em Santo Amaro os Imperadores do Brasil, sob as aclamações do povo que os acompanha à Matriz e à Câmara e os vê partir, para depois, já na intimidade de 'após-visita', aplaudir o presidente da Câmara, Sr. Manoel da Silva Machado, que se responsabilizou pelas despesas a que não podia responder o tesouro municipal. Grandes festas por motivos nacionais ainda movimentam Santo Amaro. É a Abolição da Escravatura, e o advento da República (Santo Amaro em Revista, 1961, p.2).

Nos anos 1920, com o deslocamento de parte da população do centro de São Paulo para regiões afastadas, houve o parcelamento de chácaras e sítios no entorno da capital e a criação loteamentos suburbanos em toda a ligação entre São Paulo e Santo Amaro. Vários bairros surgiram em função do bonde, tais como: Vila Clementino, Indianópolis e Brooklin Paulista (BERARDI, 1981).

A eletrificação dos antigos bondes a vapor, em 1913, e a construção de duas vias de acesso à capital, Auto-Estrada Washington Luis (1928) e a Avenida Santo Amaro transformaram a velha cidade estagnada em um dos bairros mais prósperos do Município de São Paulo (BERARDI, 1981, p.116). 
Em 1927, a Sociedade Anônima de Auto-Estradas começava a construção de estrada (hoje a avenida Washington Luis) que cortava terrenos de diversos proprietários que loteavam e vendiam terras. ${ }^{96}$
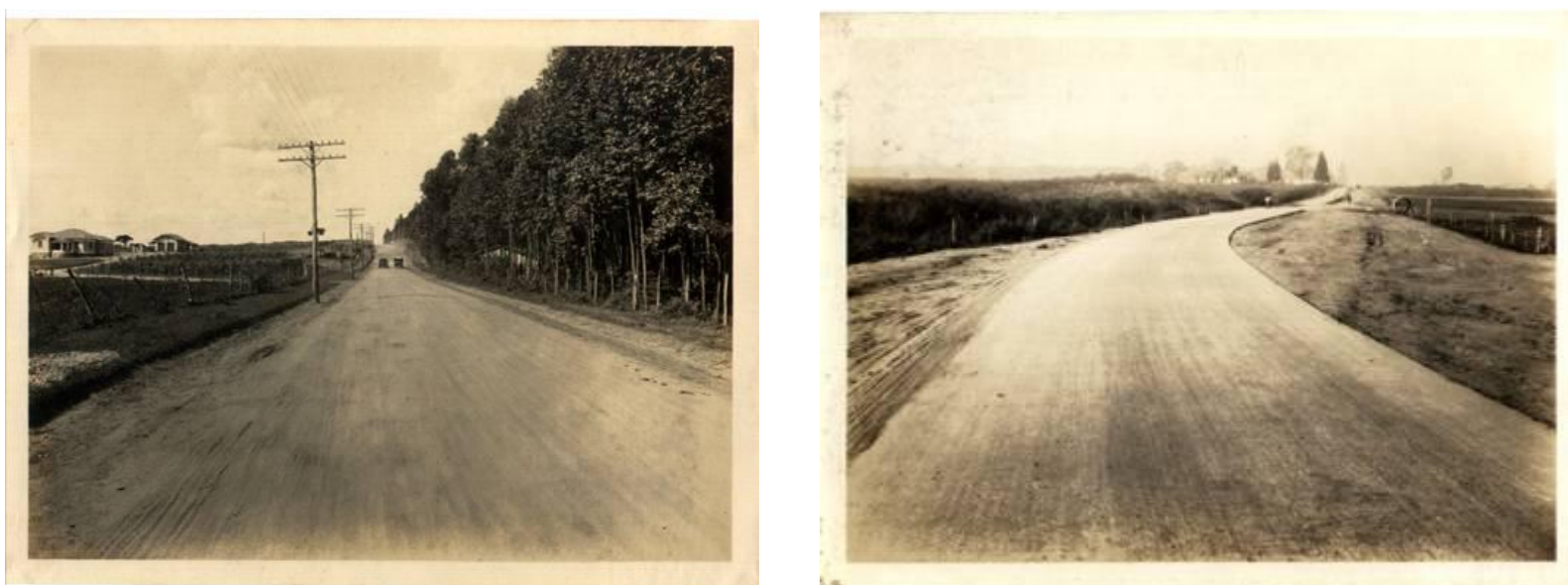

Figuras 36 e 37. Auto-estrada Santo Amaro em 1928. Fonte: Arquivo Histórico de São Paulo (Pesquisa Bibliográfica e Documental do Inventário).
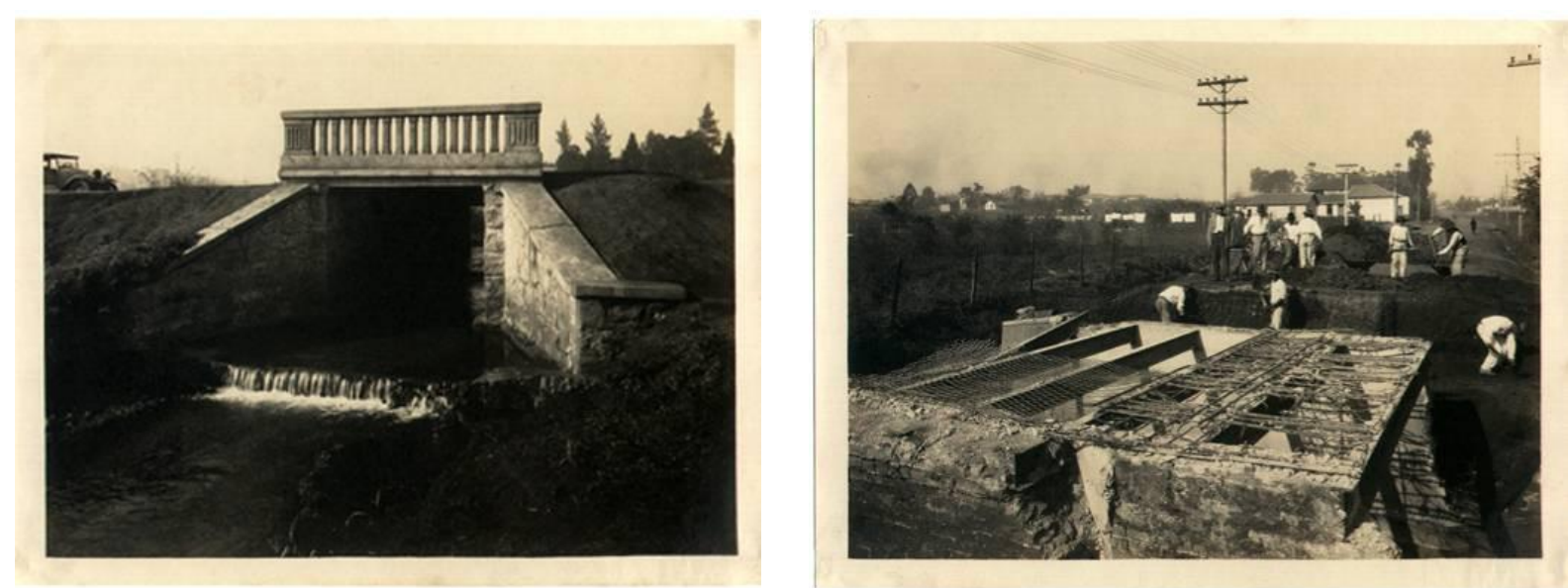

Figuras 38 e 39. Obras de pavimentação na auto-estrada Washington Luís e na estrada Santo Amaro em 1928. Fonte: Arquivo Histórico de São Paulo (Pesquisa Bibliográfica e Documental do Inventário).

O Largo Treze de Maio em 1920 possuía arruamento de terra batida e um pequeno calçamento beirando os imóveis e era o ponto final da linha do bonde. As construções eram predominantemente térreas e ocupavam pequenos lotes. Na Avenida Adolfo Pinheiro também já se observava a presença de estabelecimentos comerciais que contavam com relativa movimentação (BERARDI, 1981).

Em 22 de fevereiro de 1935, após a Revolução Constitucionalista de 1932 ${ }^{97}$, Santo Amaro foi anexada à capital transformando-se em subprefeitura pelo Decreto 6.983, do Interventor Federal, Armando de Sales de Oliveira (BERARDI, 1981):

\footnotetext{
96،Em 1927, foi constituída a Sociedade Anônima de Auto Estradas, que se propunha fazer uma ótima rodovia, ligando a capital às represas da Light, onde se construiria uma estação balneária” (BERARDI,1981, p.99).
} 
O Dr. Armando de Sales de Oliveira, interventor Federal do Estado de São Paulo, usando das atribuições que lhe são conferidas pelo Decreto Federal de 11 de novembro de 1930, decreta:

- Considerando que, dentro do plano de urbanismo da cidade de São Paulo, o município de Santo Amaro está destinado a constituir um de seus mais atraentes lugares de recreio;

- Considerando que, para a organização desse plano, o Estado tem que auxiliar as finanças de Santo Amaro, tanto que desde já declara extinta sua responsabilidade para com o Tesouro do Estado, proveniente do contrato de 18 de julho de 1931, e que muito onera o seu orçamento e dificulta sua expansão econômica e cultural;

- Considerando que o Estado de São Paulo se dispõe a não só incrementar em Santo Amaro a criação de hotéis e estabelecimentos balneários que permitiam o funcionamento de cassinos, como também já destinou verba para melhorar as estradas de rodagem que servem aquela localidade, facilitando-lhe todos os meios de comunicação rápida e eficiente com o centro urbano.

Decreta:

Art. $1^{\circ}$. - Fica extinto o Município de Santo Amaro, cujo território passará a fazer parte do Município da Capital, constituindo uma Sub-Prefeitura diretamente subordinada à Prefeitura de São Paulo.

Art. $2^{\circ}$. $-\mathrm{O}$ sub-prefeito será nomeado pelo Prefeito da Capital, com vencimentos anuais de 24:000\$000.

Art. $3^{\circ}$. - Serão mantidos os direitos dos atuais funcionários da Prefeitura de Santo Amaro em virtude do contrato de 18 de julho de 1931, abrindo-se para este fim o necessário crédito.

Art. $5^{\circ}$. - Este decreto entrará em vigor na data de sua publicação, revogadas as disposições em contrário.

Palácio de Governo do Estado de São Paulo, 22 de fevereiro de 1935.

Ass. Armando de Sales Oliveira, Waldomiro Silveira, Francisco Machado de Campos. (Decreto 6.983 in: BERARDI, 1981, p.106).

O Centro Autonomista de Santo Amaro, criado em 26 de Outubro de 1935, apresentou

a primeira tentativa pela volta à autonomia em 1948, rejeitada pela Assembléia Legislativa.

Outras tentativas sem êxito datam de 1958 e 1963 (BERARDI, 1981). ${ }^{98}$

Recordamos também junto com o presidente do CETRASA, Dr. Alexandre, do dia em que Santo Amaro, mesmo sendo mais antiga que São Paulo, perdeu a sua condição de município para se tornar bairro da capital. Fato que na época não suscitou a menor reação, mas que de longe ofuscou o orgulho dos santamarenses. E que apesar do plebiscito de anos mais tarde, se viu incapaz de reverter a situação a despeito do empenho dos cidadãos mais tradicionalistas da região. (Sra. Maria Gomes Leite Pereira, natural de Freguesia do Líria, em Portugal, que, nascida em 26 de janeiro de 1931, chegou ao Brasil com 8 anos, em 1940, a bordo do navio Angola

${ }^{97}$ A inauguração do Aeroporto de Congonhas em 1934 foi uma das razões pelas quais o decreto estadual $\mathrm{n}^{\circ}$ 6983, de 22 de fevereiro de 1935, determinou a extinção do município de Santo Amaro, incorporando-o ao município de São Paulo (durante a Revolução Constitucionalista de 1932, o Campo de Marte foi ocupado pelas tropas rebeldes, o que levou o Governo de Getúlio Vargas a procurar locais alternativos para o transporte aéreo em São Paulo). "O nome do aeroporto de Congonhas é uma homenagem ao Visconde de Congonhas do Campo, Lucas Antônio Monteiro de Barros, primeiro governante da província de São Paulo após a independência do Brasil. Congonhas é um tipo de erva-mate muito comum em Minas Gerais, na região onde se situa Congonhas do Campo, cidade natal de Monteiro de Barros. O aeroporto de Congonhas foi planejado em 1936, depois que uma enchente do Rio Tietê alagou e interditou por vários meses o aeroporto de Campo de Marte. O local foi escolhido por ter boas condições naturais como visibilidade e drenagem, além de ser um terreno plano e, naquela época, afastado do centro urbano" (Revista Enfoco Santo Amaro, 2004).

${ }^{98}$ Em 1985 (plebiscito) e 1989, novas tentativas de emancipação ocorreram. Disponível em: http://www.estadao.com.br/noticias/geral,cinco-curiosidades-sobre-santo-amaro,1603908> Acesso em:01 mar 2016. 
- SÃO PAULO, s.d. - Pesquisa Bibliográfica e Documental na Biblioteca Prestes Maia).

Após a anexação, a área do antigo município foi dividida: subdistritos de Santo Amaro, Ibirapuera, Capela do Socorro e no distrito de Parelheiros (BERARDI, 1981).

Com o plano estadual de transformar a região em local de recreio e o crescimento industrial incentivado pelo Estado e pela Subprefeitura de Santo Amaro nas décadas seguintes, o bairro foi se tornando populoso. Os novos moradores chegaram de outras regiões da capital e de todo o País, aproveitando as inaugurações das linhas de trem e do bonde na década de 30 e a abertura de avenidas e os asfaltamentos, nas décadas seguintes que facilitaram a locomoção (ASSOCIAÇÃO COMERCIAL DE SÃO PAULO, 2004, p.52 - Pesquisa Bibliográfica e Documental do Inventário).

\subsubsection{Santo Amaro Distrito de São Paulo}

Agora vou passar para minha casa, onde nasci. Era a Casa Arlindo, nome do meu pai, um armazém de secos e molhados que ficava na Alameda Santo Amaro. Eu fiz o pré na escola de D. Carmelina e aos oito anos fui para a Escola Paulo Eiró. A Alameda Santo Amaro era tranqüila e passava o bonde que vinha da Praça da Sé e ia até o Largo do Socorro. O nosso bonde era chamado de Camarão, por ser pintado de vermelho. A linha do bonde também serviu para transportar areia, tijolos para a construção da Catedral da Sé. Continuando na Alameda, as casas maiores eram só de residências e as casas comerciais eram o Armazém Arlindo, lojas de tecidos Alfredo, Padaria Hessel, alfaiataria, casa das bananas, botecos, serraria, açougue, Casa Isgasrb de materiais de construção e outros. No Largo da Matriz (atual Largo 13 de Maio) está a Igreja de Santo Amaro, atual Catedral. Em janeiro comemorávamos a festa do padroeiro na Igreja Santo Amaro, com romeiros, procissão e quermesse. Nossa! Como eram divertidas a barraquinha de doces e as bandas de música! Ainda no Largo da Matriz tínhamos a Padaria 15, que era o ponto de encontro de jovens. Tinha a Casa Rex, que vendia frios fabricados pela Indústria Éder e a Santa Casa para atender os doentes que era muito boa, e mas para frente o Colégio Jesus Maria José, que era menor. A Rua Capitão Tiago Luz era nossa Rua Direita, onde tinha a famosa farmácia do José Diniz, lojas de móveis, sapatos, sorveteria, leiteria, cabeleireiro. Mário Genari que ficava em frente ao coreto, o cinema São Francisco e o Grupo Escolar Paulo Eiró. Aos domingos os jovens de Santo Amaro e da redondeza e até Vila Mariana vinham fazer o flerte na Rua Direita que era fechada às 20 horas. Hoje na atual Laborterápica era um chácara de verduras. No Laboratório Organon era uma acivultura com aves de diversos tipos, com galinheiros estilo americano, todas casinhas separadas, e eu costumava ver as aves, pavões, perus e galinhas também macaquinhos. Nesta rua passava a boiada que era comandada pelos boiadeiros que tocavam os berrantes, às vezes os bois escapavam e invadiam as ruas. Uma vez um boi entrou numa feira livre e começou a dar chifradas nas barracas, era só gente correndo e não era brincadeira! Aí, os bois iam para o matadouro, onde hoje é a Escola Municipal Raniere Manzini, vizinha a uma fábrica de veludos Velmac, hoje Shopping Boa Vista. Antigamente, quando uma pessoa morria, o velório era na própria casa e costumava vir à funerária colocar panos pretos nas paredes da sala onde ficava o corpo. Os enterros eram feito a pé e a família não tinha o costume de acompanhar, iam até a igreja e o padre fazia uma oração depois seguiam para o cemitério, que nesta época só existia o de Santo Amaro. Um fato muito interessante foi quando morreu o pobre Bento-Portão, o enterro foi acompanhado pela banda de música e ele teve o maior túmulo feito pelos seus devotos. E assim era o bairro de Santo Amaro. (Sra. Maria de Lourdes Hessel Torres, nascida em Santo Amaro, em 25 de outubro de 1928, morou no bairro até 1976, quando passou a residir na Granja Julieta - SÃO PAULO, s.d - Pesquisa Bibliográfica e Documental na Biblioteca Prestes Maia). 
$\mathrm{Na}$ década de 1940, teve início a industrialização na Zona Sul e as indústrias começaram a se instalar em Santo Amaro. ${ }^{99}$

Com a foto da Rua Américo Brasiliense, tirada lá pelos anos de 1947, que ainda não era calçada, me lembro das esculturas feitas com o barro que se formava nos dias de chuva e também de que precisávamos trocar de sapatos enlameados quando chegávamos na Av. Santo Amaro, antes de pegar o bonde na parada da Av. Vereador José Diniz. (Sra. Maria Gomes Leite Pereira - SÃO PAULO, s.d.Pesquisa Bibliográfica e Documental).

Santo Amaro participou desse processo, região abundante de água, com terrenos amplos e baratos junto à várzea do Rio Pinheiros e com vias de transporte - Avenida Santo Amaro, Washington Luís e depois a Marginal Pinheiros, além da estrada de ferro para Santos construída entre 1952 e 1957 que se iniciava na Vila Leopoldina e conectava-se à ferrovia Mairinque-Santos no alto da Serra do Mar (BERARDI, 1981; PÁDUA, 2007 apud A LASCA, s/d.).

Esta foto foi tirada em 1967, de um grupo de crianças que fizeram a primeira comunhão na Igreja do Verbo Divino, na Rua Alexandre Dumas. Como se nota, no pátio era de terra batida. Na época ali eram realizadas as missas e as cerimônias de batizados e primeira comunhão para seus fieis. No fundo de suas dependências funcionava o posto de saúde, com sua construção de madeira, mais tarde mudou-se para a mesma rua na altura do no. 700, onde até hoje nós, do grupo de $3^{\text {a }}$. idade nos reunimos. Na época, a Chácara Santo Antonio, que pertence a Santo Amaro, tinha uma farmácia, uma padaria, um açougue e as demais compras fazíamos fora do bairro. Tínhamos que subir até a Avenida Santo Amaro para tomar ônibus. Os bondes já haviam sido tirados da Avenida Vereador José Diniz. (Sra. Neusa, nascida no bairro de Tatuapé, em 18 de dezembro de 1934. Mora no bairro de Santo Amaro desde 12 de dezembro de 1964 - SÃO PAULO, s.d. - Pesquisa Bibliográfica e Documental na Biblioteca Prestes Maia.).

Quem passa pela Avenida Águas Espraiadas, diante do grande movimento de trânsito, não imagina que o progresso acabou com a pequena mata que cobria de verde a região do Vale da Água Espraiada. Conforme relato de antigos moradores do Campo Belo, havia um trem a vapor da Cia. Ferrocarril, que fazia a viagem entre São Paulo e Santo Amaro. Entre Campo Belo e o Brooklin (atual) havia uma parada de trem chamada Parada Volta Redonda. O trem percorria belas paisagens de vegetação variada. (Sra. Diva, natural do Rio de Janeiro e que reside em Campo Belo desde que casou na Igreja Matriz de Santo Amaro e no cartório que ficava na Av. Adolfo Pinheiro. Nasceu em 26 de agosto de 1941 - SÃO PAULO, s.d. Pesquisa Bibliográfica e Documental na Biblioteca Prestes Maia.).

Depois da década de 1950 de grande desenvolvimento econômico, com verticalização do centro e sua concentração das atividades bancárias, financeiras, de serviços e comerciais; e da expansão horizontal da cidade, em 1960, Santo Amaro tornou-se um dos principais pólos industriais da cidade, com cerca de 447 empresas no período entre 1939 e 1973: a Rolamento INA; a Villares; a Metal Leve; a Walita; a Heine; a Monark; a Gradiente; entre outras; que

\footnotetext{
${ }^{99} 60 \%$ de toda a atividade industrial do Estado concentravam-se em bairros fabris como Mooca, Ipiranga e Brás (PÁDUA, 2007 apud A LASCA, s/d.)
} 
empregavam famílias migrantes, principalmente do nordeste que vieram para Santo Amaro nas décadas de 1950, 1960 e $1970 .^{100}$

[Santo Amaro] Abrigou importantes empresas da indústria farmacêutica, como os laboratórios Pfizer e Novartis e também foi um grande polo de fabricação de componentes eletrônicos, entre outros. Tínhamos a Caterpiller, a Metal Leve, a Phillips a Cargil, a Quimbrasil, primeira firma que processou urânio, a Frigor Éder, entre outras (Jaime Soler Baró, um espanhol da Catalunha que chegou ao Brasil em 1950 com 10 anos. Foi Diretor da Distrital Sul da FIESP/CIESP. in: ASSOCIAÇÃO COMERCIAL DE SANTO AMARO, 2004, p.32).

Intenso comércio e galpões industriais e pequenas casas operárias passaram a compor o cenário de Santo Amaro, que concentrava o comércio e as indústrias na região.

Havia 400 estabelecimentos comerciais em Santo Amaro, entre eles, pelo menos 15 açougues, 6 alfaiatarias, 15 lojas de tecidos, 60 armazéns, 80 bares. Mas o bairro também se tornou importante pólo industrial, com pelo menos 300 indústrias catalogadas. A região já representou $90 \%$ da indústria farmacêutica da América Latina e foi a segunda maior arrecadação de ICMS de São Paulo (ASSOCIAÇÃO COMERCIAL DE SANTO AMARO, 2004, p.52).

Vários loteamentos ocorreram na zona periférica de São Paulo (...) Ao mesmo tempo, a população de São Paulo crescia constantemente, primeiro pelas migrações estrangeiras e depois pelas migrações internas vindas de Minas e do Nordeste (BERARDI, 1981, p.114).

Em 1963, sua população estimada era de 134.638 habitantes. Tinha 115 escolas primárias, 12 estabelecimentos de ensino médio, várias escolas técnicas [...] 17 hospitais mais a Santa Casa de Misericórdia (Hospital Imaculada Conceição) (BERARDI, 1981, p.119).

A partir da década de 1980, muitas indústrias deixaram Santo Amaro ${ }^{101}$ e se instalaram em outras cidades do Estado de São Paulo, ocasionando muito desemprego e a proliferação do comércio informal, que foi organizado com a criação de calçadões (em 1978 e 1991), abrangendo a Praça Floriano Peixoto, o Largo Treze de Maio e as Ruas Herculano Freitas, Senador Dantas e José Bonifácio.

As padarias Alemã 15 e Goa eram célebres, como a Casa de Carnes Rex, propriedade do Frigor Éder. Havia também a Santa Casa, que com muita dificuldade ainda hoje sobrevive; os cinemas Cinemar, Marajá e São Francisco - em frente ao qual o famoso Felipe, o único baleiro da região, deliciava as crianças -, a escola do 'seu' Amaro, a banca do jornaleiro Lopes e os restaurantes São Paulo, Robbas,

\footnotetext{
100 “Tipos de indústrias principais - extrativas minerais, 8; minerais não metálicos, 21; metalurgias, 90; mecânicas, 48; materiais elétricos e comunicações, 46; materiais de transportes, 46; madeiras, 11; mobiliário, 37; papel e papelão, 10; borracha, 7; couro e peles, 4; perfumarias, 4; matéria plástica, 24; têxteis, 15; vestuário, calçados e tecidos, 9; produtos alimentícios, 48; bebidas, 2; editoras e gráficas, 11; diversas, 14. - Total, 496" (BERARDI, 1981, p.127).

${ }^{101}$ Atribuída também à Lei Municipal de Mananciais de 1975: "Isso transformou o bairro e, assim, começou a decadência de sua indústria (...) O bairro deixou de ser interessante para os empresários locais ou multinacionais pois ele não tinham para onde crescer e, portanto, não tinham mais razão de investir. (...) “As industrias se mudaram para o interior e Santo Amaro acabou, mas a lei não impediu seu objetivo principal: o de evitar a formação de loteamentos clandestinos" (ASSOCIAÇÃO COMERCIAL DE SANTO AMARO, 2004, p.32).
} 
Amigo Fritz e Joca. Perto da Praça Floriano Peixoto, antigo jardim da região, um vistoso edifício colonial abrigava o Grupo Escolar Paulo Eiró, que foi destruído nos anos 70 por ordem de José Maria Marin, durante a gestão Maluf. Outros edifícios como a Igreja da Matriz, a Casa Amarela e o prédio do antigo mercado, hoje Casa da Cultura de Santo Amaro, perduram até hoje. O comércio do bairro, atualmente transfigurado pelas barracas de camelôs, é lembrado pelas lojas Ykko, Modas Jurucê, a doçaria 'Saint Soucy' ou o Sete Mesas (ASSOCIAÇÃO SANTO AMARO, 2004, p.76 - Pesquisa Bibliográfica e Documental).

Os galpões industriais e vilas operárias deram lugar a empreendimentos residenciais, edifícios de escritórios, shoppings, faculdades e templos religiosos.

Na matriz de Santo Amaro foi realizado meu casamento no dia 10 de julho de 1971, pelo Monsenhor Antonio Nigro Júnior. A cerimônia aconteceu nessa paróquia porque meu marido residia com a família em uma Vila de seis casas na Rua São Jerônimo, próximo da rua Elias Mafur, da rua Nina Rodrigues e do Largo de São Sebastião que era o ponto final do Bonde Santo Amaro. (Sra. Diva - SÃO PAULO, s.d. - Pesquisa Bibliográfica e Documental na Biblioteca Prestes Maia.).

E Santo Amaro se transformou na segunda maior concentração de comércio e serviços.

No centro de Santo Amaro (Largo 13 de Maio e ruas adjacentes) estão as lojas comerciais e os bancos do bairro, e o local preferido das profissões liberais. Na Rua Capitão Tiago Luz encontramos artigos não padronizados, como vestuário, móveis etc a preços populares. Longe das áreas congestionadas pelo tráfego, encontramos lojas mais elegantes destes mesmo artigos não padronizados: Galeria Borba Gato. No mercado de utilidades, mercearias, farmácias e supermercados, há uma zona centralizada (Largo 13 de Maio) e algumas espalhadas em um raio maior. Junto das zonas comerciais centrais, agrupam-se numerosos estabelecimentos de refeições ligeiras, para atender ao grande número de pessoas que afluem das casas de comércio e dos estabelecimentos bancários, que são 21 no subdistrito (BERARDI, 1981, p. 126).

(...) também no entorno da praça estão instalados os principais equipamentos sociais: Subprefeitura, Santa Casa, Cartório, Bom Prato, Poupa Tempo, Correios e outros (SESC, 2006, p. 75).

Com suas características próprias abrange desde a periferia sempre tão carente de estrutura urbana, de transporte caótico onde o Metrô nunca chega, de invasões de terras e ao mesmo tempo com um imenso potencial econômico, traduzido nos edifícios espelhados da Vila Olímpia, Brooklin, Itaim e Moema. Do maior PIB per capita ao menor, de grandes multinacionais ao comércio de rua, Santo Amaro sempre foi um exemplo da diversidade cultural econômica paulista, e também vitrine dos abismos entre dois mundos que habitam a mesma cidade (Gazeta de Santo Amaro, 2015, s/p.). 


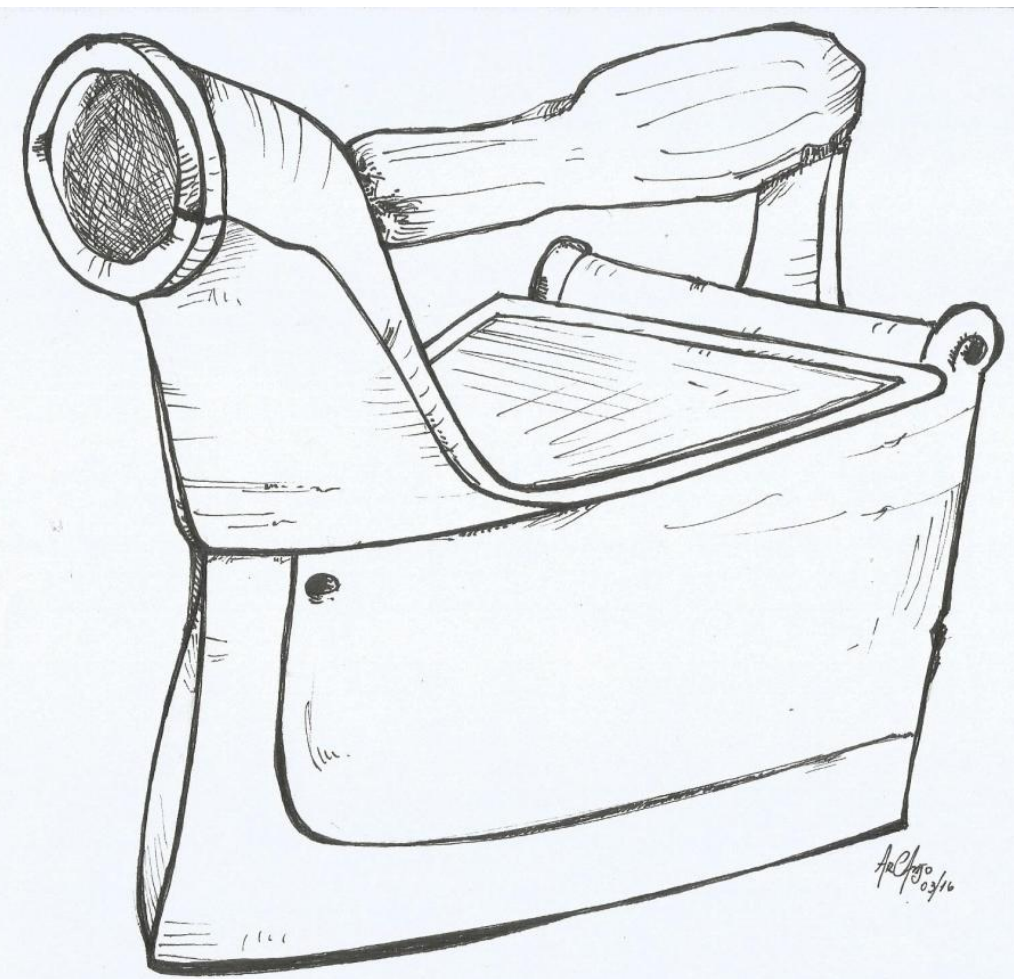




\section{CAPÍTULO 3}

\section{A PESQUISA-AÇÃO: SEU CONTEXTO, SUA TRAJETÓRIA E ALGUNS DOS SEUS RESULTADOS}

\subsection{0 contexto}

Nos anos 1980, no período de redemocratização do Brasil, depois de longo período de regime militar, que surgiram as leis que tratam da questão da proteção do Meio Ambiente no país.

A Lei 6.938, de 31 de agosto de 1981, estabeleceu a Política Nacional do Meio Ambiente - PNMA e instituiu o Sistema Nacional do Meio Ambiente - SNMA, compondo-o pelos órgãos e entidades da União, dos Estados, do Distrito Federal, dos Territórios e dos Municípios, bem como pelas fundações instituídas pelo Poder Público. E definiu o licenciamento ambiental (a Avaliação de Impactos Ambientais) como um dos instrumentos da Política Nacional do Meio Ambiente, ao lado do estabelecimento de padrões de qualidade ambiental, do zoneamento ambiental, dos incentivos à produção e instalação de equipamentos e a criação ou absorção de tecnologia, voltados para a melhoria da qualidade ambiental, entre outros, incluindo a variável ambiental nas tomadas de decisão sobre os empreendimentos ou atividades que utilizavam recursos naturais e passando a exigi-lo:

\footnotetext{
Art. 10 - A construção, instalação, ampliação e funcionamento de estabelecimentos e atividades utilizadores de recursos ambientais, efetiva ou potencialmente poluidores ou capazes, sob qualquer forma, de causar degradação ambiental dependerão de prévio licenciamento ambiental (BRASIL, 1981).
}

A PNMA e o SNMA se apresentaram como os responsáveis pela proteção e melhoria no país da qualidade ambiental, cabendo ao Conselho Nacional do Meio Ambiente CONAMA, também criado pela PNMA e estruturado pelo Sistema Nacional de Meio Ambiente, a formulação de diretrizes, normas e critérios para o licenciamento de atividades efetiva ou potencialmente poluidoras, a ser concedido pelos Estados, mediante proposta e 
supervisão do Instituto Brasileiro do Meio Ambiente e dos Recursos Naturais Renováveis IBAMA (BRASIL, 1981). ${ }^{102}$

A Resolução de $n^{\circ}$. 001, do CONAMA, de janeiro de 1986, estabeleceu as definições, responsabilidades e diretrizes para o uso e implementação da Avaliação de Impacto Ambiental e inseriu o patrimônio arqueológico no meio socioeconômico, definindo a obrigatoriedade da Arqueologia Preventiva ${ }^{103}$ junto aos Estudos de Impacto Ambiental - EIA e respectivo Relatório de Impacto no Meio Ambiente - RIMA e aos programas de mitigação e monitoramento dos impactos ambientais negativos ao meio ambiente, exigidos para obtenção (aprovação) das licenças ambientais na realização de empreendimentos públicos ou $\operatorname{privados}^{104}$.

Art. 6 O estudo de impacto ambiental desenvolverá, no mínimo, as seguintes atividades técnicas:

I - Diagnóstico ambiental da área de influência do projeto, completa descrição e análise dos recursos ambientais e suas interações, tal como existem, de modo a caracterizar a situação ambiental da área, antes da implantação do projeto, considerando: a) o meio físico - o subsolo, as águas, o ar e o clima, destacando os recursos minerais, a topografia, os tipos e aptidões do solo, os corpos d'água, o regime hidrológico, as correntes marinhas, as correntes atmosféricas; b) o meio biológico e os ecossistemas naturais - a fauna e a flora, destacando as espécies indicadoras da qualidade ambiental, de valor científico e econômico, raras e ameaçadas de extinção e as áreas de preservação permanente; c) o meio sócioeconômico - o uso e ocupação do solo, os usos da água e a socioeconomia,

\footnotetext{
102 Dentre os objetivos da PNMA, estavam: a compatibilização do desenvolvimento econômico social com a preservação da qualidade do meio ambiente e do equilíbrio ecológico; a definição de áreas prioritárias de ação governamental relativa à qualidade e ao equilíbrio ecológico, atendendo aos interesses da União, dos Estados, do Distrito Federal, dos Territórios e dos Municípios; o estabelecimento de critérios e padrões da qualidade ambiental e de normas relativas ao uso e manejo de recursos ambientais; o desenvolvimento de pesquisas e de tecnologias nacionais orientadas para o uso racional de recursos ambientais; a difusão de tecnologias de manejo do meio ambiente, a divulgação de dados e informações ambientais e a formação de uma consciência pública sobre a necessidade de preservação da qualidade ambiental e do equilíbrio ecológico; a preservação e restauração dos recursos ambientais com vistas à sua utilização racional e disponibilidade permanente, concorrendo para a manutenção do equilíbrio ecológico propício à vida; a imposição, ao poluidor e ao predador, da obrigação de recuperar e/ou indenizar os danos causados, e ao usuário, de contribuição pela utilização de recursos ambientais com fins econômicos (BRASIL, 1981). A Resolução do Conselho Nacional do Meio Ambiente CONAMA 237/97 definiu, no artigo $1^{\circ}$., parágrafo I, o licenciamento como "procedimento administrativo pelo qual o órgão ambiental competente licencia a localização, instalação, ampliação e a operação de empreendimentos e atividades utilizadoras de recursos ambientais, consideradas efetiva ou potencialmente poluidoras ou daquelas que, sob qualquer forma, possam causar degradação ambiental, considerando as disposições legais e regulamentares e as normas técnicas aplicáveis ao caso.”. Disponível em: <http://www.mma.gov.br/port/conama/res/res97/res23797.html>. Acesso em: 29 fev 2016.

${ }^{103}$ Entendendo-se como Arqueologia Preventiva (ou Conservacionista) aquela ligada essencialmente a aspectos de preservação, conservação e gestão de recursos arqueológicos, a qual apresenta correspondência com o enfoque denominado Cultural Resource Management (CRM), na literatura anglo-americana (WATERS, 1992 apud A LASCA, 2009).

${ }^{104}$ A licença ambiental corresponderia a uma espécie de autorização do poder público em relação à determinada obra ou atividade: a Licença Prévia, concedida na fase preliminar do planejamento do empreendimento ou atividade aprovando sua localização e concepção, viabilidade ambiental e estabelecendo requisitos e condicionantes para sua implementação; a Licença de Instalação, autorizando a instalação do empreendimento ou atividade, mediante ao atendimento das medidas de controle ambiental e demais condicionantes e as medidas mitigadoras e/ou compensatórias; e a Licença de Operação, que autoriza a operação da atividade ou empreendimento, mediante as medidas de controle ambiental e condicionantes determinadas para a operação.
} 
destacando os sítios e monumentos arqueológicos, históricos e culturais da comunidade, as relações de dependência entre a sociedade local, os recursos ambientais e a potencial utilização futura desses recursos. ${ }^{105}$

A Educação Ambiental que, no Brasil, ganhou o verdadeiro sentido enquanto processo político também na década de 1980 (LOUREIRO, 2004b), foi presente na Lei Federal $n^{\circ}$ 6.938 de 1981, devendo voltar-se a todos os níveis de ensino, inclusive à educação da comunidade, a fim de capacitá-la para a participação ativa na defesa do meio ambiente (BRASIL, 1981); e exigida no plano de gestão ambiental como um dos programas estabelecidos por medidas de compensação ambiental de destaque.

A educação foi vista com importância estratégica para a socialização de informações e conhecimentos, a autonomia dos grupos sociais, a participação popular e a democratização das decisões (LOUREIRO, 2009a e 2009b). ${ }^{106}$

A partir da segunda metade do século XX, que as transformações no meio ambiente se tornaram uma das maiores preocupações da sociedade contemporânea e foram responsáveis por mobilizações internacionais (reuniões, convenções, programas e protocolos nacionais e internacionais) para uma gestão mundial dos problemas ambientais e o estabelecimento de “políticas reparadoras e de preservação para o meio ambiente” (MARTINEZ, 2003, p. 219).

No decorrer das Conferências e dos Encontros Internacionais sobre Meio Ambiente, que tiveram início nos anos 1970 e dos documentos por eles produzidos, que se apresentou a necessidade de organização de ações e aprendizados nomeada de Educação Ambiental, com o propósito de transmitir conceitos sobre os problemas ambientais, desenvolver habilidades e atitudes para atuar na conservação e preservação de ambientes naturais e patrimoniais e ampliar esse debate.

Em 1975, foi lançado pela UNESCO o Programa Internacional de Educação Ambiental - PIEA, e, em 1977, a Conferência de Tbilisi (Primeira Conferência Intergovernamental sobre Educação Ambiental) e a Declaração sobre a Educação Ambiental (Declaração da Conferência Intergovernamental de Tbilisi sobre Educação Ambiental e as Recomendações da Conferência Intergovernamental sobre Educação Ambiental aos Países Membros)

\footnotetext{
${ }^{105}$ Resolução CONAMA 001/1986. Disponível em:

<http://www.mma.gov.br/port/conama/legiabre.cfm?codlegi=23>. Acesso em:29.02.2016. A exigência do Estudo de Impacto Ambiental e respectivo relatório se referia a projetos em áreas maiores que 100 hectares. E o órgão estadual competente ou o IBAMA ou o Município que fixariam as diretrizes adicionais relativas às características do projeto e/ou da área; e os prazos para conclusão e análise dos estudos (MORAIS, 2015).

${ }^{106} \mathrm{Na}$ Política Nacional de Educação Ambiental de 1999, a Educação Ambiental foi assegurada como direito. Consultar: LOUREIRO, C. F. B (org.). Educação ambiental no contexto de medidas mitigadoras e compensatórias de impactos ambientais: a perspectiva do licenciamento. Salvador: IMA, 2009; LOUREIRO, C. F. B.. Educação Ambiental e Gestão Participativa na Explicitação e Resolução de Conflitos. Gestão em Ação. v.7, no 1, jan./abr. Salvador, 2004; e LOUREIRO, Carlos Frederico Bernardo, LAYRARGUES, Philippe Pomier, CASTRO, Ronaldo Souza de (org.) Repensar a educação ambiental: um olhar crítico - São Paulo: Cortez, 2009.
} 
apresentaram os objetivos, funções, estratégias, características, princípios e recomendações para a Educação Ambiental, para a resolução dos problemas concretos do meio ambiente através de enfoques interdiciplinares e princípios da complexidade, levando em consideração os aspectos econômicos, históricos e culturais nas relações homem e natureza (abordagem complexa da questão ambiental), e uma participação ativa e responsável de cada indivíduo e da coletividade (DIAS, 1998).

De uma preocupação ambiental essencialmente ecológica, de conservação da natureza e denunciadora do esgotamento dos recursos naturais, a problemática ambiental, em Tbilisi, começou a ser vista compreendendo as questões sociais, econômicas, culturais e políticas e a Educação Ambiental, buscando dar conta dessa complexidade (JACOBI, 2005). A questão ecológica, nesses anos, passa de uma preocupação com o esgotamento dos recursos naturais para uma concepção que vê nela aspectos sociais, culturais e políticos também implicados $\left(\right.$ CASCINO, 1998) ${ }^{107}$.

A Constituição Federal de 1988 também incluiu um capítulo que tratou especialmente do Meio Ambiente, estabelecendo a todos o direito de um meio ambiente ecologicamente equilibrado, por tratar-se de um bem de uso comum de todos e que devia ser preservado para as presentes e futuras gerações (BRASIL, 1988); e incorporou o conteúdo da Resolução CONAMA 001, quanto ao estudo prévio de impacto ambiental, como instrumento técnicocientífico necessário para a eventual concessão da licença prévia de empreendimentos.

Art. 225. Todos têm direito ao meio ambiente ecologicamente equilibrado, bem de uso comum do povo e essencial à sadia qualidade de vida, impondo-se ao Poder Público e à coletividade o dever de defendê-lo e preservá- lo para as presentes e futuras gerações.

$\S 1^{\circ}$ Para assegurar a efetividade desse direito, incumbe ao Poder Público:

I - preservar e restaurar os processos ecológicos essenciais e prover o manejo ecológico das espécies e ecossistemas;

II - preservar a diversidade e a integridade do patrimônio genético do País e fiscalizar as entidades dedicadas à pesquisa e manipulação de material genético;

III - definir, em todas as unidades da Federação, espaços territoriais e seus componentes a serem especialmente protegidos, sendo a alteração e a supressão permitidas somente através de lei, vedada qualquer utilização que comprometa a integridade dos atributos que justifiquem sua proteção;

IV - exigir, na forma da lei, para instalação de obra ou atividade potencialmente causadora de significativa degradação do meio ambiente, estudo prévio de impacto ambiental, a que se dará publicidade;

V - controlar a produção, a comercialização e o emprego de técnicas, métodos e substâncias que comportem risco para a vida, a qualidade de vida e o meio ambiente;

\footnotetext{
107،Já não cabe apenas desvendar os Limites de Crescimento. Agora trata-se de pensar conjuntamente homens e mulheres e a natureza, porque fazem parte dos mesmos sistemas, existem pelas mesmas razões; há uma interdependência inquestionável. Agora, sabe-se, sem nenhuma dúvida que há um Futuro Comum. Será, portanto, nesse espaço privilegiado que se expandirá a noção de desenvolvimento sustentável" (CASCINO, 1998, p.55). Em 1992, quando se tem no Brasil a ECO-92 ou Rio 92, que se começa a se falar de um desenvolvimento que tem de ser sustentável sob vários aspectos, não somente depredador de recursos naturais.
} 
VI - promover a educação ambiental em todos os níveis de ensino e a conscientização pública para a preservação do meio ambiente;

VII - proteger a fauna e a flora, vedadas, na forma da lei, as práticas que coloquem em risco sua função ecológica, provoquem a extinção de espécies ou submetam os animais a crueldade (BRASIL, 1988). ${ }^{108}$

Também instituiu um amplo programa de "conscientização pública" sobre a necessidade de preservação do meio ambiente, principalmente em instituições públicas de ensino, em todos os níveis ${ }^{109}$, apresentando uma concepção de meio ambiente que incluía a preservação do patrimônio cultural. No Artigo 216, incluiu o patrimônio arqueológico na definição do Patrimônio Nacional Brasileiro, consolidando os preceitos estabelecidos pela Lei Federal 3.924, de 26 de julho de $1961^{110}$, que dispôs sobre os monumentos arqueológicos e pré-históricos (MORAIS, 2015):

Art. 216. Constituem patrimônio cultural brasileiro os bens de natureza material e imaterial, tomados individualmente ou em conjunto, portadores de referência à identidade, à ação, à memória dos diferentes grupos formadores da sociedade brasileira, nos quais se incluem:

I - as formas de expressão;

II - os modos de criar, fazer e viver;

III - as criações científicas, artísticas e tecnológicas;

IV - as obras, objetos, documentos, edificações e demais espaços destinados às manifestações artístico-culturais;

$\mathrm{V}$ - os conjuntos urbanos e sítios de valor histórico, paisagístico, artístico, arqueológico, paleontológico, ecológico e científico. ${ }^{111}$

Entretanto, foram, sobretudo, a Portaria SPHAN/MinC $\mathrm{n}^{\circ} .07$, de 01 de dezembro de 1988, e mais tarde, em 17 de dezembro de 2002, a Portaria do IPHAN nº 230 - revogada em 25 de março de 2015, pela Instrução Normativa IPHAN $n^{\circ} 1^{112}$ - que normatizaram e

\footnotetext{
${ }^{108}$ Constituição da República Federativa do Brasil de 1988. Disponível em: <http://www.planalto.gov.br/ccivil_03/constituicao/ConstituicaoCompilado.htm>. Acesso em: 29 fev 2016.

${ }^{109}$ Posteriormente, foi aprovada a Lei Federal $n^{\circ} 9.795$ de 27 de abril de 1999 (regulamentada pelo Decreto Federal $n^{\circ} 4.281$, de 25 de Junho de 2002), que dispôs sobre a Educação Ambiental, instituindo a Política Nacional de Educação Ambiental.

110 "Os monumentos arqueológicos e pré-históricos de qualquer natureza existentes no território nacional e todos os elementos que neles se encontram ficam sob a guarda e proteção do Poder Público, de acordo com que estabelece o art. 175 da Constituição Federal." A "Lei da Arqueologia" (como ficou conhecida a Lei Federal) que instituiu a proteção dos bens arqueológicos brasileiros, considerados bens da União e ampliou de forma significativa a proteção dos sítios arqueológicos em todo o território nacional (BASTOS, 2010). Os casos de destruição, mutilação e/ou dano desse patrimônio passaram a ser considerados crimes. Disponível em: <http://portal.iphan.gov.br/legislacao?pagina=17>. Acesso em: 29 fev 2016. E, em 1998, a Lei de Crimes Ambientais 9.605 dispôs sobre as responsabilidades e punição dos infratores das prerrogativas da legislação vigente em relação à qualidade do meio ambiente. Disponível em:

<http://www.planalto.gov.br/CCIVIL_03/leis/L9605.htm>. Acesso em: 29 fev 2016.

${ }^{111}$ Constituição da República Federativa do Brasil de 1988. Disponível em: <http://www.planalto.gov.br/ccivil_03/constituicao/ConstituicaoCompilado.htm>. Acesso em: 29 fev 2016.

112 No âmbito estadual, a Resolução SMA/SP - no. 34, de 27/08/03, também dispôs sobre as medidas necessárias à proteção do patrimônio arqueológico e pré-histórico quando do licenciamento ambiental de empreendimentos. Hoje também revogada. Disponível em: http://www.ambiente.sp.gov.br/legislacao/resolucoes-sma/resolucaosma-34-2003/> Acesso em: 29 fev 2016. A Instrução Normativa e a Portaria Interministerial do Ministério do Meio Ambiente - MMA n ${ }^{\circ}$ 60, de 24 de março de 2015 trouxeram novas diretrizes para os estudos arqueológicos
} 
legalizaram as ações de intervenção junto ao patrimônio arqueológico nacional, estabelecendo a realização:

Art. 1. Nessa fase, dever-se-á proceder à contextualização arqueológica e etnohistórica da área de influência do empreendimento, por meio de levantamento exaustivo de dados secundários e levantamento arqueológico de campo. No caso de projetos afetando áreas arqueologicamente desconhecidas, pouco ou mal conhecidas, que não permitam inferência sobre a área de intervenção do empreendimento, deverá ser providenciado levantamento arqueológico de campo pelo menos em sua área de influência direta. Esse levantamento deverá contemplar todos os compartimentos ambientais significativos no contexto geral da área a ser implantada e deverá prever levantamento prospectivo de sub-superfície (Portaria IPHAN no $\left.{ }^{\circ} 230\right)^{113}$

A Portaria SPHAN/MinC n ${ }^{\circ} .07^{114}$ regulamentou os pedidos de permissão, autorização e comunicação prévia para o desenvolvimento de pesquisas de campo e escavações arqueológicas, determinando proposta de valorização do potencial científico, cultural e educacional.

A elaboração de um relatório de caracterização e avaliação da situação atual do patrimônio arqueológico da área de estudo, sob a rubrica de diagnóstico, foi estabelecida pela Portaria IPHAN n ${ }^{\circ}$ 230, assim como a avaliação dos impactos do empreendimento sobre o patrimônio arqueológico regional.

A Portaria compatibilizou a apresentação dos programas de prospecção e de resgate arqueológico (de diagnóstico e avaliação de impactos), com o cronograma das obras e com as fases de licenciamento ambiental do empreendimento. E estabeleceu que os estudos arqueológicos do processo de licenciamento também deveriam prever o planejamento de ações de Educação Patrimonial, dispondo em seu art. $6^{\circ}$, parágrafo $7^{\circ}$, que os Programas de Educação Patrimonial estivessem previstos dentre os estudos desenvolvidos, em todas as fases de licenciamento, para a extroversão destes estudos e como medida para miminizar ou compensar os impactos acarretados (MORAIS, 2015) ${ }^{115}$.

A razão da implementação de Programas de Educação Patrimonial durante os estudos de Arqueologia Preventiva, que passaram a ser desenvolvidos, sobretudo, a partir de

no processo de licenciamento e também para a Educação Patrimonial. Ver no site do IPHAN. Disponíveis em: http://portal.iphan.gov.br/legislacao?pagina=1> Acesso em: 29 fev 2016.

${ }^{113}$ Disponível em:

http://portal.iphan.gov.br/uploads/legislacao/Portaria_n_230_de_17_de_dezembro_de_2002.pdf $>$ Acesso em: 29 fev 2016.

${ }^{114}$ Disponível em:

<http://portal.iphan.gov.br/uploads/legislacao/Portaria_n_007_de_1_de_dezembro_de_1988.pdf> Acesso em: 29 fev 2016.

115 Ações com fins científicos, culturais e educativos. Também determinou que a guarda do material arqueológico recuperado nas áreas de resgate deveria ser garantida pelo empreendedor, seja na modernização, ampliação e fortalecimento de unidades de pesquisa existentes ou, mesmo, na construção de unidades museológicas (MORAIS, 2015). 
atividades complementares aos debates e projetos das escolas localizadas nas áreas de influência do empreendimento ${ }^{116}$ sobre temas transversais e interdisciplinares, uma vez não contarem com diretrizes teóricas e conceituais, seria a apropriação de bens culturais, especialmente os arqueológicos, pela maioria da população local, a partir de ações de inclusão social, valorização das comunidades locais e da extroversão do conhecimento arqueológico, podendo avançar na construção das nossas memórias e na valorização da nossa própria cultura e patrimônio (BASTOS, 2010).

Como abordado no Capítulo 1, foi em 2004, que o IPHAN começou a constituir uma área específica voltada para as ações educativas ligadas à preservação do patrimônio cultural, criando a Coordenação de Educação Patrimonial (CEDUC). O objetivo foi promover com diversos segmentos da sociedade civil discussões sobre diretrizes, produzir documentos e propostas de encaminhamentos e fomentar a criação de redes de intercâmbio de experiências e parcerias. Assim em setembro de 2005, realizou-se o I Encontro Nacional de Educação Patrimonial - ENEP (IPHAN, 2014).

Em 2009, a Coordenação foi vinculada ao recém-criado Departamento de Articulação e Fomento - DAF do IPHAN, para promoção, coordenação, integração e avaliação da implementação de programas e projetos de Educação Patrimonial no âmbito da Política Nacional do Patrimônio Cultural. ${ }^{117}$ No II ENEP, em 2011, foi discutida a estruturação de um Programa Nacional de Educação Patrimonial e as atividades de Educação Patrimonial foram inseridas no Macrocampo da Cultura e Artes do Programa Mais Educação do Ministério da Educação (IPHAN, 2014).

Projeto do governo federal de perspectiva da Educação Integral, para a ampliação da jornada escolar, o Programa Mais Educação prioriza escolas em áreas de vulnerabilidade social, com baixo índice de desenvolvimento de educação básica - IDEB e com grande número de crianças com Bolsa Família; é operacionalizado pela Secretaria de Educação Básica do Ministério da Educação - SEB/MEC em macrocampos que envolvem temas

\footnotetext{
${ }^{116}$ São as áreas de influência: a Área Diretamente Afetada (ADA) corresponde à área do terreno diretamente afetada antrópica e fisicamente pelas obras necessárias à implantação do empreendimento, abrangendo locais onde está prevista a implantação das estações, das estruturas, dos canteiros de obras, dos acessos, das áreas de empréstimo, das áreas de bota-fora, das áreas de apoio, etc. Nesse caso, foram consideradas as áreas localizadas próximo ao traçado da Linha 5 - Lilás e que sofreram mudanças na organização espacial, uso do solo, sistema viário e sistema de transporte atualmente existente; Área de Influência Direta (AID): corresponde à área do entorno do empreendimento que possa conter vestígios arqueológicos associados ao contexto da ADA. Neste caso, foi considerada a bacia hidrográfica do rio Pinheiros; e a Área de Influência Indireta (AII): correspondente à região geo-ambiental em que está inserido o empreendimento, neste caso, deve ser considerada a Bacia Hidrográfica do Alto Tietê (A LASCA, 2009).

${ }^{117} \mathrm{O}$ Instituto Brasileiro de Museus - IBRAM também foi criado em 2009, no contexto de definição de parâmetros de atuação do âmbito da Educação Patrimonial.
} 
associados às políticas federais desenvolvidos pelos ministérios parceiros, como o Ministério da Cultura, o Ministério do Desenvolvimento Social e Combate à Fome, o Ministério da Ciência e Tecnologia, o Ministério do Esporte e o Ministério do Meio Ambiente e Coordenadoria Geral da União, entre outros. No II ENEP, que o IPHAN, numa parceria com o MEC, propôs uma atividade específica de Educação Patrimonial, de "mapeamento inicial das referências culturais e potencialidades educativas que estão imersas na realidade escolar um inventário pedagógico do patrimônio local", integrando-a ao macrocampo Cultura e Arte (IPHAN, 2014, p.33).

Em 2014, o IPHAN preparou uma publicação destacando a questão da participação das comunidades em ações educativas, como também sobre os conceitos de mediação e territórios educativos.

[...] a cidade precisa ser compreendida como território vivo, permanentemente concebido, reconhecido e produzido pelos sujeitos que a habitam. É preciso associar a escola ao conceito de cidade educadora, pois a cidade, no seu conjunto, oferecerá internacionalmente às novas gerações experiências contínuas e significativas em todas as esferas e temas da vida (MOLL, 2009, p.15 in: IPHAN, 2014, p.24).

Para a implantação das estações "Largo Treze" e "Adolfo Pinheiro" da Linha 5 do Metrô na região de Santo Amaro, foram desenvolvidos estudos arqueológicos nas áreas (de superfície e subterrâneas) entre as estações, com o objetivo de diagnosticar o potencial para a ocorrência de vestígios históricos ou arqueológicos de interesse ao Patrimônio Cultural Brasileiro e que visaram, sobretudo, identificar os riscos a que estes poderiam ser submetidos em decorrência das obras e indicar, caso necessário, ações de proteção física e/ou de resgate arqueológico. ${ }^{118} \mathrm{O}$ conceito de potencial arqueológico entendido como "a probabilidade de ocorrência de vestígios materiais de significância para o conhecimento da ocupação humana do território" e baseado nas "premissas de significância científica, histórica ou étnica e grau de preservação do solo urbano antigo" (JULIANI, 1996 apud JULIANI, 2015, p.248); e vestígio arqueológico, como "todo e qualquer elemento que caracterize ou seja indicador da presença humana na área de estudo, independente do período cronológico a que se relacione

\footnotetext{
${ }^{118}$ Os objetivos propostos foram: "Localizar e caracterizar bens de interesse ao Patrimônio Cultural da Nação (sítios históricos e sítios arqueológicos) que possam existir nas áreas de intervenção do empreendimento; Prevenir a destruição e / ou a descaracterização desses bens culturais (se localizados) em decorrência das atividades necessárias às etapas de implantação, instalação e operação do empreendimento; Elaborar planos de mitigação de impactos na área, a fim de resgatar informações a respeito dos bens ameaçados, de modo que possam ser ambiental, histórica e culturalmente contextualizados e, assim, incorporados à Memória Nacional” (A LASCA, 2009, p.5).
} 
e, também, dos possíveis critérios subjetivos de valoração científica" (JULIANI, 2015, p. 249).

Com relação aos bens tombados em Santo Amaro (seu Eixo Histórico e os bens edificados que fizeram parte de sua história e que preservam aspectos da memória do bairro quando município), foi também implantado um Programa de Preservação e Monitoramento do Patrimônio Cultural Edificado, de forma a averiguar e acompanhar, durante o desenvolvimento das obras do empreendimento, as condições estruturais e de conservação desses bens culturais relevantes (A LASCA, 2009).

O Programa de Educação Patrimonial que foi implementado com a função de colaborar na difusão dos trabalhos de evidenciação de vestígios arqueológicos e na valorização do patrimônio arqueológico e cultural da região das obras foi o que constituiu o contexto do início do processo de formatação da pesquisa-ação e do Inventário Comunitário e Escolar de Bens Culturais.

As atividades do Programa se basearam nas diretrizes do Termo de Referência para o Planejamento e Execução dos Programas de Educação Patrimonial e Inclusão Social vinculados ao licenciamento ambiental do IPHAN-SP, que estabelecia as ações de Programas de Educação Patrimonial em obras de empreendimentos modificadores do meio físico, e abrangeram moradores, atores sociais, alunos e professores inclusive de outras áreas da região de Santo Amaro (de outros distritos), pois envolveram escolas públicas e entidades e instituições localizadas nas proximidades de toda a extensão da Linha 5 do Metrô (do rua Conde de Itu, em Santo Amaro-SP, até a Estação Chácara Klabin, no bairro de Vila MarianaSP), além de trabalhadores das obras. ${ }^{119}$
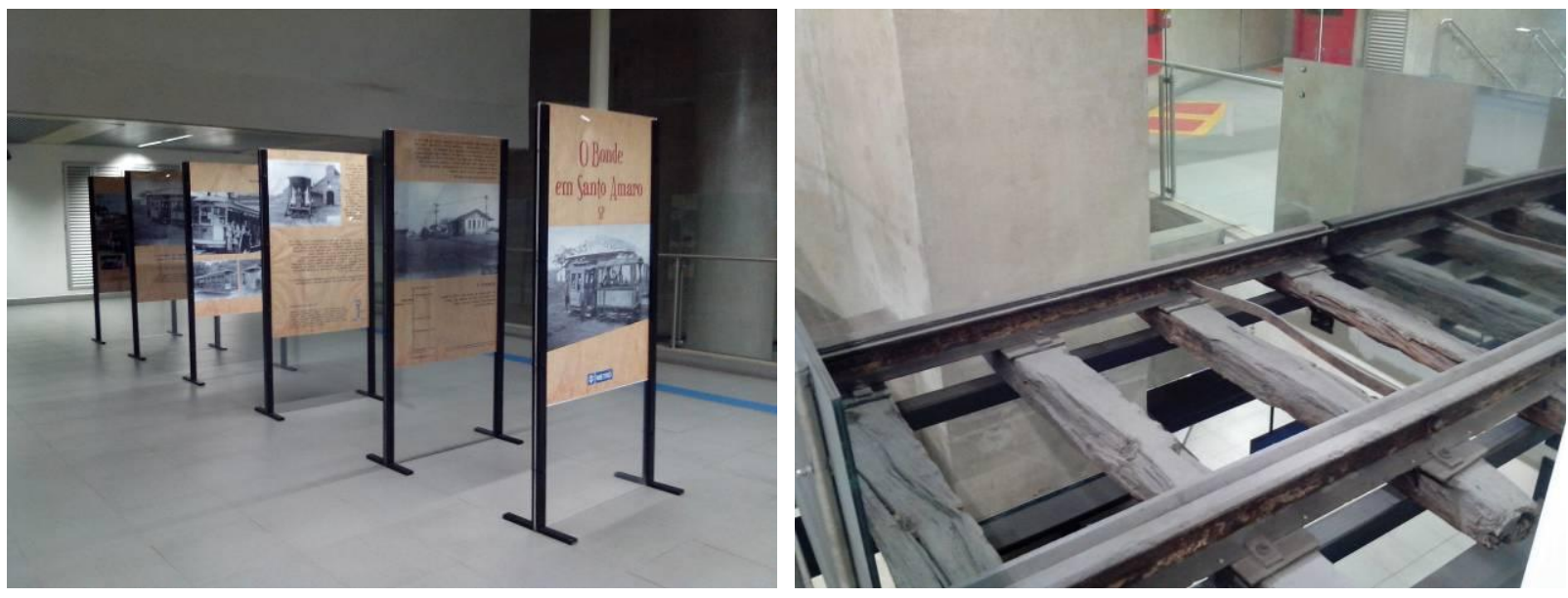

\footnotetext{
${ }^{119}$ Muito embora as ações e as atividades educativas da pesquisa-ação tenham sido realizadas somente junto à comunidade em geral e escolar do entorno imediato do Eixo Histórico de Santo Amaro.
} 
Figuras 40 e 41. Exposição permanente $O$ Bonde em Santo Amaro na Estação Adolfo Pinheiro elaborada no contexto dos Programas de Arqueologia Preventiva e de Educação Patrimonial da Linha 5 do Metrô de São Paulo. Fotos da autora.
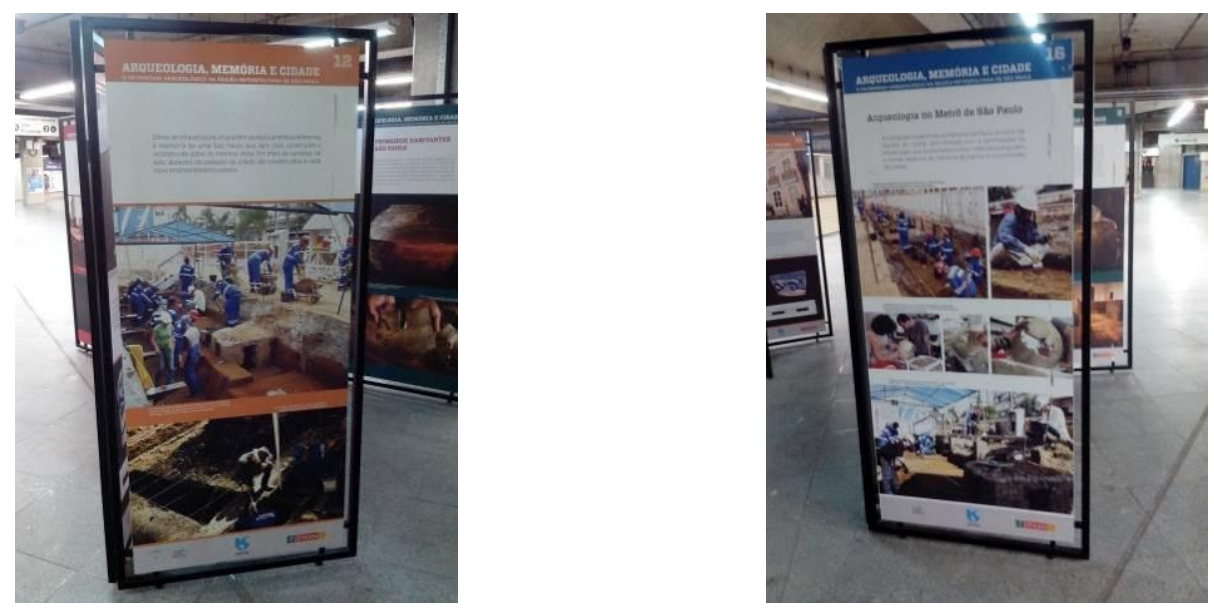

Figuras 42 e 43. Exposição Itinerante Arqueologia, Memória e Cidade, na Estação Paraíso, que também apresentou aspectos das escavações arqueológicas desenvolvidas junto às obras da Linha 5 do Metrô de São Paulo.

\subsection{A formatação da pesquisa-ação e os passos iniciais do inventário}

\subsubsection{As primeiras entrevistas, reuniões e atividades educativas na região}

1) O que você sabe sobre a história da cidade e/ou de Santo Amaro? Há quanto tempo mora aqui?

2) Que lugares você indicaria para conhecermos (pontos históricos, lugares que considera importantes para a história e cultura de Santo Amaro etc.)?

3) Você tem conhecimento e/ou participa/participou de alguma atividade cultural (religiosa, tradicional ou típica) aqui em Santo Amaro? Fale um pouco sobre ela?

4) E sobre Arqueologia? Você já ouviu falar? Tem conhecimento de algum projeto já ocorrido que tenha envolvido arqueologia na cidade ou aqui na região? E de história?

5) Você já ouviu falar de outros povos que tenham vivido aqui e/ou de algum achado histórico ou arqueológico encontrado? (Perguntas do Roteiro de Entrevista aplicado na fase inicial de diagnóstico da pesquisa-ação)

Durante todo o ano de 2013 (de maio a outubro), ao longo do desenvolvimento do referido Programa de Educação Patrimonial, foram realizadas visitas e reuniões (os primeiros contatos) na região de Santo Amaro, como também atividades educativas (workshops com professores, oficinas com alunos e encontros com a comunidade), que objetivaram, para a formatação do projeto de pesquisa, diagnosticar o conhecimento que possuíam e o relacionamento que mantinham com o patrimônio cultural e arqueológico da região os 
gestores escolares e culturais, educadores. Participaram também o público em geral das imediações do Eixo Histórico de Santo Amaro e frequentadores das instituições culturais (os atores sociais) de escolas públicas, instituições culturais e espaços públicos locais. O foco das atividades era verificar se conheciam ou tinham informação sobre os bens culturais de Santo Amaro tombados; se sentiam pertencentes ou representados por esses bens e/ou mantinham relações de pertencimento com outros bens e com quais outros bens (se existiam outros bens culturais na região aos quais atribuíam importância e significado). E também o que concebiam como patrimônio; quais posturas e ações e/ou projetos desenvolvidos sobre essa temática e sobre o patrimônio arqueológico eram existentes na região; o que sabiam sobre legislação ambiental e as novas exigências relacionadas aos estudos arqueológicos, entre outras questões.

As entrevistas, reuniões e os workshops foram realizados com a equipe pedagógica da Diretoria de Ensino da região de Santo Amaro, com os diretores, vice-diretores e coordenadores pedagógicos (gestores escolares) e com os professores, reunidos em horário de trabalho pedagógico (HTPC), na Escola Estadual Paulo Eiró, Escola Municipal de Ensino Fundamental e Médio Prof. ${ }^{\circ}$ Linneu Prestes, Escola Municipal de Ensino Fundamental Carlos de Andrade Rizzini, Escola Estadual Prof ${ }^{\circ}$. Alberto Conte e Escola Municipal de Educação Infantil Borba Gato; e os encontros e oficinas, com os frequentadores e os responsáveis das duas bibliotecas públicas municipais locais (bibliotecárias e gestores das Bibliotecas Belmonte e Prestes Maia), e com gestores e agentes culturais dos espaços culturais e casas de cultura ou de referência comunitária ou histórico-social: o Paço Julio Guerra, Casa de Cultura Manoel Cardoso Mendonça, Casa de Cultura Cora Coralina, Sesc Santo Amaro; e com a Coordenadoria de Cultura de Santo Amaro da Subprefeitura de Santo Amaro (que, na época, era a supervisora dessas instituições culturais).

Esses atores revelaram desconhecer as novidades trazidas pela legislação ambiental quanto aos direitos do cidadão e responsabilidades dos médios e grandes empreendimentos em relação ao patrimônio cultural e arqueológico, como também a atuação da Arqueologia no país, em São Paulo e no contexto de obras como a do Metrô, como também sobre os sítios arqueológicos existentes em São Paulo.

No caso das escolas, os educadores entrevistados ou que participaram dos workshops revelaram muito pouco conhecimento sobre as ações desenvolvidas pelos órgãos e instituições da cidade ligadas à preservação e extroversão do patrimônio cultural em geral. Somente mencionaram a participação das suas escolas no Programa "Cultura é Currículo" da 
Secretaria de Educação do Governo do Estado de São Paulo ${ }^{120}$ e experiências pontuais e efêmeras, desenvolvidas em sala de aula, sem envolver um projeto mais amplo, de caráter interdisciplinar, adotado pela instituição de ensino de maneira sistemática e contínua. Não foi evidenciado nenhum projeto em curso que tratasse do patrimônio arqueológico e histórico local ou cultural de modo geral (memória e a história da região) como conteúdo curricular nas escolas visitadas.

O Centro de Tradições de Santo Amaro (o Museu local) não foi mencionado em nenhuma das reuniões com os gestores escolares, nem nos workshops com professores desenvolvidos e nas atividades com a comunidade em geral, embora já participasse em conjunto com a Coordenadoria de Cultura da Subprefeitura de Santo Amaro de ações na região: da comemoração do aniversário de Santo Amaro, em 15 de janeiro e no ano de 2013, da criação por lei municipal do Dia das Tradições de Santo Amaro. O CETRASA também mantinha (e mantém) uma coluna diária num jornal tradicional local (A Gazeta de Santo Amaro), difundindo histórias e costumes de Santo Amaro e um espaço de exposição permanente de fotografias, objetos e equipamentos do seu acervo.

Esses aspectos corroboraram a importância do objetivo da pesquisa em também colaborar para a inserção da questão do patrimônio cultural e arqueológico no âmbito das preocupações e do programa curricular das escolas envolvidas no processo, fomentando o uso do Patrimônio Cultural Material e Imaterial como recurso pedagógico no contexto escolar e criando situações de vivência e reflexões sobre a memória, herança, território, preservação e novas gerações. E resultaram, ao longo de sua formatação inicial e durante toda a sua trajetória, no desenvolvimento de atividades voltadas especialmente a professores, além de oficinas com as suas turmas de alunos sobre as temáticas da Educação Patrimonial, Arqueologia e Patrimônio Cultural, que envolveram também a apresentação, concepção e criação de diversificados materiais de apoio didático para as essas ações.

\footnotetext{
${ }^{120}$ Composto pelos projetos: Lugares de Aprender: a Escola Sai da Escola, Escola em Cena e O Cinema Vai à Escola, o Programa Cultura é Currículo, tem o objetivo de democratizar o acesso a equipamentos, bens e produções culturais do patrimônio cultural da sociedade, fortalecer o ensino por meio de novas formas e possibilidades de desenvolvimento dos conteúdos curriculares, e "estimular e desenvolver a aprendizagem por intermédio de interações significativas do aluno com o objeto de estudo/conhecimento de disciplinas, reforçando-se o caráter investigativo da experiência curricular.”. Disponível em: <http://culturaecurriculo.fde.sp.gov.br/programa.aspx $>$. Acesso em 29 fev 2016.
} 


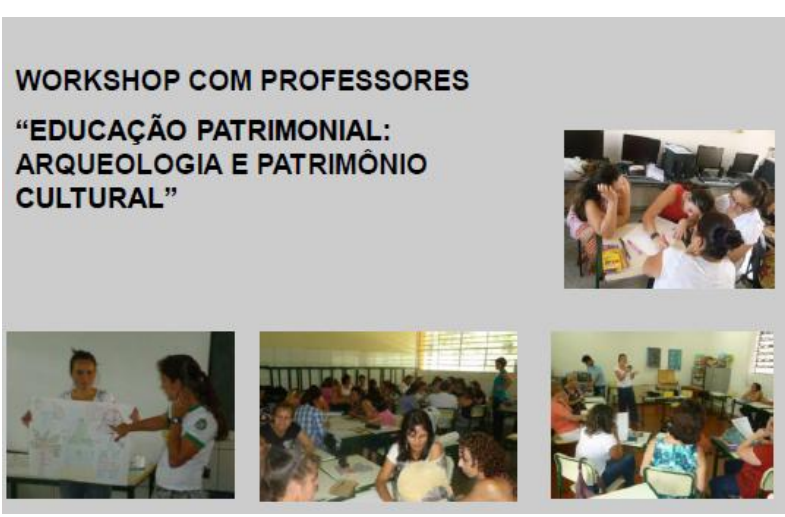

Assim, o objetivo é servir como uma estímulo para o professor e alunos (comunidade local) no sentido de envolver-se na identificação, valorização e gestão do seu próprio patrimônio cultural.
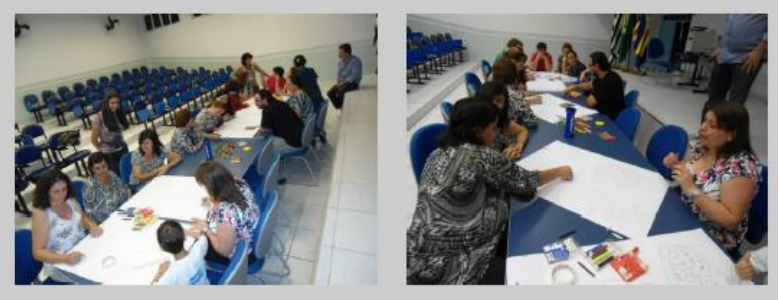

\section{OBJETIVOS:}

O workshop tem por objetivo inserir a questão da Educação Patrimonial no âmbito das preocupações do professor em sua atuação profissional.

Também objetiva difundir a inserção do patrimônio cultural como uma ferramenta que pode colaborar nos processos educativos, auxiliando no despertar do aluno para o interesse em conhecer o seu passado, estabelecendo relações com o presente e com o seu ser e estar no mundo.

\section{METODOLOGIA: \\ - Construção compartilhada e potencializadora de conhecimentos; \\ - Foco no professor pesquisador e propositor de ações no ambiente escolar local; \\ -Busca de soluções contextualizadas para projetos educativos locais.}

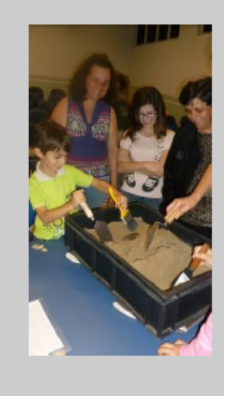

Figuras 44 a 47. Aspectos dos slides utilizados nas reuniões com os gestores escolares sobre a proposta de desenvolvimento de workshops com professores. Fonte: A LASCA, 2013.

Os Workshops desenvolvidos denunciaram que, embora esteja previsto na Lei de Diretrizes e Bases da Educação (LDB) e nos Parâmetros Curriculares Nacionais (PCN) o trabalho com conteúdos sobre cultura regional e diversidade cultural, é importante a manutenção e/ou a intensificação e o incremento das atividades de formação em Educação Patrimonial (ou Educação para o Patrimônio e/ou Educação Museal) de educadores em cursos de Licenciatura de universidades e faculdades em geral, de iniciativas de órgãos de supervisão e gestão educacional (Diretorias e Supervisões de Ensino, entre outros) e de museus e outras instituições culturais, nas suas atividades de extensão, voltadas para a comunidade em geral e de Ação Educativa para o público escolar.

Por outro lado, tanto nas entrevistas, como "pontos históricos, lugares que consideram importantes para a história e cultura da cidade e de Santo Amaro" quanto nos workshops, com os exercícios propostos pelas Oficinas de Educação Patrimonial (HORTA, el. al., 1999), foi constante a referência aos bens culturais materiais tombados, tais como: Praça Floriano Peixoto, Casa de Cultura de Santo Amaro, Biblioteca Prestes Maia, Casa Amarela, Igreja Matriz e Teatro Paulo Eiró. As tradicionais apresentações da Orquestra Filarmônica de Santo Amaro no coreto da Praça Floriano Peixoto e do Samba da Vela, na Casa de Cultura de Santo 
Amaro, foram os bens culturais imateriais citados nas entrevistas, também como de importância na região.

Outra professora disse: - Eu não vivi em Santo Amaro, mas minha mãe sim e ela contava que aqui só tinha sítio e que fazia muito frio. Ela morreu com 88 anos há cinco anos! Também foi feita menção a um MATADOURO... - Havia LITUANOS, RUSSOS E ALEMÃES em Santo Amaro, que depois foram abandonando a região disse. (Trecho extraído do Caderno de Anotações da pesquisadora. Os destaques são da pesquisadora)

\subsubsection{Os Workshops Educação Patrimonial: Arqueologia e Patrimônio Cultural}

Os workshops, intitulados Educação Patrimonial: Arqueologia e Patrimônio Cultural, foram desenvolvidos com os professores nos horários reservados aos encontros pedagógicos semanais das escolas e, assim, ocuparam mais de um HTPC (horário de trabalho pedagógico complementar) de uma hora e meia.

Trabalharam as temáticas da Arqueologia, Patrimônio Cultural e Educação Patrimonial, promovendo a comunicação sobre o estado da arte das pesquisas arqueológicas na região e no contexto dos estudos do Programa de Arqueologia Preventiva da Linha 5 do Metrô em Santo Amaro. Destacaram os mencionados achados arqueológicos evidenciados em São Paulo e no entorno do empreendimento. E trataram também do patrimônio local e do tema da construção de projetos e atividades educativas a partir dele.
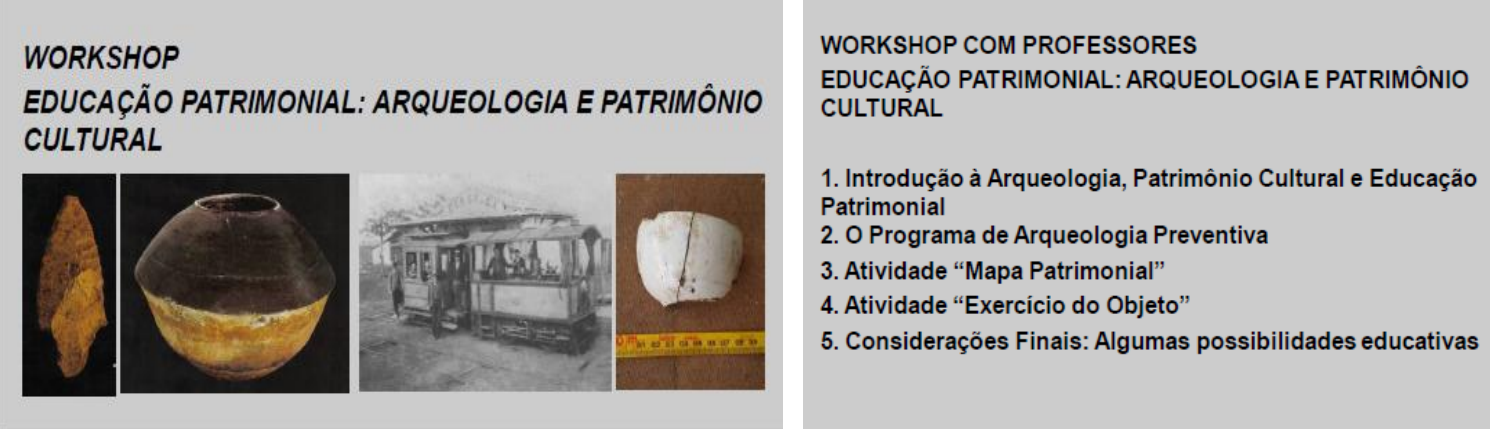

Figuras 48 e 49. Aspectos dos slides de abertura dos Workshop Educação Patrimonial: Arqueologia $e$ Patrimônio Cultural. Fonte: A LASCA, 2013.

Nos Workshops, slides apresentaram a conceituação de Arqueologia, Patrimônio Cultural e Arqueológico e de Educação Patrimonial. Mostraram alguns dos principais instrumentos legais de salvaguarda do patrimônio arqueológico e cultural brasileiro e aspectos 
de sua diversidade, como também fizeram destaque a alguns dos resultados das pesquisas arqueológicas na região do empreendimento do Metrô em Santo Amaro.

Através do patrimônio arqueológico podemos conhecer como populações que viveram antes de nós ocuparam os mesmos territórios onde, de outra maneira, vivemos hoje, buscando recursos para a sua sobrevivência e se relacionando com o meio ambiente.
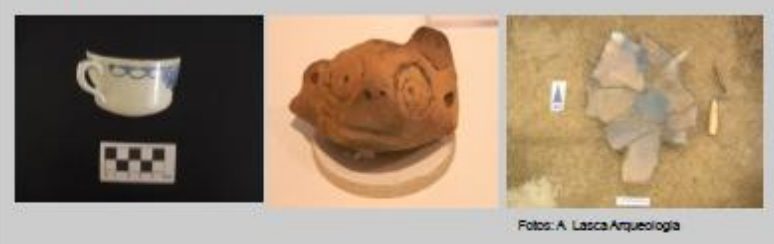

A Arqueologia estuda as paisagens naturais, transformadas e apropriadas pelas sociedades humanas.

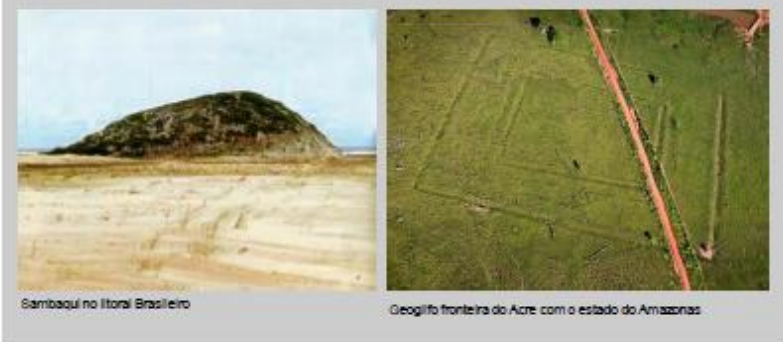

A Constituição Brasileira de 1988, em seu Art. 225, Parágrafo IV, fortaleceu os instrumentos legais de Proteção ao Patrimônio Arqueológico, ao considerar os sítios arqueológicos como patrimônio cultural brasileiro, garantindo sua guarda e proteção.
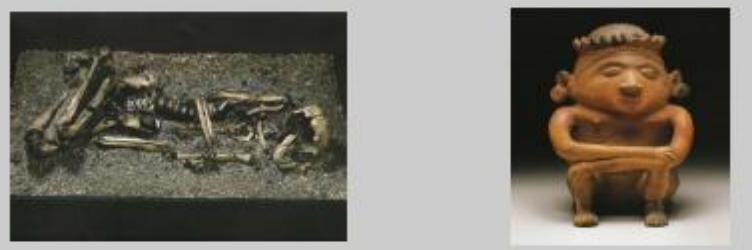

1 - Caminhada pela região para a localização de vestígios arqueológicos que aflorem na superficie do solo (devido à ação de arados, plantios etc.).

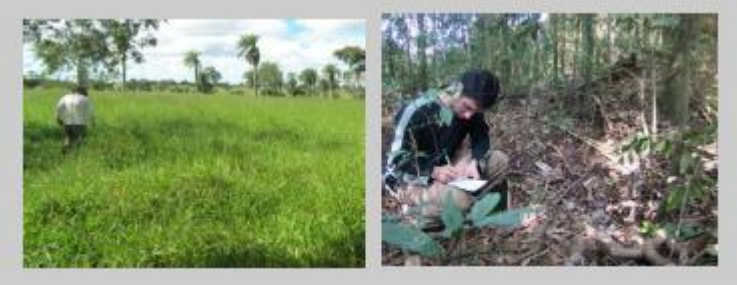

Arqueologia é uma área do conhecimento que estuda as sociedades do passado através dos vestígios por elas deixados, e que se apresentam no presente de diferentes formas no registro arqueológico. Ela busca compreender os seus modos de vida e seus costumes.
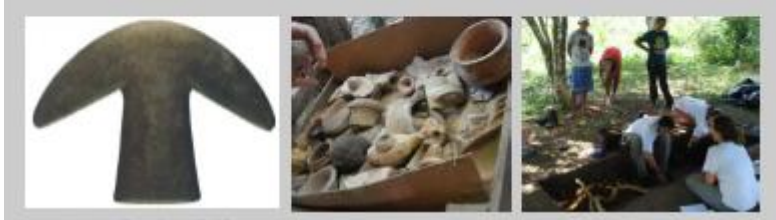

Na década de 1980 a Política Nacional do Meio Ambiente passou a exigir o licenciamento ambiental junto a empreendimentos que geram impactos ao meio ambiente.

A Resolução CONAMA n 1, de 1986, destaca que os sítios e monumentos arqueológicos são elementos a serem considerados nas diferentes fases de planejamento e implantação de um empreendimento.
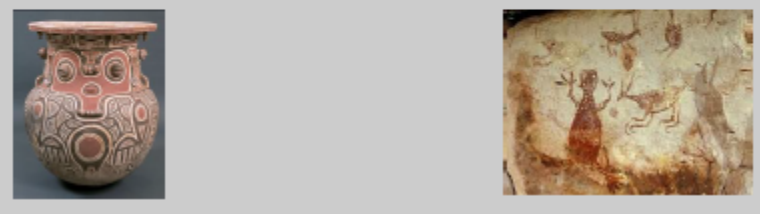

A Portaria IPHAN $n^{\circ} 230$, de 2002, normatizou os estudos e resgates arqueológicos relacionados aos Estudos de Impacto e de Licenciamento Ambiental, que passariam a ter diferentes fases e ações, como o levantamento e o resgate arqueológico, assim como as ações de educação patrimonial.
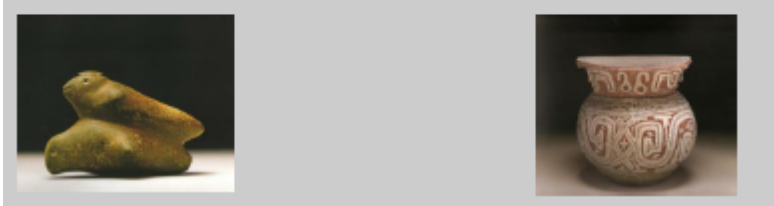

2 - Realização de sondagens com cavadeira biarticulada e delimitação de sítios arqueológicos.
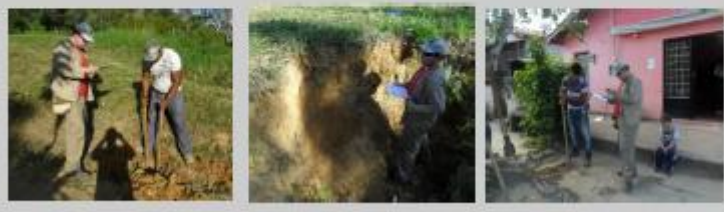

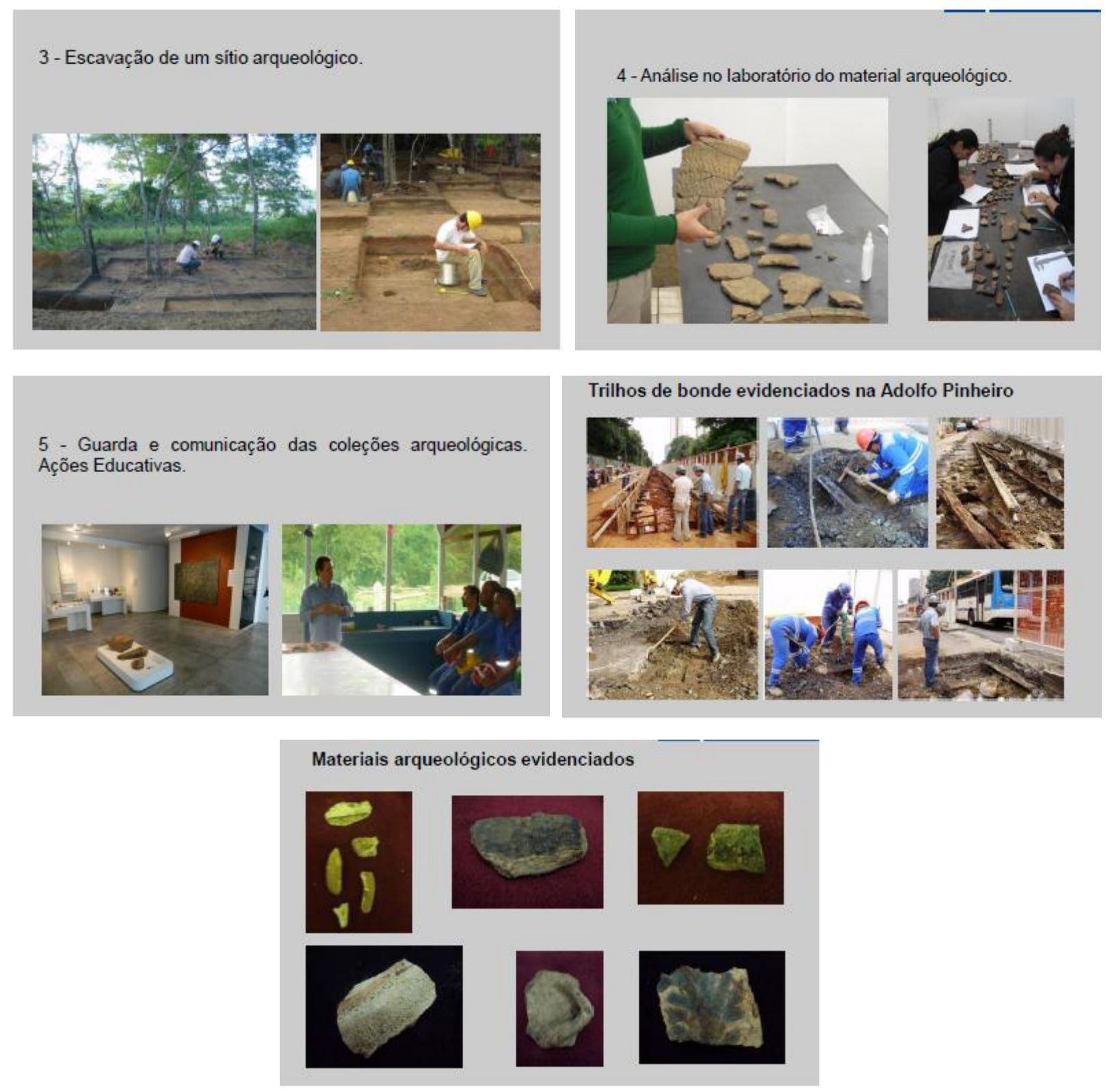

Figuras 50 a 62. Alguns dos slides utilizados nas atividades. Fonte: A LASCA, 2013.

Os workshops trabalharam com o conceito de patrimônio cultural, abrangente de outras formas de expressão cultural que constituem "o patrimônio vivo da sociedade brasileira": "artesanatos, maneiras de pescar, caçar, plantar, cultivar e colher, de utilizar plantas como alimentos e remédios, de construir moradias, a culinária, as danças e músicas, os modos de vestir e falar, os rituais e festas religiosas e populares, as relações sociais e familiares (...)" (HORTA et. al., 1999, p.7).

É preciso resgatar a história do bairro, através as pessoas e do que sobrou (monumentos, ruas, construções etc). (Trecho extraído de comentário de professor no Questionário de Avaliação do Workshop) 
A preocupação com a preservação e a valorização das expressões da chamada cultura tradicional e popular (ou bens culturais imaterial ou intangíveis), que surgiu logo após ser firmada por diversos países a Convenção da Unesco sobre a Salvaguarda do Patrimônio Mundial, Cultural e Natural, em 1972, foi abordada nos workshops.

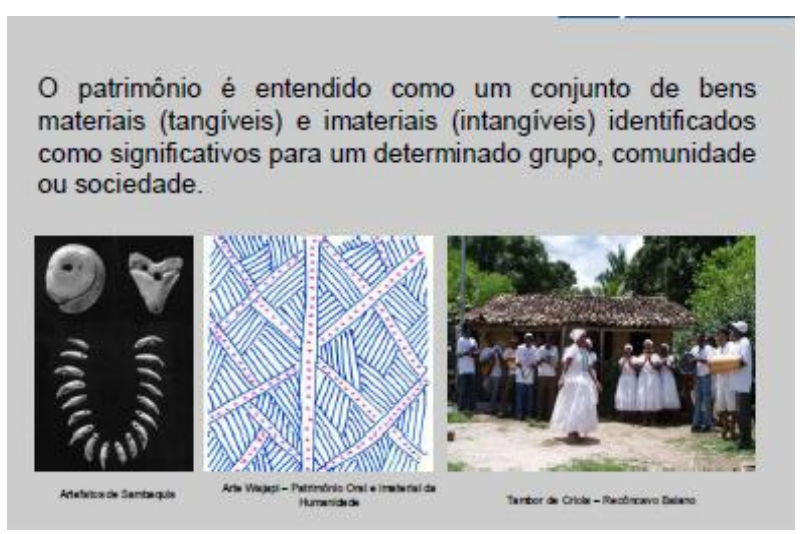

Figura 63. Aspecto de slide sobre patrimônio material e imaterial utilizado nas atividades com os professores e com participantes adultos das ações com o público em geral. Fonte: A LASCA, 2013.

O Programa Nacional do Patrimônio Imaterial, instituído no país a partir de 2000, no contexto das comemorações dos $500 \operatorname{anos}^{121}$, impulsionou a realização de mapeamentos, inventários, ações de salvaguarda e editais públicos para a realização de projetos de pesquisa, documentação, capacitação de agentes e promoção de bens culturais imateriais (IPHAN, 2009).

Por meio do Registro de Bens de Natureza Imaterial, os saberes, formas de expressão, celebrações, dentre outras práticas culturais passaram a ser reconhecidos como Patrimônio Cultural do Brasil, assim como prédios, monumentos e cidades históricas.

Entretanto, apesar de estar vinculado a uma cultura material, trata-se de um conjunto de bens culturais que não tem sido reconhecido oficialmente como patrimônio nacional (IPHAN, 2012).

A inscrição de bens de natureza imaterial nos Livros de Registro do IPHAN (de Saberes, Celebrações, Formas de Expressão e de Lugares), além de possibilitar que esses bens recebam o título de Patrimônio Cultural do Brasil, garante, por parte do poder público (nas esferas federal, estadual e municipal), a obrigação de sua documentação e divulgação ampla,

\footnotetext{
${ }^{121}$ Em 2001, o Centro Nacional de Cultura Popular, vinculado ao Departamento do Patrimônio Imaterial do IPHAN desenvolveu o projeto Celebrações e Saberes da Cultura Popular. A partir dele, foi produzido o inventário de identificação dos feijões e das mandiocas e feito o registro do Ofício das Baianas de Acarajé. Outro registro resultante do inventário de instrumentos de corda e percussão desse projeto foi o da Viola de Cocho (IPHAN, 2009).
} 
de forma a sociedade ter acesso a informações sobre sua origem, trajetória e transformações, seus produtores e modos de produção (IPHAN, 2009). ${ }^{122}$

O Registro corresponde à identificação e produção de conhecimento sobre o bem cultural e seu objetivo é "manter o registro da memória desses bens culturais, pois é a única maneira possível de preservá-los”. É um "instrumento de reconhecimento e valorização do patrimônio imaterial" (IPHAN, 2012b, p. 10).

Os workshops foram compostos pelas Oficinas de Educação Patrimonial: Mapa Patrimonial e o Exercício do Objeto, as quais procuraram, assim como as ações desenvolvidas com o público em geral na Biblioteca Belmonte e na Praça Floriano Peixoto, em parceria com a Subprefeitura de Santo Amaro, que se caracterizaram por atividades de Arte-Educação, favorecer aos participantes a construção coletiva de conhecimento relacionada ao reconhecimento de suas referências culturais inseridas em contextos de significados associados à memória social de Santo Amaro, de forma que essas referências fossem percebidas nas práticas cotidianas, colaborando para a participação social em todas as etapas da preservação desses bens:

[...] Em lugar de preservar lugares, edificações e objetos pelo seu valor em si mesmo, em um processo de reificação, as políticas públicas na área deveriam associar continuamente os bens culturais e a vida cotidiana, como criação de símbolos e circulação de significados... Qualquer que seja a ação implementada ou o projeto proposto, sua execução supõe o empenho em identificar e favorecer os vínculos das comunidades com seu Patrimônio Cultural, incentivando a participação social em todas as etapas da preservação dos bens (IPHAN, 2014, p.21).

\footnotetext{
122 Conceitualmente, enfatiza-se com a expressão patrimônio imaterial ou intangível “o conhecimento, o processo de criação e o modelo do que o resultado, embora esse seja sua expressão indubitavelmente material" (IPHAN, 2012, p.7). Essa característica tem importância na medida em que se refere ao resultado da manifestação e suas condições materiais de existência. Os bens imateriais são “oriundos de processos culturais e de relacionamento de sociabilidade de formas de sobrevivência de apropriação de recursos naturais e de relacionamento com o meio ambiente, essas manifestações possuem uma dinâmica específica de transmissão, atualização e transformação que não pode ser submetida às formas usuais de proteção do patrimônio cultural. O patrimônio imaterial não requer 'proteção' e 'conservação' - no mesmo sentido das noções fundadoras da prática de preservação de bens culturais imóveis e móveis - mas identificação, reconhecimento, registro etnográfico, acompanhamento periódico, divulgação e apoio. Enfim, mais documentação e acompanhamento e menos intervenção" (IPHAN, 2012, pp. 10 e 11).
} 
Quadro 3. Plano educativo do Workshop com Professores Educação Patrimonial: Arqueologia e Patrimônio Cultural. Fonte: A LASCA, 2013.

Workshop com professores Educação Patrimonial: Arqueologia e Patrimônio Cultural

\section{Programação:}

1. Abertura (duração prevista: 05 minutos);

2. Comunicação Introdução à Arqueologia, Patrimônio e Educação Patrimonial (duração prevista: 30 minutos)

3. Atividade Estudo do Objeto (duração prevista de 15 minutos);

4. Atividade Diagnóstica Mapa Patrimonial (duração prevista: 30 minutos);

5. Encerramento com um balanço das atividades (duração prevista: 10 minutos).

\section{Conteúdos:}

Comunicação

Conceituação de Arqueologia Preventiva e de Educação Patrimonial;

Os conceitos de Cultura e de Patrimônio;

Os Bens Tangíveis e Intangíveis:

O Patrimônio Arqueológico;

Diálogos com o Patrimônio Natural;

Vestígios Arqueológicos;

Arquitetura e Paisagem;

Arqueologia Histórica e Pré-Histórica;

Legislação que trata da Arqueologia;

Etapas do Trabalho Arqueológico;

Diferentes Tipos de Sítios;

Diversidade e Riqueza do Patrimônio Arqueológico;

\section{Atividade Diagnóstica Mapa Patrimonial}

Sinopse: Será proposto aos participantes que construam um Mapa Patrimonial, com o objetivo de identificar o olhar patrimonial sobre a região. O Mapa Patrimonial é uma adaptação do Mapa Falado que, por sua vez, é uma ferramenta de uso potencial para a realização de um diagnóstico participativo sobre temas socioambientais e sobre o olhar e a percepção que se tem sobre o meio. O seu desenvolvimento no contexto do Workshop fará a identificação do que os participantes consideram patrimônio e sobre a compreensão que têm sobre o conceito. Também funcionará como uma espécie de atividade de apresentação da região do ponto de vista de seu patrimônio cultural.

\section{Atividade Estudo do Objeto}

Sinopse: A atividade Exercício do Objeto objetivará apresentar aos educadores o uso do objeto como material didático com grande potencial para a discussão de temas relacionados à cultura, patrimônio cultural, identidade, pertencimento entre outros, a partir da formulação de perguntas sobre suas características físicas, usos e atribuição de valores.

Recursos (instalações, equipamentos e materiais):

Sala;

Datashow com áudio;

Notebook;

Extensão elétrica;

Lista de presença;

Ficha de avaliação;

Kit com Objetos arqueológicos;

Câmera fotográfica

Folhas de papel branco, tamanho A4;

Canetas;

Folhas de cartolina na cor branca;

Equipamento de Arqueologia (trena, pontalete, barbante, gps, bússola, nível, colheres diversas, pincéis, pinças e outros);

Lápis de cor, giz de cera e canetas hidrográficas. 
Na atividade Mapa Patrimonial, foi proposta aos professores a construção de uma espécie de mapa (desenho), no qual incluiriam a representação de bens que julgavam significativos na região: bens naturais (da paisagem natural), materiais (edificações) e imateriais.

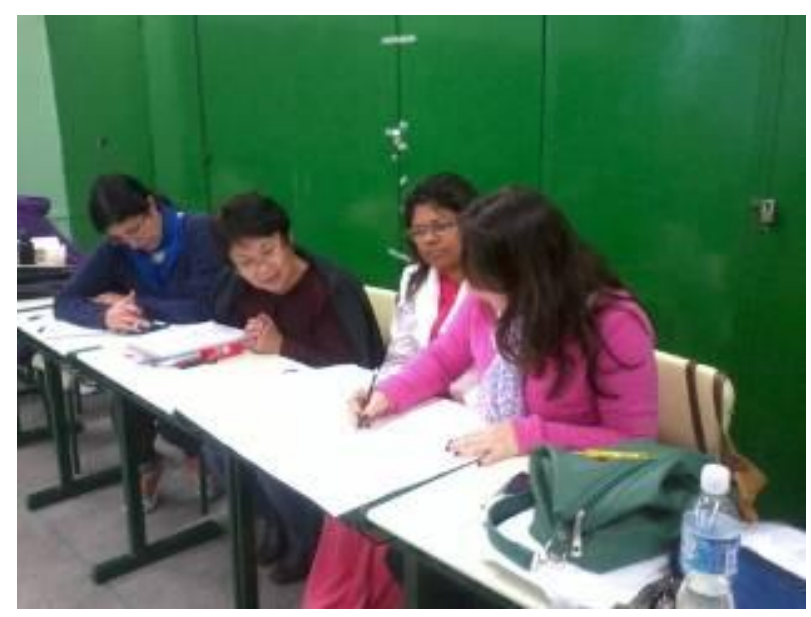

Figura 64. Professores reunidos em grupo no exercício Mapa Patrimonial. Fonte: A LASCA, 2013.

(...) Adoramos mapear a região e discutir a área do entorno da UE (unidade escolar). (Trecho de comentário de professor participante no Questionário de Avaliação do workshop).

Como mencionado, a atividade almejou e permitiu a identificação do olhar patrimonial dos professores, ou seja, o que compreendiam por patrimônio, se o conceito conhecido incluía bens imateriais ou se limitava aqueles bens oficialmente tombados na região; se apresentavam os elementos da paisagem natural como bens patrimoniais e se faziam alguma distinção desses em relação aos outros bens locais.

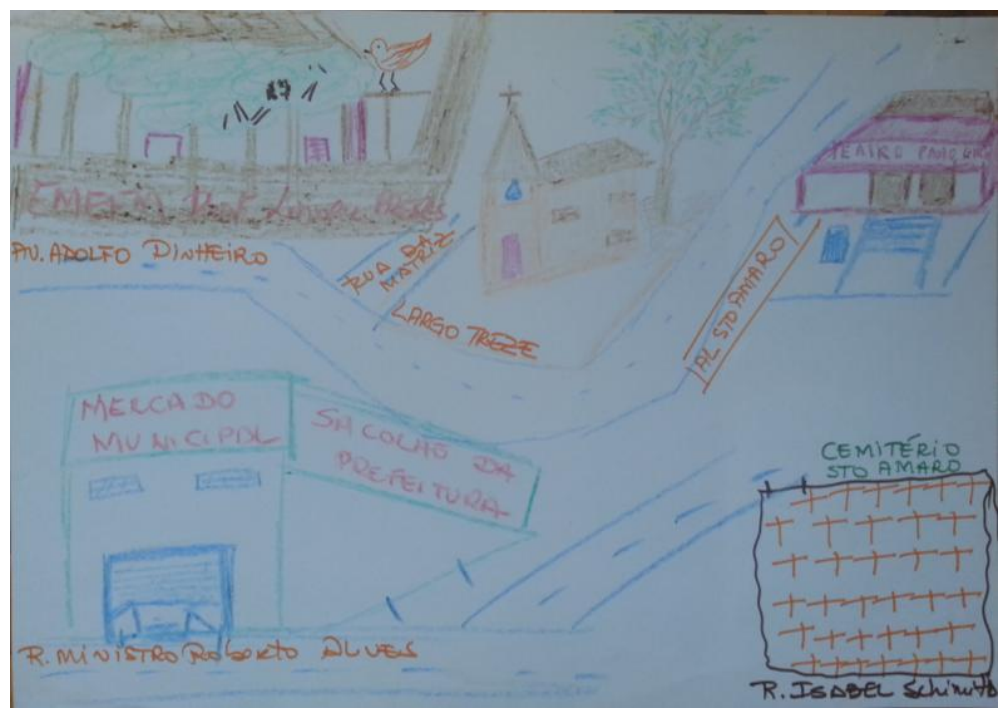




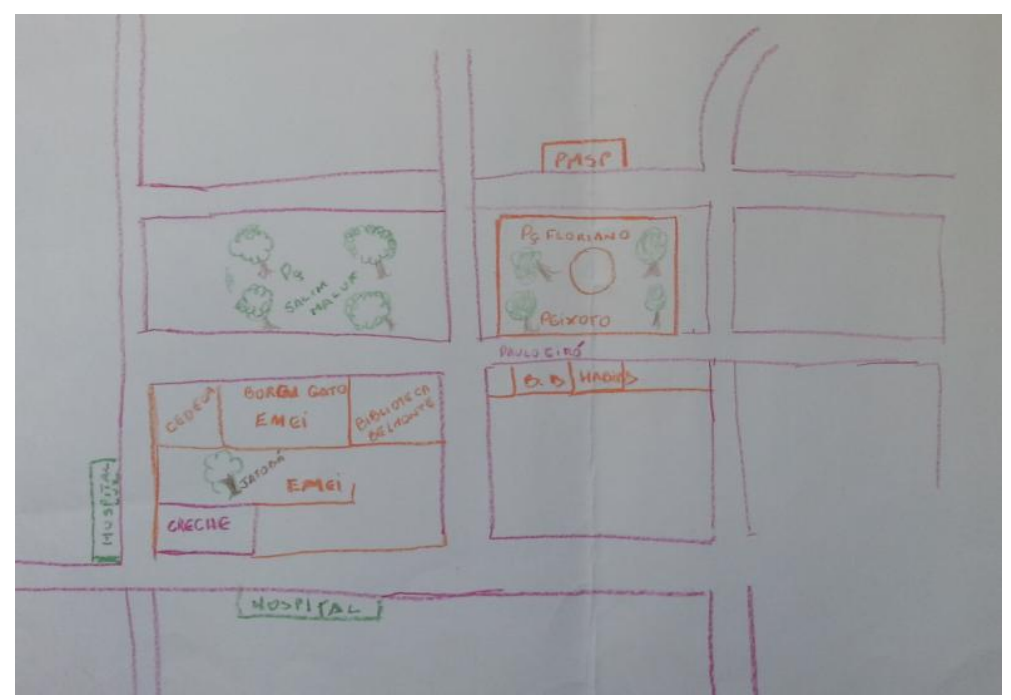

Figuras 65 e 66. Dois desenhos ("mapas") com os lugares significativos de Santo Amaro representados pelos professores participantes da atividade Mapa Patrimonial. Fonte: A LASCA, 2013.

$\mathrm{Na}$ apresentação pelos professores dos seus "mapas", além dos edifícios do Eixo Histórico de Santo Amaro oficialmente tombados, foram narradas histórias da região, que revelaram em certos aspectos bens imateriais valorados pela comunidade, porém não reconhecidos e nem registrados. Alguns professores (e não poucos) demonstraram não conhecer a história de Santo Amaro.

A ESCOLA CONTE foi identificada como sendo foco de resistência à Ditadura
Militar, havia o movimento estudantil e os militares invadiam a escola e tiravam os
alunos da sala de aula! Com o tempo, os estudantes foram ficando com medo e
poucos passaram a fazer parte do grêmio - disse outro professor participante. Alguns
completaram o que outros docentes disseram: - A gente lembra do barulho das botas
dos soldados no corredor, fazíamos um silêncio sepulcral enquanto invadiam a
escola, dava muito medo. A escola teve alguns alunos ilustres como: Michaelis e
Regina Fraga. (Trecho extraído do Caderno de Anotações da pesquisadora. Os
destaques são da pesquisadora).

Adoro conhecer sobre a história do bairro de Santo Amaro. Foi muito produtivo e relevante (...) (Trecho de comentário de professor participante no Questionário de Avaliação do workshop).

Foram citados e representados como bens "históricos" e ou de relevância para a região de Santo Amaro nos workshops que contaram com 67 professores participantes: a Biblioteca Belmonte (Infantil), Clube Jeorg Bruder, a Biblioteca Prestes Maia, a Casa de Cultura de Santo Amaro, a Casa Amarela, a Estátua do Borba Gato, Teatro Paulo Eiró (em reforma na ocasião), Cemitério de Santo Amaro, Igreja Matriz de Santo Amaro (também em reforma). O Eixo Histórico tombado e os bondes também foram mencionados.

[...] uma das professoras, moradora há 52 anos no bairro de Santo Amaro, contou que seu pai fazia compras na atual CASA DA CULTURA, que antes era um mercado e ainda completou:" - Meu pai diz que se fazia o FOOTING em volta do CORETO NA PRAÇA FLORIANO PEIXOTO, também ele lembra que onde hoje é a Kalunga, era o LARGO SÃO SEBASTIÃO. Meus pais eram de Bragança Paulista 
e quando vieram para São Paulo, instalaram-se em Santo Amaro de onde nunca saíram! Nasci na R. Bragança Paulista e depois mudei para a R. João de Godoy de onde nunca mais saí.

Também foi feita menção à CAVALARIA que passa no LARGO TREZE, em ROMARIA no dia do ANIVERSÁRIO DE SANTO AMARO.

O primeiro a relatar suas memórias foi o professor de história: - Eu morava na periferia e vinha de ônibus estudar em Santo Amaro, o ponto final era ao lado da CATEDRAL DE SANTO AMARO. Era chic estudar aqui. A escola Conte era de elite e eu estudava na Linneu Prestes, vim estudar aqui em 1969 e havia uma rixa entre os alunos das duas escolas, inclusive com brigas! O CLUBE JEORG BRUDER (MUNICIPAL) cedia a quadra pra gente fazer educação física porque [a escola] não tinha espaço.

Havia uma professora em especial, que cuidava da biblioteca da escola, que comentou que foi uma das últimas passageiras do "BONDE" que cortava a região de Santo Amaro, em meados dos anos 1960; mencionou também o COMÉRCIO POPULAR da "PRAÇA FLORIANO PEIXOTO", que acontece até hoje, que tem CORETO e onde se realizava O FOOTING (PASSEIO E PAQUERA QUE ACONTECIA NA PRAÇA).

(Trechos extraídos do Caderno de Anotações da pesquisadora. Os destaques são da pesquisadora).

A atividade objetivou também a realização de uma reflexão sobre se a questão patrimonial estava presente no rol de preocupações da Educação Formal e/ou na grade curricular de alguma disciplina e como poderia ou deveria ser trabalhada.

A construção de um mapa patrimonial, incluindo os bens arqueológicos, da paisagem natural e os patrimônios material e imaterial da região constituiu o objetivo geral do Workshop. Foi acompanhado das atividades práticas [...] $\mathrm{O}$ Workshop foi finalizado pela atividade de construção, elaboração e discussão sobre as atividades e exercícios para o trabalho educativo com bens patrimoniais e culturais com alunos, a partir dos materiais arqueológicos apresentados.

Você considera que o Workshop contribuiu de alguma maneira para uma reflexão sobre o trabalho com a questão do patrimônio cultural e arqueológico da região? Faça um comentário ou uma observação a respeito e/ou avalie a(s) atividade(s) realizada(s), apontando o que mais gostou e/ou o que gostaria que fosse também trabalhado. (Conteúdo do Questionário de Avaliação de Atividades).

Nesse sentido, no Exercício do Objeto - outra atividade desenvolvida nos workshops os professores conheceram e experenciaram a utilização da Tabela Prática de Educação Patrimonial - proposta metodológica que envolve as etapas de observação, registro, exploração e apropriação, aplicada a qualquer bem cultural apresentada no Guia de Educação Patrimonial de autoria de HORTA (et. al., 1999) - para a observação e descrição de objetos e artefatos culturais. Nele, a discussão sobre a Educação Patrimonial na Educação Formal e seu tratamento transversal pelos temas do meio ambiente e diversidade cultural dos PCN's pode ser realizada. 


\begin{tabular}{|c|c|c|c|}
\hline $\begin{array}{l}\text { Aspectos } \\
\text { principais a } \\
\text { observar }\end{array}$ & Outras perguntas & $\begin{array}{c}\text { Aspectos } \\
\text { descobertos pela } \\
\text { observação }\end{array}$ & $\begin{array}{l}\text { Aspectos a } \\
\text { pesquisar }\end{array}$ \\
\hline $\begin{array}{l}\text { Aspectos fisicos } \\
\text { O que parece ser } \\
\text { este objeto? }\end{array}$ & $\begin{array}{l}\text {-Que cor tem? } \\
\text {-Que cheiro tem? } \\
\text {-Que barulho faz? } \\
\text {-De que material é feito? } \\
\text {-O material é natural ou } \\
\text { manufaturado? } \\
\text {-O objeto está completo, } \\
\text { inteiro? } \\
\text {-Foi alterado, adaptado ou } \\
\text { consertado? } \\
\text {-Está usado? }\end{array}$ & & \\
\hline $\begin{array}{l}\text { Construção } \\
\text { Como foi feito? }\end{array}$ & \begin{tabular}{|l|}
-Onde foi feito? \\
-Foi feito manualmente ou a \\
partir de uma máquina? \\
-Foi feito em uma peça única, \\
ou em partes separadas? \\
-Com uso de molde ou \\
modelado a mão?
\end{tabular} & & \\
\hline \begin{tabular}{|l|} 
Função \\
Para que foi feito?
\end{tabular} & $\begin{array}{l}\text {-Quem o fez? } \\
\text {-Para que finalidade? } \\
\text {-O uso inicial foi modificado? }\end{array}$ & & \\
\hline \begin{tabular}{l|} 
Forma (Design) \\
O objeto tem uma \\
boa forma? É bem \\
desenhado?
\end{tabular} & $\begin{array}{l}\text {-De que maneira a forma } \\
\text { indica a função? } \\
\text {-Ele é bem adequado para o } \\
\text { uso pretendido? } \\
\text {-É decorado? Como é a } \\
\text { decoração? } \\
\text {-O que a decoração indica? }\end{array}$ & & \\
\hline $\begin{array}{l}\text { Valor } \\
\text { Quanto vale este } \\
\text { objeto? }\end{array}$ & $\begin{array}{l}\text {-Para as pessoas que } \circ \\
\text { fabricaram? } \\
\text {-Para as pessoas que o usam? } \\
\text { (ou usaram?) } \\
\text {-Para as pessoas que o } \\
\text { guardaram? } \\
\text {-Para você? } \\
\text {-Para um museu? }\end{array}$ & & \\
\hline
\end{tabular}

Figura 67. Tabela Prática de Educação Patrimonial (HORTA et. al., 1999).

$\mathrm{Na}$ atividade, a tabela foi aplicada aos objetos arqueológicos e etnológicos do material didático (Kit) produzido pela Seção Técnica de Educação para o Patrimônio do Museu de Arqueologia e Etnologia da USP (um dos museus da Universidade de São Paulo), apresentado ao professores; e teve início um intenso processo de observação dos artefatos do Kit, mediado por seu manuseio, no qual questões como matéria prima, forma, função, possível produtor e grupo social auxiliaram no processo investigativo.

Essas questões a partir do olhar, analisar e interpretar, apresentadas como exercício para a compreensão da materialidade do objeto, corresponderam à forma como o arqueólogo estabelece conexões com o meio sociocultural que produziu os artefatos estudados. E almejaram ampliar a visão sobre o potencial informativo do universo material produzido pela ação humana, inserindo dessa forma a discussão sobre a noção de cultura material. 
O objeto mais comum de uso doméstico ou cotidiano pode oferecer uma vasta gama de informações a respeito do seu contexto histórico-temporal, da sociedade que o criou, usou e transformou, dos gostos, valores e preferências de um grupo social, do seu nível tecnológico e artesanal, de seus hábitos, da complexa rede de relações sociais. A observação direta, a manipulação e o questionamento do objeto, feito com perguntas apropriadas, podem revelar estas informações em um primeiro nível de conhecimento, que deverá ser extrapolado por meio do estudo e da investigação de fontes complementares como livros, fotografias, documentos, arquivos cartoriais e eclesiásticos, pesquisas, entrevistas etc. (HORTA et.al., 1999, p.12)

O Museu tem no seu acervo mais de 190 mil objetos, dentre os quais, cerâmicas, armas, pinturas, adornos, utensílios domésticos, instrumentos musicais e de trabalho, relacionados à cultura da América, como também do Mediterrâneo, Médio Oriente e África. (MAE, 2000). No Kit trabalhado, havia essencialmente réplicas de peças arqueológicas e artefatos etnológicos de sociedades indígenas brasileiras.

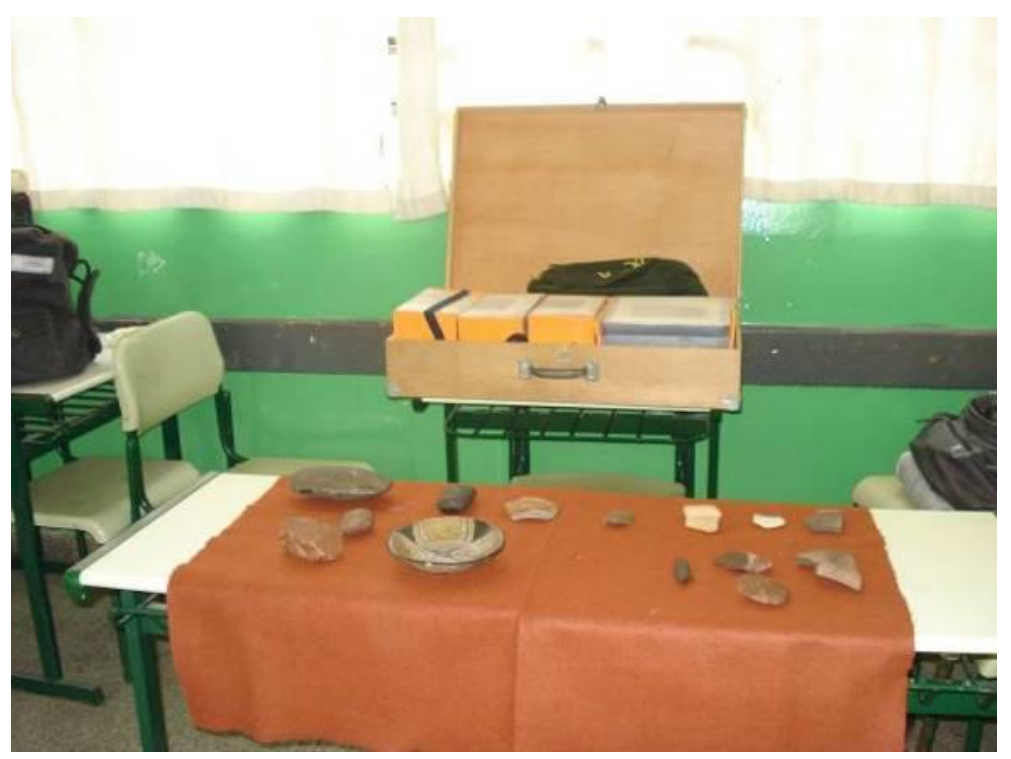

Figura 68. Material didático do MAE-USP apresentado e trabalhado pelos professores nas Oficinas de Educação Patrimonial, no Exercício do Objeto. Foto da autora.

Além das réplicas das peças arqueológicas e de objetos etnológicos originais, o material didático, chamado de Kit Educativo com Objetos Arqueológicos e Etnológicos, apresenta textos com as definições de Cultura, Arqueologia e Etnologia, que subsidiam o trabalho com essas e outras temáticas correlatas, e cartazes que detalham as técnicas de lascamento de artefato lítico e de acordelamento de potes cerâmicos. Emprestado ao professor, o Kit é utilizado pelo Museu nas atividades voltadas aos educadores de preparação da visita de alunos às suas exposições.

Este recurso pedagógico propõe desafios que envolvem o olhar, o observar, o manusear, o sentir, o relacionar, o questionar, o investigar e o comparar, além de 
desenvolver atitudes que permitem a cada um perceber-se sujeito na produção cultural que nos cerca. ${ }^{123}$

O exercício permitiu discutir as várias camadas de leitura possíveis a partir dos objetos e sua relação com (ou representação de) aspectos diversos da vida humana, que, inclusive, ultrapassam os limites de cada disciplina: o potencial de cada objeto como fonte de informações sobre o momento histórico e outros aspectos da sociedade que o produziu.

Ainda para possibilitar uma reflexão sobre as potencialidades educativas do patrimônio cultural de modo geral, os workshops propuseram aos professores participantes a concepção em conjunto de projetos relacionados aos bens culturais de Santo Amaro. Disso resultou de imediato o desenvolvimento de Oficinas de Educação Patrimonial com alunos, especialmente aqueles que cursavam o sexto ano do Ensino Fundamental II e que estavam estudando o tema da Arqueologia na disciplina de História. Os professores participantes da Educação Infantil da EMEI Borba Gato e do Ensino Fundamental I da EE Paulo Eiró também manifestaram interesse em envolver os seus alunos em bate papos, rodas de conversa e nas oficinas de Educação Patrimonial que trabalhariam o patrimônio arqueológico, inclusive com a ideia de participação de pais e familiares.

Na EMEI Borba Gato, durante a atividade houve a discussão sobre maneiras de aplicar os conteúdos para a faixa etária dos alunos, com as devidas adequações. Os professores apresentaram a sua perspectiva de inserção da questão da Arqueologia e da memória no cotidiano escolar. (Trecho extraído do Caderno de Anotações da Pesquisadora).

\subsubsection{Recursos e Materiais Educativos elaborados}

As oficinas de Educação Patrimonial com estudantes, concebidas em conjunto com os professores nos workshops, foram desenvolvidas de acordo com o contexto pedagógico revelado de ausência de abordagem do tema do patrimônio cultural e do arqueológico. Resultaram nas atividades: Conversando sobre o meu Patrimônio, constituídas por rodas de conversas, jogos e brincadeiras tradicionais, e a oficina Sítio Arqueológico Simulado (simulação de uma escavação arqueológica), para as quais foram elaborados recursos e materiais educativos:

(...) ações pontuais e esporádicas de promoção e divulgação se acotovelam com propostas educativas continuadas, inseridas na dinâmica social das localidades; projetos e encontros, materiais de apoio, cadernos temáticos e publicações resultantes definidas se misturam a práticas significativas em que esses materiais

\footnotetext{
${ }^{123}$ Disponível em: http://www.intranet.mae.usp.br/modules/educativo/content.php?id=37 > Acesso em: 29 fev 2016.
} 
não constituem um fim em si mesmo; ao contrário, compõem partes de processos educativos (IPHAN, 2014).

O patrimônio arqueológico e histórico-cultural de uma região, entendido como “(...) os aspectos físicos, naturais e artificiais, associados às atividades humanas, incluindo sítios, estruturas e objetos possuindo significância, individualmente ou em grupo, em história, arquitetura, arqueologia ou desenvolvimento (cultural) humano" (FOWLER, 1982 apud CALDARELLI, 1999, p.347), é constituído pelos vestígios materiais remanescentes, representativos dos processos culturais que nela se sucederam em períodos pré-históricos e históricos, podendo apresentar, portanto, uma ampla abrangência temporal (A LASCA, 2009).

Durante as pesquisas arqueológicas do Programa de Arqueologia Preventiva da Linha 5 - Lilás do Metrô, foram encontrados: uma pederneira de arma de fogo, fuso de rede de pesca, fragmento de garrafa em grés, um frasco de medicamento de vidro com a inscrição PHENOMENAL, fragmentos de cerâmicas de cozinha (panelas) e de louça portuguesa, pequena malga de faiança fina e fornilho de cachimbo de barro (vestígios dos séculos XVIII e XIX); além de 600 metros de trilhos e dormentes da antiga linha de bonde, dos quais, como mencionado, 3 metros de vias estão expostos na Estação Adolfo Pinheiro.

Esse bem patrimonial da região foi apresentado e abordado tanto em imagens ampliadas e projetadas em slides, como também em pranchas, no formato A3 $(33$ x $48 \mathrm{~cm})$, em conjunto com fotografias históricas de Santo Amaro (dos bondes, da Igreja Matriz) e outras imagens de referência, tais como: desenhos de personagens de filmes, de animais préhistóricos, pinturas rupestres, cenas e objetos arqueológicos, ilustrações do livro de Hans Staden e desenho esquemático sobre as aldeias indígenas existentes no território de São Paulo na época colonial. ${ }^{124}$

\footnotetext{
${ }^{124}$ Respectivamente, duas imagens da publicação de Hans Staden Warhaftige be schreibung eyner landschafft der wilden nacketen grimmigen, de 1557. Fonte: Biblioteca Nacional; e desenho de Vallandro Keating, 2009. Extraído de Escavando o Passado: Arqueologia na cidade de São Paulo. Departamento do Patrimônio Histórico - DPH. Escavando o Passado: arqueologia na cidade de São Paulo. São Paulo: Centro de Arqueologia de São Paulo. Museu da Cidade de São Paulo. Departamento do Patrimônio Histórico - DPH. Secretaria Municipal de Cultura - PMSP. S.d.
} 
Quadro 4. As Pranchas Educativas e alguns dos temas e conteúdos trabalhados .

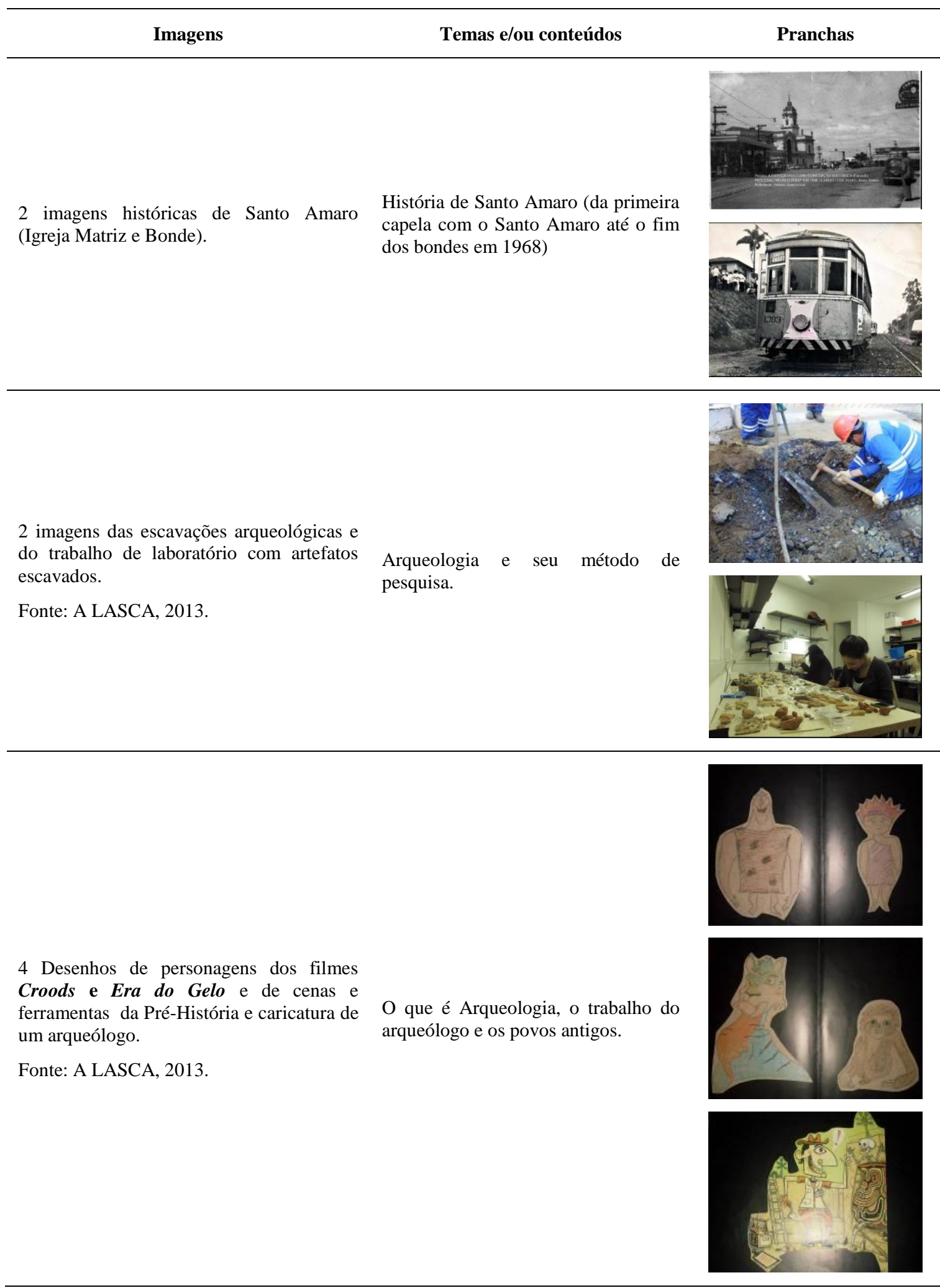




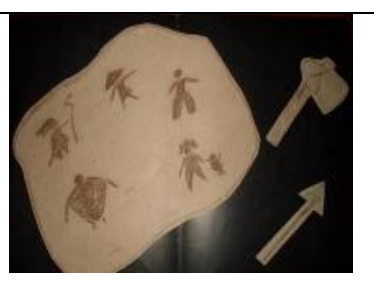

2 imagens de Pintura Rupestre e de pontas de flechas.

Povos pré-coloniais (pré-históricos):

Fonte: A LASCA, 2013. os caçadores-coletores.
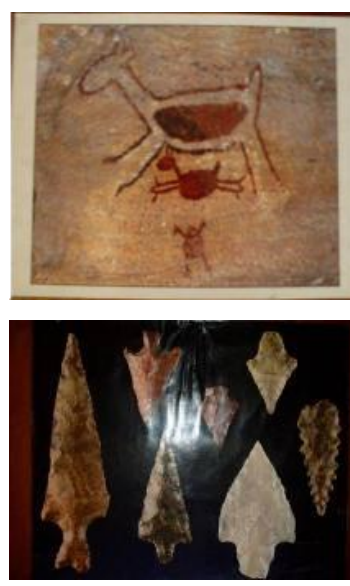

Povos Tupis habitantes do território ocupado por São Paulo e Santo 2 imagens da obra de Hans Staden caracterizando os grupos Tupinambás. Amaro e sua imagem difundida.

OBS.: prancha utilizada como exemplo similar aos Tupiniquins, antigos ocupantes da região.
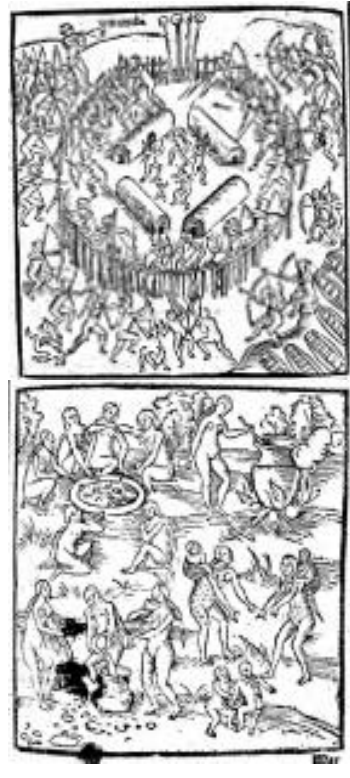

Características das produções dos povos que viviam no território 4 imagens de objetos cerâmicos. brasileiro.

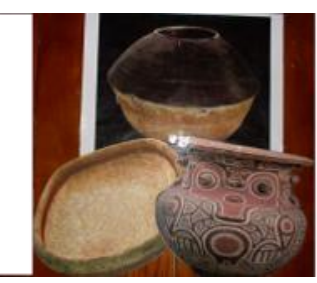
Acervo MAE-USP

A Pré-História brasileira

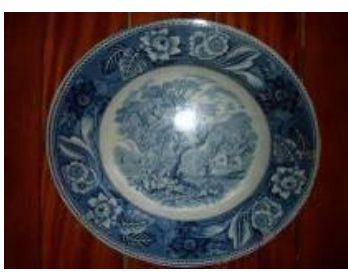


1 desenho retratando as principais aldeias existentes quando da chegada dos portugueses.

As aldeias de Piratininga, Ururaí (São

Miguel) e Geribatiba (Santo Amaro).

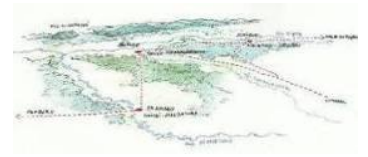

5 pranchas com imagens de fragmentos cerâmicos, fuso de rede e com outros vestígios encontrados na região de Santo Amaro.

Apresentação da riqueza cultural evidenciada em Santo Amaro pela Arqueologia.

Fonte: A LASCA, 2013

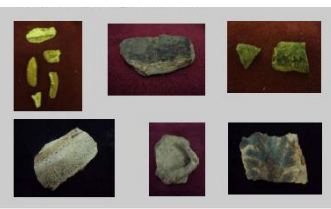

Essas Pranchas Educativas, ao lado dos referidos objetos arqueológicos do Kit educativo do MAE-USP, constituíram os materiais educativos das oficinas de Educação Patrimonial e de Arte Educação, que foram também utilizados nas atividades com o público em geral.

Circulando junto com cada objeto arqueológico do Kit educativo do MAE-USP nas rodas de conversas e bate papos desenvolvidos com alunos e público em geral, as Pranchas Educativas possibilitaram a realização de exercícios e processos de leitura de imagens e de artefatos culturais, nas oficinas de Educação Patrimonial e de Arte Educação, que foram integrados à atividade prática.

Ao serem observados e apreciados, os objetos instigam os nossos sentidos, trazendo a tona os nossos referenciais culturais e pessoais, propiciando investigações, discussões, análises e pesquisas sistemáticas. (MAE, 2000).

Esses materiais de apoio compartilharam da ideia de que a construção de uma experiência de leitura do patrimônio arqueológico, natural, paisagístico, arquitetônico e cultural e de imagens com seu contexto histórico, social e cultural de formação, possibilitada pela Educação Patrimonial e pela Arte Educação, poderia motivar alunos e demais participantes das ações a reconhecer o patrimônio cultural de que são herdeiros e colaborar para sua participação nas decisões relacionadas ao destino da região em que moram, almejando favorecer o empoderamento e fortalecimento de ações locais, considerando que os espaços da escola e de instituições e entidades locais podem ser fecundos para o exercício de construção da cidadania, desde que não ignorem "o conjunto complexo de valores, de representações, de conhecimentos vivos e circulantes no entorno" a favor de uma orientação fortemente conteudista, estruturada em saberes fragmentados, disciplinares e muitas vezes descontextualizados (FRANCO, 2010, p.105). 
O princípio da leitura crítica, presente na Educação para os patrimônios naturais e culturais (Educação Patrimonial), como interpretação cultural, muito influenciado por Paulo Freire, fundamenta também o ensino e aprendizagem da arte, hoje relacionada à formação cultural e à potencialização da leitura de processos de criação cultural, tecnológica, históricos e sociais implicados nas imagens (artísticas ou não). A imagem é um âmbito de realidade que torna fundamental e importante que se reflita sobre ela, que perceba seu sentido (BARBOSA, 1998).

\subsubsection{As atividades com estudantes e com o público em geral}

Concomitantes aos workshops desenvolvidos com professores em HTPC e de acordo com os projetos e interesses por eles expressos ${ }^{125}$, foram programadas e realizadas em conjunto as oficinas de Educação Patrimonial que fizeram parte das ações iniciais do projeto (de formatação e início do inventário de bens culturais), com os estudantes das escolas públicas: EMEFM Prof. Linneu Prestes, E.E Paulo Eiró e EMEI Borba Gato. E nos meses de agosto a outubro de 2013, os bate papos e oficinas de Arte Educação com pessoas da comunidade em geral na Biblioteca Belmonte e na Praça Floriano Peixoto, conforme desenho em conjunto. Também foram organizadas pela coordenação da Biblioteca Belmonte e pela Coordenadoria de Cultura de Santo Amaro da Subprefeitura de Santo Amaro, respectivamente, atividades com professores e alunos da EEPSG Maria Petronila e com crianças e jovens atendidos pela ONG CCA - Carmem Mendes Conceição da região.

As atividades com alunos Conversando sobre o meu patrimônio, foram desenvolvidas nos horários de aula com as turmas de $6^{\circ}$ anos da Educação Infantil da EMEI Borba Gato, $4^{\circ}$. e $5^{\circ}$. anos do Ensino Fundamental I da E.E Paulo Eiró e $6^{\circ}$ anos do Ensino Fundamental II da EMEFM Prof. Linneu Prestes.

Face aos objetivos de iniciativas e de planos de aula que começaram a ser concebidos nos workshops e que continuaram a ser elaborados pelos coordenadores pedagógicos e professores dessas escolas interessados em experienciar o trabalho com o patrimônio cultural, essas atividades tiveram a duração de uma a duas aulas de 50 minutos e foram caracterizadas por rodas de conversa, brincadeiras, jogos e uma oficina que simulou uma escavação arqueológica.

\footnotetext{
${ }^{125} \mathrm{~A}$ adesão ao projeto foi espontânea e, como foram realizados em HTPC, participaram dos workshops professores das diversas disciplinas e níveis de ensino reunidos semanalmente.
} 


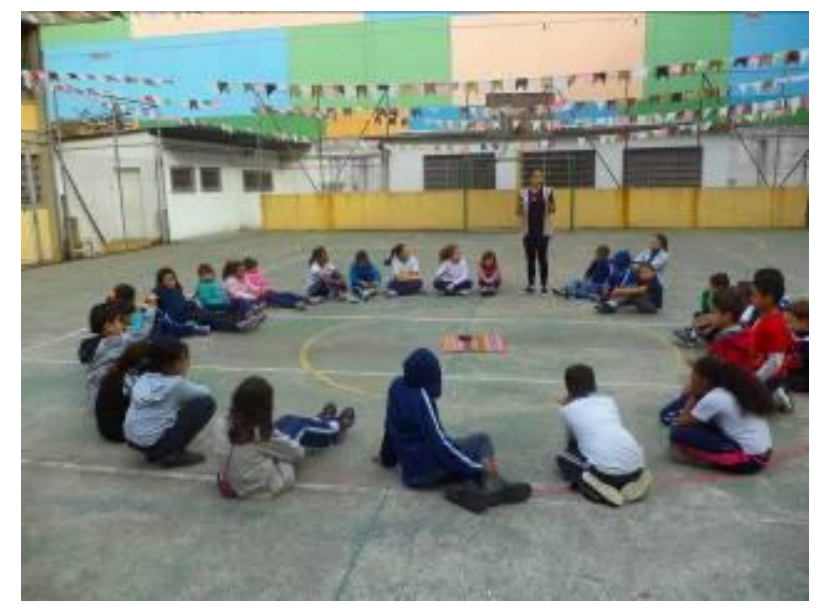

Figura 69. Roda de conversa sobre patrimônio, herança, Arqueologia; ao centro os objetos do Kit educativo do MAE-USP que junto às Pranchas Educativas passaram por um processo de leitura pelos alunos. Fonte: A LASCA, 2013.

\begin{abstract}
Nas rodas de conversa, com o auxílio de artefatos arqueológicos e das pranchas com imagens, era discutido o papel da Arqueologia e do arqueólogo, que, a partir dos vestígios materiais de povos do passado, tecem hipóteses sobre seus modos de vida, tecnologia, sua relação com o meio ambiente entre outras questões: como se alimentavam, se vestiam e se comportavam. A partir de perguntas sobre cada um dos objetos formuladas eram aventadas as ações, relações e cenas relativas aos seus produtores e criadores, como também às tecnologias de produção, bem como os recursos e matérias primais utilizadas na sua preparação. (Trecho extraído do Caderno de Anotações da pesquisadora).
\end{abstract}

Além de buscar estimular ações dos professores e das escolas para com o patrimônio local, procuraram abordar a relação dos alunos com a região, valorizando aspectos da identidade local e de sua paisagem cultural. E falaram sobre patrimônio cultural, a partir da Arqueologia e do patrimônio arqueológico, tratando da questão da ocupação pretérita do território hoje correspondente ao bairro de Santo Amaro por outros povos pré-coloniais.

Os objetos arqueológicos foram utilizados como fonte de informação (documento) para a compreensão dos diferentes aspectos do grupo cultural que os produziu ou utilizou. Na medida em que os alunos compartilhavam as informações, novas reflexões eram propostas no processo exploratório.

A atividade foi iniciada com as crianças sentadas em círculo para uma conversa e as Pranchas Educativas e a pedra de machado e os fragmentos de cerâmica arqueológica do ki educativo do MAE sendo distribuídos às crianças. A cada objeto que circulava na roda, os alunos eram incentivados a apresentar hipóteses sobre o seu uso e sobre o modo e os materiais utilizados na sua confecção, a partir da observação. Eram também incentivados a ler e fazer relações desses objetos com as pranchas com imagens de pontas de flechas e cerâmicas. (Trecho extraído do Caderno de Anotações da pesquisadora).

As turmas dos $6^{\circ}$. anos do EF II, que estavam estudando Pré-História e as Primeiras Civilizações na disciplina de História, criavam e contavam verdadeiras histórias sobre a vida do homem pré-histórico, descrevendo onde moravam e do que se alimentavam e com base nas pranchas com os personagens dos filmes (Croods e Era do Gelo) e os painéis, que mostravam a preparação de uma ferramenta de caça ou 
pesca e a produção de uma cerâmica colaboravam na leitura dos objetos arqueológicos apresentados. (Extraído do Registro da Atividade in: A LASCA, 2013)

Nas rodas de conversa, os objetos arqueológicos do Kit Educativo do MAE-USP trabalhados com os estudantes permitiram um exercício coletivo de investigação (de observação, análise, levantamento de hipóteses, troca de ideias, confrontação e incorporação de novas informações) sobre a forma, função e usos de cada um desses objetos e possíveis evidências de práticas cotidianas e rituais dos povos que lhes deram origem. E possibilitaram a introdução do conceito de patrimônio arqueológico e a migração deste para o de patrimônio cultural (bens materiais e imateriais), que, por sua vez, foi vinculado com histórias de família e memórias: como podemos conhecer o passado mais distante se não existem pessoas para contar?

As atividades iniciavam-se com a discussão sobre o significado da palavra patrimônio. Nesses diálogos, o conceito era construído coletivamente a partir da expressão herança, extrapolando a sua vinculação comum a algo monetário, incluindo a referência a um bem patrimonial de caráter afetivo ou familiar, proveniente de uma pessoa querida. A escola e as brincadeiras antigas eram também apresentadas como bens patrimoniais herdados. Uma narrativa sobre um brinquedo herdado e que passava por diversas gerações e a realização de brincadeiras tradicionais com os estudantes, em especial com aqueles da Educação Infantil e do Ensino Fundamental I, permitiam a introdução do conceito de patrimônio.

(Trecho extraído do Caderno de Anotações da pesquisadora).

Essa turma foi bem participativa. Contaram várias histórias e descreveram alguns objetos que guardam de lembrança de seus avôs, como um caminhão de madeira, que o aluno Carlos guardava, que recebeu de seu pai, deixado pelo seu bisavô.

Sobre as brincadeiras de roda, os alunos se empolgaram dizendo que, brincadeiras como: pega-pega, ciranda-cirandinha, amarelinha, entre outras, foram seus pais que lhes ensinaram. Muitos também mencionaram guardar lembranças de suas avós e avôs, como: bonecas feitas de pano por elas mesmas, bolinhas de gude, peão do bisavô feito de madeira.

As crianças se envolveram tanto na história, que a cada imagem e objeto mostrado para compor a história, elas faziam gestos de surpresa, susto e alegria. Muitos personagens da história foram identificados por elas, em desenhos e filmes que já haviam assistido, como: "A Era do Gelo" e "Os Croods".

(Trechos extraídos do Registro da Atividade in: A LASCA, 2013).

Os alunos também participaram de uma escavação simulada e conheceram as etapas de uma pesquisa arqueológica e os diferentes saberes exigidos pelo estudo arqueológico e de um bem cultural em geral.

Na simulação, fragmentos de cerâmica e outras peças arqueológicas eram dispostos e enterrados num canteiro com terra nas escolas e os alunos construíam as quadras e manuseavam alguns instrumentos e ferramentas para escavação. (Trecho extraído do Caderno de Anotações da pesquisadora). 
Os alunos dessa turma fizeram bastante questionamento, como: - Esses objetos foram deixados pelos homens antigos mesmo?; - Qual matéria da escola tenho que estudar mais para trabalhar com isso?; - Como o Museu cuida desses objetos?

Na simulação do sítio arqueológico, que foi feita do lado de fora da sala de aula, ao chegarem no local da atividade, todos os alunos formaram um círculo em volta dos cacos deixados no espaço de terra, dividiram as ferramentas e trabalharam em equipe, dividindo as tarefas.

Conhecer mais sobre os homens pré-históricos e saber a diferença entre "Arqueologia" e "Paleontologia" foram os assuntos mais trabalhados com os alunos dessa turma.

(Trechos extraídos do Registro da Atividade in: A LASCA, 2013).

As atividades Conversando sobre o meu Patrimônio desenvolvidas com alunos basearam-se na ideia desses reconhecerem e valorizarem seu patrimônio cultural, aquele presente no seu território de vida (onde moravam e estudavam) e expresso por sua família nos seus modos de ser e seus saberes, como também adquirirem e exercitarem a habilidade de interpretar bens culturais.

Assim como a arte que além de expressão é cultura construída histórica e socialmente (AZEVEDO, 2000) ${ }^{126}$, e que devemos aprender a interpretá-la e avaliá-la (BARBOSA, 2009), “cada produto da criação humana, utilitário, artístico ou simbólico, é portador de sentidos e significados, cuja forma, conteúdo e expressão devemos aprender a ler ou decodificar" (HORTA et. al., 1999, p.9), para a valorização da diversidade cultural e para o fortalecimento de vínculos das crianças e suas famílias com seu patrimônio cultural (sua identidade cultural).

Tratou-se de uma postura epistemológica que incluiu a abordagem de cada manifestação cultural como uma das respostas possíveis a determinada necessidade (abrigo, rituais, alimentação entre outras), de forma os alunos fazerem correlações com objetos de seu cotidiano e com a atribuição de valores por eles a cada um deles.

Ao refletir sobre as necessidades que motivaram a fabricação de um determinado documento material, é possível comparar as respostas dadas verificando as semelhanças e diferenças existentes entre os variados bens que as sociedades produzem ao longo do tempo. A constatação que muitos objetos, embora diferentes, foram produzidos para responder a necessidades semelhantes, procurou possibilitar uma percepção da complexidade do agir humano refletido pelo mundo material (a cultura material). Culturas diferentes podem ou não produzir respostas iguais para questões parecidas (MARQUES, 2005).

\footnotetext{
${ }^{126}$ Azevedo (2000) fala que, com a Proposta Triangular proposta por Ana Mae Barbosa, que caracteriza a mudança de paradigma no Ensino Pós-Moderno de Arte, há uma transição entre o ensino modernista ancorado na ideia de Arte como expressão para um ensino pós-modernista baseado na ideia de Arte como disciplina do saber escolar, e que ambos (um modo não exclui o outro) formam a complexidade da Arte-Educação contemporânea.
} 
Também foram realizadas oficinas de Educação Patrimonial com o público em geral participante das atividades promovidas pela Biblioteca Belmonte, no seu espaço, e pela Coordenadoria de Cultura da Subprefeitura de Santo Amaro, na Praça Floriano Peixoto. Caracterizadas pela produção de cerâmicas e pela contação de histórias, receberam o nome de: Contando histórias com os materiais arqueológicos da Linha 5 do Metrô e Fazendo Cerâmica como no passado e foram baseadas na Proposta Triangular para o Ensino Contemporâneo de Arte, novamente promovendo e integrando as ações do "fazer arte" (prática artística), "ler" e "contextualizar" (BARBOSA, 2009). ${ }^{127}$

O ambiente foi cuidadosamente preparado para a atividade com toalha florida, bule, xícaras e louças postas à mesa como se fosse tomar um chá, um baú contendo pá de brinquedo, panelinhas de brinquedo, pandeiro, um metrozinho movido a pilha, um notebook como se fosse um álbum de fotografias da família. E o livro com a história infantil $O$ teimoso trenzinho curioso - escrito por Jonas Ribeiro- Ed Franco, 2002- conduzia a contação.

$\mathrm{Na}$ história contada, o trenzinho, protagonista, cansado de sua rotina no campo, resolve visitar seu primo - o Metrozinho na cidade de São Paulo - no seu novo endereço, o bairro de Santo Amaro. Após visitar as obras do Metrô e passar por muitas aventuras e descobertas, ele resolve visitar o vovô Bonde para tomar um delicioso chá. Enquanto a história era contada, imagens de Santo Amaro antiga e dos bondes eram mostradas e permitiam a abordagem sobre a importância dos objetos deixados por antigas culturas. (Trecho Extraído do Registro da Atividade in: A LASCA, 2013).

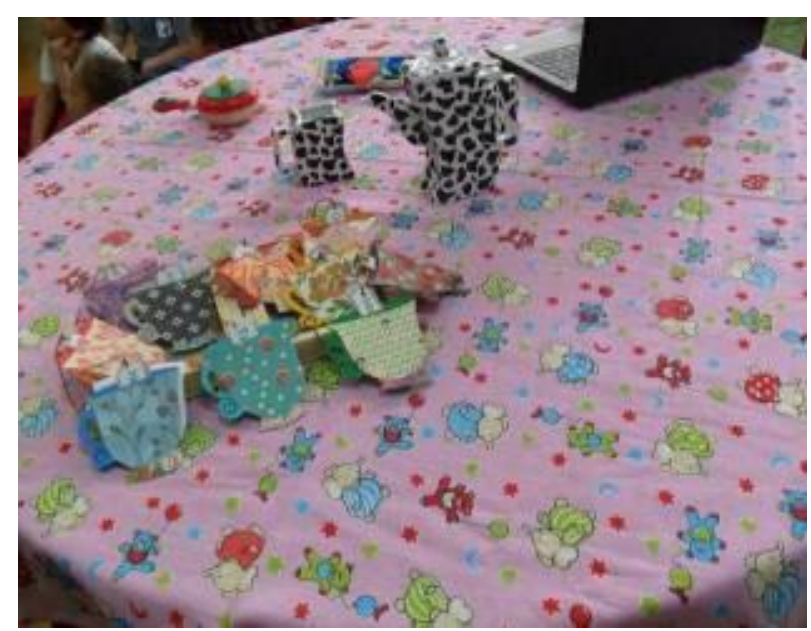

Figura 70. Alguns dos recursos utilizados nas oficinas de Arte Educação. Fonte: A LASCA, 2013.

\footnotetext{
${ }^{127}$ Ver também: RIZZI, Maria Christina de Souza Lima. Olho Vivo. Arte-Educação na Exposição da Moda: Uma Aventura Infantil. Tese (Doutorado), São Paulo: ECA-USP, 1999 e RIZZI, Maria Christina de Souza Lima. Reflexões sobre a Abordagem de Ensino da Arte. In: BARBOSA, Ana Mae (org.) Ensino da Arte: memória e história. São Paulo: Perspectiva, 2008.
} 


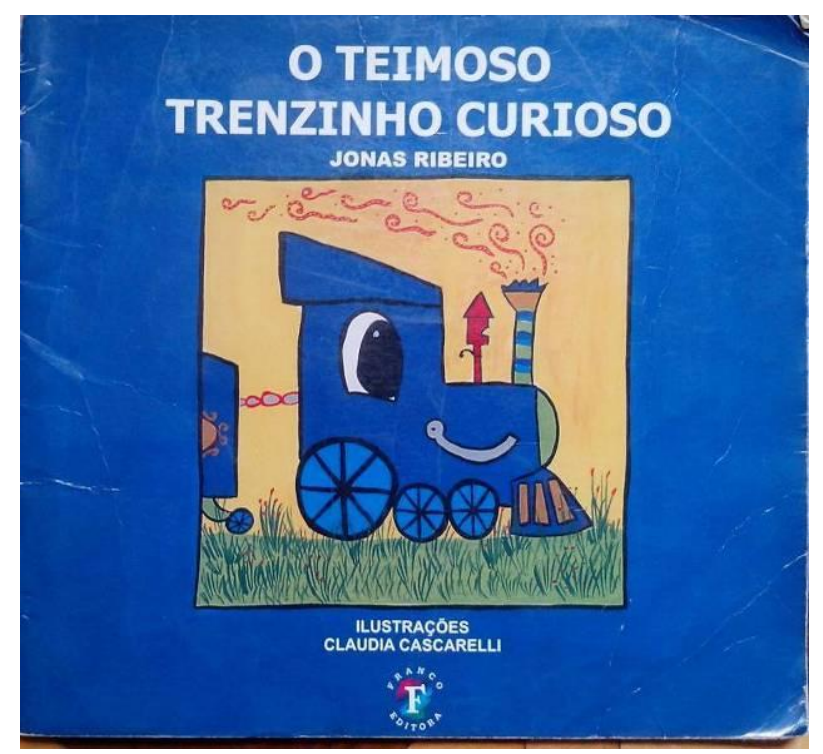

Figura 71. Capa do livro de história infantil de Jonas Ribeiro (Ed Franco, 2002) utilizado nas oficinas. Foto da autora.

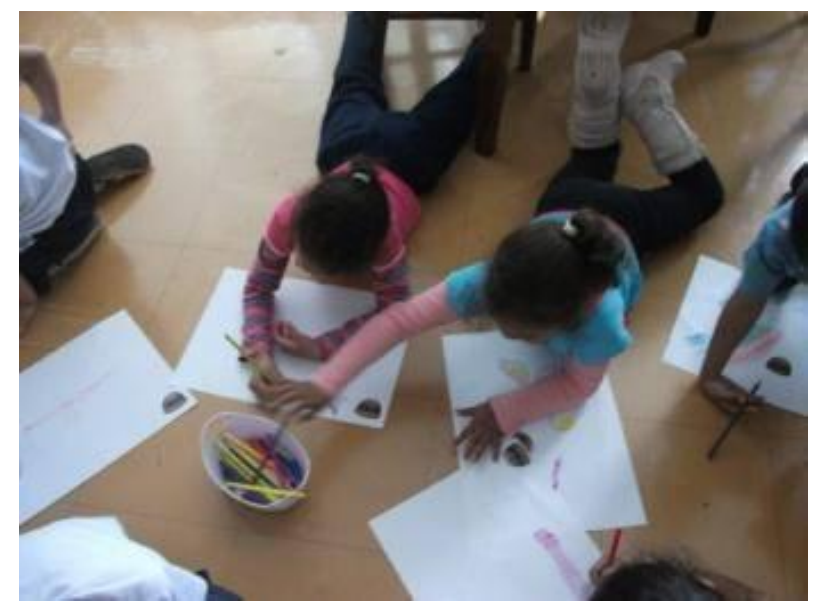

Figura 72. Momento de criação pelos alunos da EMEI Borba Gato de suas próprias histórias. Fonte: A LASCA, 2013.

Nas Oficinas de Cerâmica, logo após a apresentação inicial dos conteúdos a serem desenvolvidos dentro da temática Confeccionando Cerâmicas como os Povos do Passado: a Cerâmica Arqueológica Tupiguarani, tais como: a questão da técnica de produção cerâmica, sua especificidade e beleza; cerâmica colonial e pré-colonial; diversidade cultural e tecnológica; relação do homem com o meio ambiente; e patrimônio cultural, herança e legado, era feita uma contextualização preliminar para o trabalho de produção cerâmica, a partir do uso do Mapa Etnográfico Ilustrado do Brasil, produzido pela Coordenação Geral de Apoio às Escolas Indígenas da Secretaria de Educação Fundamental de Brasília - DF, bem como de diversas imagens de cerâmicas tupiguaranis existentes em acervos museológicos ou de fragmentos arqueológicos encontrados na área das obras, projetadas em data show. Essas informações forneciam dados fundamentais sobre o contexto histórico e cultural para a produção cerâmica tupiguarani e permitiram a leitura das especificidades de sua produção, com os atributos de forma e decoração. (Extraído do Registro da Atividade in: A LASCA, 2013). 

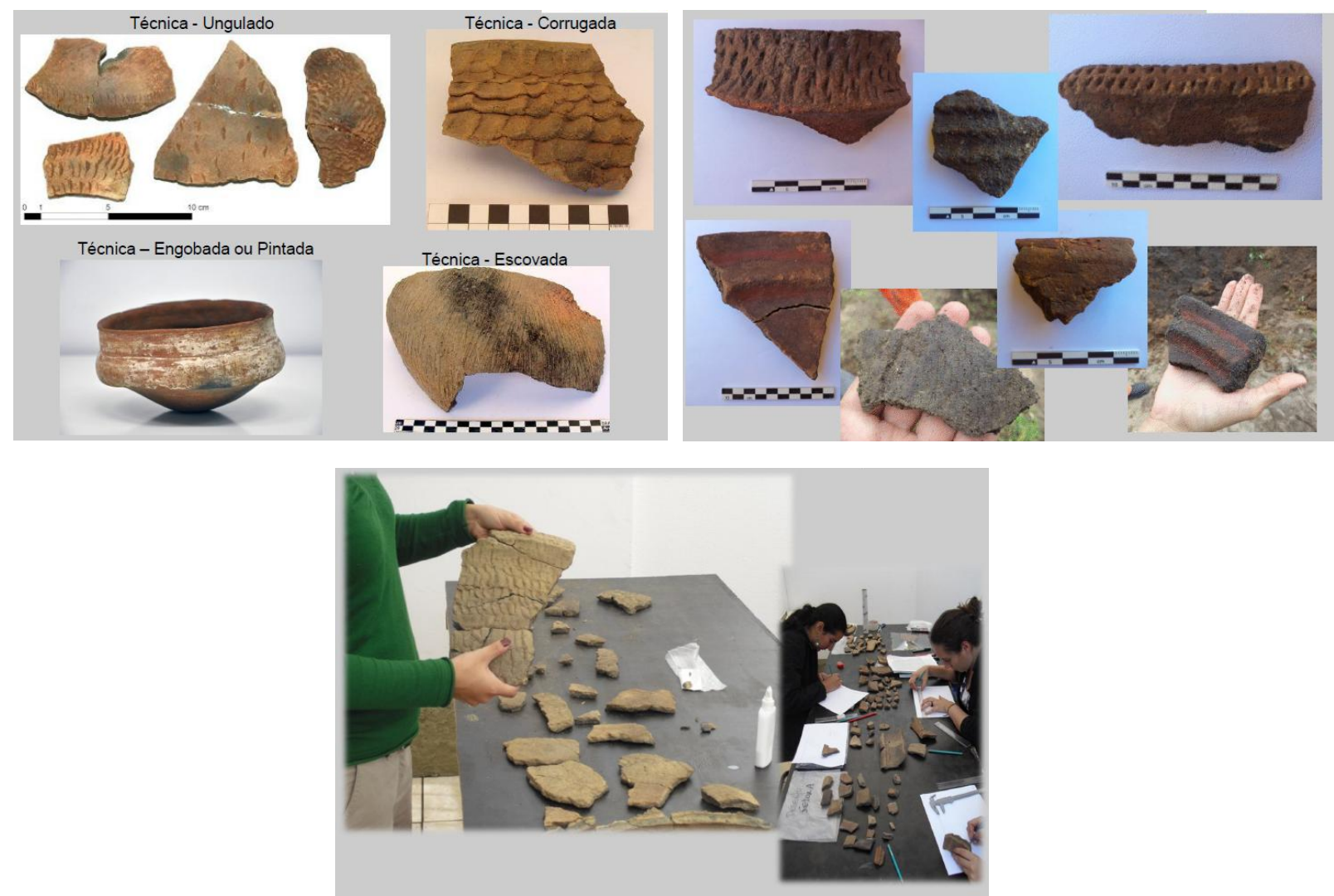

Figura 73 a 75. Imagens de cerâmicas projetadas nas oficinas de cerâmica desenvolvidas na Biblioteca Belmonte. Fonte: A LASCA, 2013.

As oficinas educativas, especialmente quando da presença de adultos - por exemplo, nas Oficinas de Contação de Histórias que participaram os alunos de outras turmas da vizinha EMEI Borba Gato e inclusive os pais e familiares desses alunos, e em todas as de Cerâmica destacaram a questão das exigências legais ligadas ao empreendimento de promoção da difusão das informações sobre o patrimônio arqueológico evidenciado para a comunidade local diretamente afetada pelas obras como um direito a ser garantido à população e às futuras gerações. Não obstante, procuraram, sobretudo, possibilitar aos participantes uma reflexão sobre o patrimônio como aquele que possui valor e significado para as pessoas, sobre sua inserção no rol das afetividades, das experiências de vida e de construção de identidades.

Concordamos com Meneses (1992, p.191), quando destaca que "sem ignorar a necessidade de dar a alguns princípios e necessidades básicas o suporte que lhes pode trazer uma norma constitucional, forçoso é reconhecer que, mais uma vez, nossa sociedade preferiu resolver simbolicamente seus problemas e transferir suas culpas e utopias para a Carta Magna, sem prever vontade política ou instrumento para enfrentar, na prática social, nossas aterradoras desigualdades. Assim, nenhum destes princípios conta com meios eficazes para coibir a tesaurização, a especulação (principalmente a imobiliária), a destruição, o acesso diferencial à cultura e assim por diante". 


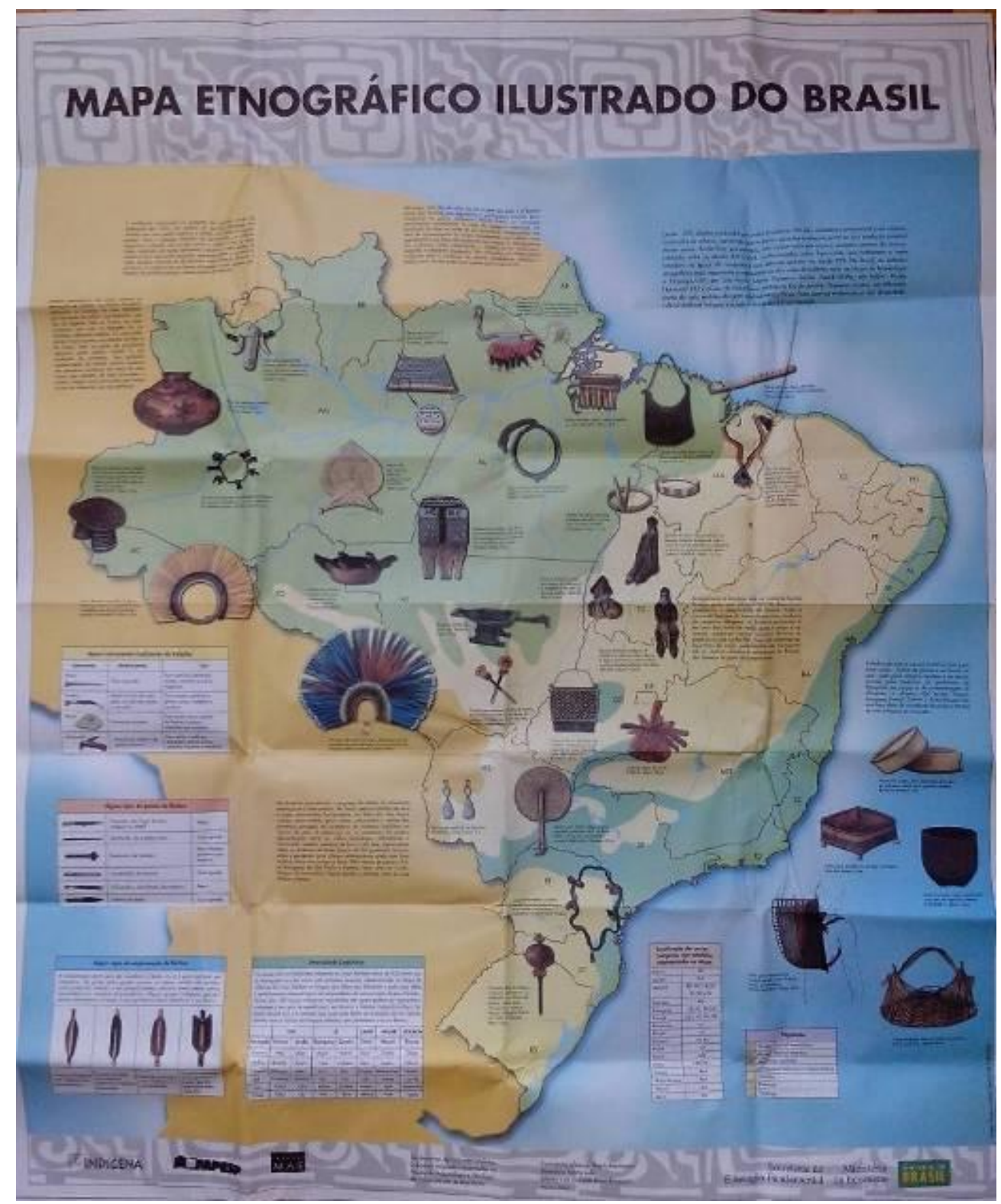

Figura 76. Aspecto do Mapa Etnográfico Ilustrado do Brasil da publicação produzida pela Secretaria de Educação Fundamental do Ministério da Educação (Coordenação Geral de Apoio às Escolas Indígenas: Parâmetros em Ação: Educação Escolar Indígena. s. d.) utilizado nas oficinas de cerâmica.

Dr. João Dentista, Dr. Hélio. Sr. Sales tinha uma loja grande. Lá comprei uma máquina de costura. Loja da D. Juventina que era de roupas. Onde é a farmácia, na esquina da Ponto Frio, era uma sapataria de dois irmãos. De 1950 pra cá eu lembro tudo. Foi quando eu comecei a trabalhar. $\mathrm{Na}$ [rua] Carlos Araújo, tinha barbeiro. Ali que cortava cabelo. Tinha dentista, o Sr. Laércio. Não sobrou nada. Barrozinho. A casa de esquina Abrantes, ao lado da igreja, vendia farelo, para criação. D. Irene Kiss.

A gente ia ate a cidade para trazer o filme.Teve um incêndio lá. Foi demolido. Tinha um armazém do lado. De antiguidade lá não sobrou nada. Só a praça e o coreto que ficaram lá. E a Casa Amarela. Sr. Tarcísio Silva.

(Trechos transcritos de falas dos participantes nos Encontros Memória e Patrimônio Cultural de Santo Amaro). 
Para a pesquisa-ação essas atividades permitiram pensar a Educação Patrimonial a partir da adoção de ferramentas participativas e revelaram o valor e a importância de se evidenciar o patrimônio cultural da região, no momento atual de grandes transformações da paisagem de Santo Amaro, com a implementação de obras e novos serviços urbanos. A verticalização do bairro, com o adensamento de prédios em contraponto às antigas casas térreas, parece também exigir uma posição propositora no sentido de desenvolver estratégias locais de valorização da memória e do legado herdado, preservando-os para as futuras gerações.

\begin{abstract}
As histórias de vida muitas vezes decorrem em sobrados de pequena classe média que não merecem tombamento porque lá não morou nenhum barão, mas foram adquiridos com prestações custosas, privações sem fim, que resultaram nessas casas adoráveis que conhecemos: a máquina de costura a um canto da sala, a TV redimida por uma toalha de crochê, os gerânios... Salas onde a gente ficaria um século escutando, onde as meias paredes filtram conversas, exercícios de piano, a água correndo, a canção dominical (se faz sol). E os caminhos familiares percorridos por D. Ema, D. Ana, D. Lola, da porta para o portão, do portão para a quitanda, para a feira, para a igreja (BOSI, 1992, p. 147).
\end{abstract}

As escolas que participaram das atividades possuíam mais de 50 anos e se constituíam em ponto de referência para a comunidade local, com alunos egressos que mantinham filhos ou netos estudando na mesma unidade escolar, o que demonstrava o aspecto afetivo e de significado dessas escolas como espaço de experiência de vida individual e comunitária.

A Biblioteca Belmonte se apresentou como outro espaço de referência na região, com possibilidade de sediar debates com a comunidade sobre o que consideram ser relevante e digno do crivo de Patrimônio de Santo Amaro.

Desse ponto de vista, ao assumir funções de mediação, as instituições públicas devem, mais do que propriamente determinar valores a priori, criar espaços de aprendizagem e interação que facultem a mobilização e reflexão dos grupos sociais em relação ao seu próprio patrimônio (IPHAN, 2014).

Uma exposição, a princípio denominada Arqueologia, Patrimônio e Memória constituída com os bens culturais revelados nas entrevistas, reuniões e nas atividades de Educação Patrimonial desenvolvidas nessa etapa de formatação da pesquisa, começou a ser curada $^{128}$ também em conjunto com alguns educadores participantes interessados, para itinerar

\footnotetext{
${ }^{128}$ A ideia e a prática de curadoria, ou seja, de curar ou cuidar de bens patrimoniais presentes em instituições museológicas, são anteriores ao museu público: "Já existiam em relação às coleções particulares, que eram a dos reis, nobres e ricos comerciantes, que colocavam a seu serviço uma pessoa para organizá-las e conservá-las (no caso de coleções de pintura, por exemplo, essa pessoa costumava ser um pintor, que também realizava obras para integrar a coleção): era a figura do Conservador”. Paises como os Estados Unidos, a Inglaterra e a Alemanha aplicam o termo "curador" (curator e kurator) para designar o profissional responsável por trabalhos como coleta, pesquisa e exposições envolvendo os acervos. O termo varia de país para país, mas a ideia de ser responsável pelo acervo se mantém. O termo "curador" também tem sido utilizado para designar o profissional
} 
nas escolas e instituições abrangidas pelas ações e colaborar com os trabalhos de evidenciação e valorização do Patrimônio Arqueológico e Cultural do bairro de Santo Amaro e região.

O objetivo da exposição, além de compartilhar os resultados preliminares dos estudos arqueológicos no contexto do processo de licenciamento da obra do Metrô em Santo Amaro, foi estimular pais, familiares e visitantes em geral a apresentarem e ao mesmo tempo difundirem (curadoria educativa) memórias, narrativas e histórias que também fariam parte da sua curadoria e conteúdo. A principal finalidade era colaborar na promoção de ações em conjunto com a comunidade da região de identificação e conhecimento dos bens culturais locais significativos.

O conceito de curadoria foi vinculado ao processo pedagógico, à aprendizagem coletiva, visando favorecer a troca de saberes, a mobilização social, o fortalecimento da autoestima e da tomada de consciência. A curadoria não pode ser separada do processo de mediação, na medida em que não só apresenta obras, mas também representa sujeitos sociais e seus discursos (RIZZI, 1998) ${ }^{129}$.

Entretanto, justamente em razão desse seu caráter educativo e de curadoria compartilhada, sua realização foi inviabilizada pelo calendário de atividades de final do ano letivo de 2013 das escolas, que contava com as avaliações dos indicadores escolares promovidas pelo SARESP, de âmbito estadual, e Prova Brasil ${ }^{130}$, federal; como também pela Copa do Mundo, em 2014.

responsável pela concepção de exposição e pelo gerenciamento de sua produção e montagem. Hoje, entretanto, além da coleta, preservação e pesquisa de bens, artefatos e objetos, os museus são responsáveis pela comunicação e/ou divulgação dos acervos e/ou coleções. O termo "curadoria" refere-se ao tratamento com o acervo desde a coleta, documentação, conservação até a comunicação (Semana dos Museus da USP, 1997, São Paulo. Anais I Semana dos Museus da USP. São Paulo: Pró-Reitoria de Cultura e Extensão Universitária Universidade de São Paulo, 1999, p.57).

${ }^{129}$ Seu conteúdo seria também disponibilizado num folder no formato de cartaz, que se apresentaria como material de referência sobre o patrimônio cultural arqueológico da região e permaneceria afixado nas escolas e demais instituições por onde a Mostra passasse: “[...] as práticas educativas em museu são mais que atividades desenvolvidas a partir da exposição museológica.[...]. A educação no museu pode ser encarada como curadoria educativa, e, dessa forma, é parte integrante de processo amplo de ações curatoriais (que compreendem todo o fluxo de trabalho em torno do acervo) e não só uma estratégia de disseminação de conhecimentos produzidos" (MARQUES, 2005, p. 78-79)

${ }^{130}$ Aplicado pela Secretaria da Educação do Estado de São Paulo, no Sistema de Avaliação de Rendimento Escolar do Estado de São Paulo - SARESP, os alunos do $2^{\circ}, 3^{\circ}, 5^{\circ}, 7^{\circ}$ e $9^{\circ}$ anos do Ensino Fundamental e da $3^{\mathrm{a}}$ série do Ensino Médio têm seus conhecimentos avaliados por meio de provas com questões de Língua Portuguesa, Matemática, Ciências Humanas, Ciências da Natureza e redação. Os resultados integram o cálculo do Índice de Desenvolvimento da Educação do Estado de São Paulo - IDESP. Disponível em: <http://www.educacao.sp.gov.br/saresp > Acesso em: 29 fev 2016. A Prova Brasil, desenvolvida pelo Instituto Nacional de Estudos e Pesquisas Educacionais Anísio Teixeira - INEP/MEC, junto com o Sistema Nacional de Avaliação da Educação Básica - SAE, avaliam a qualidade do ensino oferecido pelo sistema educacional brasileiro a partir de testes aplicados na $4^{\mathrm{a}}$.e $8 \mathrm{a}$. séries $\left(5^{\circ}\right.$. e $9^{\circ}$. anos) do ensino fundamental. Subsidiam o cálculo do Índice de Desenvolvimento da Educação Básica - IDEB. Disponível em: <http://portal.mec.gov.br/prova-brasil > Acesso em: 29 fev 2016. 
A Mostra Educativa Arqueologia, Memória e Patrimônio circulante ou itinerante iniciava apresentando um panorama da ocupação humana local e na cidade de São Paulo a partir das pesquisas arqueológicas pregressas desenvolvidas, algumas das transformações vivenciadas por Santo Amaro e outros bairros adjacentes e seus respectivos bens patrimoniais materiais (edificados) tombados na região. Ações educativas (novas oficinas de Arte Educação e de Educação Patrimonial) fariam parte de sua proposta pedagógica de curadoria educativa e convidariam os visitantes a colaborar com fotos, histórias, memórias da região, de forma intensificar o mapeamento participativo dos bens culturais de Santo Amaro, constituindo-se no Inventário Escolar e Comunitário de Bens Cultural: o método da pesquisaação então formatada.

Figura 77. Imagens e textos (conteúdo) preparados para os painéis expositivos da Mostra Educativa Arqueologia, Memória e Patrimônio.

\section{PAINEL 01 \\ OS PROGRAMAS DE ARQUEOLOGIA PREVENTIVA E DE EDUCAÇÃO PATRIMONIAL}

A Companhia do Metropolitano de São Paulo - Metrô, em respeito à legislação brasileira que normatiza as regras do licenciamento ambiental de grandes e médios empreendimentos e a proteção e salvaguarda do Patrimônio Arqueológico e Cultural do país, tem realizado um trabalho preventivo de diagnóstico, prospecção, monitoramento e resgate de qualquer vestígio arqueológico encontrado nas áreas afetadas por todos os seus empreendimentos; bem como desenvolve trabalhos de Educação Patrimonial, para contribuir para a promoção do reconhecimento, da valorização, da proteção e da fruição do patrimônio arqueológico da região, por meio da comunicação dos conhecimentos gerados pela pesquisa arqueológica e da promoção de ações de discussão e reflexão sobre as questões patrimoniais nas comunidades locais, entendidas como relevantes para a vinculação social, a proteção e gestão dos bens culturais.

Chamados de Programas de Arqueologia Preventiva e de Educação Patrimonial procuram garantir um direito que cabe ao cidadão brasileiro: a proteção do patrimônio cultural.

Esta Mostra Circulante que integra o Programa de Educação Patrimonial foi desenvolvida com o objetivo de colaborar para a difusão dos trabalhos de evidenciação e valorização do Patrimônio Arqueológico e Cultural da região, contribuindo para a sua salvaguarda e proteção.

Além da Capela do Morumbi e Sítio da Ressaca, e assim como o Eixo Histórico de Santo Amaro, outros bens culturais caracterizam o rico e diversificado patrimônio edificado da região, dentre os quais: o próprio

Aeroporto de Congonhas, a passarela de pedestres da Av.Washington Luís, o Estádio do Morumbi, o Colégio Visconde de Porto Seguro, a Chácara Tangará, a Casa do Sertanista, no Caxingui, entre outros. Alguns já são tombados e outros em processo de proteção municipal elou estadual.

O sítio arqueológico pré-histórico Morumbi, com datação estimada de 6 mil anos e evidenciado no bairro do Morumbi, já foi escavado e hoje integra o acervo do Centro de Arqueologia de São Paulo.

A difusão deste patrimônio material, associada ao reconhecimento e à valorização dos bens imateriais, fortalece vínculos comunitários e sedimenta caminhos mais promissores para a preservação e proteção do Patrimônio Arqueológico e Cultural local. 

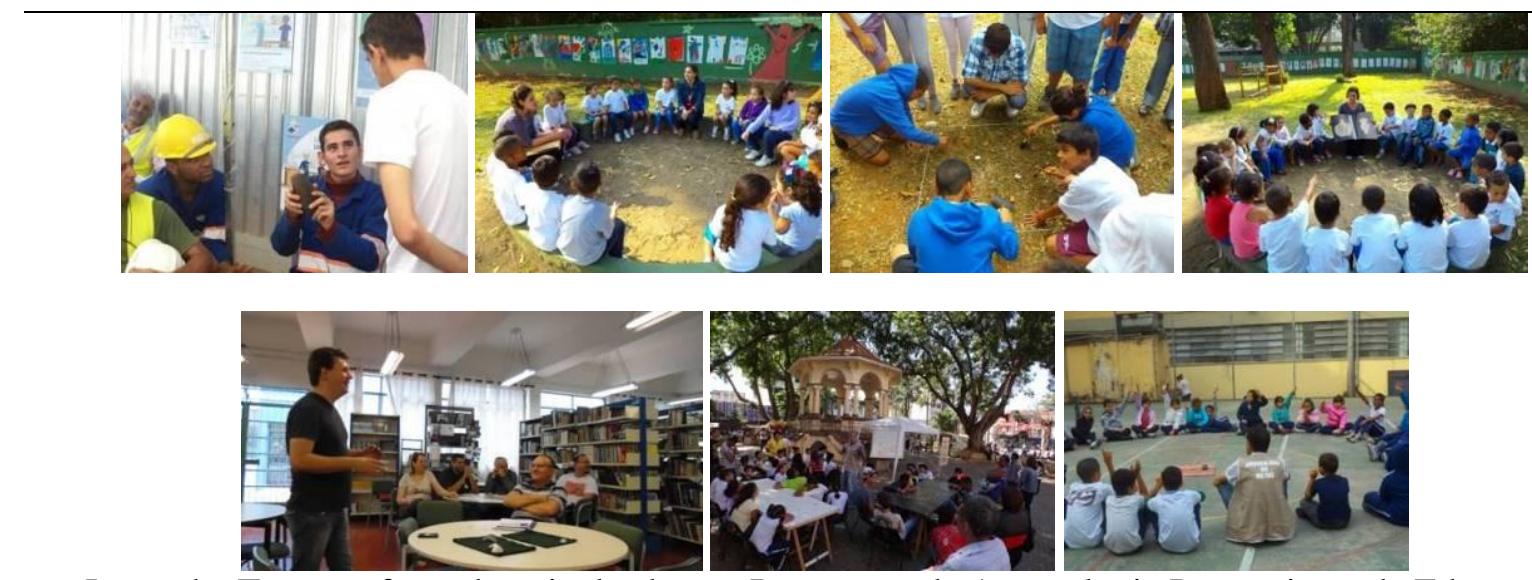

Legenda: Textos e fotos do painel sobre os Programas de Arqueologia Preventiva e de Educação

Patrimonial propostos para compor a Mostra Educativa.

\section{PAINEL 02 \\ OS PRIMEIROS MORADORES}

Inúmeros povos habitavam a região de São Paulo há milhares de anos, vivendo da caça, pesca e coleta de alimentos. Eram grupos de caçadores- coletores nômades que tinham como auxílio uma variedade de artefatos de pedra lascada e polida.

$\mathrm{Na}$ época da chegada dos europeus, povos indígenas viviam em aldeias na região da bacia do rio Tietê. Eram povos de diferentes etnias, como os Tupiniquins, Guaianás, Maromimis e Guarulhos, muitos com uma diversificada produção cerâmica.

O modo de vida destes povos foi desestruturado com a chegada dos europeus, que em seu processo de conquista, utilizaram-se das trilhas indígenas: os Peabirus - caminhos que interligavam o litoral com o Planalto e o interior do continente.

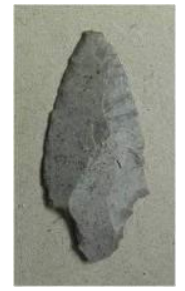

Legendas: Ponta de flecha pertencente a povos caçadores- coletores encontrada no Sítio Arqueológico Morumbi, no bairro do Morumbi, em São Paulo, característico dos povos que viveram no território paulista há milhares de anos. Acervo Museu da Cidade, DPH/SMC/PMSP.

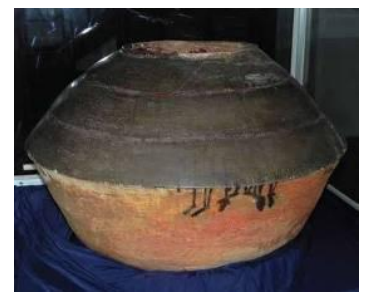

Urnas funerárias de povos tupiguaranis foram identificados em diferentes bairros. Exposição Escavando o Passado: arqueologia na cidade de São Paulo. Acervo Museu de Arqueologia e Etnologia da Universidade de São Paulo - MAE/USP. 
O estabelecimento dos europeus no planalto se deu em 1553 com a criação de Santo André da Borda do Campo por Martin Afonso de Souza e logo, em 1554, na transferência do núcleo para São Paulo de Piratininga pelos jesuítas.

Nos séculos seguintes o território ao redor de São Paulo foi doado em sesmarias a colonos que, aproveitando-se da mão de obra indígena, dedicaram-se a mineração, agricultura e pecuária. Entre os séculos XVIII e XIX um cinturão de chácaras, sítios e fazendas formou-se em São Paulo, produzindo um pouco de quase tudo o que era vendido nas feiras e pequenos armazéns de secos e molhados dispersos pelas estradas e na área central da cidade.

Com o passar do tempo, estas terras, por herança, doação ou compra, foram parceladas, originando pequenas propriedades rurais pertencentes a algumas famílias.

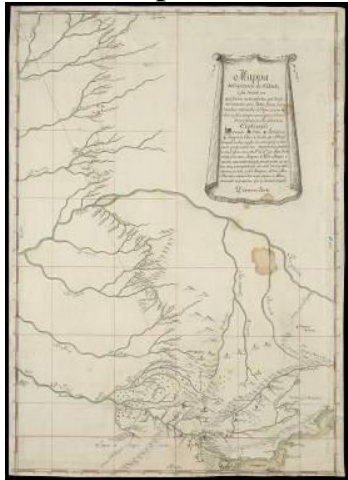

Legendas: Mapa da Capitania de São Paulo, e seu sertão (...) delineado por Francisco Tosi Columbina. Este mapa do século XVIII mostra as estradas para o transporte de muares. Acervo Biblioteca Nacional, RJ.

\section{PAINEL 04 \\ O BAIRRO DE SANTO AMARO}

Santo Amaro, que já foi município, é hoje um dos bairros mais antigos da cidade. Após a fundação da vila de São Paulo, em 1554, os jesuítas foram distribuídos na Capitania em locais, objetivando a catequese indígena: São Vicente, São Paulo, São Miguel e Jeribatiba. A primeira missa, feita por José de Anchieta, ocorreu em 14 de julho de 1560.

Por muito tempo a região recebeu diferentes nomes: Birapuera; Virapuera; Ibirapuera; Geribatiba;

Geribativa; Jeribatiba; Santo Amaro de Virapuera; Santo Amaro de Ibirapuera, até assumir em definitivo o seu nome atual.

Em 1832 tornou-se município, separado de São Paulo,

Em 1886 foi inaugurada a linha férrea de São Paulo a Santo Amaro, com a presença do Imperador Dom Pedro II [...]

\section{PAINEL 05 \\ O BAIRRO DO MORUMBI}




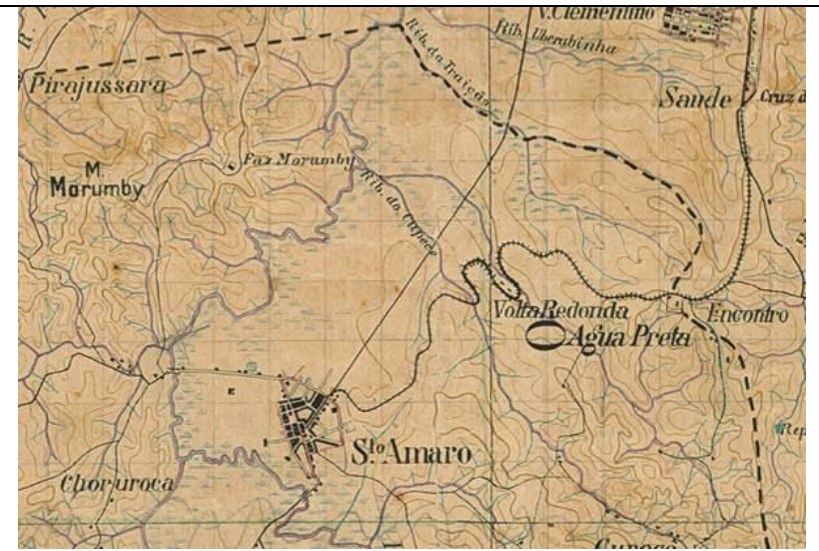

Detalhe da Folha Topográfica da Comissão Geográfica e Geológica, de 1906, com a região do Morumbi. Acervo Instituto Geográfico e Cartográfico - IGC.

Os primeiros registros sobre a região remontam ao início do século XIX, quando a área pertencia à antiga Fazenda Morumbi. Nos Registros de Terras da Freguesia de Santa Ifigênia, existentes no Arquivo do Estado de São Paulo, e datados de 1856, aparece como proprietário o inglês John Rudge. O local possuía poucos nódulos de povoamento, com alguma ocupação em Pinheiros e Santo Amaro, e poucas habitações nos bairros de Pirajussara e Botequim. Nas primeiras décadas do século XX, a fazenda Morumbi foi partilhada em pequenos sítios e chácaras, vendidos a imigrantes estrangeiros como os Scarpa, Petrella, Vidigal e outros.

Acompanhando o crescimento da cidade, em fins da década de 1940, o engenheiro Oscar Americano adquiriu glebas de terras no local, parcelando-as, iniciando o processo de urbanização em nome da Companhia Imobiliária Morumby.
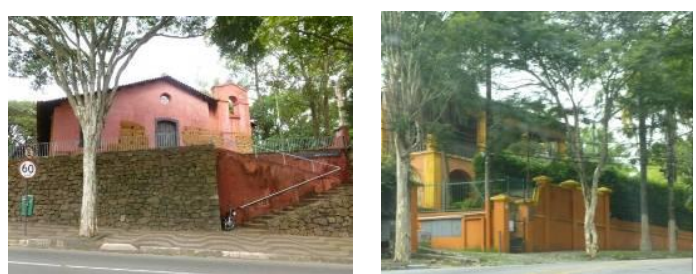

Legendas: Capela do Morumbi.

Sede da Fazenda Morumbi.

\section{PAINEL 06 \\ O BAIRRO DO JABAQUARA}

As origens do bairro são pouco conhecidas, contudo, sabe-se que sua história está ligada a de Santo Amaro e aos antigos caminhos de tropas que percorriam a cidade comercializando mercadorias. De acordo com documentos do Arquivo Histórico Municipal de São Paulo, a região do Jabaquara pertenceu em meados do século XVIII à Companhia de Jesus e, após a sua expulsão do país, a inúmeros fazendeiros e sitiantes.

Entre os anos de 1886 e 1913, o bairro recebeu uma ferrovia, unindo Vila Mariana a Santo Amaro, muito utilizada pelos moradores para a compra de mantimentos. Contudo, logo foi desativada, substituída em 1906 pelos bondes da Light and Power Co. A partir dos anos 1930, o bairro recebeu as suas primeiras indústrias, a Igreja de São Judas Tadeu, culminando na década de 1940, com a construção do Aeroporto de Congonhas. 


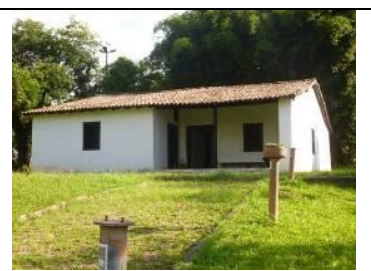

Legendas: Sítio da Ressaca. Museu da Cidade de São Paulo.

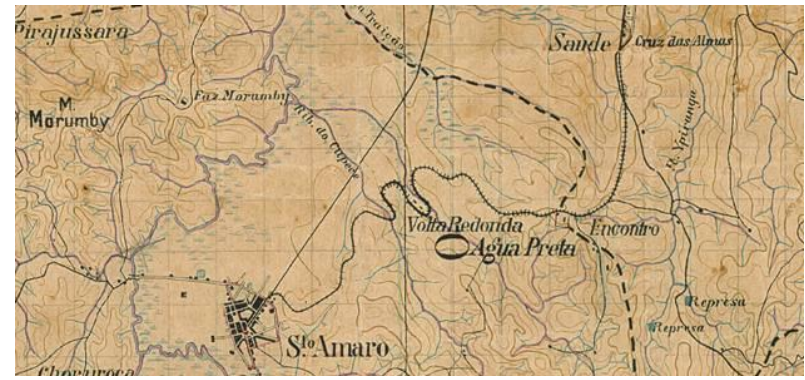

Detalhe da Folha Topográfica da Comissão Geográfica e Geológica, de 1906, com a antiga ligação ferroviária entre Vila Mariana e Santo Amaro. Acervo Instituto Geográfico e Cartográfico - IGC.

Durante a elaboração da Mostra Educativa e ao longo das ações educativas, além da pesquisa bibliográfica que fundamentou as discussões e as abordagens dos temas da Arqueologia, Educação Patrimonial e Aprendizagem Social, foi também desenvolvido um levantamento documental em fontes e bases de dados de bibliotecas públicas e acervos de instituições da região, bem como processos de tombamento, resoluções e decretos de órgãos públicos responsáveis pela salvaguarda de bens da cidade de São Paulo (CONPRESP e CONDEPHAAT), que forneceu informações para o inventário de bens culturais.

Essas informações levantadas, ao lado dos bens culturais conhecidos nas oficinas de Educação Patrimonial desenvolvidas em 2013, dialogaram e subsidiaram as análises dos dados auferidos também pelas novas ações educativas de 2015 na região, que receberam o nome de Encontros sobre Memória e Patrimônio Cultural de Santo Amaro: Conversando sobre Arqueologia, Memória, Patrimônio Cultural, Identidade e História de Santo Amaro. Essas novas ações deram continuidade à pesquisa-ação, iniciaram sua etapa de desenvolvimento e consolidaram o aspecto comunitário do Inventário de Bens Culturais proposto. Tiveram o objetivo de continuar a promover formas coletivas de pensar o patrimônio cultural de Santo Amaro com as organizações da sociedade civil e alguns de seus atores sociais conhecidos na etapa anterior. 


\title{
1.3 Os Encontros sobre Memória e Patrimônio Cultural de Santo Amaro
}

\begin{abstract}
Recomenda-se que indivíduos ou grupos sejam declarados oficialmente "Tesouros Humanos Vivos" e passem a receber do Estado ajuda financeira com vistas à transmissão dos seus conhecimentos às novas gerações. Mais utilizado em países, Coréia, Tailândia e Filipinas, o dispositivo vem sendo estudado por países ocidentais, já tendo sido posto em prática na França, através do sistema dos Maitres d'Art (IPHAN, 2012, p.8).
\end{abstract}

No dia 11 de agosto de 1991, começava o Congresso Internacional Patrimônio Histórico e Cidadania, promovido pelo Departamento do Patrimônio Histórico - DPH da Secretaria Municipal de Cultura de São Paulo - SMC. E nele a expressão "O direito à memória", que, depois virou título do volume que publicou parte do material e dos textos apresentados e discutidos no encontro, logo se transformou "[...] em um slogan rapidamente incorporado pelas especialistas presentes no encontro, e tornou-se objeto de um debate". ${ }^{131}$

A questão do patrimônio, entre a maioria dos profissionais de órgãos de proteção atuantes e reunidos no Congresso, ainda mantinha uma noção muito restrita de patrimônio histórico, em que o especialista tinha o poder da "última palavra" do que havia ou não de ser "tombado" (CUNHA, 1992).

Apesar de hoje em dia muitos expressarem a máxima de que o conceito de patrimônio histórico não se reduz apenas às edificações e manchas urbanas, a maior parte dos profissionais, órgãos e entidades ligados à preservação acaba, na prática, por reiterar esta restrição. Fruto de uma longa tradição no Brasil, esta noção restrita de patrimônio histórico vem sendo questionada há muito tempo e em várias direções, mas os resultados deste debate têm aparecido pouco no nosso trabalho (CUNHA, 1992, p.10).

Entretanto, no Congresso, a memória preconizada era aquela com uma dimensão política e fundamental para a cidadania (CUNHA, 1992) e que incluía o patrimônio como um direito social, pensando-o a partir da participação da sociedade civil na discussão e no processo de sua preservação ou não, tratando dessa questão como uma prática social, em que se pode reconhecer diversos agentes sociais em disputa pelo território ou espaço na cidade (ARANTES, 1984).

Nos planos federal, estadual e municipal práticas diferenciadas e orientações por vezes opostas indicam ainda que a memória constitui um campo privilegiado da política - e em torno dela se desenvolve surdamente um embate nem sempre explicitado. Nesta perspectiva, à nossa condição de sujeitos do conhecimento deve se juntar a de sujeitos da história. A questão da memória como uma dimensão fundamental da cidadania aparece aqui como um eixo fundamental da discussão

\footnotetext{
${ }^{131}$ In: São Paulo. Secretaria Municipal de Cultura. Departamento do Patrimônio Histórico. O direito à memória: patrimônio histórico e cidadania.São Paulo: DPH, 1992 (Parte do material apresentado e discutido no Congresso Internacional Patrimônio Histórico e Cidadania, promovido pelo DPH/SMC, p.5).
} 
capaz de associar nosso papel profissional com a dimensão política de nosso trabalho (CUNHA, 1992, pp.10 e 11).

Os Encontros sobre Memória e Patrimônio Cultural de Santo Amaro foram elaborados em conjunto com as instituições e aparelhos públicos parceiros da pesquisa na sua etapa de formatação e nos passos iniciais do seu inventário e com base nas informações obtidas a partir da participação e convivência com esses atores sociais da região nas suas ações cotidianas locais de promoção de atividades socioculturais, como por exemplo, aquelas relacionadas ao Dia das Tradições de Santo Amaro de 2015: Caminhada Cultural, Café da Manhã "Santo Amaro, meu bem - querer: como te quero", entre outras.
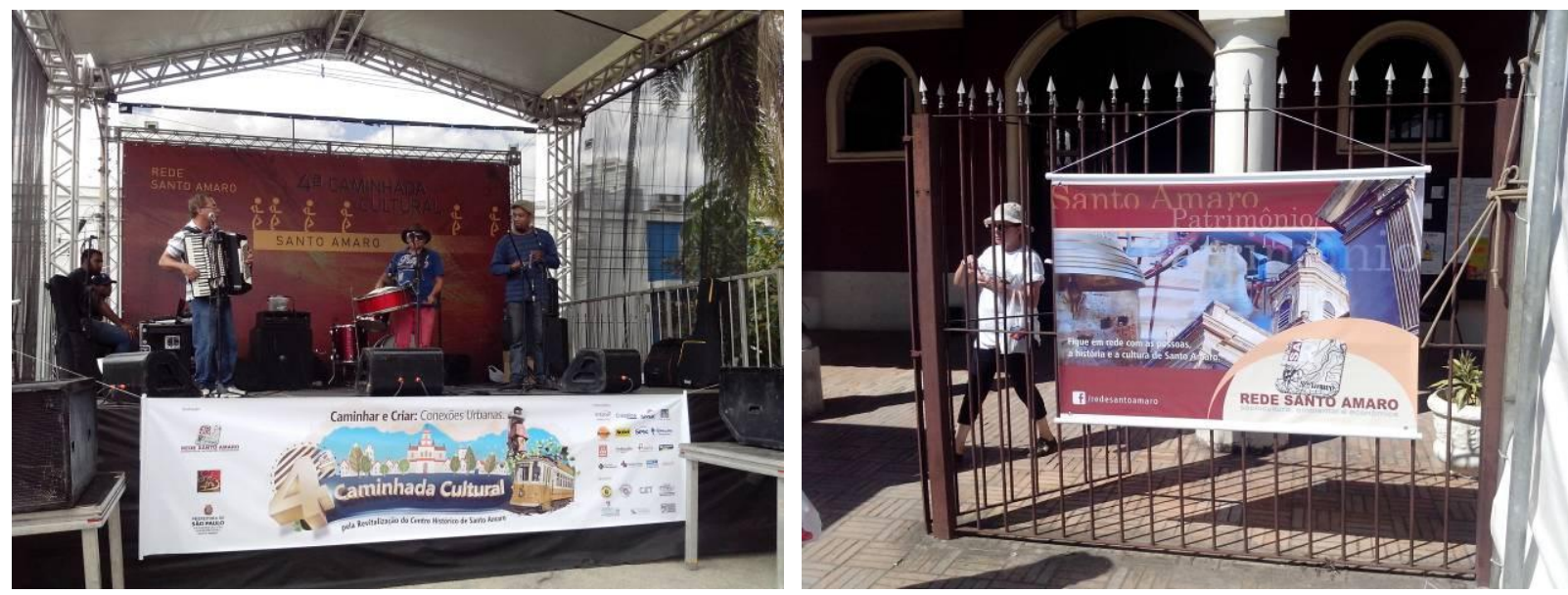

Figuras 77 e 78. Duas das faixas no Dia das Tradições de Santo Amaro que apresentaram as instituições locais envolvidas nas atividades. Fotos da autora.
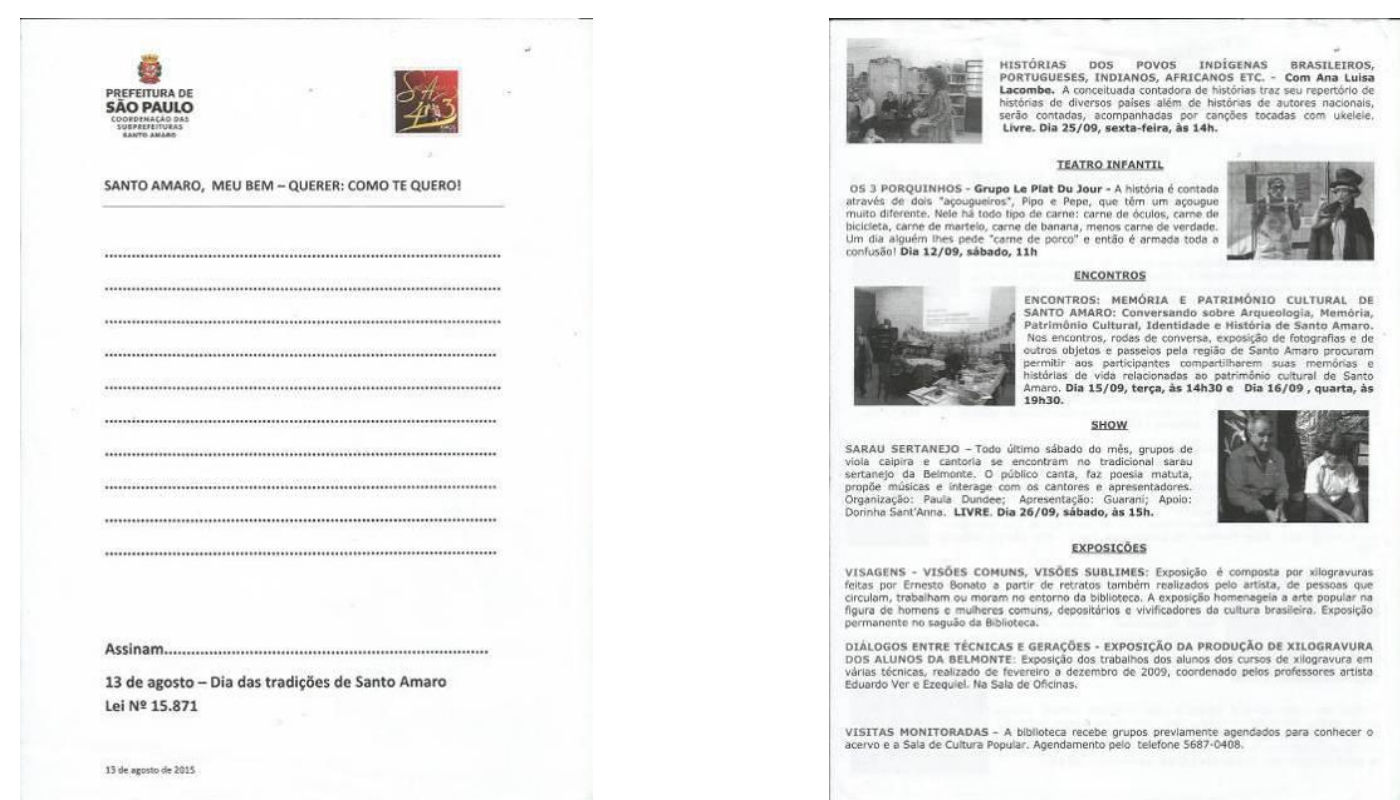

Figuras 79 e 80. Paper da atividade Café da Manhã "Santo Amaro, meu bem - querer: como te quero" que reuniu para uma conversa, no Dia das Tradições de Santo Amaro, formadores de opinião locais, representantes do comércio e responsáveis por projetos e ações na região e folheto com a programação mensal de atividades da Biblioteca Belmonte. 
As novas oficinas de Educação Patrimonial procuraram abranger o público bem diversificado que era (e é) uma característica da região, com santamarenses tradicionais (os Botinas Amarelas), alguns provenientes de famílias de imigrantes (alemães, italianos, japoneses, lituanos, por exemplo); outros que também se autodenominavam santamarenses e que eram oriundos ou do interior de São Paulo ou de outros estados do país, como Minas Gerais e cidades de Nordeste brasileiro, e que se estabeleceram em locais que no passado pertenceram ao município de Santo Amaro e que hoje se constituem em cidades da Região Metropolitana de São Paulo e/ou bairros também periféricos (Itapecerica da Serra, Capão Redondo, Vila das Belezas, entre outros). E conceberam patrimônio e a memória como elementos relacionados e fundamentais para a identificação e reconhecimento da Santo Amaro que tinham em comum: Santo Amaro como seu território de vida, lugar de memória (NORA, 1993) e de identidade cultural e de prática cidadã.

Os lugares de memória nascem e vivem do sentimento que não há memória espontânea, que é preciso criar arquivos, que é preciso manter aniversários, organizar celebrações, pronunciar elogios fúnebres, notariar atas, porque essas operações não são naturais. É por isso a defesa, pelas minorias, de uma memória refugiada sobre focos privilegiados e enciumadamente guardados nada mais faz do que levar à incadescência a verdade de todos os lugares de memória. Sem vigilância comemorativa, a história depressa os varreria. São bastiões sobre os quais se escora. Mas se o que eles defendem não estivesse ameaçado, não se teria, tampouco, a necessidade de construí-los. Se vivêssemos verdadeiramente as lembranças que eles envolvem, eles seriam inúteis. E se, em compensação, a história não se apoderasse deles para deformá-los, transformá-los, sová-los e petrificá-los eles não se tornariam lugares de memória. É este vai-e-vem que os constitui: momentos de história arrancados do movimento da história, mas que lhe são devolvidos (NORA, 1993). ${ }^{132}$

O objetivo das novas oficinas de Educação Patrimonial foi o de promover o Inventário Escolar e Comunitário de Bens Culturais, com base nas ações educativas anteriormente desenvolvidas e em novas metodologias participativas e processos de Aprendizagem Social, de forma sensibilizar os atores sociais locais conhecidos, incluindo novamente o público escolar (alunos, professores, pais e familiares), e aqueles que, nas atividades de convite e de divulgação da pesquisa-ação, manifestaram interesse em participar e se inscreveram, sobre a corresponsabilidade de todos na identificação, valorização, proteção e preservação de bens culturais da região.

\footnotetext{
${ }^{132}$ NORA, Pierre. Entre Memória e História. A problemática dos lugares. In: Projeto História. Revista do Programa de Estudos Pós-Graduados em História e do Departamento de História da PUC-SP. São Paulo; 10, dez 1993. Texto traduzido por Yara Aun Khoury e extraído de: Les lieux de mémoire. I La République, Paris, Galiimard,1984, pp. XVIII-XLII, quando era Diretor de Estudos na "Ecole de Hautes Etudes em Sciences Sociales".
} 

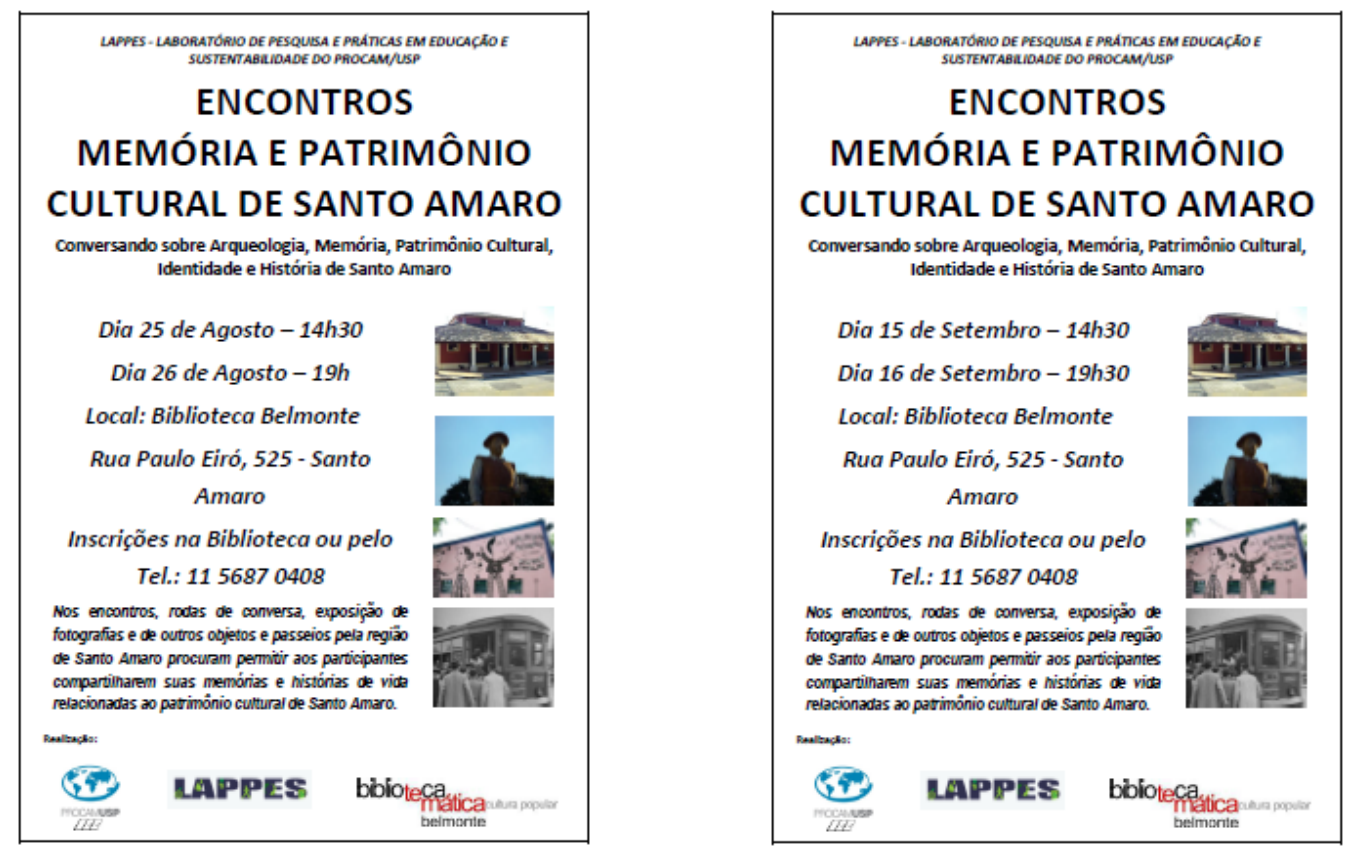

Figuras 81 e 82. Cartazes de divulgação de 2 dos 8 Encontros planejados e 29 desenvolvidos de agosto de 2015 a fevereiro de 2016, afixados nos aparelhos culturais de Santo Amaro, para divulgação.

Voltadas para o empoderamento e fortalecimento de ações e saberes locais relacionados ao patrimônio cultural de Santo Amaro, nessas Oficinas/Encontros Memória e Patrimônio Cultural de Santo Amaro, os participantes, a partir de objetos, fotografias, narrativas, passeios pelo bairro, visitas a lugares significativos da região, buscas e pesquisas e preparação de exposições e apresentações compartilharam lembranças, recordações, memórias e histórias de Santo Amaro, e revelaram:

A Santo Amaro do bonde, dos romeiros, da Casa de Cultura, (antigo Mercado Velho), do Colégio Paulo Eiró, da Casa Amarela, das Missas na Igreja Matriz, das benzedeiras, da Festa do Divino Espírito Santo, do Carnaval, do Cine São Francisco. A Santo Amaro de todos nós! (Trecho extraído de um dos dois painéis da Mostra Educativa de apresentação da pesquisa-ação).

Nos Encontros sobre a memória e o patrimônio cultural de Santo Amaro, os objetos e artefatos culturais de diversas procedências, assim como reproduções de fotografias de edificações componentes do Eixo Histórico de Santo Amaro tombado foram mediadores da construção coletiva da pesquisa participativa (do inventário) sobre saberes e bens culturais produzidos pelos próprios participantes e associados à sua memória individual e à coletiva local. 


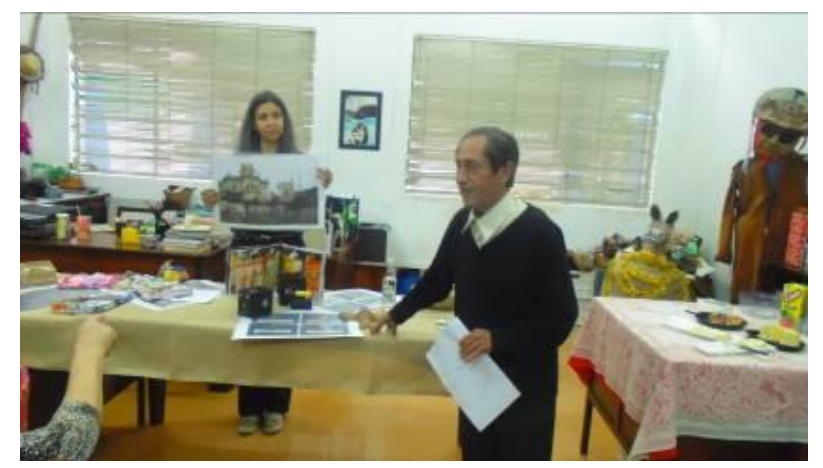

Figura 83. Sr. Tarcísio Silva, de 88 anos, na atividade do Exercício do Objeto: o objeto significativo do primeiro encontro, narrando sobre seu cotidiano em Santo Amaro e no demolido Colégio Paulo Eiró. Foto da autora.

Às vezes tinha aula na primeira classe, às vezes na última, conforme trocava os professores. (...) Dr. Renato Braga era o diretor. Tinha outra pessoa também que fazia faxina e que era muito amiga da gente lá. Eu faltava muita na aula também, porque os amigos falavam: vamos nadar? Aprendi a nadar. Graças a Deus! E a gente ia num "tancão" aqui. A gente pescava aqui. Aqui no Terminal [Terminal de ônibus Santo Amaro] tinha peixe. Eu pegava cada cara desse tamanho grande. Andava de barco e pescava. Tinha uma lagoa que depois aterraram. (Sr. Tarcísio Silva. Trecho transcrito das falas produzidas pelos participantes nas atividades).

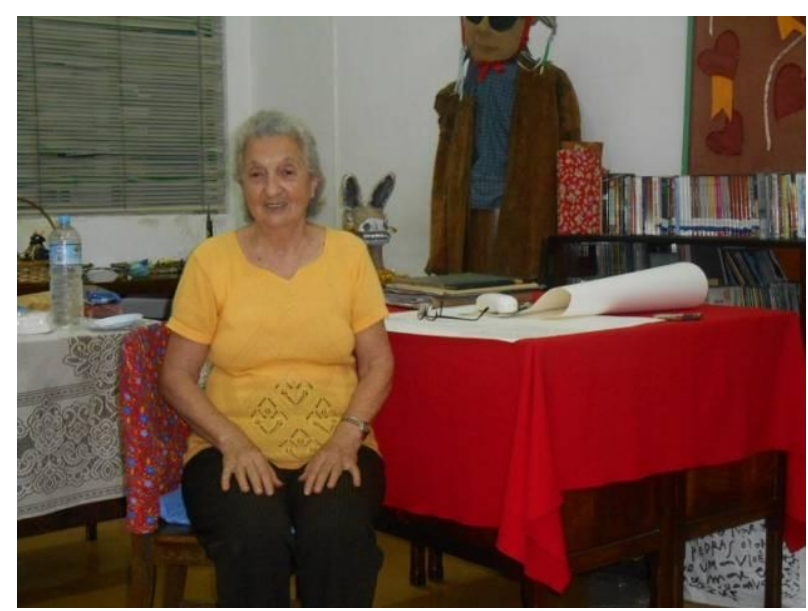

Figura 84. D. Irene Kiss Fontes, moradora de Santo Amaro há mais de 70 anos, também narrou sobre o cotidiano do bairro nos anos 1940-1950, na atividade Mapa Patrimonial no segundo encontro. Foto da autora.

Casei na Matriz de Santo Amaro. Tive dois filhos que foram batizados. Meu marido fundou a Dux (...) Andei muito de bonde. Quando criança vinha muito na farmácia do Seu Zé. Estudei harmônica com Mário Genário Filho, na rua Direita, compramos muita coisa na loja de Sr. Sales e até hoje eu tenho uma máquina de costura comprada na loja dele. Tratei os dentes com o Dr. Joãozinho (dentista antigo!). Namorei muito na Praça do Coreto. Isso em 1949. (...) Na mesma casa estou há 60 anos. Aqui na Rua Joaquim dos Reis. (D. Irene Kiss. Trecho transcrito das falas dos participantes nas atividades). 
Quadro 6. Recursos utilizados nas Oficinas. ${ }^{133}$

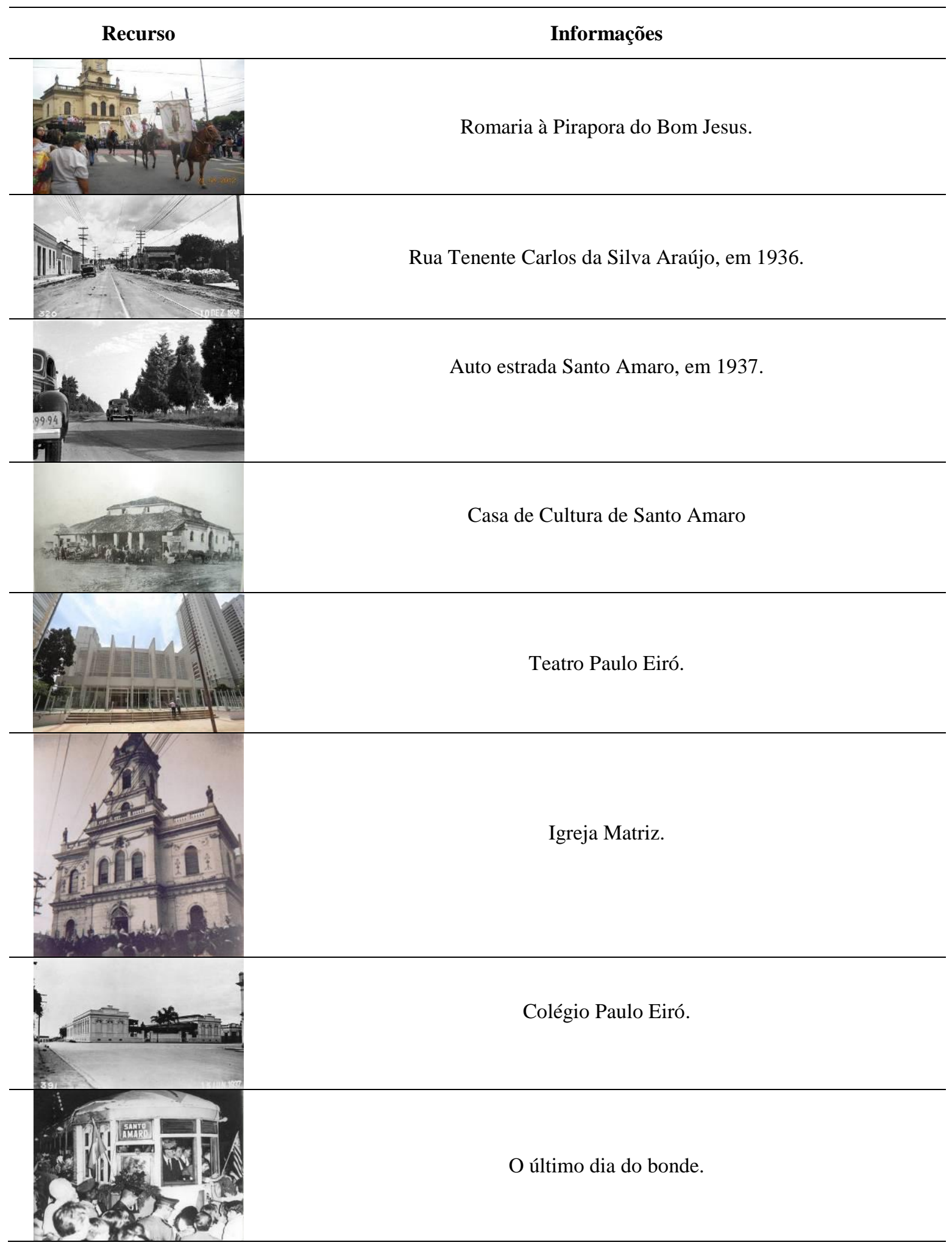

133 Recursos patrimoniais e educativos utilizados nos exercícios das oficinas de Educação Patrimonial dos Encontros. As imagens foram projetadas e disponibilizadas em prancha no tamanho A3 e utilizadas especialmente nas atividades Objeto Significativo e Mapa Patrimonial dos encontros; junto aos objetos, foram recursos também nas entrevistas e bate papos da pesquisa-ação. 


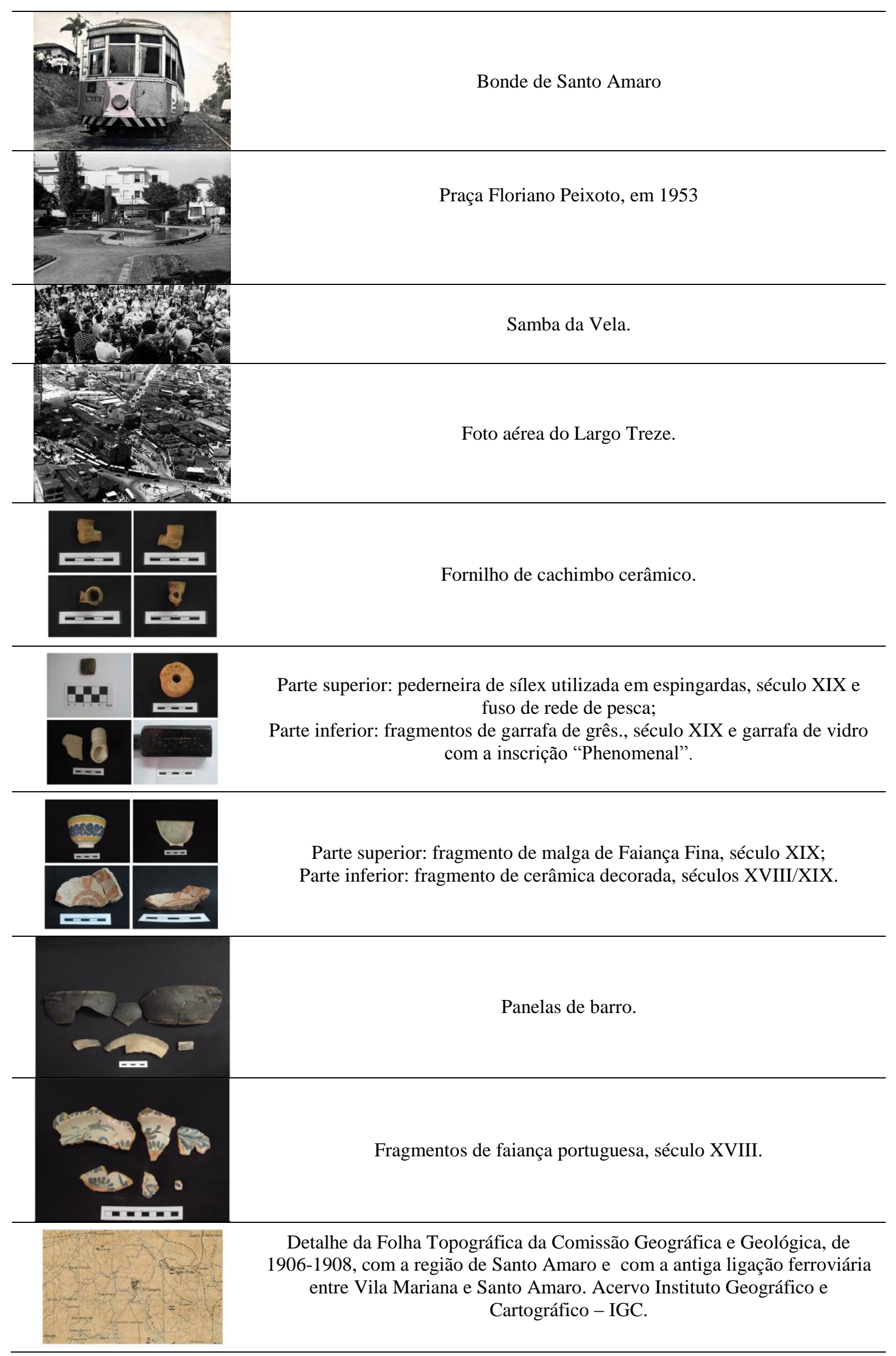




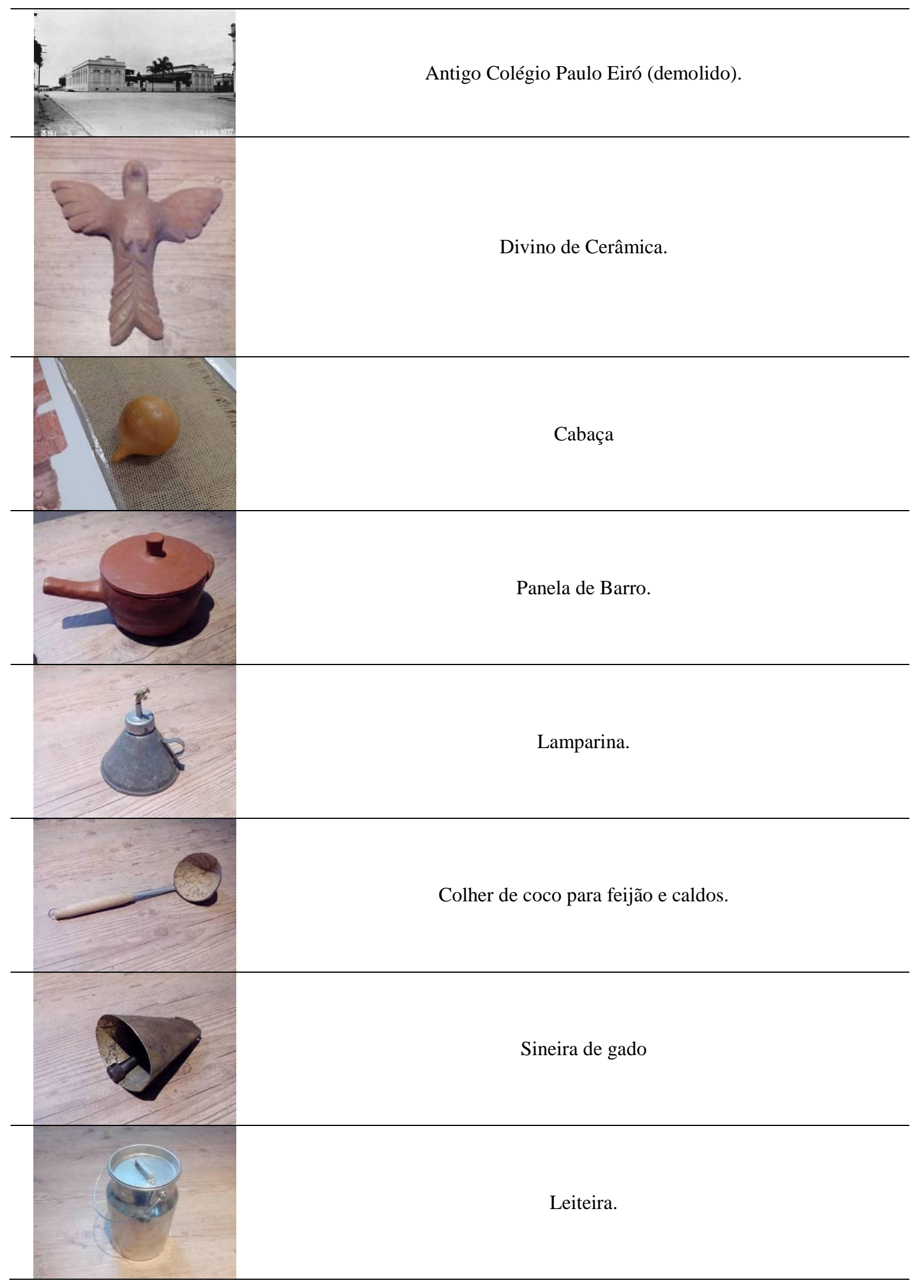

O método do inventário participativo da pesquisa-ação e presente nos exercícios propostos nas novas oficinas de Educação Patrimonial de cada um dos Encontros 
desenvolvidos permitiu conhecer os valores e as referências culturais pertencentes à identidade cultural dos participantes, associados a cada um dos recursos patrimoniais e educativos apresentados.

A preservação dos bens culturais é uma prática social, inserida nos contextos culturais, nos espaços de vida das pessoas. A Educação Patrimonial deve submeter os objetos a um universo de ressignificação (FLORÊNCIO, 2012, p.26).

Os Encontros partiram da ideia de que "Só assim, por meio da dessacralização do patrimônio, e da consideração desse repertório simbólico como fruto de uma prática social, as novas gerações poderão 'descobrir' e recriar, no presente, os sentidos e valores que manterão vivos esses bens" (TOLENTINO, 2012) (134; $^{134}$ em contraposição à postura preponderante destacada por Brandão (1996) das políticas públicas na área patrimonial no país preservarem lugares, edificações e objetos pelo seu valor em si mesmo:

(...) pensar em patrimônio agora é pensar com transcendência, além das paredes, além dos quintais, além das fronteiras. É incluir as gentes. Os costumes, os sabores, os saberes. Não mais somente as edificações históricas, os sítios de pedra e cal. Patrimônio também é o suor, o sonho, o som, a dança, o jeito, a ginga, a energia vital, e todas as formas de espiritualidade de nossa gente. O intangível, o imaterial. (Ministro da Cultura Gilberto Gil, in: IPHAN, 2008).

\footnotetext{
${ }^{134}$ Texto 1 do Caderno Temático 2 In: TOLENTINO, Átila Bezerra (Org.). Educação Patrimonial: reflexões e práticas. João Pessoa: IPHAN-PB, 2012. (Caderno Temático 2).
} 


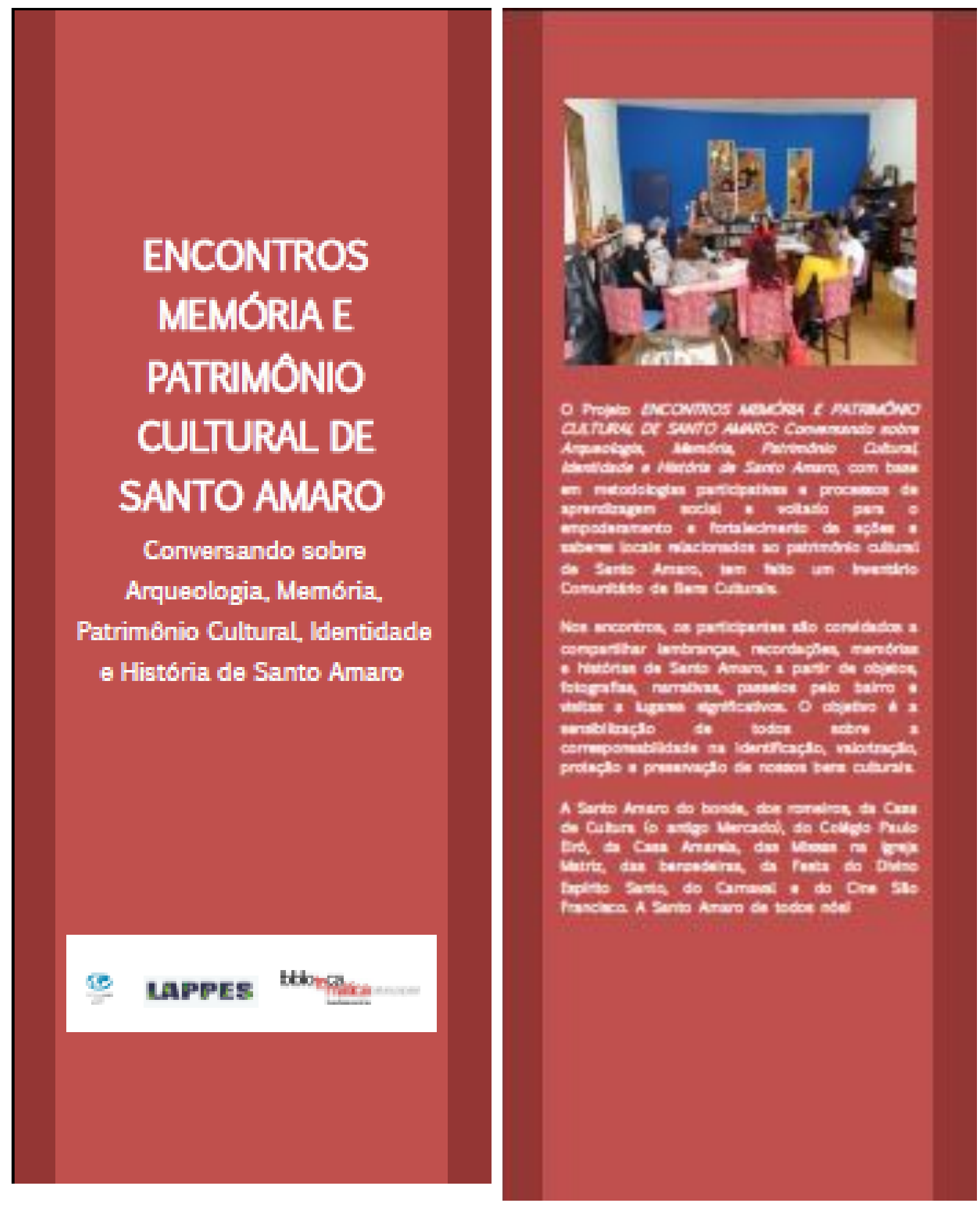

Figuras 86 e 87. Painéis da Mostra Educativa dos Encontros Memória e Patrimônio Cultural de Santo Amaro de apresentação do projeto (da pesquisa-ação). A exposição com alguns dos bens inventariados teve a curadoria dos participantes, itinerou pela Biblioteca Belmonte, em novembro e dezembro de 2015, e na Casa de Cultura de Santo Amaro, em janeiro e fevereiro de 2016.

Dos 8 encontros de agosto a novembro de 2105 ( 2 a cada mês, nos períodos da tarde e da noite) inicialmente planejados para desenvolvimento em conjunto com a Biblioteca Belmonte, conforme as suas demandas de público e de atividade e em articulação com as 
escolas públicas do entorno: EE Alberto Conte e EMEFM Prof. Linneu Prestes, foram realizados 29 encontros, incluindo aqueles relacionados aos ensaios para as apresentações da abertura da mostra com alguns dos bens inventariados em 2015 e às suas novas exibições, em 2016, como também as atividades de recepção de visitantes e de elaboração do projeto de continuidade em 2016; os quais, inclusive, a partir de outubro de 2015, estenderam para outros espaços locais, como o CETRASA, Casa Amarela e a Casa de Cultura de Santo Amaro, e continuaram nos meses de dezembro de 2015 e janeiro e fevereiro de 2016.

Nesses encontros, dentre as ações educativas e de aprendizagem social desenvolvidas, a partir da adoção de ferramentas participativas, visando consolidar o caráter participativo e de produção coletiva de conhecimento dessa pesquisa-ação e de seu inventário comunitário de bens culturais, os participantes:

1) organizaram-se em Grupos de Trabalho e se juntaram aos demais integrantes das turmas de dança vocacional da Casa Amarela, como, por exemplo, o Grupo Yellow, para as pesquisas, intervenções e apresentações;

2) participaram de atividades de caminhada fotográfica pelo Eixo Histórico de Santo Amaro e outros 'lugares de memória", como o Museu de Santo Amaro/CETRASA, revelando diversos costumes e histórias relacionadas aos objetos e às peças do acervo expostos;

3) buscaram, levantaram, expuseram e exibiram fotos e outros itens das suas coleções particulares, acompanhados de narrativas;

4) compartilharam seus saberes e habilidades especiais, como também valores e modos de ser;

5) promoveram buscas de materiais sobre Santo Amaro, convidando amigos e familiares para participação na pesquisa participativa com depoimentos e histórias de vida associadas à região;

6) participaram da elaboração e curadoria da primeira mostra dos bens culturais pesquisados e identificados, preparando um espetáculo envolvendo dança, teatro e música para a abertura, que resultou em muitos ensaios;

7) conceberam em conjunto com os gestores de dois espaços culturais locais de novas apresentações e exibições (no formato de saraus), para as atividades de aniversário de Santo Amaro e para a visitação acompanhada de grupos atendidos por instituições sociais da região, de estudantes de escolas do entorno e de familiares e amigos à primeira Mostra; 
8) promoveram manifestos (proposta de abaixo assinados, por exemplo) e colaboraram em performances artísticas a favor dos patrimônios locais;

9) participaram da elaboração, preparação e inscrição do projeto em edital da Secretaria Municipal de Cultura da Prefeitura de São Paulo.

\subsubsection{Do planejamento dos Encontros à formação do seu Grupo de Trabalho e de Ação}

Prezado(a),

São Paulo, 13 de agosto de 2015.

O LAPPES - Laboratório de Pesquisa e Práticas em Educação e Sustentabilidade do IEE/USP, em parceria com a Coordenadoria de Cultura da Subprefeitura de Santo Amaro, convida para participação no Projeto Diálogos entre Patrimônio, Meio Ambiente e Aprendizagem Social.

O Projeto é caracterizado por parcerias com instituições da região para realização de encontros sobre Memória e Patrimônio Cultural de Santo Amaro, que objetivam, com base em metodologias participativas e processos de aprendizagem social, o desenvolvimento de um Inventário Comunitário de Bens Culturais e de uma Mostra Educativa desses bens culturais inventariados pela comunidade local e/ou escolar, voltados para o empoderamento e fortalecimento de ações e saberes locais relacionadas à questão patrimonial.

A Mostra Educativa com o formato de totens com textos e fotografias e composta pelos bens culturais inventariados nos Encontros, ao lado de objetos da cultura popular da coleção da Biblioteca Temática Belmonte e de outros acervos locais, itinerará em espaços da região, de acordo também com as parcerias estabelecidas, visando sensibilizar a todos sobre os cuidados e a corresponsabilidade na preservação e proteção de bens culturais locais, como também chamar à atenção para a riqueza patrimonial da região de Santo Amaro.

O primeiro Encontro Memória e Patrimônio Cultural de Santo Amaro: Conversando sobre Arqueologia, Memória, Patrimônio Cultural, Identidade e História de Santo Amaro será no próximo dia 25 de agosto (terça-feira), às 14h30, na Biblioteca Belmonte, e voltado para Grupos da Terceira Idade participantes das atividades promovidas pela Casa de Cultura de Santo Amaro, dentre outros grupos e interessados, que estão sendo convidados a compartilhar suas lembranças, recordações, memórias e histórias de Santo Amaro, a partir de objetos, fotografias e qualquer outro documento importante.

Saudações.

(Texto da Carta-Convite encaminhada pela pesquisadora às instituições parceiras locais)

As ações de concepção e planejamento dos Encontros foram desenvolvidas por intermédio de reuniões com agentes e gestores culturais das instituições e dos aparelhos públicos da região com (e alguns ainda sem) parceira estabelecida em 2013; conversas informais e bate papos com os frequentadores de oficinas e cursos promovidos por essas e 
outras instituições de Santo Amaro sobre horários e sugestão de espaços para os encontros; e falas, comunicações e acompanhamento/participação em eventos locais com a distribuição de convites e inscrição de interessados.
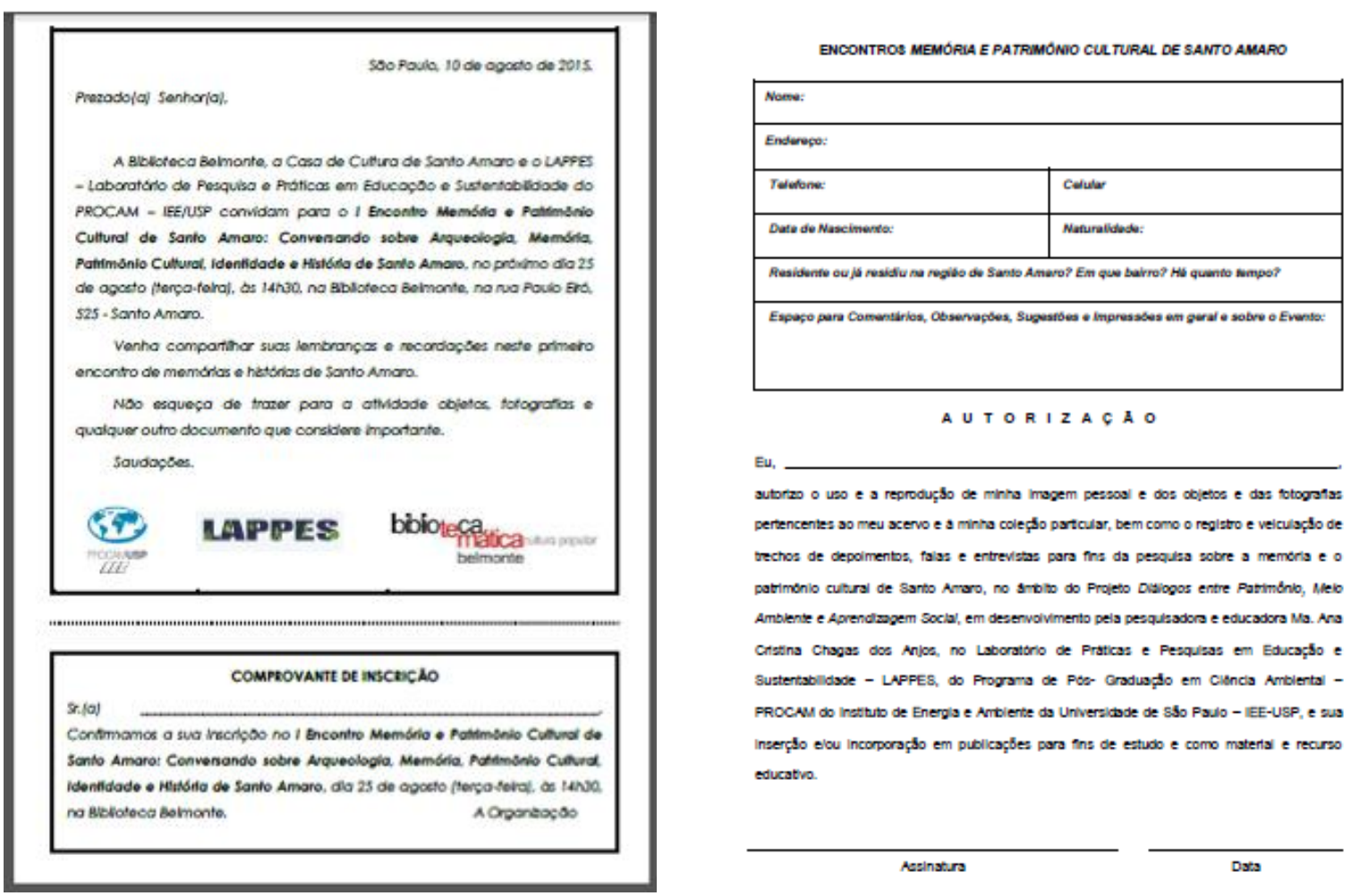

Figuras 88 e 89. Convite com Comprovante de Inscrição e Ficha de Inscrição acompanhada do Termo de Autorização de Uso de Imagem preenchida por cada participante.

A partir dessas reuniões e ações de divulgação, consultas, convívio, esclarecimento e envolvimento do público frequentador das programações culturais dos aparelhos públicos da região (Casa de Cultura de Santo Amaro, Biblioteca Belmonte, Biblioteca Prestes Maia, Casa Amarela, Rede Santo Amaro) para a formatação dos Encontros, que os Encontros foram planejados com periodicidade mensal e com realização nos períodos da tarde e noite, distribuídos em dois dias da semana, de forma a contemplar a diversidade de público dessas instituições: formadores de opinião/agentes culturais, integrantes de Grupos da Terceira Idade, crianças e jovens e seus pais e familiares, como também permitir a participação de adultos fora do horário de trabalho e estudantes do horário noturno de cursos de EJA de escolas do entorno. 


\section{ENCONTROS MEMÓRIA E PATRIMÔNIO CULTURAL DE SANTO AMARO}

Figura 90. Tela de abertura dos slides utilizados nos Encontros da pesquisa-ação desenvolvidos.

O público da Terceira Idade e os adultos moradores da região e também trabalhadores e estudantes em Santo Amaro, que, nas atividades educativas voltadas para a comunidade em geral de 2013, pareceram melhor representar a característica de ocupação histórica do município e depois bairro por imigrantes estrangeiros e por brasileiros que migraram de outras localidades do país atraídos pelo pólo industrial ali instalado nos anos 1960 e 1970, foram o foco nessa etapa da pesquisa-ação, de modo a possibilitar um conhecimento mais abrangente dos bens culturais da região no processo de inventário, além do público escolar também incorporado nessas novas atividades.

[...] Ensinar o respeito ao passado, mais do que sua simples valorização, é contribuir para a formação de uma sociedade mais sensível e apta a construir um futuro menos predatório e descartável, menos submetido à lógica econômica de um mercado cada vez mais voltado para os jovens, seus hábitos e seus gostos (ou a falta ou volatilidade destes). É construir uma sociedade que respeite seus velhos como portadores de saberes e tradições que precisam e devem ser reinventados ou transmitidos, em sua integridade, às gerações futuras. Uma sociedade culta é uma sociedade cultivada, seja pelos meios formais de educação - a escola -, seja pelos informais - a famílias, os mestres, as práticas sociais etc. E será culta, no sentido mais amplo de portadora de uma cultura, na medida em que for capaz de escolher no passado e no presente, aqueles - objetos, signos, pessoas, tradições etc. - com os quais quer construir sua linha do tempo no mundo (CASCO, s/d, p.3)

O primeiro Encontro foi realizado no dia 25 de agosto, na Biblioteca Belmonte e dele participaram: 4 agentes culturais locais, 3 moradores tradicionais de Santo Amaro e 4 com residência na região, integrantes de um dos Grupos da Terceira Idade de destaque de Santo Amaro - o Grupo Anos Dourados - e participantes do Curso de Dança Vocacional, promovido pela Casa Amarela (duas das participantes acompanhadas por suas filhas). 


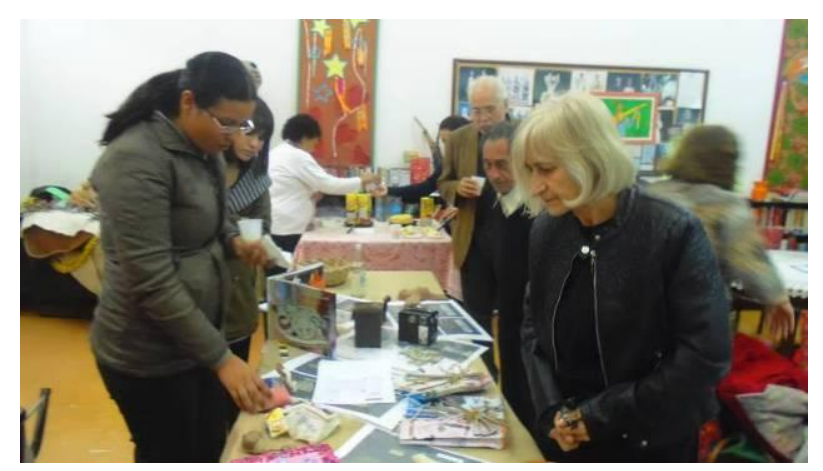

Figura 91. Participantes observando os objetos e pranchas com imagens ampliadas (recursos patrimoniais e educativos) no primeiro Encontro. Foto da autora.

No Encontro, os agentes culturais e os moradores de Santo Amaro e da região participantes experienciaram o processo de identificação e eleição de bens culturais a partir da dinâmica Exercício do Objeto: Objeto Significativo.

Depois da apresentação da proposta do projeto de realização de uma pesquisa participativa sobre os bens culturais de Santo Amaro, que estava sendo chamada de Inventário Comunitário e Escolar de Bens Culturais; dos antecedentes do projeto: as atividades educativas desenvolvidas nas escolas e nos espaços culturais em 2013, por ocasião das obras do Metrô da Linha 5; de alguns dos resultados da escavação arqueológica implementada também em 2013 e da sugestão de programação para o encontro, a primeira oficina foi iniciada, solicitando aos participantes a escolha de pelo menos 3 objetos e/ou fotografias expostas em mesas do espaço com o acervo de cultura popular da biblioteca. Cada participante, indagado sobre os motivos da escolha dos itens, compartilhou com todos as razões e quais outros objetos relacionados à sua história e vida na região poderiam também ser incorporados à atividade e trazidos num próximo encontro. (Extraído do Caderno de Anotações da pesquisadora)

Escolhi o FERRO DE PASSAR. Sou do tempo desse ferro de passar. Como era horrível, cheio de carvão. Tinha que assoprar e saía muita fumaça.

Também escolhi a foto do Colégio Paulo Eiró. Conheci muita gente que estudou lá, inclusive, o meu marido que dizia: - EU ESTUDO NO COLÉGIO PAULO EIRÓ, ONDE ENTRA BURRO E SAI COIÓ... E brincava.

[sobre a lamparina]: Meu pai tinha uma carvoaria ali. Nós, com 8 anos, meu pai fazia entregarmos carvão e querosene. Não tinha luz, não tinha ônibus, não tinha nada.

Era uma vida sofrida. Hoje tudo é moderno. Hoje tem máquina de lavar, tem secadora... Naquela época, as mulheres sofriam. Aquele lençol branco! Lembro da minha mãe pondo para quarar e depois para enxaguar tinha que por anil para ficar branco.

(Trechos extraídos das falas dos participantes nas atividades. Os destaques são de autoria da pesquisadora).

Na dinâmica, os participantes falaram de suas histórias de vida por meio dos referidos recursos patrimoniais e educativos expostos e perceberam existir convergências entre eles: histórias e memórias individuais semelhantes; conhecimento em comum de costumes, 
manifestações e festividades tradicionais de Santo Amaro; convivência com personagens da região; acompanhamento de fatos e acontecimentos locais de destaque, entre outros.

Infelizmente, no Brasil - seja na perspectiva da Antropologia ou na da Arqueologia, pouca atenção tem sido dada às experiências de ensino-aprendizado que buscam a valorização dos bens patrimonializáveis pelas comunidades nas quais os mesmos desempenham algum papel em sua dinâmica cultural, mas especificamente aquelas tentativas de envolver as pessoas que convivem diariamente com os bens a serem conservados em projetos de desenvolvimento a fim de que considerem os seus saberes e fazeres acumulados ao longo do tempo e suas relações com os patrimônios como relevantes para o próprio âmbito da conservação (SILVEIRA; BEZERRA, 2007, p.86).

O exercício, assim como as outras atividades de Educação Patrimonial conduzidas de forma participativa (Mapa Patrimonial, Fotografando Santo Amaro, Visita ao CETRASA, Curadoria Educativa) nos demais Encontros, resultou numa expressiva aproximação dos participantes, gerando a formação de um Grupo de Trabalho. Isto possibilitou a continuidade das atividades, com a realização de novos encontros, que passaram a ter sua periodicidade alterada de mensal para semanal (com até dois encontros por semana), colaborando sobremaneira para a efetivação da pesquisa-ação e seu inventário.

Objetos como o ferro de passar e a panela de ferro permitiram um processo de ensino e aprendizagem entre a geração que os utilizou e conhecia o cotidiano difícil em que esses objetos se inseriam e aquela que os escolheu porque: '[...] acho bonita e dizem que a comida fica mais saborosa. Quanto a isso não posso afirmar, pois vivo na era das coisas descartáveis até panelas'. As participantes com mais idade deram uma verdadeira aula de como se utilizava o ferro de passar roupa as mais jovens. (Extraído do Caderno de Anotações da pesquisadora)

A cada novo encontro o Grupo de Trabalho levava colegas e familiares interessados em participar da pesquisa, como também objetos e fotografias do seu acervo pessoal para as atividades de inventário:

Todo um complexo sistema de relações e conexões está contido em um simples objeto de uso cotidiano, uma edificação, um conjunto de habitações, uma cidade, uma paisagem, uma manifestação popular, festiva ou religiosa, ou até mesmo em um pequeno fragmento de cerâmica originário de um sítio arqueológico (HORTA et.al., 1999, p.9). 

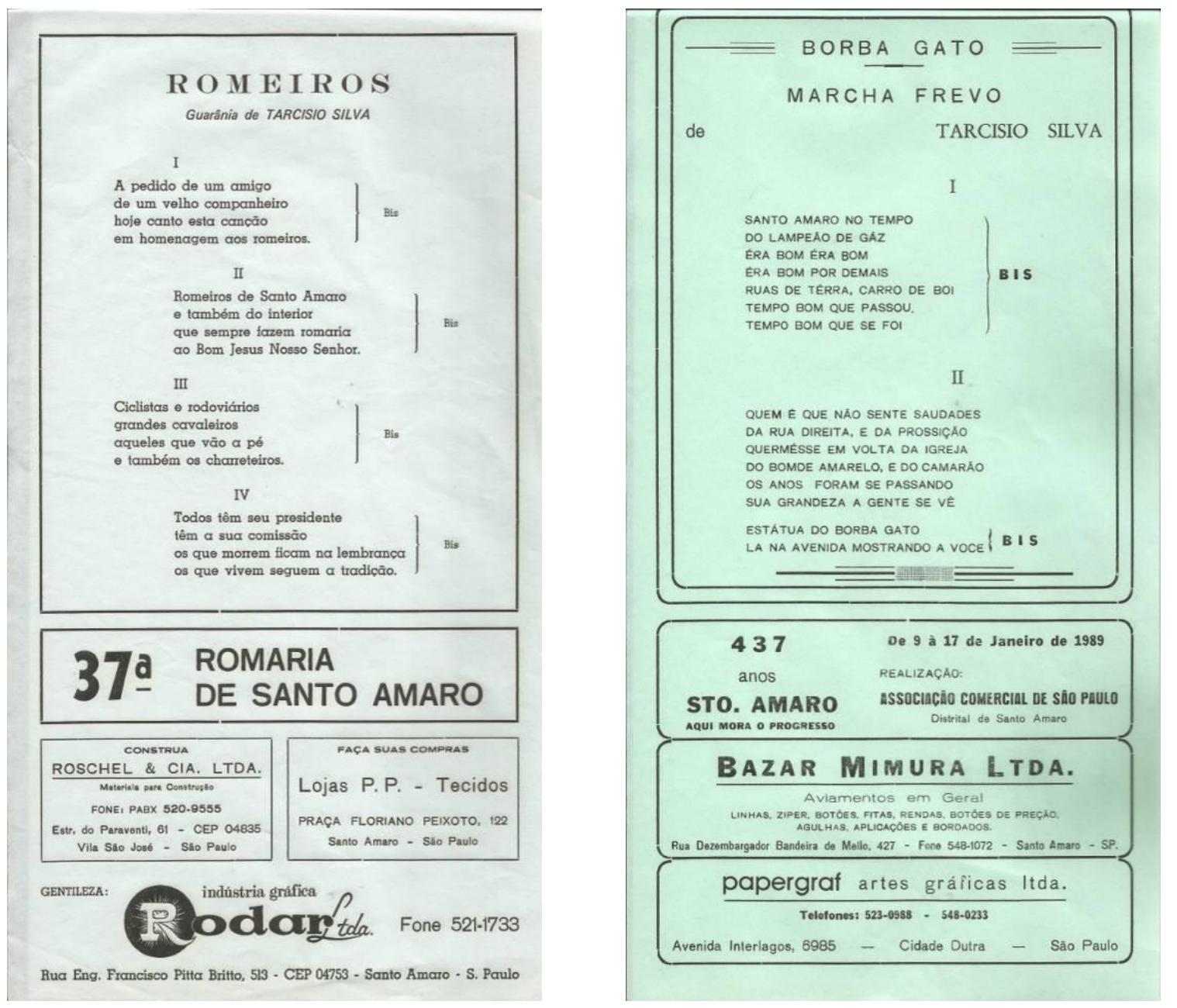

Figuras 92 e 93. Letras de canções sobre dois bens patrimoniais de Santo Amaro: Borba Gato e Romaria, de autoria do Sr. Tarcísio Silva, compositor e morador tradicional do bairro, participante do Grupo de Trabalho, apresentadas e cantadas nos Encontros.

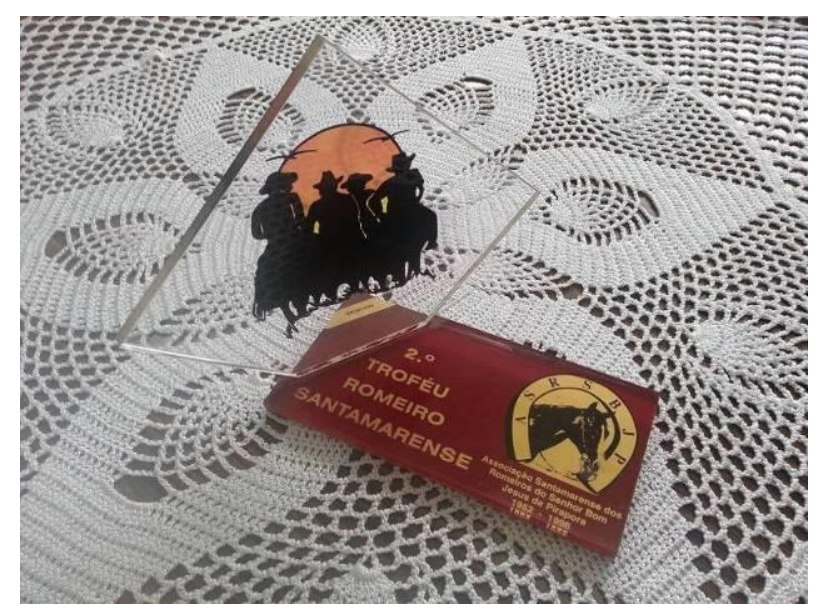

Figura 94. Troféu Romeiro Santamarense recebido pelo Sr. Tarcísio Silva levado por ele junto de suas composições para os Encontros. Foto da autora. 


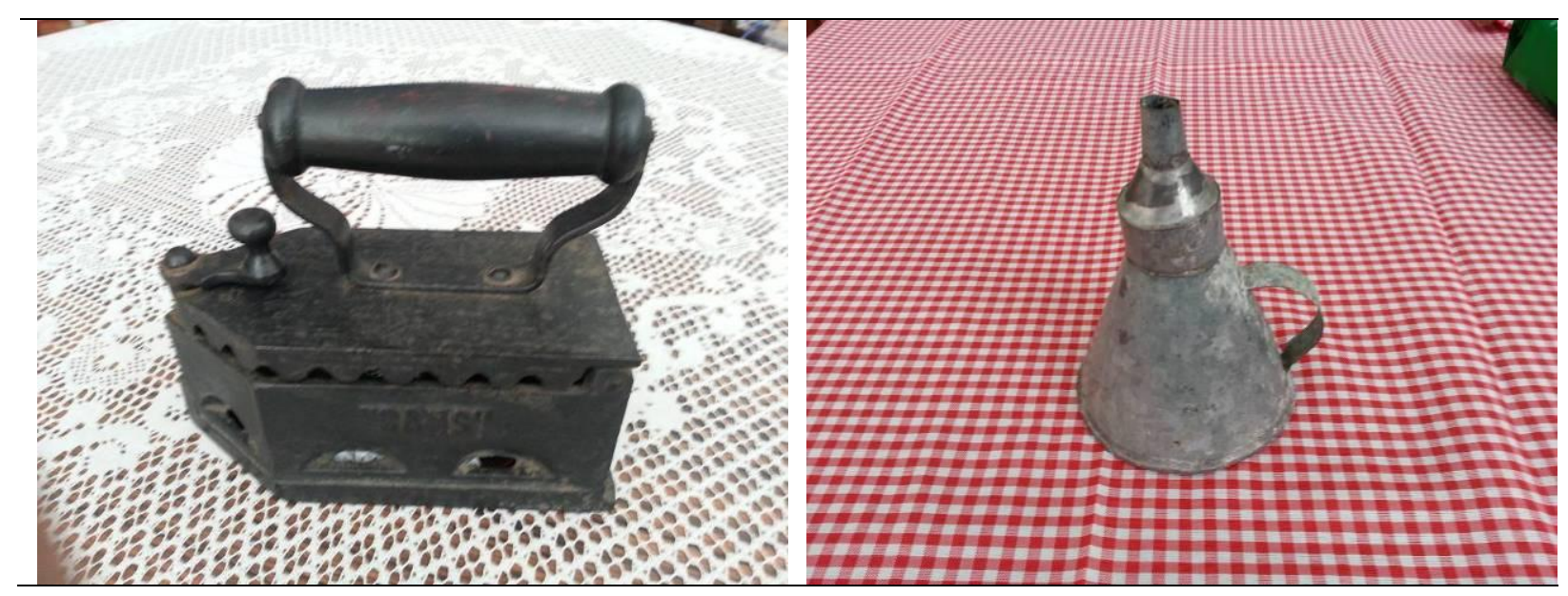

Figuras 95 e 96. Ferro de passar e lamparina incorporados também pelos participantes aos objetos utilizados como recursos patrimoniais e educativos nas oficinas de Educação Patrimonial dos Encontros. Fotos da autora.

Os exercícios das oficinas de Educação Patrimonial, desde o primeiro encontro, demonstraram aos participantes que suas narrativas apresentavam origens e histórias de vida semelhantes e, por essa razão, coletivas.

Quando os presentes justificavam as motivações que levaram a escolher um determinado objeto, é que as histórias se cruzavam. Foi assim com a história da uma benzedeira que morava próximo ao hoje Shopping Boa Vista, que era conhecida pelas participantes: D. Cida, D. Irene e pela Dorinha. (Extraído do Caderno de Anotações da pesquisadora).

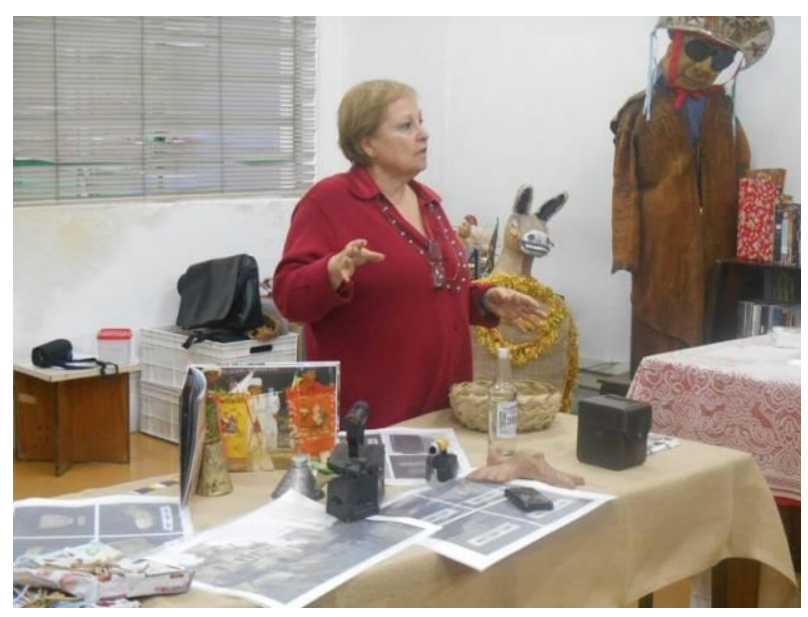

Figura 97. A participante Dorinha com os objetos e fotografias expostos narrando sobre a história da benzedeira D. Paula no Encontro. Foto da autora.

D. Paula benzia com uma machadinha. (...) Ela morava no fundo de quintal. Na primeira ou segunda casa na Barão de Duprat, ali perto do Shopping [Shopping Boa Vista] (...) Era uma senhorinha pequenininha. Ela batia na porta e benzia com uma machadinha. (...) Eu trabalhei, durante 9 anos eu fui chefe daquela junta militar ali na Rua Darwin. (...) Todo mundo da Junta ia lá na D. Paula e levava um quilo de açúcar. Ela gostava de sopinha de pacote. Todo mundo que ia lá se benzer na D. Paula ia lá com um saquinho. Ela vivia das coisinhas que levavam. Ela adorava quando a gente levava leite em pó. Ela vivia sozinha. Ela morava lá no fundo. D. Paula era a super estar do bairro. Muita gente deve saber dela. (Dorinha). 
Eu levava os meus filhos para benzer. Era uma senhorinha que morava nos fundos... (D. Irene Kiss). (Trechos extraídos dos textos e falas produzidos pelos participantes).

Ao considerar o objeto também como fonte de informação sobre as relações sociais e o contexto em que foram produzidos e utilizados, as oficinas de Educação Patrimonial: construção dos "mapas patrimoniais" e visitas acompanhadas ou não da atividade de fotografia ao Eixo Histórico de Santo Amaro, ao CETRASA e a outros lugares significativos (inclusive, ressignificados) da região (na atividade fotografando Santo Amaro, as participantes quiseram registrar o Centro da Cidadania da Mulher - Santo Amaro, que ocupa hoje a área do antigo Colégio Paulo Eiró, frequentado por elas), por exemplo, foram conduzidas nos Encontros toda semana. E possibilitaram a continuidade na exploração teórica e prática das dimensões material e imaterial do patrimônio cultural de Santo Amaro e suas categorias para ações de Registro (especialmente daqueles bens imateriais) e na explicitação das histórias de vida e dos conhecimentos de cada um dos participantes, tecendo relações e conexões entre eles.

"Tudo o que acontece no dia a dia daria para contar? Seria história? As minhas lembranças do passado, aquilo que eu conheci poderia servir para alguma coisa? Sim, descobri que as minhas recordações fazem parte de uma história não oficial, mas viva, pois eu estava lá enquanto a história oficial acontecia (...) apesar de não participar de nenhum grupo engajado com as tradições do bairro, aqui vivi e vivo e então percebi o quanto a minha vida e ele estão totalmente entrelaçados."

Sr. a Romilda, que morou em Santo Amaro de 1958 a 1962; quando se casou, foi morar na Chácara Santo Antônio.
“(...) O que nos permite voltar ao passado é o contato com uma foto antiga, a receita de um livro antigo de cozinha envelhecido pelo tempo, ou mesmo o modelo de um traje parecido ou com a mesma cor de quando éramos crianças. Até mesmo o sabor ou cheiro nos parece que ainda conseguimos senti-los, dos pratos preparados no passado por nossas mães e avós."

Sra. Neusa mais uma vez!

Figuras 98 e 99. Slides utilizados no segundo Encontro que apresentaram as categorias para o Registro oficial de bens culturais imateriais. 


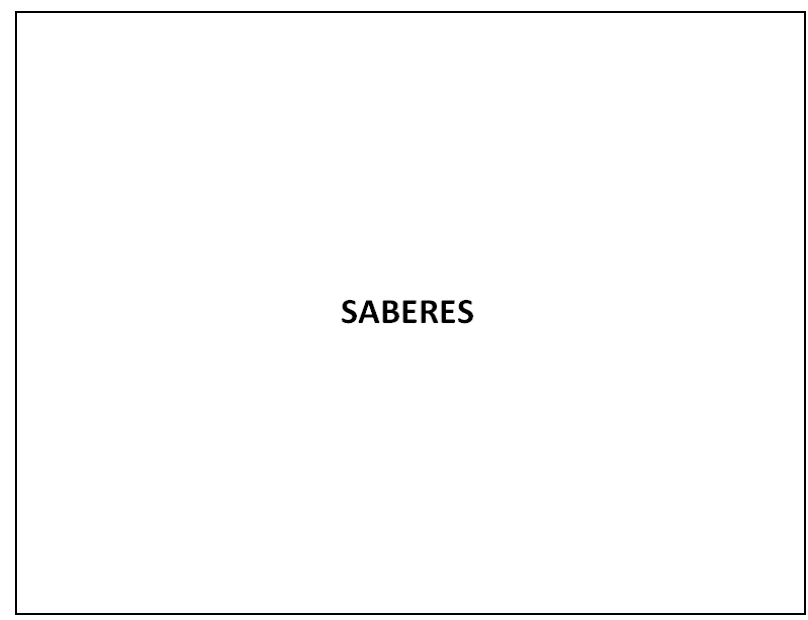

Figura 100. Slide utilizado no segundo Encontro que apresentou as categorias para o Registro oficial de bens culturais imateriais.

Meneses (1992, p.189) destaca que falar de patrimônio cultural é falar de valores, os quais, por serem atribuídos, "são sempre historicamente marcados" e exigem o conhecimento “das redes de interação por intermédio dos quais são produzidos, armazenados, postos em circulação, consumidos, reciclados e descartados os valores"; por intermédio das "coisas materiais", que desempenham papel de enorme relevância, que "os indivíduos e grupos sociais categorizam os fenômenos, as formas de relação, as instituições, as pessoas, sinalizando e qualificando, negativa ou positivamente, induzindo, enfim, a uma determinada repartição de direitos e obrigações", tratando-se de uma atividade "concreta, prática política".

No exercício do Mapa Patrimonial, de reconhecimento do território de vida e dos "lugares de memória" (NORA, 1993) do segundo Encontro, os participantes foram divididos em duplas e retrataram em cartolina, com giz de cera e lápis de cor, aqueles elementos que consideravam representativos do patrimônio cultural de Santo Amaro, embora ainda muito relacionados aos bens culturais que fazem parte do Eixo Histórico de Santo Amaro tombado.

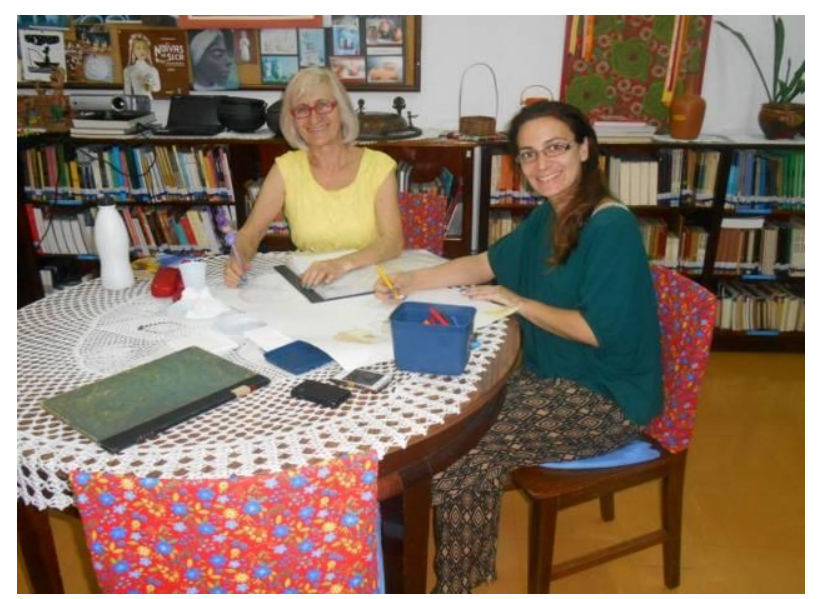




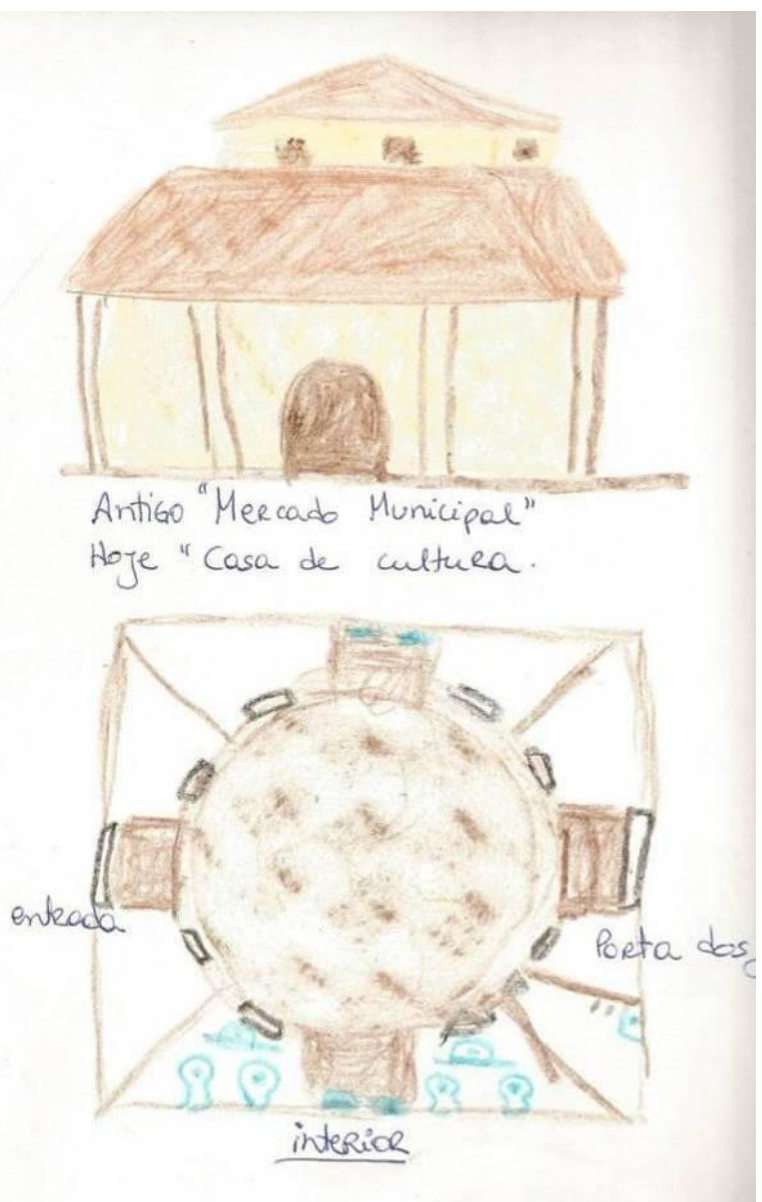

Figuras 101 e 103. D. Cida e sua filha Vanessa na atividade e a representação que fizeram da Casa de Cultura de Santo Amaro, local no qual juntas participam de diversos cursos e oficinas. Fotos da autora.

Divididos em duplas, os participantes desenharam os elementos que, para eles, representavam o patrimônio do lugar em que vivem, ou seja, aquilo que consideravam os importantes patrimônios de Santo Amaro. Cada grupo apresentou seu desenho e os motivos pelos quais foram retratados aqueles elementos desenhados. No exercício, o desenho facilitou a exposição das ideias e foi resultado de uma discussão e negociação (um acordo) do que a dupla ia representar. (Extraído do Caderno de Anotações da pesquisadora)
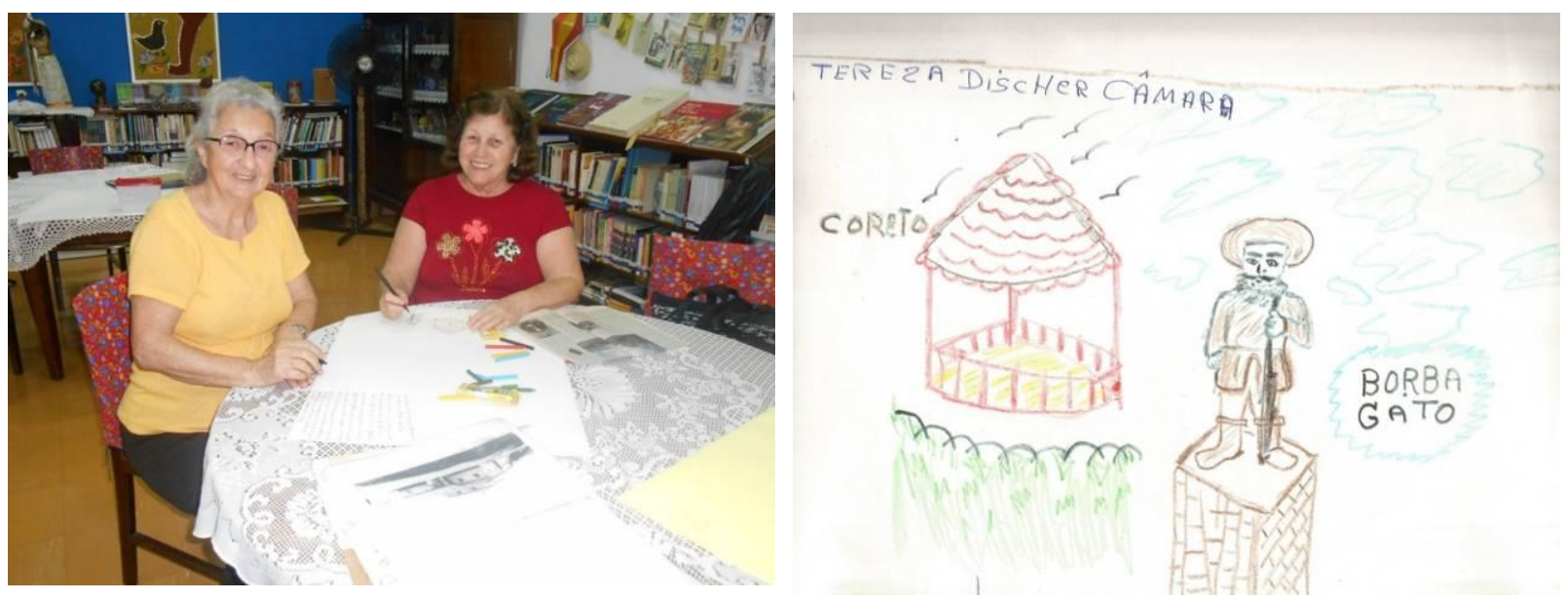
Figuras 104 e 105. D. Teresa Discher Câmara e D. Irene Kiss produzindo o mapa em conjunto e o desenho preparado pela D. Teresa Discher Câmara, retratando a estátua de Borba Gato e o coreto da Praça Floriano Peixoto.

Falar de Santo Amaro tem que falar do Borba Gato. Tem muitas ruas. Tem Bartolomeu de Gusmão. Como é o outro? Manoel Borba, Manoel Feijó...Todos nomes de bandeirantes. Minha sogra gostava muito. Ela sempre falava do Borba Gato e desses bandeirantes. Tem um deles que não lembro direito. Ele significa Deus do Fogo. Para ele assustar os índios, ele punha fogo no álcool e falava que ia por fogo no rio. Os índios ficavam apavorados pensando que ele ia por fogo nos rios. Ela gostava de contar essa história, dos bandeirantes. D. Teresa Discher Câmara. (Trecho transcrito das falas dos participantes nas atividades).

Ecléa Bosi (1992, p.147) destaca que os bairros têm não somente uma fisionomia como também uma biografia:

O bairro tem sua infância, juventude e velhice. [...]. Nas histórias de vida podemos acompanhar as transformações do espaço urbano: a relva que cresce livre, a ponte lançada sobre o córrego, a divisão dos terrenos, a primeira venda, o primeiro bazar. As casas crescem do chão e vão mudando: canteiros, cercas, muros, escadas, cores novas, a terra vermelha e depois o verde umbroso. Arbustos e depois árvores, calçadas, esquinas...

Outros dois Encontros foram caracterizados por visitas aos "lugares de memória" (NORA, 1993) de Santo Amaro, alguns retratados nos Mapas Patrimoniais, como os elementos componentes do Eixo Histórico de Santo Amaro. Embora não representado, o Museu local (o Centro de Tradições de Santo Amaro), que apresenta a "biografia do bairro" (BOSI, 1992), também foi visitado pelos participantes.

Essas oficinas de Educação Patrimonial, conduzidas com ferramentas participativas, encerraram a primeira fase de planejamento e desenvolvimento inicial dos Encontros Memória e Patrimônio Cultural de Santo Amaro, e resultaram na formação e a consolidação do seu Grupo de Trabalho e de Ação.

As ações foram agregando mais e mais participantes, com a adesão espontânea de pessoas que já participavam de outras atividades nos espaços culturais locais, originando um grupo bastante coeso que prontamente identificou-se com a proposta dos Encontros: de fomentar uma ação cultural e educativa que trabalhasse a memória e o patrimônio cultural de Santo Amaro não como algo acabado ou já definido - congelado - como verdade por memorialistas e especialistas, mas uma memória e história de Santo Amaro concebidas - no calor - na história de vida dos participantes, que agregassem diversos olhares e concepções, que trouxessem tanto a memória dos primeiros colonos, dos imigrantes alemães e de outras nacionalidades, dos migrantes de outros Estados, em especial nordestinos que migraram nos anos 60 e 70 em busca de melhores condições de vida na indústria local nascente, ou daqueles nascidos na região. Uma memória e história que nunca se encontra pronta, mas que é continuamente reelaborada, revivida e repensada a luz do cotidiano de vida e do diálogo com a memória de outros participantes, gestada e reelaborada no contexto das atividades propostas e que pudesse ser compartilhada com outras pessoas e grupos da região, crianças, jovens e adultos, a luz de metodologias participativas. Foi assim que os Encontros ganharam vida e receberam a participação de mais pessoas e, inclusive de inúmeros integrantes do Grupo de Terceira Idade Anos Dourados da Casa de Cultura de Santo Amaro, 
incorporando às suas ações que contabilizam mais de 15 anos. (Trechos extraídos do Projeto Encontros, Memória e Patrimônio Cultural de Santo Amaro para sua continuidade via Programa VAI da SMC)
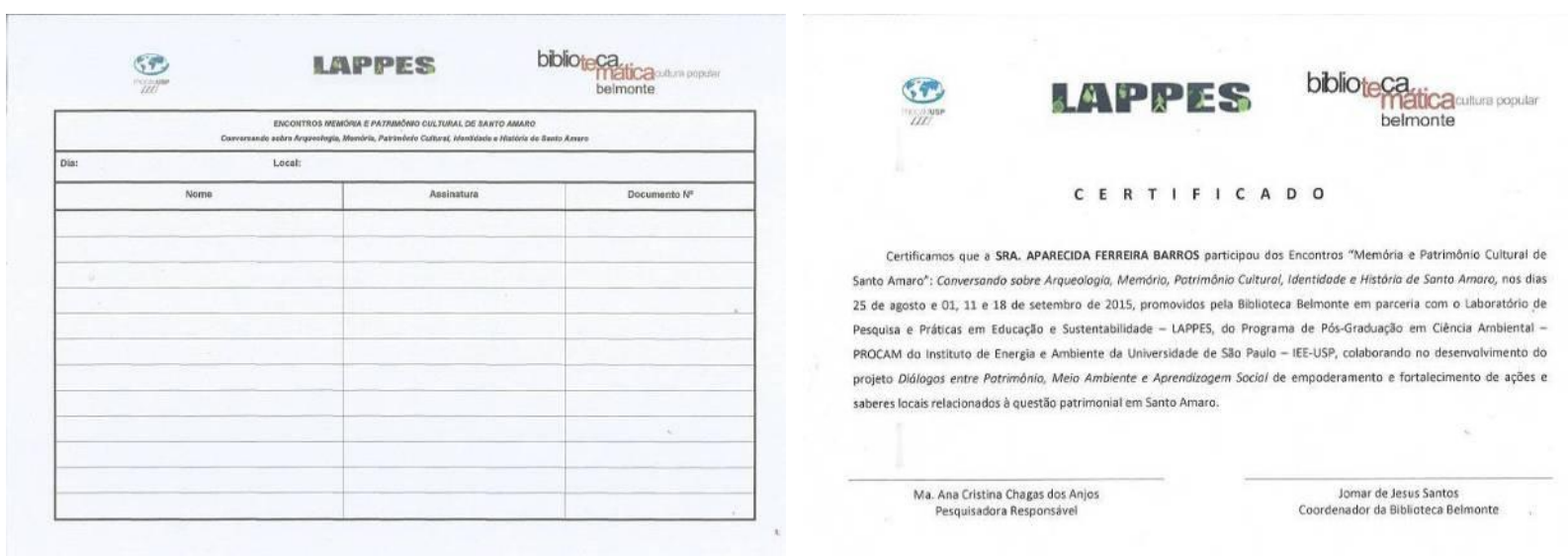

Figuras 106 e 107. Modelo da Lista de Presença e do Certificado (também nos Anexos).

A atividade começou com a explicação da proposta de realização em dois ou mais Encontros de passeios pela região de forma a produzir material (fotografias) para uma exposição sobre o patrimônio cultural de Santo Amaro. As participantes mulheres quiseram iniciar a atividade fotografando o Centro da Cidadania da Mulher, construído onde era o Colégio Paulo Eiró, pela importância que atribuem à entidade. É o local onde realizam diversos cursos e onde conhecem histórias de vida de mulheres semelhantes aquelas que viveram no passado. Depois de percorrerem a parte superior do centro histórico de Santo Amaro (da Casa Amarela na Praça Floriano Peixoto até a Igreja Matriz, que foram retratados), o Sr. Tarcísio manifestou interesse em levar o grupo para a entrada da nova estação Largo Treze e mostrar que sua casa ficava no terreno ao lado. (Extraído do Caderno de Anotações da pesquisadora).
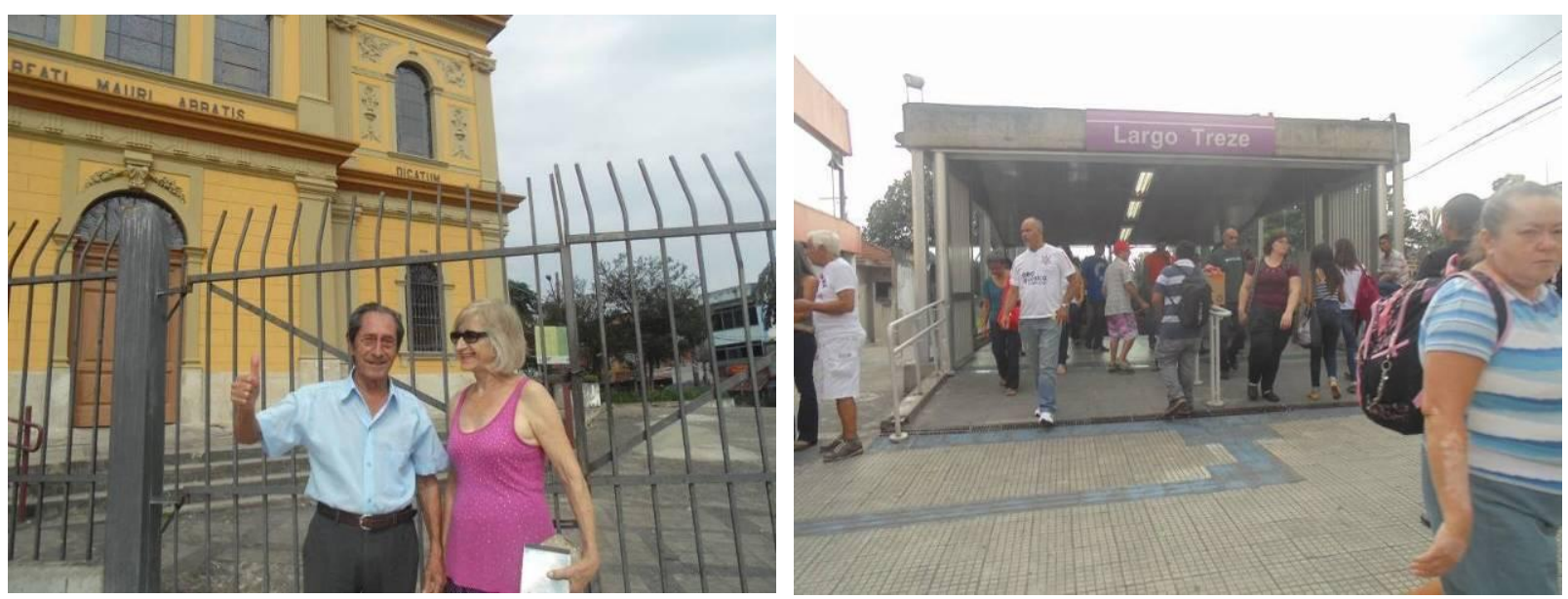

Figuras 108 e 109. Sr. Tarcísio Silva e D. Aparecida Barros (D. Cida) junto à Igreja Matriz muito fotografada pelos participantes por ter sido palco de seus batizados e de seus filhos e de seus respectivos casamentos e a visita à Estação Largo Treze do Metrô também retratada na atividade. Fotos da autora.

Eu brincava de carrinho aqui. E foi aqui que quando tinha 6 anos, vi pela janela um monte de "escoteiros". E quando perguntei pra minha mãe o que era e ela me disse que era uma concentração. E na verdade era a Revolução de 1932. Sr. Tarcísio Silva. (Trecho transcrito das narrativas produzidas pelos participantes nas atividades) 

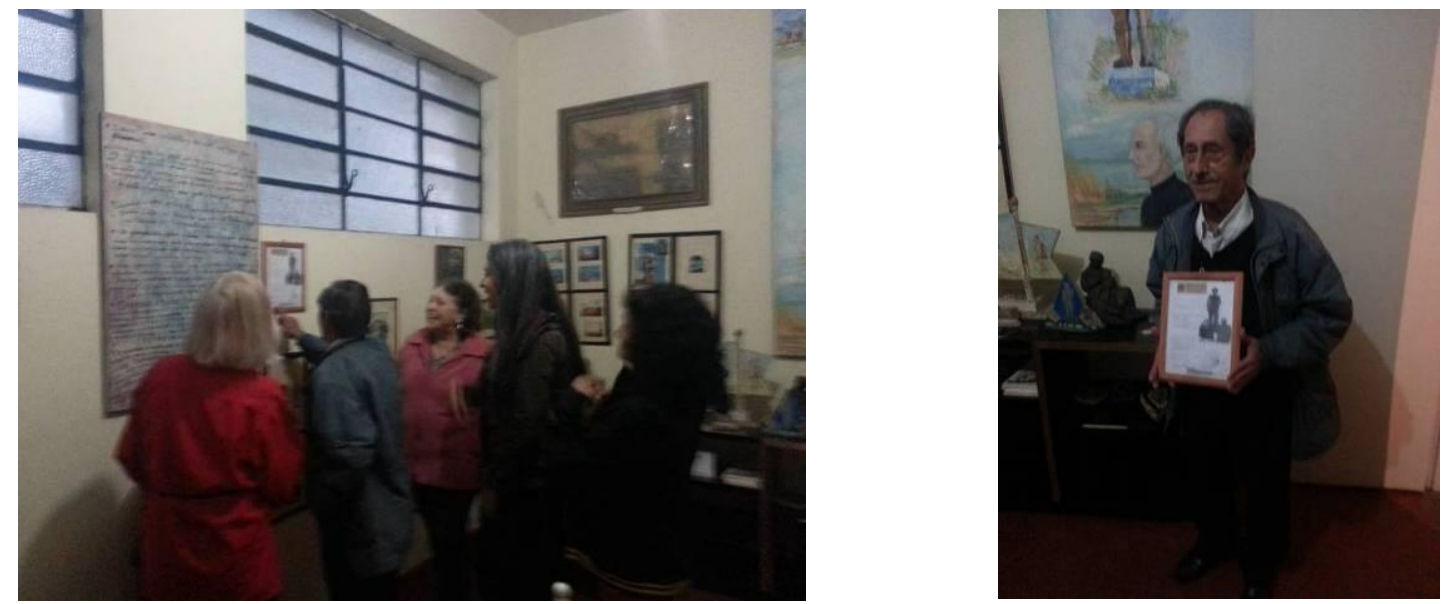

Figuras 110 e 111. Grupo de participantes na visita ao CETRASA identificando a composição do Sr. Tarcísio Silva sobre a estátua de Borba Gato na exposição permanente do acervo. Fotos da autora.

Bruno (1996) define herança como a consciência da existência do patrimônio. Ressalta que é na cadeia operatória da museologia, que o reconhecimento do patrimônio se dá a partir da sua preservação.

a musealização é um processo constituído por um conjunto de fatores e procedimentos que possibilitam que parcelas do patrimônio cultural se transformem em herança, na medida em que são alvo de preservação e comunicação (KASEKER, 2014, p.36).

Apoiada em práticas coletivas e colaborativas e metodologias participativas para capacitação, participação e exercício da cidadania, a atividade do Objeto Significativo também foi aplicada em dois outros Encontros planejados com os 135 alunos do Ensino Fundamental do curso Educação de Jovens e Adultos da EMEFM Prof. Linneu Prestes, por intermédio da articulação e convite da Biblioteca Belmonte; deles participaram os 5 alunos do curso de Dança Vocacional da Casa Amarela, chamado GrupoYellow.

$\mathrm{Na}$ fase de preparação e curadoria da Mostra Educativa dos Encontros que teve início em outubro de 2015, esses alunos, acompanhados pela professora Angélica Rovida, formaram o Grupo de Ação dos Encontros e se envolveram na defesa do patrimônio cultural local em geral de Santo Amaro e em especial da Casa Amarela - seu espaço/território de encontro e ressignifcado também por aqueles que participam das outras atividades educativo-culturais por ele promovidas. 

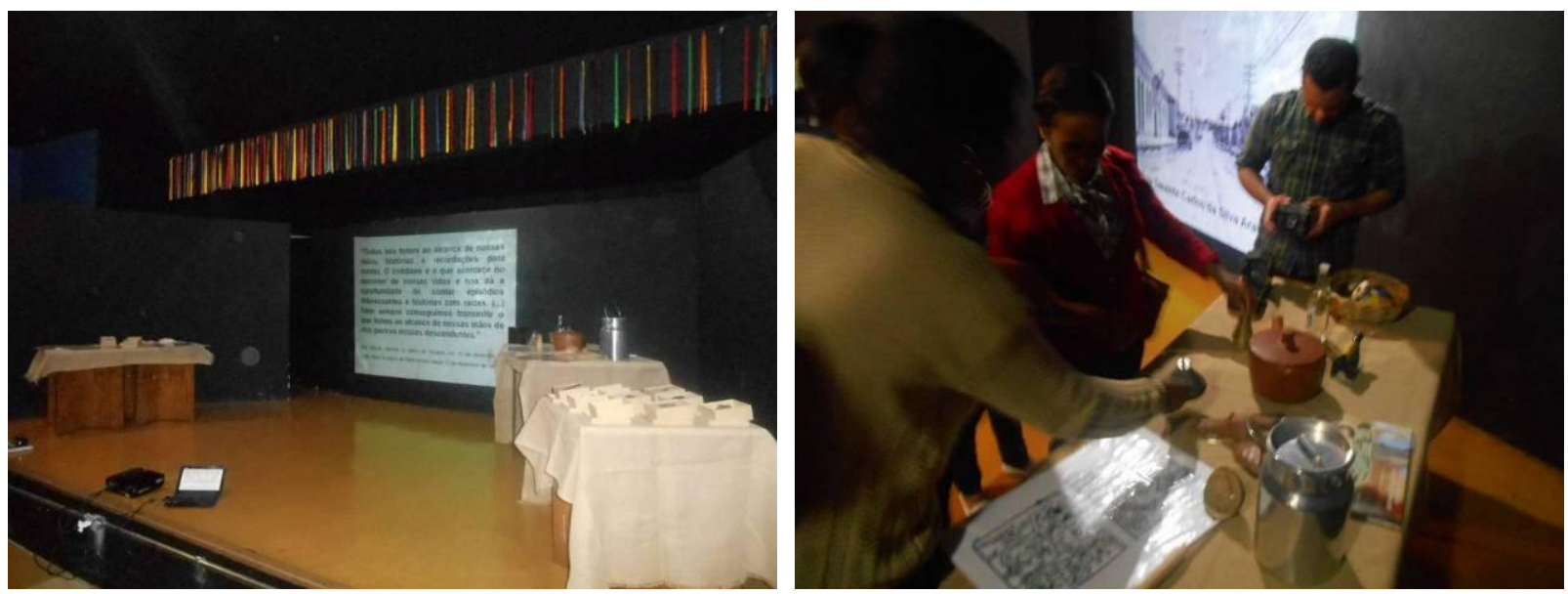

Figuras 112 e 113. Objetos e pranchas expostos e em utilização no Exercício do Objeto: Objeto Significativo com os alunos do EJA Ensino Fundamental e com os integrantes do curso noturno de Dança Vocacional da Casa Amarela (Grupo Yellow), no auditório da Biblioteca Belmonte. Fotos da autora.

\section{ENCONTRO COM ALUNOS DE EJA DE SANTO AMARO}

Outro encontro também desenvolvido no âmbito do projeto foi realizado no dia 26 de agosto, no auditório da Biblioteca Belmonte, no horário das $18 \mathrm{~h} 30$.

Participaram desse encontro 60 alunos do curso de Educação de Jovens e Adultos EJA da Escola Municipal de Ensino Fundamental e Médio Prof. Linneu Prestes.

Nesse encontro, também foram revelados diversos bens culturais de Santo Amaro, especialmente aqueles trazidos pelos alunos quando saíram das suas cidades de origem nas regiões Norte e Nordeste do país, que hoje fazem parte do universo patrimonial da região.

No próximo dia 16 de setembro, novamente às 19h30, no auditório da Biblioteca Belmonte, novas turmas de alunos do EJA participarão de outro Encontro Memória e Patrimônio Cultural de Santo Amaro: Conversando sobre Arqueologia, Memória, Patrimônio Cultural, Identidade e História de Santo Amaro.

Informações e inscrições:

Biblioteca pública Belmonte Temática em Cultura Popular

Rua Paulo Eiró, 525 - Santo Amaro

Tel.: 1156870408 .

(Trechos do texto de release sobre os Encontros com os alunos do EJA publicado no site do LAPPES, entre outros).

As oficinas de Educação Patrimonial desenvolvidas com as turmas do EJA, nos dois dias de Encontros, além de promoverem uma discussão sobre a importância de iniciativas da sociedade e de movimentos sociais de elencar e atribuir valores a bens para preservação e encaminhar propostas de tombamento e registros realizaram também um levantamento de referenciais afetivos na história da vida de cada um dos participantes e sua valorização como um bem cultural. 


\section{PATRIMÔNIO CULTURAL}

"Todos nós temos ao alcance de nossas mãos, histórias e recordações para contar. O cotidiano é o que acontece no decorrer de nossas vidas e nos dá a oportunidade de contar episódios interessantes e histórias com raízes. (...) Nem sempre conseguimos transmitir o que temos ao alcance de nossas mãos de rico para os nossos descendentes."

Sra. Neusa, nascida no bairro de Tatuapé, em 18 de dezembro de 1934. Mora no bairro de Santo Amaro desde 12 de dezembro de 1964.

Figuras 114 e 115. Slides sobre patrimônio imaterial utilizados para tratar do patrimônio cultural de Santo Amaro

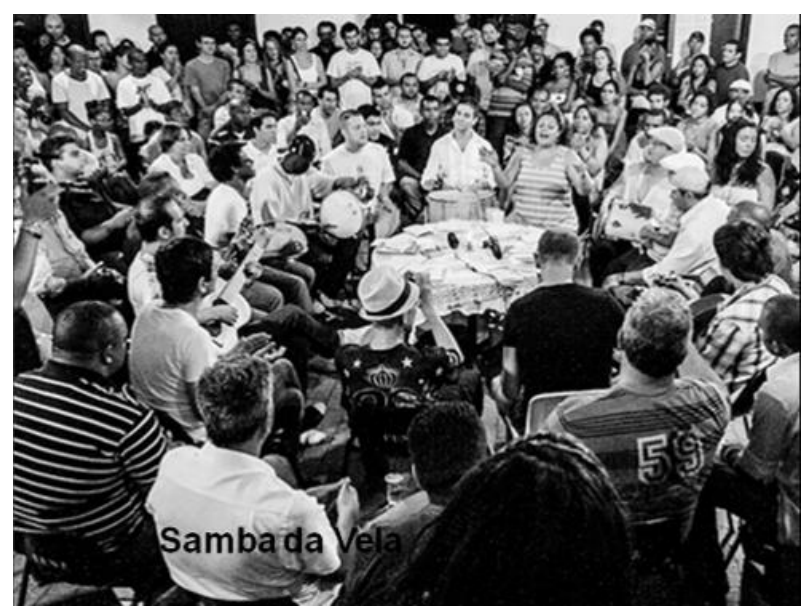

“(...) 0 que nos permite voltar ao passado é o contato com uma foto antiga, a receita de um livro antigo de cozinha envelhecido pelo tempo, ou mesmo o modelo de um traje parecido ou com a mesma cor de quando éramos crianças. Até mesmo o sabor ou cheiro nos parece que ainda conseguimos senti-los, dos pratos preparados no passado por nossas mães e avós."

Sra. Neusa mais uma vez!

Figuras 116 e 117. Slides sobre patrimônio imaterial utilizados para tratar do patrimônio cultural de Santo Amaro.

O objeto mais escolhido foi a leiteira. No compartilhamento dos motivos da escolha do objeto por cada um dos participantes que o selecionou foi possível estabelecer os laços entre os presentes, os quais, oriundos de diferentes partes do país, naquele momento, construíram uma unidade, já que aquele objeto e tantos outros coincidentes também foram apontados como parte da história de vida de muitos. Tratou-se de um objeto que foi importante para pessoas de idades e locais totalmente diferentes. (Trecho extraído do Caderno de Anotações da pesquisadora).

A quase totalidade dos presentes era das regiões Norte e Nordeste do país, com uma pequena parcela de pessoas advinda de Minas Gerais e cidades do interior de São Paulo. A grande maioria nascida e criada em casas rurais de taipa de mão e cujos utensílios domésticos eram produzidos na própria casa por mães, pais, avós e avôs.

A relação de valorização do bem patrimonial passou necessariamente pela história de vida e da memória relacionadas a cada um dos objetos exibidos e selecionados pelos participantes. A relação imediata com a infância foi feita pela grande parte dos participantes. (Trecho extraído do Caderno de Anotações da pesquisadora) 
A discussão da apropriação e da "adoção" de um novo local como território de vida estimulou os participantes a apresentar receitas culinárias e pratos típicos e antigos costumes como formas de fortalecer e tornar presentes a identidade e a memória do passado na construção de uma nova história em um novo lugar.

\begin{abstract}
A maioria conhecia ou participava do Samba da Vela às segundas-feiras, na Casa de Cultura de Santo Amaro; inclusive, a professora de Artes tinha feito uma visita com os alunos. Foram diversos os itens citados pelos participantes, especialmente da culinária nordestina: baião de dois; caldo de mocotó ou gogó, vaca atolada, buchada de bode, bodoque; aos quais atribuíram importância como bens patrimoniais.

As denominações dos pratos típicos e conhecidos pelos participantes variavam muito conforme a localidade, assim como os objetos expostos. Santo Amaro se revelou hospedando brasileiros de várias cidades do país: Piauí, Bahia, Maranhão, Fortaleza, que chegaram nos anos 1970 pelo bairro e pela região.

$\mathrm{Na}$ atividade, os presentes explicaram, inclusive, como se produzia a goma de polvilho doce para engomar a roupa passada com o ferro de brasa.

(Extraído do Caderno de Anotações da pesquisadora).
\end{abstract}

O uso de imagens impressas e ampliadas de bens patrimoniais de Santo Amaro, incluindo aquelas dos vestígios arqueológicos evidenciados na região, possibilitou também compartilhar informações sobre a Arqueologia na região, os aldeamentos indígenas e o modo de vida desses povos.

Dois objetos arqueológicos - duas lâminas de machado de diferentes tamanhos e peso - foram manuseados pelos participantes que indagaram sobre sua origem e usos. O exercício de levantamento de hipóteses possibilitou a vivência dos presentes sobre o exercício do arqueólogo na construção de possíveis definições e categorizações dos materiais arqueológicos e também os instigou a pensar sobre o tema; muitos se recordaram de ter encontrado objetos semelhantes durante sua vida (Trecho extraído do Caderno de Anotações da pesquisadora).

Esses Encontros deram início também a um novo projeto de Educação Patrimonial com a escola sobre o tema do patrimônio cultural de Santo Amaro, com Oficinas de Arqueologia voltadas para alunos do $8^{\circ}$. e $9^{\circ}$. do Ensino Fundamental e $1^{\circ}$. ano do Ensino Médio, envolvidos nas atividades de comemoração do aniversário da escola.

Prezada Professora,

Conforme conversado com a pesquisadora e educadora Ana Cristina Chagas dos Anjos, o Laboratório de Pesquisa e Práticas em Educação e Sustentabilidade do Instituto de Energia e Ambiente da Universidade de São Paulo - LAPPES vem manifestar satisfação, disponibilidade e interesse na realização de atividades voltadas aos alunos dessa unidade escolar sobre Memória e Patrimônio Cultural de Santo Amaro. [...] (Trecho do ofício encaminhado para a coordenadora pedagógica do Ensino Fundamental da EMEFM Prof. Linneu Prestes).

As Oficinas de Arqueologia tiveram o objetivo para a pesquisa-ação de sensibilizar à escola sobre a importância na promoção de levantamentos e estudo especialmente sobre os bens culturais imateriais e arqueológicos de Santo Amaro. Propuseram o envolvimento dos alunos em iniciativas de inventários de bens culturais, assim como o previsto pela pesquisaação. 


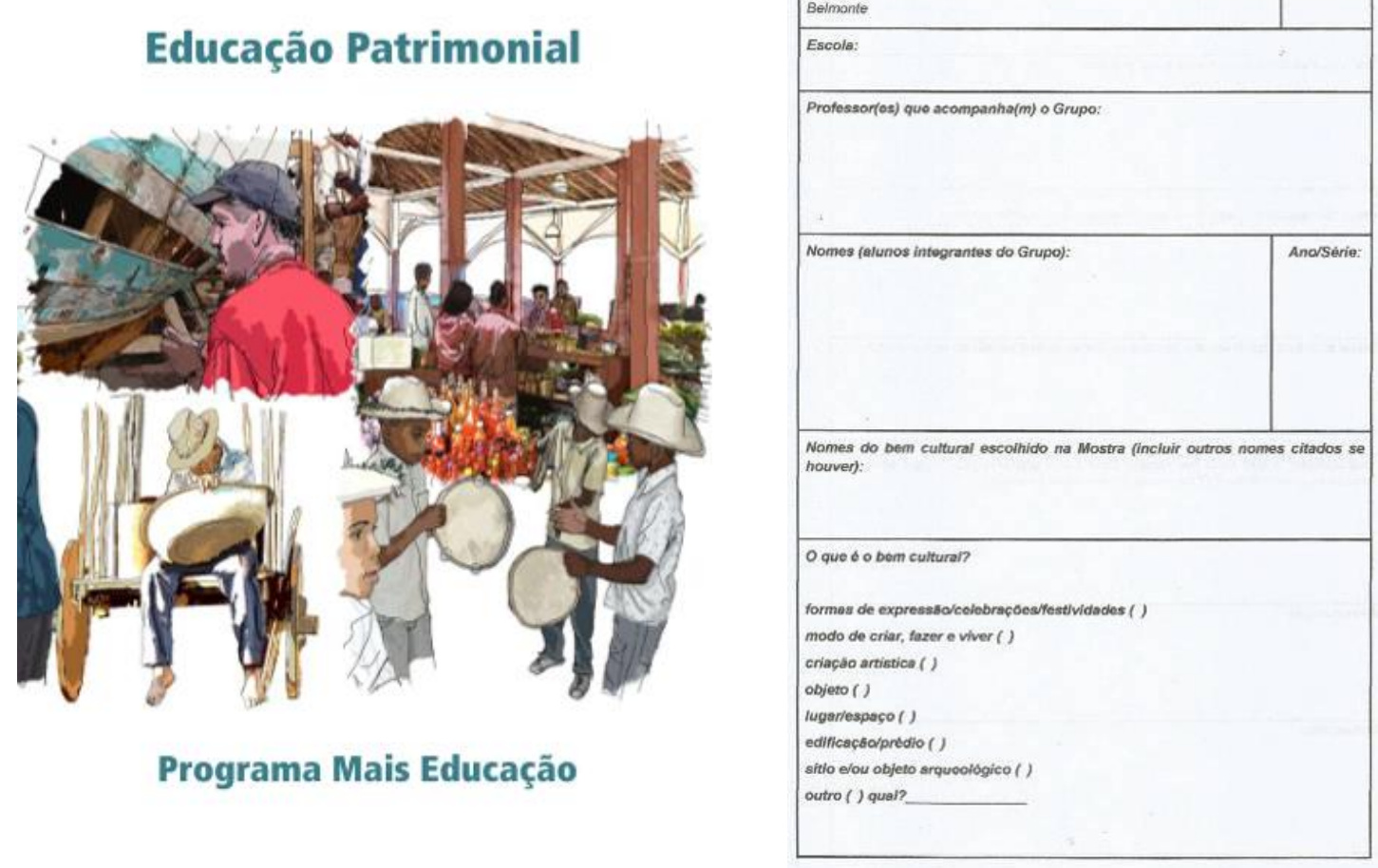

Figuras 118 e 119. Capa do Manual de Educação Patrimonial do Programa Mais Educação apresentado para a coordenação pedagógica da escola e proposta de ficha (frente) para entrevista dos alunos aos participantes dos Encontros entre outros moradores da região numa atividade/oficina de inventário. 
Quadro 7. Plano didático das oficinas desenvolvidas com as turmas definidas pela EMEFM Prof. Lineu Prestes

\section{Oficinas de Arqueologia para os alunos da EMEFM Prof. Linneu Prestes}

\section{Programação e Conteúdos em Geral:}

Apresentação do Projeto;

Importância da região e do local em que moram do ponto de vista do patrimônio cultural;

Conceituação de Patrimônio e Herança;

Herança Financeira, Afetiva e Familiar;

Outras Heranças: o Patrimônio Imaterial (Brincadeiras Infantis);

O Patrimônio Material (a Escola);

Herança e Família: as narrativas orais, as fotografias e as lembranças;

Outras Heranças e quando a memória não pode mais ser narrada: a Cultura Material;

A Cultura Material: Arqueologia e Memória;

Santo Amaro;

Ocupação Humana Pré-Histórica e as primeiras aldeias conhecidas quando da chegada dos portugueses;

Arqueologia e paisagem;

Vestígios arqueológicos;

Como o aluno aprende na escola (conhece)?

Como o arqueólogo aprende (conhece)?

Os artefatos arqueológicos (manuseio);

Os artefatos arqueológicos de Santo Amaro;

O Arqueólogo e suas ferramentas;

Arqueologia e as disciplinas do conhecimento.

Recursos (instalações, equipamentos e materiais):

- Kit educativo do MAE-USP;

- Ferramentas do arqueólogo (cavadeira, peneira, colheres, bússola, trena, entre outros);

- Câmera fotográfica;

- Pano de base.

- Prancheta;

- Papel milimetrado;

- Lápis;

- Caixas de madeira;

- Pranchas;

- Terra;

- Objetos diversos fragmentados (quebrados);

- Ficha de Análise de Artefato;

- Espátulas de madeira;

- Caneta;

- Lápis;

- Borracha;

- Mesa;

- Bancos;

- Extensão elétrica.

\section{Estratégia metodológica:}

Todas as atividades contarão com roda de conversa e/ou bate papos e estímulo ao diálogo e participação dos alunos com memórias e depoimentos. A atividade contará com o uso de artefatos arqueológicos, pranchas e imagens para estimular a participação e troca de informações e percepções voltadas para os temas propostos (Arqueologia, Patrimônio e Educação Patrimonial). As estratégias de abordagem serão diferenciadas, em adequação à faixa etária dos alunos:

As atividades serão estruturas em três momentos subsequentes:

$1^{0}$ Momento de Contextualização de exposição com linguagem apropriada dos principais conceitos, com amplo uso dos materiais arqueológicos, pranchas e painéis como recurso educativo, permeando a fala com narrativas e histórias;

$2^{\circ}$ Momento de Leitura com o manuseio dos materiais arqueológicos e observação das imagens presentes nas pranchas e painéis educativos; 
$3^{\text {o }}$ Momento de Atividade Prática com a possibilidade de aplicação de duas estratégias diferenciadas: o Sítio Arqueológico Simulado e o Laboratório de Arqueologia.

Na primeira atividade os alunos participarão da montagem de um Sítio Arqueológico Simulado. Construirão as quadras com o uso de trenas, barbante, pontaletes, peças simuladas, pranchetas, papel milimetrado, bússola, entre outros instrumentos. E serão convidados a estabelecer hipóteses sobre usos e práticas culturais referentes ao objeto, relacionando com a ação dos arqueólogos.

$\mathrm{Na}$ segunda atividade os alunos realizarão o Laboratório de Arqueologia, no qual, por meio de palitos de sorvete (de madeira), escavarão uma pequena caixa de mdf, procurando artefatos. A localização e retirada do artefato da caixa exigirão o preenchimento de uma ficha de análise que auxiliará na interpretação do objeto.
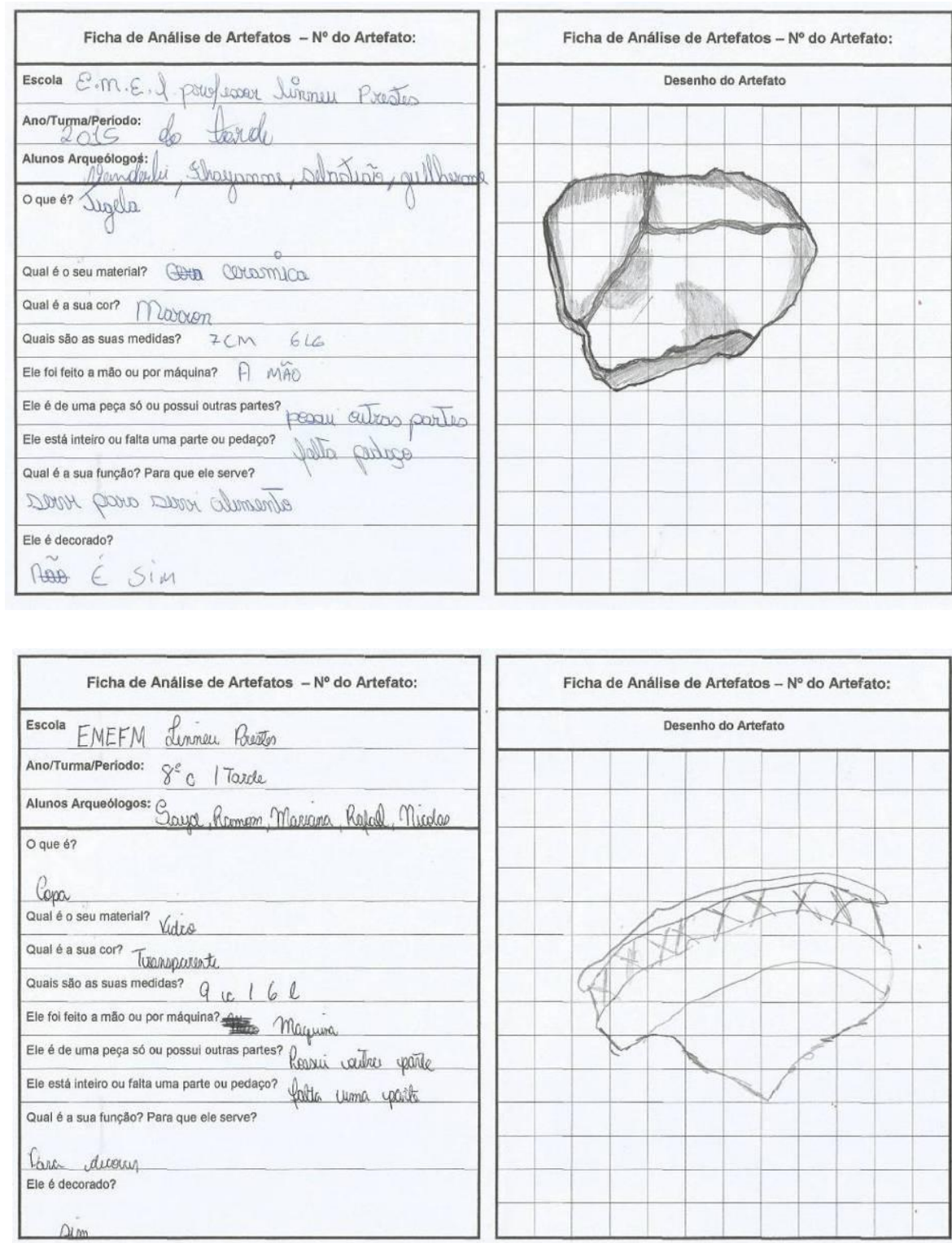

Figuras 120 e 121. Duas fichas preenchidas por alunos nas atividades de Laboratório de Arqueologia nas oficinas desenvolvidas. 


\subsubsection{A Mostra Educativa dos Encontros Memória e Patrimônio Cultural de Santo Amaro.}

Obrigado, Sr. Ângelo Diniz.

Uma salva de palmas para o Sr. Ângelo que hoje também vai abrilhantar essa noite cantando uma bela canção... Boa noite Senhoras e Senhores! É com grande alegria que recebemos todos vocês aqui nessa noite tão especial! Muitos já participantes e colaboradores nesse projeto, né? Agradecemos a presença de cada um de vocês! Nessa noite, estamos apresentando alguns dos resultados da pesquisa em desenvolvimento sobre o patrimônio Cultural de Santo Amaro. Projeto desenvolvido pelo LAPPES - Laboratório de Pesquisa e Práticas em Educação e Sustentabilidade da USP, pela Biblioteca Temática Belmonte e pela Casa Amarela.

Aliás, como o assunto é esse Patrimônio de Santo Amaro não podemos deixar de destacar e registrar sempre a importância e o vigor do trabalho realizado pelo CETRASA - Centro de Tradições de Santo Amaro que tem a sua frente o Dr. Alexandre.

Vamos começar então chamando para esse palco para receber o carinho de vocês algumas das pessoas responsáveis pelo sucesso desse Projeto. O Sr. Jomar dos Santos, aqui da Biblioteca Belmonte, o Sr. Thiago Bronzoni, da Casa Amarela, a querida Professora de Dança Vocacional da Casa Amarela Angélica Rovida; os pesquisadores do LAPPES da USP, os também queridos Ana Cristina Chagas dos Anjos e Marcos Rogério Ribeiro de Carvalho. Os professores da Escola Lineu Prestes, o compositor Tarcísio Silva, a poetisa Dona Aparecida Barros, a exímia bonequeira Tereza Discher, a alegre Dona Hollywood, Dona Maria Camargo Ops! Essas pessoas ainda não, né? Desculpe! É que a pesquisa não aconteceria sem eles, né?

Então, vamos dar continuidade para vocês poderem conhecer essas pessoas tão importantes quanto essas que estão aqui para o sucesso do Projeto... Obrigado e podem sair do palco agora

Vocês devem ter ouvido e verão na exposição expressões como essas: "Naquela época, as mulheres sofriam aquele lençol branco... Lembro da minha mãe pondo para quarar... E depois para enxaguar tinha que por anil para ficar branco" (D. Tereza Discher). "Tinha só um tamanco para usar pra ir para escola era um colégio de freira. Trabalhava na Vergueiro numa fábrica de chocolate. Às 5 horas marcava cartão e fazia hora extra até 7 da noite. Entrava 7 e meia na escola. Com o meu primeiro ordenado, comprei cinco pares de sapato. Fiquei um ano pagando. (Dona Cida). "Dr. João Dentista, Dr. Hélio, Sr. Sales tinha uma loja grande. Lá comprei uma máquina de costura. Loja da D. Juventina que era de roupas. Onde é a farmácia na esquina do Ponto Frio era uma sapataria de dois irmãos. De 1950 prá cá eu lembro tudo. Foi quando eu comecei a trabalhar... Na Carlos Araújo, tinha barbeiro 
ali que cortava cabelo, tinha dentista, O Sr. Laércio. Não sobrou nada. Barrozinho. A casa de esquina Abrantes, ao lado da Igreja, vendia farelo, para criação". (D. Irene). "No Cine São Francisco, no Carnaval, a gente tirava todas essas poltronas. Naquele tempo eu era mais jovem e saia na Escola de Samba. Nós inventamos uma Escola de Samba. Fazia desfile até no Pacaembu. Era a primeira Escola de Samba de Santo Amaro. Tenho uma foto com os músicos em cima do palco. Sr. Tarcísio Silva."

Pois são expressões como essas que carregam informações importantíssimas sobre como era viver e morar em Santo Amaro e que nos ajudam a revelar o verdadeiro patrimônio aqui da região.

Esse patrimônio relacionado ao território de vida e aos valores. Saberes, ou seja, modos de fazer e de viver; festividades, religiosas ou não; e são esses patrimônios de moradores da região, nascidos aqui ou que adotaram Santo Amaro para morar no passado ou vivem o seu cotidiano agora no presente que a pesquisa desenvolvida com diversas mãos tem levantado e começa a apresentar nessa primeira Mostra.

Lembrando que algo que é presente na memória e recordação de mais uma pessoa pode tratar-se de um bem cultural coletivo e virar Patrimônio Cultural daquela região.

Então, vamos começar vendo um pouco como tem sido esse processo que a gente apresenta hoje alguns resultados. Essa é só a primeira de várias Mostras que teremos daqui pra frente.

Depois desse Making Off, vocês assistirão à apresentação preparada especialmente pelos participantes do Projeto Memória e Patrimônio Cultural de Santo Amaro: Conversando sobre Arqueologia, Memória, Patrimônio Cultural, Identidade e História de Santo Amaro e daremos início ao Sarau.

Já temos o Sr. Ângelo Diniz, Sr. Tarcísio Silva, D. Maria Alice das Dores inscritos e sei que veio gente da Escola Linneu Prestes que também participará do Sarau, né?

(Texto/roteiro utilizado na abertura da I Mostra na Biblioteca Belmonte).

Nos Encontros, o Grupo de Trabalho juntou-se ao de Ação e ambos - formados para a coaprendizagem de práticas de cidadania orientadas para o uso sustentável dos recursos culturais de Santo Amaro - passaram a se reunir também na Casa Amarela e a partir de janeiro de 2016, na Casa de Cultura de Santo Amaro, para os ensaios das apresentações de dança, teatro e música, que fizeram parte da curadoria educativa da I Mostra com alguns dos bens inventariados.

Durante os Encontros foi se esboçando a possibilidade de se criar uma exposição que realizasse a promoção e entrecruzamento das diferentes memórias de vida e lembranças do bairro de Santo Amaro. O envolvimento dos participantes foi pleno, com o compartilhamento de objetos referenciais de memória, como o ferro de passar de carvão utilizado pelo pai de Vanessa que era alfaiate ou do troféu recebido pelo Sr. Tarcísio como lembrança dos antigos romeiros. Todos os participantes se 
envolveram na elaboração da Mostra. (Extraído do Caderno de Anotações da pesquisadora).

As atividades de curadoria educativa desenvolvidas nesses Encontros se caracterizaram pela construção coletiva dos conteúdos para exibição na Mostra, assim como das ações de recepção dos seus visitantes: a definição do calendário de exibições, convite e divulgação, a programação de atividades/oficinas relacionada, entre outras ações.
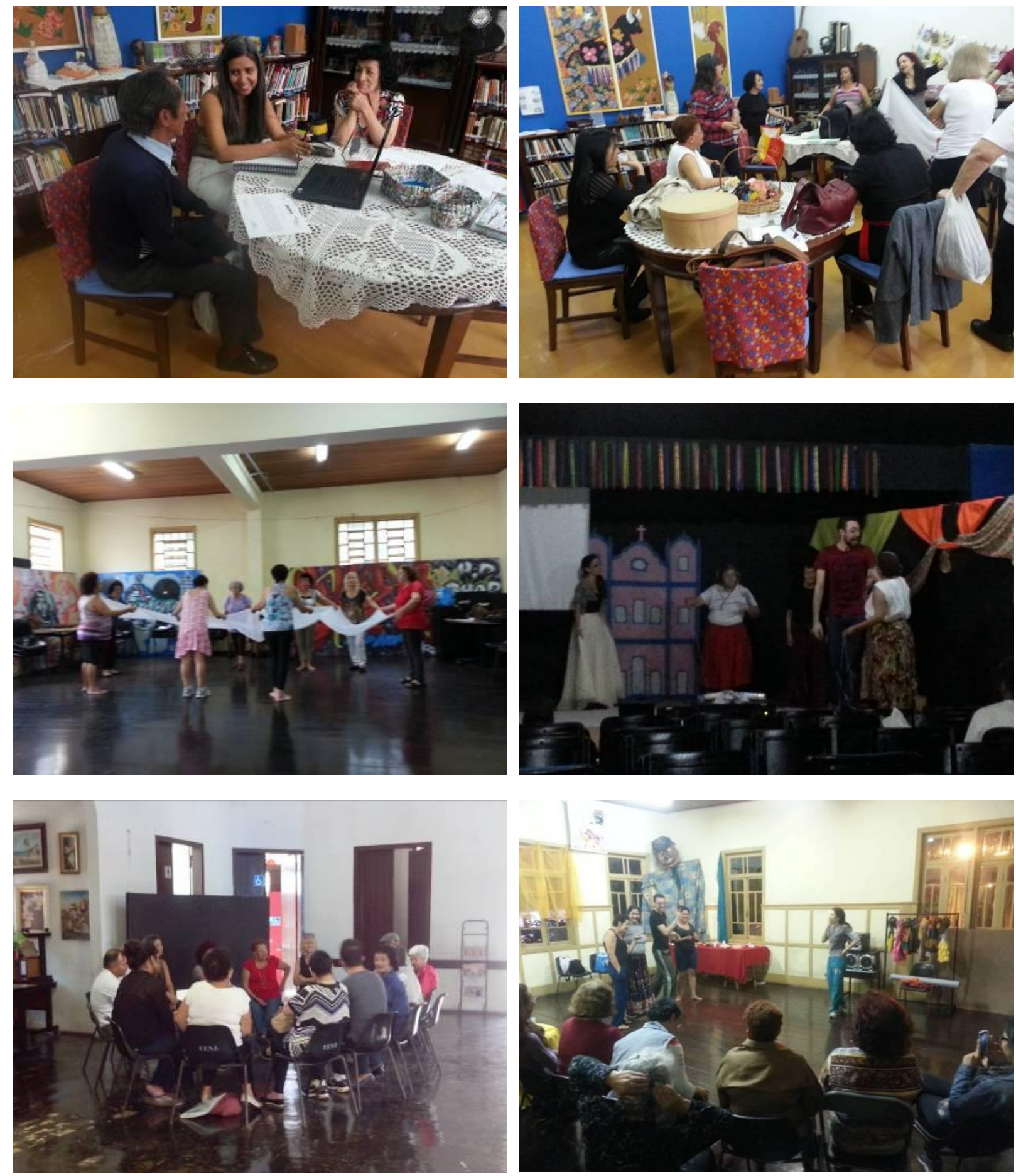
Figuras 122 a 127. Reuniões de curadoria, ensaio e preparação das atividades de visitação e novas exibições da Mostra na Biblioteca Belmonte, na Casa Amarela e na Casa de Cultura de Santo Amaro. Fotos da autora.

Na curadoria educativa da Mostra, foram desenvolvidas de forma compartilhada e colaborativa a sistematização das informações e dos dados levantados e a preparação e seleção dos textos (trechos das falas e narrativas dos Encontros) e fotografias e objetos para apresentação. Os ensaios das apresentações de dança, teatro e música para as suas duas primeiras exibições em 2015 e 2016 foram concomitantes.

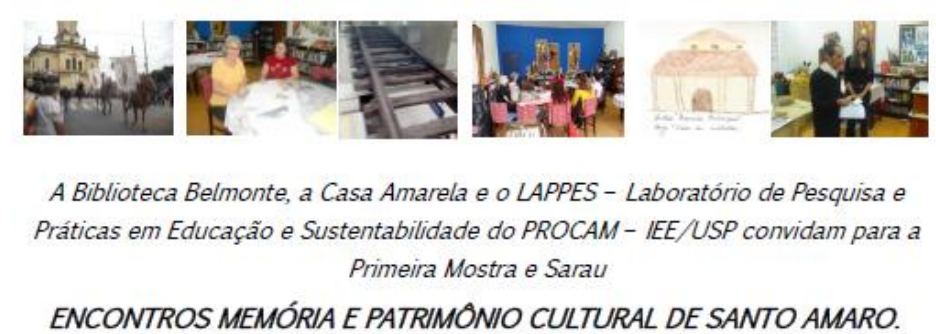

Dia 25 de Novembro, 19h30, no auditório da Biblioteca Belmonte. Rua Paulo Eiró, no 525 - Santo Amaro - Telefone: 1156870408

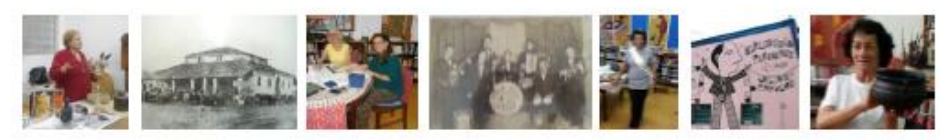

Figura 128. Convite da primeira exibição da I Mostra Educativa, na Biblioteca Belmonte (de novembro e dezembro de 2015). A segunda exibição ocorreu na Casa de Cultura de Santo Amaro de 15 de janeiro a 11 de fevereiro de 2016.

Os Encontros sobre Memória e Patrimônio Cultural de Santo Amaro, a partir de outubro de 2015, caracterizaram-se por novos procedimentos coletivos tanto no levantamento de dados e informações quanto na sua interpretação e tratamento, para as atividades relacionadas à curadoria educativa da primeira Mostra. O compartilhamento de informações e dados e a construção coletiva de conhecimento sobre o patrimônio cultural de Santo Amaro foram uma constante em todo o processo da pesquisa-ação e nessa fase de primeira sistematização e apresentação/difusão de resultados. 


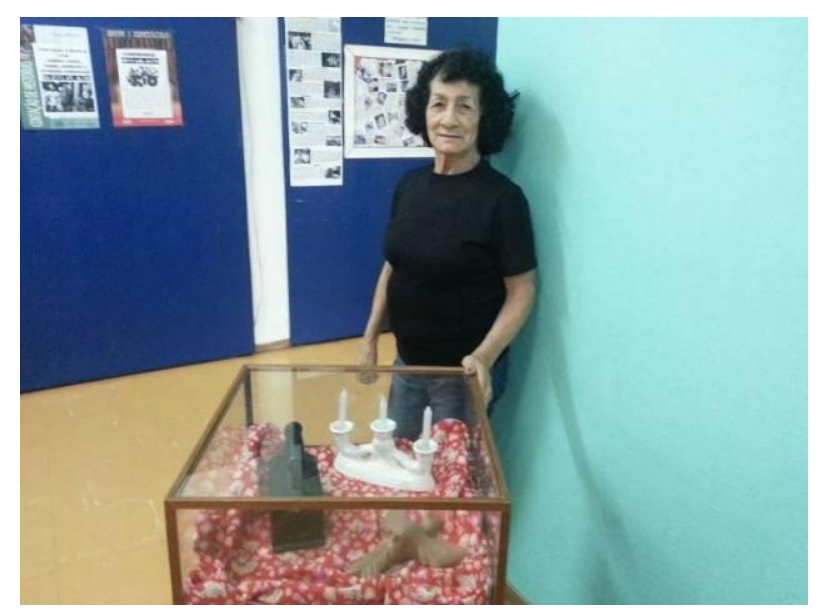

Figura 129. D. Maria Alice das Dores, no dia da abertura da Mostra na Biblioteca Belmonte junto a uma das vitrines com os objetos exibidos. O candelabro pertencera à sua avó. Foto da autora.

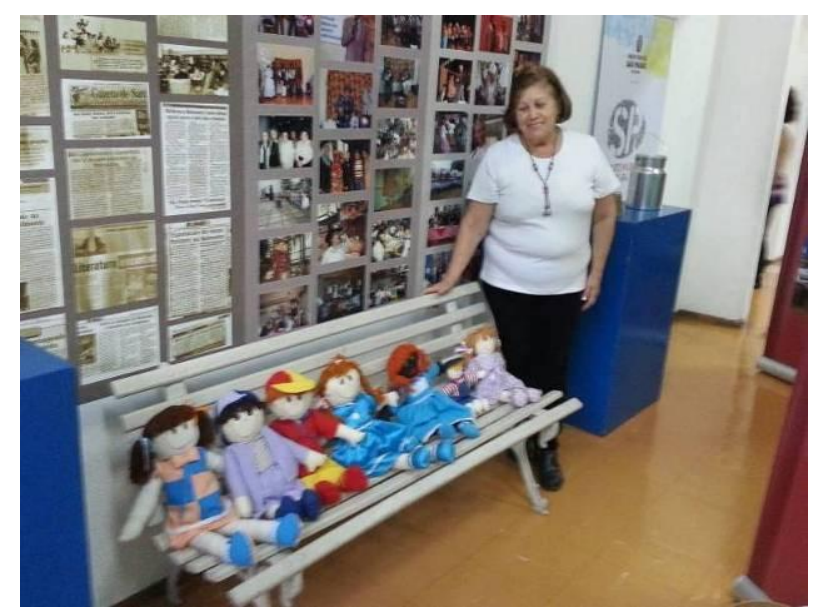

Figura 130. D. Teresa Discher sua coleção de bonecas exposta na Mostra também no dia de sua abertura na Biblioteca Belmonte. Um das bonecas fez parte do causo contado por ela na apresentação. Foto da autora.

Os ensaios foram conduzidos pela professora de dança do Curso Vocacional de Dança da Casa Amarela, e também participante do Grupo de Ação formado, Prof. Angélica Rovida. Prezado Thiago Bronzoni,

Conforme conversado com a pesquisadora e educadora Ana Cristina C. Anjos, o Laboratório de Pesquisa e Práticas em Educação e Sustentabilidade do Instituto de Energia e Ambiente da Universidade de São Paulo - IEE-USP vem manifestar satisfação na realização de parceria com essa instituição, de forma a possibilitar que os alunos do Curso Vocacional de Dança, ministrado pela Prof. Angélica Rovida, participem da elaboração das apresentações musicais, de dança e teatro que acompanharão a Mostra Educativa "Encontros Memória e Patrimônio Cultural de Santo Amaro".

A Mostra Educativa apresentará alguns dos bens culturais levantados nos Encontros sobre Memória e Patrimônio Cultural de Santo Amaro: Conversando sobre Arqueologia, Memória, Patrimônio Cultural, Identidade e História de Santo Amaro que, voltados para a comunidade em geral local, têm sido desenvolvidos 
desde 25 de agosto passado, na Biblioteca Belmonte. (Trecho do ofício encaminhado ao gestor cultural da Casa Amarela sobre os ensaios da I Mostra Educativa).

O Grupo de Ação, constituído por 5 dançarinos/bailarinos que se reúnem no espaço da Casa Amarela para as aulas de Dança Vocacional, sob a supervisão da Prof. Angélica Rovida, nesse período, participou de três Encontros caracterizados por atividades de formação conduzidas pela pesquisadora sobre Patrimônio Cultural, Arqueologia e Educação Patrimonial.

O primeiro encontro foi de introdução sobre os conceitos de patrimônio cultural material e imaterial, de patrimônio arqueológico e de Educação Patrimonial. Ele foi desenvolvido com a mediação das pranchas e objetos manuseados pelos presentes. A leitura de cada um desses recursos educativos possibilitou a abordagem do tema da trajetória de alargamento do conceito de patrimônio cultural no país. A consulta e análise das resoluções do CONPRESP de tombamentos de bens da região foram acordadas com o grupo, para a concepção de ações relacionadas ao patrimônio cultural de Santo Amaro, nos próximos encontros. (Extraído do Caderno de Anotações da Pesquisadora).
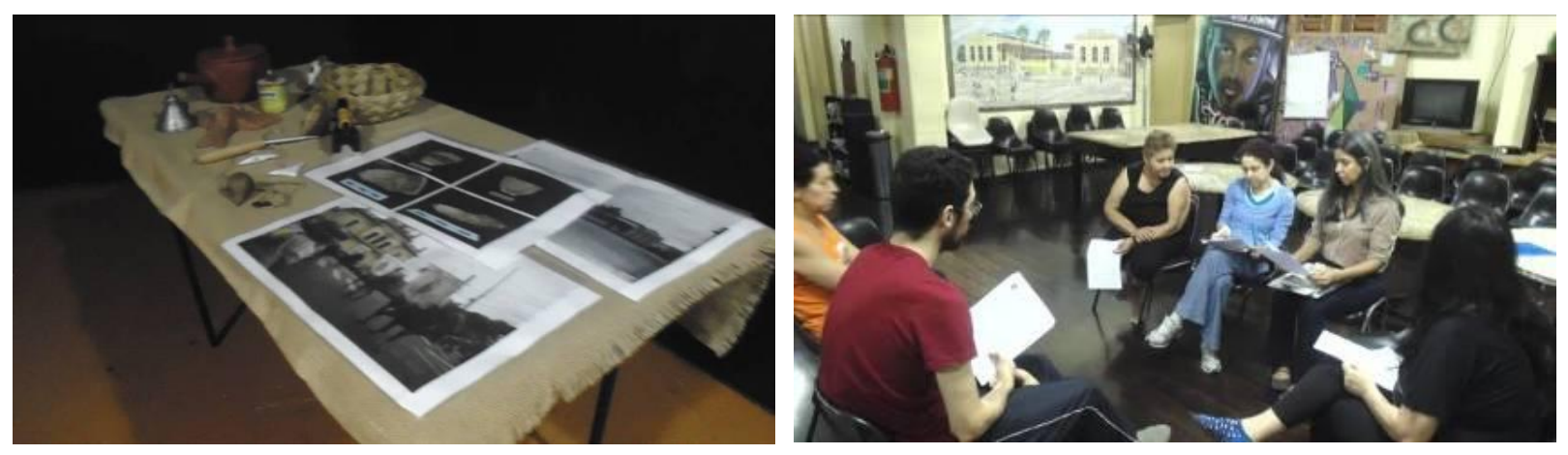

Figuras 131 e 132. Pranchas e objetos utilizados como recursos educativos no primeiro Encontro e atividade com o Grupo de Ação de consulta às Resoluções de Tombamento do CONPRESP de bens de Santo Amaro no segundo Encontro. Fotos da autora.

Como se tratavam de bailarinos (o Grupo Yellow de dança), enquanto ocorriam os Encontros de curadoria da Mostra Educativa, eles prepararam e apresentaram, nas atividades de encerramento de final de ano do Curso de Dança Vocacional, performances em defesa à preservação e restauração da Casa Amarela. 


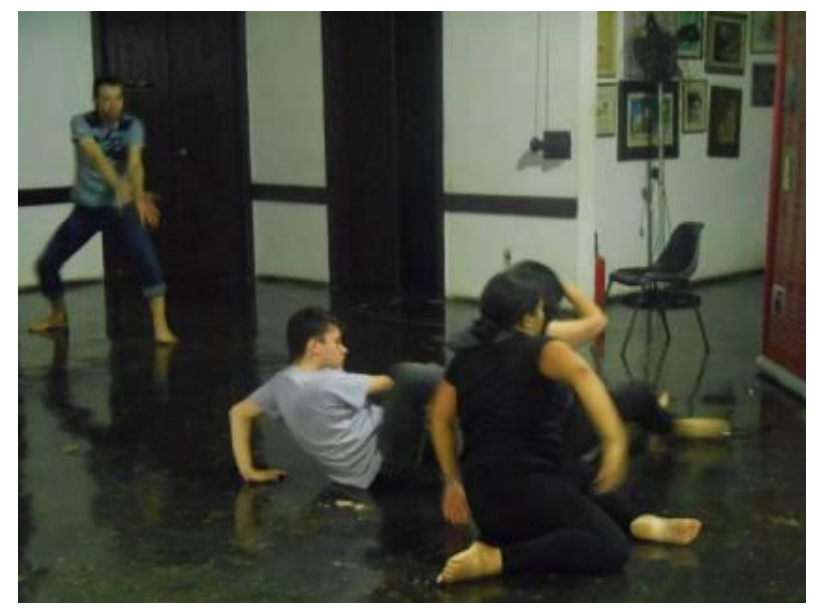

Figura 133. Uma das performances do Grupo Yellow. Foto da autora.

A Mostra Educativa foi constituída por painéis que apresentaram alguns dos primeiros resultados do Inventário Comunitário de Bens Culturais de Santo Amaro e por um espetáculo, concebido pelos Grupos de Trabalho e de Ação dos Encontros.

O Projeto permite a valorização das memórias individuais, a sua costura com outras memórias e inserção no contexto da história do bairro e valorização dos seus diversos bens culturais. Por outro lado, esta valorização é agregada por ações culturais como as apresentações por meio de Saraus e a contínua atualização da Mostra Encontros Memória e Patrimônio Cultural de Santo Amaro, compartilhando saberes e memórias com familiares e demais pessoas da comunidade, ressignificando-os. (Extraído da apresentação do Projeto Encontros, Memória e Patrimônio Cultural de Santo Amaro para o Programa VAI do Grupo de Trabalho) 


\title{
BENZEDEIRAS, ORAÇÕESE FESTIVIDADES RELIGIOSAS...
}

\author{
*.Dona Paula benzia com uma \\ machadinha.
}

Ela morava no fundo de quintal $\mathrm{Na}$ primeira ou segunda casa na Barấo de Duprat, alj perto do Shopping (Shopping Boa Vista] ()) Era uma senhorinha pequenininha. Ela batia na porta e benzia com uma machadinha (.) EU trabalhei, durante 9 anos, como chefe daquela junta militar ali na Rua Darwin (.) Todo mundo da Junta ia lá na D. Paula e levava um quilo de açúcar. Ela Bostava de sopinha de pacote Todo mundo que ia lá se benzer na D. Paula ia lá com um saquinho. Ela vivia das coisinhas que levavam. Ela adorava quando a gente levava leite em pó. Ela vivia sozinha. $E$ morava lá no fundo. D. Paula era a 'Super Star' do bairro. Muita gente deve saber dela."

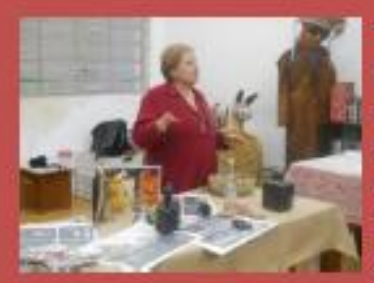

Dorinha" da Biblioteca Belmonte, moradora há 45 anos em Santo Amaro, lembra também da tradicional Festa do Divino nas redondezas do Largo da Matriz.

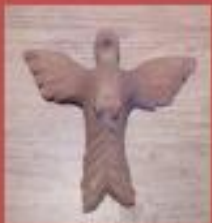

Vinde Esplinto Santo, enchei os coraçöes dos vossos fiéis, e acendei neles $o$ fogo de vosso amor Enviai $o$ vasso Esplinto $e$ tudo será criado $e$ renovareis a face da terra Oremos ó Deus que iluminais os coraçôes dos vossos fiéis com as luzes do Esplíito Santo, conceder-nos que no mesmo Esplíto saibamos o

Oraça do Divino Esplrito que $e$ reto, e gozemos sempre de suas consolaçóes. Por nosso Santo Senhor Jesus Cristo, na unidade do Esplíto Santo. Amém. 


\section{MISSAS, CASAMENTOS, BATIZADOS EROMARIAS}

"Casei na Matriz de Santo Amaro.

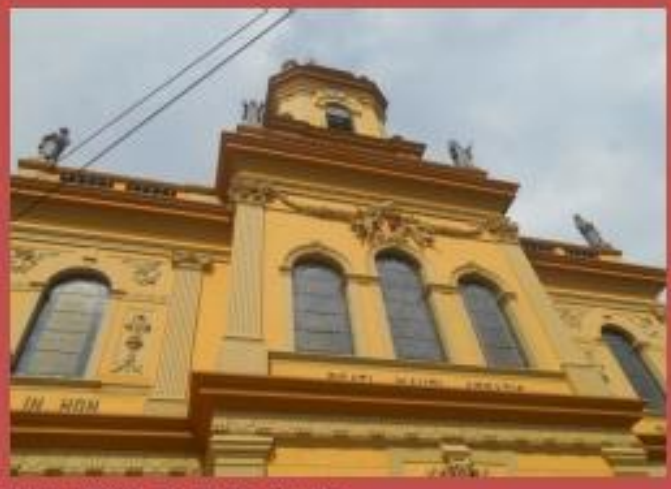

IBreja Matriz de Santo Amaro.

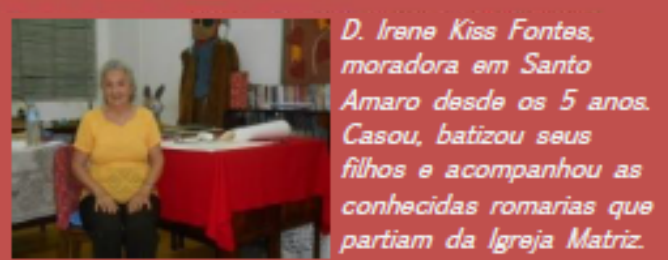

"Andej muito de bonde. Quando criança vinha muito na farmácia do Seu Zé. Estudei harmonica com Mário Genário Filho, na nua Direita, compramos muita coisa na loja de Sr. Sales e até hoje eu tenho uma máquina de costura comprada na loja dele. Tratei os dentes com o Dr. Joäozinho (dentista antigol). Namorei muito na Praça do Coreto. Isso em 1949. Lembro tudo. (.) Na Romaria, os romeiros tomando a benção na frente da Igreja e depois descerem na Casa de Cultura que era o Mercado Velho. E all então se reuniam todos $e$ eles desciam pela Joäo Dias $e$ pegavam a Estrada de Itapecerica (.) Como meu marido era taxista, nós famos de táxi atrás da Romaria em 1961 e 1962 (_) Eu acho que ainda tem a Romaria Eu escuto os fogos." 


\section{A SANTO AMARO QUE DEIXOU SAUDADES...}

_das Chácaras, do antigo Mercado...

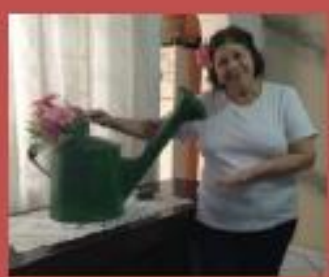

D. Tereza Discher Camara, residente em Santo Amaro há 50 anos.

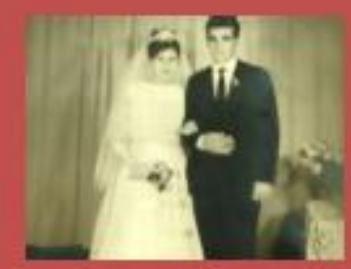

Eu casei com 18 anos o dosdo 1966 vim morar om. Santo Amaro na rua Lupi (travessa da Rio Brancol MaU marido veio de Portugal com 2 anos $E$ quando olo tinha 28 anos $\theta$ eu 18 anos nos casamos."

A gento morava na na Jupi e era uma chácara onorme. Minha sogra era chacareira. Fazia fundos ondo all í a Herbalifo na Joáo Dias. Ela plantava verduras o flores."

e das

fábricas, do trabalho e das dificeis tarefas de casa.

Meu cunhado trabalhou muto tempo na Velnac. Era uma fábrica de veludo. Minha cunhada trabalhou lí, meu marido e o marido da minha cunhada tamberm. () Era onde hoje é o Shopping Boa Vista ( ) Quando eu conheci meu marido, a Velnac era nos fundos. $E$ tinha um sobradinho que era da Velnac e os funcionários moravam all. () Meu marido trabalhou na Wapsa, Plavinil ()) Tinha Laborterapica. Depois foram saindo.-

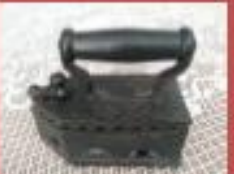

Eu tinha 8 ou 9 anos. E minha mâle tinha esse ferro. Que tristezal Que sofnimentol $(9)$ Abre Enche de canväa. Acende. Fecha Tem que manter ele acesso. Ele tem um buraco e tinha que ficar soprando Soprava e soprava Saia fumaça Era pesado para passar roupa. Tinha gue tomar cuidado para nâo cair cinza na roupa: 


\section{SANTO AMARO TEM CORAL,}

\section{CURSO DE VIOLÃO, TEATRO,}

\section{DANÇA...}

...tem poesia, música e circo

Esses pés representam a minha historia.

Desde criança que esses pés têm muita história pra contar. Quando andava, deixavam a desejar,

Suas juntas todas estalavam, pareciam se comunicar. Querendo dizer alguma coisa, mas tinha que adivinhart Adlininhar de que jeito? Tenho tudo bem guardado com muito carinho dentro do peito. Quando olhava sendo analfabeta, não conseguia ver direito.

Ao inves de ver qualidades, so via defertos.

Mas tudo passou e o sonho se realizou.

Pensando positivo meu sonho se completou

Conhecendo a professora Ray que tanto me ensinou, com muito amor e carinho, pezinhos e dedinhos exercitou.

E, assim, näo só os pés, mas todo o corpo, mente e esplinto e tudo se alegrou

Hoje, não vejo mais defeito. Vejo boas qualidades $e$ tudo mudou.

Sou alegre e passo alegnia,

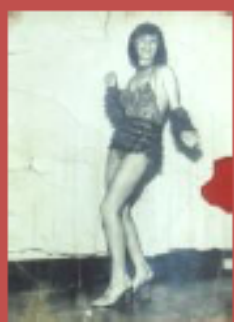

Dona Cida quando dançarina $e$ assistente de

mágico em Circo de Santo Amaro.
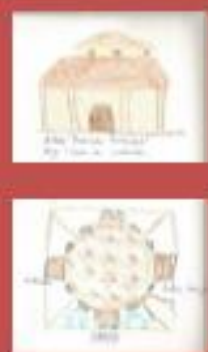

Casa de Cultura de Santo Amaro en desenho de Vanessa Ferreira de Barros Ortiz recebo caninho e amor.

"Esta é a minha história em forma de poesia."

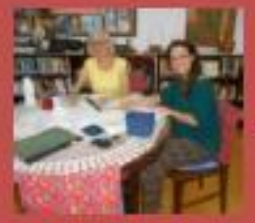

D. Aparecida Ferreira Barros, a Dona Cida". que participa das atividades culturais em Santo Amaro, na Casa de Cultura e na Casa Amarela Algumas delas com sua filha Vanessa. 


\section{SANTO AMARO DO}

\section{CORETO, DO CINE SÃO}

\section{FRANCISCO, DOS}

CARNAVAIS...

. e das belas composiçốes

musicals.

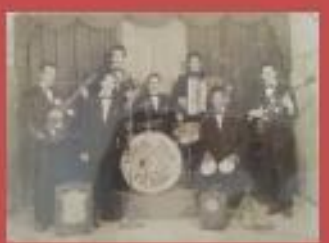

Seu Tarcisio Siva nasceu em 1927, em Santo Amaro. Compos musicas sobre Santo Amaro, sua história e seus costumes.

Banda Tarcisio Silva tocando no Cine Stio Francisco.

FIZ música sobre os Romeiros, sobre o baile da saudade, sobre o Camaval Deixarei para a Santa Casa todas elas."
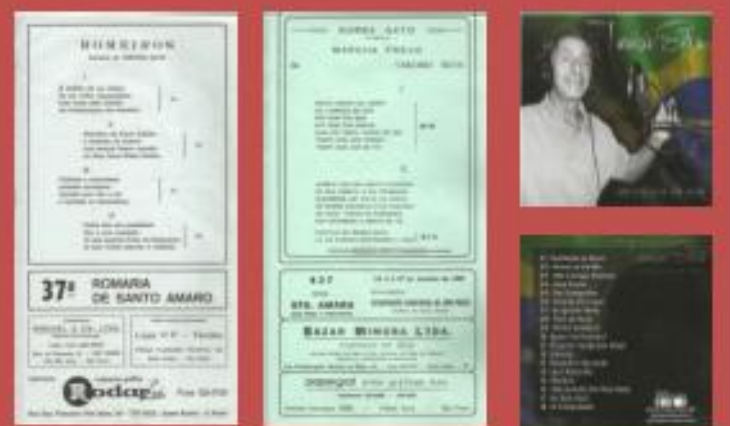

"Quando morava na Praça Floriano Peixoto em frente ao coreto e tinha $\sigma$ anos, vi pela janela um monte de escoteiros:- Perguntei pra minha mäe o que era e ela me disse que era uma concentração. Era a Revoluçẫo de 1932:"

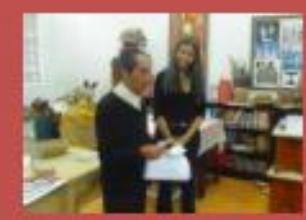




\section{A SANTO AMARO DA VIDA,}

\section{DAS ALEGRIAS...}

...e da luta diária de quem

a adotou para viver.

Meu pai tinha uma carvoaria ali. Nós, corm 8 anos $e$ meu pai fazia entregarmos carvão $e$ querosene Não tinha luz, não tinha onibus, não tinha nada.

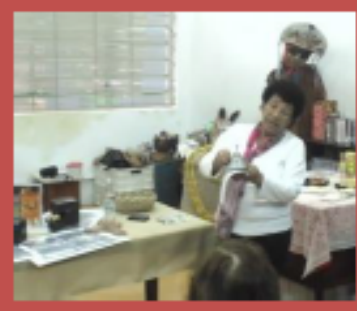

Dona Maria Camargo, moradora há 65 anos na regiấo e conhecida por "Dona Hollywood", com uma lamparina de querosene, lembra de quando chegou em Santo Amaro vinda de Minas Gerais.

Chegada de Dona Maria Camargo na Matriz de Santo Amaro no seu casamento.
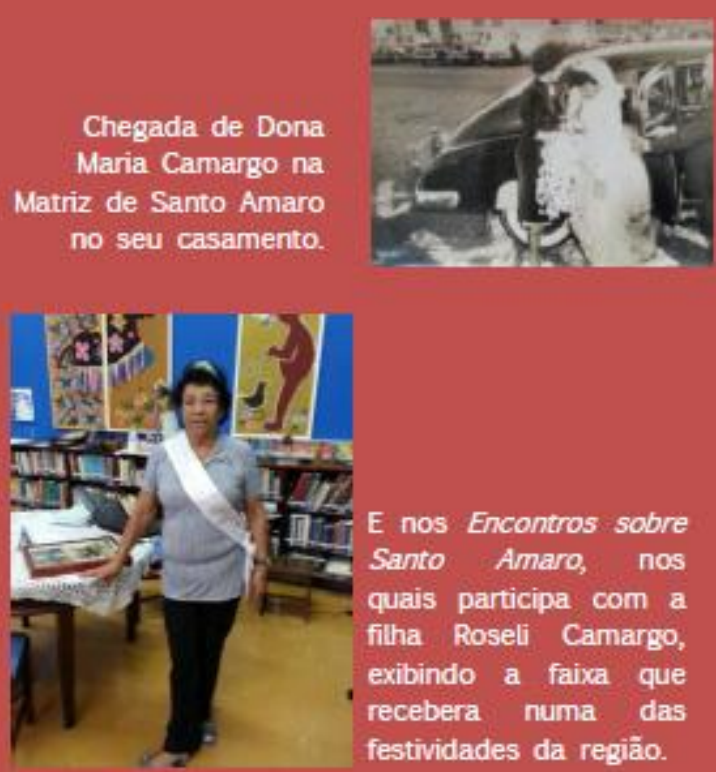


\title{
UMA SANTO AMARO...
}

\author{
...que lembra a infância vivida \\ no interior de São Paulo.
}

"Para ralar a mandioca, tinha uma manivela movida a máo para rodar a roda. Depois ia para a prensa. Tinha um fuso com quatro buracos que rodava até secar e ir para o tipiti (cesto), feito com cipó do mato. Depois que aquela massa ficava seca, ia para o formo. Um forno grande. $A$ gente ficava mexendo durante uns 15 dias até torrar a farinha Minha avó pegava o amido da gamela e desmanchava e lavava. Esperava assentar e guardava para fazer tapioca Aquele Ulquido da mandioca era veneno. Se a galinha comia no terreno onde tivesse jogado o Lquido ela morria -

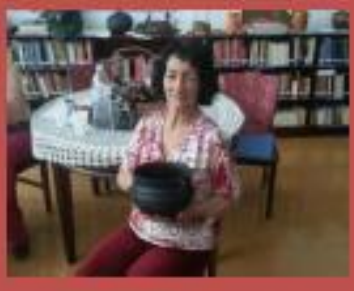

Cozinhava foijto numa panela como essa".
Dona Maria Alice nasceu no Vale do Ribeira e mora na regiäo há $\mathbf{4 5}$ anos.

Trabalhou muito durante toda a sua vida e conta com saudades as recordaçōes da infancia.

Depois de secar o cafe, escolhia os melhores ()) No dia de torrar, não podia fazer nada. Minha avó falava assim. Fazia um torräo que parecia pé de moleque.

Figuras 134 a 140. Painéis da I Mostra Educativa dos Encontros. 
Os textos e fotos dos painéis expositivos compartilharam os bens culturais de Santo Amaro identificados nos Encontros. E as apresentações de dança, teatro, contação de histórias, de músicas e os saraus também abordaram esses bens: a procissão do Divino do Espírito Santo; a chegada do navio com imigrantes estrangeiros; composições musicais sobre a Romaria de Santo Amaro e o Carnaval do Cine São Francisco; encenação de um casal de nordestinos; causos e narração de histórias de vidas relacionadas ao patrimônio tombado do centro histórico (Praça Floriano Peixoto, Casa de Cultura) e o cotidiano, os saberes e modos de ser e viver dos moradores da região representados por alguns objetos de uso comum apresentados, como bonecas feitas de costura e ferro de passar roupa.
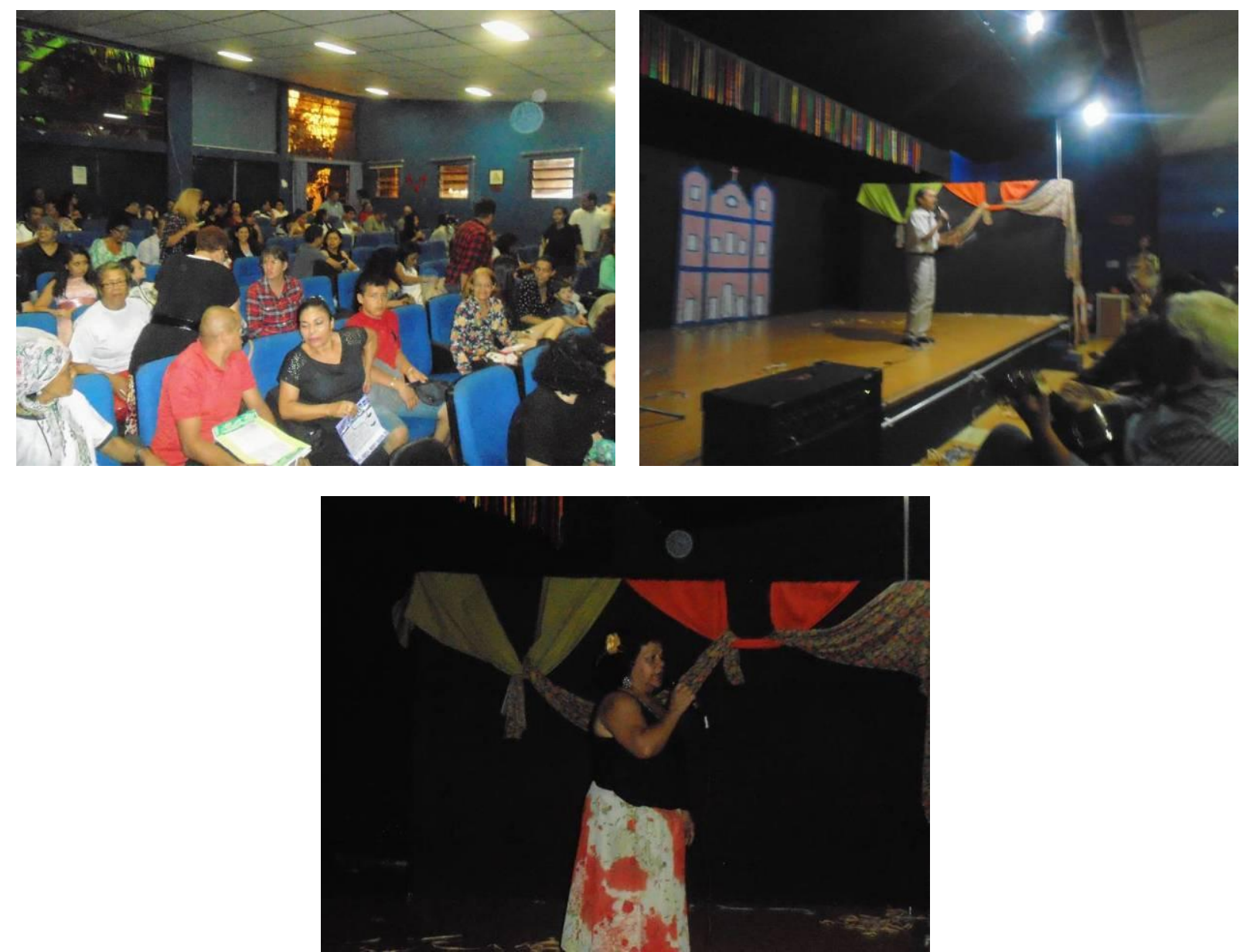

Figuras 141 a 143. Abertura da I Mostra Educativa Encontros Memória e Patrimônio Cultural de Santo Amaro. Fotos da autora.

A Arte contribui para a educação com o que outros campos de estudos não podem contribuir (EISNER, 1972). Contribui para o desenvolvimento do "pensamento nãodiscursivo" ou artístico, também importante para um "conhecimento totalizador de si e dos outros" (BARBOSA, 1984, p.56). 
Através da poesia, dos gestos, da imagem, as artes falam aquilo que a história, a sociologia, a antropologia etc. não podem dizer porque elas não são capazes de codificar nuances culturais (BARBOSA, 1998, p.16).

Produto e registro de emoções, vivências e de pesquisas, a Arte integra a experiência isolada e particular do indivíduo com a experiência da humanidade, pois permite, por intermédio de pensamentos transformados em metáforas produzidas a partir de desenhos, cores, linhas, ideias, corpos e performances conceber verdadeiros projetos de vida, em relação ao ambiente assim como refletir sobre eles (ANJOS, 2010).

A arte não está isolada de nosso cotidiano, de nossa história pessoal. Apesar de ser um produto da fantasia e imaginação, a arte não está separada da economia, política e dos padrões sociais que operam na sociedade [...] (BARBOSA, 2009, p.20)

A Arte participa da busca de sentido para a realidade individual e social de nós humanos e por ser um produto e registro nosso de emoções, vivências e de pesquisas, a atividade artística pode propiciar interações que possibilitam nos conhecermos. Os processos artísticos podem também permitir uma aproximação ao real e serem significativos para o entendimento da interdependência entre os seres vivos e seu ambiente, colaborando na construção de intervenções e ações mais conscientes e coletivas (SENE, 1998). Nesse sentido, atividades artísticas e estéticas podem contribuir para conhecer as noções básicas que nos orientam, que influenciam nosso comportamento, que estão na formação da identidade de cada um.

Boa tarde/noite Senhoras e Senhores!

É com grande alegria que daremos início ao Sarau que abrirá essa exposição que alguns inclusive já puderam apreciar. Quem ainda não visitou está convidado a fazêlo.

A Mostra que abre hoje ficará na Casa de Cultura até dia 11 de fevereiro. Aliás, em nome dos realizadores da Mostra e do Projeto, gostaria de agradecer o convite dessa Casa de Cultura para sua exibição e pela oportunidade de participação nessa data tão importante para Santo Amaro que é seu aniversário. E agradecer a presença de todos vocês que vieram prestigiá-la.

A Mostra apresenta os primeiros resultados de uma pesquisa coletiva em desenvolvimento sobre o Patrimônio Cultural de Santo Amaro e que envolve algumas pessoas conhecidas de vocês que estão aqui (daqui a pouco chamarei essas pessoas).

O Projeto é desenvolvido em parceria com o LAPPES - Laboratório de Pesquisa e Prática em Educação e Sustentabilidade da USP, representado aqui pela Socióloga Ana e pelo Arqueólogo Rogério, pela Biblioteca Temática Belmonte, representada pelo Jomar Santos, pela Casa Amarela e turmas do Curso de Dança Vocacional do ano passado, aqui representados pelo Sr. Thiago e pela Professora de Dança 
Angélica e pela Escola Municipal Linneu Prestes, Coordenadoria de Cultura da Subprefeitura de Santo Amaro e Casa de Cultura de Santo Amaro.

Vou chamar aqui rapidamente alguns dos realizadores e pesquisadores desse Projeto: o compositor Tarcísio Silva, a poetisa Dona Aparecida Barros e sua filha Vanessa, a exímia bonequeira Tereza Ditscher, a alegre Dona Hollywood, Dona Maria Camargo. A D. Maria Alice que vindo de Iguape, adotou Santo Amaro, D. Irene - uma autêntica Santoamarense.

Sr. Ângelo Diniz, detentor de uma das vozes mais marcantes da rádio. D. Arlen, também uma cantora fabulosa. Lucy, conhecida pelas suas performances, e o Grupo Yellow de dança da Casa Amarela: Glauber, Stela, Beth, Carol.

Uma salva de palmas pra todos eles!!!

Como o assunto é Patrimônio de Santo Amaro, não podemos deixar de destacar e registrar sempre a importância e o vigor do trabalho realizado pelo CETRASA Centro de Tradições de Santo Amaro, que tem a sua frente o Dr. Alexandre,

Quem ainda não conhece deve conhecer, pois trata-se do Museu de Santo Amaro que guarda fotos, objetos, equipamentos e muita memória e história de Santo Amaro...

Ele fica na Av. Professor Alceu Maynard de Araújo, 32, depois da Biblioteca Prestes Maia e do Clube Hípico.

Vocês devem ter ouvido e verão na exposição Expressões como essas.

"Naquela época, as mulheres sofriam...[...]

Pois são expressões como essas que carregam informações importantíssimas sobre como era viver e morar em Santo Amaro e que nos ajudam a revelar o verdadeiro patrimônio aqui da região.

Esse patrimônio relacionado ao território de vida e aos valores, saberes, ou seja, modos de fazer e de viver;

Festividades religiosas ou não;

E são esses patrimônios de moradores da região, nascidos aqui ou que adotaram Santo Amaro para morar no passado ou vivem o seu cotidiano agora no presente que a pesquisa desenvolvida com diversas mãos tem levantado e começa a apresentar nessa primeira Mostra.

Essa é só a primeira de várias Mostras que teremos daqui pra frente.

E quem quiser fazer parte só precisa participar dos encontros sobre memória e patrimônio e das reuniões do grupo de trabalho que acontecem todas as tardes de terça-feira na Biblioteca Belmonte, a partir das 14h30...

Lembrando que algo que é presente na memória e recordação de mais de uma pessoa pode tratar-se de um bem cultural coletivo e virar patrimônio cultural daquela região.

Na Mostra vocês poderão ver também um pouco do processo de construção da pesquisa e da exposição que estará projetado... 
Então, bem vindos e vamos começar o Sarau.

Sr. Ângelo e Sr. Tarcísio, os senhores serão os primeiros? Inscrições comigo ou com a Ana.

(Texto do roteiro da Abertura da I Mostra na Casa de Cultura de Santo Amaro, integrante da programação de atividades comemorativas do aniversário de Santo Amaro, em 15 de janeiro de 2016).

Para a pesquisa-ação, a I Mostra Educativa representou a continuidade e ampliação do processo de inventário participativo ainda em desenvolvimento. Além de possibilitar a difusão dos primeiros resultados desse inventário, a partir da sua itinerância pelos aparelhos culturais de Santo Amaro e das atividades de visitação, permitindo aos participantes dos Encontros sobre Memória e Patrimônio Cultural de Santo Amaro a experienciação do exercício de curadoria também de forma coletiva e colaborativa, a Mostra permitiu a incorporação de novos "pesquisadores" a cada exibição e visitação das pessoas em geral e grupos agendados (a Associação Mão Branca de Amparo a Idosos foi um exemplo de grupo visitante), como também de familiares e amigos dos participantes, inclusive, alguns responsáveis por ações culturais tradicionais na região, como, por exemplo: o Sarau Literário e a Domingueira Sertaneja da Casa de Cultura de Santo Amaro.
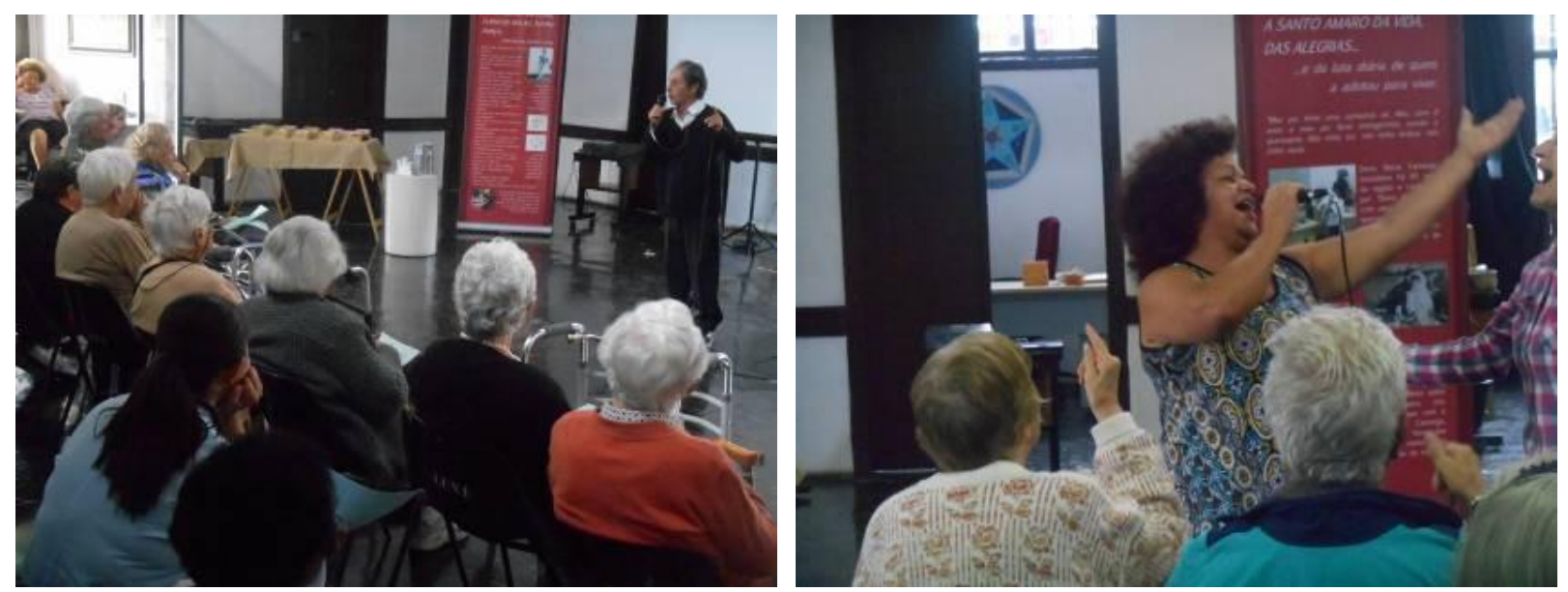

Figuras 144 e 145. Apresentação do Sr. Tarcísio e de D. Arlen no Sarau que acompanhou a atividade de visitação dos idosos atendidos pela Associação Mão Branca da região à I Mostra Educativa na Casa de Cultura de Santo Amaro. Fotos da autora. 


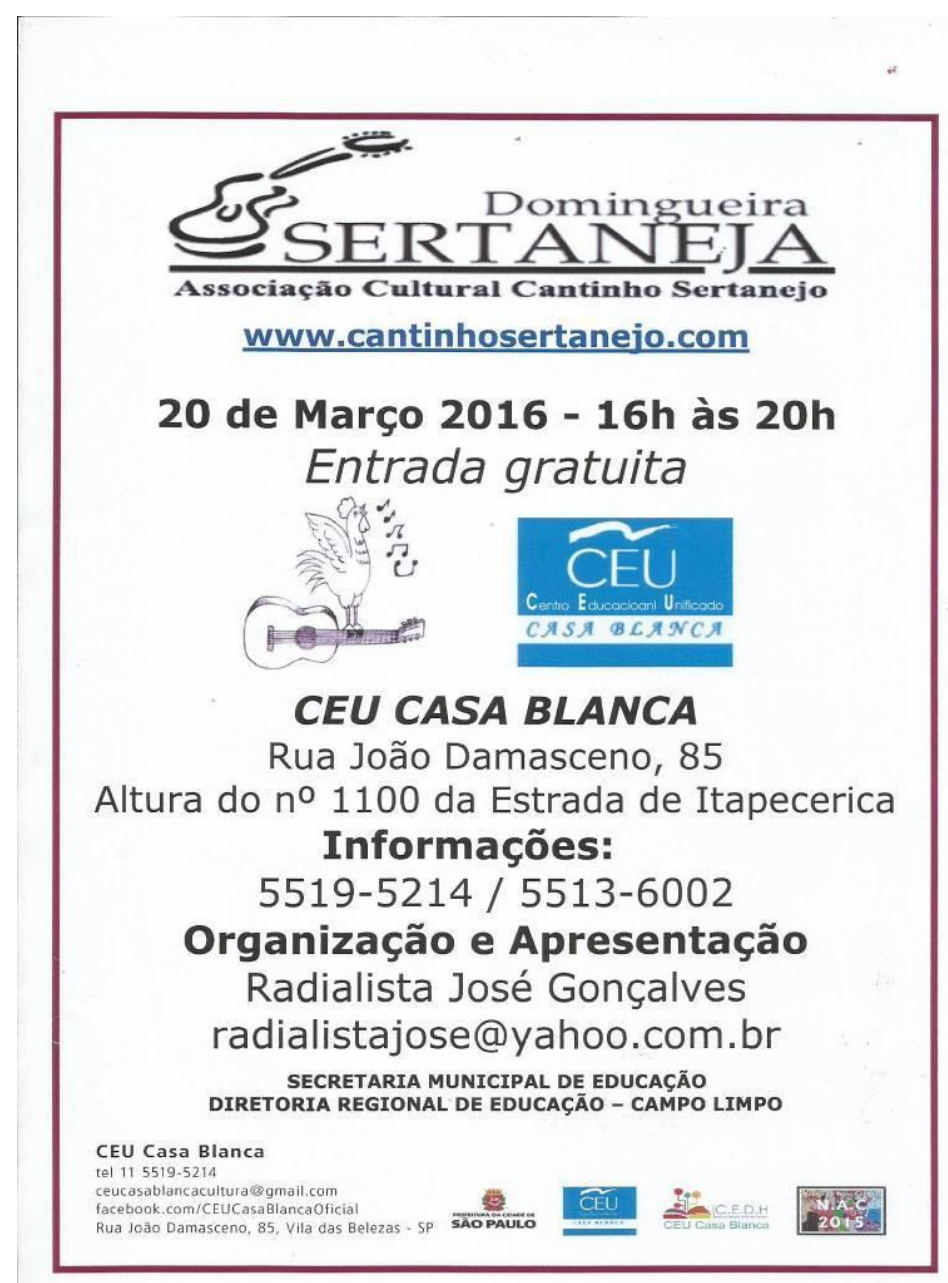

Figura 146. Cartaz de divulgação entregue pelo Sr. José Gonçalves, radialista da Associação Cultural Cantinho Sertanejo e responsável pela Domingueira Sertaneja, quando participou do Sarau da atividade de visitação de amigos e parentes do Grupo de Trabalho e de Ação, no dia 29 de janeiro de 2016, na Casa de Cultura de Santo Amaro.

A Mostra também teve o objetivo de dar início a uma nova fase dos Encontros Memória e Patrimônio Cultural de Santo Amaro, incentivando e estimulando a participação do público escolar de outras escolas localizadas no entorno do centro histórico nas ações do Inventário Comunitário e Escolar de Bens Culturais de Santo Amaro.

O Grupo de Trabalho preparou um projeto para sua continuidade no âmbito de edital da Secretaria Municipal de Cultura de São Paulo de valorização de iniciativas culturais (Programa VAI).

Todas as Oficinas integram também a Mostra Educativa Memória e Patrimônio Cultural de Santo Amaro. As Oficinas receberão o nome de Oficina de Saberes por se constituírem em um momento muito especial do Projeto. Nos Encontros, os participantes, incluindo aqueles pertencentes ao Grupo de $3^{\mathrm{a}}$ Idade Anos Dourados da Casa de Cultura de Santo Amaro, falarão de seu passado, de suas histórias e memórias, por meio da promoção de oficinas a partir de suas habilidades e saberes, como a confecção de bonecas de pano, preparo de pratos tradicionais, artesanato 
com trançado, confecção de lamparinas, jardinagem, entre outros, voltadas especialmente para crianças e jovens de escolas da região de Santo Amaro. (Extraído do Projeto Encontros, Memória e Patrimônio Cultural de Santo Amaro para o Programa VAI do Grupo de Trabalho)
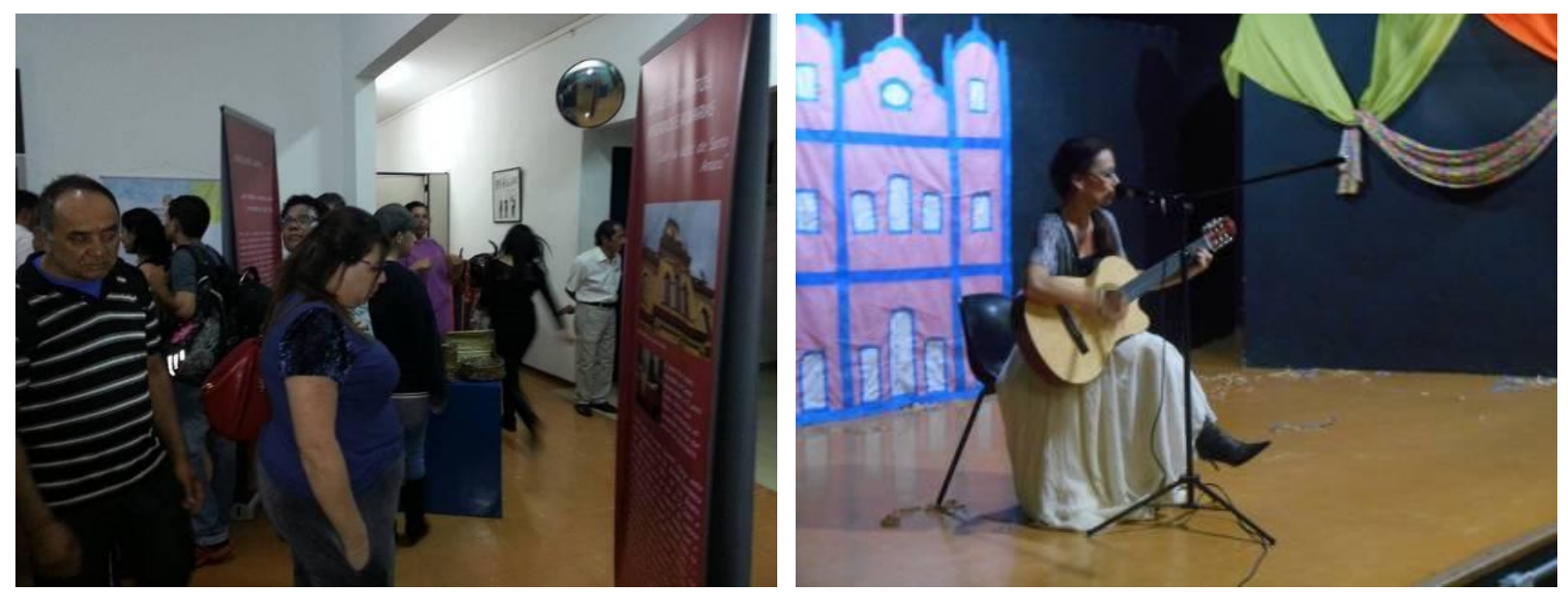

Figuras 147 e 148. Alunos do EJA na visita à Mostra Educativa e participando do Sarau das atividades de abertura na Biblioteca Belmonte. Fotos da autora. 


\title{
CONSIDERAÇÕES
}

Jacobi (2015) destaca que a consolidação de propostas participativas representa a potencialização e a ampliação de práticas comunitárias, através da mobilização de pessoas que multiplicam atividades em prol do reconhecimento de direitos e estimulam estratégias de envolvimento e corresponsabilização. Esse pode ser um dos caminhos para o fortalecimento de uma sociedade sustentável, que implica na necessidade de se multiplicarem as práticas sociais para promover ações sustentáveis. A sustentabilidade fortalece valores coletivos e solidários, a partir de práticas educativas que contribuam para uma atitude de ação-reflexãoação:

\begin{abstract}
Assim, se coloca o desafio de criar oportunidades para o real envolvimento dos sujeitos em relações de diálogo, que favoreçam: a percepção da diversidade de opiniões e visões de mundo; a mediação de interesses individuais e coletivos; e, a possibilidade de ampliação de repertórios que aumentem a capacidade de contextualizar e refletir (JACOBI, 2015, p.8).
\end{abstract}

Responsáveis pela construção e pelo desenvolvimento da nossa história nós vivemos hoje e fazemos parte de uma história da qual foram protagonistas nossos bisavós, avós e pais. Entretanto, “[...] vemos que os bens reunidos na história por cada sociedade não pertencem realmente a todos, mesmo que formalmente pareçam ser de todos e estejam disponíveis para que todos os usem" (CANCLINI, 2011, p.194).

O desenvolvimento de uma sociedade sustentável depende das condições de sustentabilidade em diversas áreas. A sustentabilidade cultural refere-se à necessidade de manter a diversidade cultural, os valores e as práticas sociais que compõem ao longo do tempo as identidades dos povos. ${ }^{135}$

Jacobi (2015) fala de fortalecimento de novas instituições, de mudanças no relacionamento do quadro técnico com os usuários, e da ampliação de uma nova mentalidade sobre a gestão da coisa púbica. E a instalação de espaços de convívio entremeados pela experiência de pensar e agir de forma dialógica, solidária e ecologicamente sistêmica cria solo fértil para a cultura da participação e para a construção de novos potenciais de governança. A participação entendida como um processo continuado de democratização da vida dos cidadãos e que requer uma sociedade civil organizada e capaz de influenciar o Estado para garantir a manutenção de direitos essenciais e de monitorar e influenciar os processos.

135 Desenvolvimento Sustentável e Agenda 21. Guia para Sociedade Civil, Municípios e Empresas, p.10. Disponível em: 〈www.oficinamunicipal.com.br〉. Acesso em: 02 mar 2016. 
A Aprendizagem Social apresenta-se como base para a incorporação de atitudes individuais e coletivas para a sustentabilidade. Possui potencial para a emergência de inovações, de compromissos coletivos e de práticas de cidadania orientada para a sustentabilidade (JACOBI et.al., 2009).

Envolve metodologias participativas e colaborativas que articulem as dimensões social, ambiental, cultural e afetiva, processos de informação reflexiva e engajada, sensibilização e a construção de espaços políticos-educativos de formação cidadã, de diálogos colaborativos, a internalização das questões ambientais, o comprometimento ético e político com novas posturas e sentidos comuns diante das urgências que se apresentam para a construção da sustentabilidade, que com o processo de globalização dos riscos, passa a ser de caráter planetário (JACOBI; FRANCO, 2011).

[...] Portanto, a aprendizagem social estimula e articula as pessoas a mudarem suas práticas, e combina também informação e conhecimentos, assim como capacitação, motivação e estímulos para a mudança de atitudes, habilidades adquiridas para participar de processos de negociação e avança para uma ação compartilhada e concertada (JACOBI, 2015, p.15).

A educação deve assumir seu papel de agente no processo de formação de sujeitos ativos e livres na construção de sua própria vida e da dimensão coletiva a ela inerente (CASCO, s/d):

É essa dimensão coletiva, conquistada e reafirmada que permite ao público ressignificar termos como cidadania, participação, responsabilidade e pertencimento. A educação pode ser um dos meios através dos quais se desvende o rosto digno da diversidade brasileira (CASCO, s/d, p.4).

É preciso que os grupos sociais produtores de bens culturais nas suas práticas sociais e simbólicas cotidianas participem das definições dos destinos de seus patrimônios (SILVEIRA; BEZERRA, 2007).

A sociedade cada vez mais demandará uma educação crítica (SAVIANI, 2002), problematizadora, contextualizada e interdisciplinar, que permita se inserir no mundo politicamente e de forma consciente, responsável e solidária (FREIRE, 1966); e uma aprendizagem como um processo contextualizado, compartilhado e participativo que alavanca o tema da cidadania, de direitos e responsabilidades, de práticas participativas, de processos decisórios de interesse público (JACOBI, 2015).

$\mathrm{Na}$ sociedade de risco, em que o risco é produto do próprio desenvolvimento da sociedade contemporânea e a torna reflexiva, o que significa dizer que ela se torna um tema e um problema para ela própria (BECK, 1997), o reconhecimento da ausência de previsibilidade das ameaças geradas pelo processo de desenvolvimento técnico industrial 
requer processos educativos para abrir a possibilidade de desenvolvimento de ações que tenham como objeto a real transformação da realidade. Requer a redefinição da prática educativa como aquela que, juntamente com outras práticas sociais, está implicada no fazer histórico, é produtora de saberes e valores e, por excelência, constitutiva da esfera pública e da política, onde se exerce a ação humana (CARVALHO, 1992; 1995).

Nesse sentido, a Educação tem um importante papel social a cumprir, além dos limites dos museus, instituições educacionais e espaços de preservação de nosso patrimônio, devendo se disseminar como um importante instrumento de valorização dos bens patrimoniais locais, alicerçando trabalhos educativos em entidades não governamentais de atuação social local, assim como em processos gerais de aprendizagens sociais (RIZZI, 2008).

A mediação cultural, atuando sobre o objeto cultural e desenvolvendo práticas educacionais, pode ser um poderoso instrumento educacional, uma vez que promove o diálogo em contexto, trabalha com os saberes e com a bagagem cultural. Esse fato pode realçar o papel do educador como agente social de transformação. Por outro lado, é um termo complexo e em discussão, pois lida com um conjunto de questões que perpassam os campos de discussão ética e teórica (SILVEIRA; BEZERRA, 2007; CHAGAS, 2004).

A Educação pode assumir tanto um papel de conservação da ordem social, reproduzindo valores, ideologias e interesses dominantes socialmente, como um papel emancipatório, promovendo a renovação cultural, política e estética da sociedade e o pleno desenvolvimento das potencialidades dos indivíduos que a compõem (LOUREIRO, 2004a e 2004b).

A pedagogia freireana, ao propor uma educação alternativa à educação tradicional e acrítica, favorece a tomada de consciência, por parte dos educandos, de sua condição social e seu "ser no mundo", para romperem com a organização de uma sociedade elitista capitalista e transformarem sua própria realidade. Paulo Freire $(1966,2006,2011)$ defende uma educação problematizadora, contextualizada e interdisciplinar, que permita se inserir no mundo politicamente de forma consciente, responsável e solidária.

Assim, os princípios e objetivos de uma ação educativa devem partir de uma concepção de Educação do tipo emancipatória e devem propor uma pesquisa e um fazer educativo orientados na busca de transformação social, nos quais a prática constante do diálogo, do exercício da cidadania, do fortalecimento dos sujeitos, da compreensão do mundo em sua complexidade e do entendimento da vida em sua totalidade passam a ser imprescindíveis. 
O ato de educar é, acima de tudo, um ato político e, o educador, ao traçar os objetivos da educação "revela sua atitude em face da realidade e adota uma posição em relação a ela; orienta-se no sentido de contribuir para a reprodução, ou para a transformação da ordem social vigente" (GONÇALVEZ, 2004, p.473).

O Patrimônio Cultural Brasileiro não se restringe aos objetos históricos e artísticos, aos monumentos representativos da memória nacional ou aos centros históricos já consagrados e protegidos pelas instituições e agentes governamentais. Outras formas de expressão cultural também constituem o patrimônio cultural da sociedade brasileira e são produzidas por pessoas no cotidiano dos seus afazeres e pelas práticas sociais.

Assim, na pesquisa-ação, que procurou propiciar a participação dos atores sociais envolvidos em todas as suas etapas, o conhecimento científico e o popular tiveram relevância e foram complementares (TOLEDO; JACOBI, 2012). A pesquisa-ação proporcionou atividades que fortaleceram práticas colaborativas e interconexões entre pessoas, ideias e ações, voltadas para o conhecimento e a preservação do Patrimônio Cultural de Santo Amaro, como um dos pilares do desenvolvimento sustentável na região.

As atividades educativas tiveram o objetivo de fortalecer formas coletivas de pensar e enfrentar os problemas associados ao uso sustentável da cultura. A Educação Patrimonial não deve encontrar suporte somente na ciência e na técnica para a chancela dos bens culturais; deve se ancorar também nas experiências, no saber e nas práticas cotidianas, para uma gestão integrada de conhecimentos e saberes e uma cultura de corresponsabilização e de participação democrática, que relacionem o conceito de cidadania ao do sujeito histórico, ativo na cena política e que participa cotidianamente nas mais variadas instâncias, reivindicando e exigindo direitos. Deve se apresentar como instrumento para fortalecer o papel dos cidadãos na gestão pública do patrimônio cultural.

O que se pode observar é que ao garantir a participação da sociedade civil na gestão pública introduz uma importante mudança, pois a presença dos cidadãos garante que as decisões sejam tomadas de forma transparente e no seu benefício (JACOBI, 2015, p.33).

Neste sentido, a concepção de Educação Patrimonial aqui adotada entendeu o patrimônio e a memória como elementos motivadores para a ação cidadã, considerando-a como possibilidade e condição de intervir na realidade, de forma cada grupo tornar-se produtor, guardião e difusor de sua própria história, tratando da questão da preservação como uma prática social, na qual se pode reconhecer diversos agentes sociais em disputa pelo território ou espaço na cidade (ARANTES, 1984). 
Todos os envolvidos devem ser entendidos como sujeitos históricos, deixando o papel de expectador e atuando na seleção e interpretação do seu patrimônio histórico e cultural, numa perspectiva de educação que leve em consideração a existência de conflitos e contradições. Desse modo, as metodologias e ferramentas participativas aplicadas na pesquisa-ação se basearam em processos educativos de integração de diferentes atores sociais, de diálogo de saberes e construção coletiva de conhecimentos.

Conjugar a política de preservação ao processo dinâmico de desenvolvimento das cidades implica direcionar as mudanças a favor dos patrimônios, trabalhando na perspectiva do desenvolvimento sustentável (PRATA, 2009):

\footnotetext{
Embora o conceito de paisagem cultural traga como uma de suas premissas a preservação com sustentabilidade[...], ao observar as práticas mais correntes das instituições responsáveis pelo patrimônio, constata-se que a toada dominante ainda é a da intocabilidade de bens (PRATA, 2009, p.132).
}

A Constituição de 1988, em seu artigo 216, fala que o poder público, com a colaboração da comunidade, promoverá e protegerá o Patrimônio Cultural Brasileiro, por meio de inventários, registros, vigilância, tombamento e desapropriação, e de outras formas de acautelamento e preservação (BRASIL,1988).

Preservar é o reconhecimento por parte das diversas comunidades de seus valores identitários e de memória, competindo somente a ela preservar, com o apoio do Estado, esses bens para as gerações futuras. É à comunidade, enquanto detentora/agenciadora de seus próprios valores, que cabe selecionar e zelar por tudo o que é relevante para ela. Ao Estado (em âmbito federal, estadual e municipal) cabe apenas reconhecer e garantir este exercício de cidadania com a criação de mecanismos legais, para tornar pleno esse exercício, estabelecendo restrições ao uso de bens públicos ou privados sempre que o interesse maior da coletividade assim o exigir (CASCO, s/d.)

No sentido de uma construção coletiva de conhecimento e de significados atribuídos ao patrimônio cultural (material e imaterial) de Santo Amaro que foi desenvolvida essa pesquisa-ação. Partindo de atividades de Educação Patrimonial e Arte-Educação, com base na Aprendizagem Social, buscou a evidenciação e valorização dos bens culturais da região.

A pesquisa-ação elaborou e desenvolveu atividades pautadas pela aplicação de metodologias participativas e colaborativas que visaram estimular o interesse, o engajamento e uma participação mais ativa de moradores tradicionais do bairro, do público participante das ações culturais mantidas por algumas instituições e entidades locais, agentes culturais e formadores de opinião da região e alunos e professores de escolas públicas existentes em 
Santo Amaro para com seu patrimônio cultural: uma postura de ação-reflexão-ação em torno da problemática patrimonial, baseada na premissa "aprender juntos para gerir juntos" (HARMONICOP, 2003).

Por meio de um processo educativo e investigativo de inventário de bens patrimoniais locais, a pesquisa-ação levantou e problematizou em conjunto e de forma colaborativa com esses atores sociais locais algumas histórias e memórias da região de Santo Amaro, como também as ações no presente de grupos locais nos espaços culturais da região, que revelaram "vestígios, testemunhos, documentos, imagens, discursos, sinais visíveis do que foi [...]" (NORA, 1993, p. 15), buscando favorecer a capacidade crítica e de participação desses grupos na política de preservação de bens culturais de Santo Amaro.

\footnotetext{
Nenhuma época foi tão voluntariamente produtora de arquivos como a nossa, não somente pelos meios técnicos de reprodução e de conservação de que dispõe, mas pela superstição e pelo respeito ao vestígio. À medida em que desaparece a memória tradicional, nós nos sentimos obrigados a acumular religiosamente vestígios, testemunhos, documentos, imagens, discursos, sinais visíveis do que foi, como se esse dossiê cada vez mais prolífero devesse se ornar prova em não se sabe que tribuna da história (NORA, 1993).
}

A aplicação das metodologias participativas almejou a capacitação, participação e o exercício da cidadania. $\mathrm{Na}$ fase inicial da pesquisa-ação, as metodologias aplicadas possibilitaram o reconhecimento do território de estudo, diagnóstico e o mapeamento dos órgãos colegiados e movimentos e organizações sociais locais, como também, e em todo o processo, a melhoria da relação entre os participantes e a ampliação dos diálogos e laços de confiança.

Durante os três anos da pesquisa-ação, elas permitiram a todos os participantes vivenciar o lugar para propor mudanças. Relacionando com as outras metodologias específicas da Educação Patrimonial e da Arte Educação, serviram para introduzir a questão do alargamento da abrangência do conceito de patrimônio cultural e sensibilizar e mobilizar os atores sociais locais; muito embora na pesquisa-ação os grupos da Terceira Idade, as turmas do Curso de Dança Vocacional da Casa Amarela e uma das comunidades escolares da região tenham sido os mais receptivos às atividades com as metodologias participativas, apresentando uma postura ativa em todo o projeto, que estimulou a colaboração e a corresponsabilidade e a construção de práticas capazes de atender ao interesse público e conhecer, entender, reclamar seus direitos, de forma os cidadãos serem parte integrante de uma política pública inclusiva, democrática e sustentável, que lhe garanta direitos essenciais e acesso às informações, representação técnica e participação nos processos de formulação de políticas, de planejamento e de avaliação de serviços públicos. (JACOBI, 2015). 

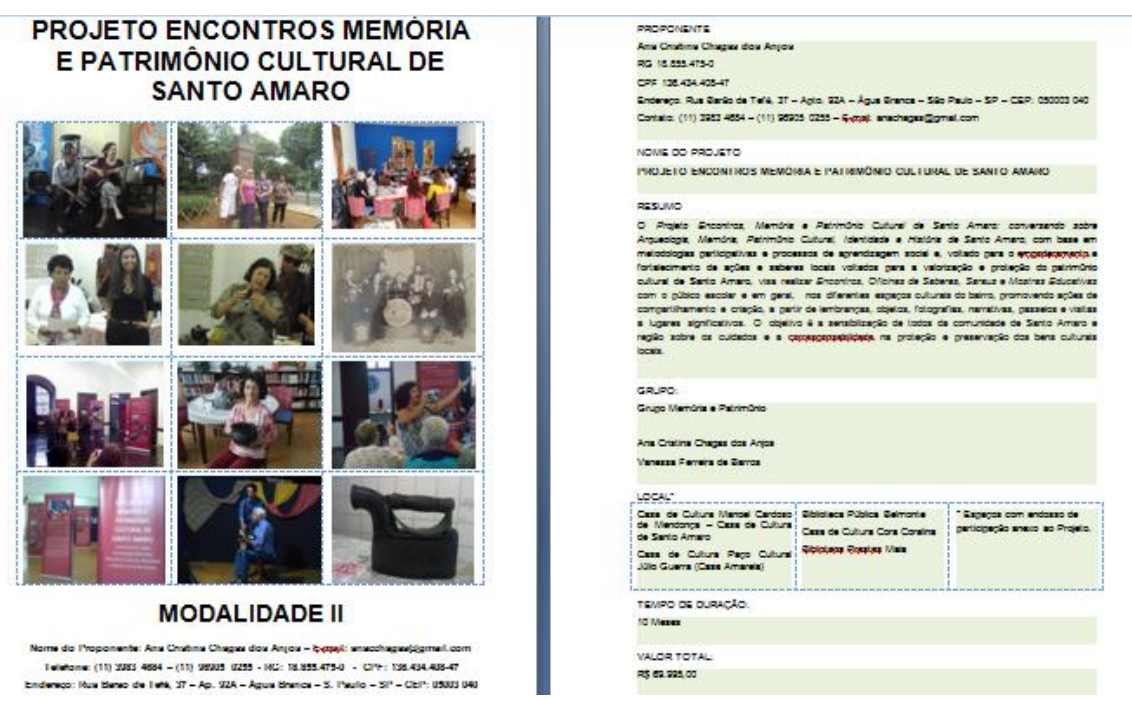

Figuras 149 e 150. Capa e contra capa do projeto encaminhado para a Secretaria Municipal de Cultura de São Paulo para concorrer ao Edital VAI de 2016.

A pesquisa-ação teve seus objetivos específicos cumpridos. Conheceu e analisou conjuntamente com os atores sociais locais a trajetória de reflexões e proposições que fundamentaram os tombamentos e ações de preservação realizadas na região de Santo Amaro, em especial aquele relativo ao chamado Eixo Histórico. Desenvolveu ações e processos educativos para e com os atores sociais locais relacionados ao inventário e à reflexão sobre o patrimônio cultural em geral e o arqueológico em especial da região de Santo Amaro, para a promoção do fortalecimento de valores coletivos e solidários. Investigou a contribuição de metodologias participativas aplicadas a partir do trabalho pedagógico com a questão do patrimônio, como ferramentas de Aprendizagem Social no desenvolvimento de práticas mediadoras em Educação para a Sustentabilidade Socioambiental e Cultural. Promoveu diversos espaços de aprendizado coletivo, envolvendo pessoas com conhecimentos específicos e representações sociais bem peculiares e circunscritos aos seus modos particulares de viver. Contribuiu com parâmetros para a elaboração de programas educacionais com foco na sustentabilidade e com base na Aprendizagem Social, vinculados ao desenvolvimento das pesquisas arqueológicas em processos de licenciamentos ambientais. Colaborou para a inserção da questão do patrimônio cultural e arqueológico também no âmbito das preocupações e do programa curricular das escolas envolvidas no processo, fomentando o uso do Patrimônio Cultural Material e Imaterial como recurso pedagógico no contexto escolar, objetivando criar situações de vivência e reflexões sobre a memória, herança, território, preservação e novas gerações junto aos alunos. 


\section{REFERÊNCIAS}

A LASCA ARQUEOLOGIA. Santo Amaro. São Paulo: A Lasca Consultoria e Assessoria em Arqueologia S. S. Ltda, s.d.

\section{A LASCA ARQUEOLOGIA. Diagnóstico arqueológico complementar ao RAP - Linha 5}

- Lilás do Metrô. Trecho Largo Treze e Estação Adolfo Pinheiro. São Paulo: A Lasca Consultoria e Assessoria em Arqueologia S. S. Ltda, 2009.

\section{A LASCA ARQUEOLOGIA. Programa de Prospecção e Monitoramento Arqueológico} no Trecho Largo Treze a Adolfo Pinheiro Linha 05 - Lilás do Metrô de São Paulo - SP. Plano de Trabalho e Relatório de Atividades do Programa de Educação Patrimonial. São Paulo: A Lasca Consultoria e Assessoria em Arqueologia S. S. Ltda, 2013.

ABREU, Regina. Museus Etnográficos e Práticas de Colecionamento. Antropofagia dos Sentidos. Revista do Patrimônio Histórico e Artístico Nacional. Brasília: IPHAN, n. 31, p.101-125, 2005

ALCÂNTARA, Aureli Alves de. Paulo Duarte: entre sítios e trincheiras em defesa da sua dama: a pré-história. Dissertação (Mestrado), Museu de Arqueologia e Etnologia da Universidade de São Paulo, São Paulo, 2007.

ALENCAR, Vera Maria A. Museu-Educação: se faz caminho ao andar. Dissertação (Mestrado), Departamento de Educação da Pontifícia Universidade Católica, Rio de Janeiro, 1987.

ALMEIDA, Márcia Bezerra. O Australopiteco Corcunda: as crianças e a arqueologia em um projeto de Arqueologia Pública na Escola. Tese (Doutorado), Faculdade de Filosofia, Letras e Ciências Humanas / Museu de Arqueologia e Etnologia da Universidade de São Paulo, São Paulo, 2002. 
ANDRADE, Antonio Luiz Dia de. Um estado completo que pode jamais ter existido. Tese (Doutorado), Faculdade de Arquitetura e Urbanismo da Universidade de Sãoe Paulo, São Paulo, 1993.

ANJOS, Ana Cristina Chagas dos Anjos. Arte Educação e Educação Ambiental. Uma reflexão sobre a colaboração teórica e metodológica da Arte Educação para a Educação Ambiental. Dissertação (Mestrado), Escola de Comunicação e Artes da Universidade de São Paulo, São Paulo, 2010.

ARANTES, Antonio A. Produzindo o passado: estratégias de construção do patrimônio cultural. São Paulo: Brasiliense, 1984.

. O patrimônio cultural e seus usos: a dimensão urbana. In: Hábitus,

Goiânia, v. 4, n. 1, p. 425-435, jan/jun, 2006.

ARÉVALO, Marcia Conceição da Massena. Sentir para agir: avaliando uma proposta de educação patrimonial. Dissertação (Mestrado), Instituto do Patrimônio Histórico e Artístico Nacional - IPHAN, Rio de Janeiro, 2013.

ASSOCIAÇÃO COMERCIAL DE SÃO PAULO. Jubileu de Ouro. Distrital Santo Amaro 50 anos. São Paulo: Associação Comercial de São Paulo, 2004.

AZEVEDO, Fernando Antônio G. Movimentos Escolinhas de Arte: em cena memórias de Noemia Varela e Ana Mae Barbosa. Dissertação (Mestrado). Escola de Comunicação e Artes da Universidade de São Paulo, São Paulo, 2000.

AZEVEDO, Paulo Ormindo de. Renato Soeiro e a institucionalização do setor cultural no Brasil. In: AZEVEDO \& CORREIA (Org). Estado e sociedade na preservação do patrimônio. Salvador: EDUFBA, 2013.

BACCI, Denise. L. C.; SANTOS, Vânia. M. N. Mapeamento socioambiental como contribuição para a gestão dos recursos naturais. In: JACOBI, Pedro R. (coord.). 
Aprendizagem social e unidades de conservação: diálogos entre ciência e a governança ambiental. São Paulo: IEE/PROCAM/USP, 2013.

BANDURA, A. Social Learning Theory. New Jersey: Prentice-Hall, 1977.

BARBOSA, Ana Mae. Arte-Educação: conflitos e acertos. São Paulo: Max Limonad, 1984.

. Tópicos Utópicos. Belo Horizonte: C/Arte, 1998.

. (Org.) Ensino da Arte: memória e história. São Paulo: Perspectiva,

2008.

A imagem no ensino da arte: anos oitenta e novos tempos. $7^{\mathrm{a}} \mathrm{ed}$.

São Paulo: Perspectiva, 2009.

BARRETO, Cristiana. Arqueologia brasileira: uma perspectiva comparada. Revista do Museu de Arqueologia e Etnologia. São Paulo, Suplemento 3, p. 201-212, 1999.

BASTOS, Rossano Lopes. Uma arqueologia dos desaparecidos: identidades vulneráveis e memórias partidas. São Paulo: Superintendência do IPHAN em São Paulo, 2010.

A arqueologia pública no Brasil: novos tempos. In: MORI, V. et. al.

(Org.). Patrimônio: atualizando o debate. Instituto do Patrimônio Histórico e Artístico Nacional. São Paulo: IPHAN-SP, 2015.

BECK, Ulrich. A reinvenção da política: rumo a uma nova teoria da modernização reflexiva. In: BECK, U.; GIDDENS, A. LASH, S (Org). Modernização Reflexiva: Política, Tradição e Estática na Ordem Social Moderna. São Paulo: Unesp, 1997.

BERARDI, Maria Helena Petrillo. Santo Amaro. vol. 4. São Paulo: DPH, 1981. (Coleção História dos Bairros de São Paulo). 
Santo Amaro: memória e história: da botina amarela ao chapéu de couro. São Paulo: Scortecci, 2003.

BINFORD, Lewis Roberts. Em busca del pasado: descifrando el registro arqueológico. Barcelona: Crítica, 1994.

BOSI, Ecléa. Memória da cidade: lembranças paulistanas. In: São Paulo. Secretaria Municipal de Cultura. Departamento do Patrimônio Histórico. O direito à memória: patrimônio histórico e cidadania. São Paulo: DPH, 1992.

BRANDÃO, Carlos Rodrigues. Cultura, Educação e Interação: observações sobre ritos de convivência e experiências que aspiram torná-las educativas In: BRANDÃO, Carlos Rodrigues et. al., O difícil espelho: limites e possibilidades de uma experiência de cultura e educação. Rio de Janeiro: IPHAN, 1996.

. (Org.). Repensando a Pesquisa Participante. São Paulo:

Brasiliense, 1999.

BRASIL. Lei no . 3.924, de 26 de julho de 1961. Dispõe sobre os monumentos arqueológicos e pré-históricos. Disponível em:

<http://portal.iphan.gov.br/legislacao?pagina=17>. Acesso em: 29 fev 2016.

BRASIL. Lei nº 6.938, de 31 de agosto de 1981. Da Política Nacional de Meio Ambiente. Disponível em:

<http://www.planalto.gov.br/ccivil_03/Leis/L6938compilada.htm>. Acesso em 29 fev 2016.

BRASIL. Constituição da República Federativa do Brasil, 1988. Disponível em: <http://www.planalto.gov.br/ccivil_03/constituicao/ConstituicaoCompilado.htm> Acesso em: 29 fev 2016.

BRASIL. Lei $\mathrm{n}^{\circ}$. 9.394, de 20 de dezembro de 1996. Estabelece as diretrizes e bases da educação nacional. Disponível em:

<http://www.planalto.gov.br/CCIVIL_03/leis/L9394.htm>. Acesso em 29 fev 2016. 
BRASIL. Resolução CONAMA nº. 237, de 19 de dezembro de 1997. Disponível em: <http://www.mma.gov.br/port/conama/res/res97/res23797.html >. Acesso em 29 fev 2016.

BRASIL. Lei $n^{\circ}$. 9.605, de 12 de fevereiro de 1998. Dispõe sobre as sanções penais e administrativas derivadas de condutas e atividades lesivas ao meio ambiente, e dá outras providências. Disponível em:

<http://www.planalto.gov.br/CCIVIL_03/leis/L9605.htm> Acesso em: 29 fev 2016.

BRASIL. Decreto $\mathrm{n}^{\circ}$. 3.551, de 4 de agosto de 2000. Institui o registro de bens culturais de natureza imaterial que constituem patrimônio cultural brasileiro, cria o Programa Nacional de Patrimônio Imaterial e dá outras providências. Disponível em:

<http://www.planalto.gov.br/ccivil_03/decreto/D3551.htm>. Acesso em: 29 fev 2016.

BRASIL. Portaria $n^{\circ}$. 127, de 30 de abril de 2009. Estabelece a chancela da Paisagem Cultural Brasileira.

Disponível

em: http://portal.iphan.gov.br/uploads/ckfinder/arquivos/Livreto_paisagem_cultural.pdf>. Acesso em: 04 mar 2016.

BRASIL. Decreto $n^{\circ}$. 8.124, de 17 de outubro de 2013. Regulamenta dispositivos da Lei $\mathrm{n}^{\mathrm{o}}$ 11.90a4, de 14 de janeiro de 2009, que institui o Estatuto de Museus, e da Lei $\mathrm{n}^{\circ}$ 11.906, de 20 de janeiro de 2009, que cria o Instituto Brasileiro de Museus - IBRAM. Disponível em: <http://www.planalto.gov.br/ccivil_03/_Ato2011-2014/2013/Decreto/D8124.htm> Acesso em: 01 mar 2016.

BRASIL. Lei de Diretrizes e Bases da Educação Nacional, Lei no 9.394, de 20 de dezembro de 1996. Ministério da Educação. Disponível em:

<http://www.planalto.gov.br/CCIVIL_03/leis/L9394.htm> Acesso em: 01 mar 2016

BRASIL. Lei Federal 6.513, de 20 de dezembro de 1977. Dispõe sobre a criação de Áreas Especiais e de Locais de Interesse Turístico; sobre o Inventário com finalidades turísticas dos bens de valor cultural e natural; acrescenta inciso ao art. $2^{\circ}$ da Lei $\mathrm{n}^{\circ} 4.132$, de 10 de setembro de 1962; altera a redação e acrescenta dispositivo à Lei no 4.717, de 29 de junho de 1965; e dá 
outras providências. Disponível em: http://www.planalto.gov.br/ccivil_03/leis/L6513.htm> Acesso em: 02 mar 2016.

BRASIL. Instrução Normativa IPHAN $\mathrm{n}^{\circ}$ 1, de 25 de março de 2015. Estabelece procedimentos administrativos a serem observados pelo Instituto do Patrimônio Histórico e Artístico Nacional nos processos de licenciamento ambiental dos quais participe. Disponível em:

<http://portal.iphan.gov.br/legislacao?pagina=1> Acesso em: 29 fev 2016.

BRASIL. Ministério do Meio Ambiente. Disponível em: 〈http://www.mma.gov.br>. Acesso em: 29 fev 2016.

BRASIL. Parâmetros Curriculares Nacionais. Ministério da Educação. Disponível em: 〈http://portal.mec.gov.br/arquivos/pdf/pne.pdf >. Acesso em 15 de maio de 2014.

BRASIL. Prova Brasil. Disponível em: 〈http://portal.mec.gov.br/prova-brasil> Acesso em: 29 fev 2016.

BRUNO, M. C. O. Musealização da Arqueologia: um estudo de modelos para o projeto Paranapanema. Tese (Doutorado), Faculdade de Filosofia, Letras e Ciências Humanas/Museu de Arqueologia e Etnologia da Universidade de São Paulo, São Paulo, 1995.

Museologia: algumas ideias para a sua organização disciplinar. Cadernos de Sociomuseologia, Lisboa, UHLT, n. 9, 1996.

A importância dos processos museológicos para a preservação do patrimônio. Revista do Museu de Arqueologia e Etnologia. São Paulo: Suplemento 3, p. 333-337, 1999.

Museologia: a luta pela perseguição ao abandono. Tese (LivreDocência). Museu de Arqueologia e Etnologia da Universidade de São Paulo, São Paulo, 2001. 
CALDARELLI, S. B. Levantamento arqueológico em planejamento ambiental. Revista do Museu de Arqueologia e Etnologia, São Paulo, Suplemento 3, p. 347-369, 1999.

CAMPOFIORITO, Ítalo. Muda o mundo do patrimônio: notas para um balanço crítico. In: Revista do Brasil, n. 4, 1985, p. 32-43.

CAMPOS, Eudes. A vila de São Paulo do Campo e seus caminhos. Revista do Arquivo Histórico. São Paulo, DPH, v. 204, 2006.

CANCLINI, Néstor Garcia. Culturas Híbridas - estratégias para entrar e sair da modernidade. $4^{\text {a } . ~ E d ., ~ S a ̃ o ~ P a u l o: ~ E D U S P, ~} 2011$.

CARNEIRO, Carla Gibertoni. Ações educacionais no contexto da arqueologia preventiva: uma proposta para a Amazônia. Tese (Doutorado), Museu de Arqueologia e Etnologia da Universidade de São Paulo, São Paulo, 2009.

CARVALHO, Isabel C. M. Educação, meio ambiente e ação política. In: ACSELRAD, H. (Org.). Meio Ambiente e democracia. Rio de Janeiro: IBASE, 1992.

Movimentos Sociais e Políticas de Meio Ambiente. A Educação Ambiental aonde fica? In: SORRENTINO, Marcos; TRAJBER, Rachel; BRAGA, Tânia. Fórum de Educação Ambiental. Cadernos do II Fórum de Educação Ambiental. São Paulo: Gaia, 1995.

CARVAlHO, Marcos Rogério R. de. Nos caminhos da Serra: Arqueologia, História, Patrimônio e Memória. A ocupação humana na Serra da Cantareira entre os séculos XVII e XX. Tese (Doutorado), Museu de Arqueologia e Etnologia da Universidade de São Paulo, São Paulo, 2012.

CASCO, Ana Carmem Amorim Jara. Sociedade e Educação Patrimonial. Disponível em: <http://portal.iphan.gov.br/portal/baixaFcdAnexo.do?id=526>. Acesso em: 29 fev 2016. 
CASTILlO RUIZ, J. Hacia uma nueva definición de patrimônio histórico? PH Boletim del Instituto Andaluz del Patrimônio Histórico, Sevilla, IAPH, n. XVI, setiembre, 1996.

CASTRIOTA, Leonardo Barci. Intervenções sobre o patrimônio urbano: modelos e perspectivas. Fórum Patrimônio: amb. constr. e patr. sust Belo Horizonte, v.1, n.1, set/dez, 2007.

CASTRO, Sonia Rabelo de. O Estado na preservação de bens culturais. Rio de Janeiro: Renovar, 1991.

CASCINO, Fábio Alberti. Princípios Interdisciplinares para a construção de uma educação ambiental. Dissertação (Mestrado). São Paulo: PUC-SP, 1998.

CHAGAS, Mário. Diabruras do Saci: museu, memória, educação e patrimônio. In: MUSAS Revista Brasileira de Museus e Museologia. Brasília, IPHAN, n. 1, p. 136-146, 2004.

Educação, museu e patrimônio: tensão, devoração e adjetivação. Revista Eletrônica do IPHAN. 2006. Disponível em:

<http://www.labjor.unicamp.br/patrimonio/materia.php?id=145>. Acesso em: 29 fev 2016.

CHILDE, V. Gordon. O que aconteceu na História. Rio de Janeiro: Zahar, s.d. Para uma recuperação do passado - a interpretação dos dados arqueológicos. São Paulo: Difel, 1976.

CHOAY, Françoise. A alegoria do patrimônio. 4a . Ed. São Paulo: Estação Liberdade/Editora UNESP, 2006.

CHUVA, Márcia. R. R. Os arquitetos da memória: sociogênese das práticas de preservação do patrimônio cultural no Brasil (anos 1930-1940). Rio de Janeiro: UFRJ, 2009. 
CRAPS, M. (Editor). Social learning in river basin management. Report of work package 2 of de HarmoniCOP project. 2003. Disponível em <http://www.harmoni-cop.info/_files/down/SocialLearning.pdf>. Acesso em: 29 fev 2016.

\& PRINS, S. Participation and Social Learning in the Development Planning of a Flemish River Valley. Case Study Report Produced under Work Package 5. Centre for Organizational and Personnel - Psychology, K.U. Leuven, 2004.

CUNHA, Danilo Fontenele Sampaio. Patrimônio cultural: proteção legal e constitucional. Rio de Janeiro: Letra Legal, 2004.

CUNHA, Maria Clementina Pereira. Patrimônio histórico e cidadania: uma discussão necessária. In: São Paulo. Secretaria Municipal de Cultura. Departamento do Patrimônio Histórico. O direito à memória: patrimônio histórico e cidadania. São Paulo: DPH, 1992

CURY, Isabelle. (org.). Cartas Patrimoniais. Ministério da Cultura, Instituto do Patrimônio Histórico e Artístico Nacional. Rio de Janeiro: IPHAN, 2004.

DIAS, Genebaldo F. Educação Ambiental: princípios e práticas. São Paulo: Gaia, 1998.

DIEGUES, Antonio Carlos. Os mitos bioantropomórficos, os neomitos e o mundo natural. In: O mito moderno da natureza intocada. 6 ${ }^{a}$. Ed. São Paulo: HUCITEC/NUPAUB, 2008.

EISNER, Elliot. Educating artistic vision. Ney York: Macmillan, 1972.

EL ANDALOUSSI, K. Pesquisas-ações: ciências, desenvolvimento, democracia. São Carlos: EdUFSCar, 2004.

ELIAS, Maria José. Museu Paulista: Memória e História. Tese (Doutorado) - Faculdade de Filosofia, Letras e Ciências Humanas. São Paulo: Universidade de São Paulo, 1996. 
Encontra Santo Amaro. História de moradores de Santo Amaro. Disponível em: http://www.encontrasantoamaro.com.br/historias-de-moradores-de-santo-amaro/> Acesso em 02 mar 2016.

FERDIÈRE, A. Les prospections au sol. In: DABAS et al. La prospection. Paris: Ed. Errance. 1998.

FERNANDES, Tatiana Costa. Vamos criar um sentimento?! Um olhar sobre a Arqueologia Pública no Brasil. Dissertação (Mestrado) - Museu de Arqueologia e Etnologia. São Paulo: Universidade de São Paulo, 2007.

FERREIRA SANTOS, Marcos. Cultura imaterial e processos simbólicos. Revista do Museu de Arqueologia e Etnologia. São Paulo, n. 14, p. 139-151, 2004.

FIGUEIREDO, Vanessa Gayego Belo. Da tutela dos monumentos à gestão sustentável das paisagens culturais complexas: inspirações à política de preservação cultural do Brasil. Tese (Doutorado). Faculdade de Arquitetura e Urbanismo da Universidade de São Paulo, São Paulo, 2014.

FLORÊNCIO, Sônia Regina Rampim. Educação Patrimonial: um processo de mediação. In: TOLENTINO, Átila Bezerra (Org.). Educação Patrimonial: reflexões e práticas. João Pessoa: IPHAN-PB, 2012. (Caderno Temático 2).

FONSECA, Maria Cecília Londres. O Patrimônio em processo: trajetória da política federal de preservação no Brasil. $2^{\text {a }}$ Ed. Rio de Janeiro: Editora UFRJ/MinC-IPHAN, 2005.

FRANCO, Maria Isabel. Educação Ambiental e Pesquis-ação Participante: registro analítico-crítico de uma práxis educativa. Tese (Doutorado). Faculdade de Educação da Universidade de São Paulo, São Paulo, 2010.

FREIRE, Paulo. Educação como prática da liberdade. Rio de Janeiro: Paz e Terra, 1966.

Ação cultural para a liberdade e outros escritos. $11^{a}$ Ed. São Paulo: Paz e Terra, 2006. 
. Pedagogia do oprimido. Rio de Janeiro: Paz e Terra, 2011.

FUNARI, Pedro Paulo. A Arqueologia Brasileira: visão geral e reavaliação. Revista de História da Arte e Arqueologia. Campinas, n. 1, p. 23-41, 1994

A importância da teoria arqueológica internacional para a arqueologia sul-americana: o caso brasileiro. Revista do Museu de Arqueologia, São Paulo, p. 74-85, dez./fev. 1999-2000.

. Turismo e patrimônio cultural. São Paulo: Contexto, 2001.

; PELEGRINI, S. C. A. Patrimônio histórico e cultural. Rio de Janeiro: Zahar, 2006.

et. al. Arqueologia pública no Brasil e as novas fronteiras. Praxis Archaeologica. n. 3, p. 131-138, 2008.

\& CARVAlHO, A. Patrimônio cultural, diversidade e comunidades. Campinas-SP: IFCH/UNICAMP, 2011.

FUNTOWICZ S \& RAVETZ, J. R. Ciência Pós-normal e comunidades ampliadas de pares face aos desafios ambientais. História, Ciência, Saúde, v. 4, n. 2, p. 219-230, 1997.

GARAEIS, V. H. Educação patrimonial: práticas alternativas, memórias, identidades e representações. Revista de Letras e História Textura, Canoas, n. 11, jan./jun. 2005.

Gazeta de Santo Amaro. Edição Histórica Comemorativa. São Paulo: Editorial, 17 a 23 jan. 2015. 
GLASSER, H. Minding the gap - the role of social learning in linking our stated desire for a more sustainable world to our everyday actions and policies. In: WALS, A. (Ed.) Social learning: towards a sustainable world. Wageningen: Academic Publishers, 2007.

GONÇALVES, José R. S. A retórica da perda: os discursos do patrimônio cultural no Brasil. Rio de janeiro: UFRJ/IPHAN, 2002.

Patrimônio como categoria de pensamento. In: ABREU, Regina \& CHAGAS, Mário. Memória e patrimônio. Ensaios contemporâneos. Rio de Janeiro: DP\&A, 2003.

GONZÁLEZ-VARAS. I. Conservación de bienes culturales. Madrid: Cátedra, 2003.

GRUNBERG, E. Manual de atividades práticas de educação patrimonial. Brasília - DF: Instituto do Patrimônio Histórico e Artístico Nacional - IPHAN, 2007.

HARMONICOP. Social Learning Pool of questions. HarmoniCOP combined WP2/WP3 deliverable. K.U. Leuven - Centre for Organizational and Personnel Psychology. 2003.

HART, P. Social learning as action inquiry: exploring education for sustainable societies In: Wals, A. Social Learning - towards a sustainable world. Wageningen: Academic Publishers, pp.313-329, 2007

HERNÁNDEZ-HERNÁNDEZ. F. El patrimonio cultural: la memoria recuperada. Guijon: Trea, 2002

HOBSBAWN, Eric. J. A invenção das tradições. Rio de Janeiro: Paz e Terra, 1984.

HODDER, Ian. Reading the past: current approaches to interpretation in archaeology. Cambridge: Cambridge University Press, 1986. 
HORTA, Maria L. P.; GRUNBERG, Evelina; MONTEIRO, Adriane Queiroz. Guia Básico de Educação Patrimonial. Brasília: Instituto do Patrimônio Histórico e Artístico Nacional IPHAN/Museu Imperial, 1999.

HORTA, Maria L. P. Lições das Coisas: o enigma e o desafio da Educação Patrimonial. Revista do Patrimônio Histórico e Artístico Nacional. Brasília: IPHAN, no. 31, p. 220-233, 2005 .

Instituto do Patrimônio Histórico e Artístico Nacional - IPHAN. Inventário Nacional de Referências Culturais - INRC. Manual de Aplicação. IPHAN/MinC, 2000.

Instituto do Patrimônio Histórico e Artístico Nacional - IPHAN. Relatório da $1^{\text {a }}$ Oficina de Capacitação em Educação Patrimonial e Fomento a Projetos Culturais nas Casas do Patrimônio/IPHAN. IPHAN, 2008. (documento).

Instituto do Patrimônio Histórico e Artístico Nacional - IPHAN. Patrimônio Cultural Imaterial. Para saber mais. Brasília - DF: IPHAN/MinC, 2009.

Instituto do Patrimônio Histórico e Artístico Nacional - IPHAN. O registro do patrimônio imaterial. Dossiê final das atividades da Comissão e do Grupo de Trabalho Patrimônio Imaterial. 5ª Ed. Brasília-DF: MinC/IPHAN, 2012.

Instituto do Patrimônio Histórico e Artístico Nacional - IPHAN. Educação Patrimonial: Manual de aplicação: Programa Mais Educação. Brasília, DF: IPHAN/DAF/COGEDIP/CEDUC, 2013.

Instituto do Patrimônio Histórico e Artístico Nacional - IPHAN. Educação Patrimonial. Histórico, conceitos e processos. Brasília, DF: IPHAN/DARF/COGEDIP/CEDUC, 2014.

Instituto Pólis. Mapa Santo Amaro em Rede - Culturas de Convivência. Disponível em: $<$ http://polis.org.br/acoes/mapa-santo-amaro-em-rede-culturas-de-convivencia/>. Acesso em 29 fev 2016. 
ISON, R. L; STEYAERT, P; ROGGERO, P. P; HUBERT, B; JIGGINS, J. Social learning for the integrated management and sustainable use of water at catchment scale. 2004.

JACOBI, Pedro. R. Gestão Participativa de Bacias Hidrográficas no Brasil e os desafios do fortalecimento de espaços públicos colegiados. In: NOBRE, M.; COELHO, V. Participação e Deliberação. São Paulo: Ed. 34, 2004

Educação Ambiental: o desafio da construção de um pensamento crítico, complexo e reflexivo. Educação e Pesquisa, São Paulo, v.31, n. 2, p.233-250, mai/ago. 2005.

Aprendizagem Social, práticas educativas e participação da sociedade civil como estratégias de aprimoramento para a gestão compartilhada em bacias hidrográficas. São Paulo em Perspectiva. São Paulo, v.20, n.2, p. 5-18, 2006.

; TRISTÃO, Virgínia; FRANCO, Maria Isabel. A função social da educação ambiental nas práticas colaborativas: participação e engajamento. In: Caderno Cedes, Campinas, v. 29. n. 77, p. 63-79, 2009.

(Coord.). Aprendizagem social. Diálogos e ferramentas participativas: aprender juntos para cuidar da água. São Paulo: IEE/PROCAM, 2011.

; FRANCO, Maria Isabel G.C. Sustentabilidade, Participação, Aprendizagem Social. In: JACOBI, Pedro R. (Coord.). Aprendizagem social. Diálogos e ferramentas participativas: aprender juntos para cuidar da água. São Paulo: IEE/PROCAM, 2011.

Aprendizagem social e pesquisa-ação: semelhanças na construção de saberes e transformação de realidades complexas. In: TOLEDO, Renata F. \& JACOBI, Pedro Roberto (Org.). A Pesquisa-ação na interface da saúde, educação e ambiente. Princípios, desafios e experiências interdisciplinares. São Paulo: Annablume: FEUSP, PROCAM, IEE, FAPESP, 2012. 
Educação, Meio Ambiente e Interdisciplinaridade. In: $36^{\mathrm{a}}$

Reunião Anual da Anped. Educação Ambiental e Interdisciplinaridade. 2013.

; TOLEDO, R. F.. A pesquisa-ação na interface das áreas da saúde, educação e ambiente: princípios, desafios e experiências interdisciplinares. São Paulo: AnnaBlume, 2013.

(Coord.) Aprendizagem Social no Saneamento Básico: metodologia para o fortalecimento do controle social. São Paulo: IEE/USP, 2015.

JIGGINS, J. Managing Change in Water Conservation Through Multi-Stakeholder. Andelst: Learning Processes, 2002.

JULIANI, Lúcia C. O. Gestão arqueológica em Metrópoles: uma proposta para São Paulo. Dissertação (Mestrado) - Museu de Arqueologia e Etnologia da USP, São Paulo, 1996.

A Geologia e o Homem: Arqueologia e depósitos tecnogênicos na cidade de São Paulo. In: In: MORI, V. et. al. (org.). Patrimônio: atualizando o debate. São Paulo: Instituto do Patrimônio Histórico e Artístico Nacional - IPHAN , 2015.

KASEKER, Davidson P. Museu, terriório, desenvolvimento: diretrizes do processo de musealização na gestão do patrimônio de Itapeva. Dissertação (Mestrado). Museu de Arqueologia e Etnologia da Universidade de São Paulo, São Paulo, 2014.

KOK, Glória. Peregrinações, conflitos e identidades indígenas nas aldeias quinhentistas de São Paulo. In: XXV SIMPÓSIO NACIONAL DE HISTÓRIA E ÉTICA. Fortaleza: Universidade Federal do Ceará, Jul.2009. Disponível em:

< http://www.ifch.unicamp.br/ihb/Trabalhos/ST36Gloria.pdf > Acesso em: 01 mar 2016.

LAPPES - Laboratório de Pesquisa e Práticas em Educação e Sustentabilidade do IEE/USP. Disponível em: <http://lappes.iee.usp.br/lappes/>. Acesso em: 29 fev 2016. 
LANGENBUCH, J. R. A estruturação da Grande São Paulo: estudo de geografia urbana. São Paulo: Biblioteca Geográfica Brasileira, 1971

LEWIN, K. Action research and minority problems. Journal of Social Issues, n. 2, p.34-36, 1946.

LOPES, Maria Margareth. A favor da descolarização dos museus. In: Revista Educação \& Sociedade, Campinas, n. 40, dez. 1991

As Ciências Naturais e os museus no Brasil no século XIX. Tese

(Doutorado). Faculdade de Filosofia, Letras e Ciências Humanas da Universidade de São Paulo. São Paulo, 1993.

LOUREIRO, C. F. B. Educação ambiental e gestão participativa na explicitação e resolução de conflitos. Gestão em Ação, Salvador, v.7, n.1, jan./abr. 2004.

Trajetória e fundamentos da Educação Ambiental. São Paulo:

Cortez, 2004.

Educação ambiental no licenciamento: aspectos legais e teóricometodológicos. In: LOUREIRO, Carlos Frederico Loureiro (Org.) Educação ambiental no contexto de medidas mitigadoras e compensatórias de impactos ambientais: a perspectiva do licenciamento. Salvador: IMA, 2009.

; LAYRARGUES, Philippe Pomier, CASTRO, Ronaldo Souza de (Org.) Repensar a educação ambiental: um olhar crítico - São Paulo: Cortez, 2009.

MARQUES, D. C. P. C. Arqueologia e educação: uma proposta de leitura do patrimônio. Tese (Mestrado). Faculdade de Educação da Universidade de São Paulo, São Paulo, 2005.

MARTINEZ, Paulo Henrique. História e Meio Ambiente: considerações sobre a formação continuada em pesquisa, ensino e aprendizagem. Revista Núcleos de Ensino. São Paulo, v.1, p.217-229, 2003. 
MARTINS, Maria Helena Pires. Preservando o Patrimônio e construindo identidades. São Paulo: Moderna, 2001.

MENESES, Ulpiano T. Bezerra de. Patrimônio ambiental urbano: do lugar comum ao lugar de todos. CJ Arquitetura, Rio de Janeiro, n. 19, 1978.

A cultura material no estudo das sociedades antigas. Revista de História, São Paulo, n. 115, p. 103-117, 1983. (nova série), 1983.

O patrimônio cultural entre o público e o privado. In: São Paulo. Secretaria Municipal de Cultura. Departamento do Patrimônio Histórico. O direito à memória: patrimônio histórico e cidadania.São Paulo: DPH, 1992

A paisagem como fato cultural. In: YAZIGI, Eduardo (Org.). Turismo e paisagem. Campinas: Contexto, 2002.

O campo do Patrimônio Cultural: uma revisão de premissas. In:

IPHAN. I Fórum Nacional do Patrimônio Cultural: Sistema Nacional de Patrimônio Cultural: desafios, estratégias e experiências para uma nova gestão, Ouro Preto/MG, 2009. Brasília: IPHAN, 2012, p.25-39. (Anais, v. 2, t.1).

A paisagem como fato cultural, p. 29-64. In: YAZIGI, Eduardo (Org.).Turismo e paisagem. São Paulo: Contexto, 2002. (Turismo Contexto).

A exposição museológica e o conhecimento histórico. In: FIGUEIREDO, B. G.; VIDAL, Diana G. (Org.). Museus: dos gabinetes de curiosidades ao Museu moderno. Belo Horizonte: Argumentum - CNPQ, p. 15-84, 2005.

MERRIMAN, Nick (Org.). Public Archaeology. Routledge, 2004.

MONTEIRO, Fernando. Para além da participação: aprendizagem social na gestão dos recursos hídricos. Tese (Doutorado). São Paulo, PROCAM-USP, 2009. 
MONTEIRO, John M. Negros da Terra: índios e bandeirantes nas origens de São Paulo. São Paulo: Ed. Companhia das Letras, 2013.

MORAIS, José Luiz de. Perspectivas geoambientais da Arqueologia do Paranapanema Paulista. Erechim: Habilis, 2011.

Reflexões acerca da arqueologia preventiva. In: MORI, V. et. al. (org.). Patrimônio: atualizando o debate. Instituto do Patrimônio Histórico e Artístico Nacional. São Paulo: IPHAN, 2015.

MORIN, André. Pesquisa-ação integral e sistêmica - uma antropopedagogia renovada. Rio de Janeiro: DP\&A, 2004.

MOSTERT, E. Public participation and the water framework directive. A Framework for Analysis. HarmoniCOP inception report. 2003. Available at harmonicop.info

Museu de Arqueologia e Etnologia da Universidade de São Paulo. Brasil: 50 mil anos. Guia temático para professores. Uma viagem ao passado pré-colonial. São Paulo: Museu de Arqueologia e Etnologia da Universidade de São Paulo, 2000.

NIMUENDAJU, Curt. Mapa Etno-Histórico do Brasil. Rio de Janeiro: IBGE. 1981.

NORA, Pierre. Les Lieux de mémoire. Paris: Gallimard, 1984.

Entre Memória e História: a problemática dos lugares. Projeto História. São Paulo, n.10, dez 1993.

OlIVEIRA, Cleo A. P. de. A Educação Patrimonial no IPHAN. Monografia. Escola Nacional de Administração Pública. Rio de Janeiro. 2011.

PADUA, Rafael Faleiros de. Implicações socioespaciais da desindustrialização e da reestruturação do espaço em um fragmento da metrópole de São Paulo. Dissertação 
(Mestrado). Faculdade de Filosofia, Letras e Ciências Humanas da Universidade de São Paulo. São Paulo, 2007.

PAHL-WOSTL, C. Towards sustainability in the water sector - The importance of human actors and processes of social learning. Aquatic Sciences, n. 64, p. 394-411, 2002.

; CRAPS, M.; DEWULF, A.; MOSTERT, E.; TABARA, D.;

TAILLIEU, T. Managing change toward adaptive water management through Social Learning. Ecology and Society. v. 12, no. 2, 2007.

PATTERSON, T. Algunas tendencias teoricas de la pos-guerra en la Arqueologia estadunidense. Boletim de Antropologia Americana, n. 21, p. 5-23, 1990.

SCIFONI, Simone. A construção do patrimônio natural. Tese (Doutorado) - Faculdade de Filosofia, Letras e Ciências Humanas, USP, São Paulo, 2006.

Educação e Patrimônio Cultural: reflexões sobre o tema. In: TOLENTINO, Átila Bezerra (Org.). Educação Patrimonial: reflexões e práticas. João Pessoa: IPHAN-PB, 2012. (Caderno Temático 2).

PRATA, J. M. Patrimônio Cultural e Cidade: práticas de preservação em São Paulo. Tese (Doutorado). Faculdade de Arquitetura e Urbanismo da Universidade de São Paulo, São Paulo, 2009.

RAVETZ, J. The post-normal science of precaution. Futures, Guildford, v. 36, p. 347-357, 2004.

RENFREW, C.; BAHN, P. Arqueologia - teorias, métodos y práctica. Torrejón de Ardoz (Madrid): Akal, 1993.

REPEP - Rede Paulista de Educação Patrimonial. Disponível em: http://repep.fflch.usp.br/.> Acesso em: 04 mar 2016. 
Revista Enfoco Santo Amaro. Publicação da Associação de Voluntários Gota de Esperança. Ano 1, n.6, set/out 2004. Disponível em:

<http://docslide.com.br/documents/revista-enfoco-santo-amaro-no-6.html $>$. Acesso em jan 2016.

RIZZI, Maria Chrisina de Souza Lima. Além do artefato: apreciação em museus e exposições.

Revista do Museu de Arqueologia e Etnologia de São Paulo, São Paulo, n. 8, 215-220, 1998.

Olho Vivo. Arte-Educação na Exposição da Moda: Uma

Aventura Infantil. Tese (Doutorado). Escola de Comunicação e Artes da Universidade de São Paulo. São Paulo, 1999.

Reflexões sobre a Abordagem de Ensino da Arte. In: BARBOSA, Ana Mae (Org.) Ensino da Arte: memória e história. São Paulo: Perspectiva, 2008.

ROBRAHN-GONZÁLEZ, Érika M. Arqueologia e Sociedade. Tese (Livre Docência). Museu de Arqueologia e Etnologia da Universidade de São Paulo. São Paulo, 2005.

RODRIGUES, Marly. Imagens do passado: a instituição do patrimônio em São Paulo, 19691987. São Paulo: UNESP/IMESP/CONDEPHAAT/FAPESP, 2000.

RUBINO, Silvana. As fachadas da história: as origens, criação e os trabalhos do SPHAN, 1936-1967. Dissertação (Mestrado). UNICAMP/IFCH/Antropologia Social. Campinas, 1992.

SACHS, I. Ecodesenvolvimento: crescer sem destruir. São Paulo: Vértice, 1986.

Rumo à Ecossocioeconomia - teoria e prática do desenvolvimento. São Paulo: Cortez Editora, 2007.

SANT'ANNA, M. G. Da cidade-monumento à cidade-documento: a trajetória da norma de preservação de áreas urbanas no Brasil (1937-1990). Dissertação (Mestrado). Faculdade de Arquitetura e Urbanismo da Universidade Federal da Bahia. Salvador, 1995. 
Santo Amaro em Revista. Interlagos. Edição dedicada ao Quarto Centenário da Cidade de Santo Amaro. São Paulo, n. XX, ano XI, set. 1961.

SANTOS, Maria V. M. O tecido do tempo: a ideia de patrimônio cultural no Brasil 19201970. Tese (Doutorado). ICH/UnB. Brasília - DF, 1992.

SANTOS, Vânia Maria N.; BACCI, Denise. L.C Mapeamento socioambiental para a aprendizagem social. In: JACOBI, P.R. (Org.). Aprendizagem social: diálogos e ferramentas participativas: aprender juntos para cuidar da água. São Paulo: GovAmb/ IEE/ PROCAM/ USP, 2011.

. Formação de professores para o estudo do ambiente: projetos escolares e a realidade socioambiental local. Tese (Doutorado) - Instituto de Geociências, Universidade Estadual de Campinas, 2006.

Educar no ambiente: construção do olhar geocientífico e cidadania. São Paulo: Annablume, 2011.

\& JACOBI, Pedro R. Aprendizagem social e metodologias participativas para a sustentabilidade socioambiental, 2013 (arquivo digital fornecido pelos autores).

SÃO PAULO (Cidade). Arquivo Histórico de São Paulo. Secretaria municipal de Cultura. Disponível em: <http://www.estadao.com.br/noticias/geral,cinco-curiosidades-sobre-santoamaro,1603908>. Acesso em: 29 fev 2016.

SÃO PAULO. (Cidade). Conselho Municipal de Preservação do Patrimônio Histórico, Cultural e Ambiental da Cidade de São Paulo - CONPRESP. Índice geral de bens tombados. Disponível em:

<http://www.prefeitura.sp.gov.br/cidade/secretarias/cultura/conpresp/indice_geral/index.php? p=1142>. Acesso em: 29 fev 2016. 
SÃO PAULO (Cidade). Secretaria Municipal de Cultura - SMC. Escavando o passado. Arqueologia na cidade de São Paulo. São Paulo: Departamento do Patrimônio Histórico Divisão de Preservação. Museu da Cidade de São Paulo. Centro de Arqueologia de São Paulo. Departamento do Patrimônio Histórico - Divisão de Preservação. Museu da Cidade de São Paulo. Centro de Arqueologia de São Paulo., s.d. (Catálogo).

SÃO PAULO. (Cidade). São Paulo Minha Cidade. Disponível em:

<http://www.saopaulominhacidade.com.br/conteudo/77/Santo+Amaro >. Acesso em jan. 2015.

SÃO PAULO. (Cidade). Programa Patrimônio e Referências Culturais nas Subprefeituras. Prefeitura do Município de São Paulo - PMSP. Secretaria Municipal de Cultura - SMC. Departamento do Patrimônio Histórico - DPH. Divisão de Preservação. Subprefeitura de Santo Amaro. Disponível em:

http://www.prefeitura.sp.gov.br/cidade/upload/SantoAmaro_web_1392057658.pdf. Acesso em 29 fev 2016.

SÃO PAULO. (Cidade). Secretaria Municipal de Cultura. Secretaria Municipal de Saúde. Revivendo o Bairro de Santo Amaro. Projeto São Paulo 450 Anos - Memória Viva e Cidadania. São Paulo, s.d.

SÃO PAULO. (Cidade). Suprefeitura de Santo Amaro. Disponível em: <http://www.prefeitura.sp.gov.br/cidade/secretarias/subprefeituras/santo_amaro/>. Acesso em 29 fev 2015.

SÃO PAULO (Cidade). Secretaria Municipal de Cultura. Departamento do Patrimônio Histórico. $\mathrm{O}$ direito à memória: patrimônio histórico e cidadania.São Paulo: DPH, 1992.

SÃO PAULO (Estado). Resolução SMA/SP nº 34, de 27 de agosto de 2003. Dispõe sobre as medidas necessárias à proteção do patrimônio arqueológico e pré-histórico quando do licenciamento ambiental de empreendimentos e atividades potencialmente causadores de significativo impacto ambiental, sujeitos à apresentação de EIA/RIMA, e dá providências correlatas (revogada). Disponível em:

<http://www.ambiente.sp.gov.br/legislacao/resolucoes-sma/resolucao-sma-34-2003/> 
Acesso em: 29 fev 2016.

SÃO PAULO. (Estado). Governo do Estado de São Paulo. Secretaria Estadual de Cultura. Programa Cultura é Currículo. Disponível em:

$<$ http://culturaecurriculo.fde.sp.gov.br/programa.aspx $>$ Acesso em 29 fev 2016.

SÃO PAUlO. (Estado). Conselho de Defesa do Patrimônio Histórico, Arqueológico, Artístico e Turístico - CONDEPHAAT. Patrimônio cultural paulista: CONDEPHAAT, bens tombados 1968-1998. São Paulo: Imprensa Oficial do Estado, 1998.

SÃO PAULO (Estado). Secretaria da Educação do Estado de São Paulo. SARESP. Sistema de Avaliação. Disponível em: http://www.educacao.sp.gov.br/saresp> Acesso em: 29 fev 2016.

SATO, M; SANTOS, J. E. Tendências nas pesquisas em educação ambiental. In: NOAL, F; BARCELOS, V. (Org). Educação ambiental e cidadania: cenários brasileiros. Santa Cruz do Sul: EDUNISC, 2003.

SAVIANI, D. Pedagogia Histórico-Crítica. São Paulo: Autores Associados, 2003..

SPHAN. Proteção e revitalização do patrimônio cultural no Brasil: uma trajetória. Brasília: Ministério da Educação e Cultura, Secretaria do Patrimônio Histórico e Artístico Nacional, Fundação Nacional Pró-Memória, n. 31, 1980. (Publicações da Secretaria do Patrimônio Histórico e Artístico Nacional).

SCHMIDT, Afonso. A vida de Paulo Eiró. São Paulo: Companhia Nacional, 1940 (Coleção Brasiliana)

SCIFONI, Simone. A construção do patrimônio natural. Tese (Doutorado). Faculdade de Filosofia, Letras e Ciências Humanas da Universidade de São Paulo. São Paulo, 2006.

Educação e Patrimônio Cultural: reflexões sobre o tema. In:

TOLENTINO, Á. B. (Org.). Educação patrimonial: reflexões e práticas. João Pessoa: Superintendência do IPHAN na Paraíba, 2012. 
SENE, Maria L. R. Artes visuais, meio ambiente e educação escolar: um estudo sobre professores e aulas em arte em $3^{\circ}$ e $4^{\circ}$ ciclos de escolas de ensino fundamental em São Paulo. Dissertação (Mestrado). Faculdade de Educação da Universidade de São Paulo. São Paulo,

SESC. Caminhos de Santo Amaro. São Paulo: SESC - SP, 2006.

Santo Amaro em rede: culturas de convivência. São Paulo: Serviço Social do Comércio - SESC/Instituto PÓLIS, 2011.

Santo Amaro em rede. Culturas de convivência. Disponível em:

<http://www.mostrasescdeartes.com.br/stoamaroemrede/>. Acesso em: 29 fev 2016.

SILVEIRA, F. L. A.; BEZERRA, M. Educação Patrimonial: perspectivas e dilemas. Antropologia e Patrimônio Cultural. Diálogos e Desafios Contemporâneos. ABA, Goiânia, 2007

SIVIERO, Fernando P. Um mapa para outros fazeres: territórios educativos e patrimônio cultural. Dissertação (Mestrado Profissional em Preservação do Patrimônio Cultural). Instituto do Patrimônio Histórico e Artístico Nacional - IPHAN. Rio de Janeiro, 2014.

SLIM. Social learning as a policy approach for sustainable use of water. A field-tested framework for observing, reflecting and enabling, 2004.

STIEL, Waldemar C. História dos transportes coletivos em São Paulo. São Paulo: McGraw-Hill, 1978

THIOLLENT, Michel. Metodologia da Pesquisa-ação. 18ª . Ed. São Paulo: Cortez, 2011. . (Org.). Pesquisa-ação e projeto cooperativo na perspectiva de Henri Desroche. São Carlos: EdUFScar, 2006. 
Fundamentos e desafios da pesquisa-ação: contribuições na produção de conhecimentos interdisciplinares. In: TOLEDO, Renata F.; JACOBI, Pedro Roberto (Org.). A Pesquisa-ação na interface da saúde, educação e ambiente. Princípios, desafios e experiências interdisciplinares. São Paulo: Annablume/FEUSP, PROCAM/IEE/FAPESP, 2012.

TOLEDO, Renata Ferraz de. Educação, saúde e meio ambiente: uma pesquisa-ação no Distrito de Iauaretê do Município de São Gabriel da Cachoeira/AM. Tese (Doutorado). Faculdade de Educação da Universidade de São Paulo. São Paulo, 2006.

; JACOBI, Pedro Roberto (Org.). A Pesquisa-ação na interface da saúde, educação e ambiente. Princípios, desafios e experiências interdisciplinares. São Paulo: Annablume/FEUSP/PROCAM/IEE/FAPESP, 2012.

TOLENTINO, Átila Bezerra (Org.). Educação Patrimonial: reflexões e práticas. João Pessoa: IPHAN-PB, 2012. (Caderno Temático 2)

TONOZI-REIS, M. F. C. (Org.). A Pesquisa-ação participativa em educação ambiental: reflexões teóricas. São Paulo: Annablume, 2007.

TORRES, Maria Celestina T. M. Ibirapuera. São Paulo: DPH, 1977. (Coleção História dos Bairros de São Paulo).

TRIGGER, Bruce G. História do Pensamento Arqueológico. São Paulo: Odysseus, 2004.

TRIPP, D. Pesquisa-ação: uma introdução metodológica. Educação e Pesquisa. São Paulo, v.31, n.3, p. 443-466, set/dez, 2005.

TRISTÃO, Virgínia T. V. Educação Ambiental Não Formal: a experiência das organizações do terceiro setor. Tese (Doutorado). Faculdade de Educação da Universidade de São Paulo, São Paulo, 2011.

UNESCO. Representação da UNESCO no Brasil. Disponível em: 
<http://www.unesco.org/new/pt/brasilia/culture/international-instruments-clt/\#c1052695>.

Acesso em: 29 fev 2016.

VIOLA, E. J; LEIS, H. R. A evolução das políticas ambientais no Brasil. 1971-1991: do bissetoralismo preservacionista para o multissetorialismo orientado para o desenvolvimento sustentável. Campinas: UNICAMP, 1992.

Universidade de São Paulo. Museu de Arqueologia e Etnologia. Disponível em: <http://www.intranet.mae.usp.br/modules/educativo/content.php?id=37> Acesso em: 29 fev 2016.

WALS, A. Social Learning- towards a sustainable world. Wageningen Academic Publishers, Netherlands: Wageningen Academic Publishers, 2007.

WARNER, J. Multi-Stakeholder Platforms for Integrated Water Management. Aldershot, UK., 2007.

The Beauty of the Beast: Multi-Stakeholder Participation for Integrated Water Management In: WARNER, J. Multi-Stakeholder Platforms for Integrated Water Management. Aldershot, UK: Ashgate, 2006.

WATERS, Michael R. Principles of geoarchaeology: a North American perspective. Tucson: University of Arizona Press, 1992.

WENGER, E. Communities of practice: learning, meaning, and identity. New York: Cambridge University Press, 1998.

Communities of practice and Social Learning Systems. SAGE Social Science Collections, 2000, n. 7, p. 225-246.

WOODHILL, J. Sustainability, Social Learning, and the democratic Imperative: Lessons from Australia Landscape Movement. In LEEUWIS, C. \& PYBURN, E.(Ed.). Weelbarrows Full 
of Frogs: Social Learning in Rural Management. Assen: Koninklijke van Gorcum, p. 317$331,2002$.

ZANIRATO, Silvia Helena. Usos sociais do Patrimônio cultural e natural. Patrimônio e Memória. Assis: UNESP, v.5, n. 1, p. 145-160, 2009.

O Patrimônio como fator de identidade territorial e de desenvolvimento local In: JACOBI, P. (coord.). Aprendizagem social e unidades de conservação: aprender juntos para cuidar dos recursos naturais. São Paulo: IEEE/PROCAM, 2013.

ZENHA, Edmundo. A colônia alemã de Santo Amaro: sua instalação em 1829. São Paulo: Departamento Municipal de Cultura, Revista do Arquivo. V. CXXXI, 1950.

. Onde a primeira fundição de ferro no Brasil? São Paulo: Revista do Arquivo Municipal de São Paulo, CXL, 1951.

O Santo Amaro de Paulo Eiró. São Paulo: Departamento Municipal de Cultura, 1952.

A vila de Santo Amaro. São Paulo: Imprensa Oficial do Estado, 1977 
ANEXOS

\section{Bens Patrimoniais Inventariados}

Bens culturais com atribuição de valor em Santo Amaro

\begin{tabular}{|c|c|}
\hline $\begin{array}{c}\text { Bem Cultural (Material e/ou } \\
\text { Imaterial) }\end{array}$ & Observações \\
\hline Estátua de Borba Gato & 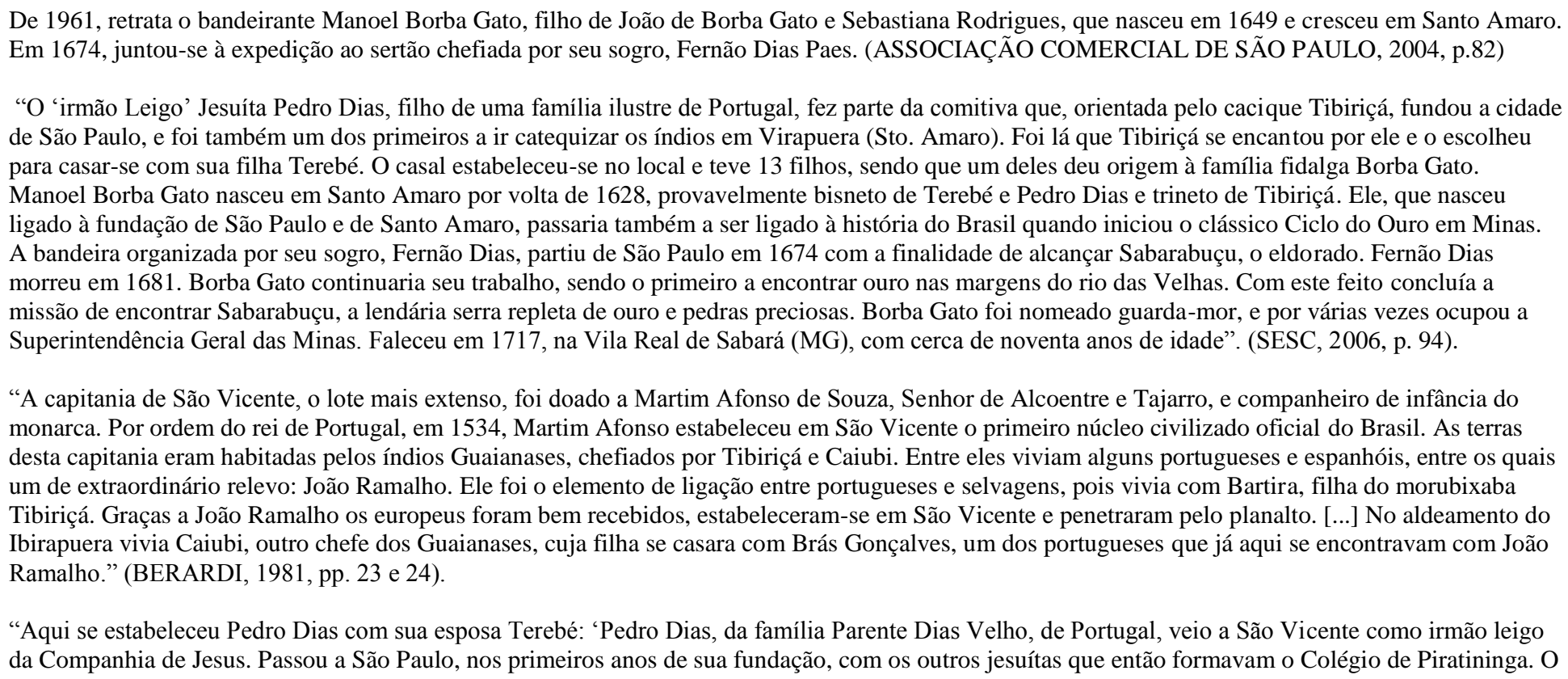 \\
\hline
\end{tabular}


Bens culturais com atribuição de valor em Santo Amaro

\begin{tabular}{|c|c|c|}
\hline $\begin{array}{c}\text { Bem Cultural (Material e/ou } \\
\text { Imaterial) }\end{array}$ & \multicolumn{2}{|r|}{ Observações } \\
\hline & \multicolumn{2}{|c|}{$\begin{array}{l}\text { cacique Tibiriçá afeiçoou-se pelo leigo, pedindo-o para seu genro. Como visse nesse enlace grande vantagem para o efeito de congraçar os portugueses } \\
\text { com os índios, o provincial dos jesuítas consultou o superior geral da Ordem (Santo Inácio de Loyola) e foi resolvido que, querendo o leigo, se casasse, } \\
\text { para o que foi desligado os votos. Terebé, a segunda filha do cacique Tibiriçá, foi então batizada com o nome de Maria da Grã (em homenagem ao Padre } \\
\text { Luiz da Grã), e se casou com Pedro Dias"” (Silva Leme: Genealogia Paulistana, vol. VIII, p.3). O casal ficou em Ibirapuera, e de seus seis filhos } \\
\text { originaram-se três santamarenses: Um bandeirante - Borba Gato; uma figura venerável - Padre Belchior de Pontes; e um poeta - Paulo Eiró. Todos } \\
\text { descendentes da indiazinha Terebé" (BERARDI, 1981, p.28). } \\
\text { Manoel de Borba Gato, casado com Maria Leme, quinta filha de Fernão Dias Paes, acompanhou o sogro ao sertão, em busca da Terra das Esmeraldas. } \\
\text { Faleceu após } 7 \text { anos e o Borba Gato, seu genro, resolveu continuar as explorações pelo sertão, brigando com o espanhol D. Rodrigo Castelo Branco, } \\
\text { perito em mineração, enviado pela Corte Portuguesa para "auxiliar a bandeira e testemunhar os achados". (BERARDI, 1981, p.34). } \\
\text { Faleceu em 1718, com quase } 90 \text { anos, no cargo de juiz ordinário da Vila de Sabará e foi enterrado na Capela de Sant'Ana, no arraial do Rio das Velhas. } \\
\text { (BERARDI, 1981, p.36). }\end{array}$} \\
\hline & Bens imateriais relacionados & $\begin{array}{l}\text { Pintor Julio Guerra } \\
\text { "'Fiz o Borba Gato / Diferente / Não parece túmulo e não tem o pedestal enfeitado / E quando fazia esquecia de } \\
\text { Policleto e lembrava de Aleijadinho / E dos bonecos da arte popular / Depois de pronto eu gostei / E o povo da minha } \\
\text { terra também gostou / Fizeram festa / E os romeiros recordaram a Santo Amaro das chácaras e das poesias / Muitos } \\
\text { olhos umedeceram / E os letrados, que Leonardo já ironizava xingaram o Borba Gato / De bonecão / Boi parado / } \\
\text { Monstromento / E que era feito de pastilhas / Mas não é. Ele é feito de pedras e mármores.” (Julio Guerra in: } \\
\text { BERARDI, 1981, p.124). } \\
\text { "Quando terminava o filme, eu e meus amigos íamos para a Rua Direita passear e ver a banda de música tocar no } \\
\text { coreto do jardim. Esse era o nosso domingo... Na avenida João Dias morava o famoso escultor e escritor Julio Guerra, } \\
\text { que na época estava fazendo no quintal de sua casa a estátua do Borba Gato. Por eu ser de uma família tradicional de } \\
\text { Santo Amaro e o Julio Guerra ser muito amigo de meus pais, ele me deu um quadro do Mercado Velho de Santo } \\
\text { Amaro pintado por ele em 1928, que guardo com muito carinho.” História do Morador: Agenor Borba Junior. Local: } \\
\text { São Paulo. Publicado em: 08 de março de 2010. Santo Amaro, que saudades. (Disponível em: } \\
\text { http://www.encontrasantoamaro.com.br/historias-de-moradores-de-santo-amaro/> Acesso em 02 mar 2016.). } \\
\text { Nasceu em 1912, na então cidade de Santo Amaro. Frequentou, na década de 1930, a Escola de Belas Artes de São } \\
\text { Paulo. }\end{array}$ \\
\hline
\end{tabular}


Bens culturais com atribuição de valor em Santo Amaro

\begin{tabular}{|c|c|}
\hline $\begin{array}{c}\text { Bem Cultural (Material e/ou } \\
\text { Imaterial) }\end{array}$ & Observações \\
\hline & $\begin{array}{l}\text { "Apesar de sua escultura pública mais notória, principal referência de Santo Amaro com seus dez metros de altura, } \\
\text { ser o Borba Gato, na avenida João Dias, a força do seu trabalho está mais representada no monumento dedicado à } \\
\text { Mãe Preta, no Largo do Paissandu. É uma refinada escultura de 1955, feita para as comemorações do IV Centenário } \\
\text { da Cidade de São Paulo. Em Santo Amaro, três obras mostram um lado onde Júlio transitava com muita força } \\
\text { artística: os mosaicos que em quatro atos contam toda a história da fundação de Santo Amaro. Em frente à Casa de } \\
\text { Cultura, no Largo São Benedito, Júlio imortalizou, em delicados mosaicos, a mais importante tradição de Santo } \\
\text { Amaro, a Romaria de Pirapora. E na entrada do Teatro Paulo Eiró, ele postou, de forma cifrada, a sua paixão pelo } \\
\text { poeta.”. (SESC, 2006, p.96). } \\
\text { "Filho, neto e bisneto de família nascida na região, Júlio Guerra se autodefinia como 'santamarense quatrocentão'. } \\
\text { Aos } 14 \text { anos, ele ajudava o pai no bar e se dedicava a desenhar os personagens que freqüentavam o estabelecimento. } \\
\text { Cresceu perto do Rio Pinheiros, onde havia uma olaria, e costumava brincar com argila. Começava a se revelar, } \\
\text { então, o futuro artista. } \\
\text { Em 1938, Guerra ingressou na Faculdade de Belas Artes e decidiu ser escultor para poder esculpir tudo o que se } \\
\text { referisse a Santo Amaro. Tornou-se amigo de Brecheret e o ajudou a executar o monumento a Duque de Caxias, hoje } \\
\text { instalado na avenida de mesmo nome, no centro de São Paulo. Mas o que pouca gente sabe é que, além de tudo, Júlio } \\
\text { Guerra era um exímio pintor. Fiel guardiã da memória de seu pai, Elza mantém a casa dele intacta, com todas as } \\
\text { paredes forradas pelas pinturas que o pai fez retratando Santo Amaro de antigamente e escrevendo comentários sobre } \\
\text { o bairro atrás das telas. São verdadeiros documentos iconográficos e históricos que não podem se perder". } \\
\text { (ASSOCIAÇÃO COMERCIAL DE SÃO PAULO, 2004, p.86). } \\
\text { "Em 1930, ingressou na Escola de Belas Artes, tendo se diplomado em escultura. Em 1939, recebeu o Prêmio de } \\
\text { Aperfeiçoamento Artístico no estrangeiro. Em 1942, foi contratado pela Prefeitura de São Paulo para colaborar no } \\
\text { monumento a Duque de Caxias" (BERARDI, 1981, p.124). }\end{array}$ \\
\hline Largo Treze de Maio & $\begin{array}{l}\text { "Tudo começou no Largo 13. Santo Amaro nasceu onde era a aldeia dos índios guaianases comanda pelo cacique Caá-ubi, à beira do rio Jeribatiba, na } \\
\text { localidade de Ibirapuera. Em uma de suas muitas visitas à Aldeia de Jeribatiba, o Padre José de Anchieta percebeu que, devido ao elevado número de } \\
\text { índios catequizados e colonos instalados na região, era possível construir ali um povoado, ideia que os moradores aprovaram. Era necessário erguer uma } \\
\text { capela e definir a quem essa capela seria dedicada. Ao saberem da proposta do Padre Anchieta, o colono João Paes e sua esposa, Suzana Rodrigues, } \\
\text { doaram a imagem que possuíam do santo de sua devoção, Santo Amaro, para a capela feita de taipa de pilão." (Santo Amaro em Revista, 1961, p.1) }\end{array}$ \\
\hline
\end{tabular}


Bens culturais com atribuição de valor em Santo Amaro

\begin{tabular}{|c|c|c|}
\hline $\begin{array}{c}\text { Bem Cultural (Material e/ou } \\
\text { Imaterial) }\end{array}$ & & Observações \\
\hline & Bens culturais relacionados & $\begin{array}{l}\text { Hotel do Ponto } \\
\text { "A nossa permanência em Santo Amaro, foi bastante movimentada. Visitamos a Casa Grande ou Cubatão, como era } \\
\text { chamado aquele vasto barracão construído especialmente para acolher os que não possuíam outras acomodações em } \\
\text { Santo Amaro. Havia somente o 'Hotel do Ponto', no Largo } 13 \text { de Maio.” (Santo Amaro em Revista, 1961, p.12) }\end{array}$ \\
\hline Santa Casa & \multicolumn{2}{|c|}{$\begin{array}{l}\text { A Sociedade Beneficente Nossa Senhora da Conceição foi fundada em } 15 \text { de dezembro de } 1895 \text { e a pedra fundamental para construção do hospital em } \\
\text { terreno cedido por Bona Bena Vieira de Morais foi lançada em 1896. Em 1899, foi inaugurado o edifício. (Santo Amaro em Revista, 1961, p.1) }\end{array}$} \\
\hline \multirow[b]{2}{*}{ Grupo Escolar Paulo Eiró } & \multicolumn{2}{|c|}{$\begin{array}{l}\text { Chamado Novo Grupo Escolar, foi inaugurado em } 1910 \text { e demolido em } 1979 . \\
\text { "Tinha duas alas: de um lado duas salas grandes e a salinha do diretor. Do outro, três salas grandes. Os meninos tinham aula pela manhã, das } 8 \text { ao meio } \\
\text { dia. As aulas para as meninas eram à tarde." (BERARDI, 1981, p.94). }\end{array}$} \\
\hline & Bens imateriais relacionados & $\begin{array}{l}\text { Francisco Antônio das Chagas } \\
\text { "A Escola Pública fora oficializada em } 1830 \text { e no ano seguinte, o primeiro mestre-escola oficial santamarense prestou } \\
\text { seu exame perante o Conselho da Província. Pediu depois um terreno devoluto na extremidade da Rua Direita, para } \\
\text { formar sua escola. Ali e levantou a casa onde foi por muitos anos a escola primária e mais tarde o teatrinho de seu } \\
\text { filho Paulo Eiró." (BERARDI, 1981, p.59). } \\
\text { "Mestre Chagas, tendo-se dedicado ao estudo da botânica, conhecia algumas ervas medicinais, e tratava com elas as } \\
\text { pessoas da família e todos quantos o procurassem na esperança de um remédio 'diferente”" (BERARDI, 1981, p.78). } \\
\text { "Quatro anos são passados desde que Santo Amaro, como parte do Brasil, presta obediência a seu Primeiro } \\
\text { Imperador. A educação deve ampliar seu campo de ação, deve alcançar o povo. A primeira escola primária surge } \\
\text { ligada ao nome de Francisco Antônio das Chagas, homem de grande preparo literário e científico, embora não possua } \\
\text { diploma que o declare apto ao magistério. Pessoa de importância na época, é ele quem dirige o movimento que visa a } \\
\text { criação do município, o que é realizado em } 10 \text { de julho de 1832. 'Instalada a Câmara e eleitos os } 7 \text { primeiros } \\
\text { vereadores, Francisco das Chagas figura entre eles, de olhos voltados para todo melhoramento que à sua terra seja } \\
\text { possível obter'." (Santo Amaro em Revista, 1961, p. 2). }\end{array}$ \\
\hline
\end{tabular}


Bens culturais com atribuição de valor em Santo Amaro

\begin{tabular}{|c|c|c|}
\hline $\begin{array}{c}\text { Bem Cultural (Material e/ou } \\
\text { Imaterial) }\end{array}$ & & Observações \\
\hline \multirow[b]{2}{*}{ Bondes } & \multicolumn{2}{|c|}{$\begin{array}{l}\text { "Tendo sido decretada a liquidação forçada da ‘Companhia Carris de Ferro São Paulo - Santo Amaro’, em } 8 \text { de fevereiro de 1900, foi seu acervo } \\
\text { arrematado pela Companhia Light, que continuou explorando a linha a vapor até 1913, quando propôs à municipalidade, um acordo para a instalação dos } \\
\text { serviços de luz elétrica, força e tramway, como era na época chamado o bonde” (BERARDI, 1981, p.94). } \\
\text { “[...] O bonde que vinha da Praça João Mendes até o Largo do Socorro era nossa diversão. Na porta de trás do bonde ficava uma pessoa para abrir e } \\
\text { fechar a porta, quando essa pessoa faltava, era eu que estava lá, abrindo e fechando a porta. Às vezes, antes de o bonde parar, eu abria a porta, o bonde } \\
\text { dava um tranco e um estouro. Levava uma bronca do motorneiro" História do Morador: Agenor Borba Junior. Local: São Paulo. Publicado em: 08 de } \\
\text { março de 2010. Santo Amaro, que saudades. (Disponível em: http://www.encontrasantoamaro.com.br/historias-de-moradores-de-santo-amaro/> Acesso } \\
\text { em } 02 \text { mar 2016.). }\end{array}$} \\
\hline & Bens culturais relacionados & $\begin{array}{l}\text { Trem de Santo Amaro } \\
\text { "Em 1862, quando Santo Amaro era uma área rural com fazendas de criação de gado e produção de cereais, o } \\
\text { transporte até São Paulo era feito em tropas de burros ou carros de bois. } \\
\text { A implantação de uma ferrovia destinada a servir o sul da província levou o engenheiro Alberto Kuhlmann a pensar } \\
\text { num projeto, com } 200 \text { quilômetros de extensão, que passaria por Santo Amaro. O projeto acabou sendo reduzido e } \\
\text { transformado em uma linha de tramways a vapor, que partiria da Vila Mariana e chegaria a Santo Amaro. } \\
\text { Assim, a } 14 \text { de março de } 1886, \text { o Presidente da Província de São Paulo, Conselheiro João Alfredo, inaugurou a nova } \\
\text { lotação para } 24 \text { pessoas por vaga e o tempo de viagem era estimado em hora e meia. } \\
\text { Seu percurso: saía da Estação São Joaquim, seguia pelas ruas Vergueiro e Domingos de Moraes, avenida Jabaquara } \\
\text { até onde é hoje a igreja São Judas Tadeu. Ali, na estação de encontro, reabastecia-se de carvão e água, seguindo então } \\
\text { para os bairros do Aeroporto e Campo Belo até o Brooklin Paulista. Depois, ia pela Chácara Flora, e entrava em } \\
\text { Santo Amaro por uma curva, onde passava pelas ruas que agora se chamam Nove de Julho e São José, para acabar no } \\
\text { ponto final em frente à Praça Santa Cruz." . (SESC, 2006, p.53). } \\
\text { "Se antes, além das rodovias, o trem era o meio de transporte de Santo Amaro às regiões adjacentes como meio de } \\
\text { locomoção rápido e seguro, foi, paulatinamente, caindo no esquecimento dos responsáveis por esse meio de } \\
\text { transporte." (A TRIBUNA, 26/01/1979, s/p.) } \\
\text { O suburbinho era a denominação dada ao trem que faz o percurso entre Jurubatuba e Pinheiros. (A TRIBUNA, } \\
\text { 26/01/1979, s/p.) } \\
\text { Alberto Kuhlmann }\end{array}$ \\
\hline
\end{tabular}


Bens culturais com atribuição de valor em Santo Amaro

\begin{tabular}{|c|c|c|}
\hline $\begin{array}{c}\text { Bem Cultural (Material e/ou } \\
\text { Imaterial) }\end{array}$ & & Observações \\
\hline & & $\begin{array}{l}\text { Engenheiro que projetou a ferrovia até o sul da Província de São Paulo, com } 200 \text { quilômetros. "Obteve autorização } \\
\text { para o empreendimento por vinte e cinco anos. Foi responsável pela linha que seguia pelas atuais Rua Vergueiro, Rua } \\
\text { Domingos de Morais, Avenida Jabaquara, até o local onde está a Igreja de Seção Judas Tadeu. Ali ficava a estação do } \\
\text { encontro, fazia-se o reabastecimento dos trens com combustível e água. Seguia depois por vastos campos, onde hoje } \\
\text { estão os bairros do Aeroporto e Campo Belo, e alcançavam o Brooklin Paulista. Depois seguia para a Chácara Flora, } \\
\text { e entrava em Santo Amaro pelas atuais ruas São José e Nove de Julho. O ponto final era na Praça Santa Cruz, onde é } \\
\text { hoje a Escola Linneu Prestes. (BERARDI, 1981, p.94). }\end{array}$ \\
\hline \multirow[b]{2}{*}{ Teatro Paulo Eiró } & \multicolumn{2}{|c|}{$\begin{array}{l}\text { "nome dado em homenagem ao poeta de grande projeção, nascido na Vila de Santo Amaro, foi inaugurado no final dos anos } 50 \text {, com a peça Sangue } \\
\text { Limpo, um drama em três atos publicado em } 1863 \text {. No entorno de sua fachada está instalado um belíssimo painel do artista santamarense Júlio Guerra } \\
\text { dedicado ao poeta e a sua obra. Inicialmente o teatro tinha a função de complementar o programa pedagógico das escolas construídas na mesma época. } \\
\text { Ao longo dos seus } 50 \text { anos, os principais artistas de São Paulo brilharam em seu palco, e com mais frequiência o santamarense Raul Cortez." (SESC, } \\
\text { 2006, p.22). }\end{array}$} \\
\hline & Bens imateriais relacionados & $\begin{array}{l}\text { Paulo Eiró (Paulo Francisco ou Paulo Emílio de Sales). } \\
\text { Paulo Francisco Emílio de Sales nasceu na vila de Santo Amaro em } 15 \text { de abril de } 1836 \text { e foi aluno da Faculdade de } \\
\text { Direto do Largo São Francisco. } \\
\text { "Filho de Francisco das Chagas e Maria Angélica, ele nasceu quando Santo Amaro era município, em } 15 \text { de abril de } \\
\text { 1836. Seu pai fundou a primeira escola da região e foi também o primeiro presidente da Comarca de Santo Amaro.” } \\
\text { (ASSOCIAÇÃO COMERCIAL DE SÃO PAULO, 2004, p.86). } \\
\text { "Sangue Limpo, uma de suas obras, é um drama em } 3 \text { atos que Paulo Eiró publicou em vida em 1863, e no qual ele, } \\
\text { com consciência plena de pregação abolicionista, denuncia a marca negra da escravidão.” (SESC, 2006, p. 97). } \\
\text { "Aos } 11 \text { anos, o jovem poeta apaixonou-se pela prima Cherurbina Angélica de Sales, que se tornou sua musa. Mas o } \\
\text { amor não correspondido e a decepção acompanharam o rapaz até a maturidade" (ASSOCIAÇÃO COMERCIAL DE } \\
\text { SÃO PAULO, 2004, p.87). } \\
\text { No poema Fatalidade, “[...] deposita toda sua dor por ter entrado ao acaso em uma igreja onde se realizava justamente } \\
\text { o casamento de sua amada." (ASSOCIAÇÃO COMERCIAL DE SÃO PAULO, 2004, p.87). }\end{array}$ \\
\hline
\end{tabular}


Bens culturais com atribuição de valor em Santo Amaro

\begin{tabular}{|c|c|c|}
\hline $\begin{array}{c}\text { Bem Cultural (Material e/ou } \\
\text { Imaterial) }\end{array}$ & \multicolumn{2}{|r|}{ Observações } \\
\hline & & $\begin{array}{l}\text { “Aos } 31 \text { anos, o poeta foi internado no Hospício dos Alienados, localizado na várzea do Carmo, na Rua Tabatinguera, } \\
\text { em São Paulo. Durante } 5 \text { anos ele definhou entre crises de demência e lucidez, enquanto sua família ia acabando. Seu } \\
\text { pai morreu em } 1867 \text { e sua escrava, Ana, em } 1869 \text {. Em } 27 \text { de junho de 1871, ele faleceu de meningite aos } 36 \text { anos de } \\
\text { idade.” (ASSOCIAÇÃO COMERCIAL DE SÃO PAULO, 2004, p.88). } \\
\text { Sexto filho de Francisco Antonio das Chagas e de sua segunda esposa, Nhá Géquinha (Maria Angélica das Dores), } \\
\text { "Depois de diplomado pela Escola Normal, em 1855, foi nomeado para reger a escolinha de Santo Amaro, até 1859, } \\
\text { quando se matriculou na Academia de Direto.” (BERARDI, 1981, p.62). } \\
\text { "Foi buscar esse sobrenome de um antepassado, o Capitão Miguel de Eiró, que se casara em Santo Amaro no ano de } \\
\text { 1705, com Inês Domingues Pontes, sobrinha do padre Belchior de Pontes.” (BERARDI, 1981, p.62). } \\
\text { "Já fazia estudos folclóricos no ano de nascimento de Silvio Romero e cantou a Abolição dez anos antes de Castro } \\
\text { Alves. Foi também o primeiro poeta republicanista, inspirando jornalistas, fazendeiros e políticos além de estudantes, } \\
\text { a formarem fileiras na luta pela República. Foi o baluarte da Convenção de Itu, realizada em 1873, quando vinde anos } \\
\text { antes escreveu o poema 'Verdade e Mentiras', apregoando a libertação dos escravos e prenunciando o advento da } \\
\text { República. Uma plêiade de jovens estudantes, contemporâneos de Paulo Eiró, inspiraram-se nos versos do tímido } \\
\text { santamarense, autor de poesias incisivas e corajosas." (Henrique L. Alves apud BERARDI, 1981, p. 63). }\end{array}$ \\
\hline Universidade de Santo Amaro & \multicolumn{2}{|c|}{$\begin{array}{l}\text { Criada em 1968, como Organização Santamarense de Educação e Cultura (OSEC), por um grupo de empresários, médicos, dentistas e professores, "com } \\
\text { o objetivo de oferecer ensino superior de qualidade para a numerosa população da região. Seu funcionamento começou com os cursos de Medicina, } \\
\text { Física, Matemática, Pedagogia e Letras. Juntos deram origem à Faculdade de Santo Amaro (FASA). Em 1994, a Instituição tornou-se Universidade e } \\
\text { passou a se chamar Universidade de Santo Amaro (UNISA). Hoje a Unisa conta com três campi na região de Santo Amaro.” (SESC, 2006, p.22). }\end{array}$} \\
\hline Clube da Cidade Joerg Bruder & Bem imaterial relacionado & $\begin{array}{l}\text { Capoeira } \\
\text { Junto com a Federação Paulista de Atletismo, "O Clube também oferece } \\
\text { uma ampla programação sócio-esportiva para todas as idades e preserva a } \\
\text { tradição da Capoeira em Santo Amaro". (SESC, 2006, p.23). }\end{array}$ \\
\hline
\end{tabular}


Bens culturais com atribuição de valor em Santo Amaro

\begin{tabular}{|c|c|}
\hline $\begin{array}{c}\text { Bem Cultural (Material e/ou } \\
\text { Imaterial) }\end{array}$ & Observações \\
\hline & $\begin{array}{l}\text { "Através da Secretaria do Bem Estar Social, a administração Faria Lima, atendendo a uma programação que visa humanizar São Paulo, construiu e } \\
\text { desenvolveu tais centros recreativos, com equipamentos modernos, e destinados a proporcionar recreação sadia, prática de esportes sob orientação } \\
\text { especializada. Inaugurado em janeiro de 1967, o Centro Recreativo da Prefeitura em Santo Amaro tem cinco piscinas, quadras de tênis, anfiteatro e } \\
\text { outros melhoramentos." (BERARDI, 1981, p.123). }\end{array}$ \\
\hline $\begin{array}{c}\text { Biblioteca Municipal Infantil } \\
\text { Belmonte }\end{array}$ & Foi inaugurada em 25 de janeiro de 1953, com o nome de Biblioteca Infantil Benedito Bastos Barreto (Belmonte). \\
\hline Casa Amarela & $\begin{array}{l}\text { “Em 1985, na Praça Floriano Peixoto foi erguida uma edificação para abrigar a cadeia pública, que ficou conhecida por Casa Amarela. } \\
\text { Esse prédio foi demolido em 1928, e no mesmo local foi construído o atual, para a sede da então Prefeitura Municipal de Santo Amaro, inaugurada a } 10 \\
\text { de janeiro de 1929. Santo Amaro deixou de ser município em fevereiro de 1935, mas o casarão continuou servindo a vários órgãos administrativos da } \\
\text { Prefeitura de São Paulo. } \\
\text { Hoje, após ter o prédio passado por obras de restauração, nele funciona o Paço Cultural Júlio Guerra.” (SESC, 2006, p. 74). }\end{array}$ \\
\hline Praça Floriano Peixoto/Coreto & $\begin{array}{l}\text { "Esta foto foi tirada no jardim de Santo Amaro em abril de 1958. Hoje Praça Floriano Peixoto" } \\
\text { Sra. Romilda, que morou em Santo Amaro de } 1958 \text { a 1962, quando se casou e foi morar na Chácara Santo Antônio." (SANTO AMARO, s.d.). } \\
\text { Na Rua Capitão Tiago Luz, tínhamos o jardim com um coreto e aos domingos banda de música que tocava das } 20 \text { h às } 22 \text { h." } \\
\text { Sra. Maria de Lourdes Hessel Torres, nascida em Santo Amaro, em } 25 \text { de outubro de } 1928 \text {, morou no bairro até } 1976 \text { e na éposidia na Granja Julieta. } \\
\text { (SANTO AMARO, s.d.) }\end{array}$ \\
\hline Teatro Pindorama & $\begin{array}{l}\text { Inaugurado em 1900, em um terreno doado pela Câmara na Praça Floriano Peixoto: } \\
\text { "[...] Francisco Sales, chamado também de Chico Turco, foi o primeiro da cinematografia em Santo Amaro. Trouxe para o Teatro Pindorama a Lanterna } \\
\text { Mágica, que projetava em um lençol molhado pendurado na parede..[...]" (BERARDI, 1981, p. 96). }\end{array}$ \\
\hline
\end{tabular}


Bens culturais com atribuição de valor em Santo Amaro

\begin{tabular}{|c|c|c|}
\hline $\begin{array}{l}\text { Bem Cultural (Material e/ou } \\
\text { Imaterial) }\end{array}$ & & Observações \\
\hline & Bens culturais relacionados & $\begin{array}{l}\text { Cine São Francisco } \\
\text { Criado a partir do Cine Sant'ana e Teatro Pindorama, incendiou-se em } 1953 . \\
\text { "Na manhã de um dia do ano de } 1956 \text { que não prometia a claridade primaveril, negra e espessa fumaça via-se nos } \\
\text { lados da prado do Jardim. Rapidamente a notícia se espalhou - O São Francisco pegou fogo! [...] } \\
\text { Nos dias felizes após a guerra de 1914, o povo mais alegre procurava divertir-se intensamente e encontrava no } \\
\text { Cinema-Teatro São Francisco, tudo para sua completa satisfação: as engraçadíssimas 'fitas do Chico Bola', os } \\
\text { dramalhões de Rodolfo Valentino, Wilma Banky, Jean Acker, Pola Negri, o cowboy Willian Hart, ídolo das } \\
\text { barulhentas 'matinês infantis'. Às vezes, anunciava-se que o 'dono' do São Francisco, Chico Sales, fora à Capital } \\
\text { especialmente para trazer a famosa fita em } 4 \text { partes, cuja função começaria mais cedo” (Santo Amaro em Revista, } \\
\text { 1961, p.52). } \\
\text { “[...] Em Santo Amaro tinha dois cinemas: São Francisco e Cine Mar. Todos os domingos nós íamos assistir a } \\
\text { matinê.” História do Morador: Agenor Borba Junior. Local: São Paulo. Publicado em: O8 de março de 2010. Santo } \\
\text { Amaro, que saudades. (Disponível em: http://www.encontrasantoamaro.com.br/historias-de-moradores-de-santo- } \\
\text { amaro/> Acesso em } 02 \text { mar 2016.). }\end{array}$ \\
\hline Clube Hípico de Santo Amaro & \multicolumn{2}{|c|}{$\begin{array}{l}\text { “A } 7 \text { de setembro de 1935, nas terras da Fazenda Itaquerê, o Dr. João Carlos Kruel fundou o Clube Hípico de Santo Amaro. Sucessivas gestões } \\
\text { dedicadas ao esporte eqüestre fizeram do Clube uma entidade despojada, porém um exemplo e parâmetro para os demais clubes hípicos do país. } \\
\text { Com uma área de } 300 \text { mil metros quadrados, seus grandes bosques com velhas árvores típicas de nossa mata atlântica permitem a prática do hipismo em } \\
\text { integração com a natureza. } \\
\text { A sede da fazenda, o Casarão, hoje restaurado, abriga o Conselho Deliberativo do Clube, e seu Centro Cirúrgico é considerado o mais completo da } \\
\text { América Latina. O clube sedia vários torneios, em especial 'Derby de Santo Amaro', que acontece no aniversário do bairro, dia } 15 \text { de janeiro.” (SESC, } \\
\text { 2006, p.82) }\end{array}$} \\
\hline \multirow{2}{*}{$\begin{array}{l}\text { Cemitério de Santo } \\
\text { Amaro/Cemitério Público }\end{array}$} & \multicolumn{2}{|c|}{ Construído na gestão do Coronel Isaías quando Prefeito de Santo Amaro de 1917 a 1928. (BERARDI, 1981, p.99). } \\
\hline & Bens culturais relacionados & $\begin{array}{l}\text { Bento do Portão } \\
\text { "Bento do Portão, segundo conta uma antiga moradora de Santo Amaro, era 'um caboclo baixinho e gordo, que } \\
\text { chegava no portão das casas e dizia: ‘tou c'uma fome siá dona!', e sentava no quintal esperando a comida. Âs vezes }\end{array}$ \\
\hline
\end{tabular}


Bens culturais com atribuição de valor em Santo Amaro

\begin{tabular}{|c|c|c|}
\hline $\begin{array}{c}\text { Bem Cultural (Material e/ou } \\
\text { Imaterial) }\end{array}$ & & Observações \\
\hline & & $\begin{array}{l}\text { ia buscar água para a dona da casa, ou rachava lenha para ela. Mas na maior parte das vezes saía quietinho; mas } \\
\text { ninguém ligava: era uma boa alma. Depois que Bento faleceu, sua sepultura tornou-se muito procurada no cemitério } \\
\text { local. São-lhe atribuídas muitas graças" (BERARDI, 1981, p.91). }\end{array}$ \\
\hline Biblioteca Prestes Maia & Inaugurada em & Coleção Prestes Maia, pertencente à biblioteca Mário de Andrade. \\
\hline Comunidade Samba da Vela & $\begin{array}{l}\text { "Noite de segur } \\
\text { eles formaram } \\
\text { Amaro todas as }\end{array}$ & $\begin{array}{l}\text { ro jovens compositores da periferia reuniram-se no bairro de Santo Amaro. Com cavaquinho, pandeiro, surdo e tamborim, } \\
\text { oda e começaram a cantar sambas. [...] Hoje, são uma comunidade de compositores. Reúnem-se na Casa de Cultura Santo } \\
\text { as, numa roda de samba com uma vela acesa no centro.” (SESC, 2006, p. 86). }\end{array}$ \\
\hline $\begin{array}{c}\text { Antigo Mercado/Casa de Cultura } \\
\text { de Santo Amaro }\end{array}$ & $\begin{array}{l}\text { "Iniciando a Nc } \\
\text { eleições, foram } \\
\text { Essa Câmara cc } \\
\text { regime passado } \\
\text { intendente capi } \\
\text { empreiteiro de }\end{array}$ & $\begin{array}{l}\text { 1892, os seus primeiros passos sob o amparo constitucional, dentro do regime republicano, em Santo Amaro, após as } \\
\text { primeiros vereadores municipais da república em Santo Amaro [...] } \\
\text { eminentes cidadãos santamarenses, os quais, imbuídos das novas ideias republicanas, sem menosprezar a administração do } \\
\text { efetivar as realizações projetadas pela antiga edilidade. Assim sendo, por ato de } 8 \text { de maio de } 1894 \text { era autorizado o } \\
\text { a providenciar a construção do prédio para o mercado e, em } 15 \text { de junho foi iniciada a construção sob a orientação do } \\
\text { Romigoni." (Santo Amaro em Revista, 1961, s/p.). }\end{array}$ \\
\hline \multirow[b]{2}{*}{ Represa de Guarapiranga } & \multicolumn{2}{|c|}{$\begin{array}{l}\text { "Em 1907, a 'São Paulo Light and Power' iniciou a construção de uma barragem de terra com reforço de zinco no Rio Guarapiranga. Desta maneira, os } \\
\text { antigos vales deste rio e de seus tributários (M’Boi Guassu, Santa Rita e Lavras) foram inundados. Formou-se assim um grande lago, de } 34 \text { quilômetros } \\
\text { quadrados e com capacidade para } 200 \text { milhões de metros cilíndricos de água. Essa represa tinha por finalidade uma usina em Sant'Ana de Parnaíba, que } \\
\text { dependia das águas do Rio Tietê. A barragem do Rio Guarapiranga garantia que a usina funcionasse mesmo nas estiagens.” (BERARDI, 1981, p.98). }\end{array}$} \\
\hline & $\begin{array}{l}\text { Bem imaterial } \\
\text { relacionado }\end{array}$ & $\begin{array}{l}\text { "A Represa de Guarapiranga é a que fornece água para uma boa parte de São Paulo, e antigamente, era costume as pessoas } \\
\text { de São Paulo vir passear no aterro da represa e andar de barco que era de aluguel e assim podiam ir do outro lado, que era } \\
\text { a Riviera. Nas margens da represa tinham muitas casas que eram chácaras e os donos moravam na cidade e iam passar o } \\
\text { fim de semana e aproveitavam para velejar na represa. Também tinha um salão de baile, o famoso Vila Sofia. Aqui temos } \\
\text { o campo de golfe São Paulo Golfe Clube que é muito bem freqüentado pela elite. Temos o clube da Hípica que até hoje } \\
\text { tem competições" }\end{array}$ \\
\hline
\end{tabular}


Bens culturais com atribuição de valor em Santo Amaro

\begin{tabular}{|c|c|}
\hline $\begin{array}{c}\text { Bem Cultural (Material e/ou } \\
\text { Imaterial) }\end{array}$ & Observações \\
\hline & $\begin{array}{l}\text { Sra. Maria de Lourdes Hessel Torres, nascida em Santo Amaro, em } 25 \text { de outubro de 1928, morou no bairro até } 1976 \text { e na } \\
\text { época residia na Granja Julieta. (SÃO PAULO,s.d.). }\end{array}$ \\
\hline Represa Billings & $\begin{array}{l}\text { "A seca de } 1924 \text { foi das maiores que se sentiu em São Paulo. As águas do Rio Tietê baixaram para cerca de } 30 \% \text { de seu volume. Em maio de } 1925,70 \% \\
\text { da energia elétrica de São Paulo teve de ser cortada: pararam os cinemas, a iluminação pública foi interrompida e as fábricas passaram a trabalhar apenas } \\
\text { três dias por semana. } \\
\text { Foi quando Asa White Kenney Billings, engenheiro da Light, planejou represar os rios Jurubatuba e Bororé, afluentes do Pinheiros, formando um outro } \\
\text { lago: essas águas seriam lançada a } 800 \text { metros de altura sobre as turbinas da Usina de Cubatão que iria suprir São Paulo da energia que faltava. A estas } \\
\text { águas se acrescentaram as do reservatório do Guarapiranga, e as do próprio Rio Pinheiros, impulsionadas em sentido inverso por um canal.” (BERARDI, } \\
\text { 1981, p.100). }\end{array}$ \\
\hline $\begin{array}{l}\text { Colégio Espírito } \\
\text { Santo/Congregação }\end{array}$ & $\begin{array}{l}\text { "A foto do dia da minha primeira comunhão, quando eu tinha mais ou menos onze anos, foi tirada na varanda da minha casa. O evento se deu na capela } \\
\text { do Colégio Espírito Santo, na Av. Vereador José Diniz e hoje no local se encontra apenas o convento da mesma congregação." } \\
\text { Sra. Maria Gomes Leite Pereira, natural de Freguesia do Líria, em Portugal ( } 26 \text { de janeiro de 1931), chegou ao Brasil, com } 8 \text { anos, em 1940, a bordo do } \\
\text { navio Angola. (SÃO PAULO, s.d.). }\end{array}$ \\
\hline Centro Empresarial SP & $\begin{array}{l}\text { “O Centro Empresarial SP foi o primeiro empreendimento no Brasil com o conceito de ‘Escritórios Inteligentes’. O Centro Empresarial São Paulo, } \\
\text { inaugurado em 1977, está instalado em uma área de } 200 \text { mil m2 que abriga mais de } 60 \text { empresas, shopping de conveniência, com mais de } 70 \text { lojas, } \\
\text { restaurantes, agências bancárias e serviços. O projeto, pioneiro nesse sistema, é do arquiteto João Henrique Rocha.” (SESC, 2006, p.32). }\end{array}$ \\
\hline $\begin{array}{l}\text { Antiga Fundição (SESC, 2006, } \\
\text { p.32)/Engenho de Ferro } \\
\text { (ASSOCIAÇÃO COMERCIAL } \\
\text { DE SÃO PAULO, 2004, p.29) }\end{array}$ & $\begin{array}{l}\text { "Nela [Santo Amaro] também abundava o minério de ferro e, assim, no começo de } 1600 \text { fundou-se o primeiro engenho de metal, de propriedade de dom } \\
\text { Francisco de Souza, Diogo de Quadros e Francisco Lopes. Não durou contudo mais de } 30 \text { anos, por falta de mão-de-obra adequada, dificuldades no } \\
\text { transporte e a morte de um dos sócios." (reportagem Gazeta Sto Amaro idem in: ASSOCIAÇÃO COMERCIAL DE SÃO PAULO, 2004, p.46). } \\
\text { "Quanto ao ferro é certo que dele se fundiu enquanto houve a fábrica em Santo Amaro, nas proximidades de São Paulo. Era um ferro brando (...). Cabe } \\
\text { ao menos certa importância histórica ao engenho de Santo Amaro, por ser, cronologicamente, o mais antigo de que há notícia no hemisfério ocidental, } \\
\text { embora ao de Jamestown, na Virgínia, se dê comumente essa primazia". (Sérgio Buarque de Holanda, in: ASSOCIAÇÃO COMERCIAL DES ÃO } \\
\text { PAULO, 2004, p.29). }\end{array}$ \\
\hline
\end{tabular}


Bens culturais com atribuição de valor em Santo Amaro

\begin{tabular}{|c|c|c|}
\hline $\begin{array}{c}\text { Bem Cultural (Material e/ou } \\
\text { Imaterial) }\end{array}$ & \multicolumn{2}{|r|}{ Observações } \\
\hline Comunidade Monte Azul & \multicolumn{2}{|c|}{$\begin{array}{l}\text { De iniciativa de Ute Craemer, que "veio da Alemanha em 1971, dava aulas num colégio alemão e morava na frente da favela. Em 1980, abandonou o } \\
\text { colégio e passou a dedicar-se à vida da favela, criando a Associação Comunitária Monte Azul." (SESC, 2006, p.33). }\end{array}$} \\
\hline \multirow[t]{2}{*}{ Aeroporto de Congonhas } & \multicolumn{2}{|c|}{$\begin{array}{l}\text { Tombado. } \\
\text { "O nome do aeroporto de Congonhas é uma homenagem ao Visconde de Congonhas do Campo, Lucas Antônio Monteiro de Barros, primeiro governante } \\
\text { da província de São Paulo após a independência do Brasil. Congonhas é um tipo de erva-mate muito comum em Minas Gerais, na região onde se situa } \\
\text { Congonhas do Campo, cidade natal de Monteiro de Barros. O aeroporto de Congonhas foi planejado em 1936, depois que uma enchente do Rio Tietê } \\
\text { alagou e interditou por vários meses o aeroporto de Campo de Marte. O local foi escolhido por ter boas condições naturais como visibilidade e drenagem, } \\
\text { além de ser um terreno plano e, naquela época, afastado do centro urbano." (Revista Enfoco Santo Amaro. Publicação da Associação de Voluntários } \\
\text { Gota de Esperança. Ano 1. n.6 set/out 2004). }\end{array}$} \\
\hline & Bem cultural relacionado & Passarela \\
\hline \multirow[b]{2}{*}{$\begin{array}{l}\text { Auto estrada Washington Luiz } \\
\text { (hoje Avenida) }\end{array}$} & \multicolumn{2}{|c|}{$\begin{array}{l}\text { "Em } 1927 \text { foi constituída a Sociedade Anônima de Auto Estradas, que se propunha fazer uma ótima rodovia, ligando a capital às represas da Light, onde } \\
\text { se construiria uma estação balneária" (BERARDI, 1981, p.99). } \\
\text { "Havia muitas chácaras e fazendas aqui, depois vieram os estabelecimentos comerciais e a região prosperou muito". (ASSOCIAÇÃO COMERCIAL DE } \\
\text { SÃO PAULO, 2004, p.109). }\end{array}$} \\
\hline & Bens culturais relacionados & $\begin{array}{l}\text { Carro de boi } \\
\text { "[...] O carro de boi, como era chamado, não deixava de ser disputado pelos homens de negócios, pois, naquele } \\
\text { tempo, podia-se, somente, admitir remota possibilidade da estrada de ferro no Brasil. Era, no entanto, o carro de boi, } \\
\text { o veículo sem competidor e os seus proprietários, considerados os magnatas dos transportes. } \\
\text { Toda a produção das fazendas, situadas no vale do Paraíba, que deveria ser exportada pelo porto de Santos, era } \\
\text { transportada por esses veículos. } \\
\text { Achamos, portanto, que o carro de boi merece um lugar no Museu Estadual, junto ao avião de Santos Dumont e ao }\end{array}$ \\
\hline
\end{tabular}


Bens culturais com atribuição de valor em Santo Amaro

\begin{tabular}{|c|c|c|}
\hline $\begin{array}{c}\text { Bem Cultural (Material e/ou } \\
\text { Imaterial) }\end{array}$ & & Observações \\
\hline & & $\begin{array}{l}\text { 'Jaú' do Comandante João de Barros.” (Santo Amaro em Revista, 1961, s/p). } \\
\text { "Era um tempo em que só dava para ir para Santos de carro de boi, não podia ser a cavalo, pois o caminho era difícil } \\
\text { e só o boi tinha força para puxar o carro se ele atolasse". Oswaldo Hertel Roschel. (ASSOCIAÇÃO COMERCIAL } \\
\text { DE SÃO PAULO, 2004, p.108). }\end{array}$ \\
\hline Gazeta de Santo Amaro & $\begin{array}{l}\text { Fundada em } 1960 \text { (por Armand } \\
\text { Gazeta do Brooklin \& Campo }\end{array}$ & $\begin{array}{l}\text { a Silva Prado), hoje se transformou num "grupo de semanários”: O Grupo Sul News, que atualmente edita os jornais } \\
\text {, Jornal de Moema, Interlagos News e Itaim News. (SESC, 2006, p.68). }\end{array}$ \\
\hline \multirow[t]{2}{*}{ Pólo Industrial de Santo Amaro } & \multicolumn{2}{|c|}{$\begin{array}{l}\text { Santo Amaro "Abrigou importantes empresas da indústria farmacêutica, como os laboratórios Pfizer e Novartis e também foi um grande pólo de } \\
\text { fabricação de componentes eletrônicos, entre outros". "Tínhamos a Caterpillar, a Metal Leve, a Phillips a Cargil, a Quimbrasil, primeira firma que } \\
\text { processou urânio, a Frigor Éder, entre outras" - Jaime Soler Baró, um espanhol da Catalunha que chegou ao Brasil em } 1950 \text { com } 10 \text { anos (era Diretor da } \\
\text { Distrital Sul da FIESP/CIESP). (ASSOCIAÇÃO COMERCIAL DE SÃO PAULO, 2004, p.32). } \\
\text { "A facilidade de transporte (primeiro pela Avenida Santo Amaro, Washington Luis e estrada de ferro para Santos, e, ultimamente, pela Avenida } \\
\text { Marginal), ao lado da abundância de água, da facilidade para escoamento de detritos, trouxeram para Santo Amaro várias indústrias pesadas." } \\
\text { (BERARDI, 1981, p.127). }\end{array}$} \\
\hline & Bens imateriais relacionados & $\begin{array}{l}\text { Greves operárias em Santo Amaro - Santo Dias } \\
\text { "Santo Dias da Silva, líder operário bastante reconhecido no meio dos trabalhadores, foi assassinado friamente pela } \\
\text { PM paulista quando comandava um piquete de greve no dia } 30 \text { de outubro de 1979, em Santo Amaro. Como } \\
\text { homenagem por sua luta e seu exemplo, foi então criado o Centro Santo Dias de Direitos Humanos da Arquidiocese } \\
\text { de São Paulo." (SESC, 2006, p.60). }\end{array}$ \\
\hline Festa do Divino & \multicolumn{2}{|c|}{$\begin{array}{l}\text { Santo Amaro, que saudades... Eu, Agenor Borba Junior, conhecido por todos como Nonô, gostaria de contar algumas passagens da minha infância em } \\
\text { Santo Amaro, lugar onde nasci, em 1939. Tinha eu mais ou menos } 7 \text { anos de idade, meus pais me levavam para ver a festa do Divino, no Largo } 13 \text { de } \\
\text { Maio. Era uma festa muito bonita, com muitas barracas e muita gente que vinha dos povoados vizinhos. No mês de junho tinha muitas festas nas casas, } \\
\text { erguiam o mastro em homenagem a Santo Antônio, São João e São Pedro, tinha fogueira, soltavam balões e muitos fogos, era muito alegre. }\end{array}$} \\
\hline
\end{tabular}


Bens culturais com atribuição de valor em Santo Amaro

\begin{tabular}{|c|c|c|}
\hline $\begin{array}{c}\text { Bem Cultural (Material e/ou } \\
\text { Imaterial) }\end{array}$ & \multicolumn{2}{|r|}{ Observações } \\
\hline & \multicolumn{2}{|c|}{ 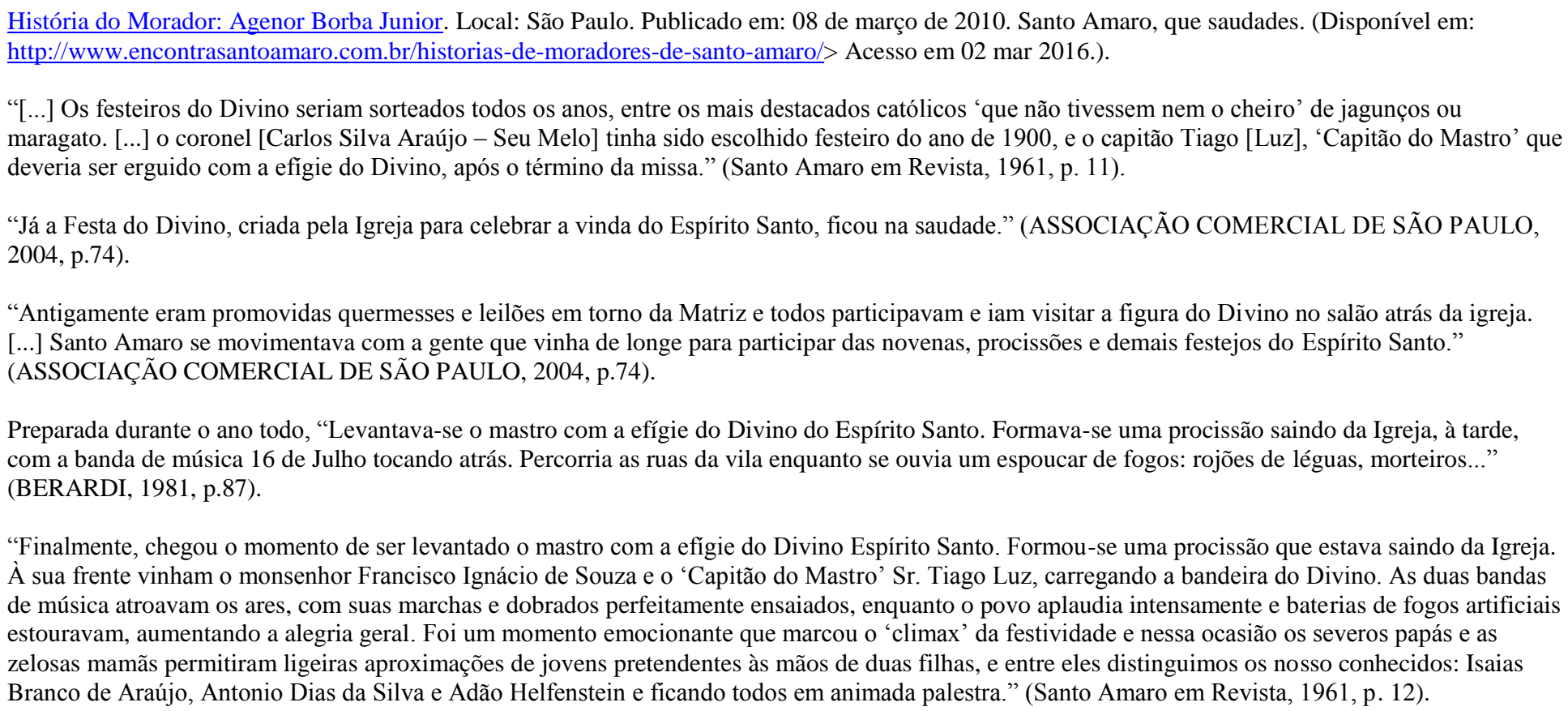 } \\
\hline & Bens culturais relacionados & $\begin{array}{l}\text { Estampido dos rojões, corporações musicais que tocavam, a corrida do porquinho, rezas puxadas em latim, } \\
\text { lamparinas de querosene, sanfona de oito baixos e os violeiros itinerantes, quadrilha, polca e da mazurca. } \\
\text { (BERARDI, 1981, p.87). }\end{array}$ \\
\hline
\end{tabular}


Bens culturais com atribuição de valor em Santo Amaro

\begin{tabular}{|c|c|c|}
\hline $\begin{array}{c}\text { Bem Cultural (Material e/ou } \\
\text { Imaterial) }\end{array}$ & & Observações \\
\hline \multirow[b]{2}{*}{ Farra do Boi } & \multicolumn{2}{|c|}{$\begin{array}{l}\text { "Cheguei até ver carros de boi trazendo lenha para o meu vizinho. Estudei no grupo escolar Paulo Eiró, onde fiz até o } 4^{\circ} \text { ano do primário. Aos } 12 \text { anos de } \\
\text { idade já comecei a ter meus amigos, como dizia antigamente "minha turma" E que turma na rua Anchieta, esquina com a rua Santo Antônio, onde eu } \\
\text { nasci, tinha muitas árvores dos dois lados da rua. Nós subíamos nas árvores esperando a boiada passar e, quando estava no meio da boiada, com um } \\
\text { galho da árvore nós espantávamos os bois, até que um ou dois bois se assustavam e saíam correndo pelas ruas. O boiadeiro ia logo atrás do boi fujão, } \\
\text { laçava e amarrava as patas até que um caminhão viesse buscar, às vezes, no dia seguinte. Aí era a parte mais gostosa da brincadeira: passando algumas } \\
\text { horas, lá estávamos nós para desatar as amarras das patas do boi, ele levantava e saía correndo pelas ruas, chegava até o Largo } 13 \text { de Maio assustando a } \\
\text { todos. Era a farra do boi. Na avenida João Dias, próximo ao Mercado Velho, existia uma chácara de verduras, onde entrei correndo para pegar um balão } \\
\text { que estava caindo. Estava olhando para cima quando caí num poço com água, me molhando todo, levando um baita susto.[...]" História do Morador: } \\
\text { Agenor Borba Junior. Local: São Paulo. Publicado em: } 08 \text { de março de } 2010 \text {. Santo Amaro, que saudades. (Disponível em: } \\
\text { http://www.encontrasantoamaro.com.br/historias-de-moradores-de-santo-amaro/> Acesso em } 02 \text { mar 2016.). }\end{array}$} \\
\hline & Bens culturais relacionados & $\begin{array}{l}\text { Frigorífico Éder e Orlando Donadio. } \\
\text { Seu pai "provavelmente foi o primeiro motorista de caminhão da localidade e ele próprio combateu com as Forças } \\
\text { Expedicionárias Brasileiras na Itália, durante a Segunda Guerra Mundial”. (ASSOCIAÇÃO COMERCIAL DE SÃO } \\
\text { PAULO, 2004, p.104). } \\
\text { Embora nascido no Belenzinho, morou em Santo Amaro desde } 1 \text { ano de idade: “'Meu pai foi trabalhar como cocheiro } \\
\text { em uma chácara do então município, chamada Castelo"”. (ASSOCIAÇÃO COMERCIAL DE SÃO PAULO, 2004, } \\
\text { p.104). } \\
\text { "Ainda jovem, em } 1935 \text { o próprio Orlando foi trabalhar na Frigor Éder como contínuo, fez carreira dentro da empresa } \\
\text { e só saiu de lá } 50 \text { anos depois, ao se aposentar." (ASSOCIAÇÃO COMERCIAL DE SÃO PAULO, 2004, p.104). } \\
\text { "Depois ele [seu pai, que trabalhava como cocheiro numa chácara no município de Santo Amaro] foi chamado para } \\
\text { trabalhar como motorista de caminhão, quando estava sendo fundado o Frigorífico Santo Amaro (depois Frigor Éder) } \\
\text { e acho que ele foi o primeiro motorista da região, ou pelo menos um deles, permanecendo no cargo e na empresa por } \\
25 \text { anos." (ASSOCIAÇÃO COMERCIAL DE SÃO PAULO, 2004, p.104). }\end{array}$ \\
\hline
\end{tabular}


Bens culturais com atribuição de valor em Santo Amaro

\begin{tabular}{|c|c|}
\hline $\begin{array}{c}\text { Bem Cultural (Material e/ou } \\
\text { Imaterial) }\end{array}$ & Observações \\
\hline & $\begin{array}{l}\text { Romaria de Pirapora dos cavaleiros (a mais antiga manifestação religiosa). (SESC, 2006, p.21). } \\
\text { "[...] Todos os anos saíam de Santo Amaro duas romarias a Pirapora, com muitos cavaleiros, charretes e ônibus. Uma era do Cinerino, que tinha um } \\
\text { armazém. Na calçada, havia uma argola no chão para amarrar os cavalos dos donos que vinham fazer compras. A outra romaria era do Vereador José } \\
\text { Oliveira de Almeida Diniz, conhecido na época como Zé da Farmácia, pai do Zezito, grande amigo meu. Nós íamos amansar os cavalos que vinham das } \\
\text { olarias para levar na romaria, isso era no Varjão onde hoje é a Marginal do Rio Pinheiros.” História do Morador: Agenor Borba Junior. Local: São Paulo } \\
\text { Publicado em: } 08 \text { de março de 2010. Santo Amaro, que saudades. (Disponível em: http://www.encontrasantoamaro.com.br/historias-de-moradores-de- }\end{array}$ \\
\hline
\end{tabular}
santo-amaro/> Acesso em 02 mar 2016.).

"Entre outras tradicionais manifestações do povo santamarense, existem as peregrinações religiosas, promovidas nos meses de Abril e Maio, pelas duas associações existentes em Santo Amaro. Desde o século passado, já era costume dos santamarenses promoverem peregrinações, em louvor dos santos de suas predileções. Essa prática vinha de seus antepassados, os quais também as praticavam, de acordo com os seus ascendentes portugueses, que trouxeram para o Brasil os costumes existentes na Mãe-Pátria.

As peregrinações eram, até a primeira década deste século, promovidas circunstancialmente, em virtude de promessas que se faziam aos santos, a que os religiosos, na sua boa fé, atribuíam inúmeros milagres. Eis que, em 1918, Cenerino Branco de Araújo, em cumprimento a uma promessa feita ao Senhor Bom Jesus de Pirapora, em certo dia do mês de abril daquele ano, em horas matinais, deu início à sua peregrinação a pé, chegando à Basílica de Pirapora à noite do mesmo dia. Era um sacrifício para aqueles que assim procediam, todavia, segundo a crença, conforme a importância das curas alcançadas; seriam as penitências prometidas em maior intensidade. Assim, por alguns anos mais, Cenerino continuou só na extensa caminhada, percorrendo, sob sol escaldante, a estrada cheia de pó, até que, em 1948, tendo organizado uma verdadeira romaria à Basílica de Pirapora, em louvor do Senhor bom Jesus, tal foi o sucesso das adesões, aumentando sucessivamente, ano a ano, que este ano foi realizada uma das maiores romarias, mesmo porque, comemorava-se o IV centenário de fundação da cidade de Santo Amaro. Após a realização da primeira romaria, foi organizada a Associação sob a égide de bem elaborado estatuto e para cuja denominação escolheu-se a mais interessante, Associação dos Cavaleiros do Senhor Bom Jesus de Pirapora de Santo Amaro atual" (Santo Amaro em Revista, 1961, p. 30).

De acordo com o Centro das Tradições de Santo Amaro (CETRASA) a história da Romaria remonta o século XIX, de acordo com relatos de Adolfo Pinheiro. No século XX, após a gripe espanhola, um grupo de comerciantes e moradores da então cidade de Santo Amaro (anexada à capital em 1935) liderados por Cenerino Branco de Araújo, viajava rumo a Pirapora do Bom Jesus para agradecer o fato de poucas pessoas da região terem contraído a grave doença. No início dos anos 1950, para marcar a história, a Romaria foi oficializada e desde então reúne moradores da região em uma demonstração de fé e tradição. (Disponível em: http://www.difundir.com.br/site/c_mostra_release.php?emp=4519\&num_release=151725\&ori=A $>$ Acesso em: 02 mar 2016.).

"[...] ela se repete todos os anos, desde 1920, no último fim de semana de maio. Os romeiros vestidos a caráter, alguns montados a cavalo (antigamente iam instalados em carroças) outros a pé, saem do Largo Treze de Maio em direção a Piraporinha - um trajeto de 70 quilômetros.”. (ASSOCIAÇÃO 
Bens culturais com atribuição de valor em Santo Amaro

\begin{tabular}{|c|c|c|}
\hline $\begin{array}{c}\text { Bem Cultural (Material e/ou } \\
\text { Imaterial) }\end{array}$ & \multicolumn{2}{|r|}{ Observações } \\
\hline & \multicolumn{2}{|c|}{ 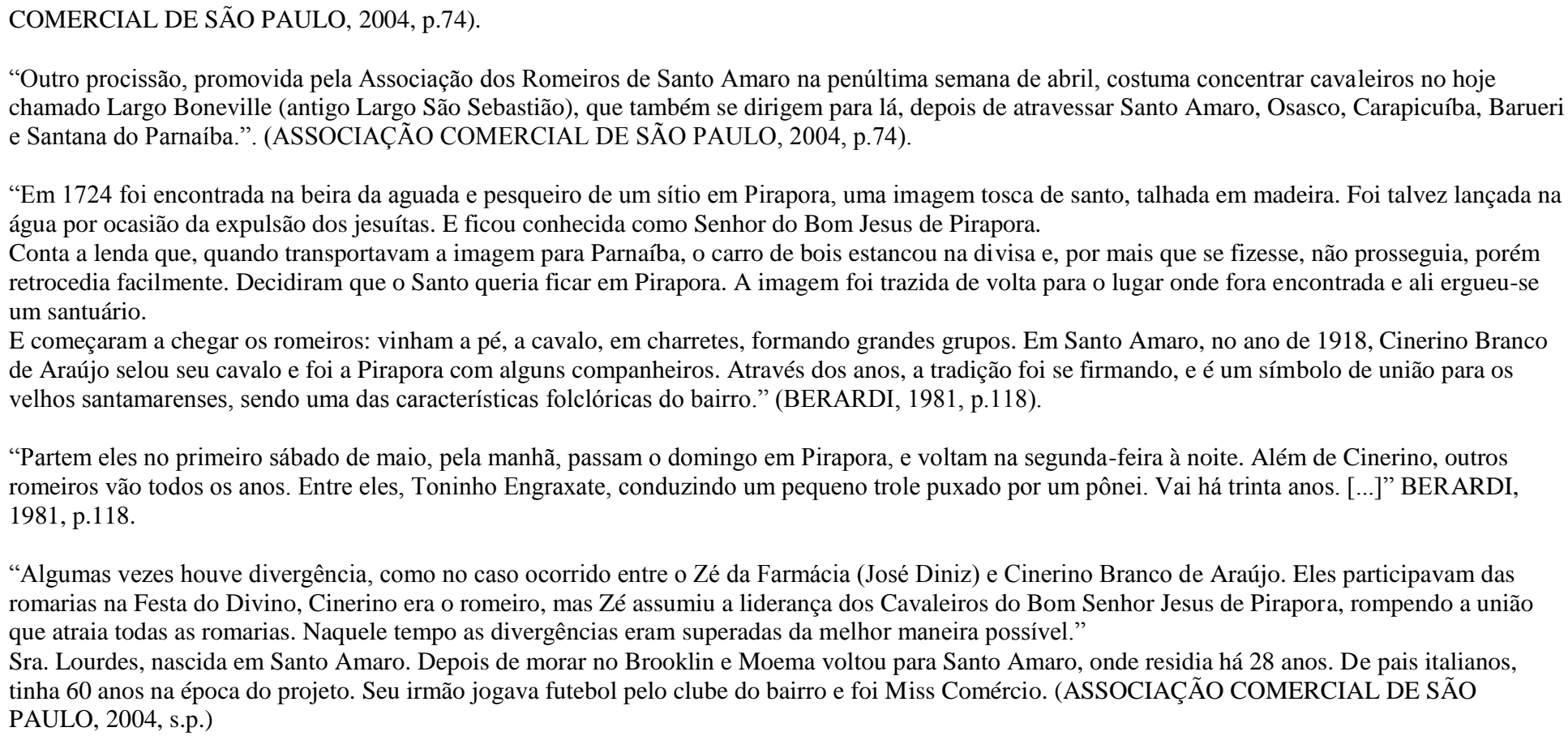 } \\
\hline & Bens culturais relacionados & $\begin{array}{l}\text { Placa/Monumentos aos Romeiros. (ASSOCIAÇÃO COMERCIAL DE SÃO PAULO, 2004, p.55). } \\
\text { Outros velhos romeiros: Carlos Sgarbi Sobrinho, Mario Escudeiro, José Canevale Netto, Antonio Rodrigues Cruz, } \\
\text { Juvenal Mariano Cruz, Antonio Gonçalves de Souza Junior, Oswaldo Cortada de Almeida, Oclave Senne. (Santo } \\
\text { Amaro em Revista, 1961, p.30). }\end{array}$ \\
\hline
\end{tabular}


Bens culturais com atribuição de valor em Santo Amaro

\begin{tabular}{|c|c|}
\hline $\begin{array}{c}\text { Bem Cultural (Material e/ou } \\
\text { Imaterial) }\end{array}$ & Observações \\
\hline $\begin{array}{c}\text { Time de Futebol } \\
\text { (Benfica - time amador de Santo } \\
\text { Amaro) }\end{array}$ & 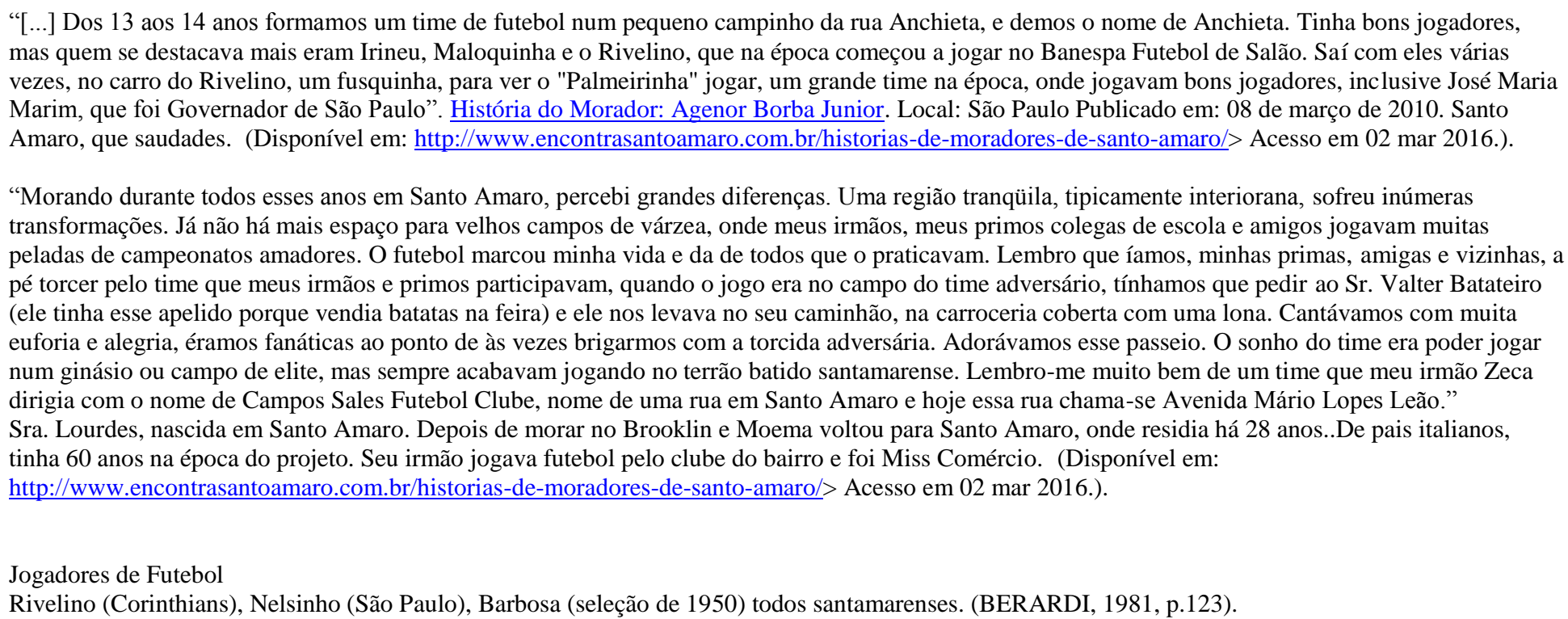 \\
\hline Culinária de Santo Amaro & $\begin{array}{l}\text { Carne de congonha e içás (formigas gigantes) } \\
\text { "A população de Santo Amaro conhecia ainda o uso da Congonha e a carne em longas tiras, processo que facilitava o preparo da paçoca de carne feita } \\
\text { em pilão. Como base na alimentação, figurava o feijão: com couve picada, com farinha de mandioca, com couro de porco torrado. A carne de caça bem } \\
\text { moqueada, os içás: comiam a formiga torrada, sem o abdomem. O costume vinha talvez dos jesuítas, como meio de impedir a multiplicação das terríveis } \\
\text { formigas. Ou dos índios, que ensinaram também processos destruidores de pesca por envenenamento." (BERARDI, 1981, p.79). } \\
\text { Filhoses ou Rabanada } \\
\text { "Todos os anos, no Natal, minha avó ia para a cozinha para fazer os esperados 'Filhotes', doce típico com massa de pão com ovos, que depois de fritos } \\
\text { ela os passava no açúcar com canela." } \\
\text { Sra. Maria Gomes Leite Pereira, natural de Freguesia do Líria, em Portugal (26 de janeiro de 1931), chegou ao Brasil, com } 8 \text { anos, em 1940, a bordo do } \\
\text { navio Angola. (Disponível em: http://www.encontrasantoamaro.com.br/historias-de-moradores-de-santo-amaro/> Acesso em } 02 \text { mar } 2016 \text {.). }\end{array}$ \\
\hline
\end{tabular}


Bens culturais com atribuição de valor em Santo Amaro

\begin{tabular}{|c|c|}
\hline $\begin{array}{c}\text { Bem Cultural (Material e/ou } \\
\text { Imaterial) }\end{array}$ & Observações \\
\hline & 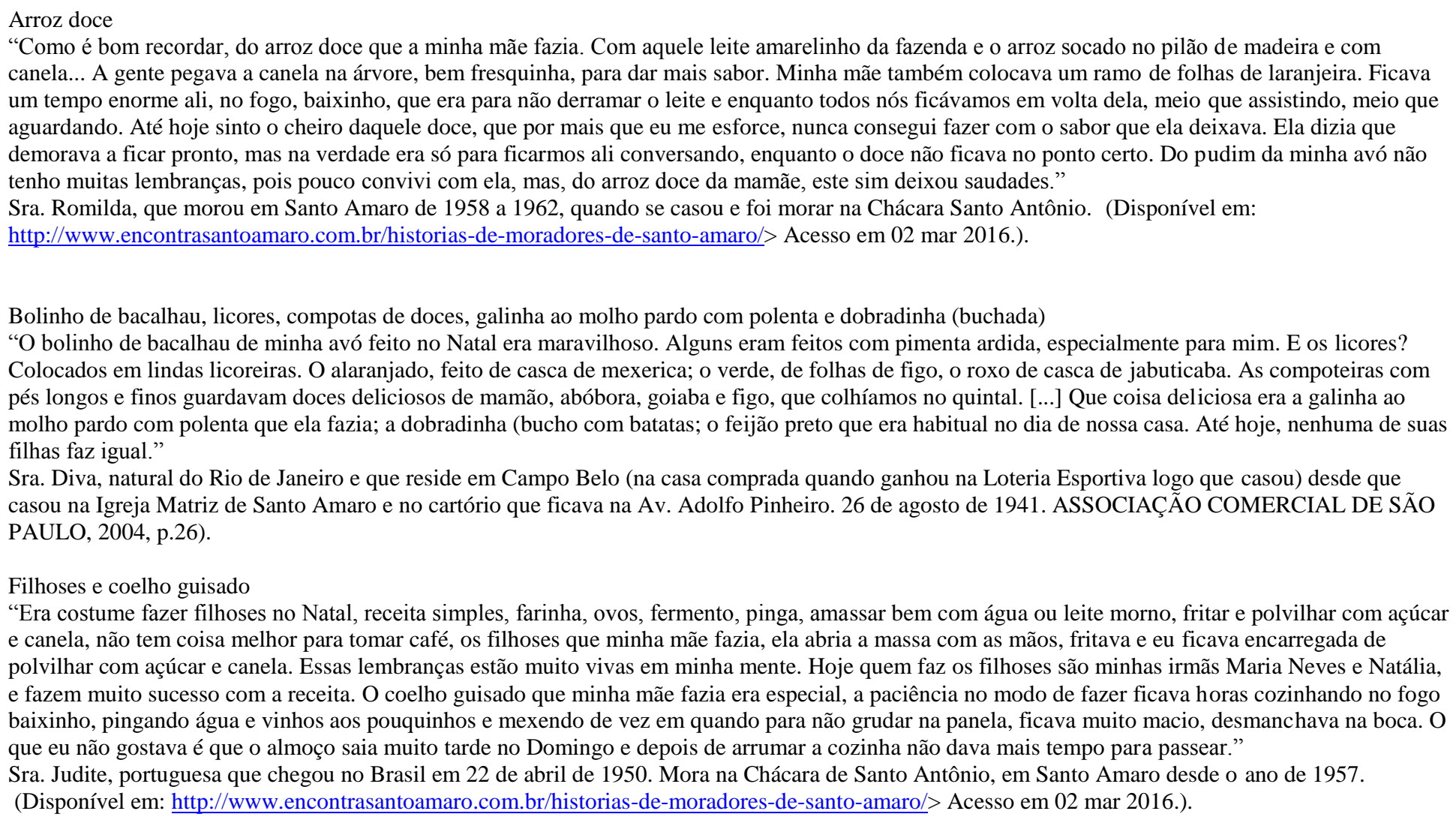 \\
\hline
\end{tabular}


Bens culturais com atribuição de valor em Santo Amaro

\begin{tabular}{|c|c|c|}
\hline $\begin{array}{c}\text { Bem Cultural (Material e/ou } \\
\text { Imaterial) }\end{array}$ & & Observações \\
\hline & \multicolumn{2}{|c|}{$\begin{array}{l}\text { Doces e sobremesas e virada de frango } \\
\text { "Eu me lembro que quando minha mãe fazia doces de frutas como pêssego em calda, figo, mamão, abóbora, eram uma delícia, e os manjares de leite e } \\
\text { coco, o arroz doce, nem é bom lembrar de tão gostoso que era. Mas na época do Natal e da Páscoa os doces eram outros: bom bocado, queijadinha de } \\
\text { coco, pão doce. Além dos doces, minha mãe era uma ótima cozinheira, pois fazia pratos salgados deliciosos como tortas, frango assado, carne e batatas } \\
\text { no forno e uma especialidade virada de frango com batatas e ervilhas." } \\
\text { Sra. Maria de Lourdes Hessel Torres, nascida em Santo Amaro, em } 25 \text { de outubro de 1928, morou no bairro até } 1976 \text { e na época residia na Granja Julieta. } \\
\text { (Disponível em: http://www.encontrasantoamaro.com.br/historias-de-moradores-de-santo-amaro/> Acesso em } 02 \text { mar 2016.). } \\
\text { "Morávamos na Avenida João Dias, numa casa com um terreno enorme, como se fosse uma chácara. Todas as casas eram assim, muitas com pomar, } \\
\text { horta, criações de porcos, galinhas e cavalos. Lembro muito bem de minha mãe preparando o almoço de domingo. A massa e o molho do macarrão eram } \\
\text { feitos em casa. Mamãe acordava cedo para acender o fogo de carvão, enquanto meu pai matava e limpava o frango no quintal. Papai o matava bem longe } \\
\text { da cozinha, porque minha mãe tinha pena da ave, pois era ela quem alimentava diariamente as galinhas. Nós tínhamos quase de tudo no quintal para o } \\
\text { nosso consumo. [...] Tinha uma matadouro onde é atualmente a Rua Darwin e me lembro que o gado passava na avenida em direção a esse matadouro. } \\
\text { Era uma alegria só, com todos reunidos para os almoços dos domingos. Conversávamos sobre vários assuntos, e terminado o almoço, ajudávamos minha } \\
\text { mãe limpar a cozinha. Depois, meus irmãos e primos iam jogar bola enquanto eu e minha irmã íamos à casa de minhas primas ou elas vinham em casa. } \\
\text { Tínhamos uma convivência grande com nossos parentes, pois eles moravam perto." } \\
\text { Sra. Lourdes, nascida em Santo Amaro. Depois de morar no Brooklin e Moema voltou para Santo Amaro, onde residia há } 28 \text { anos..De pais italianos, } \\
\text { tinha } 60 \text { anos na época do projeto. Seu irmão jogava futebol pelo clube do bairro e foi Miss Comércio. (Disponível em: } \\
\text { http://www.encontrasantoamaro.com.br/historias-de-moradores-de-santo-amaro/> Acesso em 02 mar 2016.). }\end{array}$} \\
\hline \multirow[b]{2}{*}{ Igreja Matriz de Santo Amaro } & \multicolumn{2}{|l|}{ Tombada. } \\
\hline & Bens imateriais relacionados & $\begin{array}{l}\text { Tocar do Sino. } \\
\text { Bandas 'Treze de maio' e “16 de julho' } \\
\text { "Finalmente, em } 1899 \text {, foi determinado o feriado de } 8 \text { de dezembro para a inauguração do edifício [Santa Casa]. Na } \\
\text { sóbria capela, despretensiosa de proporções e adornos, mas singela, dentro de seus enormes recursos de conforto } \\
\text { espiritual, celebrou o revdmo. Pe. Dr. Adelino Montenegro, a primeira missa, iniciando as cerimônias. Foi festiva a }\end{array}$ \\
\hline
\end{tabular}


Bens culturais com atribuição de valor em Santo Amaro

\begin{tabular}{|c|c|}
\hline $\begin{array}{c}\text { Bem Cultural (Material e/ou } \\
\text { Imaterial) }\end{array}$ & Observações \\
\hline & $\begin{array}{l}\text { comemoração, como entusiásticas foram as palavras dos drs. Raphael Correa Sampaio e Carlos Samuel de Araujo e } \\
\text { vibrante o repertório das duas bandas presentes: "Treze de Maio" e "16 de julho". (Santo Amaro em Revista, 1961, } \\
\text { p.15). } \\
\text { Imagem de Santo Amaro } \\
\text { "O casal João Paes e Suzana Rodrigues doou uma pequena imagem de madeira, que representava Santo Amaro } \\
\text { (discípulo de São Bento e padroeiro dos agricultores) [...]" (BERARDI, 1981, p.27). } \\
\text { "O primeiro registro de doação de terras na região data de } 12 \text { de agosto de 1560: suas léguas de terras na margem } \\
\text { esquerda do rio, então chamado de Jeribatiba, para os padres jesuítas. Data dessa época a denominação Santo Amaro, } \\
\text { homenagem dos jesuítas que trouxeram de Portugal uma imagem do santo. O padre José de Anchieta rezou ali uma } \\
\text { missa dos primeiros anos do cristianismo, nascido em } 513 \text { d.C., na Itália). Santo Amaro ou Santo Mauro tem sua } \\
\text { festa celebrada em } 15 \text { de janeiro e é o santo protetor dos carroceiros, carregadores e fabricantes de velas." "Antes de } \\
\text { São Paulo já havia Santo Amaro in: ASSOCIAÇÃO COMERCIAL DE SÃO PAULO, 2004, p.42). } \\
\text { "Naquela época, uma imensa planície deserta e desabitada, sem nome nem ruas, separava São Paulo de Santo Amaro. } \\
\text { Em Cupecê, próximo ao local, o casal João Paes e Suzana Rodrigues, vindos de Portugal com Martim Affonso de } \\
\text { Souza, passou a lavrar as terras recebidas por sesmaria, cujo documento original encontra-se hoje no Arquivo } \\
\text { Nacional Devotos, eles guardavam em casa a imagem de Santo Mauro, depois denominado Santo Amaro." "Antes de } \\
\text { São Paulo já havia Santo Amaro in: ASSOCIAÇÃO COMERCIAL DE SÃO PAULO, 2004, p.42). } \\
\text { "Anchieta e seus irmãos jesuítas catequizaram os índios da região e, como era de costume, decidiram construir ali } \\
\text { uma capela, que depois passou a abrigar a figura de Santo Amaro, doada por João Paes e sua mulher em 1560. Nesse } \\
\text { mesmo ano, Anchieta, o jesuíta que hoje está em processo de canonização no Vaticano, rezou a primeira missa na } \\
\text { região". "Antes de São Paulo já havia Santo Amaro in: ASSOCIAÇÃO COMERCIAL DE SÃO PAULO, 2004, } \\
\text { p.42). }\end{array}$ \\
\hline
\end{tabular}


Bens culturais com atribuição de valor em Santo Amaro

\begin{tabular}{|c|c|}
\hline $\begin{array}{c}\text { Bem Cultural (Material e/ou } \\
\text { Imaterial) }\end{array}$ & Observações \\
\hline $\begin{array}{c}\text { Zé da Farmácia/José de Oliveira } \\
\text { Almeida Diniz }\end{array}$ & $\begin{array}{l}\text { "Também é um depositário da memória dos melhores tempos de Santo Amaro [Aloyso Luz Cataldo], nos idos da década de 50. Filho de João Baptista } \\
\text { Cataldo e de Germana Luz Cataldo, o então menino vivia no Largo Treze de Maio - que, por incrível que hoje pareça era tranqüilo e pacato - e } \\
\text { costumava tocar o sino da Igreja da Matriz para chamar os fiéis à missa. Sua mãe, farmacêutica formada na Faculdade de Três Rios, ajudou durante } 14 \\
\text { anos os irmãos Almeida Diniz no estabelecimento do 'Zé da Farmácia”. O homem que deu o apelido à drogaria chamava-se José de Oliveira Almeida } \\
\text { Diniz e, com os seus irmãos, administrava a botica da região e ministrava medicamentos manipulados. Homem generoso com os pobres e benfeitor do } \\
\text { bairro, foi eleito vereador duas vezes. Hoje seu nome é o da Avenida José Diniz". ASSOCIAÇÃO COMERCIAL DE SÃO PAULO, 2004, p.26). }\end{array}$ \\
\hline Cultura Nordestina & $\begin{array}{l}\text { "Outra presença forte em Santo Amaro, em especial no entorno do pequeno bairro do Largo } 13 \text { de Maio, é a cultura nordestina. Os nordestinos que } \\
\text { moram em bairros afastados do distrito de Santo Amaro fizeram do largo o grande referencial: um ícone do Norte em São Paulo." (ASSOCIAÇÃO } \\
\text { COMERCIAL DE SÃO PAULO, 2004, p.26). }\end{array}$ \\
\hline Famílias imigrantes estrangeiras & $\begin{array}{l}\text { "Além dos alemães e italianos já citados, Santo Amaro congrega uma população heterogênea (russos, húngaros, ingleses, americanos e outros), } \\
\text { distribuída em diversas categorias: operários, comerciários, bancários, ao lado de outros estrangeiros de nível mais alto, que trabalham em empresas } \\
\text { particulares ou exercem cargos de chefia nas indústrias locais (os americanos e alemães). } \\
\text { Os portugueses aqui formaram granjas: entre eles merece destaque José Abrantes, que chegou a receber medalha do Governo da Holanda por haver-se } \\
\text { dedicado à criação de gado holandês. } \\
\text { Os de origem síria, turca ou judia, dedicaram-se ao comércio de tecidos e armarinhos, ou móveis, como Salomão Karlik. Salomão aqui chegou em } 1919 . \\
\text { Iniciou com uma lojinha de móveis, roupas feitas e calçados. Foi o primeiro a usar o sistema de vendas a crédito em Santo Amaro: vendia colchão de } \\
\text { capim a } 28 \text { mil réis a prazo. Para o crédito, apenas uma informação colhida ali mesmo, no Largo } 13 \text { de Maio. Foi um pioneiro. } \\
\text { Os espanhóis, vindos principalmente da região da Catalunha, dedicaram-se especialmente ao comércio, com lojas femininas (Rose Mary e Montiserrat, } \\
\text { por exemplo, ambas na Rua Anchieta). } \\
\text { Os japoneses, em sua maioria, vieram depois de 1945. Os que já estavam em Santo Amaro, foram gradualmente deixando a fase eminentemente agrícola, } \\
\text { para iniciarem outras atividades, às vezes derivadas da primeira ocupação. Assim, de agricultores passaram a atacadistas e feirantes. Os filhos de } \\
\text { tintureiros e peixeiros vieram a tornar-se farmacêuticos, dentistas, médicos, atingindo todas as profissões liberais." BERARDI, } 1981 \text {, pp.110 e } 111 . \\
\text { "Eram tempos difíceis: de guerra. Lembro-me, que o navio foi abordado em alto mar e que aguardamos, por vinte e quatro horas, para que os alemães } \\
\text { nos autorizassem finalmente, a continuar a viagem. Horas em que a tripulação acalmava pacientemente os viajantes assustados que gritavam e choravam } \\
\text { de medo." } \\
\text { "Lembro-me dos passeios aos domingos na chácara do Almeida, hoje Granja Julieta, onde eu e o meu pai pegávamos cobras para levar ao Instituto }\end{array}$ \\
\hline
\end{tabular}


Bens culturais com atribuição de valor em Santo Amaro

\begin{tabular}{|c|c|}
\hline $\begin{array}{c}\text { Bem Cultural (Material e/ou } \\
\text { Imaterial) }\end{array}$ & Observações \\
\hline & $\begin{array}{l}\text { Butantã. Tenho saudades dos tempos em que se andava sem medo, a qualquer hora pelo bairro, pois todos se conheciam, o que nos dava segurança e } \\
\text { tranquilidade. Tomávamos banho na praia do rio Pinheiros, com roupas comuns, mesmo tendo por perto o clube alemão de nudismo.” } \\
\text { Sra. Maria Gomes Leite Pereira, natural de Freguesia do Líria, em Portugal ( } 26 \text { de janeiro de 1931), chegou ao Brasil, com } 8 \text { anos, em 1940, a bordo do } \\
\text { navio Angola. (Disponível em: http://www.encontrasantoamaro.com.br/historias-de-moradores-de-santo-amaro/> Acesso em 02 mar } 2016 \text {.). } \\
\text { "Com a vinda de número crescente de famílias européias, que acorrem à nação pujante de vida, na sua incipiente autonomia, estabeleceram-se 'as } \\
\text { colônias'. Santo Amaro recebe colonos alemães, que se fixam como raízes no solo protetor e farão brotar como raízes e desenvolver-se gerações que } \\
\text { alcaçaram vasto futuro. Guilger, Forster, Helfstein, Teisen, Klein, são dos primeiros a chegar, permanecer na terra e seguir-lhe o ritmo do progresso." } \\
\text { (São Paulo em Revista, 1961, p.2) } \\
\text { Maria Montanaro Roschel e Oswaldo Hertel Roschel. } \\
\text { "[...] casal descendente de alemães responsável pelo primeiro movimento migratório da então freguesia." (ASSOCIAÇÃO COMERCIAL DE SÃO } \\
\text { PAULO, 2004, p.104). } \\
\text { "O bisavô de Oswaldo, Johann Roschel, chegou na região em 1857, dando início a esta linhagem”. "Oswaldo e Maria se conheceram quando ela ia } \\
\text { comprar leite na casa da atua sogra, sua vizinha que possuía vacas leiteiras e vendia o produto. Em 1950, os dois se casaram na Igreja da Matriz." } \\
\text { (ASSOCIAÇÃO COMERCIAL DE SÃO PAULO, 2004, p.108). }\end{array}$ \\
\hline Personagens de Santo Amaro & $\begin{array}{l}\text { Nhô Tito-arroz de festa } \\
\text { "Aparecia em qualquer festinha familiar, mesmo sem ser convidado. E bebia muito. Mas todos lhe queriam bem.” (BERARDI, 1981, p.91). } \\
\text { João Peru } \\
\text { "[...] andava curvadinho, com uma bengala debaixo do braço, e a molecada gritava: Peru, João Peru” (BERARDI, 1981, p.91). } \\
\text { Padre Belchior e João de Pontes (seu irmão) } \\
\text { "Nasceram às margens do Rio Pirajussara, em Santo Amaro, a duas léguas de São Paulo. Foram ambos alunos dos jesuítas. Belchior tornou-se padre aos } \\
\text { vinte e três anos e dedicou-se ao gentio. Percorria as aldeias montado em cavalo sem cela nem arreios, na cabeça um barrete de algodão, tão surrado que } \\
\text { perdera a cor. Sob o braço levava um bordão, que lhe dava aspecto de um cavaleiro medieval, de lança em riste." (BERARDI,1981, p.38). } \\
\text { "Aos setenta e cinco anos padre Belchior ainda estava lépido, e viajava constantemente. Foi a Paranaguá, Iguape e Curitiba. Faleceu em 22 de setembro } \\
\text { de 1719. É considerado outro dos motivos de orgulho para o santamarense. É-lhe devida a fundação do mosteiro de M'Boi, de arquitetura tipicamente } \\
\text { jesuítica, considerado hoje monumento nacional”. (BERARDI, 1981, p.39). }\end{array}$ \\
\hline
\end{tabular}


Bens culturais com atribuição de valor em Santo Amaro

\begin{tabular}{|c|c|}
\hline $\begin{array}{c}\text { Bem Cultural (Material e/ou } \\
\text { Imaterial) }\end{array}$ & Observações \\
\hline & 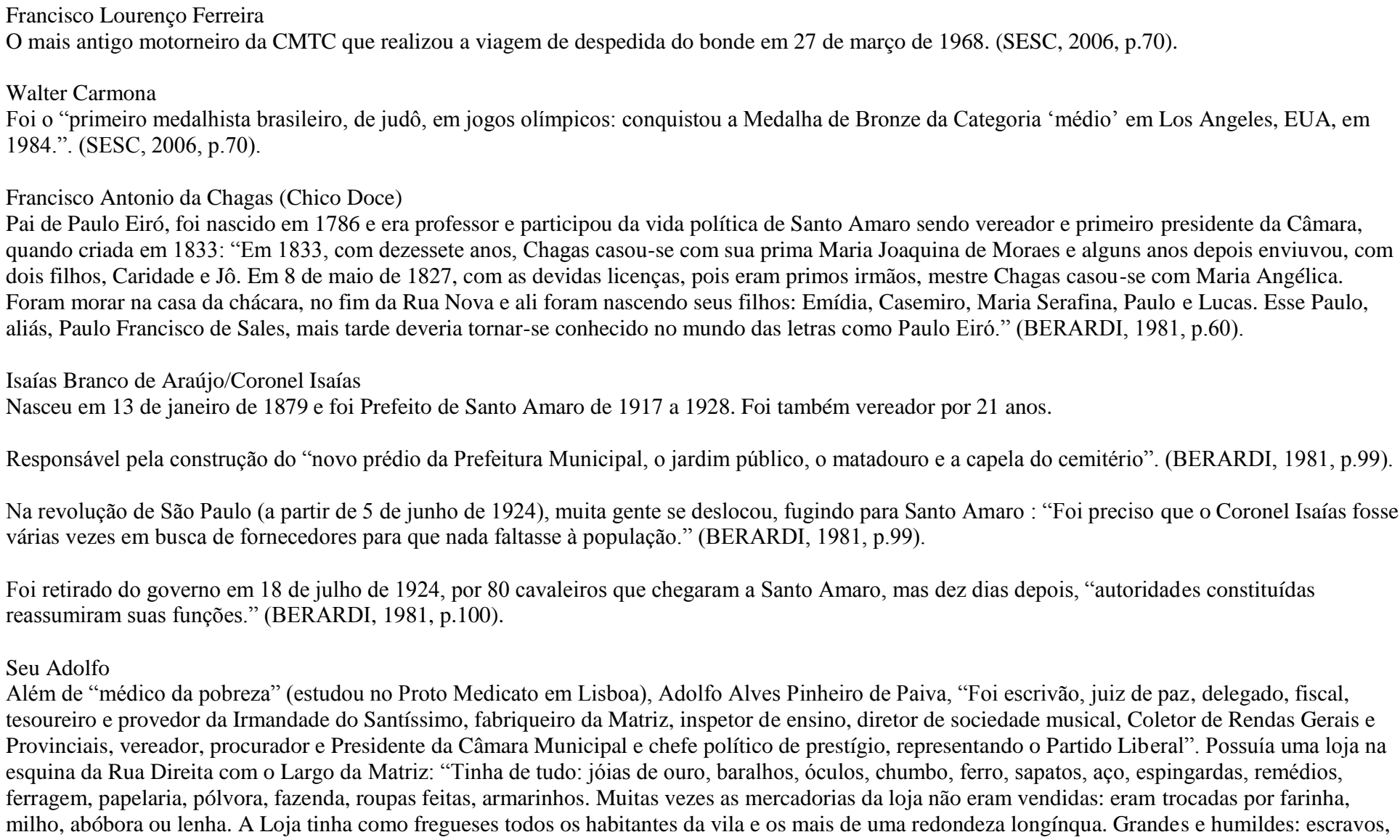 \\
\hline
\end{tabular}


Bens culturais com atribuição de valor em Santo Amaro

\begin{tabular}{|c|c|}
\hline $\begin{array}{c}\text { Bem Cultural (Material e/ou } \\
\text { Imaterial) }\end{array}$ & Observações \\
\hline & 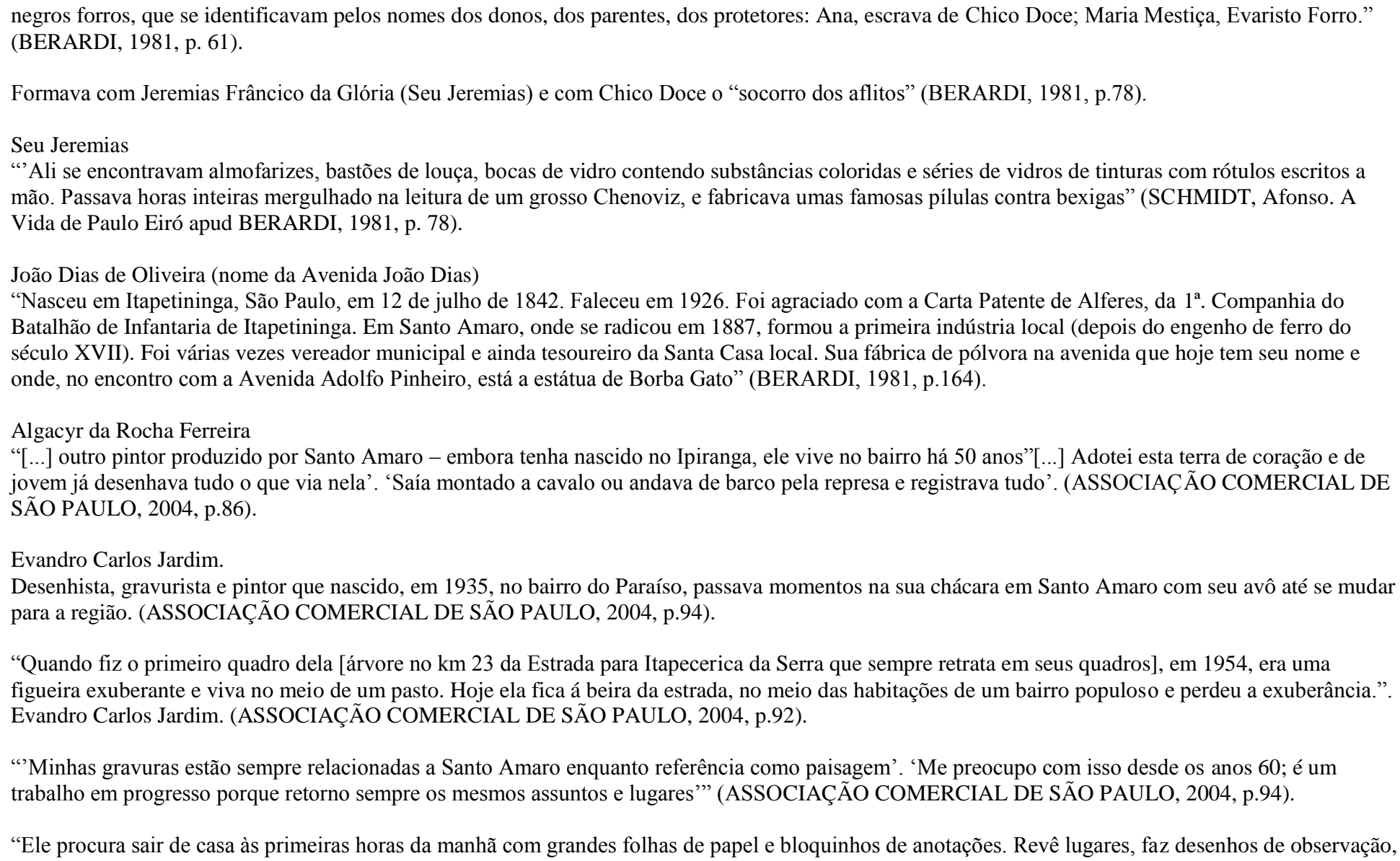 \\
\hline
\end{tabular}


Bens culturais com atribuição de valor em Santo Amaro

\begin{tabular}{|c|c|}
\hline $\begin{array}{c}\text { Bem Cultural (Material e/ou } \\
\text { Imaterial) }\end{array}$ & Observações \\
\hline & 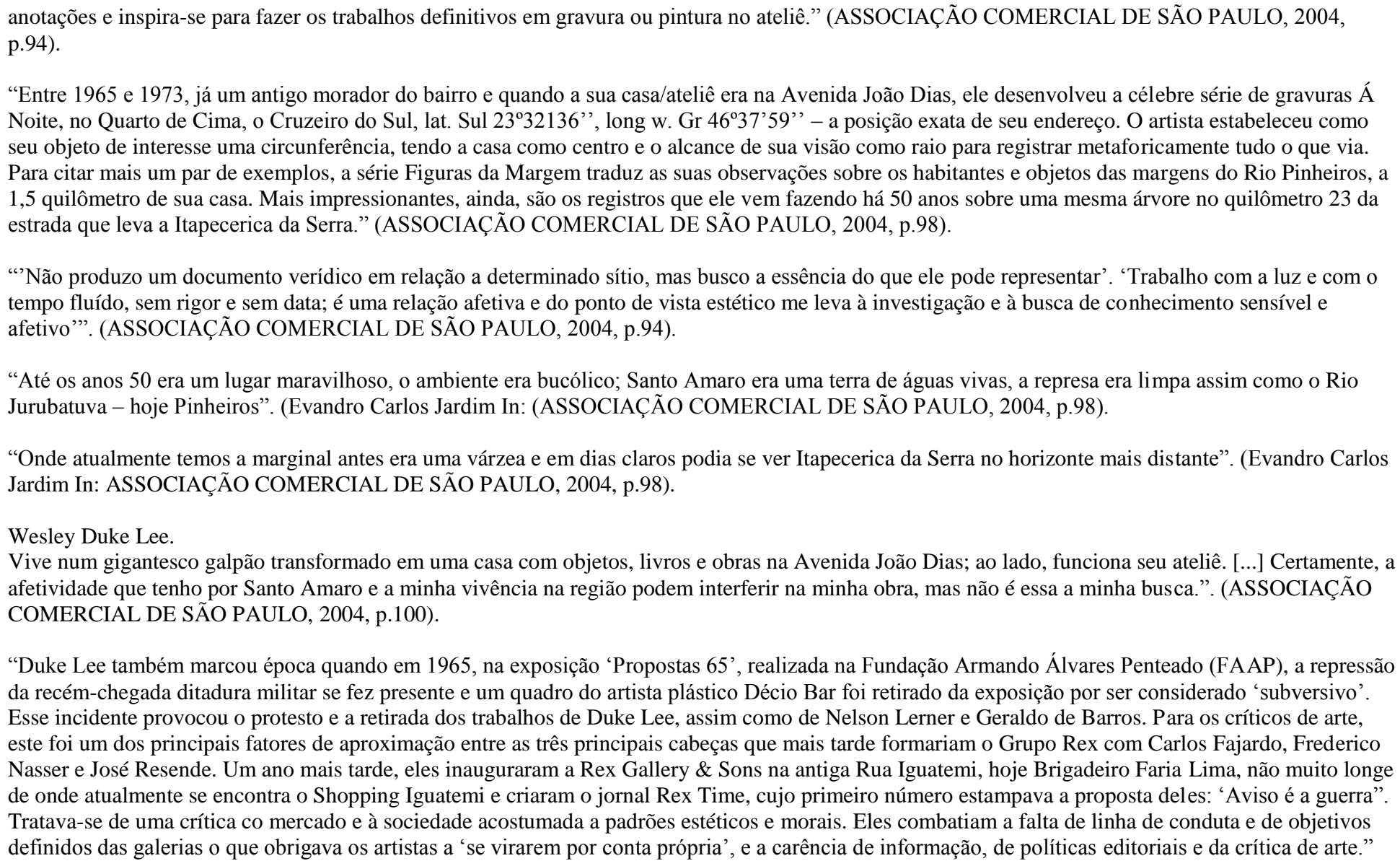 \\
\hline
\end{tabular}


Bens culturais com atribuição de valor em Santo Amaro

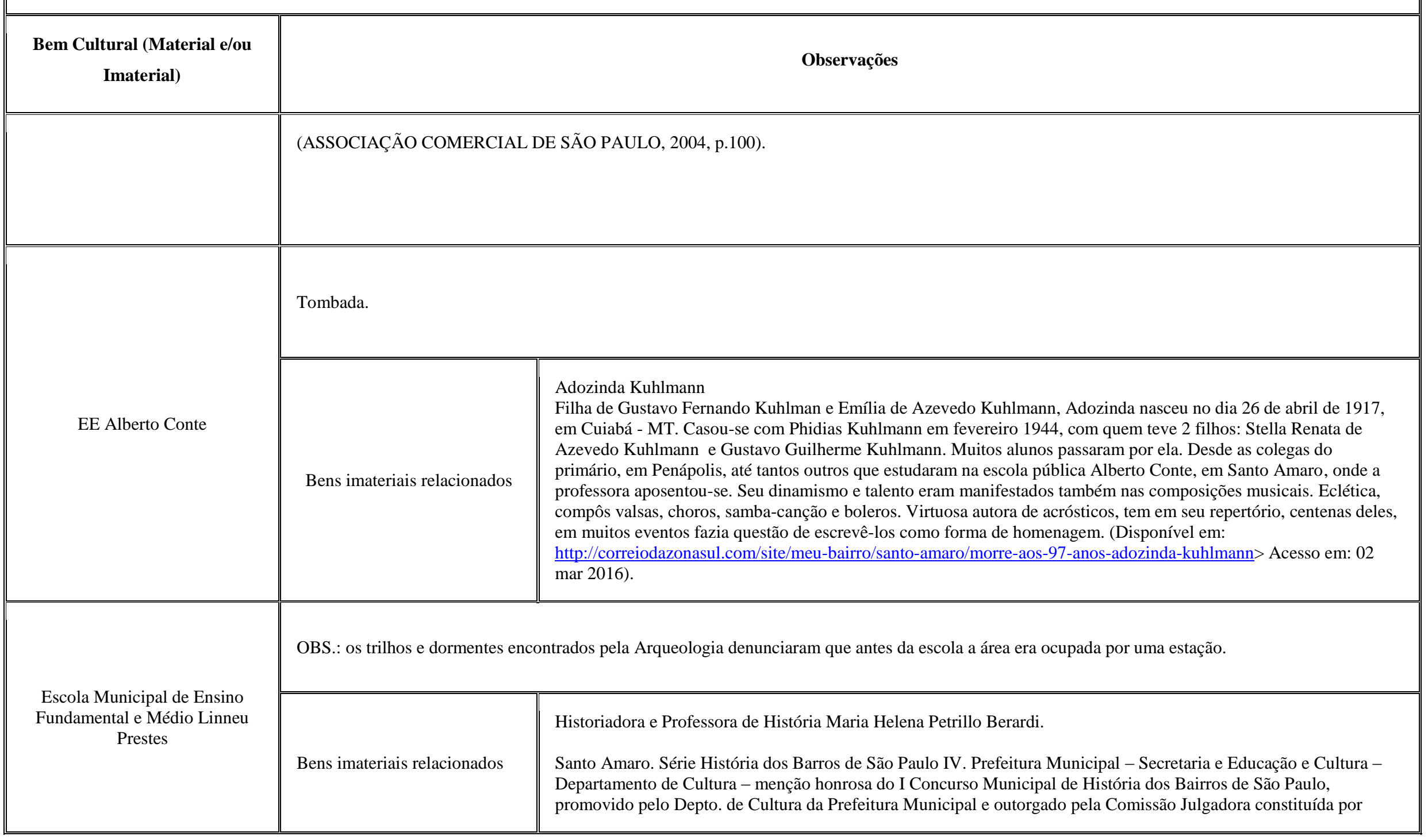


Bens culturais com atribuição de valor em Santo Amaro

\begin{tabular}{|c|c|}
\hline $\begin{array}{c}\text { Bem Cultural (Material e/ou } \\
\text { Imaterial) }\end{array}$ & Observações \\
\hline & $\begin{array}{l}\text { Myriam Ellis, Ernani Silva Bruno e Pedro Brasil Bandecchi. } \\
\text { (Apresenta as indústrias existentes na década de 1980). } 4^{\circ} \text { volume - } 19812^{\mathrm{a}} \text {. edição } \\
\text { Seu primeiro trabalho publicado chamou-se história de Santo Amaro e fazia parte de uma coleção: História dos } \\
\text { Bairros de são Paulo, premiada pela secretaria de cultura do município. } \\
\text { Publicou: Santo Amaro: memória e história: da botina amarela ao chapéu de couro. São Paulo: Scortecci, } 2003 .\end{array}$ \\
\hline Botina Amarela & $\begin{array}{l}\text { Os caipiras mais caipiras do Estado: “como o trovador Cornélio Pires (1884-1958), nascido em Tietê, no interior de } \\
\text { São Paulo, classificava os nascidos em Santo Amaro no início do século XX.” (ASSOCIAÇÃO COMERCIAL DE } \\
\text { SÃO PAULO, 2004, p.72). } \\
\text { “'No século XIX, os santamarenses tinham por hábito agradecer os benesses depois da colheita nestes atos de fé', } \\
\text { explica Moreira Neto sobre as romarias. Por isso, de acordo com ele, até hoje eles se vestem com bombachas e } \\
\text { botinas, que são os trajes típicos levados a Santo Amaro pelos mercenários do Pará na Guerra do Paraguai. O calçado } \\
\text { destes romeiros tipifica os santamarenses que são chamados de 'Botina Amarela”. (ASSOCIAÇÃO COMERCIAL } \\
\text { DE SÃO PAULO, 2004, p.74). } \\
\text { "Época em que nossa gente passou a ser conhecida como ‘Os Botinas Amarelas'. Sitiantes pobres, mas orgulhosos } \\
\text { das suas tradições. Oh Santo Amaro" Porque tanto te quero? Por que foi nesse berço de felicidades que fui colhido } \\
\text { pelos braços de minha mãe, ajudado por uma senhora negra que se tornou famosa, por tantas pessoas segurar de } \\
\text { vindas de vindas ao mundo de tantos outros ventres, para também viver no seio desta cidade.” (Roberto Pavanelli. In: } \\
\text { ASSOCIAÇÃO COMERCIAL DE SÃO PAULO, 2004, p. 116). }\end{array}$ \\
\hline
\end{tabular}


291

a parrela de Barras

- ferra de de pasar

o camla de vidro

escali a panela de Bano page limblui da tastóra de mutía māe

a garrala pangue lumbri de nen indáa es lakrida a 2 anes e Tentia mitas saudado clile

eo ferro de pasá luntoro de men tinedo mario

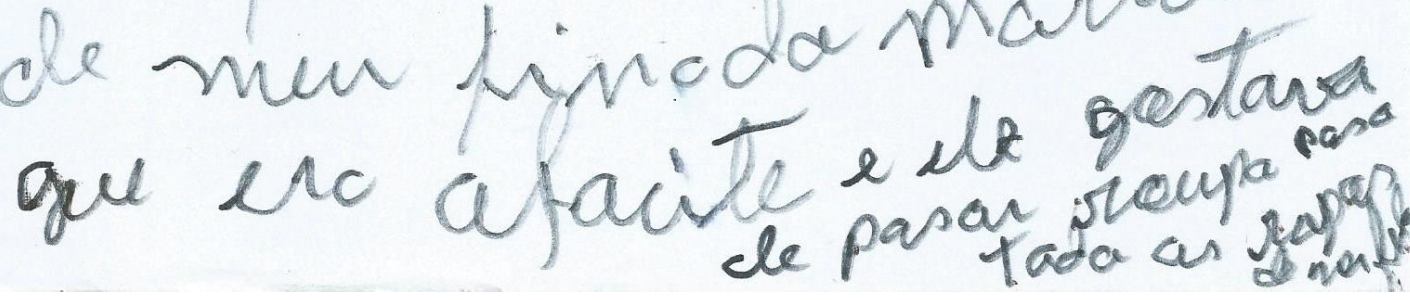
Texto produzido por participantes na atividade Exercício do Objeto: Objeto Significativo dos Encontros.

291 


\section{Ferro de Fassar}

2- Pí̃o de MAdelra

3- Foto dócolegio Paulo eití

1 - Sou de Tempo desse Ferrode PASSAR. como era haviviel, cheio de carvōo tinha que assoprar e muitafumaca $20 m_{e}$ laz himbrar os moleques brineanda de peõo era mevito engragado. ove 0 piaĩi rodar.

3. Eolegio Paulo Ei i ó conhecimuita gente pre estudou la inglusire o men marido. que dizio cer studo no celegio Paulo EIRO ENTRA burroe saia coió. e hincadeira

Texto produzido por participantes na atividade: Exercício do Objeto: Objeto Significativo. 
- Ferro passar

- Panela barro

- Pedea pontuda

1: Porqu o mau pai rea affaiate e tinha um ferro de carvöo qu hoge ele é um enfeite uma Lembranca do meu pai e da historia dele.

2: A ponela de barro porque acho bonita e dizem qe a comida fica mais soborosa, conb a isso näro posso afirmar, pois vivo ha erra das caisa descartaceis. até panelas.

3: es colhi porque Gosto de pedras, e conchas sempre que vaw a um Lu gar e vejo uma diferente petao de Lembrompa. a Gostei do formato da pedra que escolhi. 
Hent pies Jantes

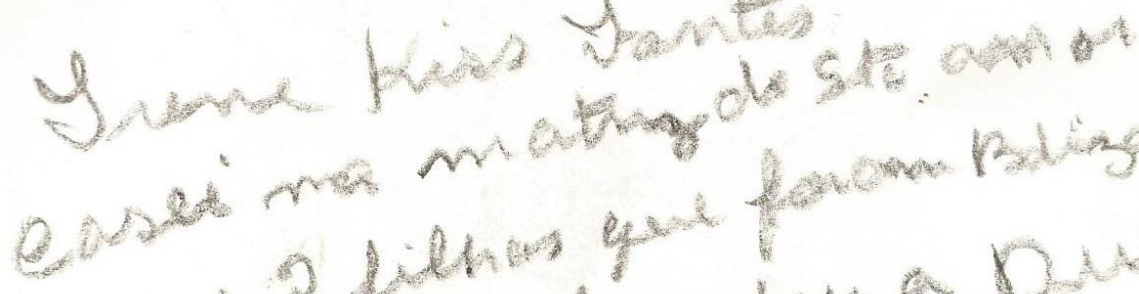

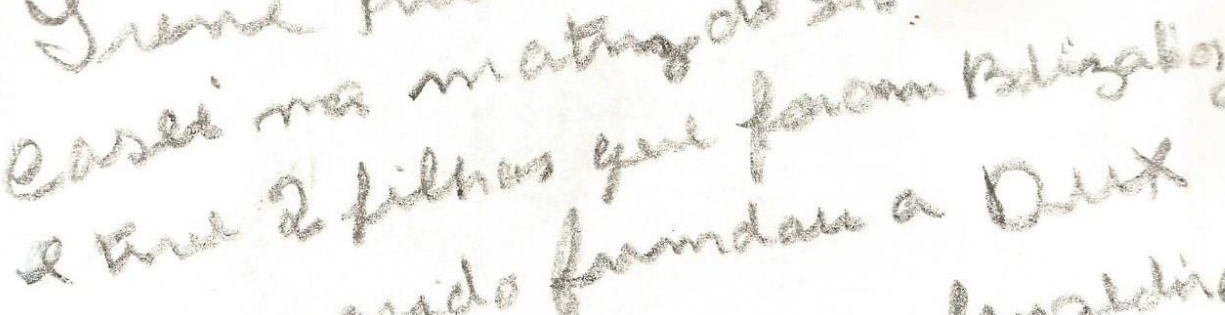

ayon monto mande fondaw a Dot

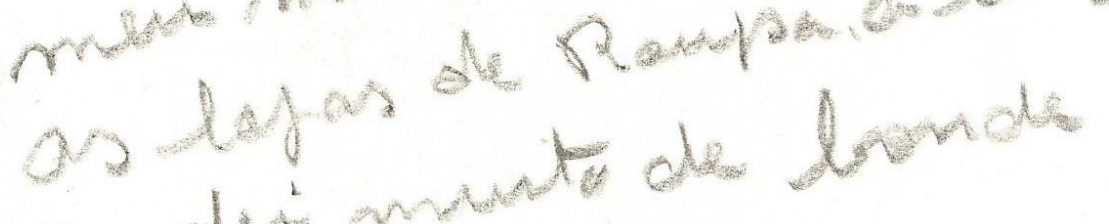

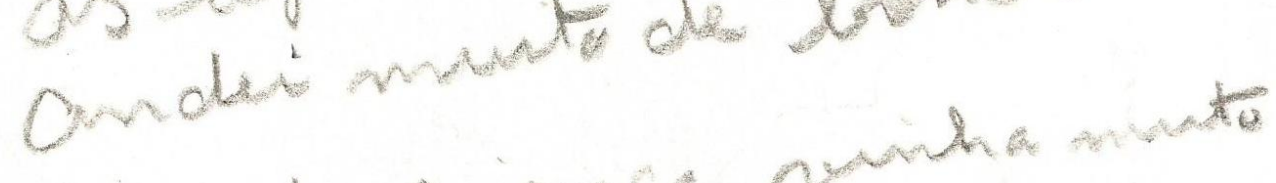

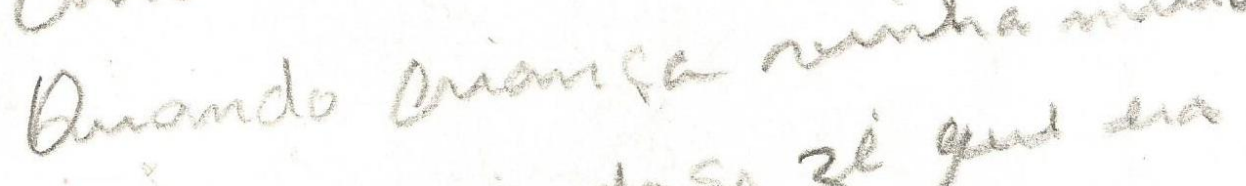

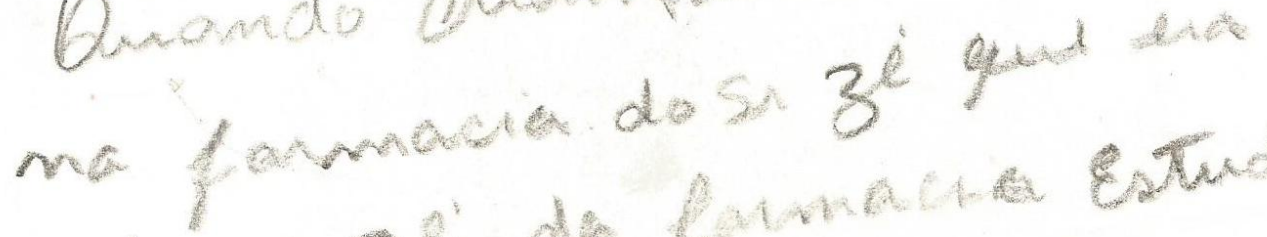
Chama $3^{2}$ da famalta Esude anmamica cam ofuftason mario gunas f the aqua ma para dinet camapemas mut cangos ma lafa do Sar Salv tomban ma para divetion to. 4 magaina di costuraté hay Trate as dentar com do. Jomain momali muit mo pare do Coulo juso en 1949

Texto produzido por participantes na atividade Mapa Patrimonial dos Encontros.

294 


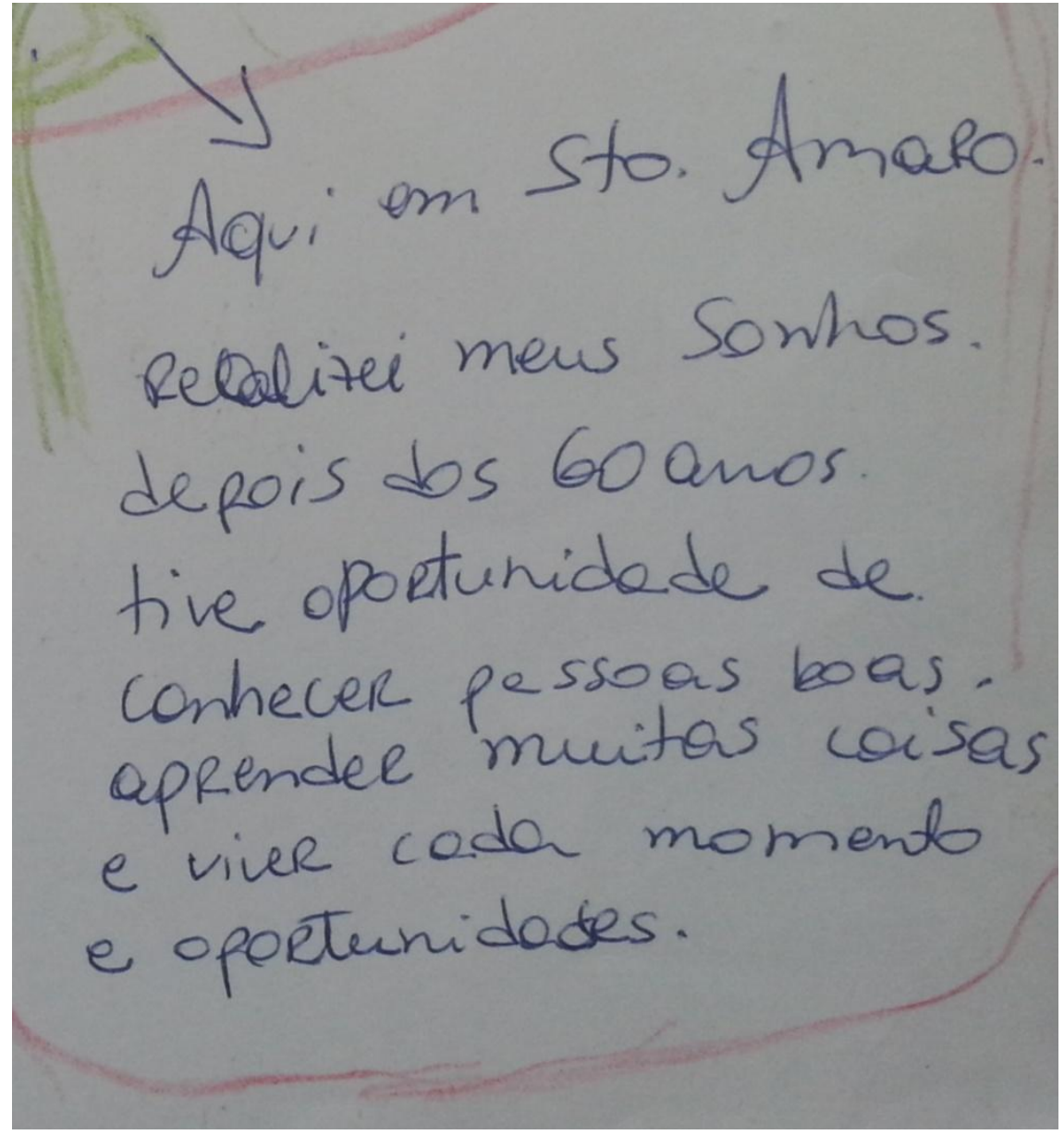

Texto produzido por participantes na atividade Mapa Patrimonial dos Encontros. 


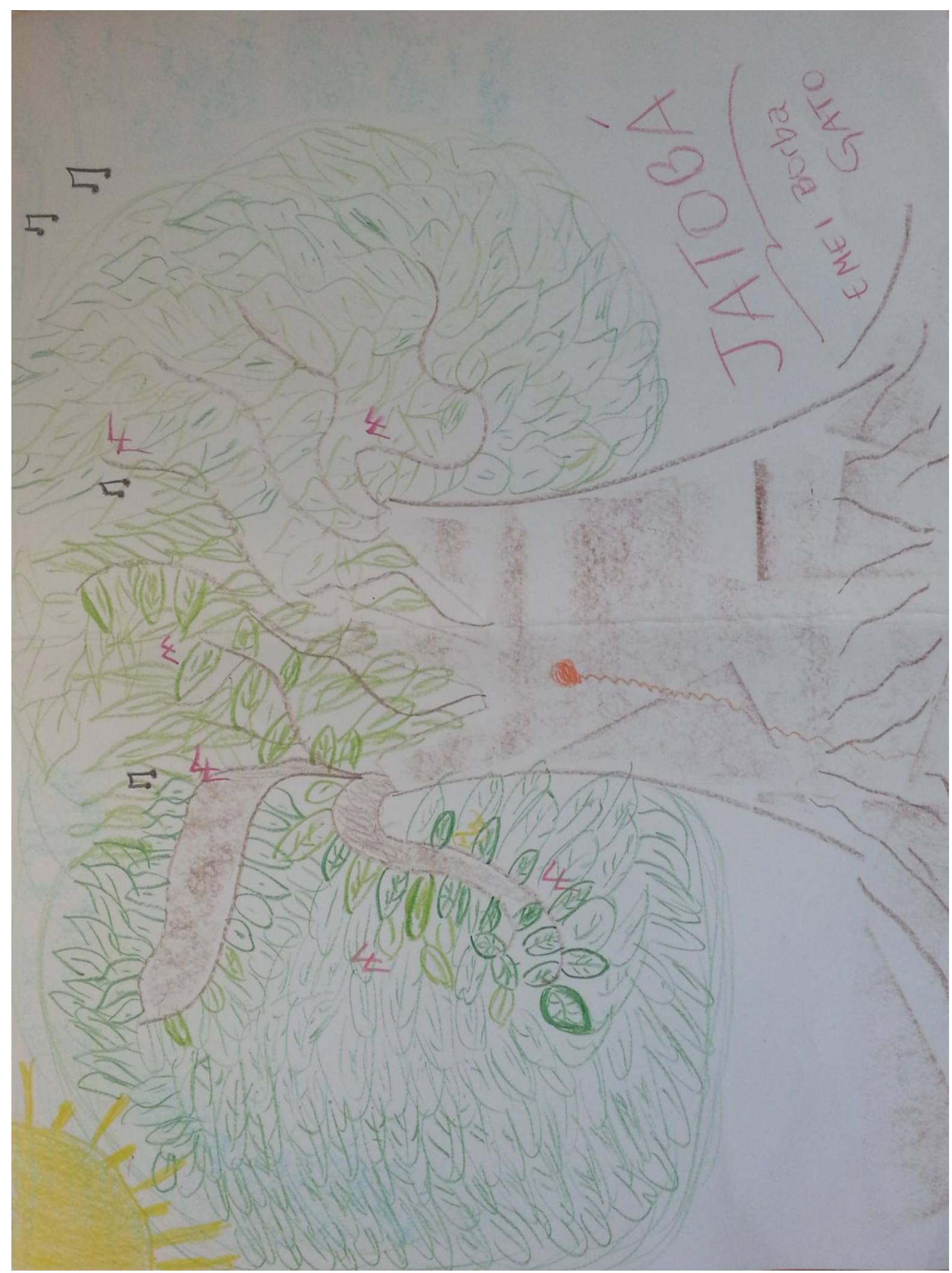

Bem patrimonial representado na atividade Mapa Patrimonial na EMEI Borba Gato. 


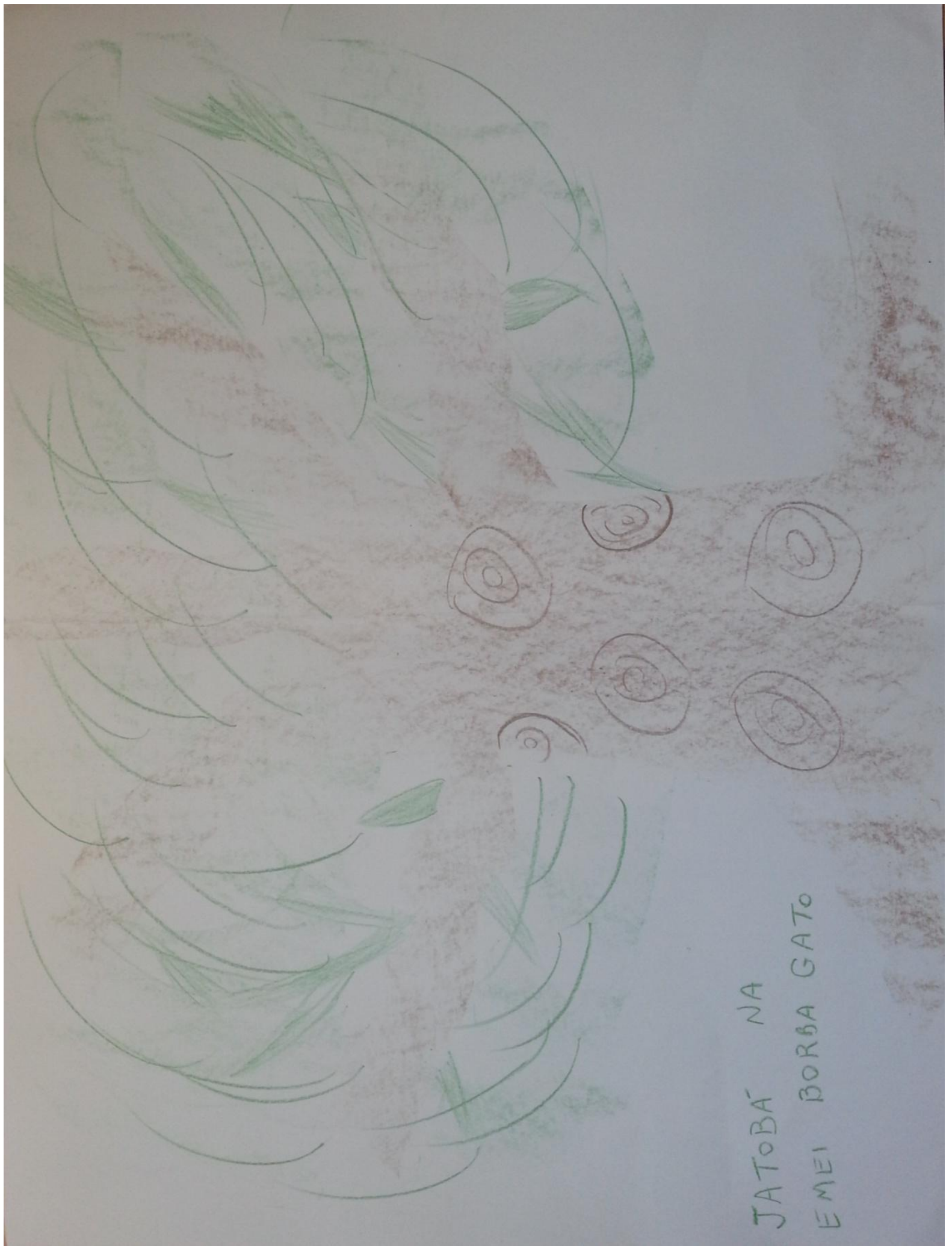

Bem patrimonial representado na atividade Mapa Patrimonial na EMEI Borba Gato. 


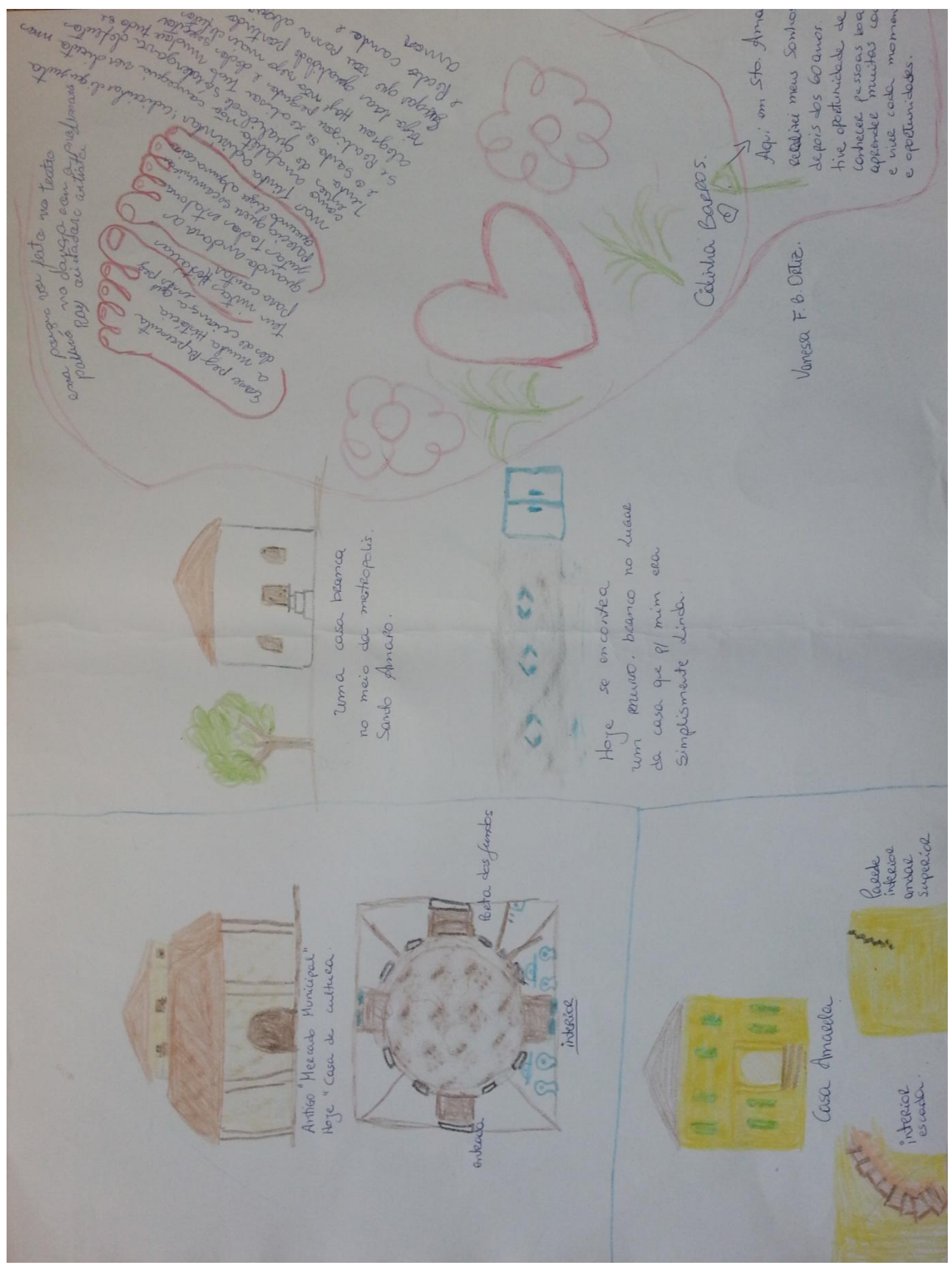

Bens patrimoniais representados nos Encontros na atividade Mapa Patrimonial. 


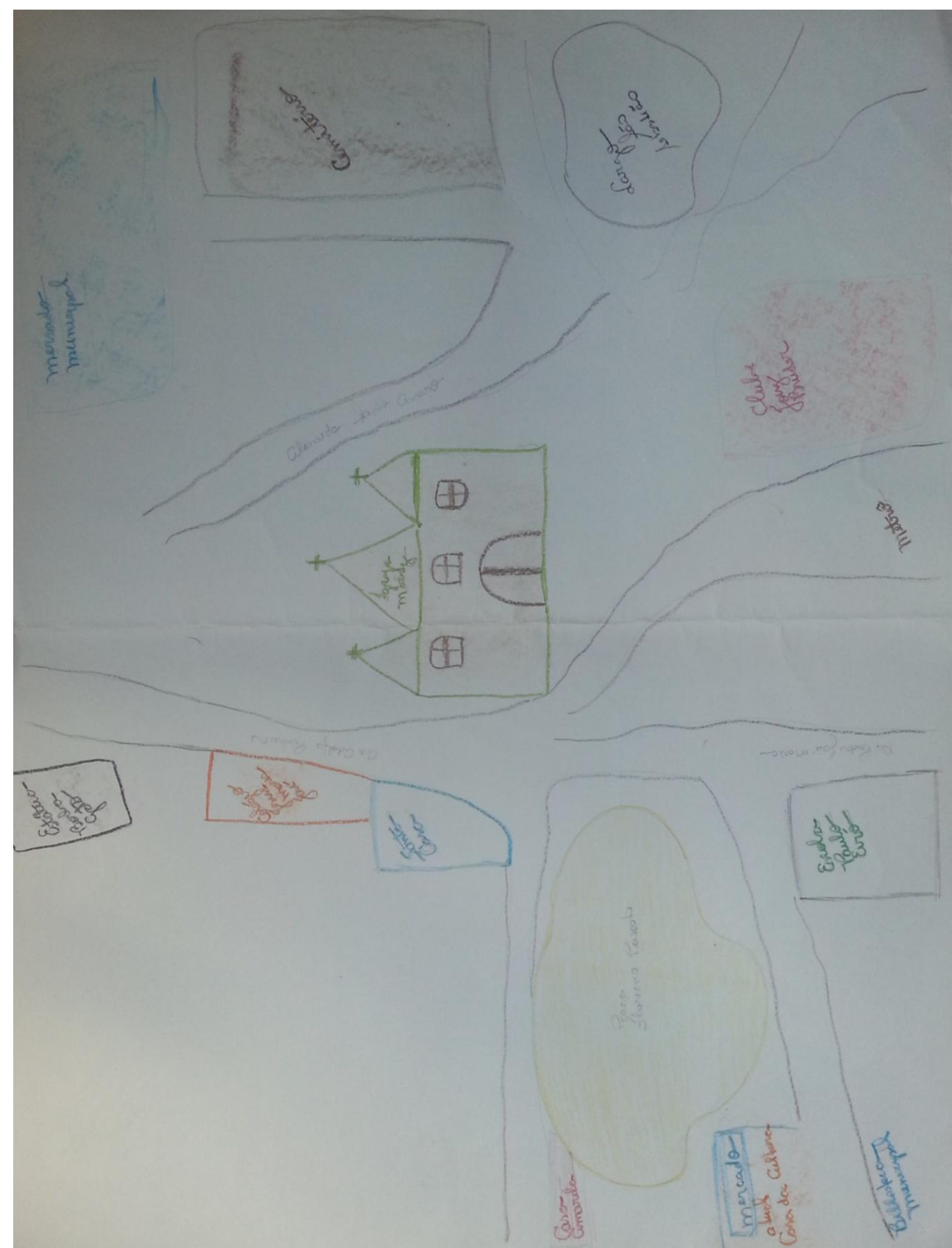

Mapa patrimonial produzido pelos professores participantes das atividades na EE Paulo Eiró. 


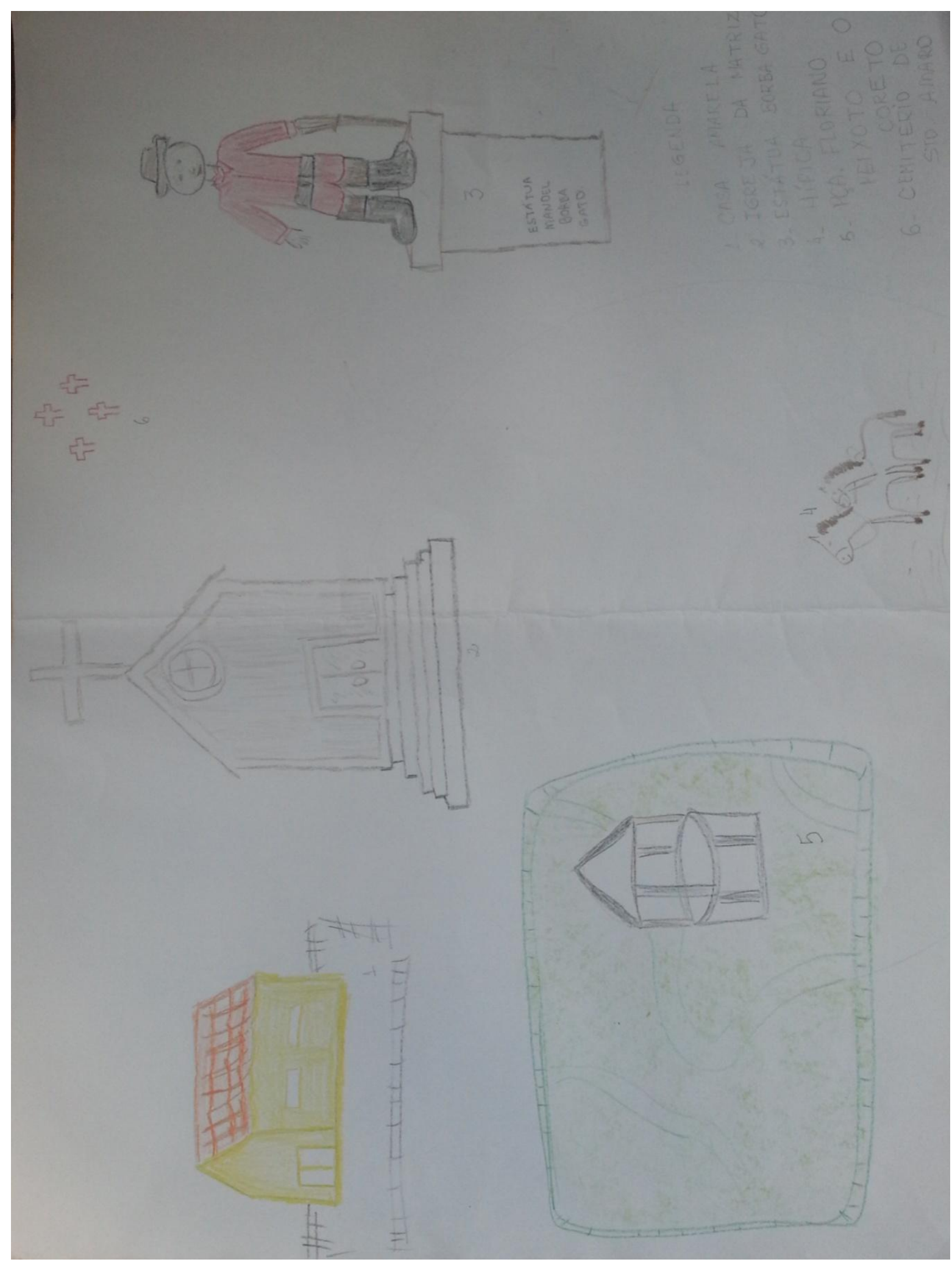

Figura. Mapa patrimonial produzido pelos professores participantes das atividades na EE Paulo Eiró. 


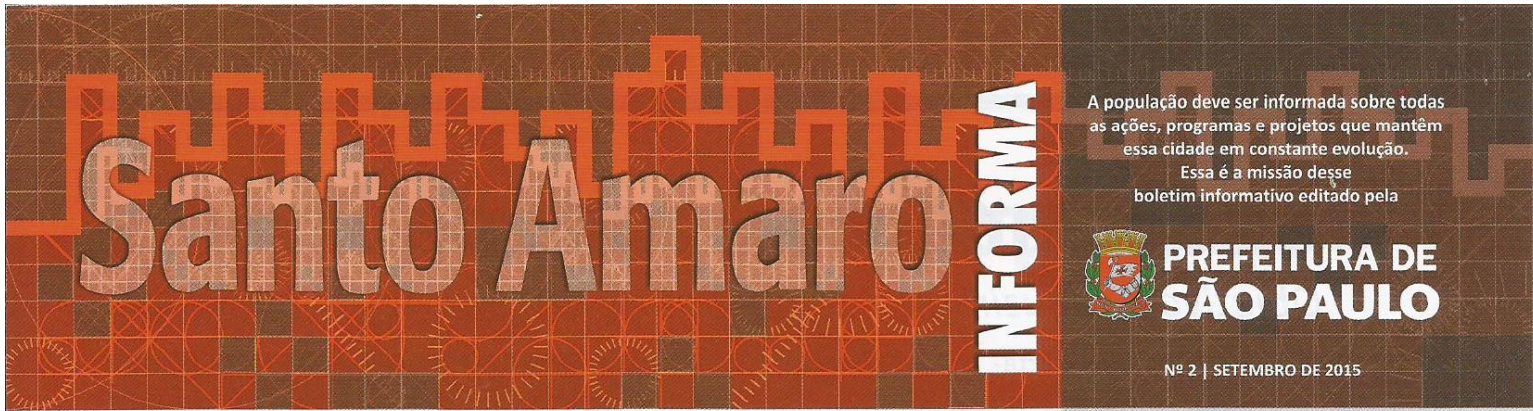

Eixo Histórico revitalizado Obras valorizaram o roteiro cultural no centro
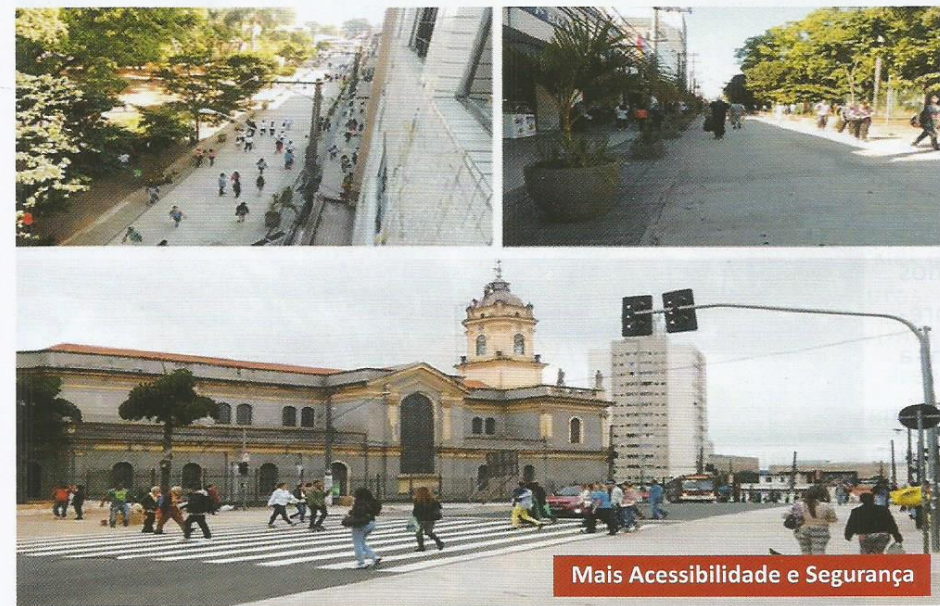

Único bairro da cidade que já foi município, São Amaro oferece à sua população e de outros pontos da capital um roteiro de atrações que fazem parte do seu Centro Histórico. A subprefeitura valorizou ainda mais a área do centro com a execução de obras de revitalização, algumas delas reivindicadas há mais de 20 anos pela comunidade.

$\mathrm{Na}$ execução do projeto de melhorias, houve a preocupação de se respeitar os aspectos ambientais, sociais e culturais e, ao mesmo tempo, contribuir com o desenvolvimento sustentável e oferecer mais acessibilidade à população de cerca de 1 milhão de pessoas que hoje circula pela região.

0 roteiro de espaços e logradouros que formam o chamado Eixo Histórico começa na Praça Marcos Manzini em frente à Biblioteca Prestes Maia, segue pela rua Ten.Cel. Carlos da Silva Araújo, avança pela Praça Salim Farah Maluf, chega à Praça Floriano Peixoto, continua no calçadão Cap. Tiago Luz e termina no Largo Treze-Igreja Matriz. Os moradores mais antigos se recordam que este Eixo foi solo, testemunho e cenário dos acontecimentos das terras dos Botinas Amarelas; caminho de fé para os romeiros que iam a Bom Jesus de Pirapora; vereda de sucesso de Inezita Barroso. Tonico e Tinoco que, em carros de bois, seguiam até a Praça da Viola, e vereda romântica que os jovens percorriam até os jardins, hoje Praça Floriano Peixoto, para praticarem o footing ao redor do Coreto, e para o público que frequentava o Cine São Francisco.

\section{Reformas de}

\section{Guias}

As revitalizações servem para que as águas pluviais tenham uma destinação correta até a boca de lobo evitando pontos de alagamentos. Este tipo de serviço ajuda o sistema de drenagem da cidade.

\section{Limpeza de Córregos}

Essa operação é realizada com o objetivo de remover o acúmulo de lixo e entulho que é despejado nas margens dos córregos e evita a proliferação de insetos e roedores.

\section{Limpeza de galerias}

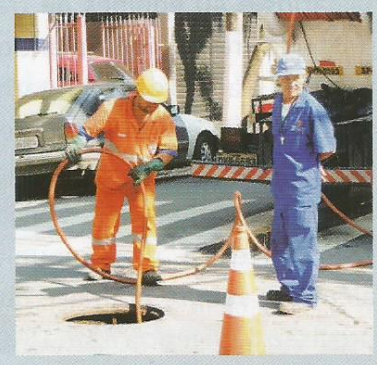

O serviço de conservação das bocas de lobo pode ser feito manual ou mecanicamente, o objetivo é garantir o escoamento da água e impedir que materiais sólidos, retidos durante as chuvas, obstruam a drenagem das águas.

Capa do boletim informativo editado pela Prefeitura de São Paulo, n. 2, setembro de 2015. 


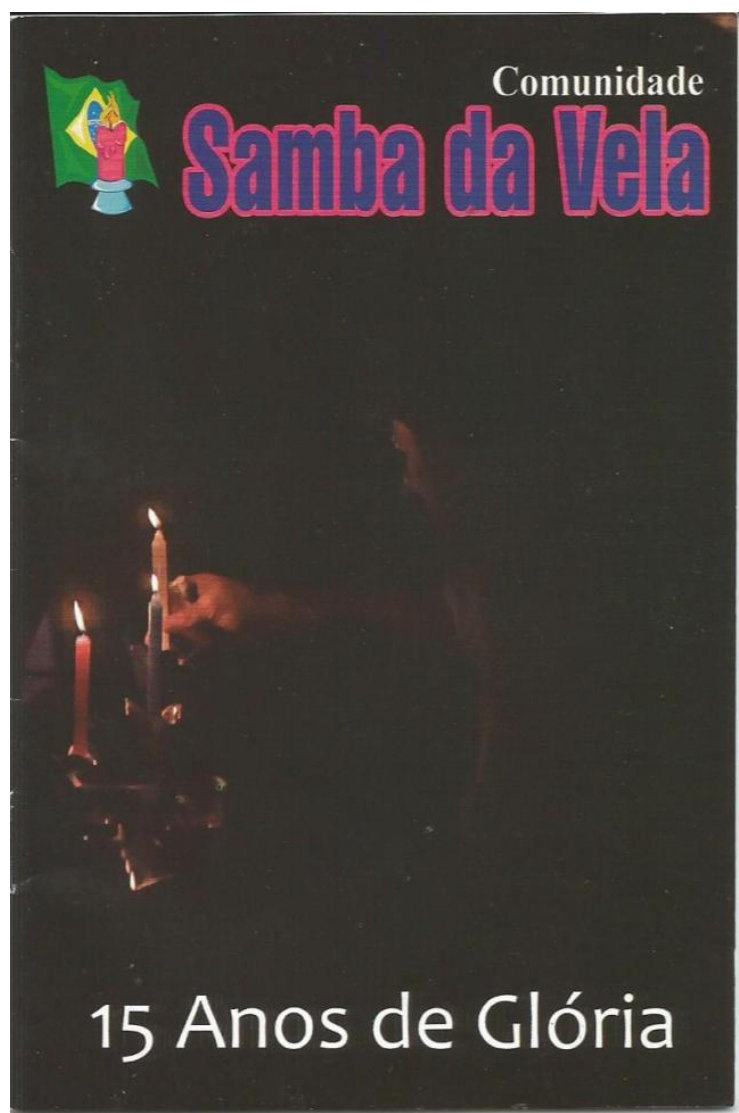

Capa da revista comemorativa de 15 Anos da Comunidade Samba da Vela. 
Prefeitura do Município de São Paulo

Secretaria Municipal de Cultura

Departamento do Patrimônio Histórico

Conselho Municipal de Preservação do Patrimônio Histórico, Cultural e Ambiental da Cidade de São Paulo

\section{Resolução Nº. 05/89}

Por decisāo unânime dos Conselheiros presentes à reuniāo realizada aos 29 de junho de 1989, o Conselho Municipal de Preservação do Patrimônio Histórico, Cultural e Ambiental da Cidade de Säo Paulo - CONPRESP, resolve, nos termos e para os fins da Lei $n^{\circ} 10.032 / 85$, com as alterações introduzidas pela Lei $n^{\circ} 10.236 / 86$, abrir processo de tombamento dos seguintes bens:

- TEATROS MUNICIPAIS: Paulo Eiró, João Caetano e Arthur Azevedo.

Resolução COMPRESP 05/89, de 29 de junho de 1989. Departamento do Patrimônio Histórico. Secretaria Municipal de Cultura. Prefeitura do Município de São Paulo. 
Prefeitura do Município de São Paulo

Secretaria Municipal de Cultura

Departamento do Patrimônio Histórico

Conselho Municipal de Preservação do Patrimônio Histórico, Cultural e Ambiental da Cidade de São Paulo

\section{Resolução n. 04/93}

O Conselho Municipal de Preservação do Patrimônio Histórico, Cultural e Ambiental da Cidade de São Paulo - CONPRESP, por decisāo unânime dos Conselheiros presentes na Reunião Ordinária realizada em 07 de outubro de 1993, no uso de suas atribuiçōes legais e nos termos da Lei $n^{\circ} 10.032 / 85$, com as alteraçōes introduzidas pela Lei $n^{\circ} 10.236 / 86$, resolve abrir processo de tombamento dos imóveis e logradouros que compõem o EIXO HISTÓRICO DE SANTO AMARO, localizados no Distrito de Santo Amaro e discriminados no Anexo I que integra esta Resolução.

SMC - CONPRESP

EIXO HISTÓRICO DE SANTO AMARO - RESOLUÇÃO Nº. 04/CONPRESP/93

ANEXO I - LISTA DE IMÓVEIS E LOGRADOUROS EM PROCESSO DE TOMBAMENTO

\begin{tabular}{|c|c|c|c|c|c|}
\hline REG & ENDEREÇO & SETOR & QUADRA & LOTE(s) & OBSERVAÇÁO \\
\hline & SETOR: $087^{\circ}$ & & & & \\
\hline & QUADRA & & & & \\
\hline 1 & CAPITÃO THIAGO LUZ, RUA & 087 & & & LOGRADOURO \\
\hline 2 & SALIM FARAH MALUF, PRAÇA & 087 & & & LOGRADOURO \\
\hline 3 & $\begin{array}{l}\text { TENENTE CORONEL CARLOS SILVA } \\
\text { ARAUJO, RUA }\end{array}$ & 087 & & & LOGRADOURO \\
\hline & QUADRA: 037 & & & & \\
\hline 4 & TREZE DE MAIO 242, LARGO & 087 & 037 & 01 e 02 & \\
\hline 5 & TREZE DE MAIO 246, LARGO & 087 & 037 & 03 & \\
\hline 6 & TREZE DE MAIO 250, LARGO & 087 & 037 & 04 & \\
\hline 7 & TREZE DE MAIO 262 E 266, LARGO & 087 & 037 & 05 & \\
\hline & QUADRA: 040 & & & & \\
\hline 8 & CAPITĀO THIAGO LUZ 109. RUA & 087 & 040 & 04 & \\
\hline 9 & CAPTTAO THAGO LUZ 113 E 117 , RUA & 087 & 040 & 03 & \\
\hline 10 & CAPITÃO THIAGO LUZ $121 \mathrm{E} 125$, RUA & 087 & 040 & 02 & \\
\hline 11 & $\begin{array}{l}\text { CAPITÃO THIAGO LUZ } 131,135,139 \text { E } 181 \text {, } \\
\text { RUA }\end{array}$ & 087 & 040 & 73 A 82 & \\
\hline 12 & CAPITÃO THIAGO LUZ 27, 29 E 33, RUA & 087 & 040 & 57 a 59 & \\
\hline 13 & CAPITÄO THIAGO LUZ 41 e 45, RUA & 087 & 040 & 64 & \\
\hline 14 & CAPITÄO THIAGO LUZ 49 , RUA & 087 & 040 & 13 & \\
\hline 15 & CAPITÃO THTAGO LUZ 3 E 30 , RUA & 087 & 040 & 72 & \\
\hline 16 & CAPITÄO THIAGO LUZ 57, RUA & 087 & 040 & 84 & \\
\hline 17 & CAPITĀO THIAGO LUZ 63 , RUA & 087 & 040 & 11 & \\
\hline 18 & CAPTTÄO THIAGO LUZ 67, RUA & 087 & 040 & 10 & \\
\hline 19 & CAPITÃO THIAGO LUZ 73, RUA & 087 & 040 & 09 & \\
\hline 20 & CAPITÄO THIAGO LUZ 77, RUA & 087 & 040 & 08 & \\
\hline 21 & CAPITÃO THIAGO LUZ 81 E 85 , RUA & 087 & 040 & 07 & \\
\hline 22 & CAPITÄO THIIAGO LUZ 89, 93 E 95, RUA & 087 & 040 & 06 & \\
\hline 23 & $\begin{array}{l}\text { CAPITĀO THTAGO LUZ } 9 \text { A 19, RUA ESQ. C/ } \\
\text { PAULO EIRÓ } 184 \text {, RUA }\end{array}$ & 087 & 040 & 71 & \\
\hline 24 & CAPITÃO THIAGO LUZ 99 E 101, RUA & 087 & 040 & 05 & \\
\hline 25 & FLORIANO PEIXOTO 386, PRACCA & 087 & 040 & 70 & \\
\hline 26 & FLORIANO PETXOTO 408 A 414, PRAÇA & 087 & 040 & 56 & \\
\hline 27 & FLORIANO PEIXOTO $422 \mathrm{E} 430$. PRACA & 087 & 040 & 55 & \\
\hline
\end{tabular}

Resolução COMPRESP 04/93, de 07 de abril de 1993. Departamento do Patrimônio Histórico. Secretaria Municipal de Cultura. Prefeitura do Município de São Paulo. 


\begin{tabular}{|c|c|c|c|c|c|c|c|}
\hline REG & \multicolumn{3}{|c|}{ ENDEREÇO } & SETOR & QUADRA & LOTE(s) & OBSERVAÇÁO \\
\hline 28 & \multicolumn{3}{|c|}{ TREZE DE MAIO 144, LARGO } & 087 & 040 & 69 & \\
\hline 29 & \multicolumn{3}{|c|}{ TREZE DE MAIO 162 , LARGO } & 087 & 040 & 19 & \\
\hline 30 & \multicolumn{3}{|c|}{ TREZE DE MAIO 170, LARGO } & 087 & 040 & 20 & \\
\hline 31 & \multirow{2}{*}{\multicolumn{3}{|c|}{ TREZE DE MAIO 174 E 178 , LARGO }} & 087 & 1440 & 21 & \\
\hline 32 & & \multicolumn{2}{|c|}{ TREZE DE MAIO 182 E 186, LARGO } & 087 & 040 & 22 & \\
\hline 33 & \multirow{2}{*}{\multicolumn{3}{|c|}{ TREZE DE MAIO 204, LARGO }} & 087 & 040 & 68 & \\
\hline 34 & & & & 087 & (1)40) & 67 & $\therefore$ \\
\hline \multirow[t]{2}{*}{35} & \multicolumn{3}{|c|}{$\begin{array}{l}\text { TREZE DE MAIO 220, LARGO } \\
\text { TREZE DE MAIO 228, LARGO }\end{array}$} & 087 & 040 & 83 & \\
\hline & \multicolumn{7}{|l|}{ QUADRA 041} \\
\hline 36 & \multicolumn{3}{|c|}{ САPITĀO THIAGO LUZ 102, 108 E 110 , RUA } & 087 & 041 & 14 & \\
\hline 37 & \multirow{2}{*}{\multicolumn{3}{|c|}{$\begin{array}{l}\text { CAPTTÃO THIAGO LUZ } 114, \text { RUA } \\
\text { CAPTTÃO THIAGO LUZ } 118 \text {, RUA }\end{array}$}} & 087 & 041 & 28 & \\
\hline 38 & & & & 087 & 041 & 16 & \\
\hline 39 & \multicolumn{3}{|c|}{ CAPITAिO THIAGO LUZ 20 E 24 RUA } & 087 & 041 & 02 & \\
\hline 40 & CAPITÃO THIAGO LUZ 3 & 2 E 28, RUA & & 087 & 041 & 03 & \\
\hline 41 & CAPITĀO THIAGO LUZ 3 & E 36, RUA & & 087 & 041 & 04 & \\
\hline 42 & CAPTTĀO THIAGO LUZ 4 & , RUA & & 087 & 041 & 05 & \\
\hline 43 & CAPITÃO THIAGO LUZ 4 & Se 50, RUA & & 087 & 041 & 06 & \\
\hline 44 & CAPITÃO THIAGO LUZ 5 & 5. RUA & & 087 & 041 & 07 & \\
\hline 45 & CAPITĀO THIAGO LUZ 6 & 2, RUA & & 087 & 041 & 08 & \\
\hline 46 & CAPTTÃO THIAGO LUZ 6 & 3, RUA & & 087 & 041 & 09 & \\
\hline 47 & CAPITÃO THIAGO LUZ 7 & 4, RUA & & 087 & 041 & 10 & \\
\hline 48 & CAPITĀO THIAGO LUZ 8 & 2, RUA & & 087 & 144 & 27 & \\
\hline 49 & CAPITÃO THIAGO LUZ 9 & 2E 88, RUA & & 087 & 041 & 12 & \\
\hline 50 & CAPITÄO THIAGO LUZ 9 & RUA & & 087 & 041 & 13 & \\
\hline 51 & TREZTE DE MAIO 104 E 10 & 8, L.ARGO & & 087 & 041 & 24 & \\
\hline 52 & TREZE DE MAIO 116 E 12 & 0, LARGO & & 087 & 041 & 25 & \\
\hline 53 & TREZE DE MAIO 124 A 13 & 8 , LARGO & & 087 & 041 & 01 & \\
\hline 54 & TREZE DE MAIO 84 E 90 , & LARGO & & 087 & 041 & 22 & \\
\hline 55 & TREZE DE MAIO 94 E 98 , & LARGO & & 087 & 041 & 23 & \\
\hline & QUADRA: 043 & & & & & & \\
\hline 56 & FLORIANO PEIXOTO 226 & PRAÇA & & 087 & 043 & 17 & \\
\hline 57 & FLORIANO PEIXOTO 254 & PRAÇA & & 087 & 043 & 35 & \\
\hline 58 & FLORIANO PEIXOTO 266 & PRAÇA & & 087 & 043 & 14 & \\
\hline 59 & FLORTANO PETXOTO 320 & PRAÇA & & 087 & 043 & 07 & \\
\hline 60 & FLORIANO PEГXOTO 369 & PRAÇA & & 087 & 043 & 60 & \\
\hline 61 & FLORIANO PEIXOTO 387 & PRAÇA & & 087 & 043 & 06 & \\
\hline 62 & FLORIANO PEIXOTO 401 & E $4115, \mathrm{PRAC}$ & & 087 & 143 & 39 А 59 & \\
\hline 63 & FLORIANO PEIXOTO 411 & $\mathrm{E} 415, \mathrm{PRAC}$ & & 087 & 043 & 38 & \\
\hline 64 & FLORIANO PECXOTO 419 & PRAÇA & & 087 & 043 & 12 & \\
\hline 65 & FLORIANO PEIXOTO 433 & PRAÇA & & 087 & 043 & 13 & \\
\hline 66 & $\begin{array}{l}\text { MARIO L. LEĀO } 229, \text { RT } \\
\text { PEIXOTO 226, PRAÇA }\end{array}$ & JA ESQ. FL & ORIANO & 087 & 043 & 17 & \\
\hline & QUADRA: 058 & & & & & & \\
\hline 67 & CERQUEIRA CESAR 162 , & RUA & & 087 & 058 & 01 & \\
\hline 68 & CERQUEIRA CESAR 170, & RUA & & 087 & 058 & 77 & \\
\hline 69 & CERQUEIRA CESAR 178 , & RUA & & 087 & 058 & 76 & \\
\hline 70 & CERQUEIRA CESAR 182 , & $182-\mathrm{AE} 184$ & RUA & 087 & 058 & 75 & \\
\hline 71 & CERQUEIRA CESAR 194, & $196.200, \mathrm{RU}$ & & 087 & 058 & 74 & \\
\hline 72 & $\begin{array}{l}\text { CERQUEIRA CESAR 198, } \\
\text { RUA }\end{array}$ & 198-FUNDC & S E 204, & 087 & 058 & 73 & \\
\hline 73 & CERQUEIRA CESAR 202. & RUA & & 087 & 058 & 72 & \\
\hline 74 & CERQUEIRA CESAR 221), & RUA & & 087 & 1158 & 71 & \\
\hline 75 & CERQUEIRA CESAR 222, & RUA & & 087 & 058 & 122 & \\
\hline 76 & CERQUEIRA CESAR 226 , & RUA & & 087 & 058 & 123 & \\
\hline 77 & CERQUEIRA CESAR 232 & 248, RUA & & 087 & 1058 & 131 & \\
\hline 78 & CERQUEIRA CESAR 266 & 266-FUND & S, RUA & 087 & 058 & 63 & \\
\hline 79 & CERQUEIRA CESAR 268. & RUA & & 087 & 058 & 62 & \\
\hline 80 & CERQUEIRA CESAR 278, & RUA & & 087 & 058 & 061 & \\
\hline 81 & CERQUEIRA CESAR 290 , & RUA & & 087 & 058 & 60 & \\
\hline 82 & CERQUEIRA CESAR 302, & RUA & & 087 & 058 & 126 & \\
\hline 83 & $\begin{array}{l}\text { TENENTE CORONEL } \\
\text { ARAUJO } 119 \mathrm{E} 129, \text { RUA }\end{array}$ & CARLOS & SILVA & 087 & 058 & 01 & $\begin{array}{l}\text { CONI. C/ TEN. } \\
\text { CEL C. S. A. } 129\end{array}$ \\
\hline 84 & $\begin{array}{l}\text { TENENTE CORONEL } \\
\text { ARAUJO 135, RUA }\end{array}$ & CARLOS & SILVA & 087 & 058 & 02 & \\
\hline 85 & $\begin{array}{l}\text { TENENTE CORONEL } \\
\text { ARAUJO } 139, \text { RUA }\end{array}$ & CARLOS & SILVA & 087 & 058 & 03 & \\
\hline 86 & $\begin{array}{l}\text { TENENTE CORONEL } \\
\text { ARAUJO } 145 \text {, RUA }\end{array}$ & CARLOS & SILVA & 087 & 058 & 04 & \\
\hline 87 & $\begin{array}{l}\text { TENENTE CORONEL } \\
\text { ARAUJO 151, RUA }\end{array}$ & CARLOS & SILVA & 087 & 058 & 05 & \\
\hline 88 & TENENTE CORONEL & CARLOS & SILVA & 087 & 058 & 06 & \\
\hline
\end{tabular}

Resolução COMPRESP 04/93, de 07 de abril de 1993. Departamento do Patrimônio Histórico. Secretaria Municipal de Cultura. Prefeitura do Município de São Paulo. 


\begin{tabular}{|c|c|c|c|c|c|c|c|}
\hline REG & \multicolumn{3}{|c|}{ ENDEREÇO } & SETOR & QUADRA & LOTE(s) & OBSERVAÇĀOO \\
\hline 89 & $\begin{array}{l}\text { ARAUJO 157 E 159, RUA } \\
\text { TENENTE CORONEL } \\
\text { ARAUJO 161, RUA }\end{array}$ & CARLOS & SILVA & 087 & 058 & 07 & \\
\hline 90 & $\begin{array}{l}\text { TENENTE CORONEL } \\
\text { ARAUJO 165, RUA }\end{array}$ & CARLOS & SILVA & 087 & 058 & $08 \mathrm{~A} 11$ & \\
\hline 91 & $\begin{array}{l}\text { TENENTE CORONEL } \\
\text { ARAUJO 167, RUA }\end{array}$ & CARLOS & SILVA & 087 & 058 & 12 & $\therefore$ \\
\hline 92 & $\begin{array}{l}\text { TENENTE CORONEL } \\
\text { ARAUJO 175, RUA }\end{array}$ & CARLOS & SILVA & 087 & 058 & 13 & \\
\hline 93 & $\begin{array}{l}\text { TENENTE CORONEL } \\
\text { ARAUJO } 181 \text {, RUA }\end{array}$ & CARLOS & SILVA & 087 & 058 & 14 & \\
\hline 94 & $\begin{array}{l}\text { TENENTE CORONEL } \\
\text { ARAUIO } 185 \text {, RUA }\end{array}$ & CARLOS & SILVA & 087 & 058 & 15 & \\
\hline 95 & $\begin{array}{l}\text { TENENTE CORONEL } \\
\text { ARAUTO 193, RUA }\end{array}$ & CARLOS & SILVA & 087 & 058 & 16 & \\
\hline 96 & $\begin{array}{l}\text { TENENTE CORONEL } \\
\text { ARAUJO 199, RUA }\end{array}$ & CARLOS & SILVA & 087 & 058 & 17 & \\
\hline 97 & $\begin{array}{l}\text { TENENTE CORONEL } \\
\text { ARAUIO 203, RUA }\end{array}$ & CARLOS & SILVA & 087 & 058 & 18 & \\
\hline 98 & $\begin{array}{l}\text { TENENTE CORONEL } \\
\text { ARAUJO 207, RUA }\end{array}$ & CARLOS & SILVA & 687 & 058 & 19 & \\
\hline 99 & $\begin{array}{l}\text { TENENTE CORONEL } \\
\text { ARAUIO 211, RUA }\end{array}$ & CARLOS & SILVA & 087 & 058 & 20 & $\begin{array}{l}\text { CONJ. Cl TEN. } \\
\text { CEI.C.S. A. } 2077\end{array}$ \\
\hline 100 & $\begin{array}{l}\text { TENENTE CORONEL } \\
\text { ARAUJO 217, RUA }\end{array}$ & CARLOS & STLVA & 087 & 058 & 21 & \\
\hline 101 & $\begin{array}{l}\text { TENENTE CORONEL } \\
\text { ARAUJO 223, RUA }\end{array}$ & CARLOS & SILVA & 087 & 058 & 22 & \\
\hline 102 & $\begin{array}{l}\text { TENENTE CORONEL } \\
\text { ARAUJO 227, RUA }\end{array}$ & CARLOS & SILVA & 087 & 058 & 23 & \\
\hline 103 & $\begin{array}{l}\text { TENENTE CORONEL } \\
\text { ARAUJO 233, RUA }\end{array}$ & CARLOS & STLVA & 087 & 058 & 24 & \\
\hline 104 & $\begin{array}{l}\text { TENENTE CORONEL } \\
\text { ARAUJO 235, RUA }\end{array}$ & CARLOS & SILVA & 087 & 058 & 25 & \\
\hline 105 & $\begin{array}{l}\text { TENENTE CORONEL } \\
\text { ARAUJO 243, RUA }\end{array}$ & CARLOS & SILVA & 087 & 058 & 26 & \\
\hline & QUADRA: 062 & & & & & & \\
\hline 106 & CERQUEIRA CESAR 301. R & RUA & & 087 & 062 & 1 & $\begin{array}{l}\text { CRECHE } \\
\text { MUNICIPAL }\end{array}$ \\
\hline 107 & MARIO L. LEÃO 120, RUA & & & 087 & 062 & 1 & $\begin{array}{l}\text { EEPG ALBERTO } \\
\text { CONTE }\end{array}$ \\
\hline 108 & MARIO L. LEÄO 228, RUA & & & 087 & 062 & 1 & $\begin{array}{l}\text { BII BENEDITA } \\
\text { BARROS }\end{array}$ \\
\hline 109 & PAULO EIRÓ 585, RUA & & & 087 & 062 & 1 & \\
\hline 110 & PAULO EIRÓ S/N ${ }^{\circ}$, RUA & & & 087 & 062 & 1 & $\begin{array}{l}\text { EMEI BORBA } \\
\text { GATO }\end{array}$ \\
\hline 111 & $\begin{array}{l}\text { QUADRA: } 064 \\
\text { TENENTE CORONEI } \\
\text { ARAUJO } 12 \text { E 20, RUA }\end{array}$ & CARLOS & SILVA & 087 & 064 & 1 & $\begin{array}{l}\text { CONJ. ClMÁRIO } \\
\text { L. LEÄO } 166 \mathrm{E} \\
\text { 168, RUA }\end{array}$ \\
\hline 112 & $\begin{array}{l}\text { TENENTE CORONEI } \\
\text { ARAUJO } 20 \text { e } 26, \text { RUA }\end{array}$ & CARLOS & SILVA & 087 & 064 & 2 & \\
\hline 113 & $\begin{array}{l}\text { TENENTE CORONEL } \\
\text { ARAUJO 30, RUA }\end{array}$ & CARLOS & SILVA & 087 & 064 & 3 & \\
\hline 114 & $\begin{array}{l}\text { TENENTE CORONEL } \\
\text { ARAUJO } 36 \mathrm{E} 40 \text {, RUA }\end{array}$ & CARLOS & SILVA & 087 & 064 & 4 & \\
\hline 115 & $\begin{array}{l}\text { TENENTE CORONEL } \\
\text { ARAUJO } 48 \text {, RUA }\end{array}$ & CARLOS & SILVA & 087 & 0664 & 5 & \\
\hline 116 & $\begin{array}{l}\text { TENENTE CORONEL } \\
\text { ARAUJO } 68 \text { A 52, RUA }\end{array}$ & CARLOS & SILVA & 087 & 064 & 6,7 e 21 & \\
\hline 117 & $\begin{array}{l}\text { TENENTE CORONEL } \\
\text { ARAUJO } 72 \text { E } 82, \text { RUA }\end{array}$ & CARLOS & SILVA & 087 & 064 & 10 & \\
\hline 118 & $\begin{array}{l}\text { TENENTE CORONEL } \\
\text { ARAUJO } 92 \text { E } 96, \text { RUA }\end{array}$ & CARLOS & SILVA & 087 & 064 & 11 & \\
\hline 119 & $\begin{array}{l}\text { TENENTE CORONEL } \\
\text { ARAUJO 98, RUA }\end{array}$ & CARLOS & SILVA & 087 & 064 & 12 & \\
\hline & QUADRA: 065 & & & & & & \\
\hline $\begin{array}{l}120 \\
121\end{array}$ & $\begin{array}{l}\text { CAPITÃO THIAGO LUZ } 13 \\
\text { CAPTĀ̄O THIAGO LUZ } 14\end{array}$ & 4. RUA & & $\begin{array}{l}087 \\
087\end{array}$ & $\begin{array}{l}065 \\
065\end{array}$ & $\begin{array}{l}1 \\
2\end{array}$ & \\
\hline 122 & $\begin{array}{l}\text { CAPITAO THIAGO LUZ } 14 \\
\text { FLORIANO PEIXOTO } 104\end{array}$ & $\begin{array}{l}2, \text { RUA } \\
\text { E } 106, \text { PRACA }\end{array}$ & & 087 & -065 & 16 & \\
\hline 123 & FLORIANO PEIXOTO 08, PI & RAÇA & & 087 & 065 & 117 & \\
\hline 124 & FLORIANO PEIXOTO 102,1 & PRAÇA & & 087 & 065 & 15 & \\
\hline
\end{tabular}

Resolução COMPRESP 04/93, de 07 de abril de 1993. Departamento do Patrimônio Histórico. Secretaria Municipal de Cultura. Prefeitura do Município de São Paulo. 


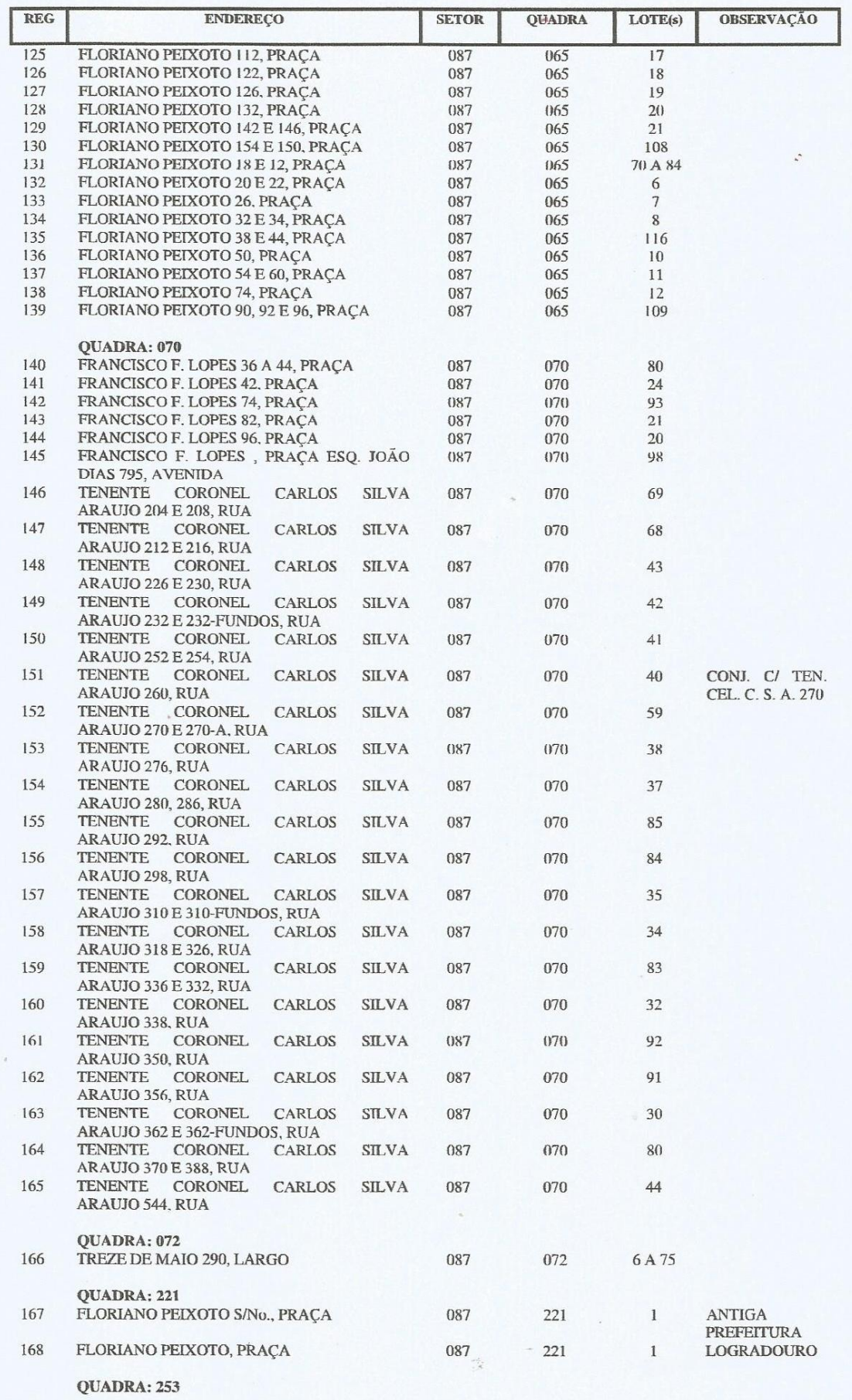

Resolução COMPRESP 04/93, de 07 de abril de 1993. Departamento do Patrimônio Histórico. Secretaria Municipal de Cultura. Prefeitura do Município de São Paulo. 


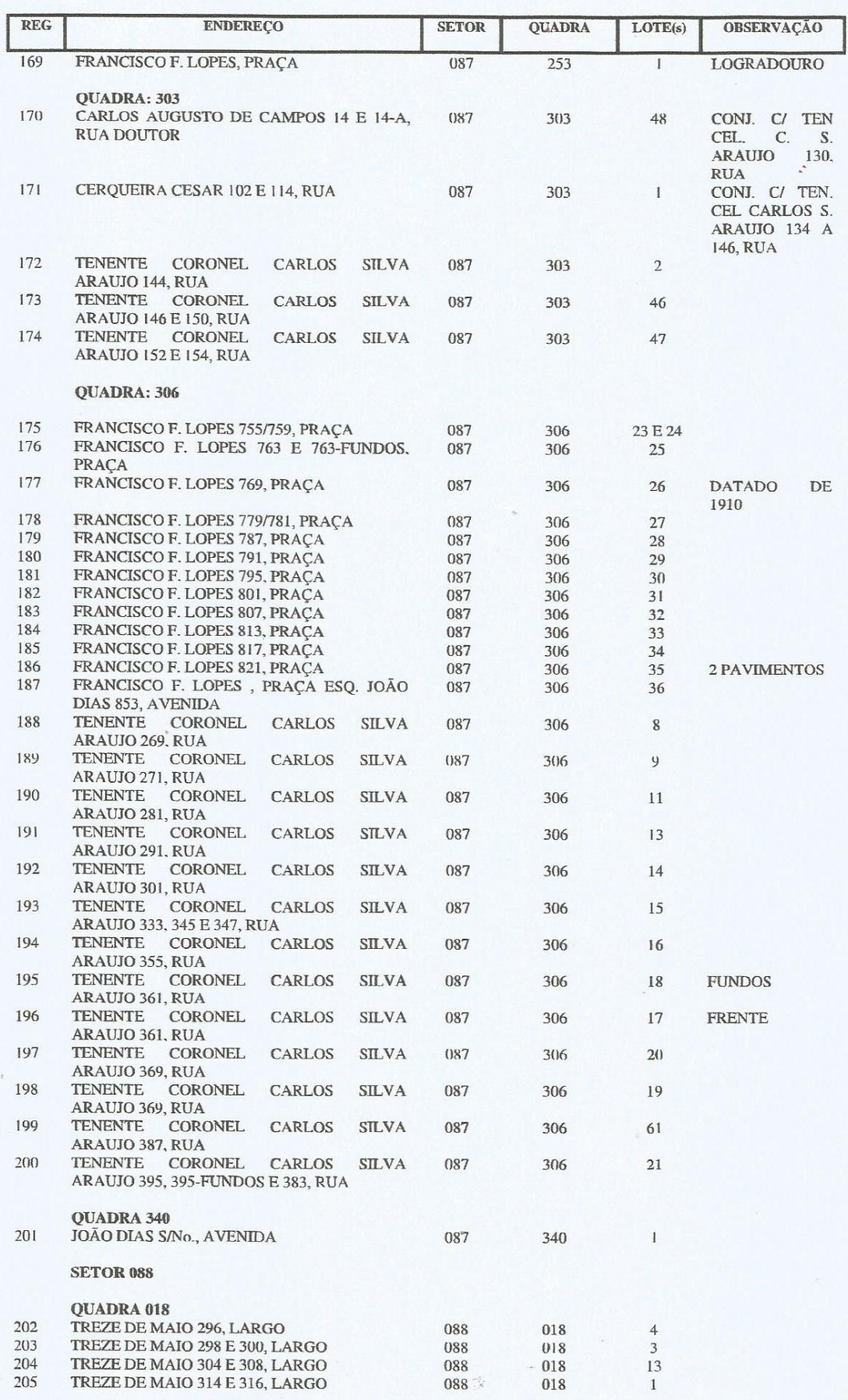

Resolução COMPRESP 04/93, de 07 de abril de 1993. Departamento do Patrimônio Histórico. Secretaria Municipal de Cultura. Prefeitura do Município de São Paulo. 


\begin{tabular}{|c|c|c|c|c|c|}
\hline REG & ENDERREÇO & SETOR & QUADRA & LOTE(s) & OBSERVAÇAO \\
\hline & QUADRA: 019 & & & & \\
\hline \multirow{2}{*}{206} & TREZE DE MATO S/No., LARGO & 088 & 019 & 1 & IGREIA MATRIZ \\
\hline & & & & & DE SANTO \\
\hline \multirow[t]{2}{*}{207} & TREZE DE MATO, LARGO & 088 & 019 & 1 & LOGRADOURO \\
\hline & QUADRA: 020 & & & & $\therefore$ \\
\hline 208 & TREZE DE MAIO 330 , LARGO & 088 & 020 & 1 & \\
\hline 209 & TREZE DE MAIO 336, LARGO & 088 & 020 & 2 & \\
\hline 210 & TREZE DE MAIO 342, LARGO & 088 & 020 & 3 & \\
\hline 211 & TRETE DE MATO 346, LARGO & 088 & 020 & 4 & \\
\hline 212 & TREZE DE MAIO 352 E 356 , LARGO & 088 & 020 & 5 & \\
\hline \multirow[t]{2}{*}{213} & TREZTE DE MATO 358 E 362 , LARGO & 088 & 020 & 8 & \\
\hline & QUADRA: 025 & & & & \\
\hline 214 & TREZE DE MAIO 101, LARGO & 088 & 025 & 56 & \\
\hline 215 & TREZE DE MAIO 374, LARGO & 088 & 025 & 28 & \\
\hline 216 & TREZE DE MATO 378 E 382 , LARGO & 088 & 025 & 29 & \\
\hline 217 & TREZE DE MAIO 390 E 394 , LARGO & 088 & 025 & 30 & \\
\hline 218 & TREZE DE MAIO 398, LARGO & 088 & 025 & 38 E 39 & \\
\hline 219 & TREZE DE MATO 402, LARGO & 088 & 025 & 32 & \\
\hline 220 & TREZE DE MAIO 406, LARGO & 088 & 025 & 33 & \\
\hline 221 & TRETE DE MAIO 414, LARGO & 088 & 025 & 34 & \\
\hline 222 & TREZE DE MAIO 424, LARGO & 088 & 025 & 35 & \\
\hline 223 & TREZE DE MAIO 430, LARGO & 088 & 025 & 36 & \\
\hline 224 & TREZE DE MAIO 440, LARGO & 088 & 025 & 37 & \\
\hline 225 & TREZE DE MAIO 454 E 460 , LARGO & 088 & 025 & 1 & \\
\hline 226 & TREZE DE MAIO 468, LARGO & 088 & 025 & 2 & \\
\hline 227 & TREZE DE MAIO 476, LARGO & 088 & 025 & 3 & \\
\hline 228 & TREZE DE MAIO 482 A 496, LARGO & 088 & 025 & 46 & \\
\hline \multirow[t]{2}{*}{229} & TREZE DE MAIO 95 c 99, LARGO & 088 & 025 & 54 & \\
\hline & QUADRA: 036 & & & & \\
\hline 230 & TREZE DE MAIO 2, LARGO & 088 & 036 & 6 & \\
\hline
\end{tabular}

Resolução COMPRESP 04/93, de 07 de abril de 1993. Departamento do Patrimônio Histórico. Secretaria Municipal de Cultura. Prefeitura do Município de São Paulo. 
Prefeitura do Município de São Paulo

Secretaria Municipal de Cultura

Departamento do Patrimônio Histórico

Conselho Municipal de Preservação do Patrimônio Histórico, Cultural e Ambiental da Cidade de São Paulo

\section{Resolução $n^{0}$. 14/2002}

O Conselho Municipal de Preservaçāo do Patrimônio Histórico, Cultural e Ambiental da Cidade de São Paulo - CONPRESP, no uso de suas atribuições legais e nos termos da Lei $n^{0} 10.032 / 85$, com as alteracões introduzidas pela Lei $n^{\circ}$ 10.236/86, conforme decisão unânime dos Conselheiros presentes à $270^{a}$ Reunião Ordinária, realizada em 13 de agosto de 2002,

CONSIDERANDO o valor histórico, urbanístico e ambiental da área identificada como Eixo Histórico de Santo Amaro, representativa da formacão e desenvolvimento desse antigo núcleo urbano que hoje integra a cidade de São Paulo;

CONSIDERANDO o valor arquitetônico e paisagístico de alguns dos elementos constitutivos desse ambiente urbano, reconhecidos por inventários e medidas legais de proteção da Prefeitura do Município de São Paulo; e

CONSIDERANDO o valor afetivo para a população do bairro de Santo Amaro e região, bem como para toda a cidade de São Paulo, desse Eixo Histórico no qual se concentram significativas formas de expressão cultural e social paulistanas,

RESOLVE:

Artigo $1^{2}$ - Tombar um conjunto de elementos constitutivos do ambiente urbano identificado como Eixo Histórico de Santo Amaro, definido pelos seguintes logradouros públicos, conforme o contido no Processo no 1993-0.007.834-8:

a) Rua Antonia Bandeira (cadlog 69.572-6)

b) Rua Visconde de Taunay (cadlog 18.749-6)

c) Praça Dr. Francisco Ferreira Lopes (cadlog 10.700-0)

d) Rua Dr. Francisco Ferreira Lopes (cadlog 10.700-0)

e) Rua Tenente Coronel Carlos da Silva Araújo (cadlog 04.328-1)

f) Rua Cerqueira César (cadlog 04.777-5) - trecho entre a Rua Paulo Eiró e a Rua Tenente Cel. Carlos da Silva Araújo

g) Praça Salim Farah Maluf (cadlog 37.749-0)

h) Rua Mário Lopes Leão (cadlog 04.053) - trecho entre a Rua Paulo Eiró e a Rua Tenente Cel. Garlos da Silva Araújo

i) Rua Capitão Tiago Luz (cadlog 18.926-0)

j) Rua Senador José Bonifácio (cadlog 10.822-7)

k) Praça Floriano Peixoto (cadlog 07.227-3)

I) Rua Paulo Eiró (cadlog 15.741-4) - trecho entre a Rua Cerqueira César e a Rua da Matriz

m) Largo Treze de Maio (cadlog 19.152-3)

n) Rua Senador Fláquer (cadlog 07.176-5) - trecho entre o Largo Treze de

Resolução COMPRESP 14/2002, de 13 de agosto de 2002.. Departamento do Patrimônio Histórico. Secretaria Municipal de Cultura. Prefeitura do Município de São Paulo. 
Maio e a Rua Herculano de Freitas

o) Rua Senador Dantas (cadlog 05.708-8) - trecho entre o Largo Treze de Maio e a Rua Herculano de Freitas

p) Avenida Padre José Maria (cadlog 11.063-9) - trecho entre a Rua Paulo Eiró e o Largo Treze de Maio.

Artigo $2^{\circ}$ - Os elementos constitutivos tombados, no ambiente urbano referido no Artigo $1{ }^{\circ}$, são os seguintes:

1) Traçado viário dos logradouros públicos identificados no Artigo $1^{0}$;

II) Praça Floriano Peixoto (cadlog 07.227-3);

III) Largo Treze de Maio (cadlog 19.152-3);

IV) Praça Salim Farah Maluf (cadlog 37.749-0);

V) Edifício da Antiga Prefeitura de Santo Amaro, localizado à Praça Floriano Peixoto (Setor 87 - Quadra 221) - preservaçäo integral;

VI) Imóvel localizado na Praça Dr. Francisco Ferreira Lopes $n^{\circ} 787$ (Setor 87 - Quadra 306) - presenvação das características arquitetônicas externas;

VII) Igreja Matriz de Santo Amaro, localizada no Largo Treze de Maio (Setor 88 - Quadra 19) - preservação integral; e

VIII) Biblioteca Pública Presidente Kennedy, localizada à Avenida João Dias no 822 (Setor 87 - Quadra 340) - preservação das características arquitetônicas externas.

Parágrafo Único - O tombamento dos itens I, II, III e IV não incide sobre equipamentos e mobiliários de caráter precário ou provisório atualmente ali implantados.

Artigo 30- Ficam definidos como espaços envoltórios desses elementos tombados as quadras e lotes discriminados no Anexo A, que integra a presente Resolucão, com as respectivas diretrizes para gabaritos máximos admissíveis e normas de ocupaçāo.

Artigo $4^{\circ}$ - Ficam definidas as seguintes diretrizes para aprovação de projetos e obras nessa área:

a) Todas as intervenções - demolições, construções, reformas, obras de conservação e restauração, bem como pedidos de regularização, nos lotes das quadras listadas no Anexo A - serão objeto de prévia aprovação, conforme o disposto nos artigos 18 e 21 da Lei no. 10.032/85.

b) Os gabaritos máximos definidos no Anexo $A$ deverão ser tomados a partir do nível médio da testada do lote até o topo da cobertura.

c) Para a Quadra 62, do Setor 87, além do gabarito máximo estipulado, ficam estabelecidas as seguintes diretrizes:

- taxa de ocupação máxima do lote $=0,5$

- área permeável mínima equivalente a $30 \%$ da área livre do lote.

d) Não serão permitidas alterações no traçado viário, bem como mudanças em guias e larguras de calçadas, sem prévia autorização, conforme

Resolução COMPRESP 14/2002, de 13 de agosto de 2002.. Departamento do Patrimônio Histórico. Secretaria Municipal de Cultura. Prefeitura do Município de São Paulo. 
disposto nos artigos 18 e 21 da Lei no. 10.032/85.

e) Os remembramentos de lotes serão possíveis desde que seja respeitado o gabarito de altura máxima previsto no Anexo A.

f) O logradouro público onde se situa a Biblioteca Pública Presidente Kennedy fica sob controle de volumetria, devendo todas as intervenções nesse logradouro serem submetidas à prévia aprovação, conforme o disposto nos artigos 18 e 21 da Lei no. 10.032/85.

g) Os espacos envoltórios de protecão dos imóveis listados no Artigo $2^{\circ}$ limitam-se às quadras e faces de quadras do Eixo Histórico, conforme definidos no Anexo A, valendo as restrições de gabarito especificadas para cada quadra.

h) A instalação de qualquer tipo de equipamento e mobiliário urbano na área definida no Artigo $1^{2}$ deverá ser submetida à prévia aprovação, conforme o disposto nos artigos 18 e 21 da Lei no. 10.032/85.

Artigo 5o- Esta Resolução passa a vigorar a partir da data de sua publicação no Diário Oficial do Município de São Paulo.

\section{ANEXO A}

EIXO HISTÓRICO DE SANTO AMARO

Espaços envoltórios - diretrizes

\begin{tabular}{|c|c|c|c|}
\hline \multicolumn{4}{|c|}{ SETOR FISCAL 87} \\
\hline $\begin{array}{l}\text { QUADRA } \\
\text { FISCAL }\end{array}$ & LOGRADOUROS & $\begin{array}{l}\text { GABARITO } \\
\text { MÁxIMO } \\
\text { (metros }\end{array}$ & $\begin{array}{l}\text { DIRETRIZES } \\
\text { ESPECIFICAS }\end{array}$ \\
\hline \multirow[t]{4}{*}{37} & Rua Paulo Eiró & 7 & \\
\hline & Rua da Matriz & 7 & \\
\hline & Largo Treze de Maio & 7 & \\
\hline & Av. Padre José Maria & 7 & \\
\hline 38 & Rua Paulo Eiró & 7 & \\
\hline 39 & Rua Paulo Eiró & 7 & \\
\hline \multirow[t]{3}{*}{40} & Rua Capitão Thiago Luz & 10 & \\
\hline & Largo Treze de Maio & 10 & \\
\hline & Av. Padre José Maria & 10 & \\
\hline
\end{tabular}

Resolução COMPRESP 14/2002, de 13 de agosto de 2002.. Departamento do Patrimônio Histórico. Secretaria Municipal de Cultura. Prefeitura do Município de São Paulo. 


\begin{tabular}{|l|l|l|l|}
\hline \multicolumn{3}{|l|}{ SETOR FISCAL 87} \\
\hline $\begin{array}{l}\text { QUADRA } \\
\text { FISCAL }\end{array}$ & LOGRADOUROS & $\begin{array}{l}\text { GABARITO } \\
\text { MÁXIMO } \\
\text { (metros }\end{array}$ & $\begin{array}{l}\text { DIRETRIZES } \\
\text { ESPECIFICAS }\end{array}$ \\
\hline & Rua Paulo Eiró & 10 & \\
\hline & Rua Amador Bueno & 10 & \\
\hline 41 & Rua Capitão Thiago Luz & 10 & \\
\hline & Largo Treze de Maio & 10 & \\
\hline 42 & Rua Senador José Bonifácio & 10 & \\
\hline 43 & Rua Paulo Eiró & 7 & \\
\hline & Rua Paulo Eiró & 10 & \\
\hline 58 & Rua Mário Lopes Leão & 10 & \\
\hline & Rua Cerqueira César & 7 & \\
& $\begin{array}{l}\text { Rua Ten.-Coronel Carlos Silva } \\
\text { Araújo }\end{array}$ & 7 & \\
\hline & & & \\
\hline
\end{tabular}

\begin{tabular}{|c|c|c|c|}
\hline 62 & Rua Cerqueira César & 7 & $\begin{array}{l}\text { a) taxa de ocupação } \\
\text { máxima do lote }=0,5 \\
\text { b) área permeável mínima } \\
\text { equivalente a } 30 \% \text { da área } \\
\text { livre do lote. }\end{array}$ \\
\hline & Rua Paulo Eiró & 7 & \\
\hline & Rua Mário Lopes Leão & 7 & \\
\hline & Rua Barão do Rio Branco & 7 & \\
\hline 64 & $\begin{array}{l}\text { Rua Ten.-Coronel Carlos Silva } \\
\text { Araújo }\end{array}$ & 7 & \\
\hline \multirow[t]{5}{*}{65} & Rua Senador José Bonifácio & 10 & \\
\hline & Rua Capitão Thiago Luz & 10 & \\
\hline & Rua Mário Lopes Leão & 10 & \\
\hline & Rua Voluntário Delmiro Sampaio & 13 & $\begin{array}{l}\text { Com exceção dos Lotes } n^{\circ} \\
27 \text { (esquina com Rua } \\
\text { Mário Lopes Leão) e } n^{\circ} 38 \\
\text { (esquina com Largo Treze } \\
\text { de Maio), que deveräo } \\
\text { obedecer o gabarito } \\
\text { máximo de } 10 \text { metros. }\end{array}$ \\
\hline & Largo Treze de Maio & 10 & \\
\hline 70 & Rua Francisco Ferreira Lopes & 7 & \\
\hline
\end{tabular}

Resolução COMPRESP 14/2002, de 13 de agosto de 2002.. Departamento do Patrimônio Histórico. Secretaria Municipal de Cultura. Prefeitura do Município de São Paulo. 


\begin{tabular}{|l|l|l|l|}
\hline & $\begin{array}{l}\text { Rua Ten.-Coronel Carlos Silva } \\
\text { Araújo }\end{array}$ & 7 & \\
\hline 303 & $\begin{array}{l}\text { Rua Ten.-Coronel Carlos Silva } \\
\text { Araújo }\end{array}$ & 7 & \\
\hline 306 & $\begin{array}{l}\text { Rua Francisco Ferreira Lopes } \\
\text { Rua Ten.-Coronel Carlos Silva }\end{array}$ & 7 & 7 \\
\hline Araújo
\end{tabular}

\begin{tabular}{|c|c|c|c|}
\hline \multicolumn{4}{|c|}{ SETOR FISCAL 88} \\
\hline $\begin{array}{l}\text { QUADRA } \\
\text { FISCAL }\end{array}$ & LOGRADOUROS & $\begin{array}{l}\text { GABARITO } \\
\text { MÁXIMO } \\
\text { (metros }\end{array}$ & $\begin{array}{l}\text { DIRETRIZES } \\
\text { ESPECIFICAS }\end{array}$ \\
\hline \multirow[t]{4}{*}{18} & Largo Treze de Maio & 7 & \\
\hline & Rua Senador Dantas & 7 & \\
\hline & Rua Des. Bandeira de Mello & 7 & \\
\hline & Alameda Santo Amaro & 7 & \\
\hline \multirow[t]{4}{*}{20} & Largo Treze de Maio & 7 & \\
\hline & Rua Senador Dantas & 7 & \\
\hline & Rua Des. Bandeira de Mello & 7 & \\
\hline & Rua Senador Flaquer & 7 & \\
\hline \multirow[t]{4}{*}{25} & Largo Treze de Maio & 7 & $\begin{array}{l}\text { Com exceção dos Lotes } \\
\text { nos } 28,54 \text { e } 56 \text { que } \\
\text { deverão obedecer r } 0 \\
\text { gabarito máximo de } 13 \\
\text { metros. }\end{array}$ \\
\hline & Avenida Adolfo Pinheiro & 13 & \\
\hline & Rua Des. Bandeira de Mello & 13 & \\
\hline & Rua Manoel Borba & 13 & \\
\hline
\end{tabular}

Resolução COMPRESP 14/2002, de 13 de agosto de 2002.. Departamento do Patrimônio Histórico. Secretaria Municipal de Cultura. Prefeitura do Município de São Paulo. 


\section{Instrumentos da Pesquisa}

ENCONTRO MEMÓRIA E PATRIMÓNIO CULTURAL DE SANTO AMARO

\begin{tabular}{|l|l|}
\hline Nome: \\
\hline Endereço: & Celular \\
\hline Telefone: & Naturalidade: \\
\hline Data de Nascimento: & \\
\hline Residente ou já residiu na região de Santo Amaro? Em que bairro? Há quanto tempo? \\
\hline Espaço para Comentários, Observações, Sugestóes e Impressões em geral e sobre o Evento: \\
\hline
\end{tabular}

A U U T O

$\mathrm{Eu}$,

autorizo o uso e a reprodução de minha imagem pessoal e dos objetos e das fotografias pertencentes ao meu acervo e à minha coleção particular, bem como o registro e veiculação de trechos de depoimentos, falas e entrevistas para fins da pesquisa sobre a memória e o patrimônio cultural de Santo Amaro, no âmbito do Projeto Diálogos entre Patrimônio, Meio Ambiente e Aprendizagem Social, em desenvolvimento pela pesquisadora e educadora Ma. Ana Cristina Chagas dos Anjos, no Laboratório de Práticas e Pesquisas em Educação e Sustentabilidade - LAPPES, do Programa de Pós- Graduação em Ciência Ambiental PROCAM do Instituto de Energia e Ambiente da Universidade de São Paulo - IEE-USP, e sua inserção elou incorporação em publicações para fins de estudo e como material e recurso educativo.

Assinatura

Data

Ficha de participação e de uso de imagem. 


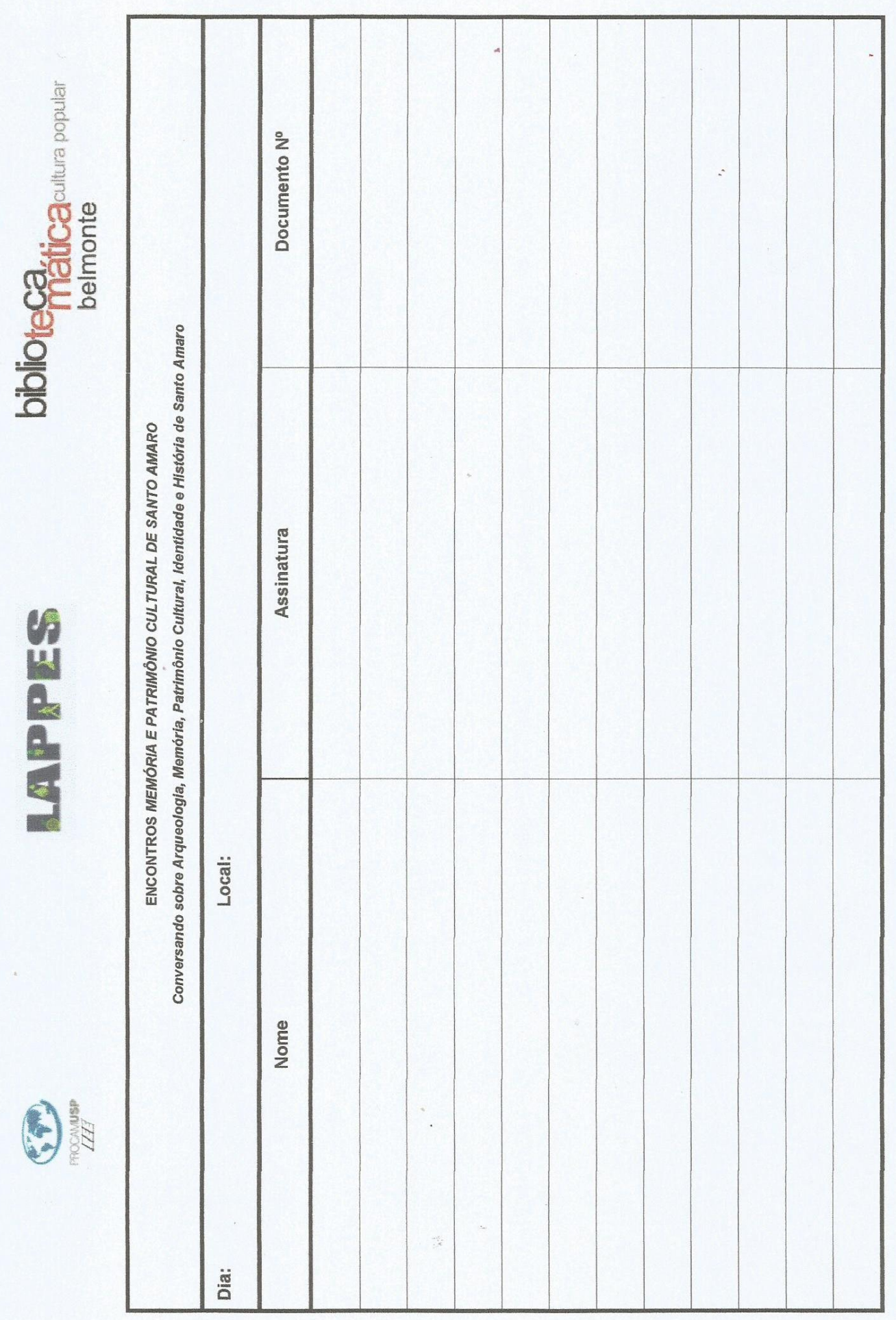

Lista de presença. 

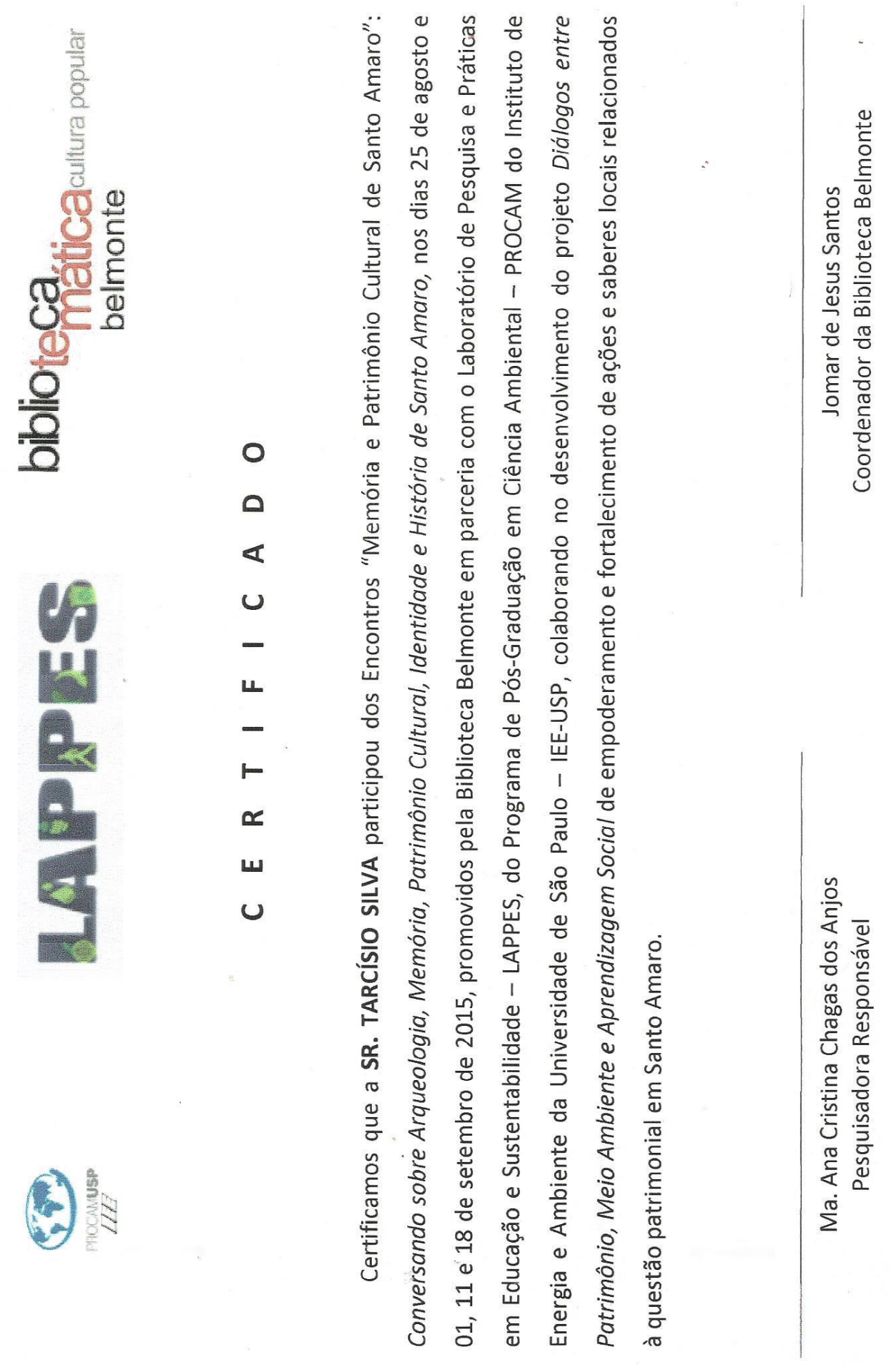

Modelo de certificado de participação. 
Ref.: - Encontros Memória e Patrimônio Cultural de Santo Amaro: Conversando sobre Arqueologia, Memória, Patrimônio Cultural, Identidade e História de Santo Amaro do Projeto Diálogos entre Patrimônio, Meio Ambiente e Aprendizagem Social.

Prezada Prof, Valéria,

Conforme conversado com a pesquisadora e educadora Ana Cristina Chagas dos Anjos, o Laboratório de Práticas e Pesquisa em Educação e Sustentabilidade do Programa de Pós Graduação em Ciência Ambiental PROCAM do Instituto de Energia e Ambiente da Universidade de São Paulo - IEE-USP vem manifestar satisfação, disponibilidade e interesse na realização de atividades voltadas aos alunos dessa unidade escolar sobre Memória e Patrimônio Cultural de Santo Amaro.

Essas atividades relacionadas às temáticas da Arqueologia, Memória, Patrimônio Cultural, Identidade e História de Santo Amaro integram o projeto Diálogos entre Patrimônio, Meio Ambiente e Aprendizagem Social, desenvolvido pela referida pesquisadora, e são caracterizadas por palestras, bate papos e oficinas que objetivam, com base em metodologias participativas e processos de aprendizagem social voltados para o empoderamento e fortalecimento de ações e saberes locais relacionados à questão patrimonial, o desenvolvimento de um Inventário Comunitário e/ou Escolar de Bens Culturais e de uma Mostra Educativa desses bens culturais inventariados pela comunidade local e/ou escolar participantes das atividades.

Com o formato de totens com textos e fotografias, a Mostra Educativa, também composta por objetos da cultura popular do acervo da Biblioteca Temática Belmonte, parceira no Projeto, ao lado dos resultados dos bens culturais inventariados, procurará itinerar em espaços públicos de Santo Amaro, visando sensibilizar a todos sobre os cuidados e a corresponsabilidade na preservação e proteção dos bens patrimoniais locais, como também chamar à atenção para a riqueza patrimonial da região.

Atenciosamente,

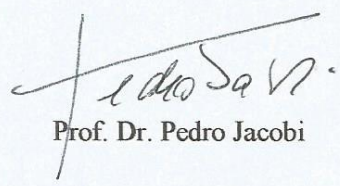

EMEFM Prof. Linneu Prestes

Coordenadoras Pedagógicas e Diretor

Av. Adolfo Pinheiro, 511 - Santo Amaro

CEP: 04733-100

SÃO PAULO - SP

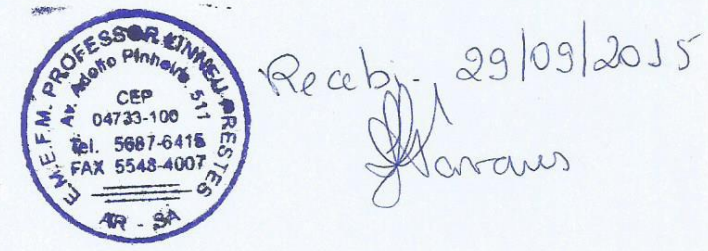

Ofício enviado para a EMEFM Linneu Prestes. 
São Paulo, 19 de novembro de 2015.

Ref.: - I Mostra Encontros Memória e Patrimônio Cultural de Santo Amaro

Prezada Prof. Valéria,

Vimos pela presente manifestar nossa satisfaçào em dar continuidade à parceria estabelecida com essa unidade escolar no projeto Diálogos entre Património, Meio Ambiente e Aprendizagem Social, e confirmar a participação dos alunos dos cursos do EJA no Sarau de abertura da I MOSTRA ENCONTROS MEMÓRIA E PATRIMONIO CULTURAL DE SANTO AMARO: Conversando sobre Arqueologia, Memória, Patrimônio Cultural, Identidade e História de Santo Amaro e a visita monitorada à exposição no espaço da Biblioteca Belmonte, nos próximos dias 02, 03 e 04 de dezembro de 2015, das turmas do Ensino Fundamental, do período da tarde.

O projeto desenvolvido pela pesquisadora e educadora Ana Cristina Chagas dos Anjos, do Laboratório de Pesquisa e Práticas em Educação e Sustentabilidade do Programa de Pós Graduação em Ciência Ambiental PROCAM do Instituto de Energia e Ambiente da Universidade de São Paulo - IEE-USP caracteriza-se por palestras, bate papos e oficinas que objetivam, com base em metodologias participativas e processos de aprendizagem social voltados para o empoderamento e fortalecimento de ações e saberes locais relacionados à questão patrimonial, o desenvolvimento de um Inventário Comunitário e/ou Escolar de Bens Culturais.

Atenciosamente

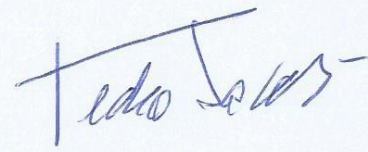

Prof. Dr. Pedro Jacobi

EMEFM Prof. Linneu Prestes

Coordenadoras Pedagógicas e Diretor

Av. Adolfo Pinheiro, 511 - Santo Amaro

CEP: 04733-100

SÃO PAULO - SP

Ofício enviado para a EMEFM Linneu Prestes. 


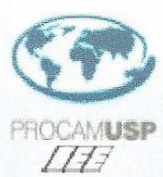

São Paulo, 13 de julho de 2015

Ref.: - Encontros Memória e Patrimônio Cultural de Santo Amaro: Conversando sobre Arqueologia, Memória, Patrimônio Cultural, Identidade e História de Santo Amaro do Projeto Diálogos entre Patrimônio, Meio Ambiente e Aprendizagem Social.

Prezado Jomar,

Conforme conversado com a pesquisadora e educadora Ana Cristina Chagas dos Anjos, o Laboratório de Práticas e Pesquisa em Educação e Sustentabilidade do Programa de Pós Graduação em Ciência Ambiental PROCAM do Instituto de Energia e Ambiente da Universidade de São Paulo - IEE-USP vem manifestar satisfação, disponibilidade e interesse na realização em parceria com essa instituição de encontros voltados para a comunidade em geral local sobre Memória e Patrimônio Cultural de Santo Amaro: Conversando sobre Arqueologia, Memória, Patrimônio Cultural, Identidade e História de Santo Amaro.

Esses encontros sobre Memória e Patrimônio Cultural de Santo Amaro integram o projeto Diálogos entre Patrimônio, Meio Ambiente e Aprendizagem Social, desenvolvido pela referida pesquisadora, e serão caracterizados por palestras, bate papos e oficinas que objetivarão, com base em metodologias participativas e processos de aprendizagem social voltados para o empoderamento e fortalecimento de açães e saberes locais relacionados à questão patrimonial, o desenvolvimento de um Inventário Comunitário de Bens Culturais e de uma Mostra Educativa desses bens culturais inventariados pela comunidade local e/ou escolar participantes das atividades.

Com o formato de totens com textos e fotografias, a Mostra Educativa, conforme sugestão, poderia também ser composta por objetos da cultura popular do acervo dessa Biblioteca Temática, ao lado dos resultados dos bens culturais inventariados nos Encontros, e itinerar em outros espaços públicos locais, de acordo com as articulações e parcerias estabelecidas, visando sensibilizar a todos sobre os cuidados e a corresponsabilidade na preservação e proteção dos bens patrimoniais locais, como também chamar à atenção para a riqueza patrimonial da região de Santo Amaro.

Atenciosamente,

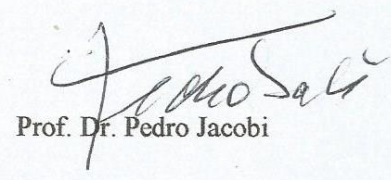

Telf $a x: 5687-0408$ 


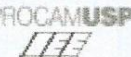

Sr. JOMAR DE JESUS SANTOS

BIBLIOTECA BELMONTE

Rua Paulo Eiró, 525 - Santo Amaro

CEP: 04752-010

SÃO PAULO - SP

Ofício enviado para a Biblioteca Belmonte. 


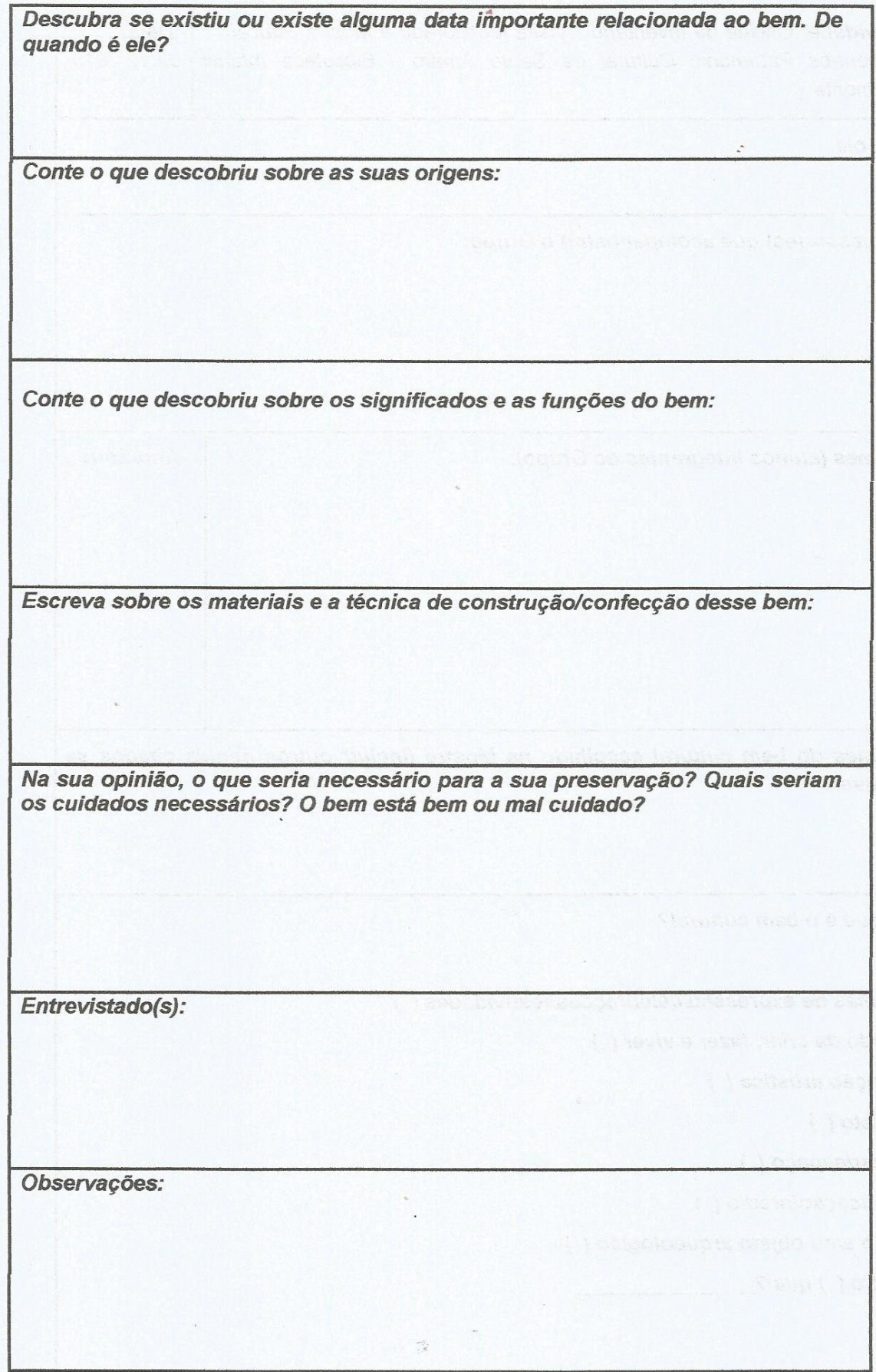

Ficha da Oficina de inventário (verso). 
Prezado(a) Senhor(a),

A Biblioteca Belmonte, a Casa de Culfura de Santo Amaro e o LAPPES - Laboratório de Pesquisa e Práticas em Educação e Sustentabilidade do PROCAM - IEE/USP convidam para o I Encontro Memória e Patrimônio Cultural de Santo Amaro: Conversando sobre Arqueologia, Memória, Patrimônio Cultural, Identidade e História de Santo Amaro, no próximo dia 25 de agosto (terça-feira), às 14h30, na Biblioteca Belmonte, na rua Pauio Eirró, 525 - Santo Amaro.

Venha compartihar suas lembranças e recordações neste primeiro encontro de memórias e histórias de Santo Amaro.

Não esqueça de trazer para a atividade objetos, fotografias e qualquer outro documento que considere importante.

Saudaçōes.

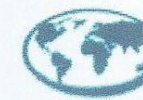 PROCAMUSP $\triangle 173$
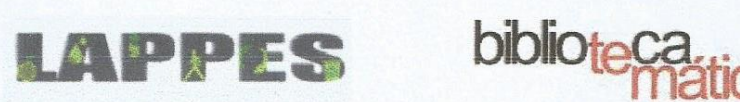 \\ belmonte}

\section{COMPROVANTE DE INSCRIÇÃO}

Sr. (a)

Confirmamos a sua inscrição no / Encontro Memória e Patrimônio Cultural de Santo Amaro: Conversando sobre Arqueologia, Memória, Patrimônio Culfural, Idenfidade e História de Santo Amaro, dia 25 de agosto (terça-feira), às 14h30, na Biblioteca Belmonte.

A Organização

Convite para o I Encontro Memória e Patrimônio Cultural de Santo Amaro: Conversando sobre Arqueologia, Memória, Patrimônio Cultural, Identidade e História de Santo Amaro. 

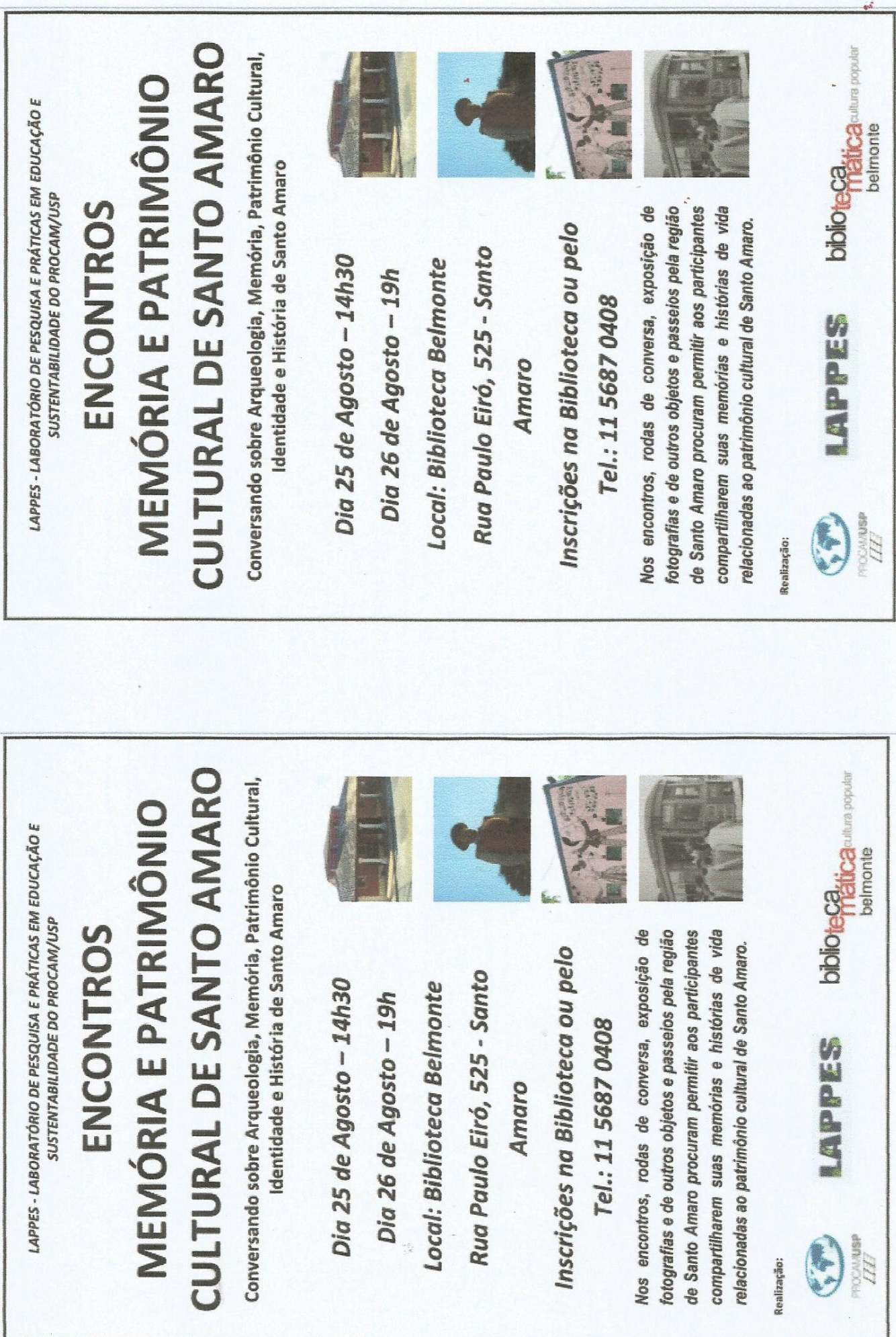

Cartaz convite para os Encontros Memória e Patrimônio Cultural de Santo Amaro: Conversando sobre Arqueologia, Memória, Patrimônio Cultural, Identidade e História de Santo Amaro. 

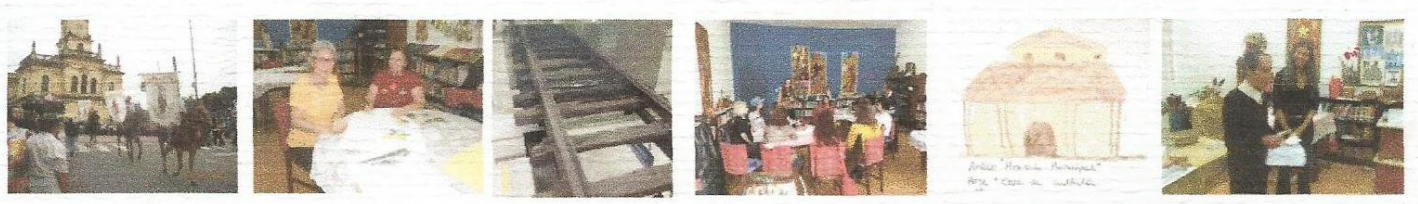

A Biblioteca Belmonte, a Casa Amarela e o LAPPES - Laboratório de Pesquisa e Práticas em Educação e Sustentabilidade do PROCAM - IEE/USP convidam para a

\section{IMOSTRA ENCONTROS MEMÓRIA E PATRIMÔNIO CULTURAL DE SANTO}

\section{AMARO}

De 25 de Novembro a 23 de Dezembro de 2015

Segunda-feira a Sexta-feira, das $10 \mathrm{~h}$ às $19 \mathrm{~h}$ e Sábado, das $9 \mathrm{~h}$ às $16 \mathrm{~h}$.

\section{Biblioteca Belmonte}

Rua Paulo Eiró, no 525 - Santo Amaro - Telefone: 1156870408
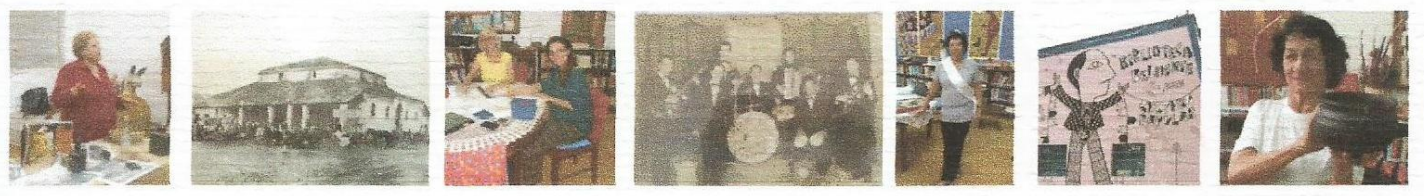

O Projeto ENCONTROS MEMỌ́RIA E PATRIMÔNIO CULTURAL DE SANTO AMARO: Conversando sobre Arqueologia, Memória, Patrimônio Cultural, Identidade e História de Santo Amaro, com o objetivo de sensibilizar a todos sobre os cuidados e a corresponsabilidade na preservação e proteção de bens culturais locais, chamar à atenção para a riqueza patrimonial da região de Santo Amaro e fortalecer ações e saberes locais relacionados ao seu patrimônio, convida para a sua I Mostra, que poderá ser visitada até 23 de dezembro de 2015, na Biblioteca Belmonte.

Venha apreciar e compartilhar as lembranças, recordações, memórias e histórias da Santo Amaro do bonde, dos romeiros, da Casa de Cultura (antigo Mercado Velho), do Colégio Paulo Eiró, da Casa Amarela, das Missas na Igreja Matriz, das benzedeiras, da Festa do Divino, do Carnaval, do Cine São Francisco, da diversidade e da singularidade de um lugar. A Santo Amaro de todos nós!
Realização:

Angélica Rovida e Turmas de Dança do Vocacional da Casa Amarela

Adoração Sanches Sant' Ana Aparecida Ferreira Barros Irene Kiss Fontes Maria Alice das Dores Maria da Silva Camargo Roseli Camargo

Tarcísio Silva

Tereza Discher Câmara Vanessa Ferreira de Barros Ortiz

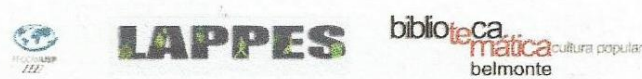




\section{səoJ́Isodxอ}
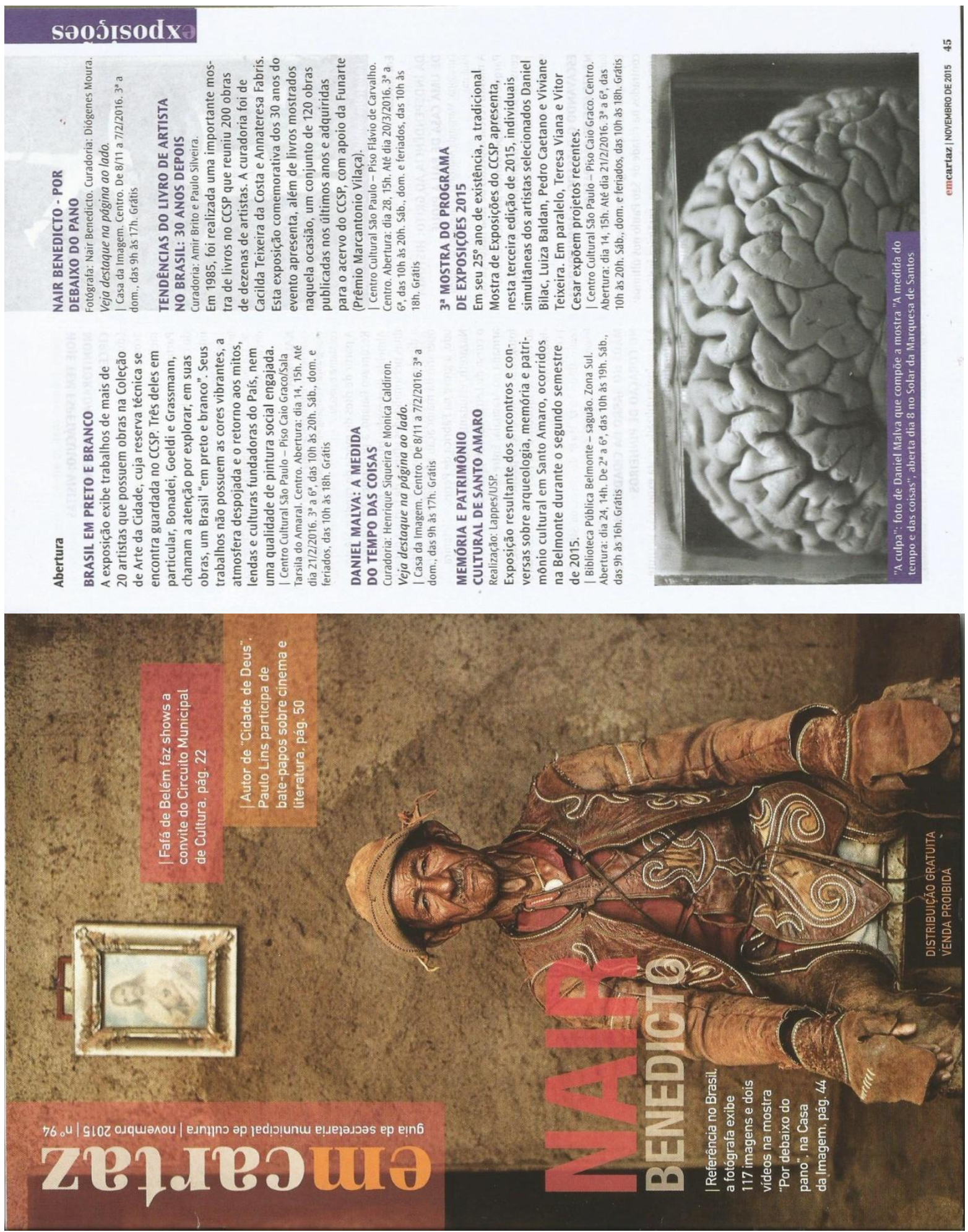

Divulgação da I Mostra Memória e Patrimônio Cultural de Santo Amaro na publicação em cartaz: guia da Secretaria Municipal de Cultural, Nov. 2015, n. 94. 


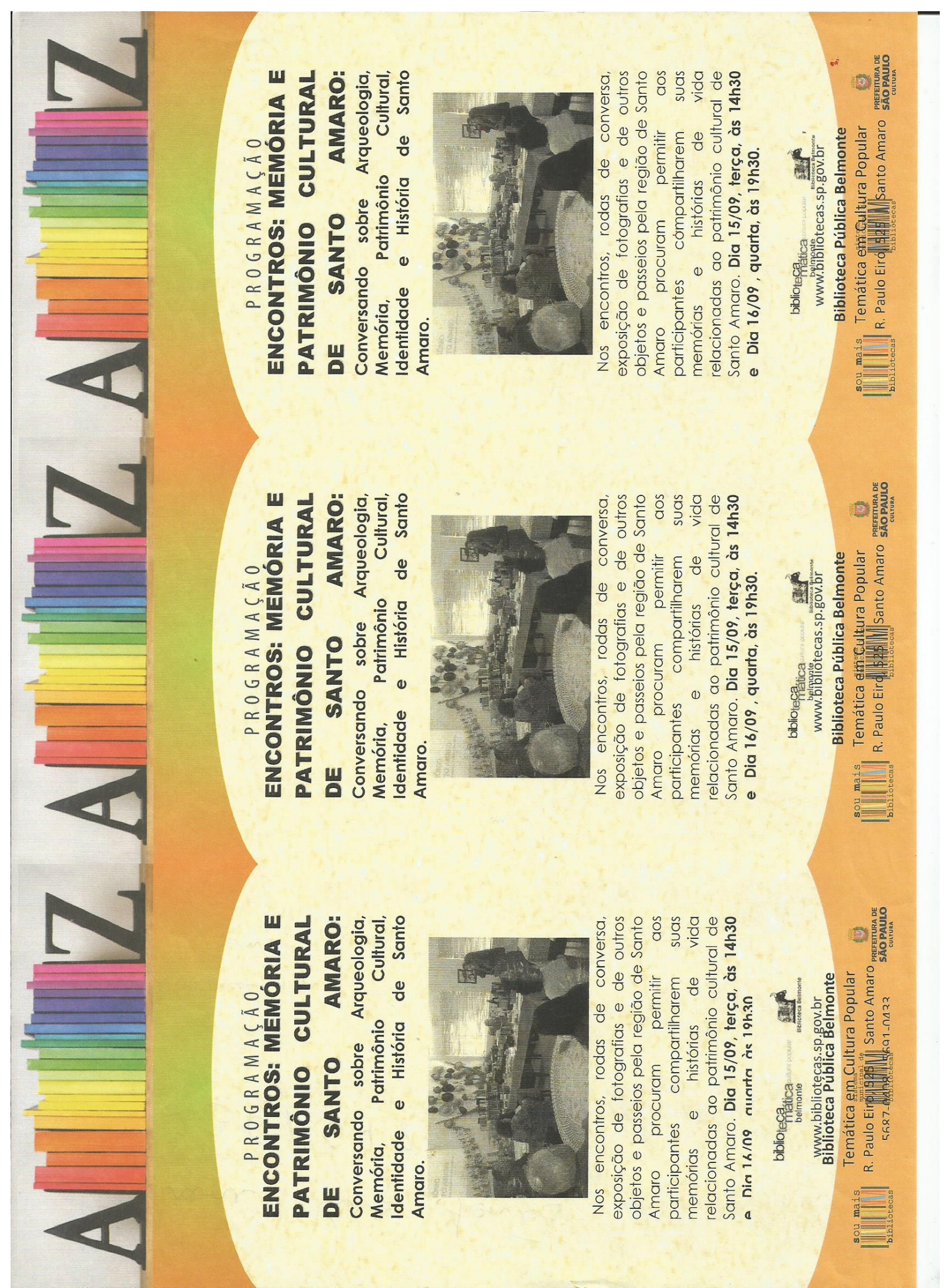

Filipetas de divulgação dos Encontros Memória e Patrimônio Cultural de Santo Amaro, da Biblioteca Belmonte. 
UIVIIUTELa, máticacultura popular belmonte

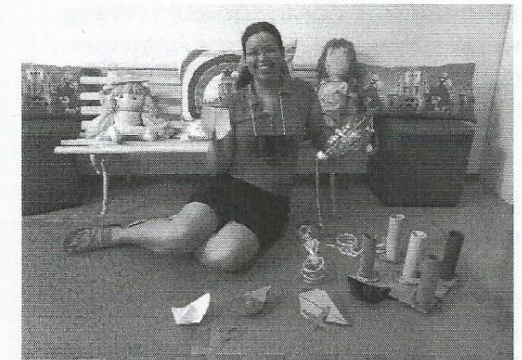

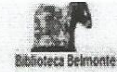

Rua Paulo Eiró, 525-Prox.P. Floriano Peixoto - Sto Amaro - F. 5687-0408 bmbelmonte@yahoo.com.br/bmbelmonteculturapopular@yahoo.com.br www. bibliotecabelmonte.blogspơt.com

OFICINA DE ENCADERNAÇĀO ARTESANAL - Com Coletivo Mínimo Diário que compartilha nesta oficina três costuras artesanais - panfleto, japonesa e correntinha - para você criar o seu próprio caderno, livro, folheto ou zine. Gratuita. 11 vagas. Material incluso. Inscrições até 12/10. Seleção por sorteio. Enviar e-mail com nome, idade e telefone para: oi@minimodiario.com.br. Sorteio e divulgação do resultado: 13/10. Apoio Programa VAl 2015 - Secretaria Municipal de Cultura de São Paulo. Duração: 2h. 14 anos. - . Dia 16/10, 6a.feira, das $15 \mathrm{~h}$ às $17 \mathrm{~h}$.

\section{PROGRAMACÃO OUTUBRO/2015}

OFICINA DE ARTASANATO INFANTIL - Com Bruna Lopes - Em comemoração ao dia das crianças, a Jovem Monitora Bruna Lopes irá criar com os participantes diversas confecções para as crianças brincarem como aviões de papel, bumerangues, barquinho de papel, binóculos, jogo de argolas e o brinquedo vai e vem. Duração: $1 \mathrm{~h}$. LIVRE. Dia $14 / 10$, quarta-feira, às $10 \mathrm{~h} 30$ e às $14 \mathrm{~h} 30$.

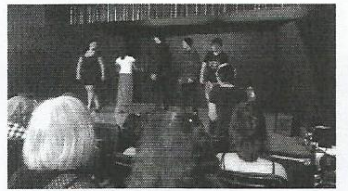

TEATRO VOCACIONAL - Orientação de Grupos de Teatro Amador, Grupos de Estudos e Leituras Dramáticas e Teatro para jovens a partir de 14 anos, com a Artista Orientadora Camila Januário, em duas turmas: sábados, das $9 \mathrm{~h}$ às $12 \mathrm{~h}$ e das $14 \mathrm{~h}$ às $17 \mathrm{~h}$. Inscrições abertas.

MINICURSO DE CONTACÃO DE HISTÓRIAS COM IVANI MAGALHĀES Por meio de atividades práticas os participantes entrarão em contato com o universo mágico da narração oral e a diversidade de elementos que o compōe: músicas, brincadeiras populares, manipulação de objetos, bonecos, entre outros. A descoberta do contador de histórias que reside dentro de cada um e apresentar alguns recursos e procedimentos que podem ser utilizados na apresentação de histórias. Dias 19 a 23/10, das $14 \mathrm{~h}$ às $17 \mathrm{~h}$.
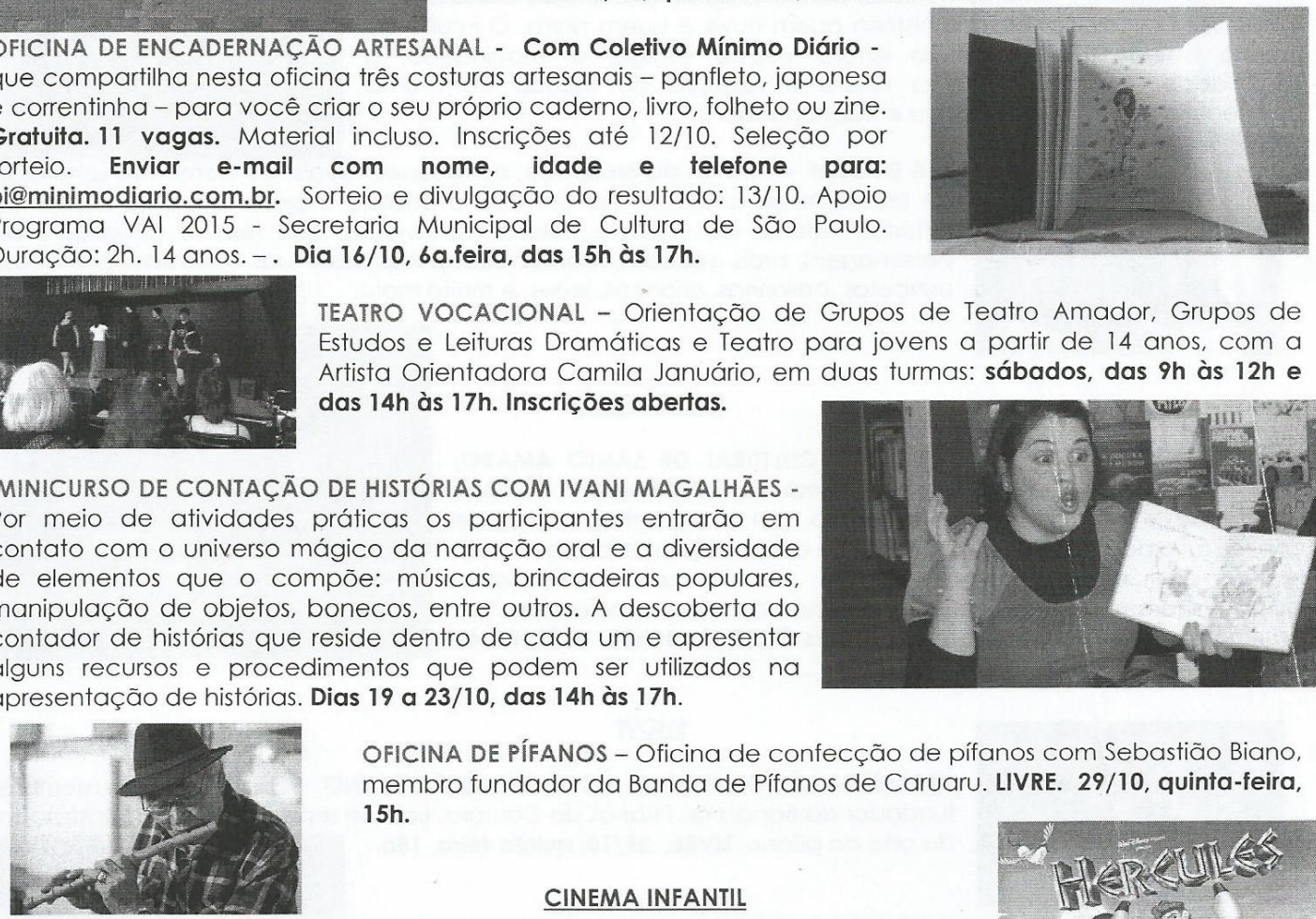

OFICINA DE PÍFANOS - Oficina de confecção de pífanos com Sebastião Biano, membro fundador da Banda de Pífanos de Caruaru. LIVRE. 29/10, quinta-feira, $15 \mathrm{~h}$.

\section{CINEMA INFANTIL}

HÉRCULES - Hercules, EUA, 1997, 92 min, dublado, DVD. Direção: John Musker, Ron Clements. Hércules precisa provar que é um bom herói para seu pai, o grande Zeus. Para isso, terá que decidir entre seus poderes e seu verdadeiro amor. Livre. Dia 3 de outubro, sábado, às $11 \mathrm{~h}$.
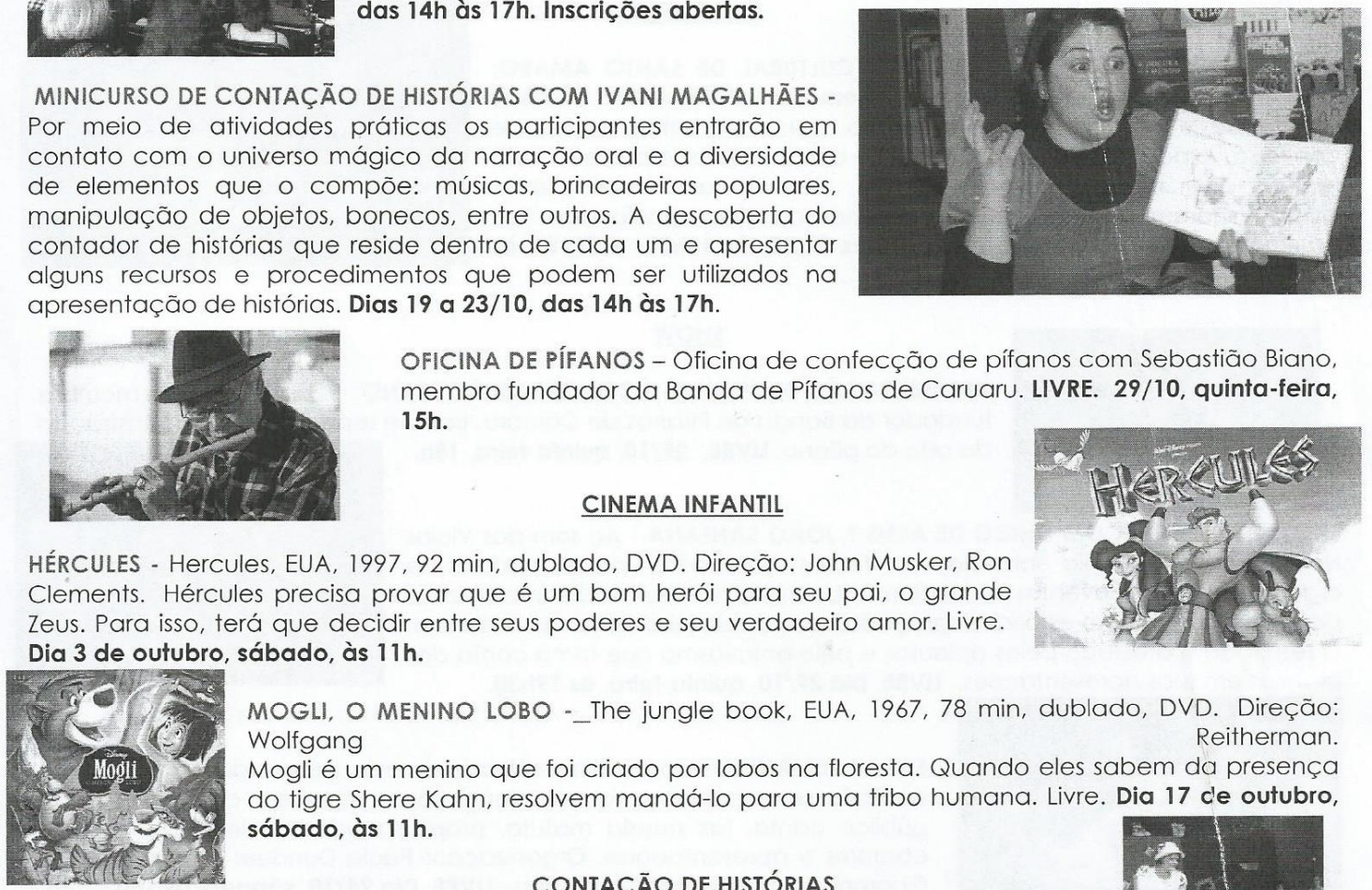

MOGL, O MENINO LOBO -_The jungle book, EUA, 1967, $78 \mathrm{~min}$, dublado, DVD. Direção: Wolfgang Reitherman Mogli é um menino que foi criado por lobos na floresta. Quando eles sabem da presença do tigre Shere Kahn, resolvem mandá-lo para uma tribo humana. Livre. Dia 17 c'e outubro, sábado, às $11 \mathrm{~h}$

\section{CONTAÇĀO DE HISTÓRIAS}

CONTAR É PRECISO, LER É INDISPENSÁVEL - Com integrantes do Projeto Conta Comigo Uniltalo, Coordenado pela profa. Ivani Magalhães - Leitura e Narrativas de histórias e contos estimulam o potencial criativo e o prazer de ler em crianças, jovens e adultos. Agendamento para turmas. Telefone: 5687-0408. LIVRE. Dia 13/10, terça-feira-feira, às $10 \mathrm{~h} 30$ e às $14 \mathrm{~h} 30$.

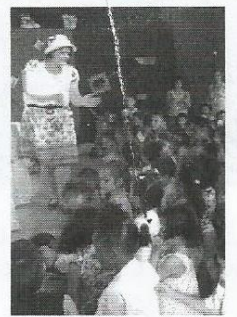

Programação de outubro de 2015 da Biblioteca Belmonte com o registro dos Encontros (no verso). 


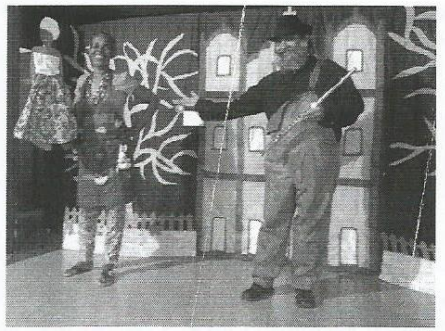

TARDE DE CONTAÇĀO E MÚSICA COM SABINO LOPES: HISTÓRIAS QUE A ॠOVÓ CONTAVA - Participaçōes de Isabel Andrade, Maria Luiza Rocha e outras vovós convidadas, além do músico Gabriel Lopes. Sabino Lopes recebe, no auditório Kiyomi Oba, çom muita alegria, música e contação de histórias, grupos de escolas infantis. As crianças se divertem, aprendem e interagem com suas histórias divertidas e músicas contagiantes. Nesta edição diversas vovós trarão seus repertórios de histórias para as crianças presentes. Livre. Dia $29 / 10$, sexta-feira, às $14 \mathrm{~h}$.

\section{FESTIVAL DE CONTACÃ̃O DE HISTÓRIAS Dia $20 / 10$, terça, às $19 \mathrm{~h}$.}

GRUPO PONTOS DE FIANDEIRAS - O grupo traz o projeto "Pé de Conto" que é uma sementeira de histórias, frutífera, pronta para ser desfrutada e acessivel a todos os públicos. Saboreia a história quem ouve e quem narra. O intuito do projeto é incentivar a cultura leitora, escrita, instigar a imaginação, a criatividade, contribuir para a leitura e releitura do mundo com uma perspectiva positiva, humanística e transformadora.

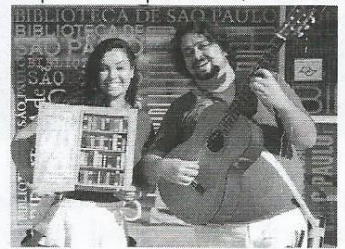

CIA BISCLOF - Através da oralidade, de recursos visuais, de elementos sonoros e de brincadeiras, a Cia. Bisclof convida o público a entrar em suas diferentes histórias, histórias de agora e histórias de outrora, que têm os cenários e os personagens mais variados, como: circos, castelos, ruas, florestas, palhaços, princesas, bailarinas, crianças, leões, e muito mais!

\section{ENCONTROS}

ENCONTROS: MEMÓRIA E PATRIMONNIO CULTURAL DE SANTO AMARO: Conversando sobre Arqueologia. Memória, Patrimônio Cultural, Identidade e História de Santo Amaro. Nos encontros, rodas de conversa, exposição de fotografias e de outros objetos e passeios pela regiāo de santo Amaro procuram permitir aos participantes compartilharem suas memórias e histórias de vida relacionadas ao patrimônio cultural de Santo Amaro. Dias $27 / 10$, às $14 \mathrm{~h} 30$ e $28 / 10$, às $19 \mathrm{~h} 30$.

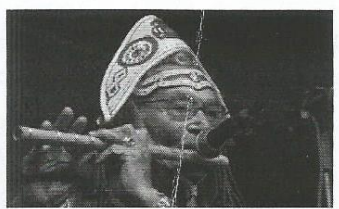

SHOW

APRESENTAÇÃO DE PÍFANOS - COM SEBASTIÃO BIANO. Sebastião Biano, membro fundador da Banda de Pífanos de Caruaru, traz um repertório de demonstração da arte do pífano. LIVRE. 29/10, quinta-feira, $18 \mathrm{~h}$.

SHOW DE REPENTE COM CHICO DE ASSIS E JOÃO SANTANA - AO sOm das Violas Nordestinas, a dupla aborda os temas solicitados pelas plateias e organizadores de eventos e declama poemas de teor socioambiental e poemas matutos com estórias engraçadas acerca do jeito de ser do sertanejo. O resultado é atestado pelos aplausos e pelo entusiasmo que toma conta das plateias em suas apresentaçōes. LIVRE. Dia 29/10, quinta-feira, às $19 \mathrm{~h} 30$.
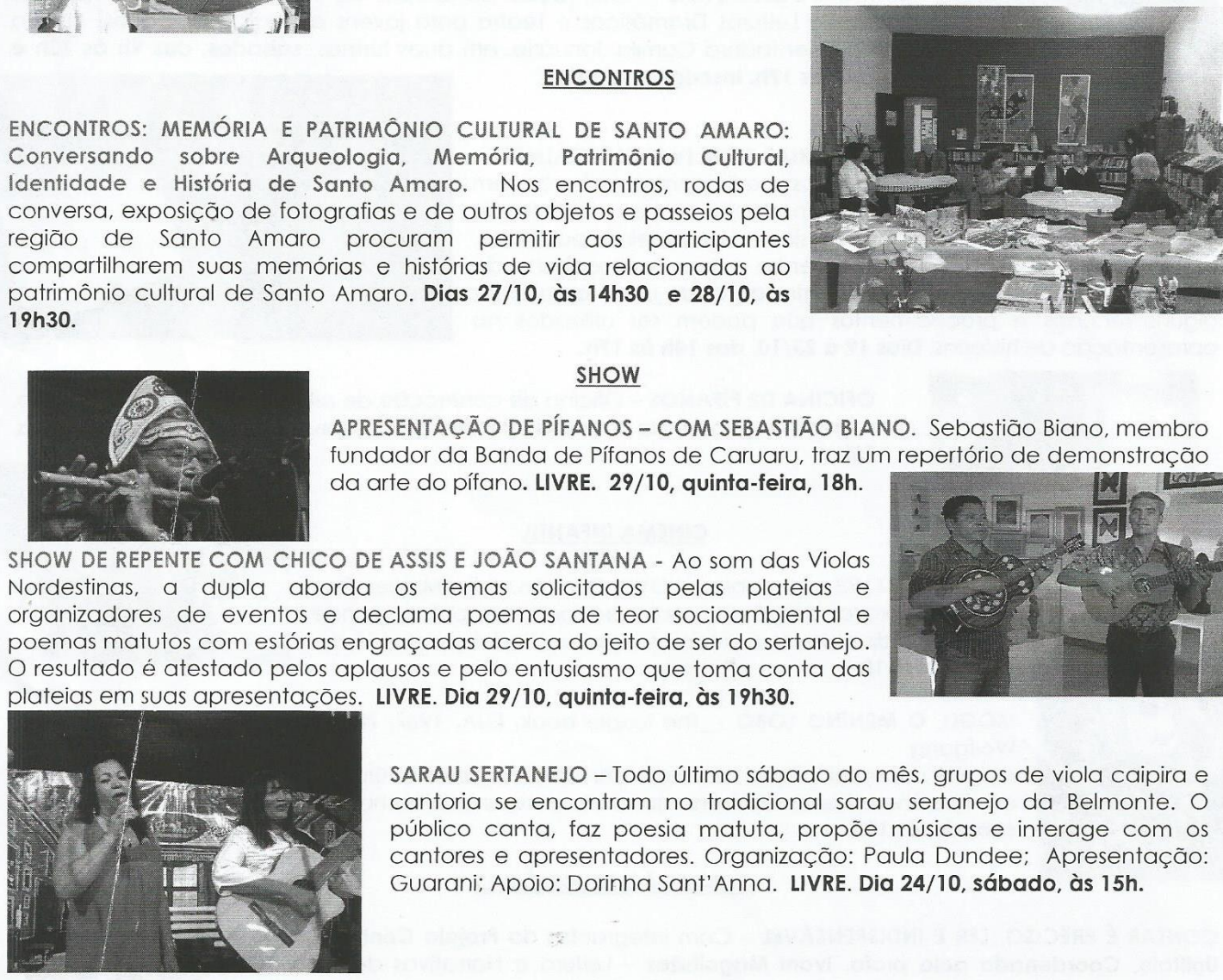

SARAU SERTANEJO - Todo último sábado do mês, grupos de viola caipira e cantoria se encontram no tradicional sarau sertanejo da Belmonte. O público canta, faz poesia matuta, propõe músicas $e$ interage com os cantores e apresentadores. Organização: Paula Dundee; Apresentação: Guarani; Apoio: Dorinha Sant'Anna. LIVRE. Dia 24/10, sábado, às $15 \mathrm{~h}$.

VISITAS MONITORADAS - A biblioteca recebe grupos previamente agendados para conhecer o acervo e a Sala de Cultura Popular. Agendamento pelo telefone 5687-0408.

Programação de outubro de 2015 da Biblioteca Belmonte com o registro dos Encontros. 
